\title{
MEJORA DE LA TECNOLOGÍA DE DESVERDIZACIÓN DE CÍTRICOS Y APTITUD A LA FRIGOCONSERVACIÓN DE NUEVAS VARIEDADES. ESTUDIOS SOBRE PARÁMETROS DE CALIDAD Y COMPOSICIÓN NUTRICIONAL
}

TESIS DOCTORAL

PRESENTADA POR:

Sawsen Sdiri

DIRECTORA:

Dra. Alejandra Salvador Pérez TUTORA:

Dra. Isabel Hernando Hernando 

Ala mémoire de mon friere

Stafedh 

Al mis padres que sembraron en mi alma el deseo del liderargo y de la superación, por su ayjuda y confiansa. Han sido un pilar importante para mí en esto nuevo desafio, con sw incondicional cariño y con las constantes. palabras de aproyo para mi desandlo prersonal y profesional A mis hermanas y hermanos, cuñadas y cuñados, sobinas ysobinos 



\section{AGRADECIMIENTOS}

La presente Tesis ha sido realizada gracias a la concesión de una Beca para extranjeros para realizar Estudios de Doctorado e Investigación en España, de la Agencia Española de Cooperación Internacional para el Desarrollo (AECID) del Ministerio de Asuntos Exteriores y de Cooperación (MAEC).

Para llevar a cabo un proyeto de Tesis Doctoral se requiere la participación directa o indirecta de muchas personas e instituciones a las cuales quiero agradecer en estas líneas.

En primer lugar quiero expresar mi agradecimiento a mi directora de Tesis Dra. Alejandra Salvador por creer y confiar siempre en mí y por darme la oportunidad de llegar hasta aquí. Sandra ha sido y es el ejemplo que a mi me gustaría seguir. Me ha transmitido valores como el esfuerzo y la profesionalidad lo que me ha generado confianza y seguridad a la hora de realizar este trabajo. Para mí no solo ha sido la mejor Directora de Tesis que he podido tener, sino que me ha demostrado en todo momento que es una amiga a la que siempre podré recurrir. Gracias por tu esfuerzo y cariño, me siento muy afortunada por tenerte como directora y como amiga.

Sin duda alguna, merece una mención especial una persona cariñosa que no dejó de apoyarme en lo profesional y lo personal, le agradezco por el gran esfuerzo que ha dedicado para ayudarme a llevar a cabo el trabajo de esta Tesis, Pilar Navarro.

Asimismo, quiero agradecer a mi tutora Isabel Hernando la colaboración prestada.

Además quiero dar las gracias a las siguientes personas y entidades que contribuyeron de forma desinteresada en el trabajo que aquí se presenta. Gracias, a la Dra. Almudena Bermejo del Departamento de Citricultura del Istituto Valenciano de Investigaciones Agrarias por su colaboración y aportación. Al Dr. Luis Navarro y a José Cuenca del Departamento de Biotecnología y Protección Vegetal del Istituto Valenciano de Investigaciones Agrarias por facilitarme el 
material vegetal y darme la oportunidad de trabajar con las nuevas variedades obtenidas en su departamento. Al Dr. Antonio Granell y José Luis Rambla del Instituto de Biología Molecular y Celular de Plantas (CSIC-UPV) de la Universidad Politécnica de Valencia por darme la oportunidad de realizar los análisis de los compuestos volátiles.

Quiero mostrar un agradecimiento especial a todas aquellas personas que durante estos años de trabajo han estado a mi lado, amigos, familia y compañeros, y que de una u otra forma han contribuido a que esta tesis haya llegado a buen fin. Considero que todo aquel que ha tenido alguna relación conmigo durante el desarrollo de esta tesis merece mi total agradecimiento. Gracias a mis amigos y compañeros del Departamento de Tecnología Postcosecha del IVIA y de fuera del del IVIA que han compartido conmigo los momentos de alegría y de penas animándome a seguir hasta el final. Gracias por su acogida y cariño demostrado durante estos años, especialmente a: Adela, Aurora, Cristina, Rebeca, Alicia, Pedro, Elena, Christian, Clara, Lluis, Berna, Cristina, Nuria, Sana, Aymen, Youssef, Mamen, José, Faten, Marie-Carmen, Loli, Ines, Zeineb, Ryma.

Y cómo no, expreso mi profundo agradecimiento a mi familia. A mis queridos padres: Hédi y Omelez, a mis hermanos: Samia, Nizar, Emna y Hafedh que aunque no pueda estar con nosotros para celebrar la obtención del título desde allí donde esté me dará su cariño y estará conmigo, a mis cuñadas: Monia y Awatef, a mi cuñado Noureddine, a mis sobrinas: Dorra, Farah y Maram y por último a mis sobrinos: Firas, Badis y Adam. 


\section{RESUMEN}

Los cítricos son frutos atractivos buscados por los consumidores en todo el mundo por su elevada calidad organoléptica y por los beneficios que tienen para la salud humana. Después de la cosecha, los frutos cítricos para consumo en fresco deben ser sometidos a diferentes tratamientos postcosecha antes de llegar al consumidor.

El proceso de desverdizado con exposición al etileno es un tratamiento postcosecha ampliamente utilizado comercialmente para acelerar el cambio de color externo de los cítricos, dado que en las condiciones climáticas del Mediterráneo, las variedades tempranas alcanzan la madurez interna antes que la plena coloración. Sin embargo la aplicación del etileno exógeno puede inducir alteraciones fisiológicas asociadas a la senescencia de la piel y sobre todo del cáliz (ennegrecimiento y caída). Con la finalidad de minimizar estas alteraciones, uno de los objetivos de la presente Tesis fue la optimización del proceso de desverdización así como la evaluación de tratamientos previos a la aplicación del desverdizado en diferentes variedades de mandarinas y naranjas de interés comercial. La aplicación de tratamientos de desverdizado combinando periodos sin exposición al etileno exógeno con periodos con aplicación de etileno, lo que se ha denominado tratamientos combinados, redujo significativamente estas alteraciones sin afectar al cambio de color externo de los frutos. La aplicación del regulador de crecimiento HF-Calibra ${ }^{\circledR}$, previamente al desverdizado con etileno, disminuyó el ennegrecimiento y caída del cáliz en las variedades ensayadas, incrementándose este efecto con la dosis de aplicación.

Otro objetivo de la presente Tesis fue estudiar el efecto de la aplicación de etileno exógeno, así como del tiempo de exposición al mismo, durante el proceso de desverdizado sobre los componentes bioactivos en diferentes variedades de clementina. La aplicación de etileno durante los diferentes periodos ensayados no afectó al contenido en ácido ascórbico total (TAA), ácido ascórbico (AA) y ácido dehidroascórbico (DHAA) y tampoco a la capacidad antioxidante.

Además se evaluó el efecto del tratamiento de desverdizado en condiciones comerciales seguido de un tratamiento de cuarentena por frío en el contenido de vitamina C, compuestos fenólicos y capacidad antioxidante, así como en los compuestos volátiles de diferentes variedades de cítricos. El tratamiento de desverdización seguido del almacenamiento en cuarentena por frío no provocó cambios relevantes en la capacidad antioxidante determinada por DPPH y FRAP ni en el contenido del AA, TAA, DHAA, fenoles totales, flavanonas y flavonas de las variedades ensayadas. Además, estas condiciones postcosecha no afectaron los componentes aromáticos-activos. 
Por otra parte, la introducción de nuevas variedades de cítricos exige el estudio de su calidad fisico-química y nutricional, así como de su comportamiento durante el periodo postcosecha. Esta evaluación ha sido llevada a cabo en la presente Tesis sobre nuevas variedades triploides de mandarina de recolección tardía, obtenidas en el Departamento de Biotecnología y Protección Vegetal del Instituto Valenciano de Investigaciones Agrarias. Los resultados obtenidos mostraron que las variedades objeto de estudio presentan elevada calidad organoléptica, con altos contenidos en azúcares y ácidos orgánicos, que las hacen altamente atractivas para su consumo en fresco. Además estas variedades muestran alta calidad nutricional, por lo que pueden considerarse como una importante fuente de componentes bioactivos en la dieta humana.

La condición de recolección tardía de las nuevas variedades triploides, hace necesario el estudio de su aptitud a la conservación frigorífica. Además de los cambios en la calidad interna que sufren los frutos durante la conservación a baja temperatura hay que tener en cuenta que algunas variedades de cítricos son susceptibles de presentar alteraciones denominadas daño por frío cuando son expuestas a bajas temperaturas. En la presente Tesis, frutos de las nuevas variedades triploides fueron almacenados a $1^{\circ} \mathrm{C}, 5^{\circ} \mathrm{C}$ y $9^{\circ} \mathrm{C}$ durante un periodo máximo de 30 días. Todas las variedades ensayadas mantuvieron una elevada calidad interna durante el almacenamiento prolongado, por lo que ésta no resultó un factor limitante. Sin embargo algunas variedades presentaron síntomas externos de daño por frío que limitaron su conservación por lo que las condiciones de temperatura-tiempo de almacenamiento recomendadas serán diferentes en función de la variedad. 


\section{RESUM}

Els cítrics són fruits atractius apreciats pels consumidors de tot el món per la seua elevada qualitat organolèptica i pels beneficis que tenen per a la salut humana. Després de la collita, els fruits cítrics per al consum en fresc han de ser sotmesos a diferents tractaments postcollita abans d'arribar al consumidor.

El procés de desverdització amb exposició a etilé és un tractament postcollita àmpliament utilitzat comercialment per accelerar el canvi de color extern dels cítrics, atés que en les condicions climàtiques del Mediterrani les varietats primerenques arriben a la maduresa interna abans que a la plena coloració. Malgrat això, l'aplicació d'etilé exogen pot induir alteracions fisiològiques associades a la senescència de la pell i sobretot del calze (ennegriment i caiguda). Amb la finalitat de minimitzar estes alteracions, un dels objectius de la present Tesi va ser l'optimització del procés de desverdització així com l'avaluació de tractaments previs a la seua aplicació en diferents varietats de mandarines i taronges d'interés comercial. L'aplicació de tractaments de desverdització combinant períodes sense exposició a etilé exogen amb períodes amb aplicació d'etilé, el que s'ha denominat tractaments combinats, va reduir significativament estes alteracions sense afectar el canvi de color extern dels fruits. L'aplicació del regulador del creixement HF-Calibraß, prèviament a la desverdització amb etilé, va disminuir l'ennegriment i caiguda de calzes en les varietats assajades, incrementant-se este efecte amb la dosi d'aplicació.

Un altre objectiu de la present Tesi va ser estudiar l'efecte de l'aplicació d'etilé exogen, així com del temps d'exposició al mateix durant el procés de desverdització, sobre els components bioactius en diferents varietats de clementina. L'aplicació d'etilé durant els diferents períodes assajats no va afectar al contingut en àcid ascòrbic total (TAA), àcid ascòrbic (AA) i àcid dihidroascòrbic (DHAA) i tampoc a la capacitat antioxidant.

A més, va avaluar-se l'efecte del tractament de desverdització en condicions comercials seguit d'un tractament de quarantena per fred en el contingut de vitamina $\mathrm{C}$, compostos fenòlics i capacitat antioxidant, així com en els compostos volàtils de diferents varietats de cítrics. El tractament de desverdització seguit de l'emmagatzemament quarantenari per fred no va provocar canvis rellevants en la capacitat antioxidant determinada per DPPH i FRAP, ni en el contingut d'AA, TAA, DHAA, fenols totals, flavanones i flavones de les varietats assajades. A més, estes condicions postcollita no van afectar els components aromàtics actius.

D'altra banda, la introducció de noves varietats de cítrics exigix l'estudi de la seua qualitat fisicoquímica i nutricional, així com del seu comportament durant el període postcollita. Esta avaluació s'ha dut a terme en la present Tesi sobre noves varietats triploides de mandarina de recol-lecció tardana, 
obtingudes al Departament de Biotecnologia i Protecció Vegetal de l'Institut Valencià d'Investigacions Agràries. Els resultats obtinguts indiquen que les varietats objecte d'estudi presenten una elevada qualitat organolèptica, amb alts continguts en sucres $i$ àcids orgànics que les fan altament atractives per al consum en fresc. A més, estes varietats presenten una alta qualitat nutricional, per la qual cosa poden considerar-se com una important font de components bioactius en la dieta humana.

La condició de recollecció tardana de les noves varietats triploides fa necessari l'estudi de la seua aptitud per a la conservació frigorífica. A més dels canvis en la qualitat interna que patixen els fruits durant la conservació a baixa temperatura, cal tindre en compte que algunes varietats de cítrics són susceptibles de presentar alteracions denominades danys per fred quan són exposades a baixes temperatures. En la present Tesi, fruits de les noves varietats triploides van ser emmagatzemats a $1^{\circ} \mathrm{C}, 5^{\circ} \mathrm{C}$ i $9^{\circ} \mathrm{C}$ durant un període màxim de 30 dies. Totes les varietats assajades van mantindre una elevada qualitat interna durant l'emmagatzemament prolongat, de manera que esta qualitat no va resultar un factor limitant. No obstant això, algunes varietats van presentar símptomes externs de dany per fred que van limitar la seua conservació, per la qual cosa les condicions de temperatura-temps d'emmagatzemament recomanades seran diferents en funció de la varietat. 


\section{ABSTRACT}

Citrus fruits are attractive fruits sought after by consumers overall the world for their unique taste, flavor, eating quality and health benefits. After harvest, fresh citrus fruit need to be manipulated at different stages with postharvest treatments before reaching consumers.

Degreening process, by exposing fruit to ethylene, is a postharvest treatment, commonly used to accelerate external color change of citrus fruit since in the Mediterranean area early-season citrus fruit are harvested when fruit reach acceptable internal maturity standards for marketing while their external peel color is still green. Nevertheless, the application of ethylene during degreening treatment, besides the desirable color change, can induce physiological disorders related to peel and calyx senescence (browning and dropping). One objective of the present Thesis was to study different postharvest treatments to improve quality of early-season citrus fruit submitted to degreening treatment. The application of degreening treatments combining periods without ethylene exposure with other with ethylene application significantly reduced the calyx alterations associated with this treatment without affecting the external color evolution. The postharvest application of HFCalibra $\AA$, a growth regulator, also decreased the calyx alteration incidence in all assayed varieties; the higher the doses applied, the lower percentage of fruit with calyx alterations symptom.

Another objective of the present Thesis was to evaluate the effect of the ethylene application, as well as the exposure time during degreening process on bioactive compounds in differente cultivars of clementines. The application of ethylene for different duration of treatment did not affect total ascorbic acid (TAA), ascorbic acid (AA), dehydroascorbic acid (DHAA) nor the antioxidant activity of mandarin fruit.

The effect of the degreening treatment under commercial conditions followed by cold-quarantine treatment on the content of vitamin $\mathrm{C}$, phenolic compounds and antioxidant activity, as well as on the volatile compounds of different citrus fruit cultivars was also evaluated. Degreening treatment followed by cold-quarantine storage plus shelf-life did not induce detrimental changes in DPPH and FRAP antioxidant capacities, AA, TAA, DHAA, total phenolic content and the total content of flavanone and flavones of the assayed early-season citrus varieties. In addition, these postharvest treatments did not affect aromaactive compounds.

The introduction of new citrus varieties makes it necessary to study their nutritional composition as well as their postharvest behavior. In the present Thesis the new mid late-season triploid mandarins obtained in the Plant Protection and Biotechnology Center in the Instituto Valenciano de Investigaciones Agrarias were analyzed for the determination of their physico- 
chemical and nutritional composition. All the new triploid mandarins showed high quality parameters of juice, with high content in sugars and organic acids, which make them good for fresh consumption. Moreover, these new varieties displayed high nutritional quality which may considerate as a significant source of health promoting components for human diet.

The condition of late harvesting of these new triploid varieties, require a study of its suitability for cold storage. In addition to changes in the internal quality experienced by fruits during storage at low temperature, must be taken into account that some varieties of citrus fruit are susceptible to chilling injury when exposed to low temperatures. In this Thesis, fruits of the new triploid varieties were stored at $1^{\circ} \mathrm{C}, 5^{\circ} \mathrm{C}$ or $9^{\circ} \mathrm{C}$ for up 30 days. In all tested varieties the high internal quality remained during prolonged storage, therefore this was not a limiting factor. Nevertheless some varieties exhibited external chilling injury symptoms that limited the storage, so that the recommended temperature-time conditions of storage will be variety-dependent. 


\section{RÉSUMÉ}

Les agrumes sont des fruits attractifs très recherchés par les consommateurs dans le monde entier pour leur excelente qualité organoleptique et leurs avantages indéniables pour la santé humaine. Après la récolte, les agrumes destinés à la consommation en frais doivent être soumis à différents traitements postrécolte avant d'arriver chez le consommateur.

Le processus de déverdissage par exposition des fruits à l'application de l'éthylène, est un traitement postrécolte couramment utilisé à l'échelle commerciale pour accélérer le changement de la couleur externe des agrumes, puisque dans les conditions climatiques de la Méditerrenée, les variétés précoces atteignent la maturité interne optimale avant d'atteindre la coloration externe propre de la variété. Cependant, l'application d'éthylène exogène durant le traitement de déverdissage, outre le changement de la couleur, peut induire des troubles physiologiques liés à la sénéscence de la peau et du calice (brunissement et chute). L'un des objectifs de la présente Thèse était l'étude de l'optimisation du processus de déverdissage et l'évaluation de différents traitements post-récolte pour améliorer la qualité des variétés précoces de mandarines et des oranges soumises au traitement de déverdissage. L'application des traitements de déverdissage combinant des périodes sans et d'autres avec expostion à l'éthylène exogène réduit considérablement les altérations des calices associées à ce traitement sans affecter cependant l'évolution de la couleur externe des fruits. L'application post-récolte du régulateur de croissance HF-Calibra avant le déverdissage avec exposition à l'éthylène a également diminué l'incidence des altérations des calices de toutes les variétés étudiées, plus la dose appliquée est élevée plus le pourcentage avec symptômes d'altérations des calices est faible.

Un autre objectif de cette Thèse était d'étudier l'effet de l'application de l'éthylene exogène ainsi que le temps d'eposition au cours du processus de déverdissage sur les composés vioactifs chez différentes variétés de clémentines. L'application de l'éthylène durant les différentes périodes étudiées n'ont pas affecté le contenu d'acide ascorbique total (AAT), de l'acide ascorbique (AA), de l'acide déhydroascorbique (ADHA) ainsi que la capacité antioxidante des fruits.

L'effet du traitement de déverdissage sous les conditions commerciales suivi par le traitement de quarantaine par le froid sur la teneur en Vitamine C, les composés phénoliques et l'activité antioxidante ainsi que sur les composés volatiles de différentes variétés précoces d'agrumes a également été évalué. Ces traitements postrécolte suivis par les conditions de simulation de la commercialisation n'ont pas induit des changements préjudiciables de la capacité antidante déterminée par les méthodes de DPPH et de FRAP, AA, AAT, ADHA, phénols totaux et le contenu totatal de flavanones et flavones des 
variétés précoces d'agrumes étudiées. En outre, ces traitements postrécolte n'ont pas affecté négativement les composés aromatiques actifs.

D'autre part, l'intoduction de nouvelles variétés d'agrumes exige l'étude de leur composition physico-chimique et nutritionnelle ainsi que leur comportement postrécolte. Cette évaluation a été réalisée dans la présente Thèse sur des nouvelles variétés de mandarines triploides à maturité tardive obtenues au Département de Biotechnologie et protection des Végétaux de l'Institut Valencian de Recherches Agronomiques. Toutes les nouvelles mandarines triploides ont présenté une excelente qualité organoleptique avec des teneurs élevés en sucres et en acides organiques ce qui les rend très attractives pour la consommation en frais. En plus, ces nouvelles variétés présentent une qualité nutritionnelle élevée, et peuvent être considéré alors comme une importante source de composés bioactifs dans l'alimentation humaine.

La condition de la récolte tardive de ces nouvelles variétés tardives exige l'étude de leur aptitude à la conservation au froid. En plus des changements de la qualité interne exprimés par les fruits pendant le stockage à basses températures, il faut tenir en compte de la sensibilité de quelques variétés d'agrumes au développement des dégâts dus au froid suite à leur exposition à des basses températures. Dans la présente Thèse, les fruits des nouvelles variétés triploides ont été conservés à $1^{\circ} \mathrm{C}, 5^{\circ} \mathrm{C}$ ou $9^{\circ} \mathrm{C}$ pendant une période allant jusqu'à 30 jours. A la fin de la période conservation prolongée, les fruits des variétés étudiées ont présenté une qualité interne de jus élevée. Toutefois, ertaines variétés ont montré des synptômes de dégâts dus au froid qui limitent leur conservation durant une période prolongée, de sorte que les conditions de température et période de conservation seront différentes selon la variété. 


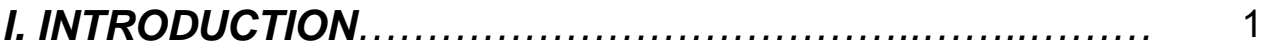

I.1. Production, Exportation, Importance of new cultivars............ 3

I.2. Postharvest degreening of citrus fruit....................... 7

I.2.1. General Aspects....................................... 7

I.2.2. Factors involved in degreening treatment................. 7

I.2.2.1. Ethylene ............................................ 7

I.2.2.2. Temperature ...................................... 9

I.2.2.3. Duration of treatment............................... 11

I.2.2.4. Oxygen and carbon dioxide ...................... 11

I.2.2.5. Humidity ......................................... 12

I.2.3. Effects of degreening treatment on fruit quality............. 12

I.2.3.1. Internal quality..................................... 12

I.2.3.2. Physiological disorders........................... 13

I.2.3.3. Pathological diseases............................. 16

I.3. Cold storage of citrus fruit............................... 17

I.3.1. General Aspects..................................... 17

I.3.2. Physiological disorders during storage. Chilling disorders. 18

I.3.3. Factors affecting chilling injury susceptibility............... 21

I.3.4. Fruit quality changes during storage $\ldots \ldots \ldots \ldots \ldots \ldots \ldots \ldots . \quad 23$

I.3.4.1. Quality attributes................................ 23

I.3.4.2. Bioactive compounds............................ 24

I.3.4.3. Volatile compounds.............................. 25

I.4. Fresh citrus fruit composition.............................. 27

I.4.1. Bioactive compounds ................................ 27

I.4.1.1. Vitamin C ........................................ 27 
I.4.1.2. Phenolic compounds............................. 28

I.4.1.3. Carotenoids...................................... 30

I.4.1.4. Limonoids......................................... 31

I.4.2. Aroma and taste ..................................... 32

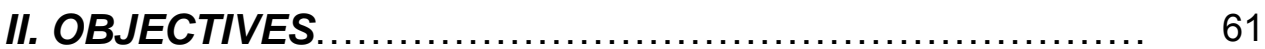

II.1. POSTHARVEST DEGREENING OF EARLY-SEASON CITRUS FRUIT

II.2. POSTHARVEST BEHAVIOR OF NEW TRIPLOIDS MANDARINS

III. RESULTS AND DISCUSSION.

III.1. POSTHARVEST DEGREENING OF EARLY-SEASON CITRUS FRUIT

\section{CHAPTER I:}

New degreening treatments to improve the quality of citrus fruit combining different periods with and without ethylene exposure.....

Reference: Postharvest Biology and Technology, 2012, 63: 25-32.

\section{CHAPTER II:}

Postharvest application of a new growth regulator reduces calyx alterations of citrus fruit induced by degreening treatment.

Reference: Postharvest Biology and Technology, 2013, 75: 68-74. 
CHAPTER III:

Antioxidant Activity and Vitamin C Are Not Affected by Degreening Treatment of Clementine Mandarins.

Reference: Acta Horticulturae, 2012, 934: 893-899.

\section{CHAPTER IV:}

Effect of postharvest degreening followed by cold-quarantine treatment on vitamin $\mathrm{C}$, phenolic compounds and antioxidant activity of early-season citrus fruit.

Reference: Postharvest Biology and Technology, 2012, 65: 13-21.

\section{CHAPTER V:}

Changes in the volatile profile of citrus fruit submitted to postharvest degreening and cold-quarantine treatment.

Submitted to: Journal of Agricultural and Food Chemistry

\section{III.2. POSTHARVEST BEHAVIOR OF NEW TRIPLOIDS MANDARINS.}

\section{CHAPTER VI:}

Phenolic composition, organic acids, sugars, vitamin $\mathrm{C}$ and antioxidant activity in the juice of two new triploid late-season mandarins.

Reference: Food Research International, 2012, 49(1): 462-468.

\section{CHAPTER VII:}

Juice of new triploids late-maturing mandarins as a rich source of vitamin C, flavonoids and antioxidant capacity.

Submitted to: Journal of Agricultural and Food Chemistry. 
CHAPTER VIII:

Postharvest behavior of 'Garbi' and 'Safor' - new triploid

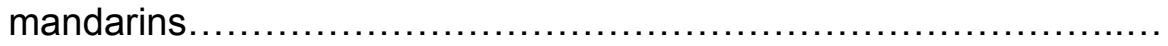

Reference: Acta Horticulturae, 2012, 945: 255-262.

CHAPTER IX:

Comportamiento postcosecha de nuevas variedades triploides de mandarinas tardias.

Reference: Submitted to Levante Agricola.

IV. GENERAL DISCUSSION ............................ 321

V. GENERAL CONCLUSIONS ............................. 339

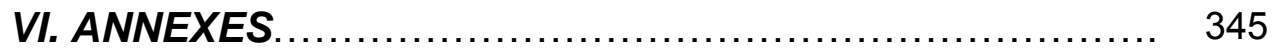




\section{ABBREVIATIONS}

\begin{tabular}{ll}
$0-E T$ & Without ethylene exposure \\
120 h E & 120 with ethylene exposure \\
120 h noE & 120 h without ethylene exposure \\
$2,4-D$ & 2,4 -dichlorophenoxyacetic acid \\
AA & Ascorbic acid \\
AAE & Ascorbic Acid Equivalent \\
ABTS & 2,2 --azino-bis(3- ethylbenzothiazoline-6-sulfonate \\
ACN & Acetonitrile \\
BS & Basol \\
C $_{2} \mathrm{H}_{4}$ & Ethylene \\
CCI & Citrus Color Index \\
CGA & Chlorogenic acid \\
Cl & Chilling Injury \\
CN & Clemenules \\
CR & Clemenrubí \\
DAD & Diode Array Detector \\
DHAA & Dehydroascorbic acid \\
DID & Didymin \\
DPPH & 2,2 -diphenyl-2-picryl-hidrazyl \\
DSM & Diosmin \\
DTT & Dithiothreitol \\
EC & Amount of antioxidant needed to decrease the radical \\
& concentration by 50\% \\
ET & Ethylene \\
EtOH & Ethanol \\
EU & European Union \\
FRAP & Ferric Reducing Antioxidant Power \\
GAE & Gallic Acid Equivalent \\
GC & Gaz Chromatography \\
HES & Hesperidin \\
HPLC & High-Performance Liquid Chromatography \\
IVIA & Instituto Valenciano de Investigaciones Agrarias \\
MI & Maturity Index \\
NAR & Naringin \\
NAT & Narirutin \\
ND & Compound not detected. \\
NOB & Nobiletin \\
NV & Navelina \\
OR & Oronules \\
& \\
\hline
\end{tabular}




$\begin{array}{ll}\text { PC } & \text { Principal Component } \\ \text { PCA } & \text { Principal Component Analysis } \\ \text { PMFs } & \text { Polymethoxyflavones } \\ \text { PR } & \text { Prenules } \\ \text { QUE } & \text { Quercetin } \\ \text { RH } & \text { Relative Humidity } \\ \text { RT } & \text { Retention time } \\ \text { SI } & \text { Specific ion } \\ \text { SIN } & \text { Sinensetin } \\ \text { SSC } & \text { Soluble Solid Content } \\ \text { TA } & \text { Titratable Acidity } \\ \text { TAA } & \text { Total Ascorbic Acid } \\ \text { TAN } & \text { Tangeretin } \\ \text { TPC } & \text { Total Phenolic Content } \\ \text { TPTZ } & \text { 2,4,6-Tris(2-pyridyl)-s-triazine } \\ \text { TSS } & \text { Total Soluble Solids } \\ \text { VIT C } & \text { Vitamin C } \\ \text { VOCs } & \text { Volatile organic compounds } \\ \text { With ET } & \text { With ethylene exposure }\end{array}$


I. INTRODUCTION 



\section{I.1. PRODUCTION, EXPORTATION, IMPORTANCE OF NEW CULTIVARS}

Citrus are the world's most popular and an economically important fruit crop grown in tropical and subtropical climates in a large number of countries. The worldwide production was estimated at over 100 million tons in 2009, in which 21 million tons being mandarins, clementines and satsumas (FAO, 2009). World's production trends indicate that oranges constitute about $60 \%$ of the total citrus output, followed by mandarins, clementines and satsumas, which comprise about $20 \%$ of the output. The group of lemons and limes constitute $11-12 \%$, and grapefruit and pomelos comprise roughly $5-6 \%$. The main citrus fruit-producing countries are Brazil, China, the United States and Mexico, although the whole Mediterranean region ranks first worldwide accounting for $19 \%$ of the world citrus production. In this region, citrus fruits are produced mainly for fresh consumption (CLAM, 2007).

Spain is the fifth worldwide producer of citrus fruits and the first one in the Mediterranean region. The yields of the different varieties have increased in recent years to reach $316623 \mathrm{Ha}$ in 2009, including the production of oranges, mandarins, lemons and pummelos. The area devoted to the oranges crop is $48 \%$ of the total designated to farm citrus fruits in 2009 . Below this mandarins were harvested from $38 \%$ of the area, lemons from $12 \%$ and pummelos and others from the rest of the area. The distribution of the citrus area throughout Spain is mainly concentrated in the Mediterranean region. Taking into account the whole area designated for farming citrus in Spain, the region of Valencia accounted for $56.89 \%$ of the total area. Furthermore, $26.85 \%$ was located in the south of the country in the region of Andalucia (MAGRAMA, 2010).

The production of Spanish citrus is characterized by its significant growth. In the last 10 years the production of citrus fruits has increased by $11.5 \%$ reaching 6.07 million tons in 2010 (Figure 1). The production was estimated of about 5,68 million tons in 2011 (MAGRAMA, 2012). More than $85 \%$ of the citrus production is designated to the fresh consumption. In the worldwide market of citrus fruits, Spain is considered one of the most important traders in citrus because of its exports, being the first world exporting country of fresh mandarins. In 2009, Spain exported 2,72 million tons being the northern European countries and the U.S.A. the main destination markets (MAGRAMA, 2010). 


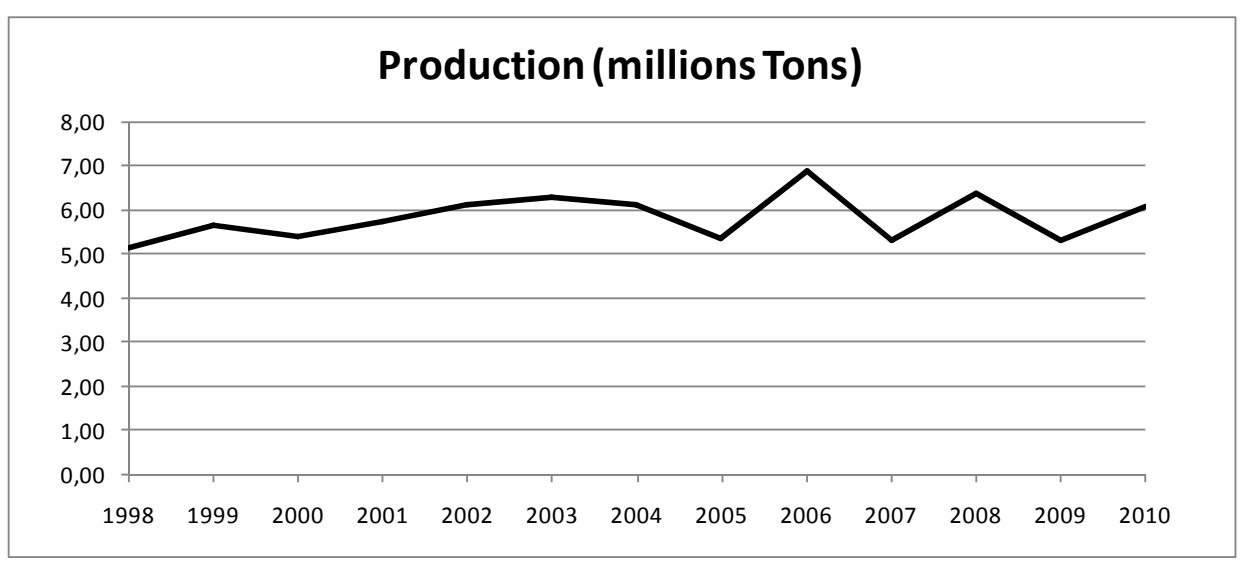

Figure 1. Citrus production in Spain in the period 1998-2010. (Data source: MAGRAMA, 2012).

The main varieties cultivated in Spain are Navel orange ('Navelina', 'Newhall', 'Washington Navel', 'Navelate'), oranges without navel ('Salustiana', 'Valencia Late', 'Barberina'), mandarins (Clementines, hybrids and Satsumas), lemons ('Verna' and 'Mesero') and pomelos. Among mandarins, $66.52 \%$ of the production are Clementines. The main commercial clementine varieties are 'Clemenules', 'Marisol', 'Oronules' and 'Clemenpons'. The harvest season of citrus fruits in Spain is summarized in the Figure 2. 


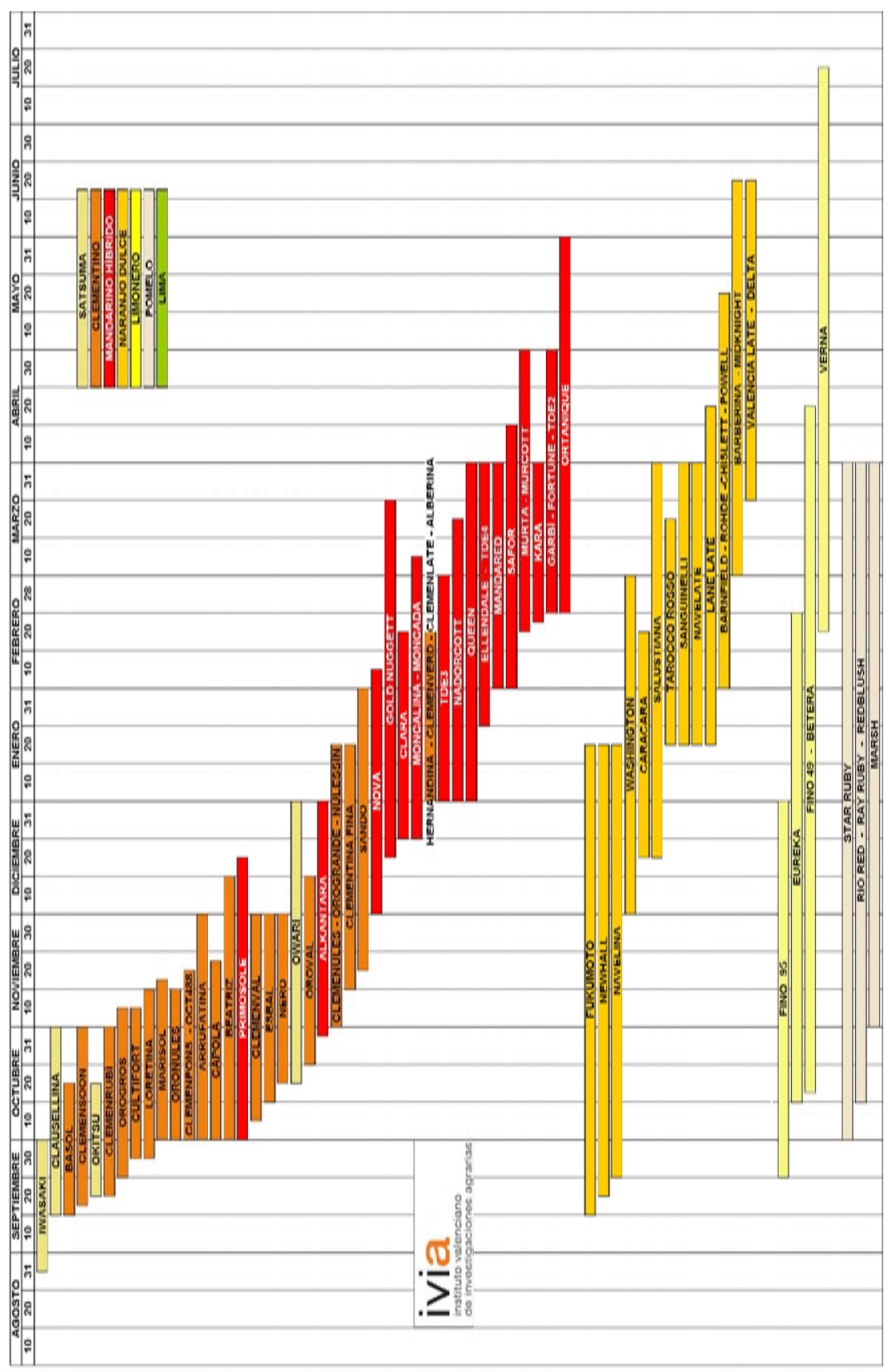

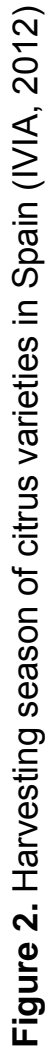


There are two clearly differentiated markets in the citrus sector: fresh citrus fruits market and processed citrus products market, mainly orange juice. In Spain market, nearly 4.49 million tons of citrus fruits have been commercialized as fresh produce (either domestically or exported) (MAGRAMA, 2010). Over the last years, the trade of small citrus fruits (clementines, mandarins and satsumas) has increased at the expense of fresh oranges. This is due to the evolution of consumer preferences more oriented to small-sized, easy-peeler and seedless fruits. Considering consumers' preferences worldwide, important objectives in fresh citrus fruit breeding programs are the production of new varieties which have seedless fruits with optimal size and shape, an easily removable peel, new organoleptic properties of the fruits (flavor), early or late ripening and resistance of trees against diseases and climactic conditions.

In Spain, the harvested season of Satsumas and Clementines, seedless fruits, are traditionally harvested from the beginning of September until mid February. Although mandarin hybrids are harvested until May, they produce fruits with seeds which cause substantial economic losses. The lack of seedless mandarin production after February and the steady increase in consumption and demand for these sweet fruits leads to find new varieties to supply the market, mainly in the period from February to May. Since 1996, a breeding program is carried out in the Plant Protection and Biotechnology Center in the Instituto Valenciano de Investigaciones Agrarias (IVIA) located at Moncada (Valencia, Spain), in order to obtain new triploid mandarin varieties with late harvest (Navarro et al., 2005).

Currently, the new triploids, which are with great interest and have good agronomic performance, have been selected for the commercial production. Fruits from these new hybrids are mid- and late-maturing, and excellent traits regarding to fruit quality, including fruit size, seedless, good rind color and easy peeling. Besides of these quality parameters, it would be interesting to know the nutritional quality of these new varieties since chemical and nutritional composition is an important trait for fresh citrus consumption.

On the other hand, these new cultivars are being released for commercial propagation. Therefore, the study of postharvest behavior of fruit, and in particular the assessment of the suitability for cold storage, in order to extend the fruit marketing is required. 


\section{I.2. POSTHARVEST DEGREENING}

\section{I.2.1. GENERAL ASPECTS}

The external color of citrus fruit is a critical quality parameter to consider for the fresh market, since the consumer use the visual appearance as an indicator for purchase and relates internal maturity with the external coloration of the fruit. Nevertheless, this relation is not always right; in fact most of early-season varieties of citrus, overall mandarins and oranges grown under sub-tropical and Mediterranean climates, reach internal maturity before full external coloration. These citrus fruits are harvested usually mature and palatable before the green peel color is replaced by the characteristic color of these cultivars. Hence, the external color of these fruits must be improved to market acceptance.

Ethylene, a plant growth hormone, has a crucial role in color change of citrus fruit, since it induces two simultaneous but independent processes: chlorophyll degradation and carotenoids synthesis. This effect of ethylene on fruit color change is being used commercially in the postharvest treatment called 'degreening', in which the fruit is subjected to exogenous ethylene in storage chambers.

During degreening treatment, ethylene hastens the color change of the citrus fruit flavedo, however in this process; besides ethylene other important factors such as temperature, humidity or carbon dioxide and oxygen in the atmosphere are involved.

In the commercial application of degreening treatment, the control of all these factors, as well as the duration of the process, is a requirement in order to improve the external color of the fruit and to not promote undesirable reactions related to the senescence and therefore the loss of fruit quality.

\section{I.2.2. FACTORS INVOLVED IN DEGREENING TREATMENT}

\subsubsection{Ethylene}

Despite its structural simplicity, ethylene, also known as stress hormone, is a gaseous hormone that has numerous effects on the growth, development and 
storage life of many fruits, vegetables and ornamental crops (reviewed in Saltveit, 1999). Ethylene participates in many aspects of plant developmental processes, including seed germination, cell elongation, fruit ripening, flower induction, organ senescence, root nodulation, programmed cell death, abscission, and responses to environmental stress, and pathogen attack (Abeles et al., 1992; Brown and Burns, 1998; Johnson and Ecker 1998; Bleecker and Kende, 2000; Malik et al., 2003; Maruthasalam et al., 2010).

Citrus fruits are classified according to their respiration rates as nonclimacteric, since fruit show no changes in their generally low carbon dioxide and ethylene production rate during maturation. The ripening of non-climacteric fruit is generally considered to be an ethylene-independent; nevertheless, although the mechanism of ripening control of this fruit is unknown, endogenous ethylene may be implicated in the regulation of some aspects of citrus fruit maturation (Vendrell and Lara, 2003; reviewed in Iglesias et al., 2007).

During maturation and senescence, citrus fruits exhibit relatively low respiration rates and ethylene production when in a non-stressed state, however, citrus albedo and flavedo tissues exhibit a dramatic increase in ethylene production in response to a variety of stresses, including wounding (Evenson et al., 1981; Riov and Yang, 1982), low temperature (Eaks, 1980; McCollum and McDonald, 1991), and infection by pathogens (Achilea et al., 1984; Mullins et al., 2000).

Exposure of harvested citrus fruits to exogenous ethylene induces changes in the plastid pigments of the flavedo, mainly the destruction of cholorophyll (reviewed in Iglesias et al., 2007), but also the synthesis and development of carotenoids (Rodrigo and Zacarías, 2007); these ethylene effects cause color change of flavedo and are physiologically harmless and commercially beneficial. Thus, exogenous ethylene is used worldwide to promote degreening peel in many citrus species, especially in early season fruit in which the pulp reaches internal maturity and becomes edible when the peel is still green.

In addition to the external color change, application of exogenous ethylene causes other physiological and biochemical changes, including increases in activity of phenylalanine ammonia lyase (Cajuste and Lafuente, 2007), and cellulase (Kazokas and Burns, 1998), alteration of protein complement (Alonso et al., 1992), and gene expression (Alonso and Granell, 1995; Alonso et al., 1995; Jacob-Wilk et al., 1997, 1999; Kazokas and Burns, 1998). 
The effect of exogenous ethylene on the mechanisms leading to chlorophyll breakdown in the flavedo of citrus fruit has received considerable attention. The first step of chlorophyll breakdown pathway is catalyzed by the chlorophyllase enzyme (Jacob-Wilk et al., 1999). Chlorophyllase activity increases after ethylene application, which accelerates chlorophyll degradation (Shimokawa et al., 1978; Trebitsh et al., 1993; Azuma et al., 1999; Fujii et al., 2007). The expression patterns of carotenoid biosynthetic genes and an associated abundance of carotenoids during ripening have recently been reported (Kato et al., 2004; Rodrigo et al., 2004; Alós et al., 2006). Analysis of the changes in individual carotenoids reveal that ethylene stimulates an increase in phytoene, phytofluene, (9Z)-violaxanthin, which is the main carotenoid in fully ripened orange peel, and the apocarotenoid $\beta$ - citraurin, and also causes a decrease in the concentration of chloroplastic carotenoids (Rodrigo and Zacarías, 2007).

An aspect to take into account is that the application of exogenous ethylene, as well as causing the desirable color change in citrus fruit, can produce undesirable effects related to the acceleration of fruit senescence (reviewed in Saltveit, 1999). These negative effects depend mainly on the concentration and duration of exposure of the fruit to ethylene. There are numerous reports describing the effects of atmospheric ethylene and its relationship with storage life; high ethylene concentrations induce acceleration of senescence process leading to important quality loss and reduction in shelflife (Wills and Warton, 2000; Wills et al., 1999, 2001). In this sense, it has been a goal in degreening technology to achieve effective control of ethylene. Exposure of fruit to 1-5 ppm of ethylene causes a color change during the citrus degreening without significantly affecting the fruit quality (Petracek and Montalvo, 1997; Cuquerella et al., 2005). Levels of ethylene above this threshold can enhance fruit deterioration causing serious quality losses.

\section{I.2.2.2. Temperature}

Temperature during fruit maturation is known to have an effect on the 'typical orange color' development of the fruit. The color development in citrus fruit is regulated by temperature, since the biochemical processes that affect the degradation of chlorophyll and carotenoid biosynthesis require optimal temperatures (Davies and Albrigo, 1994). 
Citrus trees grown under more extreme conditions with large day-night temperature fluctuations produce bright, orange-colored fruit (Agustí, 1999). In the period of fruit maturation, night cool temperatures, from 0 to $12^{\circ} \mathrm{C}$, cause a favorable effect on the fruit color (Loussert, 1992). Thus color break in subtropical areas generally takes place mid-autumn when temperatures go down and day length diminishes. Besides temperature, the changes associated to external color are influenced by environmental conditions, nutrient availability and hormonal activity (reviewed in Iglesias et al., 2007).

Color changes during postharvest degreening treatment involve both destruction of chlorophyll, revealing carotenoids already present, and development of carotenoid pigments to produce the orange color. These enzymatic reactions have different optimal temperatures (Davies and Albrigo, 1994). Numerous studies have reported that degreening treatment at temperatures close to $30^{\circ} \mathrm{C}$ lead to a rapid chlorophyll loss, but very little carotenoid synthesis occurs and not much orange color develops (Stewart and Wheaton, 1972; Jahn et al., 1973; Cohen, 1978; Plaza et al., 2004). Lower temperatures, between 20 and $22^{\circ} \mathrm{C}$, are more suitable for carotenoid synthesis and are usually recommended to obtain satisfactory results when orange-red varieties are submitted to degreening treatment (Martínez-Jávega at al., 2008). An aspect to take into account is that very low temperatures during the process, close to $5^{\circ} \mathrm{C}$, can repress carotenoid accumulation and affect to carotenoid composition in flavedo (Matsumoto et al., 2009).

In Spain, the best results during degreenig process are shown when fruit are submitted to $1-5 \mathrm{ppm}$ of ethylene at $18-21^{\circ} \mathrm{C}$ for mandarin fruit and $20-22^{\circ} \mathrm{C}$ for orange fruit (Martinez-Jávega et al., 2008). Similar conditions are being applied in Israel, where degreening is commonly done at $20^{\circ} \mathrm{C}$ (Porat et al., 1999) or in California where recommended temperatures are also between 20$22^{\circ} \mathrm{C}$ (Smilanick et al., 2006). However in Florida, citrus fruits are commercially degreened at a relatively high temperature, of $28-29^{\circ} \mathrm{C}$ (Ritenour et al., 2003; Zhang, 2007). In Australia, temperatures between $20^{\circ} \mathrm{C}$ and $25^{\circ} \mathrm{C}$ for oranges and up to $30^{\circ} \mathrm{C}$ lemons are considered ideal for color development (Tugwell, 1999). In the same way in South Africa, citrus fruits are degreened under the standard commercial practices applying $2 \mathrm{ppm}$ of ethylene at $23^{\circ} \mathrm{C}$ (Barry and Van Wyk, 2006). 


\section{I.2.2.3. Duration of treatment}

An important factor to consider in the degreening process is the time required to reach the desired color of the fruit that is principally dependent on cultivar and on initial fruit color, which in turn, is controlled by fruit maturity and grove conditions.

The rind color of citrus fruit enhances with the time of exposure to the ethylene during degreening. However the negative ethylene effects induced by ethylene are also greater the higher the exposure time (Petracek and Montalvo, 1997; Martínez-Jávega et al., 2008). Therefore the degreening treatment duration time should be minimized through the use of optimum conditions of temperature, ethylene concentration, humidity and aeration. To avoid the appearance of alterations in the fruit is recommended not to exceed 72-96 hours of treatment (Martínez-Jávega et al., 2008), although some commercial operators use much longer treatments.

\section{I.2.2.4. Oxygen and carbon dioxide.}

Both synthesis and action of ethylene involve complicated metabolic processes, which require oxygen and are sensitive to elevated concentrations of carbon dioxide.

Under degreening conditions, carbon dioxide from fruit respiration may accumulate in the degreening room. Carbon dioxide is known as an ethylene antagonist; at higher concentrations, is a competitive inhibitor of ethylene action which may prevent autocatalytic ethylene production (reviewed in Lelièvre et al., 1997). Consistent with this hypothesis, atmospheres with up to $5 \% \mathrm{CO}_{2}$ levels limit the induction of ACC synthase and ACC oxidase activities (Blanke, 1991) and mRNA (Gorny and Kader, 1996). In addition, high $\mathrm{CO}_{2}$ levels in the atmosphere, at normal oxygen concentration, induce acetaldehyde and ethanol production, with the risk of occurrence of off-flavors in the fruit (Porat et al., 1999).

During degreening treatment, the oxygen concentration has to be maintained above of $20 \%$, since besides its role for the respiration activity, the oxygen is necessary for chlorophyll degradation and carotenoid biosynthesis. Therefore, ventilation is required to supply the oxygen needed for ethylene to 
induce color changes, rather than to remove carbon dioxide from the degreening room.

\subsubsection{Humidity}

The efficiency of the degreening treatment depends also on the relative humidity in the degreening room. About $95 \% \mathrm{RH}$ is desirable in order to achieve satisfactory results in the change of fruit color and to maintain its quality. When humidity is low, the color change can be greatly retarded (Cohen, 1978) and physiological disorders are increased as discussed below.

\section{I.2.3. EFFECTS OF DEGREENING TREATMENT ON FRUIT QUALITY}

\section{I.2.3.1. Internal quality}

\section{Soluble solids and acidity}

During postharvest shelf-life of citrus fruit, soluble solids remain more and less unchanged, while acidity decreases slightly. Exogenous ethylene applied at low concentration does not affect these quality parameters. In this sense, Martínez-Jávega et al. (2008) in the study of response of new clementines to degreening treatment report that fruit submitted to degreening treatment show similar physical and biochemical changes compared to untreated fruit; in addition, although a decrease of firmness occur during degreening, no differences exist between treatments with or without ethylene.

Nevertheless, a point to note is that when fruit is submitted to high ethylene concentration and high temperature, the respiration rate can increase, which induce consumption of citric acid, a metabolic substrate in fruit respiration causing a marked decrease in citric acid content on fruit (Plaza et al., 2004). 


\section{Aroma and bioactive compounds}

An increase in respiration rates also promotes, as mentioned above, ethanol and acetaldehyde production and, it is well documented the relationship between the concentration of these volatiles, overall ethanol, and the off-flavors perception in the citrus fruit juice (Hagenmaier and Baker, 1994; Hagenmaier, 2002).

Regarding other volatile compounds responsible for the aroma fruit, it has not been well studied the effect of postharvest ethylene application on the flavoring compounds of citrus fruit. Recent studies have shown that exogenous ethylene stimulates emission of volatile organic compounds in citrus peel such as terpenoids and aliphatic esters (Herrera et al., 2007). So, one of the objectives of this Thesis is to study the changes that occur in the volatiles compounds when fruit are submitted to degreening treatment.

On the other hand an important aspect to consider, especially when it comes to citrus fruit, is the effect of postharvest treatment on bioactive compounds. In this sense, the few studies carried out about the effect of exogenous ethylene on those compounds showed that ethylene had no effect on naringin content, or on ascorbic acid content and total phenolics content (Maier et al., 1973; El Kazzaz et al., 1983; Sdiri et al., 2012a).

In this Thesis a comprehensive study of the effect of degreening treatment on the main bioactive compounds has been conducted.

\section{I.2.3.2. Physiological disorders}

As mentioned above, in citrus fruit exogenous ethylene exposure promote a desirable external color change, but in some cases it can also induce physiological disorders related to peel and calyx senescence. The incidence of these alterations although is dependent on cultivar and preharvest conditions, mainly is associated with inappropriate condition of degreening process; the longer the exposure time, the more susceptible citrus fruits are to senescence alterations. Furthermore, the incidence of these disorders is accentuated by the post-treatment storage time taken until market. The fruit destined for the European Union does not present serious physiological disorders during marketing. Nevertheless, a significant percentage of the Spanish citrus fruits is 
exported to more distant countries like the USA or Japan. In addition to the distance, these countries require strict quarantine measures against Mediterranean fruit fly (Ceratitis capitata). To satisfy the phytosanitary requirements of those countries, a quarantine cold treatment is usually applied during overseas transport (14-18 days at $1.1-2.2^{\circ} \mathrm{C}$ ) (USDA-APHIS, 2002). These conditions may adversely affect the final quality of the fruit, especially when it has been previously degreened. Therefore, the fruits that are exported under the quarantine treatment should be subjected to a degreening treatment as short as possible to prevent the appearance of physiological disorders.

One of the studies contained in this Thesis is the evaluation of various new degreening treatments combining different periods of exposure to ethylene with periods without the addition of ethylene in different citrus cultivars to be exported to the USA, with the objective to improve the final quality and to reduce the physiological disorders.

The most common symptoms of the disorders associated with degreening treatment are shown below.

\section{Calyx senescence}

It is well established that plant growth hormones are deeply involved in abscission and that among them ethylene is thought to be its natural regulator. Ethylene is known that accelerate abscission in tissues but may not be required to initiate the process (Patterson, 2001; Taylor and Whitelaw, 2001; Pozo et al., 2004). Although there is as yet no clear evidence for a direct link between the ethylene perception and the onset of abscission, it is well documented that the progress of the abscission process is concomitant with an increase in the production of the hormone (Abeles et al., 1992; Patterson and Bleecker, 2004). Ethylene induces synthesis and secretion of several cell wall and middle lamella hydrolytic enzymes involved in the separation of the abscinding organs (Tucker et al., 1991; Kalaitzis et al., 1995; Del Campillo and Bennet, 1996; Burns et al., 1998; Brummell et al., 1999).

As a postharvest treatment, the application of ethylene during degreening treatment can accelerate transpiration and drying, browning and abscission of the calyx (Cohen, 1978; Cronjé et al., 2005; Salvador et al., 2008). The susceptibility to these undesirable effects of ethylene is cultivar dependent 
(Carvalho et al., 2008). Furthermore, the period of exposure to ethylene must be adequate, using optimum conditions of temperature, ethylene concentration, humidity and air renewal.

In order to retard calyx senescence that occurs as a consequence of the degreening process, synthetic auxins like 2,4-dichlorophenoxy propionic acid $(2,4-D)$ have been studied as a postharvest treatment to maintaining the final quality of the degreened fruit (Sonkar et al., 1999; Tatli and Ozguven, 1999; Cronjé et al., 2005).

Since, at the present, none of the cited products are already registered in the European Union for postharvest application and the use of 2,4-D is restricted even as preharvest application, it is necessary to find other synthetic auxins as alternative to the 2,4-D in order to avoid the physiological changes in the calyx of citrus fruits submitted to postharvest degreening.

Our research group (Postharvest Center of IVIA) is evaluating the effect of different auxins, registered for their use in preharvest, on control of physiological disorders associated with degreening treatment. In this sense, a positive results have been obtained with the postharvest application of 3,5,6TPA (Carvalho et al., 2008; Salvador et al,. 2010), and at this moment this auxin is being registered for its use on postharvest.

Besides 3,5,6 TPA, other products are being studying; this Thesis includes the study of the efficacy of a new growth regulator in reducing calyx alterations induced by postharvest ethylene exposure.

\section{$\underline{\text { Peel disorders }}$}

Often some alterations in the skin of the degreened fruit are attributed to improper treatment conditions. Low humidity, excessive temperature, high $\mathrm{CO}_{2}$ levels and the exposure for a long time can increase peel injuries which can extend when passed into packing line machinery.

Fruit of certain cultivars of citrus, which have very thin skin, especially mandarins, can be readily injured by ethylene during degreening, resulting in a form of bruising referred as 'Zebra skin'. Really the damage does not occur during the degreening treatment, if not during handling in packing line, which 
causes peel epidermal cells rupture in areas over the fruit segments. Zebra-skin is exacerbated by degreening and the posterior brushing; fruit which picked when poorly colored, are more subject to this injury. To reduce this alteration is highly recommended that the fruit is stored for at least 12 hours after degreening before packaging.

Oleocellosis, a common postharvest disorder in citrus fruits, results from damage to the peel due to rupture of oil glands. Cells encircling oil glands die when oil from ruptured glands leak into the surrounding tissues and the cells turn brown and form spots on the fruit surface. In general, fruit are more susceptible to oleocellosis when peel turgidity is high, since in these conditions the cells are much more susceptible to breakage and pressure of the hand at harvest is enough to cause the output of essential oils. When oleocellosis is caused during harvest in green fruit the symptoms can be non-visible, but if this fruit is subjected to degreening treatment, the damaged areas of the skin maintain green color after treatment. In order to reduce this disorder, harvesting fruit in the early morning or while dew should be avoided.

Another disorder that can increase with postharvest degreening, is Stemend rind breakdown (SERB). SERB is characterized by a collapse and subsequent darkening of the peel in irregularly-shaped regions near the stem end. SERB is closely associated with excessive water loss. To avoid this disorder, a holding period for 12 to 24 hours after degreening and before packing is necessary.

On the other hand, it has demonstrated that ethylene plays a role reducing peel damage in mature citrus fruits exposed to abiotic stresses (Lafuente et al., 2004; Cajuste and Lafuente, 2007). Moreover, it has been reported that ethylene increases total and soft epicuticular wax content in mature citrus fruits and induces structural changes in surface wax that might be related to the formation of new waxes. That epicuticular wax is involved in reduction in transpiration and maintenance of water balance as well as in regulation of gas exchange in plants (Cajuste et al., 2010).

\section{I.2.3.3. Pathological diseases}

In practice, concentrations of commercial ethylene treatments often exceed those needed for adequate removal of chlorophyll and may cause excessive 
losses from decay; the two principal diseases which can increase are stem-end rot (SER) caused by Diplodia natalensis and anthracnose caused by Colletotrichum gloeosporioides.

D. natalensis is often present and grows at the stem end of harvested fruit, in necrotic tissue on the surface of the floral calyx. The incidence increases when degreening treatment is conducted at high temperature close to $30^{\circ} \mathrm{C}$, since this temperature is optimal for growth of D. natalensis (Barmore and Brown, 1985). The significant enhance in disease incidence also by the use of high concentrations of ethylene may be related to the activity of the abscission enzymes, polygalacturonase and cellulose (Brown and Burns, 1998).

Ethylene also plays a role in the induction of anthracnose decay (Colletotrichum gloeosporiodes); ethylene applied during degreening, induces germination of the appressoria by causing nutrients to be released or made more available at the fruit surface (Wild, 1990). Severity of this disease is dependent upon duration of degreening and ethylene concentration (Tuset et al., 1988).

Exogenous ethylene can also induce the incidence of Penicillium digitatum depending on the temperature used during degreening treatment. Thus, in California where degreening is conducted at $20-22^{\circ} \mathrm{C}$, the losses by $\mathrm{P}$. digitatum are high (Smilanick et al., 2006), while in Florida where degreening is conducted at higher temperatures, of about $28-29^{\circ} \mathrm{C}$, this pathogen is inhibited (Ritenour et al., 2003).

\section{I.3. COLD STORAGE OF CITRUS FRUIT}

\section{I.3.1. GENERAL ASPECTS}

Storage at low temperature is the predominant method used to preserve postharvest life and to extend marketing time of citrus fruits as well as the most of the perishable fruits and vegetables. Maintaining the fruit at low temperature can substantially slow the biological activity of the product, slow the growth and spread of microorganisms and reduce product moisture loss and susceptibility to damage from ethylene gas. 
In the specific case of citrus fruits, besides to prolong the postharvest life, the use of low temperature is required for Spanish citrus fruits exported to free fruit fly (Ceratitis capitata Wied.) countries for quarantine purposes. This treatment consists on maintaining at one of the following time-temperature combination: $0.6^{\circ} \mathrm{C}$ for $10-12$ days, $1.6^{\circ} \mathrm{C}$ for 14 days, or $2.2^{\circ} \mathrm{C}$ for 17 days.

In the temperature management during cold storage is important to take into account that citrus fruits, as well as other tropical and subtropical commodities, are susceptible to chilling injury $(\mathrm{Cl})$ development during cold storage when held below a critical temperature (Chalutz et al., 1985; Paull, 1990; Kader and Arpaia, 1992). The exposure of chilling-sensitive citrus fruit varieties to low temperature causes the alteration of multiple metabolic processes and leads to visual symptoms and subsequently cell death if the tissue is exposed to the damaging temperature for too long (Jackman et al., 1988; Raison and Orr, 1990; Saltveit and Morris, 1990; Serrano et al., 1996; Sevillano et al., 2009).

\section{I.3.2. PHYSIOLOGICAL DISORDERS DURING STORAGE. CHILLING INJURY}

Chilling injury $(\mathrm{Cl})$ is a physiological disorder that can reduce the quality and value of citrus fruits as a consequence of their exposure to low but nonfreezing temperatures, typically below $10^{\circ} \mathrm{C}$ (Kader and Arpaia, 1992; Schirra et al., 1998; Martínez-Jávega et al., 1999; Sala and Lafuente, 1999). Cl severity is directly related to temperature and duration of exposure; that is, injury symptoms generally increase as temperature decreases and storage period is extended (Henriod et al., 2005).

Exposing sensitive citrus fruit to the damaging low temperature causes a variety of symptoms, that depend greatly on the species and varieties of citrus fruit as well as the maturity stage of the fruit (Chalutz et al., 1985; Almela et al., 1992; Underhill et al., 1995; Sala, 1998; Martínez-Jávega et al., 1999; Bajwa and Anjum, 2007). Most of the disorders appearing on surface of the fruits are related to rupture of oil glands and subsequent water loss (Ladaniya and Sonkar, 1996). Several hypotheses have been proposed to clarify the mechanisms of Cl (Saltveit and Morris, 1990; Serrano et al., 1996). However, the exact mechanisms of this disorder and its effects are not completely 
understood. The original hypothesis was proposed by Lyons (1973) and cited phase transition changes of cell membranes as the primary cause of chillingsensitivity. For several years $\mathrm{Cl}$ was thought to be a direct consequence of the transition of lipids in cell membranes from a liquid to a gel state, occurring at a critical temperature, which led to a complete loss of permeability control (Lyons, 1973; Marangoni et al., 1996). The phase transition temperature of pure lipids or lipid mixtures is determined to a large extent by the fatty acid composition on the glycerol backbone of phospholipids. The greater the unsaturation of the fatty acids, the lower the phase transition temperature. Therefore, membranes that contain highly unsaturated fatty acids tolerate lower storage temperatures than membranes with more saturated fatty acids (Markhart, 1989).

As the names suggest, classification of $\mathrm{Cl}$ disorders is based mainly upon visual symptoms, which sometimes may occur during low temperature storage or more commonly after transfer to a warmer temperature (Saltveit and Morris, 1990; Purvis and Yelenosky, 1993; Serrano et al., 1996). However, if the tissue is not stored at low temperatures for a long period, many of these symptoms can be reversed by returning the tissue to non-chilling temperatures before damage occurs (Raison and Orr, 1990; Saltveit and Morris, 1990).

The most common symptoms of $\mathrm{Cl}$ in citrus fruits are shown below:

\section{Pitting:}

Peel pitting is the most common form of $\mathrm{Cl}$ in citrus fruits. This disorder has been closely examined in mandarins, tangerines, oranges, grapefruit and lemons (Artès et al., 1993; Lafuente et al., 1995; Underhill et al., 1995; Yuen et al., 1995; Petracek et al., 1998; Schirra et al., 1998; Sala and Lafuente, 1999; Dou and Ismail, 2000; Bajwa and Anjum, 2007). It is a physiological disorder characterized by the collapse of small, circular regions of the peel which turn from brown to dark sunken lesions with increasing incidence. The pitted areas turn into brown spots (stains) on the rind with enhanced decay. In grapefruit, circular depressions (cell collapse) on the peel surface are characteristic visible symptoms of chilling injury usually developing after 2 to 3 weeks of continuous storage at $5^{\circ} \mathrm{C}$ (Purvis, 1980; Purvis and Grierson, 1982). Peel pitting disorder in 'Fortune' mandarin fruit as well as in other sensitive citrus species is characterized by sunken lesions and darkening of oil glands, which can affect large parts of the fruit (El-hilali et al., 2003). Injury is more severe at low relative 
humidity than at high relative humidity. Depressions in the peel tend to develop more rapidly if the fruit are transferred to non-chilling temperatures after chilling injury has been initiated (Purvis and Yelenosky, 1993).

\section{Stem-end rind breakdown}

Another common $\mathrm{Cl}$ symptom in citrus fruit is Stem End Rind Breakdown (SERB). It is a physiological disorder characterized by the collapse and subsequent darkening of the flavedo around the stem end of citrus fruit. SERB is caused by excessive dehydration of the rind around the stem end of detached fruit which leads to removal of rind along with the stem portion. SERB has been characterized as an imbalance in nutrition, besides water loss between picking and packing influences storage at low temperatures. SERB injury provokes an excessive loss of moisture and enhances aged fruit leaving the fruit in unmarketable condition. This disorder is triggered by low temperature storage of citrus, usually small and thin-skinned fruit for prolonged periods (Lafuente and Zacarías, 2006).

\section{Peteca}

Peteca is a physiological disorder of lemons that generally is expressed during the storage period. It greatly reduces fruit appearance and quality through the development of sunken necrotic lesions that damage the albedo and occasionally the flavedo (Wild, 1991). This problem occurs mainly in fruit developing at stress conditions that occur before harvest such as low temperatures in the orchard. Its incidence has also been linked to fruit calcium; the lack of calcium in the fruit in the rind and it can be favored by applications of oils in preharvest and waxing in postharvest (Wild, 1991; Storey and Treeby, 2002; Undurraga et al., 2006). The incidence of peteca increases during storage and is affected by storage at low temperature depending on the cultivar. The maturity stage influences the development of peteca and the evolution of the disorder is affected by fruit size as well as storage temperature and period (Artés et al., 1993; Undurraga et al., 2002, 2007, 2009). 


\section{Other symptoms}

Some specific $\mathrm{Cl}$ symptoms occur in determinate species of citrus, such as membranous staining in lemons. This disorder is characterized by a superficial and fairly uniform browning or darkening of the membranes or carpellary walls between segments, sometimes affecting the inner core tissues and inner tissues of the rind. It is reduced by avoiding storage of lemons below $13^{\circ} \mathrm{C}$ and improving ventilation in storage (Gross and Smilanick, 2004).

Darkening of oil glands, which can affect large parts of the fruit, is also another $\mathrm{Cl}$ symptom common in grapefruit, tangelos and hybrids. It is characterized by irregular patches around the fruit surface (Grierson, 1981; Wardowski et al., 1986).

Watery breakdown may develop in any citrus fruit stored at low temperature for 2 or 3 months. Affected fruits are soft, spongy and watersoaked in both peel and fresh and look as if they had been frozen. Affected fruits develop a fermented odor when they are held at room temperature (Ladaniya and Sonkar, 1996).

Scald or brown stain of citrus fruit involves a superficial and fairly uniform browning over relatively large areas of rind, differing from pitting in the large areas affected and is not being sharply depressed. This disorder is more prevalent in oranges and appears to be associated with the oil gland. Affected areas at first are firm, but in severe cases the surface becomes spongy and soft and resembles to an early stage of watery breakdown.

\section{I.3.3. FACTORS FFECTING CHILLING INJURY SUSCEPTIBILITY}

The development of $\mathrm{Cl}$ symptoms during cold storage, beside the variety and storage temperature depends on other pre and postharvest factors.

Susceptibility to $\mathrm{Cl}$ development has been reported that depends on fruit maturity and harvest time; usually the later the harvest date, the lower the $\mathrm{Cl}$ incidence in citrus fruit (Houck et al., 1990; Schirra et al., 2000; Pailly et al., 2004). Fruit maturity is important in citrus storability and susceptibility to $\mathrm{Cl}$ symptoms (Purvis and Grierson, 1982; Lafuente et al., 2003). 
The climate during fruit development affects its response to low temperature during postharvest storage. Exposure of fruit at freezing temperatures previously to harvest can induce physiological disorders during postharvest life, even when fruit are maintained at optimum storage temperatures (Toivonen and Hodges, 2011).

Relative humidity $(\mathrm{RH})$ in the storage environment had been reported as one of the major factors that affects the severity of $\mathrm{Cl}$. High $\mathrm{RH}$ during the postharvest period reduces fruit moisture loss by depressing the rate of fruit transpiration or sub-cuticle evaporation, especially at low temperature. As a consequence of the increased moisture retention under high $\mathrm{RH}$ conditions, fruit are often reported to have a higher degree of rind firmness and tissue turgidity at out-turn. Moreover, high RH conditions have been associated with a decrease in the incidence of $\mathrm{Cl}$ disorders (Ben Yehoshua et al., 2001; Porat et al., 2004; Henroid, 2006). At low RH fruits exhibit higher transpiration rates, earlier senescence, and greater deterioration in visual appearance, inducing more severe $\mathrm{Cl}$ symptoms, than fruits stored at higher humidity (D'Aquino et al., 2003).

Air ventilation and air movement are other important parameters of storage. Therefore, adequate ventilation must be maintained during cold storage. Ventilation rates in the storage room influences the internal atmosphere and thus the incidence of decay. Rates of ventilation affected the $\mathrm{CO}_{2}$ concentrations more than the $\mathrm{O}_{2}$ levels of both the external and internal atmospheres of citrus fruit.

Ethylene also plays a significant role during the storage of citrus fruit. It has been reported that ethylene increases the appearance of $\mathrm{Cl}$ symptoms (Yuen et al., 1995; Porat et al., 1999). Removal of ethylene from storage rooms can reduce senescence, $\mathrm{Cl}$ susceptibility and incidence of fungal decay. Nevertheless, development of chilling damage has been shown to be reduced by applying of ethylene during cold storage of citrus fruits (Lafuente et al., 2001). This beneficial effect appears to be mainly related to the effect of ethylene on increasing the activity of the enzyme PAL and the increase of the flavedo tissue antioxidant potential by favoring the induction of CAT (Lafuente et al., 2004). Ethylene has been also reported to be very effective reducing nonchilling peel pitting (Lafuente and Sala, 2002; Sala and Lafuente, 2004; Cajuste and Lafuente, 2007). 
The severity of $\mathrm{Cl}$ symptoms can be reduced by different postharvest treatments such as wax coatings, preconditioning heat treatments and controlled atmospheres. These treatments were reported that induce fruit tolerance to low temperatures during cold storage of citrus fruits (Schirra and Cohen, 1999; Schirra et al., 2000; D’Aquino et al., 2005; Erkan et al., 2005; Safizadeh et al., 2007; Lafuente et al., 2011).

\section{I.3.4. FRUIT QUALITY CHANGES DURING STORAGE}

\section{I.3.4.1. Quality attributes}

After harvest citrus fruits show different chemical and biological changes that affect to fruit quality attributes during postharvest period (D'Aquino, 2003). Softening of fruit and development of insipid taste and off-flavor are the major deteriorative changes that take place during storage of citrus fruits. Changes are rapid if fruits held under hot and dry ambient conditions; while under optimum refrigerated conditions with high $\mathrm{RH}$ changes are gradual and at times may be insignificant.

Weigh loss is the result of the transpiration of water from the rind epidermal cells, which result in the concentration of existing carbohydrates, particularly total sugars and reduction in fruit weight. During postharvest life the weight loss in citrus fruits can be reduced further using low temperatures of storage, by incorporating different wax coatings (Martínez-Jávega et al., 1992).

Changes in total soluble solids, sugars and titratable acidity (TA) contents of the juice depend on the conditions under which citrus fruits are stored. Juice acidity decreased slightly during storage which is mainly the result of a decrease in citric acid. TA decreases with storage duration, and storage temperature which led to increase in Maturity index (TSS/TA). The increase in levels of TSS in citrus fruits is usually cause by the water loss. However a gradual decrease in sugars also has been reported in some citrus varieties during cold storage (Pailly et al., 2004). The percentage of juice can also decrease during storage which is associated to the water loss that occurs under prolong conservation periods (Ladaniya, 2008). 


\section{I.3.4.2. Bioactive compounds}

Temperature and storage time can also affect vitamin $C$ content of citrus fruits depending on the storage conditions as well as the variety. Some studies have shown that cold storage of 'Clemenules' mandarins and 'Tarocco Messina', 'Tarocco Meli' and 'Navelina' oranges led to a decrease in their vitamin $\mathrm{C}$ content; the longer the storage temperature and period, the greater the loss (Perez et al., 2005; Rapisarda et al., 2008; Plaza et al., 2011). Nevertheless, a significant increase in the vitamin C content in 'Cara Cara' and 'Valencia Late' oranges and in 'Fortune' mandarins after storage at low temperatures has been recorded (Huang et al., 2008; Rapisarda et al., 2008; Sdiri et al., 2008). Palma et al. (2005) did not find any changes in the vitamin C content during cold storage.

The changes in antioxidant activity during storage depend on the varieties; for instance, antioxidant activity in cold-stored 'Navelina' oranges and 'Fortune mandarins remained relatively constant during cold storage (Lafuente et al., 2011; Plaza et al., 2011). Nevertheless, Rapisarda et al. (2008) reported an increase in antioxidant capacity, measured by the DPPH - assay, in blood and blond oranges after long-term cold storage at $6^{\circ} \mathrm{C}$.

The levels of total phenolics can also be affected during storage; in different orange cultivars and grapefruit, an increase in TPC has been reported after long-term cold storage depending on the storage conditions as well as on the cultivar (Patil et al., 2004; Rapisarda et al., 2008). Nevertheless, Palma et al. (2005) found no differences in the TPC of 'Fortune' mandarins after $90 \mathrm{~d}$ of storage at $5^{\circ} \mathrm{C}$.

Anthocyanin content of blood oranges may significantly increase throughout cold storage (Rapisarda et al., 2001a, 2008; Crifò et al., 2012). This accumulation was reported to be related with the activation of the enzymes involved in the biosynthesis of anthocyanins by low temperature (Lo Piero et al., 2005; Crifò et al., 2011).

Carotenoids are highly temperature sensitive and small variations $\left(1^{\circ} \mathrm{C}\right)$ from the optimum temperature may affect color development. Neither the content nor the composition of carotenoid changes in the peel and pulp of citrus fruits during postharvest storage when fruit harvested at optimum rind coloration (Carmona et al., 2007). Nevertheless, when fruit are harvested with low peel 
color, low-temperature storage of citrus fruits can limit color development (Matsumoto et al., 2009; Van Wyk et al., 2009).

\section{I.3.4.3. Volatiles compounds}

Postharvest storage of citrus fruits exhibit changes in numerous flavor related volatiles. Patterns of change varied depending on the compound, some increasing and others decreasing during storage with waxing and type of wax being key factors in determining the amounts present. Some of the volatiles could have positively influenced flavor while others may have had a negative influence. Ethanol and acetaldehyde has been found to be volatile components undergoing the greatest change occurring in citrus during storage. During shelflife, the content of ethanol and acetaldehyde increases to considerably higher levels than those recorded at the end of the respective storage periods. The accumulation of these two volatiles increases with storage duration and temperature and can produce off-flavors (Ke and Kader, 1990; Hagenmaier, 2002). Ethanol and acetaldehyde levels in coated and uncoated mandarins are significantly different due to creation of a modified atmosphere. The accumulation of ethanol in the fruit during low temperature storage was correlated with the sensitivity of the citrus cultivars to chilling injury (Chalutz et al., 1985). The greater increase occurred in fruit parallel to the stimulated respiration associated with the conditions that caused the greatest incidence of chilling injury. The threshold values of ethanol level for off-flavor detection are cultivar dependent; meanwhile $150 \mathrm{mg} / 100 \mathrm{~mL}$ in mandarins (Hagenmaier, 2002) and $500 \mathrm{mg} / 100 \mathrm{~mL}$ in oranges (Hagenmaier, 2000) have been reported as limit for off-flavor. Although adverse changes in flavor quality were evidenced by increased off-flavor apparent, the sensory attributes of richness, sweetness and typical flavor intensity, overall likeability (hedonic score) were not altered by storage (Biolatto et al., 2005; Obenland et al., 2011).

Moreover, long storage can result in increases in content of ethyl acetate, isopentanol, 2-methyl-3-buten-2-ol, and ethyl benzoate which are in general correlated with increases in ethanol. The magnitude of internal volatiles changes are correlated with postharvest wax application, a standard practice for reducing weight loss and imparting gloss to the citrus fruits (Hagenmaier and Baker 1994; Hagenmaier and Shaw, 2002). The wax composition also affects the internal $\mathrm{CO}_{2} / \mathrm{O}_{2}$ levels which can increase the content of the volatiles compounds responsible of the off-flavor development. 
Since the susceptibility to $\mathrm{Cl}$ symptoms is variety dependent, it is necessary to establish recommendations of suitable storage temperature, relative humidity and duration of optimum storage maintaining the highest fruit quality (Table 1).

Table 1. Recommended temperatures, relative humidity and storage life of the major Citrus sp. grown in Spain

\begin{tabular}{lccc}
\hline Citrus sp. & $\begin{array}{c}\text { Temperature } \\
\left({ }^{\circ} \mathrm{C}\right)\end{array}$ & $\begin{array}{c}\text { Relative humidity } \\
(\%)\end{array}$ & $\begin{array}{c}\text { Storage life } \\
\text { (week) }\end{array}$ \\
\hline Sweet oranges & & $90-95$ & $10-14$ \\
$\quad$ Navelina & $2-3$ & $90-95$ & $8-10$ \\
Washington Navel & $2-3$ & $90-95$ & $8-12$ \\
$\quad$ Navelate & $3-4$ & $90-95$ & $10-14$ \\
Lanelate & $2-3$ & $90-95$ & $10-14$ \\
$\quad$ Blanca común & $2-3$ & $90-95$ & $12-16$ \\
$\quad$ Salustiana & $2-3$ & $90-95$ & $12-16$ \\
$\quad$ Valencia Late & $2-3$ & & \\
Mandarins & & $90-95$ & $4-6$ \\
$\quad$ Satsumas & $2-3$ & $90-95$ & $6-10$ \\
$\quad$ Clementines & $4-5$ & & \\
Hybrids & & $90-95$ & $4-6$ \\
$\quad$ Fortune mandarin & $9-10$ & $90-95$ & $2-4$ \\
$\quad$ Nova mandarin & $9-10$ & $90-95$ & $2-6$ \\
$\quad$ Minneola tangelo & $9-10$ & $90-95$ & $8-10$ \\
$\quad$ Ellendale tangor & $5-6$ & $90-95$ & $10-12$ \\
$\quad$ Ortanique tangor & $5-6$ & & \\
Lemons & & $90-95$ & $12-16$ \\
$\quad$ Fino & $11-12$ & $90-95$ & $16-20$ \\
$\quad$ Verna & $13-14$ & $90-95$ & $6-10$ \\
Limes & $9-10$ & $90-95$ & $8-12$ \\
Grapefruit & $12-13$ & & \\
\hline
\end{tabular}

Source: Martínez-Jávega et al., 1999. 


\section{I.4. FRESH CITRUS FRUIT COMPOSITION}

\section{I.4.1. BIOACTIVE COMPOUNDS}

Nowadays, consumers demand high sensory, nutritional and health related qualities of fruit and their derivatives products. Citrus fruits are recognized as an important component of the human diet, providing a range of key nutrients as well as very many non-nutrient phytochemicals which are important to human nutrition since they possess antioxidant properties. The antioxidant and antiradical activity of citrus fruits is mainly due to the hydrosoluble fraction containing vitamin $\mathrm{C}$ and polyphenols and also to the apolar fraction including carotenoids, leading to their protective effects against chronic and degenerative diseases (Byers and Perry, 1992; Gorinstein et al., 2001; Tripoli et al., 2007).

\section{I.4.1.1. Vitamin C}

Citrus fruits are highlighted as an important source of vitamin C. Vitamin C is considered as a most important water-soluble antioxidant that destroys oxygen free radicals (Gadjeva et al., 2005). It protects compounds in extracellular and intracellular spaces in most biological systems (Kaur and Kapoor, 2001). It can directly scavenge superoxide radical, singlet oxygen, hydrogen peroxide and hydroxyl radical.

The vitamin $C$ content in Citrus sp. depends on the species and the cultivar; it has been reported that among Citrus sp., the vitamin C content in orange fruit is higher than that found in mandarins (Dhuique-Mayer et al., 2005; Wang et al., 2007; Cano et al., 2008; Sdiri et al., 2012b). The level of vitamin C also depends on other factors such as the ripening time, method of harvest, storage, processing, the climate and other different agronomic factors (Lee and Kader, 2000; Huang et al., 2007; Rapisarda et al., 2008).

Vitamin $C$ is an umbrella term for ascorbic acid (AA) and dehydroascorbic acid (DHAA). AA is the dominant reduced form of Vitamin C and DHAA is the oxidized form. These are found to be in equilibrium in most fruits and vegetables. However, ascorbic acid is very labile and, under adverse conditions, under-goes oxidation. The oxidation of L-ascorbic acid, the active form of the vitamin, to DHAA does not result in loss of biological activity since DHAA is readily reconverted to L-ascorbic acid; however, the subsequent 
conversion to diketogulonic acids is irreversible. Therefore, it was suggested that measurements of vitamin $C$ in fruits and vegetables in relation to their nutritional value should include both AA and DHAA (Davey et al., 2000).

\section{I.4.1.2. Phenolic compounds}

Citrus fruit contains phenolic compounds especially flavonoids and phenolic acids. In recent years, more attentions had been paid on phenolic compounds of citrus fruits since many epidemiological studies suggest that consumption of polyphenol-rich foods and beverages is associated with a reduced risk of cardiovascular diseases, stroke and certain forms of cancer. It has been suggested that these compounds play an important role on the antioxidant capacity of citrus fruits (Wang et al., 1996; Rapisarda et al., 1999; Gardner et al., 2000). Moreover, the presence of phenolics contributes to the sensory quality of fruit and juice through their effect on color, bitterness, astringency and flavor (Sousa et al., 2004).

Among the phenolic coumpouds, flavonoids have aroused considerable interest recently because of their potential beneficial effects on human health such as antiviral, anti-allergic, anti-inflammatory, antioxidant activities, and protection against cardiovascular diseases and certain forms of cancer (Salah et al., 1995; Benavente-García et al., 1997; Kawaii et al., 1999a; Mandalari et al., 2007; Tripoli et al., 2007; Benavente-Garcia and Castillo, 2008; Du and Chen, 2010; González-Molina et al., 2010; Huang and Ho, 2010).

Flavonoids are the most abundant phenolics in citrus fruits (Nogata et al., 2006). The most common flavonoids found in Citrus sp. can be classified into different groups: flavanones, flavones, flavanols and anthocyanins (specific and unique of the pigmented oranges) (Benavente-García et al., 1997).

The highest concentrations found in Citrus sp. correspond to flavanone glycosides, followed by flavones, flavonols and the fully polymethoxylated flavones (Kawaii et al., 1999b; Nogata et al., 2006; Peterson et al., 2006; Tripoli, et al., 2007). Hesperidin, narirutin, naringin, eriocitrin and neohesperidin are the major flavanone glycosides (Mouly et al., 1994; Peterson et al., 2006). Flavonoid compounds have been studied in many Citrus species such as oranges (Mouly et al., 1994; Kawaii et al., 1999b; Franke et al., 2004; Nogata et al., 2006; Abeysinghe et al., 2007; Gattuso et al., 2007), grapefruits (Mouly et 
al., 1994; Kawaii et al., 1999b; Belajová and Suhaj, 2004; Franke et al., 2004; Nogata et al., 2006; Peterson et al., 2006; Gattuso et al., 2007), lemons (Mouly et al., 1994; Kawaii et al., 1999b; Del Rio et al., 2004; Nogata et al., 2006; Peterson et al., 2006; Gattuso et al., 2007) and limes (Mouly et al., 1994; Kawaii et al., 1999b; Nogata et al., 2006; Peterson et al., 2006; Gattuso et al., 2007). Each species of citrus is characterized (especially in the fruits) by a particular flavanone glycoside pattern. In sweet oranges, mandarins, lemons and limes, the most common citrus flavanone glycosides are hesperidin, narirutin and didymin (Mouly et al., 1994; Leuzzi et al., 2000; Proteggente et al., 2003; Nogata et al., 2006; Peterson et al., 2006). In grapefruit, naringin is distinctly dominant, accompanied by narirutin (Rouseff et al., 1987). Naringin, neohesperidin and, to some extent, neoeriocitrin are distinctive of bitter orange (Marini and Balestrieri, 1995).

Polymethoxylated flavones (PMFs) are also present and they exist exclusively in Citrus genus especially in the peels of mandarins, sweet and bitter oranges (Gattuso et al., 2007). Although citrus juice contains low concentrations of PMFs, being sometimes at limit of detection, these compounds exhibit high biological activity and have been reported as having anti-inflammatory, antiviral, anti-tumor and anticarcinogenic activity (Murakami et al., 2000; Suzuki et al., 2005; Li et al., 2007; Walle, 2007; Du and Chen, 2010). The composition of PMFs varies among Citrus species (Nogata et al., 2006; Peterson et al., 2006; Green et al., 2007).

Anthocyanins, found in blood (pigmented) citrus fruits, have been also associated with potentially beneficial effects on various diseases such as capillary fragility, diabetic retinopathy and human platelet aggregation (Rapisarda et al., 2001b). In addition, anthocyanins are known to be potent antioxidants (Wang et al., 1997; Kähkönen and Heinonen, 2003) and anthocyanin-rich fruit or juice has been associated with higher antioxidant capacity. The main anthocyanins are cyanidin-3-glucoside (Cy3G) and cyanidin3-(6"-malonyl)-glucoside (Cy3MG) (Maccarone et al., 1998), and their level in the fruit always varies among varieties. It was reported that Cy3G has a higher antioxidant activity than other more common anthocyanins (Wang et al., 1997), and that Cy3MG protects plant cells against UV-induced damage (Takahashi et al., 1991).

In addition to flavonoids, a major part of phenolic compounds of citrus fruits are benzoic and hydroxycinnamic acids. Previous studies have reported that hydroxycinnamic acids also possess significant antioxidant acticity and 
chemoprotective effects (Natella et al., 1999). The most important phenolic acid in citrus juice is hydroxycinnamic acid and its derivates: ferulic, $\rho$-coumaric, sinapic, caffeic and chlorogenic acids (Kelebek and Selli, 2011). Hydroxycinnamic acids are a class of polyphenolic compounds that are hydroxy derivatives of cinnamic acid. Hydroxybenzoic acids such as gallic and protocatechuic acid are also present in low concentrations (Kelebek et al., 2008). It has been reported that hydroxycinnamic acid possess significantly higher antioxidant activity than hydroxybenzoic acids (Rice-Evans et al., 1996; Rapisarda et al., 1999; Pulido et al., 2000).

\section{I.4.1.3. Carotenoids}

Although the antioxidant capacity of citrus juices has been mainly associated with the hydrosoluble fraction containing polyphenols and vitamin C, the more apolar fraction including carotenoids could also contribute to the antioxidant capacity of the juices. Carotenoids exert also potential action against certain types of cancer, protect against age-related macular degeneration and cataracts prevent cardiovascular diseases (Narisawa et al., 1999; Tanaka et al., 2000a; Trumbo and Ellwood, 2006; Voutilainen et al., 2006). Carotenoids also play an important indirect role in mandarin flavor by being precursors of potent aroma-active volatiles (Winterhalter and Rouseff, 2002; Mahattanatawee et al., 2005).

Citrus fruits are a complex source of carotenoids with the largest number of carotenoids. Approximately 115 different carotenoids have been reported in citrus, including a large number of isomers (Goodner et al., 2001). Among carotenoids present in citrus, $\alpha$ - and $\beta$-carotene, lycopene, $\beta$-cryptoxanthin, lutein, and zeaxanthin are the major carotenoids in mandarin with relatively high concentrations in orange fruit (Kato et al., 2004). Some carotenoid compounds (mainly $\alpha$ - and $\beta$-carotene, $\beta$-cryptoxanthin) are the main precursor of provitamin A in citrus (Mares-Perlman et al., 2002).

Carotenoid accumulation occurs in juice sacs of citrus during fruit maturation (Gross, 1987; Ikoma et al., 2001; Kato et al., 2004; Rodrigo et al., 2004). Carotenoid content and composition in citrus fruit vary greatly among cultivars (Goodner et al., 2001; Kato et al., 2004; Fanciullino et al., 2006; Matsumoto et al., 2007). Carotenoids produced by mandarins are similar to 
those produced by oranges; however, they differ in the quantities of individual compounds produced (Lee and Castle, 2001; Kato et al., 2004; Fanciullino et al., 2006; Matsumoto et al., 2007).

Although the genetic factor has been shown to play an important in citrus carotenoid composition, other factors such as maturity stage, geographical origin and cultural practices and postharvest treatments have been reported to affect the content and composition of carotenoids in citrus fruit (Mouly et al., 1999; Lee and Castle, 2001; Lester et al., 2007; Rodrigo and Zacarias, 2007; Beltran-González et al., 2008; Fanciullino et al., 2008; Girennavar et al., 2008; Matsumoto et al., 2009; Navarro et al., 2010).

\section{I.4.1.4. Limonoids}

Citrus are the only edible fruits containing significant amounts of limonoids that occur abundantly in Rutaceae and Meliaceae families and less frequently in Cneoraceae and Harrisonia sp. of Simaroubaceae (Roy and Saraf, 2006). Limonoids are highly oxygenated triterpenoids that are present in all citrus species. These compounds are known to influence the organoleptic properties of citrus fruit and juice producing bitterness and are reported to possess a number of biological activities. Limonoids have numerous health benefits displaying anticarcinogenic, anti-inflammatory and antimalarial activity and reducing the effects of HIV infections and cholesterol (Miller et al., 1992, 2004; Lam et al., 1994; So et al., 1996; Tanaka et al., 2000b, 2001; Battinelli et al., 2003). Limonoids occur as aglycones, glucosides, and A-ring lactones (Breksa et al., 2011). A-ring lactones and glucosides are tasteless and water-soluble and can be altered to create tastelessness through acetylation, whereas aglycones exhibit limited water solubility and are bitter. The biosynthesis of Aring lactones and aglycones occurs throughout citrus plants, while glucosides are only formed in fruits and seeds (Breksa et al., 2011). Limonin is consistently the most abundant limonoid aglycone followed by nomilin, obacunoic acid, ichangin, deoxylimonoic acid and nomilinic acid; these compounds are present relatively in large concentrations in citrus seeds and molasses and have been identified to be inherently bitter (Hasegawa and Miyake, 1996; Manners, 2007). Limonoid aglycones are endogenously converted into tasteless limonoid glucosides as the fruit ripens (Endo et al., 2002). The limonoid glucoside in highest concentration in most citrus juice is limonin 17- $\beta$-D-glucopyranoside, with glucoside derivatives of nomilin and other 
limonoid glucosid present in lesser amounts (Hasegawa et al., 1989, Herman et al., 1990; Ozaki et al., 1991).

\section{I.4.2. AROMA AND TASTE}

Flavor and aroma, which play an important role in the quality of fresh citrus fruit, are composed of complex combinations of soluble compounds mostly acids, sugars, flavonoids and volatile compounds.

Citrus fruits are classified as acid fruits, since their soluble solids are composed mainly of organic acids and sugars. Organic acids, including citric, malic, succinic, and tartaric acids in citrus juice are important components which contribute to flavor attributes and largely affect taste characteristic and organoleptic quality (Igual et al., 2010). High concentrations of organic acids and low $\mathrm{pH}$ in most fruits are critical for the preservation of derivative products. They also help to stabilize other compounds such as ascorbic acid and anthocyanins (Uckoo et al., 2011). Sugars are the major components of citrus juice soluble solids and sweetness of citrus juice is intrinsic to its sugar composition. Sucrose is present in the largest amounts in citrus juice followed by fructose and glucose (Kelebek, 2010; Kelebek and Selli, 2011).

The aroma of the fresh citrus juice results from a complex combination of a subset of the more than 300 volatiles compounds present in the fruit, defined as volatile organic compounds or VOCs, which include hydrocarbon terpenes, alcohols, aldehydes, esters and ketones (Rouseff et al., 2009; Miyasaki et al., 2010; González-Mas et al., 2011). Although hydrocarbon terpenes are the predominant chemical class within citrus volatiles this fraction makes little contribution to the odor perception because of their high odor thresholds. Aldehydes and esters seem to be the compounds with a higher impact on citrus aroma. Aldehydes have long been described to contribute to the orange aroma with citrus-like, green, fatty and metallic notes while esters would be responsible for the fruity top-notes present in fresh juice (Pérez-Cacho and Rouseff, 2008; Plotto et al., 2008).

It remains difficult to establish a link between sensory characteristics and chemical composition of volatile compounds. The sensory characteristics of a compound fragrant and in particular the threshold of perception can change depending on whether one is alone or in combination with other volatile 
compounds (Buettner and Schieberle, 2001a). A combination of Gas Chromatography / olfactometry techniques (GC/O) permits the identification of the compounds likely to contribute to aroma. Aroma-active compounds are those components with levels equal or greater than their odor threshold (Plotto et al., 2008). The most odor-active compounds found in a fresh citrus juice and their odor activity are reported in the Table 2.

Table 2. The aroma-active compounds of fresh citrus fruit and their description

\begin{tabular}{|c|c|c|}
\hline Compound & Odor description & References \\
\hline \multicolumn{3}{|l|}{ Aldehydes } \\
\hline Acetaldehyde & $\begin{array}{l}\text { Solventy, floral, fruity, } \\
\text { pungent, fermented }\end{array}$ & $\begin{array}{l}\text { Rega et al., 2003; Plotto et al., 2008; Buttner } \\
\text { and Schieberle, 2001b; }\end{array}$ \\
\hline Hexanal & Citrus, floral, green, grassy, & $\begin{array}{l}\text { Hinterholzer and Schieberle, 1998; Buttner } \\
\text { and Schieberle, 2001a, 2001b; Rega et al., } \\
\text { 2003; Arena et al., 2006; Berlinet et al., 2007; } \\
\text { Qiao et al., 2008; Obenland et al., 2009; } \\
\text { Tietel et al., 2011; Miyazaki et al., 2012. }\end{array}$ \\
\hline (Z)-3-hexenal & Green, grassy, rancid & $\begin{array}{l}\text { Bazmore et al., 1999; Buttner and } \\
\text { Schieberle, 2001a, 2001b; Plotto et al., } 2008\end{array}$ \\
\hline (E)-2-hexenal & Green, banana-like & Plotto et al., 2008 ; Qiao et al., 2008. \\
\hline Heptanal & Fatty, oily, rancid, powerful & $\begin{array}{l}\text { Obenland et al., 2008, 2009; Miyazaki et al., } \\
2012 .\end{array}$ \\
\hline Octanal & Citrus-like, green, orange peel & $\begin{array}{l}\text { Hinterholzer and Schieberle, 1998; Bazmore } \\
\text { et al., 1999; Buttner and Schieberle, 2001a; } \\
\text { Rega et al., 2003; Arena et al., 2006; Berlinet } \\
\text { et al., 2007; Obenland et al., 2009; Selli and } \\
\text { Kelebek, 2011; Miyazaki et al., 2012. }\end{array}$ \\
\hline Nonanal & Floral, citrus-like, soapy, piney & $\begin{array}{l}\text { Hinterholzer and Schieberle, 1998; Buttner } \\
\text { and Schieberle, 2001a, 2001b; Rega et al., } \\
\text { 2003; Arena et al., 2006; Berlinet et al., } 2007 .\end{array}$ \\
\hline Decanal & $\begin{array}{l}\text { Floral, citrus, green, soapy, } \\
\text { fatty, musty }\end{array}$ & $\begin{array}{l}\text { Hinterholzer and Schieberle, 1998; Bazmore } \\
\text { et al., 1999; Buttner and Schieberle, 2001a, } \\
\text { 2001b; Rega et al., 2003; Mahattanatawee et } \\
\text { al., 2005; Arena et al., 2006; Berlinet et al.,, } \\
\text { 2007; Qiao et al., 2008; Selli and Kelebek, } \\
2011\end{array}$ \\
\hline (E)-2-nonenal & Fatty, tallow, musty, rancid & $\begin{array}{l}\text { Buttner and Schieberle, 2001a,2001b; } \\
\text { Obenland, 2008, 2009; Plotto et al., 2008; } \\
\text { Tietel et al., 2011; }\end{array}$ \\
\hline
\end{tabular}




\begin{tabular}{|c|c|c|}
\hline$(\mathrm{E}, \mathrm{E})$-2,4-decadienal & $\begin{array}{l}\text { Fatty, waxy, soapy, oily, } \\
\text { rancid, green }\end{array}$ & $\begin{array}{l}\text { Hinterholzer and Schieberle, 1998; Buttner } \\
\text { and Schieberle, 2001a, 2001b; } \\
\text { Mahattanatawee et al., 2005; Plotto et al., } \\
\text { 2008; Qiao et al., 2008; Miyazaki et al., } 2012 \text {. }\end{array}$ \\
\hline Geranial & Floral, citrus-like, green, minty & $\begin{array}{l}\text { Mahattanatawee et al., 2005; Qiao et al., } \\
\text { 2008; Selli and Kelebek, 2011; Chung et al., } \\
\text { 2012. }\end{array}$ \\
\hline \multicolumn{3}{|l|}{ Esters } \\
\hline Ethyl acetate & $\begin{array}{l}\text { Fruity, sweet, tangerine, } \\
\text { solvent-like, orange }\end{array}$ & $\begin{array}{l}\text { Hinterholzer and Schieberle, 1998; Buttner } \\
\text { and Schieberle, 1999, 2001a; Rega et al., } \\
\text { 2003; Plotto et al., } 2008\end{array}$ \\
\hline Ethyl butanoate & $\begin{array}{l}\text { Fruity, sweet, floral, tropical } \\
\text { fruit, peach, }\end{array}$ & $\begin{array}{l}\text { Hinterholzer and Schieberle, 1998; Bazmore } \\
\text { et al., 1999; Buttner and Schieberle, 2001a, } \\
\text { 2001b; Rega et al., 2003; Arena et al., 2006; } \\
\text { Berlinet et al., 2007; Obenland et al., 2008, } \\
\text { 2009; Plotto et al., 2008; Qiao et al., 2008; } \\
\text { Selli and Kelebek, 2011; Miyazaki et al., } \\
\text { 2012. }\end{array}$ \\
\hline Ethyl hexanoate & $\begin{array}{l}\text { Fruity, orange, citrus, sweet, } \\
\text { rotten at high concentration, } \\
\text { rancid }\end{array}$ & $\begin{array}{l}\text { Hinterholzer and Schieberle, 1998;Plotto et } \\
\text { al., 2008; Buttner and Schieberle, 2001a, } \\
\text { 2001b; Arena et al., 2006; Berlinet et al., } \\
\text { 2007; Obenland et al., 2009; Selli and } \\
\text { Kelebek, 2011; Miyazaki et al., 2012. }\end{array}$ \\
\hline Ethyl octanoate & $\begin{array}{l}\text { Floral, fruity, citrus, } \\
\text { herbaceous, moldy }\end{array}$ & $\begin{array}{l}\text { Arena et al., 2006; Berlinet et al., 2007; } \\
\text { Obenland et al., 2009; Selli and Kelebek, } \\
2011\end{array}$ \\
\hline Octyl acetate & $\begin{array}{l}\text { Citrus, aniseed, menthol, } \\
\text { soapy, floral, plastic, green, }\end{array}$ & $\begin{array}{l}\text { Rega et al., 2003; Berlinet et al., 2007; Plotto } \\
\text { et al., 2008; Tietel et al., } 2011\end{array}$ \\
\hline Ethyl-3-hydroxyhexanoate & $\begin{array}{l}\text { Citrusy, fruity, sweet, moldy, } \\
\text { sour }\end{array}$ & $\begin{array}{l}\text { Hinterholzer and Schieberle, 1998; Buttner } \\
\text { and Schieberle, 2001a, 2001b; Plotto et al., } \\
2008\end{array}$ \\
\hline Ethyl propanoate & $\begin{array}{l}\text { Sweet, fruity, floral, grapefruit, } \\
\text { bitter }\end{array}$ & $\begin{array}{l}\text { Hinterholzer and Schieberle, 1998; Buttner } \\
\text { and Schieberle, 1999, 2001a; Plotto et al., } \\
\text { 2008; Tietel et al., 2011 }\end{array}$ \\
\hline Methyl butanoate & $\begin{array}{l}\text { Fruity, sweet, cheesy, } \\
\text { strawberry, spoiled }\end{array}$ & $\begin{array}{l}\text { Rega et al., 2003; Arena et al., 2006; Plotto } \\
\text { et al., 2008. }\end{array}$ \\
\hline Ethyl-2-methylpropanoate & $\begin{array}{l}\text { Fruity, sweet, mask citrus } \\
\text { odor }\end{array}$ & $\begin{array}{l}\text { Hinterholzer and Schieberle, 1998; Buttner } \\
\text { and Schieberle, 2001a, 2001b; Plotto et al., } \\
2008 \text {. }\end{array}$ \\
\hline Ethyl-2-methylbutanoate & Fruity, sweet, apple, & $\begin{array}{l}\text { Hinterholzer and Schieberle, 1998; Buttner } \\
\text { and Schieberle, 2001a, 2001b; Arena et al., } \\
\text { 2006; Tietel et al., 2011; Miyazaki et al., } \\
\text { 2012. }\end{array}$ \\
\hline$p$-menth-1-en-9-yl acetate & $\begin{array}{l}\text { Citrusy, fruity, floral, } \\
\text { pineapple, passion fruit, }\end{array}$ & Rega et al., 2003; Berlinet et al., 2007. \\
\hline Terpenes & & \\
\hline
\end{tabular}




\begin{tabular}{|c|c|c|}
\hline a-pinene & $\begin{array}{l}\text { citrus, etheral, pine-tree, } \\
\text { spicy, herbaceous, chemical }\end{array}$ & $\begin{array}{l}\text { Hinterholzer and Schieberle, 1998; Buttner } \\
\text { and Schieberle, 2001a, 2001b; Rega et al., } \\
\text { 2003; Arena et al., 2006; Berlinet et al., 2007; } \\
\text { Obenland et al., 2008, 2009; Qiao et al., } \\
\text { 2008; Chung et al., 2012 ; Tietel et al., 2011 }\end{array}$ \\
\hline Myrcene & $\begin{array}{l}\text { Lemon, grapefruit, musty, } \\
\text { plastic, unpleasant, geranium, } \\
\text { fatty, mossy, balsamic }\end{array}$ & $\begin{array}{l}\text { Hinterholzer and Schieberle, 1998; Bazmore } \\
\text { et al., 1999; Buttner and Schieberle, 2001a, } \\
\text { 2001b; Rega et al., 2003; Arena et al., 2006; } \\
\text { Berlinet et al., 2007; Obenland et al., 2008, } \\
\text { 2009; Qiao et al., 2008; Selli and Kelebek, } \\
\text { 2011; Tietel et al., 2011; Chung et al., 2012; }\end{array}$ \\
\hline$\beta$-pinene & $\begin{array}{l}\text { Citrus, terpene-like, pungent, } \\
\text { piney, }\end{array}$ & $\begin{array}{l}\text { Rega et al., 2003; Arena et al., 2006; Qiao et } \\
\text { al., 2008; Miyazaki et al., } 2012 .\end{array}$ \\
\hline Limonene & $\begin{array}{l}\text { Lemon, minty, citrus-like, } \\
\text { fruity, turpentine-like, fresh }\end{array}$ & $\begin{array}{l}\text { Hinterholzer and Schieberle, 1998; Buttner } \\
\text { and Schieberle, 2001a, 2001b; Rega et al., } \\
\text { 2003; Arena et al., 2006; Berlinet et al., 2007; } \\
\text { Obenland et al., 2008, 2009; Qiao et al., } \\
\text { 2008; Selli and Kelebek, 2011; Tietel et al., } \\
2011\end{array}$ \\
\hline y-terpinene & Citrus, sweet & $\begin{array}{l}\text { Qiao et al., 2008; Obenland et al., 2009; } \\
\text { Tietel et al., 2011; Miyazaki et al., } 2012 .\end{array}$ \\
\hline Terpinolene & $\begin{array}{l}\text { Citrusy, green, grass, woody, } \\
\text { unpleasant, chemical, orange }\end{array}$ & $\begin{array}{l}\text { Rega et al., 2003; Arena et al., 2006; Berlinet } \\
\text { et al., 2007; Qiao et al., } 2008 .\end{array}$ \\
\hline \multicolumn{3}{|l|}{ Alcohols } \\
\hline Octanol & Floral, fruity, grapefruit, herbal & Rega et al., 2003; Berlinet et al., 2007. \\
\hline Linalool & $\begin{array}{l}\text { Citrus, fruity, floral, lemon, } \\
\text { spicy, green, }\end{array}$ & $\begin{array}{l}\text { Hinterholzer and Schieberle, 1998; Buttner } \\
\text { and Schieberle, 2001a, 2001b; Rega et al., } \\
\text { 2003; Arena et al., 2006; Berlinet et al., 2007; } \\
\text { Obenland et al., 2008, 2009; Qiao et al., } \\
\text { 2008; Selli and Kelebek, 2011; Tietel et al., } \\
\text { 2011; Miyazaki et al., 2012. }\end{array}$ \\
\hline Terpinen-4-ol & Green, floral, fresh & $\begin{array}{l}\text { Bazmore et al., 1999; Mahattanatawee et al., } \\
\text { 200(; Qiao et al., 2008; Selli and Kelebek, } \\
\text { 2011; Tietel et al., } 2011\end{array}$ \\
\hline a-terpineol & Lemon, piney, minty & Qiao et al., 2008; Selli and Kelebek, 2011 \\
\hline Geraniol & $\begin{array}{l}\text { Floral, lemon, minty, rose, } \\
\text { citrus, geranium }\end{array}$ & $\begin{array}{l}\text { Rega et al., 2003; Mahattanatawee et al., } \\
\text { 2005; Qiao et al., 2008; Selli and Kelebek, } \\
\text { 2011. }\end{array}$ \\
\hline Hexanol & Floral, grass & Rega et al., 2003; Arena et al., 2006. \\
\hline Nerol & Lemon, grass, sweet fruit, & $\begin{array}{l}\text { Mahattanatawee et al., 2005; Qiao et al., } \\
2008\end{array}$ \\
\hline \multicolumn{3}{|l|}{ Ketones } \\
\hline 1-Octen-3-one & Mushroom-like, & $\begin{array}{l}\text { Hinterholzer and Schieberle, 1998; Buttner } \\
\text { and Schieberle, 2001a, 2001b; Obenland et } \\
\text { al., 2009; Miyazaki et al., 2012. }\end{array}$ \\
\hline
\end{tabular}


Introduction

\begin{tabular}{|c|c|c|}
\hline Nootkatone & Grapefruit, musty, green, & $\begin{array}{l}\text { Hinterholzer and Schieberle, 1998; Plotto et } \\
\text { al., 2008; Selli and Kelebek, 2011; Miyazaki } \\
\text { et al., 2012. }\end{array}$ \\
\hline$\beta$-ionone & Violet-like, rose, floral & $\begin{array}{l}\text { Hinterholzer and Schieberle, 1998; Buttner } \\
\text { and Schieberle, 2001a; Rega et al., 2003; } \\
\text { Mahattanatawee et al., 2005; Miyazaki et al., } \\
2012 .\end{array}$ \\
\hline Carvone & Caraway, minty & $\begin{array}{l}\text { Mahattanatawee et al., 2005; Qiao et al., } \\
\text { 2008; Selli and Kelebek, 2011; Miyazaki et } \\
\text { al., 2012. }\end{array}$ \\
\hline
\end{tabular}

Aroma-active compounds in citrus fruit reported in at least two different publications.

Compounds detected in more than six different experiments are in bold type.

Odor description was taken from the cited literature and from Rouseff (2010). 


\section{REFERENCES}

Abeles, F.B., Morgan, P.W., Saltveit, M.E. (1992). Ethylene in Plant Biology (2nd ed.). Academic Press, Inc., San Diego, California. U.S.A. 420 p.

Abeysinghe, D.C., Li, X., Sun, C.D., Zhang, W.S., Zhou, C.H., Chen, K.S. (2007). Bioactive compounds and antioxidant capacities in different edible tissues of citrus fruit of four species. Food Chemistry, 104, 1338-1344.

Achilea. O., Chalutz, F., Fuchs, Y., Rot, I. (1984). Ethylene biosynthesis and related physiological changes in Penicillium digitatum- infected grapefruit (Citrus paradisi). Physiological Plant Pathology, 26, 125-134.

Agusti, M. (1999). Preharvest factors affecting postharvest quality of citrus fruit. In: Schirra, M. (Ed.). Advances in Postharvest Diseases and Disorder Control of Citrus Fruit. Research Signpost, Trivandrum, India, pp. 1-34.

Almela, V., Agustí, M., Pons, J. (1992). Rind spots in Fortune mandarin. Origin and control. Physiologia Plantarum, 85, A 60 (abstract).

Alonso, J.M. and Granell, A. (1995). A putative vacuolar processing protease is regulated by ethylene and also during fruit ripening in citrus fruit. Plant Physiology, 109, 541-547.

Alonso, J.M., Chamarro, J., Granell, A. (1995). Evidence for the involvement of ethylene in the expression of specific RNAs during maturation of the orange, a non-climacteric fruit. Plant Molecular Biology, 29, 385-390.

Alonso, J.M., García-Martínez, J.L., Chamarro, J. (1992). 2-Dimensional gelelectrophesis pattern of total, in-vivo labeled and in-vitro translated polypeptides from orange flavedo during maturation and following ethylene treatment. Physiologia Plantarum, 85, 147-156.

Alós, E., Cercós, M., Rodrigo, M. J., Zacarías, L., Talón, M. (2006). Regulation of color break in citrus fruits. Changes in pigment profiling and gene expression induced by gibberellins and nitrate, two ripening retardants. Journal of Agricultural and Food Chemistry, 54, 4888-4895.

Arena, E., Guarrera, N., Campisi, S., Nicolosi Asmundo, C. (2006). Comparison of odour active compounds detected by gas-chromatography-olfactometry between hand-squeezed juices from different orange varieties. Food Chemistry, 98, 59-63.

Artes, F., Escriche, A.J., Marin, J.G. (1993). Treating 'Primofiori' lemons in cold storage with intermittent warming and carbon dioxide. HortScience, 28, 819821. 
Azuma, R., Adachi, M., Shimokawa, K. (1999). A water soluble ethylene-induced chlorophyllase in peel of Citrus unshiu Marc. Journal of the Japanese Society for Horticultural Science, 68, 883-889.

Bajwa, B.E. and Anjum, F.M. (2007). Improving storage performance of Citrus reticulate Blanco mandarins by controlling some physiological disorders. International Journal of Food Science and Technology, 42, 495-501.

Barmore, C.R. and Brown, G.E. (1985). Influence of ethylene on increased susceptibility of oranges to Diplodia natalensis. Plant Disease, 69, 228-230.

Barry, G.H. and Van Wyk, A.A., (2006). Low-temperature cold shock may induce rind colour development of 'Nules Clementine' mandarin (Citrus reticulata Blanco) fruit. Postharvest Biology and Technology, 40, 82-88.

Battinelli, L., Menqoni, F., Lichtner, M., Maqzzanti, G., Saija, A., Mastroianni, C. M., Vullo, V. (2003). Effect of limonin and nomilin on HIV-1 replication on infected human mononuclear cells. Plant Medica, 69, 910-913.

Bazmore, R., Goodner, K., Rouseff, R. (1999). Volatiles from Unpasteurized and Excessively Heated Orange Juice Analyzed with Solid Phase Microextraction and GC-Olfactometry. Journal of Food Science, 64, 800-803.

Belajová, E. and Suhaj, M. (2004). Determination of phenolic constituents in citrus juices: method of high performance liquid chromatography. Food Chemistry, 86, 339-343.

Beltran-González, F., Perez-Lopez, A.J., Lopez-Nicolas, J.M., CarbonellBarrachina, A.A. (2008). Effects of agricultural practices on instrumental colour, mineral content, carotenoid composition, and sensory quality of mandarin orange juice, cv. Hernandina. Journal of the Science of Food Agriculture, 88, 1731-1738.

Benavente-García, O., Castillo, J., Marin, F.R., Ortuño, A., Del Río, J.A. (1997). Uses and properties of Citrus flavonoids (Reviews). Journal of Agricultural and Food Chemistry, 45, 4505-4515.

Benavente-Garcia, O. and Castillo, J. (2008). Update on uses and properties of citrus flavonoids: New finding in anticancer, cardiovascular, and antiinflammatory activity. Journal of Agricultural and Food Chemistry, 56, 61856205.

Ben-Yehoshua, S., Peretz, J., Moran, R., Lavie, B., Kim, J.J. (2001). Reducing the incidence of superficial flavedo necrosis (noxan) of Shamouti oranges (Citrus sinensis L. Osbeck). Postharvest Biology and Technology. 22, 19-27.

Berlinet, C., Guichard, E., Fournier, N., Ducruet, V. (2007). Effect of pulp reduction and pasteurization on the release of aroma compounds in industrial orange juice. Journal of Food Science, 72, 535-543. 
Biolatto, A., Vazquez, D.E., Sancho, A.M., Carduza, F.J., Pensel, N.A. (2005). Effect of commercial conditioning and cold quarantine storage treatments on fruit of 'Rouge La Toma' grapefruit (Citrus paradise Macf.). Postharvest Biology and Technology, 35, 167-176.

Blanke, M.M. (1991). Respiration of apple and avocado fruits. Postharvest News and Information, 2, 429-436.

Bleecker, A.B. and Kende, H. (2000). Ethylene: A gaseous signal molecule in plants. Annual Review of Cell and Developmental Biology, 16, 1-18.

Breksa, A.P. III, Kahn, T., Zukas, A.A., Hidalgoa, M.B., Yuena, M.L. (2011). Limonoid content of sour orange varieties. Journal of the Science of Food and Agriculture, 1789-1794.

Brown, G.E. and Burns, J.K. (1998). Enhanced activity of abscission enzymes predisposes oranges to invasion by Diplodia natalensis during ethylene degreening. Postharvest Biology and Technology, 14, 217-227.

Brummell, D.A., Hall, B.D., Bennett, A.B. (1999). Antisense suppression of tomato endo-b-1,4-glucanase Cel2 mRNA accumulation increases the force required to break fruit abscission zones but does not affect fruit softening. Plant Molecular Biology, 40, 615-622.

Buettner, A. and Schieberle, P. (1999). Characterization of the Most Odor-Active Volatiles in Fresh, Hand-Squeezed Juice of Grapefruit (Citrus paradisi Macfayden). Journal of Agricultural and Food Chemistry, 47, 5189-5193.

Buettner, A. and Schieberle, P. (2001a). Evaluation of aroma differences between hand-squeezed juices from Valencia Late and Navel oranges by quantitation of key odorants and flavor reconstitution experiments. Journal of Agricultural and Food Chemistry, 49, 2387-2394.

Buettner, A. and Schieberle, P. (2001b). Evaluation of Key aroma coumpounds in hand-squeezed grapefruit juice (Citrus paradisi Macfadyen) by quantification and flavor reconstitution experiments. Journal of Agricultural and Food Chemistry, 49, 1358-1363.

Burns, J.K., Lewandowski, D.J., Nairn, C.J., Brown, G.E. (1998). Endo-1,4-bglucanase gene expression and cell wall hydrolase activities during abscission in Valencia orange. Physiologia Plantarum, 102, 217-225.

Byers, T. and Perry, G. (1992). Dietary carotenes, vitamin C, and vitamin E as protective antioxidants in human cancers. Annual Reviews of Nutrition, 12, 139-159.

Cajuste, J.F. and Lafuente, M.T. (2007). Ethylene-induced tolerance to nonchilling peel pitting as related to phenolic metabolism and lignin content in 'Navelate' fruit. Postharvest Biology and Technology, 45, 193-203. 
Cajuste, J.F., Gonzalez-Candelas, L., Veyrat, A., Garcia-Breijo, F.J., ReigArminana, J., Lafuente, M.T. (2010). Epicuticular wax content and morphology as related to ethylene and storage performance of 'Navelate' orange fruit. Postharvest Biology and Technology, 55, 29-35.

Cano, A., Medina, A., Bermejo, A. (2008). Bioactive compounds in different citrus varieties. Discrimination among cultivars. Journal of Food Composition and Analysis, 21, 377-381.

Carmona, L., Zacarias, L., Rodrigo, M.J. (2007). Efecto de la temperatura de conservación en la sintesis y acumulación de carotenoids en frutos cítricos. $V$ Congreso Iberoamericano de Tecnología Postcosecha y Agroexportaciones, 453-461.

Carvalho, C.P., Salvador, A., Navarro, P., Monterde, A. and Martínez-Jávega, J.M. (2008). Effect of Auxin Treatments on Calyx Senescence in the Degreening of Four Mandarin Cultivars. Hortscience, 43, 747-752.

Chalutz, E., Waks, J., Schiffmann-Nadel, M. (1985). Comparision of the response of different citrus fruit cultivars to storage temperature. Scientia Horticulturae, 25, 271-277.

Chung, H., Chung, W.Y., Yoo, E.S., Cho, S.K., Oh, S.K., Kim, Y.S. (2012). Characterization of volatile aroma-active compounds in Dangyooja (Citrus grandis Osbeck). Journal of the Korean Society for Applied Biological Chemistry, 55, 133-136.

CLAM (Comité de Liaison de l'Agrumiculture Méditerranéenne) (2007). Les exportations d'agrumes du basin Méditerranéen. Statistiques, evaluations, repartitions, situation 2006-2007, 121pp.

Cohen, E. (1978). The effect of temperature and relative humidity during degreening on the coloring of Shamouti orange fruit. Journal of Horticultural Science, 53, 143-146.

Crifò, T., Petrone, G., Lo Cicero, L., Lo Piero, A.R. (2012). Short cold storage enhances the anthocyanin contents and level of transcripts related to their biosynthesis in blood oranges. Journal of Agricultural and Food Chemistry, $60,476-481$.

Crifò, T., Puglisi, I., Petrone, G., Reforgiato Recupero, G., Lo Piero, A.R. (2011). Expression analysis in response to low temperature stress in blood oranges: implication of the flavonoid biosynthetic pathway. Gene, 476, 1-9.

Cronjé, P.J.R., Crouch, E.M., Huysamer, M. (2005). Postharvest Calyx Retention of Citrus Fruit. Acta Horticulturae, 682, 369-374.

Cuquerella, J., Salvador, A., Martinez-Jávega, J. M., Navarro, P. (2005). Effect of quarantine cold treatment on early-season Spanish mandarins. Acta Horticulturae, 682, 743-747. 
Davey, M. W., Van Montagu, M., Inze, D., Sanmartin, M., Kanellis, A., Smirnoff, N., Benzie, I.J.J., Strain, J.J., Favell, D., Fletcher, J. (2000). Plant L-ascorbic acid: Chemistry, function, metabolism, bioavailability and effects of processing. Journal of the Science of Food and Agriculture, 80(7), 825-860.

D'Aquino, S., Palma, A., Fronteddu, F., Tedde, M. (2005). Effect of preharvest and postharvest calcium treatments on chilling injury and decay of cold stored Fortune mandarins. Acta Horticulturae, 682: 631-637.

D'Aquino, S., Palma, A., Agabbio, M., Tijskens, L.M.M., Vollebregt, H.M. (2003). Response of three citrus species to different hygrometric conditions. Acta Horticulturae, 604, 631-635.

Davies, F.S. and Albrigo, L.G. (1994). Cítricos. CAB International, Wallingford, U.K., 254 p.

Del Campillo, E. and Bennett, A.B. (1996). Pedicel break strength and cellulase gene expression during tomato flower abscission. Plant Physiology, 111, 813820.

Del Río, J.A., Fuster, M.D., Gómez, P., Porras, I., García-Lidón, A., Ortuño, A. (2004). Citrus limon: A source of flavonoids of pharmaceutical interest. Food Chemistry, 84, 457-461.

Dhuique-Mayer, C., Caris-Veyrat, C., Ollitrault, P., Curk, F., Amiot, M.J. (2005). Varietal and interspecific influence on micronutrient contents in Citrus from the Mediterranean area. Journal of Agricultural and Food Chemistry, 53, 2140-2145.

Dou, H. and Ismail, M.A. (2000). Effect of pre-cooling and storage temperature on postharvest pitting incidence of citrus. In: W.J. Florkowski, S.E. Prussia, and R.L. Shewfelt (Eds.). An integrated view of fruit and vegetable quality. Technomic Publ., Basel, Switzerland, pp. 131-142.

Du, Q.Z. and Chen, H. (2010). The methoxyflavones in Citrus reticulata Blanco cv. Ponkan and their antiproliferative activity against cancer cells. Food Chemistry, 119, 567-572.

Eaks, I.I. (1980). Effect of chilling on respiration and volatiles of California lemon fruit. Plant Physiology, 105, 865-869.

El-Hilali, F., Ait-Oubahou, A., Remah, A., Akhayat, O. (2003). Chilling injury and peroxidase activity changes in "fortune" mandarin fruit during low temperature storage. Bulgarian Journal of Plant Physiology, 29(1-2), 44-54.

El-Kazzaz, M.K., Chordas, A. Kader, A.A. (1983). Physiological and Compositional Changes in Orange Fruit in relation to Modification of their Susceptibility to Penicillium italicum by Ethylene Treatments. Journal of the American Society for Horticultural Science, 108, 618-621. 
Endo T., Kita M., Shimada T., Moriguchi T., Hidaka T., Matsumoto R., Hasegawa S., Omura M. (2002). Modification of limonoid metabolism in suspension cell culture of Citrus. Plant Biotechnology, 19, 397-403.

Erkan, M., Pekmezci, M., Wang, C.Y. (2005). Hot water and curing treatments reduce chilling injury and maintain postharvest quality of 'Valencia' oranges. International Journal of Food Science and Technology, 40, 91-96

Evenson, K., Bausher, M.G., Biggs, R.H. (1981). Wound-induced ethylene production in peel ex-plants of 'Valencia' orange fruit. HortScience, 16, 4344.

Fanciullino, A.L., Cercos, M., Dhuique-Mayer, C., Froelicher, Y., Talon, M., Ollitrault, P., Morillon, R. (2008). Changes in carotenoid content and biosynthetic gene expression in juice sacs of four orange varieties (Citrus sinensis) differing in flesh fruit color. Journal of Agricultural and Food Chemistry, 56, 3628-3638.

Fanciullino, A.L., Dhuique-Mayer, C., Luro, F., Casanova, J., Morillon, R., Ollitrault, P. (2006). Carotenoid diversity in cultivated citrus is highly influenced by genetic factors. Journal of Agricultural and Food Chemistry, 54, 4397-4406

FAO (Food and Agriculture Organization of the United Nations) (2009). Citrus Fruit, Fresh and Processed. Annual statistics. Retrieved June 02, 2012 from http: / faostat.fao.org/

Franke, A. A., Custer, L. J., Arakaki, C., Murphy, S. P. (2004). Vitamin C and flavonoid levels of fruits and vegetables consumed in Hawaii. Journal of Food Composition and Analysis, 17, 1-35.

Fujii, H., Shimada, T., Sugiyama, A., Nishikawa, F., Endo, T., Nakano, M., Ikoma, Y., Shimizu, T., Omura, M. (2007). Profiling of ethylene-responsive genes in mature mandarin fruit using a citrus $22 \mathrm{~K}$ oligoarray. Plant Science, 173, 340-348.

Gadjeva, V., Kuchukova, D., Georgieva, R. (2005). Vitamin combinations reduce oxidative stress and improve antioxidant status in patients with iron deficiency anemia. Comparative Clinical Pathology, 14, 99-104.

Gardner, P.T., White, T.A.C., McPhail, D.B., Duthie, G.G. (2000). The relative contributions of vitamin $\mathrm{C}$, carotenoids and phenolics to the antioxidant potential of fruit juices. Food Chemistry, 68, 471-474.

Gattuso, G., Barreca, D., Caristi, C., Gargiulli, C., Leuzzi, U. (2007). Distribution of flavonoids and furocoumarins in juices from cultivars of Citrus bergamia Risso. Journal of Agricultural and Food Chemistry, 55, 99219927. 
Girennavar, B., Jayaprakasha, G.K., Mclin, S.E., Maxim, J., Yoo, K.S., Patil, B.S. (2008). Influence of electron-beam irradiation on bioactive compounds in grapefruits (Citrus paradisi Macf.). Journal of Agricultural and Food Chemistry, 56, 10941-10946.

González-Mas, M.C., Rambla, J.L., Alamar, M.C., Gutiérrez, A., Granell, A. (2011). Comparative analysis of the volatile fraction of fruit juice from different Citrus species. PLoS ONE, 6(7), e22016. doi:10.1371/journal.pone.0022016.

González-Molina, E., Domímguez-Perles, R., Moreno, D.A., García-Viguera, C. (2010). Natural bioactive compounds of Citrus limon for food and health. Journal of Pharmaceutical and Biomedical Analysis, 51, 327-345.

Goodner, K.L., Rouseff, R.L., Hofsommer, H.J. (2001). Orange, mandarin and hybrid classification using multivariate statistics based on carotenoid profiles. Journal of Agricultural and Food Chemistry, 49, 1146-1150.

Gorinstein, S., Martin-Belloso, O., Park, Y., Haruenkit, R., Lojek, A., Ciz, M., Caspi, A., Libman, A., Trakhtenberg, S. (2001). Comparison of some biochemical characteristics of different citrus fruits. Food Chemistry, 74, 309-315.

Gorny, J.R. and Kader, A. (1996). Controlled-atmosphere suppression of ACC synthase and ACC oxidase in 'Golden delicious' apple during long-term cold storage. Journal of the American Society for Horticultural Science, 121, 751755.

Green, C.O., Wheatley, A.O., Osagie, A.U., Morrison, E.Y.St.A., Asemota, H.E. (2007). Determination of polymethoxylated flavones in peels of selected Jamaican and Mexican citrus (Citrus spp.) cultivars by high-performance liquid chromatography. Biomedical Chromatography, 21, 48-54.

Grierson, W. (1981). Physiological disorders of citrus fruits. Proceedings of the International Society of Citriculture, 2, 764-767.

Gross, J. (1987). Pigments in fruits. In: Schweigert, B.S. (Ed.). Food science and technology: a series of monographs. Academic Press, London, UK., pp. 87-98.

Gross, K.C. and Smilanick, J.L. (2004). Lemon. In: Gross, K.C., Wang, C.Y., and Saltveit, M. (Eds.). The Commercial Storage of Fruits, Vegetables, and Florist and Nursery Stocks. Draft revised. USDA, ARS. Agricultural Handbook Number 66. Available at: http://www.ba.ars.usda.gov/hb66/082lemon.pdf.

Hagenmaier, R.D. (2000). Evaluation of a polyethylene-candelilla coating for 'Valencia' oranges. Postharvest Biology and Technology, 19, 147-154.

Hagenmaier, R.D. (2002). The flavor of mandarin hybrids with different coatings. Postharvest Biology and Technology, 24, 79-87. 
Hagenmaier, R.D. and Baker, R.A. (1994). Wax microemulsions and emulsions as citrus coatings. Journal of Agricultural and Food Chemistry, 42, 899-902.

Hagenmaier, R.D. and Shaw, P.E. (2002). Changes in volatile components of stored tangerines and other specialty Citrus fruits with different coatings. Journal of Food Science, 65, 1742-1745.

Hasegawa, S. and Miyake, M. (1996). Biochemistry and biological functions of citrus limonoids. Food Reviews International, 12, 413-435.

Hasegawa, S., Bennet, R.D., Herman, Z., Fong, C.H., Ou, P. (1989). Limonoid glucosides in citrus. Phytochemistry, 28, 1717-1724.

Henriod, R. E., Gibberd, M. R., Treeby, M. T. (2005). Storage temperature effects on moisture loss and the development of chilling injury in 'Lanes Late' navel orange. Australian Journal of Experimental Agriculture, 45(4), 453-458.

Henriod, R. E. (2006). Postharvest characteristics of navel orange following high humidity and low temperature storage and transport. Postharvest Biology and Technology, 42(1), 57-64.

Herman, Z., Fong, C.H., Ou, P., Hasegawa, S. (1990). Limonoid glucosides in orange juices by HPLC. Journal of Agricultural and Food Chemistry, 38, 18601861.

Herrera, A., Rodrigo, M.J., Gil, J., Zacarias, L. (2007). Ethylene stimulates emission of terpenoids and aliphatic esters in citrus fruits. In: Ramina, A., Chang, C., Giovannoni, J., Klee, H., Perata, P. and Woltering, E. (Eds.). Advances in Plant Ethylene Research: Proceeding of the 7 th International Symposium on the Plant Hormone Ethylene. Springer, Netherlands, pp. 257259.

Hinterholzer, A. and Schieberle, P. (1998). Identification of the most odouractive volatiles in fresh, hand-extracted juice of Valencia Late oranges by odour dilution techniques. Flavour and Fragrance Journal, 13, 49-55.

Houck, L.G., Jenner, J.F., Mackey, B.E. (1990). Seasonal variability of the response of desert lemons to rind injury and decay caused by quarantine cold treatments. Journal of Horticultural Science, 65, 611-617.

Huang, R., Xia, R., Hu, L., Lu, Y., Wang, M. (2007). Antioxidant activity and oxygen-scavenging system in orange pulp during fruit ripening and maturation. Scientia Horticulturae, 113, 166-172.

Huang, R., Xia, R., Lu, Y., Hu, L., Xu, Y. (2008). Effect of pre-harvest salicylic acid spray treatment on post-harvest antioxidant in the pulp and peel of 'Cara cara' navel orange (Citrus sinensis L. Osbeck). Journal of the Science of Food and Agriculture, 88, 229-236. 
Huang, Y.S. and Ho, S.C. (2010). Polymethoxyflavones are responsible for the anti-inflammatory activity of citrus fruit peel. Food Chemistry, 119, 868-873.

Iglesias, J.D., Cercós, M., Colmenero-Flores, J.M., Naranjo, M.A., Ríos, G., Carrera, E., Ruiz-Rivero, O., Lliso, I., Morillon, R., Tadeo, F.R., Talón, M. (2007). Physiology of citrus fruiting. Brazilian Journal of Plant Physiology, 19, 333-362.

Igual, M., García-Martínez, E., Camacho, M., Martínez-Navarrete, N. (2010). Effect of termal treatment and storage on the stability of organic acids and the functional value of grapefruit juice. Food Chemistry, 118, 291-299.

Ikoma, Y., Komatsu, A., Kita, M., Ogawa, K., Omura, M., Yano, M., Moriguchi, T. (2001). Expression of a phytoene synthase gene and characteristic carotenoid accumulation during citrus fruit development. Physiologia Plantarum, 111, 232-238.

I.V.I.A. (Instituto Valenciano de Investigaciones Agrarias) (2012). http://www.ivia.es. Retrieved: June 16, 2012.

Jackman, R. L., Yada, R. Y., Marangoni, A., Parkin, K. L., Stanley, D. W. (1988). Chilling injury. A review of quality aspects. Journal of Food Quality, 11, 253278.

Jacob-Wilk, D., Goldschmidt, E.E., Riov, J., Sadka, A., Holland, D. (1997). Induction of a citrus gene highly homologous to plant and yeast thi genes involved in thiamine biosynthesis during natural and ethylene-induced fruit maturation. Plant Molecular Biology, 35, 661-666.

Jacob-Wilk, D., Holland, D., Goldschmidt, E.E., Riov, J., Eyal, Y. (1999). Chlorophyll break-down by chlorophyllase: Isolation and functional expression of the Chlase 1 gene from ethylene-treated Citrus fruit and its regulation during development. The Plant Journal, 20, 653-661.

Jahn, O.L., Chace, W.G., Cubbedge, R.H. (1973). Degreening response of Hamlin oranges in relation to temperature, ethylene concentration, and fruit maturity. Journal of the American Society for Horticultural Science, 98, 177181.

Johnson, P.R. and Ecker, J.R. (1998). The ethylene gas signal transduction pathway: A molecular perspective. Annual Review of Genetics, 32, 227-254.

Kader, A.A. and Arpaia, M.L. (2002). Postharvest handling sistems: subtropical fruits. In Kader, A.A. (Ed). Postharvest tecnhology of horticultural crops. University of California, Publication 3311, pp. 375-378.

Kähkönen, M.P. and Heinonen, M. (2003). Antioxidant activity of anthocyanins and their aglycons. Journal of Agricultural and Food Chemistry, 51, 628-633. 
Kalaitzis. P., Koehler. S.M., Tucker, M.L. (1995). Cloning of tomato polygalacturonase expressed in abscission. Plant Molecular Biology, 28, 647656.

Kato, M., Ikoma, Y., Matsumoro, H., Sugiura, M., Hyodo, H., Yano, M. (2004). Accumulation of carotenoids and expression of carotenoid biosynthetic genes during maturation in citrus fruit. Plant Physiology, 134, 824-837.

Kaur, C. and Kapoor, H.C. (2001). Antioxidants in fruits and vegetables - the millennium's health. International Journal of Food Science and Technology, 36, 703-725.

Kawaii, S., Tomono, Y., Katase, E., Ogawa, K., Yano, M. (1999a). Antiproliferative activity of flavonoids on several cáncer cell lines. Bioscience, Biotechnology, and Biochemistry, 63, 896-899.

Kawaii, S., Tomono, Y., Katase, E., Ogawa, K., Yano, M. (1999b). Quantitation of flavonoid constituents in citrus fruits. Journal of Agricultural and Food Chemistry, 47, 3565-3571.

Kazokas, W.C. and Burns, J.K. (1998). Cellulase activity and gene expression in citrus fruit abscission zones during and after ethylene treatment. Journal of the American Society for Horticultural Science, 123, 781-786.

Ke, D. and Kader, A. (1990). Tolerance of 'Valencia' Oranges to Controlled Atmospheres, as Determined by Physiological Responses and Quality Attributes. Journal of the American Society for Horticultural Science, 115, 779-783.

Kelebek, H. (2010). Sugars, organic acids, phenolic compositions and antioxidant activity of Grapefruit (Citrus paradisi) cultivars grown in Turkey. Industrial Crops and Products, 32, 269-274.

Kelebek, H. and Selli, S. (2011). Determination of volatile, phenolic, organic acid and sugar components in Turkish cv. Dortyol (Citrus sinensis L. Osbeck) orange juice. J Journal of the Science of Food and Agriculture, 91, 1855-1862.

Kelebek, H., Canbas, A., Selli, S. (2008). Determination of phenolic composition and antioxidant capacity of blood orange juices obtained from cvs. Moro and Sanguinello (Citrus sinensis (L.) Osbeck) grown in Turkey. Food Chemistry, 107, 1710-1716.

Ladaniya, M.S. (2008). Citrus Fruit: biology, technology and evaluation. Academic Press, Elsevier, CA, U.S.A., 574 p.

Ladaniya, M.S. and Sonkar, R.K. (1996). Influence of Temperature and fruit maturity on 'Nagpur' mandarin (C. reticulata Blanco) in storage. The Indian Journal of Agricultural Sciences, 66, 109-113. 
Lafuente, M.T. and Sala, J.M. (2002). Abscisic acid and the influence of ethylene, humidity and temperature on the incidence of postharvest rindstaining of Navelina oranges (Citrus sinensis L. Osbeck) fruits. Postharvest Biology and Technology, 25, 49-57.

Lafuente, M.T. and Zacarias, L. (2006). Postharvest physiological disorders in citrus fruit. Stewart Postharvest Review, 1, 1-9.

Lafuente, M.T., Martinez-Téllez, M.A., González-Aguilar, G., Zacarías, L., Mulas, M. (1995). Physiological and biochemical responses associated with chilling sensitivity of "Fortune" mandarins and temperature conditioning. CIHEMOptions Mediterraneennes, 1, 125-134.

Lafuente, M.T., Zacarias, L., Martínez-Téllez, M.A., Sánchez-Ballesta. M.T., Dupille, E. (2001). Phenylalanine ammonia-lyase as related to ethylene in the development of chilling symptoms during cold storage of citrus fruits. Journal of Agricultural and Food Chemistry, 49, 6020-6025.

Lafuente, M.T., Zacarias, L., Martínez-Téllez, M.A., Sanchez-Ballesta, M.T., Granell, A. (2003). Phenylalanine ammonia-lyase and ethylene in relation to chilling injury as affected by fruit age in citrus. Postharvest Biology and Technology, 29, 308-317.

Lafuente, M.T., Sala., J.M., Zacarías, L. (2004). Active Oxygen Detoxifying Enzymes and Phenylalanine Ammonia-lyase in the ethylene-Induced Chilling Tolerance in Citrus Fruit. Journal of Agricultural and Food Chemistry, 52, 3606-3611.

Lafuente, M.T., Ballester, A.R., Calejero, J., Gonzalez-Candelas, L. (2011). Effect of high temperature-conditioning treatments on quality, flavonoid composition and vitamin $\mathrm{C}$ of cold stored 'Fortune' mandarins. Food Chemistry, 128, 1080-1086.

Lam, L.K.T., Zhang, J., Hasegawa, S. (1994). Inhibition of chemically induced carcinogenesis by citrus limonoids. In: Schut, H.A.J., Huang, M.T., Osawa, C.T.H. and Rosen, R.T. (Eds.). Phytochemicals for cancer prevention. American Chemical Society, Washington, DC, U.S.A., 546, 209-219.

Lee, H.S. and Castle, W.S. (2001). Seasonal changes of carotenoid pigments and color in Hamlin, Earlygold, and Budd Blood orange juices. Journal of Agricultural and Food Chemistry, 49, 877-882.

Lee, S.K. and Kader, A.A. (2000). Preharvest and postharvest factors influencing vitamin $\mathrm{C}$ content of horticultural crops. Postharvest Biology and Technology, 20, 207-220

Lelièvre, J.M., Latché, A., Jones, B., Bouzayen, M., Pech, J.C. (1997). Ethylene and fruit ripening. Physiologia Plantarum, 101, 727-739. 
Lester, G.E., Manthey, J.A., Buslig, B.S. (2007). Organic vs conventionally grown Rio Red whole grapefruit and juice: Comparison of production inputs, market quality, consumer acceptance, and human health-bioactive compounds. Journal of Agricultural and Food Chemistry, 55, 4474-4480.

Leuzzi, U., Caristi, C., Panzera, V., Licandro, G. (2000). Flavonoids in pigmented orange juice and second-pressure extracts. Journal of Agricultural and Food Chemistry, 48, 5501-5506.

Li, S., Sang, S., Pan, M. H., Lai, C. S., Lo, C. Y., Yang, C. S., Ho, C. T. (2007) Antiinflammatory property of the urinary metabolites of nobiletin in mouse Bioorganic \& Medicinal Chemistry Letters, 17, 5177-5181.

Lo Piero, A.R., Puglisi, I., Rapisarda, P., Petrone, G. (2005). Anthocyanins accumulation and related gene expression in red orange fruit induced by low temperature. Journal of Agricultural and Food Chemistry, 53, 9083-9088.

Loussert, R. (1992). Los agrios. Mundi-Prensa, Madrid, Spain, 319 p.

Lyons, J. M. (1973). Chilling injury in plants. Annual Reviez of Plant Physiology, 24, 445-466.

Maccarone, E., Rapisarda, P., Fanella, F., Arena, E., Mondello, L. (1998). Cyanidin-3-(600-malonyl)-b-glucoside. One of the major anthocyanins in blood orange juice. Italian Journal of Food Science, 4, 367-372.

MAGRAMA (Ministerio de Agricultura, Alimentación y Medio Ambiente). (2012). Avances de superficies y producciones de cultivos. Julio de 2012. Retrieved August 21, 2012 from: http://www.marm.es/es/estadistica.

MAGRAMA (Ministerio de Agricultura, Alimentación y Medio Ambiente). (2010). Anuario de Estadística 2010. Retrieved June 26, 2012 from: http://www.marm.es/es/estadistica.

Mahattanatawee, K., Rouseff, R., Valim, M.F., Naim, M. (2005). Identification and Aroma Impact of Norisoprenoids in Orange Juice. Journal of Agricultural and Food Chemistry, 53, 393-397.

Maier, V.P., Brewster, L.C., Hsu, A.C. (1973). Ethylene-Accelerated Limonoid Metabolism in Citrus Fruits: A Process for Reducing Juice Bitterness. Journal of Agricultural and Food Chemistry, 21, 490-495.

Malik, A.U., Agrez, V., Singh, Z. (2003). Fruitlet abscission of mango in relation to ethylene. The Journal of Horticultural Science and Biotechnology, 784, 458462.

Mandalari, G., Bennett, R.N., Bisignano, G., Trombetta, D., Saija, A., Faulds, C.B., Gasson, M.J., Narbad, A. (2007). Antimicrobial activity of flavonoids extracted from bergamot (Citrus bergamia Risso) peel, a byproduct of the essential oil industry. Journal of Applied Microbiology, 103(6), 2056-2064. 
Manners, G.D. (2007). Citrus limonoids: analysis, bioactivity, and biomedical prospects. Journal of Agricultural and Food Chemistry, 55, 8285-8294.

Marangoni, A.G., Palma, T., Stanley, D.W. (1996). Membrane effects in postharvest physiology. Postharvest Biology and Technology, 7(3), 193-217.

Mares-Perlman, J.A., Millen, A.E., Ficek, T.L., Hankinson, S.E. (2002). The body of evidence to support a protective role for lutein and zeaxanthin in delaying chronic disease. Journal of Nutrition, 132, 518S-524S.

Marini, D. and Balestrieri, F. (1995). Multivariate analysis of flavanone glycosides in citrus juices. Italian Journal of Food Science, 7, 255-264.

Markhart, A.H. (1989). Chilling injury: A review of possible causes. HortScience, $21,1329-1333$.

Martinez-Jávega, J.M., Monterde, A., Navarro, P., Salvador, A. (2008). Response of new clementines to degreening treatment. Proceeding of the International Society of Citriculture, 11, 1342-1346.

Martínez-Jávega, J.M., Saucedo, C., Del Rio, M.A., Mateos, M. (1992). Influence of storage temperatura and coating on the keeping quality of 'Fortune' mandarins. Proceeding of the International Society of Citriculture, 1102-1103.

Martínez-Jávega, J.M., Navarro, P., Cuquerella, J., del Rio, M.A. (1999) Aplicaciones del frío en postcosecha de cítricos: panorama actual. Levante Agricola-Especial Postcosecha, 348, 253-262.

Maruthasalam, S., Shiu, L.Y., Loganathan, M., Lien, W.C., Liu, Y.L., Sun, C.M., Yu, C.W., Hung, S.H., Ko, Y., Lin, C.H. (2010). Forced flowering of pineapple (Ananas comosus cv. Tainon 17) in response to cold stress, etephon and calcium carbide with or without activated charcoal. Plant Growth Regulation, 62, 83-90.

Matsumoto, H., Ikoma, Y., Kato, M., Kuniga, T., Nakajima, N., Yoshida, T. (2007). Quantification of carotenoids in citrus fruit by LC-MS and comparison of patterns of seasonal changes for carotenoids among citrus varieties. Journal of Agricultural and Food Chemistry, 55, 2356-2368.

Matsumoto, H., Ikoma, Y., Kato, M., Nakajima, N., Hasegawa, Y. (2009). Effect of Postharvest Temperature and Ethylene on Carotenoid Accumulation in the Flavedo and Juice Sacs of Satsuma Mandarin (Citrus unshiu Marc.) Fruit. Journal of Agricultural and Food Chemistry, 57, 4724-4732.

McCollum, T.G. and McDonald, R.E. (1991). Electrolyte leakage, respiration, and ethylene as indices of chilling injury in grapefruit. HortScience, 26, 1191-1192. 
Miller, E.G., Gonzales-Sanders, A.P., Couvillon, A.M., Wright, J.M., Hasegawa, S., Lam, L.K.T. (1992). Inhibition of hamster buccal pouch carcinogenesis by limonin 17-B-D-glucopyranoside. Nutrition and Cancer, 17, 1-7.

Miller, E.G., Porter, J.L., Binnie, W.H., Guo I.Y., Hasegawa, S. (2004). Further studies on the anticancer activity of citrus limonoids. Journal of Agricultural and Food Chemistry, 52, 4908-4912.

Miyazaki, T., Plotto, A., Baldwin, E.A., Reyes-De-Corcuera, J., Gmitter Jr, F.G. (2012). Aroma characterization of tangerine hybrids by gas-chromatographyolfactometry and sensory evaluation. Journal of the Science of Food and Agriculture, 92, 727-735.

Miyazaki, T., Plotto, A., Goodner, K., Gmitter, Jr F.G. (2010). Distribution of aroma volatile compounds in tangerine hybrids and proposed inheritance. Journal of the Science of Food and Agriculture, 91, 449-460.

Mouly, P.P., Arzouyan, C.R., Gaydou, E.M., Estienne, J.M. (1994). Differentiation of citrus juices by factorial discriminant analysis using liquid chromatography of flavanone glycosides. Journal of Agricultural and Food Chemistry, 42, 70-79.

Mouly, P.P., Gaydou, E.M., Lapierre, L., Corsetti, J. (1999). Differentiation of several geographical origins in single strength Valencia orange juices using quantitative comparison of carotenoid profiles. Journal of Agricultural and Food Chemistry, 47, 4038-4045.

Mullins, E.D., McCollum, T.G., McDonald, R.E. (2000). Consequences on ethylene metabolism of inactivating the ethylene receptor sites in diseased non-climacteric fruit. Postharvest Biology and Technology, 19, 155-164.

Murakami, A., Nakamura, Y., Torikai, K., Tanaka, T., Koshiba, T., Koshimizu, K., Kuwahara, S., Takahashi, Y., Ogawa, K., Yano, M., Tokuda, H., Nishino, H., Mimaki, Y., Sashida, Y., Kitanaka, S., Ohigashi, H. (2000). Inhibitory effect of citrus nobiletin on phorbol ester-induced skin inflammation, oxidative stress, and tumor promotion in mice. Cancer Research, 60, 50595066.

Narisawa, T., Fukaura, Y., Oshima, S., Inakuma, T., Yano, M., Nishino, H. (1999). Chemoprevention by the oxygenated carotenoid beta-cryptoxanthin of N-methylnitrosourea-induced colon carcinogenesis in F344 rats. Japanese Journal of Cancer Research, 90, 1061-1065.

Natella, F., Nardini, M., Di Felice, M., Scaccini, C. (1999). Benzoic and cinnamic acid derivatives as antioxidants structure-activity relation. Journal of Agricultural and Food Chemistry, 47, 1453-1459. 
Navarro, J.M., Perez-Perez, J.G., Romero, P., Botia, P. (2010). Analysis of the changes in quality in mandarin fruit, produced by deficit irrigation treatments. Food Chemistry, 119, 1591-1596.

Navarro, L., Juárez, J., Aleza, P., Pina, J.A., Olivares-Fuster, O., Cuenca, J., Julve, J.M. (2005). Programa de obtención de híbridos triploides de mandarino en España. Phytoma, 170, 36-41.

Nogata, Y., Sakamoto, K., Shiratsuchi, H., Ishii, T., Yano, M., Ohta, H. (2006). Flavonoid composition of fruit tissues of Citrus species. Bioscience Biotechnology and Biochemistry, 70, 178-192.

Obenland, D., Collin, S., Mackey, B., Sievert, J., Fjeld, K., Arpaia, M.L. (2009). Determinants of flavor acceptability during the maturation of navel oranges. Postharvest Biology and Technology, 52, 156-163.

Obenland, D., Collin, S., Sievert, J., Fjeld, K., Doctor, J., Arpaia, M.L. (2008). Commercial packing and storage of navel oranges alters aroma volatiles and reduces flavor quality. Postharvest Biology and Technology, 47, 159-167.

Obenland, D., Collin, S., Mackey, B., Sievert, J., Arpaia, M.L. (2011). Storage temperature and time influences sensory quality of mandarins by altering soluble solids and aroma volatile composition. Postharvest Biology and Technology, 59, 187-193.

Ozaki, Y., Fong, C.H., Herman, Z., Maeda, H., Miyake, M., Ifuku, Y., and Hasegawa, S. (1991). Limonoid glucosides in citrus seeds. Agricultural Biology and Chemistry, 55, 137-141.

Pailly, O., Tison, G., Amouroux, A. (2004). Harvest time and storage conditions of 'Star ruby' grape fruit (Citrus paradise Macf) for short distance summer consumption. Postharvest Biology and Technology, 34, 65-73.

Palma, A., D`Aquino, S., Agabbio, M., Schirra, S. (2005). Changes in flavonoids, ascorbic acid, polyphenol content and antioxidant activity in cold stored 'Fortune' Mandarin. Acta Horticulturae, 682, 617-622.

Patil, B.S., Vanamal, J., Hullman, G. (2004). Irradiation and storage influence on bioactive components and quality of early and late season 'Rio Red' grapefruit (Citrus parasidi Macf.). Postharvest Biology and Technology, 34, 53-64.

Patterson, S.E. and Bleecker, A.B. (2004). Ethylene-dependent and independent processes associated with floral organ abscission in Arabidopsis. Plant Physiology, 134, 194-203.

Patterson, S.E., (2001). Cutting Loose. Abscission and Dehiscence in Arabidopsis. Plant Physiology, 126, 494-500. 
Paull, R.E. (1990). Chilling injury of crops of tropical and subtropical origin. In: wang, C.Y. (Ed.). Chilling Injury of Horticultural Crops. CRC Press, Boca Raton, Florida, U.S.A., pp. 17-36.

Pérez-Cacho, P.R. and Rouseff, R.L. (2008). Processing and storage effects on orange juice aroma: a review. Journal of Agricultural and Food Chemistry, 48, 681-695.

Pérez, A.G., Luaces, P., Oliva, J., Ríos, J.J., Sanz, C. (2005). Changes in vitamin $\mathrm{C}$ and flavour components of mandarin juice due to curing of fruits. Food Chemistry, 91, 19-24.

Peterson, J.J., Dwyer, J.T., Beecher, G.R., Bhagwat, S.A., Gebhardt, S.E., Haytowitz, D.B., Holden, J.M. (2006). Flavanones in oranges, tangerines (mandarins), tangors, and tangelos: a compilation and review of the data from the analytical literature. Journal of Food Composition and Analysis, 19, S66-S73.

Petracek, P.D. and Montalvo, L. (1997). The degreening of 'Fallglo' tangerine. Journal of the American Society for Horticultural Science, 122, 547-552.

Petracek, P.D., Montalvo, L., Dou, H., Davis, C. (1998). Postharvest pitting of 'Fallglo' tangerine. Journal of the American Society for Horticultural Science, 123, 130-135.

Plaza, L., Crespo, I., de Pascual-Teresa, S., de Ancos, B., Sánchez-Moreno, C., Muñoz, M., Cano, M.P. (2011). Impact of minimal processing on orange bioactive compounds during refrigerated storage. Food Chemistry, 124, 646651.

Plaza, P., Sanbruno, A., Usall, J., Lamarca, N., Torres, R., Pons, J., Vinas, I. (2004). Integration of curing treatments with degreening to control the main postharvest diseases of clementine mandarins. Postharvest Biology and Technology, 34, 29-37.

Plotto, A., Margaria, C.A., Goodner, K.L., Baldwin, E.A. (2008). Odour and flavor thresholds for key aroma components in an orange juice matrix: esters and miscellaneous compounds. Flavour and Fragrance Journal, 23, 398-406.

Porat, R., Weiss, B., Cohen, L., Daus, A., Goren, R., Droby, S. (1999). Effects of ethylene and 1-methylcyclopropene on the postharvest qualities of 'Shamouti' oranges. Postharvest Biology and Technology, 15, 155-163.

Porat, R., Weiss, B., Cohen, L., Daus, A., Aharoni, N. (2004). Reduction of postharvest rind disorders in citrus fruit by modified atmosphere packaging. Postharvest Biology and Technology, 33, 35-43.

Pozo, L., Yuan, R., Kostenyuk, I., Alferez, F., Zhong, G.Y., Burns, J.K. (2004). Differential effects of 1-methylcyclopropene on citrus leaf and mature fruit 
abscission. Journal of the American Society for Horticultural Science, 129, 473-478.

Proteggente, A. R., Saija, A., de Pasquale, A., Rice-Evans, C. A. (2003) The Compositional Characterization and Antioxidant Activity of Fresh Juices from Sicilian Sweet Orange (Citrus sinensis L. Osbeck) Varieties. Free Radical Research, 37, 681-687.

Pulido, R., Bravo, L., Saura-Calixto, F. (2000). Antioxidant Activity of Dietary Polyphenols As Determined by a Modified Ferric Reducing/Antioxidant Power Assay. Journal of Agricultural and Food Chemistry, 48, 3396-3402.

Purvis, A.C. (1980). Influence of canopy depth on susceptibility of 'Marsh' grapefruit to chilling injury. HortScience, 15(6), 31-733.

Purvis, A.C. and W. Grierson. (1982). Accumulation ofreducing sugar and resistance of grapefruit peel to chilling injury as related to winter temperatures. Journal of the American Society for Horticultural Science, 107(1), 139-142.

Purvis, A.C. and Yelenosky, G. (1993). Inducible chilling injury of Grapefruit on Trees. HortTechnology, 3(1), 68-69.

Qiao, Y., Xie, B.J., Zhang, Y., Zhang, Y., Fan, G., Yao, X.L., Pan, S.Y. (2008) Characterization of aroma active compounds in fruit juice and peel oil of Jinchen sweet orange fruit (Citrus sinensis (L.) Osbeck) by GC-MS and GC-O. Molecules, 13, 1333-1344.

Raison, J.K. and Orr, G.R. (1990). Proposals for a better understanding of the molecular basis of chilling injury. In: Wang, C.Y. (Ed.). Chilling Injury of Horticultural Crops. CRC Press, Boca Raton, Florida, U.S.A., pp. 145-164.

Rapisarda, P., Bellomo, S. E., Intrigliolo, F. (2001b). Anthocyanins in blood oranges: Composition and biological activity. In: Pandalai, S.G. (Ed.). Recent research developments in agricultural and food chemistry. Research Signpost, Trivandrum, India, Vol 5, pp, 217-230.

Rapisarda, P., Bellomo, S.E., Intelisano, S. (2001a). Storage temperature effects on blood orange fruit quality. Journal of Agricultural and Food Chemistry, 49, 3230-3235.

Rapisarda, P., Tomaino, A., Lo Cascio, R., Bonina, F., De Pasquale, A., Saija, A. (1999). Antioxidant effectiveness as influenced by phenolic content of fresh orange juices. Journal of Agricultural and Food Chemistry, 47, 4718-4723.

Rapisarda, P., Lo Bianco, M., Pannuzzo, P., Timpanaro, N. (2008). Effect of cold storage on vitamin $\mathrm{C}$, phenolics and antioxidant activity of five orange genotypes [Citrus sinensis (L.) Osbeck]. Postharvest Biology and Technology, $49,348-354$ 
Rega, B., Fournier, N., Guichard, E. (2003). Solid phase microextraction (SPME) of orange juice flavor: odor representativeness by direct gas chromatography olfactometry (D-GC-O). Journal of Agricultural and Food Chemistry, 51, 70927099.

Rice-Evans, C.A., Miller, N.J., Paganga, G. (1996). Structure-antioxidant activity relationships of flavonoids and phenolic acids. Free Radical Biology and Medicine, 20, 933-956.

Riov, J. and Yang, S.F. (1982). Autoinhibition of ethylene production in citrus peel discs. Plant Physiology, 69, 687-690.

Ritenour, M.A., Miller, W.M., Wardowski, W.W. (2003). Recommendations for Degreening Florida Fresh Citrus Fruits. Circular 1170. Horticultural Sciences Department, Florida Cooperative Extension Service, IFAS, University of Florida, Gainesville.

Rodrigo, M. J. and Zacarias, L. (2007). Effect of postharvest ethylene treatment on carotenoid accumulation and the expression of carotenoid biosynthetic flavedo of orange (Citrus sinensis L. Osbeck) fruit. Postharvest Biology and Technology, 43, 14-22.

Rodrigo, M.J., Marcos, J.F., Zacarias, L. (2004). Biochemical and molecular analysis of carotenoid biosynthesis in flavedo of orange (Citrus sinensis L.) during fruit development and maturation. Journal of Agricultural and Food Chemistry, 52, 6724-6731.

Rouseff, R. (2010). Citrus Flavor and Color website. University of Florida, USA. (www.crec.ifas.ufl.edu/crec_websites/Rouseff/) (Accessed 18 May 2012).

Rouseff, R.L., Pérez-Cacho, P.R., Jabalpurwala, F. (2009). Historical review of Citrus flavor research during the past 100 years. Journal of Agricultural and Food Chemistry, 57, 8115-8124.

Rousseff, R.L., Martin, S.F., Youtsey, C.O. (1987). Quantitative survey of narirutin, naringin, hesperidin and neohesperidin in citrus. Journal of Agricultural and Food and Chemistry, 35,1027-1030.

Roy, A. and Saraf, S. (2006). Limonoids: Overview of significant bioactive triterpenes distributed in plants kingdom. Biological and Pharmaceutical Bulletin, 29,191-201.

Safizadeh, M.R., Rahemi, M., Aminlari, M. (2007). Effect of postharvest calcium and hot-water dip treatments on catalase, peroxidase and superoxidase dismutase in chilled Lisbon lemon fruit. International journal of Agricultural Reasearch, 2, 440-449.

Sala, J.M. (1998). Involvement of oxidative stress in chilling injury in cold stored mandarin fruits. Postharvest Biology and Technology, 13, 255-261. 
Sala, J.M. and Lafuente M.T. (2004). Antioxidant enzymes activities and rindstaining in 'Navelina' oranges as affected by storage relative humidity and ethylene conditioning. Postharvest Biology and Technology, 31, 277-285.

Sala, J.M. and Lafuente, M.T. (1999). Catalase in the heat-induced chilling tolerance of cold-stored hybrid "Fortune" mandarin fruits. Journal of Agricultural and Food Chemistry, 47, 2410-2414.

Salah, N., Miller, N.J., Paganga, G., Tijburg, L., Bolwell, G.P., Rice-Evans, C. (1995). Polyphenolic flavonols as scavenger of aqueous phase radicals and as chain-breaking antioxidants. Archives of Biochemistry and Biophysics, 2, 339-346.

Saltveit, M.E. (1999). Effect of ethylene on quality of fresh fruits and vegetables. Postharvest Biology and Technology, 15, 279-292.

Saltveit, M.E. and Morris, L.L. (1990). Overview on chilling injury of horticultural crops. In: Wang, C.Y. (Ed.). Chilling Injury of Horticultural Crops. CRC Press, Boca Raton, Florida, U.S.A., pp, 3-15.

Salvador, A., Navarro, P., Monterde, A., Martínez-Jávega., J.M. (2008). Postharvest application of auxins to control calyx senescence in clementines submitted to degreening treatment. Proceeding of the International Society of Citriculture, 11, 1377-1382.

Salvador, A., Sdiri, S., Navarro, P., Monterde, A., Marténez-Jávega, J.M. (2010). The use of auxins to maintain postharvest quality of citrus fruit. Acta Horticulturae, 877, 671-677.

Schirra, M. and Cohen, E. (1999). Long-term storage of 'Olinda' oranges under chilling and intermittent warming temperatures. Postharvest Biology and Technology, 16, 63-69.

Schirra, M., Cabras, P., D’allewin, G., Angioni, A., Garau, V.L. (1998). Seasonal susceptibility to chilling injury of 'Tarocco' oranges as affected by hot water and thiabendazole postharvest dip treatments. Journal of Agricultural and Food Chemistry, 46, 1177-1180.

Schirra, M., D'hallewin, G., Cabras, P., Angioni, A., Ben-Yehoshua, S. \& Lurie, S. (2000). Chilling injury and residue uptake in cold stored 'Star Ruby' grapefruit following thiabendazole and imazalil dip treatments at 20 and $50^{\circ} \mathrm{C}$. Postharvest Biology and Technology, 20, 91-98.

Sdiri, S., Navarro, P., Monterde, A., Benabda, J., Salvador, A. (2012b). Effect of postharvest degreening followed by a cold-quarantine treatment on vitamin $\mathrm{C}$, phenolic compounds and antioxidant activity of early-season citrus fruit. Postharvest Biology and Technology, 65, 13-21.

Sdiri, S., Monterde, A., Benabda, J., Rojas, C., Salvador, A. (2008). Effect of postharvest heat treatments on vitamin $\mathrm{C}$ content and quality of 'Fortune' 
mandarin (Citrus reticulata, Blanca). Proceeding of the International Society of Citriculture, 11, 1351-1355.

Sdiri, S., Navarro, P., Salvador, A. (2012a). Antioxidant Activity and Vitamin C Are Not Affected by Degreening Treatment of Clementine Mandarins. Acta Horticulturae, 934, 893-899.

Selli, S. and Kelebek, H. (2011). Aromatic profile and odour-activity value of blood orange juices obtained from Moro and Sanguinello (Citrus sinensis L. Osbeck). Industrial Crops and Products, 33, 727-733.

Serrano, M., Martinez Madrid, M.C., Martinez, G., Riquelme, F., Pretel, M.T., Romojaro, F. (1996). Review: Role of polyamines in chilling injury of fruit and vegetables. Food Science and Technology International, 2, 195-199.

Sevillano, L., Sanchez-Ballesta, M.T., Romojaro, F., Flores, F.B. (2009). Physiological, hormonal and molecular mechanisms regulating chilling injury in horticultural species. Postharvest technologies applied to reduce its impact. Journal of the Science of Food and Agriculture, 89, 555-573.

Shimokawa, K., Shimade, S., Yaeo, K. (1978). Ethylene-enhanced chlorophyllase activity during degreening of Citrus unshiu Marc. Scientia Horticulturae, 8, 129-135.

Smilanick, J.L., Mansour, M.F., Sorenson, D. (2006). Pre- and Postharvest Treatments to Control Green Mold of Citrus Fruit During Ethylene Degreening. Plant Disease, 90, 89-96.

So, F.V., Guthrie, N., Chambers, A.F., Moussa, M., Carroll, K.K. (1996.) Inhibition of human breast cancer cell proliferation and delay of mammary tumerogenesis by flavonoids and citrus juices. Nutrition and Cancer, 25, 167181.

Sonkar, R.K., Ladaniya, M.S., Shyam Singh. (1999). Effect of harvesting methods and postharvest treatments on storage behavior of Nagpur mandarin (Citrus reticulata) fruit. The Indian Journal of Agricultural Sciences, 69, 434-437.

Sousa, W.R., da Rocha, C., Cardoso, C.L., Silva, D.H.S., Zanoni, M.V.B. (2004). Determination of the relative contribution of phenolic antioxidants in orange juice by voltammetric methods. Journal of Foof Composition and Analysis, $17,619-633$.

Stewart, I. and Wheaton, T.A. (1972). Carotenoids in citrus: Their accumulation induced by ethylene. Journal of Agricultural and Food Chemistry, 20, 448449.

Storey, R. and Treeby, M.T. (2002). Cryo-SEM study of the early symptoms of peteca in Lisbon lemon. Journal of Horticultural Science and Biotechnology, $77,551-556$. 
Suzuki, M., Sasaki, K., Yoshizaki, F., Fujisawa, M., Oguchi, K., Cyong, J.C. (2005). Anti-hepatitis C virus effect of citrus unshiu peel and its active ingredient nobiletin. American Journal of Chinese Medicine, 33, 87-94.

Takahashi, A., Takeda, K., Ohnishi, T. (1991). Light-induced anthocyanin reduces the extent of damage to DNA in UV-irradiated Centaurea cyanus cells in culture, Plant and Cell Physiology, 32, 541-547.

Tanaka, T., Kohno, H., Murakami, M., Shimada, R., Kagami, S., Sumida, T., Azuma, Y., Ogawa, H. (2000a). Suppression of azoxymethaneinduced colon carcinogenesis in male F344 rats by mandarin juices rich in betacryptoxanthin and hesperidin. International Journal of Cancer, 88, 146-150.

Tanaka, T., Kohno, H., Tsukio, Y., Honjo, S., Tanino, M., Miyake, M., Wada, K. (2000b). Citrus limonoids obacunone and limonin inhibit azoxymethaneinduced colon carcinogenesis in rats. Biofactors, 13, 213-218.

Tanaka, T., Maeda, M., Kohno, H., Murakami, M., Kagami, S., Miyake, M., Wada, K. (2001). Inhibition of azoxymethane-induced colon carcinogenesis in male F344 rats by the citrus limonoids obacunone and limonin. Carcinogenesis, 22, 193-198.

Tatli, H. and Ozguven, A.I. (1999). The effect of some growth regulator treatments on the storage of Valencia. Turkish Journal of Agriculture and Forestry, 5, 1033-1042.

Taylor, J.E. and Whitelaw, C.A. (2001). Signals in abscission. New Phytologist, $15,323-339$

Tietel, Z., Porat, R., Weiss, K., Ulrich, D. (2011). Identification of aroma-active compounds in fresh and stored 'Mor' mandarins. International Journal of Food Science and Technology, 46, 2225-2231.

Toivonen, P.M.A. and Hodges, D.M. (2011). Abiotic Stress in Harvested Fruits and Vegetables. In: Shanker, A. and Venkateswarlu, B. (Eds.). Abiotic Stress in Plants - Mechanisms and Adaptations. InTech, Rijeka, Croatia, pp. 39-58.

Trebitsh, T., Goldschmidt, E.E., Riov, J. (1993). Ethylene induces de novo synthesis of chlorophyllase, a chlorophyll degrading enzyme, in Citrus fruit peel. Proceeding of the National Academy of Sciences, 90, 9441-9445.

Tripoli, E., La Guardia, M., Giammanco, S., Di Majo, D., Giammanco, M. (2007). Citrus flavonoids: Molecular structure, biological activity and nutritional properties: A review. Food Chemistry, 104, 466-479.

Trumbo, P.R., and Ellwood, K.C. (2006). Lutein and zeaxanthin intakes and risk of age-related macular degeneration and cataracts: An evaluation using the Food and Drug Administration's evidence-based review system for health claims. The American Journal of Clinical Nutritin, 84(5), 971-974. 
Tucker, M.L., Baird, S.L., Sexton, R. (1991). Bean leaf abscission: tissue specific accumulation of a cellulase mRNA. Planta, 186, 52-57.

Tugwell, B. (1999). A Citrus Handling Guide. Adelaide, South Australian Research and Development Institute, Australia.

Tuset, J.J., Garcia, J., Hinarejos, C. (1988). Effect of intermittent Degreening Method on Decay of Satsuma Mandarin. In: Goren, R. and Mendel, K. (Eds.). Proceeding of the Sixth International Citrus Congress, pp. 1461-1465.

Uckoo, R.M., Jayaprakasha, G.K., Nelson, S.D., Patil, B.S. (2011). Rapid simultaneous determination of amines and organic acids in citrus using high-performance liquid chromatography. Talanta, 83, 948-954.

Underhill, S.J.R., McLauchlan, R.L., Eaks, I.L. (1995). 'Eureka' lemon chilling injury. HortScience, 30, 309-312.

Undurraga, P., Olaeta, J.A., Luttges, C., Suárez, R. (2002). Efectos del calibre y madurez de limones cv. Fino 49, sobre el desarrollo de peteca en almacenaje refrigerado. Simiente, 72, 35-40.

Undurraga, P., Olaeta, J.A., Retamales, J.B., Brito, A. (2006). Efecto de inmersiones en calcio sobre peteca en limones amarillos y plateados, cosechados después de una lluvia y almacenados en refrigeración. Agricultura Técnica (Chile), 66, 3-12.

Undurraga, P., Olaeta, J.A., Retamales, J.B., Toso, A.M. (2007). Manifestation of peteca and fruit quality loss in Eureka lemon under different cold storage conditions. Agrociencia, 41, 133-139.

Undurraga, P., Olaeta, J.A., Retamales, J.B., Escobar, J., Toso, A.M. (2009). Effect of maturity and storage temperature on the development of peteca in lemons (Citrus limon (L.) Burm. F.) cv. Eureka. Scientia Horticulturae, 122, $56-61$

USDA-APHIS United States Department of Agriculture Agriculture-Animal Plant Health Inspection Service. (2002). Importation of Clementines from Spain final rule. Federal Register, 67, 64701-64739.

Van, Wyk, A.A., Huysamer, M., Barry, G.H. (2009). Extended low-temperature shipping adversely affects rind colour of 'Palmer Navel' sweet orange [Citrus sinensis (L.) Osb.] due to carotenoid degradation but can partially be mitigated by optimising post-shipping holding temperature. Postharvest Biology and Technology, 53, 109-116.

Vendrell, M. and Lara, I. (2003). Relationship between ABA and ethylene in the induction of fruit ripening. In: Vendrell, M., Klee, H., Pech, J.C. and Romojaro, F. (Eds.). Biology and Biotechnology of the Plant Hormone Ethylene III, IOS Press, Murcia, Spain, pp. 278-283. 
Voutilainen, S., Nurmi, T., Mursu, J., Rissanen, T.H. (2006). Carotenoids and cardiovascular health. American Journal of Clinical Nutrition, 83, 1265-1271.

Walle, T. (2007). Methoxylated flavones, a superior cancer chemopreventive flavonoid subclass? Seminars in Cancer Biology, 17, 354-362.

Wang, H., Cao, G., Prior, R. L. (1997). Oxygen radical absorbing capacity of anthocyanins. Journal of Agricultural and Food Chemistry, 45, 304-309.

Wang, H., Cao, G.H., Prior, R.L. (1996). Total antioxidant capacity of fruits. Journal of Agricultural and Food Chemistry, 44, 701-705.

Wang, Y.C., Chuang, Y.C., Ku, Y.H. (2007). Quantitation of bioactive compounds in citrus fruits cultivated in Taiwan. Food Chemistry, 102, 11631171.

Wardowski, W., Nagy, S., Grierson, W. (1986). Fresh citrus fruits. Wesport, Conn. AVI Publishing Co., 571 p.

Wild, B.L. (1990). Ethylene gas burn of Washington navel oranges - a form of anthracnose induce by degreening and controlled by brushing or applying fungicides. Australian Journal of Experimental Agriculture, 30, 565-568.

Wild, B.L. (1991). Postharvest factors governing the development of peteca rind pitting on 'Meyer' lemons. HortScience, 26, 287-289.

Wills, R.B.H. and Warton, M.A. (2000). A new rating scale for ethylene action on postharvest fruit and vegetables. In: Artes, F., Gil, M.I. and Conesa, M.A. (Eds.). Improving Postharvest Technologies of Fruits, Vegetables and Ornamentals, IIR Conference, Murcia, pp. 43-47.

Wills, R.B.H., Warton, M.A., Mussa, D.M.D.N., Chew, L.P. (2001). Ripening of climacteric fruits initiated at low ethylene levels. Australian Journal of Experimental Agriculture, 41, 89-92

Wills, R.B.H., Ku, V.V.V., Shohet, D., Kim, G.H. (1999). Importance of low ethylene levels to delay senescence of non-climacteric fruit and vegetables. Australian Journal of Experimental Agriculture, 39, 221-224.

Winterhalter, P. and Rouseff, R.L. (2002). Carotenoid-Derived aroma compounds: An introduction. ACS Symposium Series, 802, 1-17.

Yuen, C.M., Tridjaja, N.O., Wills, R.B.H., Wild, B.L. (1995). Cilling injury development of 'Tahitian' lime, 'Emperor' mandarin, 'Marsh' grapefruit and 'Valencia' orange. Journal of the Science of Food and Agriculture, 67, 335339.

Zhang, J.X. (2007). The potential of a new fungicide fludioxonil for stem-end rot and green mold control on Florida citrus fruit. Postharvest Biology and Technology, 46, 262-270. 

II.OBJECTIVES 

II.1. POSTHARVEST DEGREENING OF EARLY-SEASON CITRUS FRUIT

\section{GENERAL OBJECTIVES}

1.- To improve the quality of early season citrus fruit submitted to postharvest degreening by controlling physiological disorders associated to exogenous ethylene exposure.

2.- To evaluate the effect of ethylene application during postharvest degreening on nutritional composition and volatile compounds of early season citrus fruit.

\section{SPECIFIC OBJECTIVES}

1.- To evaluate the effect of new degreening treatments combining different periods with and without ethylene exposure on quality of citrus fruit exported to USA market.

2.- To study the effect of postharvest application of a new growth regulator on calyx disorders induced by degreening treatment in citrus fruit.

3.- To investigate the changes on nutritional quality of citrus fruit subjected to postharvest degreening.

4.- To study the changes on volatile organic compounds of early-season citrus fruit submitted to degreening without or with ethylene exposure.

\section{II.2. POSTHARVEST BEHAVIOR OF NEW TRIPLOIDS MANDARINS}

\section{GENERAL OBJECTIVES}

1.- To characterize the fruit quality of the new late maturing triploids mandarins obtained in the IVIA and to study their postharvest behavior. 
Objectives

\section{SPECIFIC OBJECTIVES}

1.- To determine the internal quality attributes and health-promoting properties of the new citrus cultivars comparing to those of their parents. 2.- To study the aptitude of the new citrus cultivars for cold storage, evaluating their susceptibility to low temperature. 


\section{RESULTS AND DISCUSSION}





\section{III.1. POSTHARVEST DEGREENING OF EARLY-SEASON CITRUS FRUIT}





\section{New degreening treatments to improve the quality of citrus fruit combining different periods with and without ethylene exposure}

Sawsen Sdiri ${ }^{a}$, Pilar Navarro ${ }^{\mathrm{a}}$, Adela Monterde ${ }^{\mathrm{a}}$, Jameleddine Benabda $^{\mathrm{b}}$, Alejandra Salvador ${ }^{\mathrm{a}}$

\footnotetext{
${ }^{a}$ Centro de Tecnología Postcosecha, Instituto Valenciano de Investigaciones Agrarias, Carretera Moncada-Náquera Km 4.5 s/n, 46113, Moncada, Valencia, Spain

b Département d'Agroalimentaire, Institut Supérieur Agronomique de chottMariem, 4042, Sousse, Tunisia
}

Reference: Postharvest Biology and Technology, 2012, 63: 25-32. 



\begin{abstract}
In the Mediterranean area, early-season citrus fruit reach acceptable internal maturity standards for marketing, while the fruit are still green. A degreening treatment is widely used as a postharvest practice to improve the external color. Nevertheless, the application of ethylene during this treatment can be associated with calyx senescence. The aim of this study was to evaluate new degreening treatments in order to reduce this disorder. 'Clemenules' mandarins and 'Navelina' oranges, harvested at different external colors, were submitted to different degreening treatments, combining periods with and without ethylene exposure. In both cultivars, the periods without ethylene exposure during degreening reduced the incidence of calyx disorders. To obtain a typical 'Clemenules' variety color with the lowest incidence of calyx alteration, the optimum degreening treatment was based on 72 $\mathrm{h}$ with ethylene and $48 \mathrm{~h}$ without ethylene when fruit were harvested with a color index of between -9 and -3 . On the other hand, a treatment of $24 \mathrm{~h}$ with ethylene plus $48 \mathrm{~h}$ without ethylene is recommended for fruit with an external color index higher than -2 . For 'Navelina' oranges, highly sensitive to calyx senescence during degreening, a treatment consisting of $24 \mathrm{~h}$ with ethylene plus $48 \mathrm{~h}$ without ethylene is recommended, which involves harvesting the fruit with a color index of over 0.
\end{abstract}

Keywords: Mandarin; Orange; Ethylene; Duration; Color; Calyx alterations; Fruit quality 


\section{Introduction}

Citrus fruit are classified as non-climacteric according to their respiration rate, since the fruit show no changes in their generally low carbon dioxide and ethylene production rate during maturation (Kader, 2002). Nevertheless, they are capable of responding to the application of exogenous ethylene; one of the most important responses is the hasten of the change in peel color through both chlorophyll degradation and carotenoid biosynthesis (Purvis and Barmore, 1981; Fuji et al., 2007; Iglesias et al., 2007; Shemer et al., 2008; Matsumoto et al., 2009). In fact, the application of exogenous ethylene, known as degreening treatment, is a common postharvest citrus fruit practice in order to enhance the color change in early citrus fruit which reach internal maturity and whose flesh becomes edible when the external peel is still green.

The effectiveness of the degreening treatment depends on factors intrinsic to the process such as ethylene concentration, temperature or relative humidity, as well as the cultivar and external color of the fruit.

Exposure of fruit to 1-5 (ppm) of ethylene causes a color change during the citrus degreening without significantly affecting the fruit quality (Petracek and Montalvo, 1997; Cuquerella et al., 2005); nevertheless, levels of ethylene above this threshold can increase fruit deterioration causing serious quality losses. Another important factor to consider in the degreening process is the time required to reach the desired color of the fruit, which is principally dependent on the cultivar and on the initial fruit color which, in turn, is controlled by fruit maturity and grove conditions (Martínez-Jávega et al., 2008).

The rind color of citrus fruit enhances the longer it is exposed to the ethylene. However, the longer the exposure time, the more susceptible citrus fruit are to calyx alterations, which increase with the time taken to reach market.

Both the effect of temperature on the rind color and the accumulation of carotenoids of citrus fruit have been widely investigated. It has been found that the optimal temperature for carotenoid accumulation in flavedo is in the range of $15-25^{\circ} \mathrm{C}$ (Wheaton and Stewart, 1973). Moreover, the effect of the temperature 
on carotenoid accumulation is tissue-dependent. A recent study has shown that in an ethylene-free atmosphere, storage at $20^{\circ} \mathrm{C}$ rapidly increased the carotenoid content in flavedo and maintained the content in juice sacs. In contrast, storage at 5 and $30^{\circ} \mathrm{C}$ gradually decreased the carotenoid content in juice sacs but slowly increased that in flavedo (Matsumoto et al., 2009). After degreening, low temperatures during the shipping of citrus fruit can limit the color development (Van Wyk et al., 2009).

In addition to the external color change, applying exogenous ethylene causes other physiological and biochemical changes, including increases in the activity of phenylalanine ammonialyase (Cajuste and Lafuente, 2007) and cellulase (Kazokas and Burns, 1998), the alteration of protein complement (Alonso et al., 1992), and gene expression (Alonso and Granell, 1995; Alonso et al., 1995; Jacob-Wilk et al., 1997; Kazokas and Burns, 1998).

One point to remark on is that other quality attributes may be sacrificed in the search to improve the external color of citrus fruit. It is widely known that the exogenous application of ethylene can also produce undesirable effects, such as accelerating calyx browning and abscission (Cronjé et al., 2005; MartínezJávega et al., 2008; Salvador et al., 2008), enhancing chilling injury symptoms (Yuen et al., 1995), inducing decay incidence (Smilanick et al., 2006) and increasing the development of off-flavors (Testoni et al., 1992).

The disorders associated with the degreening process are accentuated by the post-treatment storage time taken until market. The Spanish citrus fruit destined for the European Union does not present serious physiological disorders during marketing. Nevertheless, a significant percentage of the Spanish citrus fruit is exported to more distant countries like the USA or Japan. In addition to the distance, these countries require strict quarantine measures against Mediterranean fruit fly (Ceratitis capitata). To satisfy the phytosanitary requirements of those countries, a quarantine cold treatment is usually applied during overseas transport (14-18 days at $1.1-2.2^{\circ} \mathrm{C}$; USDA-APHIS, 2002) These conditions may adversely affect the final quality of the fruit, especially when it has been previously degreened. Therefore, the fruit that are exported under the quarantine treatment, should be subjected to a degreening treatment as short as possible to prevent the appearance of physiological disorders. 
The use of auxins, such as 2, 4-dichlorophenoxy acetic acid (2,4-D), has been widely applied as a postharvest treatment to reduce calyx senescence that occur as a consequence of the degreening process. Nevertheless, at the present, European Union legislation has restricted the use of 2,4-D. Although, new auxins are being tested to be a potential replacement for 2,4-D to control calyx senescence of degreened citrus fruit (Carvalho et al., 2008), it is necessary to find other treatment to maintain the quality of exported citrus fruit.

Therefore the aim of this study was to evaluate the effect of various degreening treatments combining different periods of exposure to ethylene with periods without the addition of ethylene on the quality of 'Clemenules' mandarins and 'Navelina' oranges to be exported to the USA.

\section{Materials and Methods}

\subsection{Plant material and treatments}

'Clemenules' mandarins (Citrus clementina Hort. ex Tan) and 'Navelina' oranges (Citrus sinensis L.), grown in Valencia (Spain), were harvested during two consecutive seasons (2008 and 2009) in late October and in mid-November from two different growers. After harvest, the fruit from each variety, were transported to a commercial packinghouse (FONTESTAD S.A. Company) where were sorted and separated according to the external color index $(\mathrm{CCl}=$ 1000a/Lb (Jimenez-Cuesta et al., 1981)) by a color electronic calibrator into four groups.

In the case of the 'Clemenules' mandarins, the fruit were divided into: $\mathrm{CCl}-$ 1: from -16 to -10 (Deep green), $\mathrm{CCl}-2$ : from -9 to -3 (Yellowish green), $\mathrm{CCl}-3$ : from -2 to 3 (Greenish yellow) and CCl-4: $>4$ (Yellowish orange). In that of the 'Navelina' oranges, they were divided into: $\mathrm{CCl}-1$ : from -12 to -5 (Green), $\mathrm{CCl}-2$ : from -4 to 0 (Greenish yellow), CCl-3: from 0 to $<4$ (Yellowish orange) and $\mathrm{CCl}-$ 4: $\mathrm{CCl}>4$ (Orange). Fruit from each color group were dipped in a solution of Imazalil $(400 \mathrm{mg} / \mathrm{L})$ and then submitted to different degreening treatments. 
The duration of the assayed treatments depended on the external color. In this way, fruit from $\mathrm{CCl}-1$ and $\mathrm{CCl}-2$, with a lower color index at harvest, were subjected to the following degreening treatments up to $120 \mathrm{~h}: 1) 120 \mathrm{~h}$ without ethylene exposure $(120 \mathrm{hnoE}), 2$ ) application of ethylene for $72 \mathrm{~h}$ plus $48 \mathrm{~h}$ without ethylene exposure $(72 \mathrm{hE}+48 \mathrm{hnoE}), 3)$ application of ethylene for $96 \mathrm{~h}$ plus $24 \mathrm{~h}$ without ethylene exposure (96h E+24hnoE), 4) application of ethylene for $120 \mathrm{~h}(120 \mathrm{hE})$.

Fruit from $\mathrm{CCl}-3$ and $\mathrm{CCl}-4$, with a high color index, were subjected to degreening for up to $72 \mathrm{~h}$ only, and the treatments were applied as follows: 1) $72 \mathrm{~h}$ without ethylene exposure $(72 \mathrm{hnoE}), 2)$ application of ethylene for $24 \mathrm{~h}$ plus $48 \mathrm{~h}$ without ethylene (24hE+48hnoE), 3) application of ethylene for $48 \mathrm{~h}$ plus $24 \mathrm{~h}$ without ethylene $(48 \mathrm{hE}+24 \mathrm{hnoE}), 4)$ application of ethylene for $72 \mathrm{~h}(72 \mathrm{~h}$ E).

Degreening treatments with ethylene exposure $(E)$ were carried with application of $2 \mathrm{ppm}$ of ethylene in a chamber with a continuous flow regulated at $21^{\circ} \mathrm{C}$ and $90 \% \mathrm{RH}$. When the degreening treatments were applied without ethylene exposure (noE), fruit were maintained in a chamber under the same temperature and humidity conditions without ethylene application.

After degreening treatments, fruit were transported to the Postharvest Technology Center in the Instituto Valenciano de Investigaciones Agrarias (IVIA) where were coated with a commercial wax (Waterwaxpolyethylene+carnauba+shellac, Fomesa Fruitech S.L.U, Spain) and then exposed to cold quarantine treatment at $1^{\circ} \mathrm{C}$ for 16 days to comply with the phytosanitary requirement for shipping fruit to the USA. Fruit were then stored at $20^{\circ} \mathrm{C}$ for 7 days simulating shelf-life conditions.

The following parameters were evaluated at harvest and after shelf-life: color index, calyx alterations, firmness, soluble solid content (SSC), titratable acidity (TA), maturity index (SSC/TA), ethanol contents and flavor. In addition, color index and calyx senescence were also evaluated one day after degreening treatments. 


\subsection{Analysis of quality attributes}

Peel color was measured with a Minolta colorimeter (model CR-300; Minolta Co. Ltd., Osaka, Japan) using 30 fruit per treatment and 3 measurements were taken in the equatorial zone of each fruit. The mean values for lightness (L), red-green (a), and yellow-blue (b) Hunter parameters were calculated for each fruit and expressed as citrus color index $(\mathrm{CCl}=1000 \mathrm{a} / \mathrm{Lb})$ (Jiménez-Cuesta et al., 1981).

Firmness measurements were taken with an Instron Universal Testing Machine (model 3343, Instron Limited, Buckinghamshire, UK) using 20 fruit per treatment. The results were expressed as the percentage of millimeters of fruit deformation resulting from a pressure of $10 \mathrm{~N}$ on the longitudinal axis at a constant speed.

Per treatment, three samples of ten fruit each were squeezed in an electric juice extractor with a rotating head (Lomi $囚$, Model 4, Lorenzo Miguel, S.L., Madrid, Spain). Titratable acidity (TA) was determined by titration with $0.1 \mathrm{~N}$ $\mathrm{NaOH}$ solution, using phenolphthalein as indicator and expressed as $\mathrm{g}$ of citric acid per $100 \mathrm{~mL}$ of juice. The soluble solid content (SSC) in the juice was determined by digital refractometer (Atago PR-1, Atago Co., Ltd, Tokyo, Japan) and the data were expressed as \%.

\subsection{Analysis of ethanol}

For the ethanol content, from each juice three samples were analyzed. Five milliiters of the juice were transferred to $10 \mathrm{~mL}$ vials with crimp-top caps TFE/silicone septa seal and then frozen at $-20^{\circ} \mathrm{C}$ until analysis. Ethanol levels were determined by headspace analysis on a gas chromatograph (model 1020, Perkin Elmer Corp., Norwalk, Conn., U.S.A.) equipped with a flame ionization detector and a 1/8" x $1.2 \mathrm{~m}$ Porapak QS 80/100 column. The injector was set at $175^{\circ} \mathrm{C}$, the column at $150^{\circ} \mathrm{C}$, the detector (FID) at $200^{\circ} \mathrm{C}$ and the carrier gas at $12.3 \mathrm{psi}$. A one-mL aliquot of the headspace was withdrawn from vials previously equilibrated for $1 \mathrm{~h}$ at $20^{\circ} \mathrm{C}$ and $10 \mathrm{~min}$ at $30^{\circ} \mathrm{C}$, and injected in the 
gas chromatograph. Ethanol was identified by comparison of retention time with a standard solution and expressed as $\mathrm{mg} / 100 \mathrm{~mL}$.

\subsection{Sensory evaluation}

The sensory evaluation was assessed by eight to ten semi-trained judges after degreening plus 7 days. Panelists rated flavor on a 9-point scale, where 1= extremely unpleasant, $5=$ fair (commercially acceptable), and $9=$ excellent. A sample consisting of segments taken from about 4-5 fruits per treatment was used. Samples were presented to panelists on trays labeled with random threedigit codes and served at room temperature. Spring water was provided for rinsing between samples.

\subsection{External Quality assessment}

Calyx senescence of 80 fruits per treatment was evaluated visually. This evaluation consisted of testing each fruit for a loose calyx by rubbing the hand over the calyx. Calyx counts were made after shelf-life and the calyx were classified as calyx abscission and calyx browning. The results were expressed as the percentage of alteration compared to the total number of fruit.

\subsection{Statistical analysis}

Statistical procedures were performed using a commercial statistical software (Statgraphics plus 5.1, Manugistics, Inc., Rockville, M.d., U.S.A.). All the data were subjected to analysis of variance, and means were compared using LSD test at $P<0.05$. The values of calyx senescence were arcsintransformed because the values were originally recorded as percentages. The transformed data were subjected to analysis of variance using the previously described process. 


\section{Results and Discussion}

\subsection{Effect of combined degreening treatments on color change}

\subsubsection{Color change of 'Clemenules' mandarins.}

Color changes of 'Clemenules' mandarins, submitted to different degreening treatments are represented in Figure 1. Since there was no significant effect of the grower on the color evolution of any color group, excepting the first group, the one with the lowest color index at harvest $(\mathrm{CCl}-1)$, the values represented correspond to the mean of the two growers assayed.

For the four color groups, all degreening treatments combining different periods with and without exposure to ethylene improved the external color after the simulated market period compared to the control. Nevertheless, the increase of color index was higher when ethylene exposure was longest; so, the longer the exposure to ethylene, the higher the external color index. These results correspond with previous studies (Cuquerella et al., 1999).

When degreening treatments included ethylene exposure, no significant differences were found between the peel color index measured one day after degreening and the values found after shelf-life. Nevertheless in fruit degreened without exposure to ethylene ( $120 \mathrm{~h} \mathrm{noE}$ and $72 \mathrm{~h} \mathrm{noE})$ and held in quarantine conditions, the color index continued to increase during shelf-life. Van Wyk et al. (2009) found that the carotenoid concentration of oranges shipped at $4.5^{\circ} \mathrm{C}$ or at $-0.6^{\circ} \mathrm{C}$ and held at $20^{\circ} \mathrm{C}$ without exogenous ethylene application, increased during the post-shipping holding period.

The external color of fruit harvested early in the season (CCl-1), with color index at harvest of about -13 , was improved after every degreening treatment. Nevertheless, only fruit submitted to the treatment $96 \mathrm{~h} \mathrm{E}+24 \mathrm{hnoE}$ and to the treatment with exposure to ethylene for 120 hours (120h noE), reached peel color index values of about +6 , which is required as a limit for the marketing of clementines. For fruit from the group $\mathrm{CCl}-2$, with color index at harvest of about -6 , the color index of all ethylene-treated fruit exceeded the value of 6 , reaching 
values of 7.85 to 9.25 . It is known that the color evolution in degreened fruit depends on the color of fruit at harvest (John-Karuppiah and Burns, 2010).

After shelf-life, every treatment combining different hours with and without ethylene exposure for up to $72 \mathrm{~h}(\mathrm{CCl}-3$ and $\mathrm{CCl}-4)$ improved the color of the fruit. The color index of all fruit reached values of over +6 ; the longer the exposure to ethylene, the higher the color index. The color index of fruit from the group CCl-3 (with color index at harvest of about +2 ) reached values of 6.10 to 13.24. After the application of every treatment, fruit from CCl-4, with elevated color at harvest, reached high color index values, similar to the typical orangereddish color of the variety.

\subsubsection{Color change of 'Navelina' oranges.}

In the case of 'Navelina' oranges, the color evolution of fruit from each grower and for each color group was represented separately because of the significant effect that the grower had on the external color (Fig. 2).

The fruit from $\mathrm{G} 1$, harvested with the lowest color index $(\mathrm{CCl}-1)$, increased external color to values of -0.82 after shelf-life when submitted to degreening without ethylene exposure (120h noE); however, under similar conditions, the fruit from $\mathrm{G} 2$ reached lower values, close to -3.76 . These differences between the fruit of two growers were not found when the fruit were subjected to treatments $72 \mathrm{~h} \mathrm{E}+48 \mathrm{~h}$ noE and $96 \mathrm{~h} \mathrm{E}+24 \mathrm{~h}$ noE. For both growers, the treatment that included ethylene exposure for 120 hours (120h E) showed the highest values close to +5 , that still not reaching commercial acceptability.

When fruit were harvested with a color index close to -2 (CCl-2), significant differences were found among treatments, that was so mainly in the case of $\mathrm{G} 2$; the longer the exposure to ethylene, the higher the $\mathrm{CCl}$ values. 
Chapter I

When the fruit were harvested with a high color index ( $\mathrm{CCl}-3$ and $\mathrm{CCl}-4)$, the purpose of the postharvest degreening treatment is to achieve uniform external coloring. For these color groups, every treatment improved the color index of fruit from both growers and they attained a commercially acceptable color. The highest values were observed after the 72 hour application including ethylene exposure. 


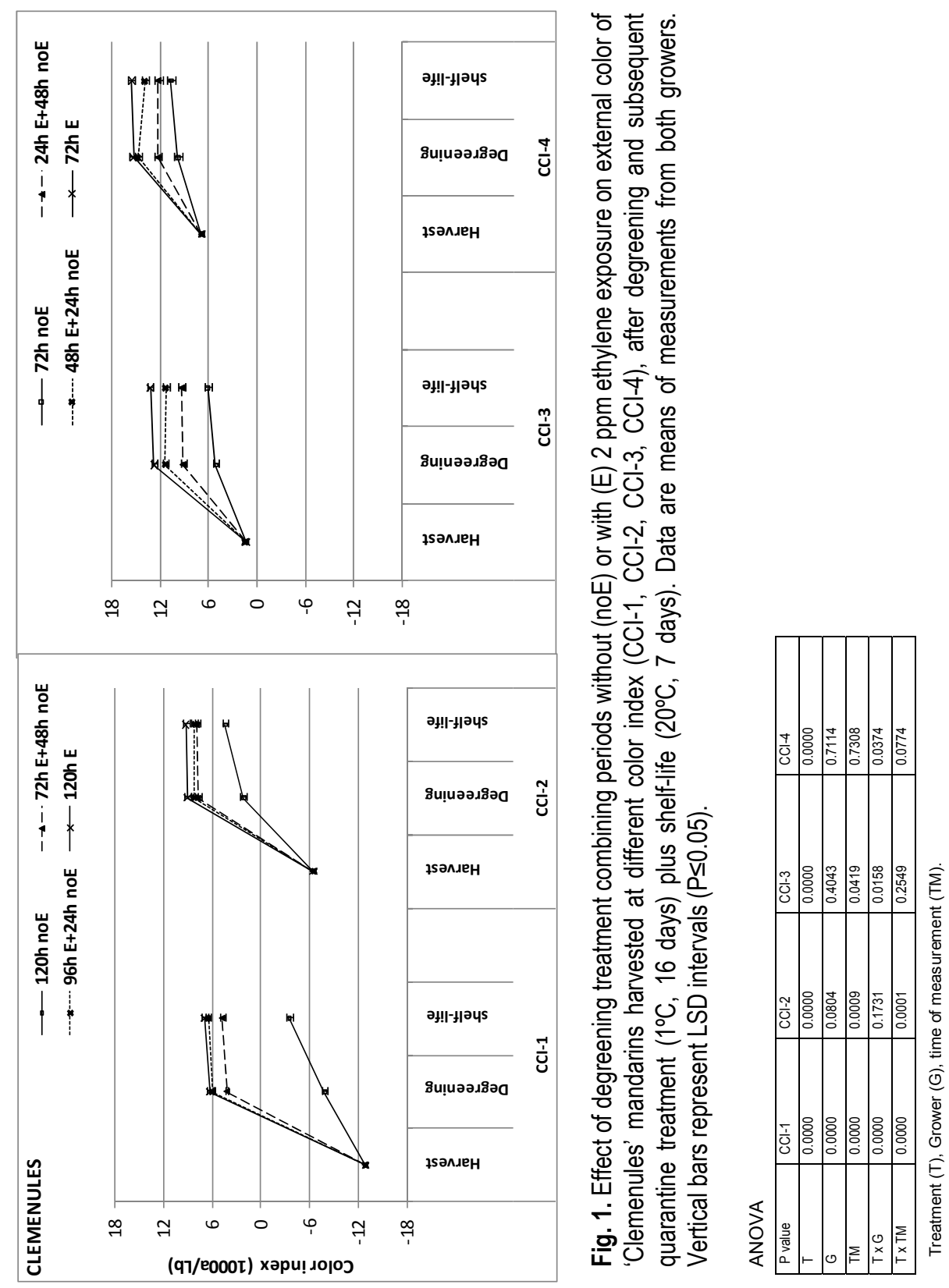




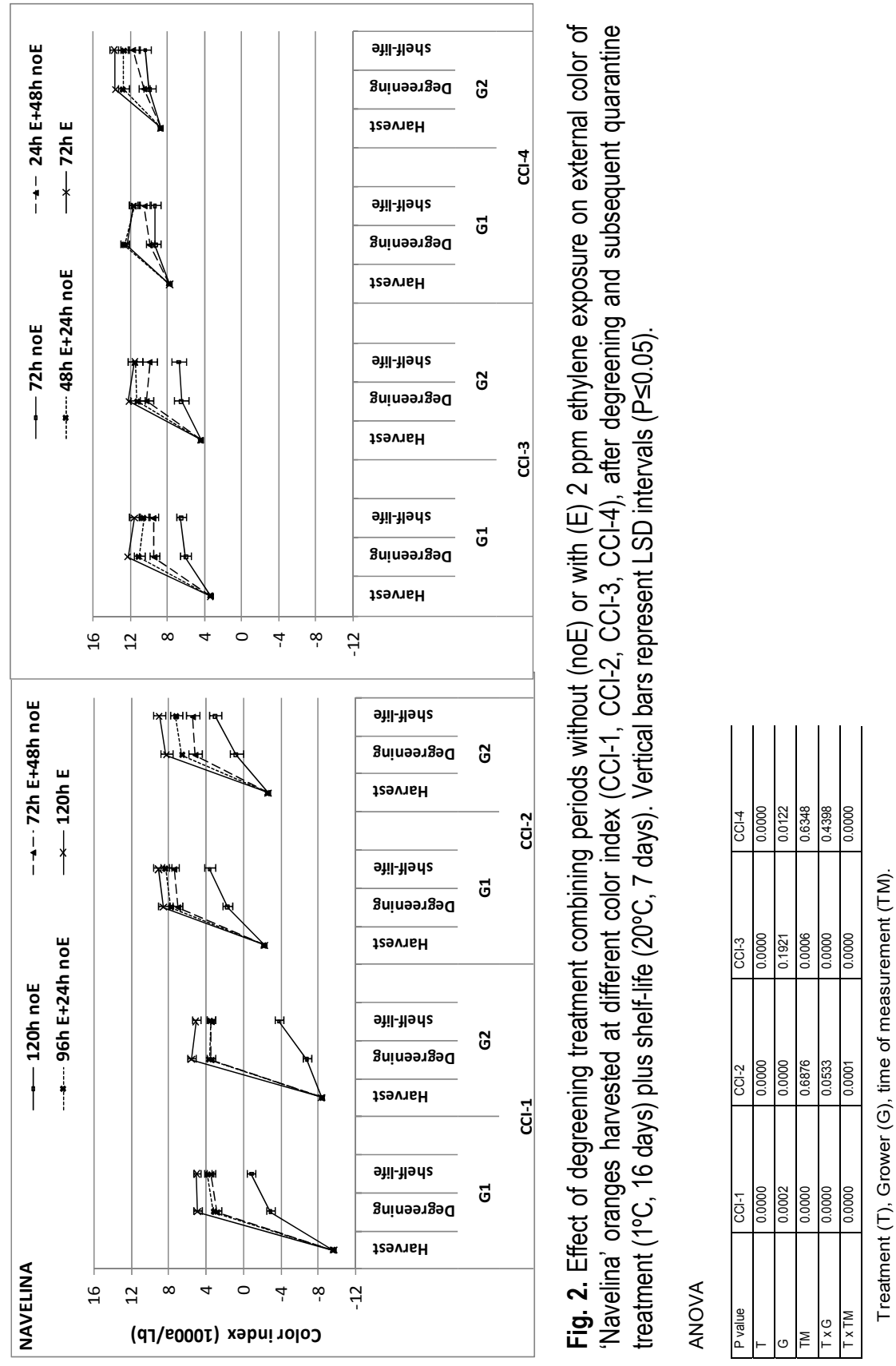




\subsection{Effect of combined degreening treatments on calyx senescence}

The postharvest application of ethylene during degreening not only affects the external color, but also brings about important responses which are usually unwanted during postharvest storage, such as the drying, browning and abscission of the calyx. It was reported that the susceptibility to these undesirable effects of ethylene is cultivar dependent (Carvalho et al., 2008).

\subsubsection{Calyx senescence of 'Clemenules' mandarins.}

The effect of different degreening treatments, combining different periods with and without ethylene exposure, on calyx alterations was examined in 'Clemenules' mandarins and the results were represented for each color group and each grower separately (Fig. 3).

For all color groups, ethylene-treated fruit presented a higher incidence of abscised and browned calyxes than fruit degreened without exogenous ethylene. Furthermore, the percentage of alteration increased the longer the exposure to ethylene. So, the incidence of calyx alterations in fruit with a higher color index at harvest (CCl-3 and $\mathrm{CCl}-4)$ submitted to shorter degreening treatments, up to $72 \mathrm{~h}$, was lower than in the fruit subjected to degreening treatments of up to $120 \mathrm{~h}(\mathrm{CCl}-1$ and $\mathrm{CCl}-2)$. In general, for all color groups, the values of calyx alterations were higher in fruit from $\mathrm{G} 1$ than from $\mathrm{G} 2$.

When the degreening treatments were performed for up to $120 \mathrm{~h}$ on color groups $\mathrm{CCl}-1$ and $\mathrm{CCl}-2$, treatments $72 \mathrm{~h} \mathrm{E}+48 \mathrm{~h}$ noE and $96 \mathrm{~h} \mathrm{E}+24 \mathrm{~h}$ noE significantly reduced the calyx alterations compared to treatment $120 \mathrm{~h}$.

Fruit from CCl-3 and $\mathrm{CCl}-4$ submitted to $24 \mathrm{~h} \mathrm{E}+48 \mathrm{~h}$ noE and $48 \mathrm{hE}+24 \mathrm{hnoE}$ treatments showed lower incidence of calyx senescence than those submitted to $72 \mathrm{~h} \mathrm{E}$; even for $\mathrm{CCl}-4$, treatment $24 \mathrm{~h} \mathrm{E}+48 \mathrm{~h}$ noE showed 
percentages of calyx senescence similar to those registered with treatment $72 \mathrm{~h}$ noE.

3.2.2. Calyx senescence of 'Navelina' oranges.

'Navelina' oranges submitted to degreening treatments showed high sensitivity to calyx senescence, even when degreened without ethylene exposure.

For color groups $\mathrm{CCl}-1$ and $\mathrm{CCl}-2$, treatment of $120 \mathrm{hE}$ provoked the highest incidence of calyx alterations, reaching a percentage of affected fruit over $90 \%$. Although treatments $72 \mathrm{~h} \mathrm{E}+48 \mathrm{~h}$ noE and $96 \mathrm{~h} \mathrm{E}+24 \mathrm{~h}$ noE significantly reduced the incidence of calyx alterations, the percentages still high and exceeded $60 \%$ for both growers.

In the case of degreening for up to $72 \mathrm{~h}$ ( $\mathrm{CCl}-3$ and $\mathrm{CCl}-4)$, the fruit presented lower incidence than those submitted to degreening for up to $120 \mathrm{~h}$. For $\mathrm{CCl}-3$ and $\mathrm{CCl}-4$, the treatment combining 24 hours with ethylene plus 48 hours without ethylene ( $24 \mathrm{~h} \mathrm{E}+48 \mathrm{~h} \mathrm{noE})$, showed the lowest percentage of fruit with calyx disorders without significant differences compared to the control. 


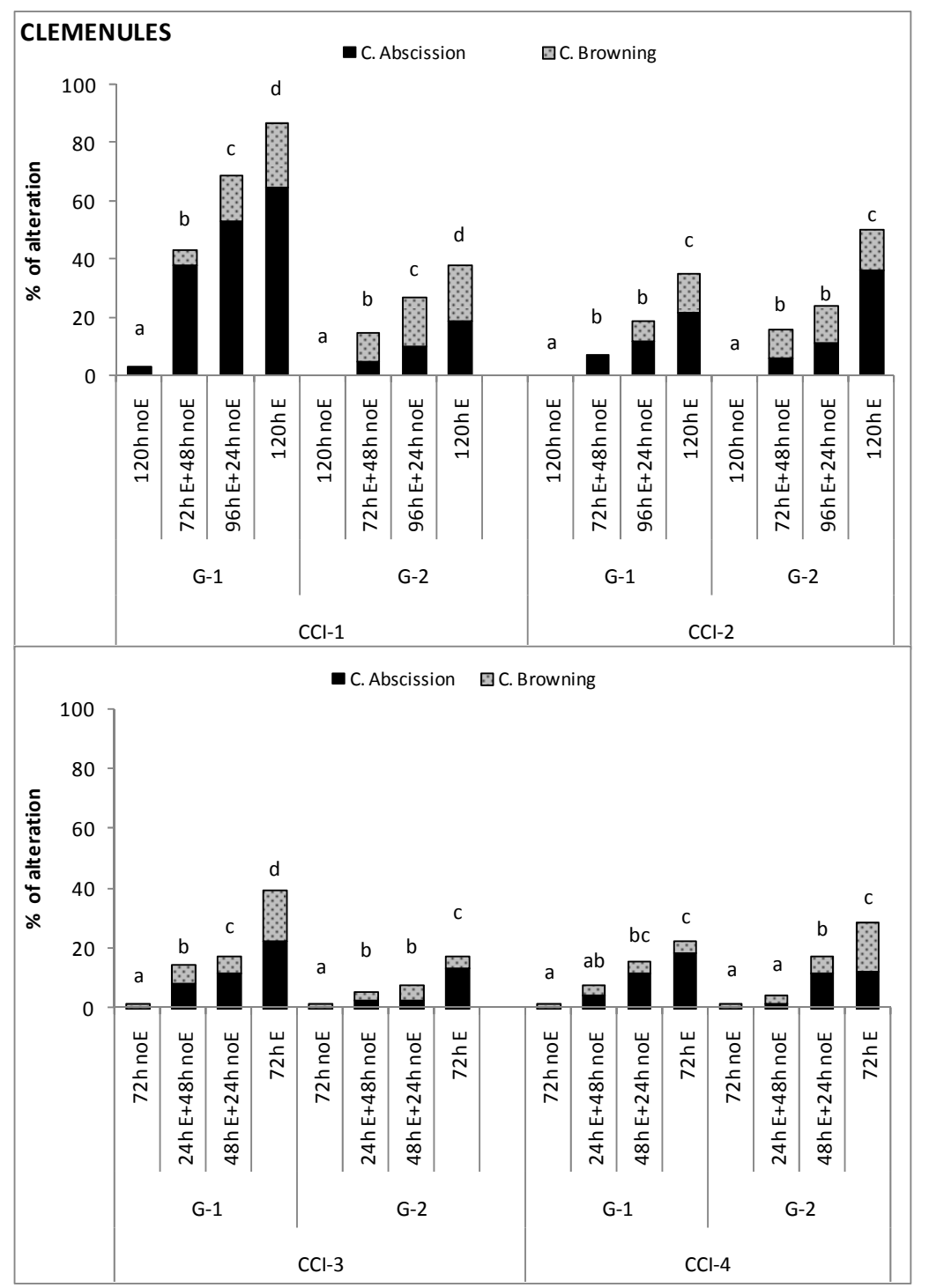

Fig. 3. Effect of degreening treatment combining periods without (noE) or with (E) 2 ppm ethylene exposure on calyx quality of 'Clemenules' mandarins harvested (from G1 and G2) at different color index (CCl-1, CCl-2, CCl-3, CCl-4), after degreening and subsequent quarantine treatment $\left(1^{\circ} \mathrm{C}, 16\right.$ days $)$ plus shelf-life $\left(20^{\circ} \mathrm{C}, 7\right.$ days $)$. Percentages with different letters within the same color group and for the same growers are significantly different according to LSD test $(P \leq 0.05)$. 


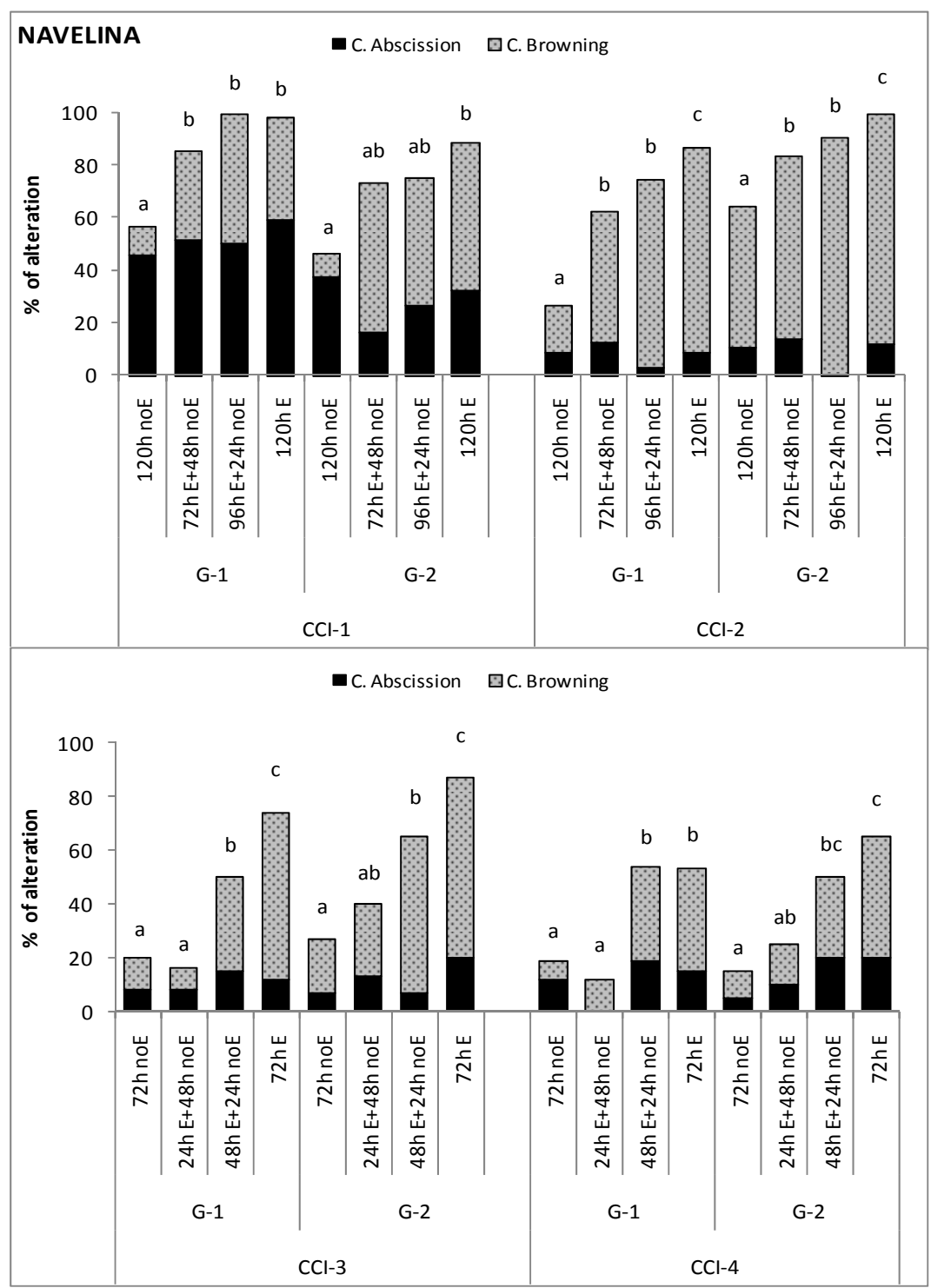

Fig. 4. Effect of degreening treatment combining periods without (noE) or with (E) 2 ppm ethylene exposure on calyx quality of 'Navelina' oranges harvested (from G1 and G2) at different color index (CCl-1, CCl-2, CCl-3, CCl-4), after degreening and subsequent quarantine treatment $\left(1^{\circ} \mathrm{C}\right.$, 16 days) plus shelf-life $\left(20^{\circ} \mathrm{C}, 7\right.$ days). Percentages with different letters within the same color group and for the same growers are significantly different according to LSD test $(P \leq 0.05)$. 


\subsection{Effect of combined degreening treatments on quality of 'Clemenules' mandarins and 'Navelina' oranges}

In general, fruit of both varieties showed an increase in Soluble Solids Contents (SSC) and a reduction in Titratable acidity (TA) after shelf-life compared with initial values at harvest (Tables 1 and 2). The decrease in juice acidity levels led to an increase in the maturity index (MI). Degreening treatments with ethylene exposure did not consistently affect the quality parameters when compared to degreening without ethylene. Previous studies reported that fruit submitted to exogenous ethylene show similar physical and biochemical changes to untreated fruit (Plaza et al., 2004; Martínez-Jávega et al., 2008; Sdiri et al., 2010; Tietel et al., 2010).

For both varieties, the ethanol content in juice increased after degreening with ethylene and the subsequent storage (Tables 1 and 2). Ethanol amounts increase the longer the exposure to exogenous ethylene during degreening treatment. In citrus fruit, the off-flavors are related to the ethanol level in the juice (Hagenmaier, 2002). For all the treatments applied, 'Clemenules' mandarins exhibited lower amounts of ethanol than 'Navelina' oranges. In this study, fruit submitted to all the degreening treatments presented an acceptable commercial flavor (score $=5$ ) and none of the treatments, including the control, presented any differences. Coinciding with these results, previous studies reported that the postharvest degreening treatment did not affect the fruit flavor (Plaza et al., 2004; Martínez-Jávega et al., 2008; Sdiri et al., 2010; Tietel et al., 2010). 
Table 1: Effect of degreening treatment combining periods without (noE) or with (E) 2 ppm ethylene exposure on firmness, SSC, acidity, MI, ethanol, and flavor of 'Clemenules' mandarins harvested at different color index (CCl-1, CCl-2, CCl-3, CCl-4), after degreening and subsequent quarantine treatment $\left(1^{\circ} \mathrm{C}, 16\right.$ days) plus shelf-life $\left(20^{\circ} \mathrm{C}, 7\right.$ days $)$.

\begin{tabular}{|c|c|c|c|c|c|c|c|c|c|c|c|c|c|}
\hline \multirow{2}{*}{$\begin{array}{l}\text { Color } \\
\text { group } \\
\text { CCl-1 }\end{array}$} & \multirow{2}{*}{$\begin{array}{l}\text { Treatment } \\
\text { Harvest }\end{array}$} & \multicolumn{2}{|c|}{$\begin{array}{c}\text { Firmness } \\
\text { (\%def.10N) }\end{array}$} & \multicolumn{2}{|c|}{$\begin{array}{l}\text { SSC } \\
(\%)\end{array}$} & \multicolumn{2}{|c|}{$\begin{array}{c}\text { TA } \\
(\mathrm{g} / 100 \mathrm{~mL})\end{array}$} & \multicolumn{2}{|c|}{$\begin{array}{c}\mathrm{Ml} \\
\text { SSC/TA }\end{array}$} & \multicolumn{2}{|c|}{$\begin{array}{c}\text { EtOH } \\
(\mathrm{mg} / 100 \mathrm{ml})\end{array}$} & \multicolumn{2}{|c|}{$\begin{array}{c}\text { Flavor } \\
(0-9)\end{array}$} \\
\hline & & 3.4 & & 10.70 & & 0.91 & & 11.87 & & 1.81 & & 8.2 & \\
\hline & $120 \mathrm{hnoE}$ & 4.1 & a & 11.28 & a & 0.82 & $b$ & 13.86 & a & 34.38 & a & 7.2 & a \\
\hline & $72 \mathrm{hE}+48 \mathrm{hnoE}$ & 4.0 & a & 11.49 & $a b$ & 0.78 & $a b$ & 14.69 & $b$ & 45.34 & $a b$ & & \\
\hline & $96 \mathrm{hE}+24 \mathrm{hnoE}$ & 3.9 & a & 11.52 & $b$ & 0.79 & $a b$ & 14.52 & $a b$ & 56.05 & $b c$ & & \\
\hline & 120hE & 4.2 & a & 11.33 & $a b$ & 0.75 & a & 15.11 & $b$ & 64.56 & $c$ & 6.5 & a \\
\hline \multirow[t]{5}{*}{$\mathrm{CCl}-2$} & Harvest & 5.1 & & 11.15 & & 0.85 & & 13.18 & & - & & 7.2 & \\
\hline & 120hnoE & 5.9 & a & 11.28 & $a$ & 0.70 & a & 16.32 & a & - & & 7.0 & a \\
\hline & $72 \mathrm{hE}+48 \mathrm{hnoE}$ & 5.8 & $a b$ & 11.33 & $a b$ & 0.68 & $a$ & 17.05 & a & - & & & \\
\hline & $96 \mathrm{hE}+24 \mathrm{hnoE}$ & 6.6 & $c$ & 11.47 & $b$ & 0.69 & a & 16.62 & a & - & & & \\
\hline & $120 \mathrm{hE}$ & 6.3 & $b c$ & 11.75 & $c$ & 0.71 & $a$ & 16.67 & a & - & & 7.0 & a \\
\hline \multirow[t]{5}{*}{$\mathrm{CCl}-3$} & Harvest & 4.9 & & 10.30 & & 0.77 & & 13.68 & & 7.43 & & 7.4 & \\
\hline & $72 \mathrm{hnoE}$ & 6.9 & $b$ & 11.17 & $b$ & 0.63 & $b$ & 17.79 & a & 57.18 & a & 5.2 & $b$ \\
\hline & $24 \mathrm{hE}+48 \mathrm{hnoE}$ & 6.2 & a & 10.99 & $a b$ & 0.60 & $a b$ & 18.46 & a & 71.37 & $a b$ & & \\
\hline & $48 \mathrm{hE}+24 \mathrm{hnoE}$ & 6.6 & $a b$ & 10.75 & $a$ & 0.59 & $a b$ & 18.45 & a & 94.44 & $c$ & & \\
\hline & $72 \mathrm{hE}$ & 7.3 & $c$ & 10.72 & a & 0.57 & $a$ & 18.68 & $a$ & 73.75 & $b$ & 6.4 & a \\
\hline \multirow[t]{5}{*}{$\mathrm{CCl}-4$} & Harvest & 5.7 & & 10.97 & & 0.75 & & 14.29 & & 8.96 & & 7.3 & \\
\hline & $72 \mathrm{hnoE}$ & 7.9 & a & 11.14 & $a$ & 0.61 & a & 18.43 & a & 45.14 & a & 6.8 & a \\
\hline & $24 \mathrm{hE}+48 \mathrm{hnoE}$ & 7.3 & a & 11.25 & a & 0.60 & a & 13.74 & a & 63.93 & $b$ & & \\
\hline & $48 \mathrm{hE}+24 \mathrm{hnoE}$ & 7.2 & a & 11.09 & a & 0.59 & $a$ & 18.94 & a & 83.87 & c & & \\
\hline & $72 \mathrm{hE}$ & 7.9 & $a$ & 11.29 & a & 0.59 & a & 19.20 & a & 54.71 & $a b$ & 6.0 & $a$ \\
\hline
\end{tabular}

Values in the same column for each color group with different letters are significantly different: $P \leq 0.05$. 
Table 2. Effect of degreening treatment combining periods without (noE) or with (E) $2 \mathrm{ppm}$ ethylene exposure on firmness, SSC, acidity, MI, ethanol, and flavor of 'Navelina' oranges harvested at different color index (CCl-1, $\mathrm{CCl}-2, \mathrm{CCl}-3, \mathrm{CCl}-4)$, after degreening and subsequent quarantine treatment $\left(1^{\circ} \mathrm{C}, 16\right.$ days) plus shelf-life $\left(20^{\circ} \mathrm{C}, 7\right.$ days).

\begin{tabular}{|c|c|c|c|c|c|c|c|c|c|c|c|c|c|}
\hline \multirow{2}{*}{$\begin{array}{l}\text { Color } \\
\text { group } \\
\text { CCl-1 }\end{array}$} & \multirow{2}{*}{$\begin{array}{l}\text { Treatment } \\
\text { Harvest }\end{array}$} & \multicolumn{2}{|c|}{$\begin{array}{l}\text { Firmness } \\
\text { (\%def.10N) }\end{array}$} & \multicolumn{2}{|c|}{$\begin{array}{c}\text { SSC } \\
(\%)\end{array}$} & \multicolumn{2}{|c|}{$\begin{array}{c}\text { TA } \\
(\mathrm{g} / 100 \mathrm{ml})\end{array}$} & \multicolumn{2}{|c|}{$\begin{array}{c}\mathrm{Ml} \\
\text { SSC/TA }\end{array}$} & \multicolumn{2}{|c|}{$\begin{array}{c}\text { EtOH } \\
(\mathrm{mg} / 100 \mathrm{ml})\end{array}$} & \multicolumn{2}{|c|}{$\begin{array}{c}\text { Flavor } \\
(0-9)\end{array}$} \\
\hline & & 1.6 & & 9.19 & & 1.32 & & 7.07 & & 7.46 & & 7.0 & \\
\hline & $120 \mathrm{hnoE}$ & 2.1 & a & 9.35 & $a$ & 1.21 & $a$ & 7.75 & a & 53.66 & a & 7.4 & a \\
\hline & $72 \mathrm{hE}+48 \mathrm{hnoE}$ & 2.0 & a & 9.51 & a & 1.21 & a & 7.98 & $a$ & 78.01 & $b$ & & \\
\hline & $96 \mathrm{hE}+24 \mathrm{hnoE}$ & 2.2 & a & 9.18 & a & 1.16 & a & 8.04 & a & 78.46 & $b$ & & \\
\hline & 120hE & 2.1 & a & 9.42 & a & 1.16 & a & 8.12 & a & 80.80 & $b$ & 6.8 & a \\
\hline \multirow[t]{5}{*}{$\mathrm{CCl}-2$} & Harvest & 2.5 & & 10.41 & & 1.24 & & 8.46 & & 12.79 & & 7.5 & \\
\hline & 120hnoE & 2.3 & a & 11.08 & a & 1.16 & a & 9.56 & a & 46.47 & a & 6.4 & a \\
\hline & $72 \mathrm{hE}+48 \mathrm{hnoE}$ & 2.4 & a & 10.97 & a & 1.12 & a & 9.85 & $a$ & 48.55 & a & & \\
\hline & $96 \mathrm{hE}+24 \mathrm{hnoE}$ & 2.5 & a & 10.95 & a & 1.13 & a & 9.74 & a & 53.74 & $a b$ & & \\
\hline & $120 \mathrm{hE}$ & 2.6 & a & 10.81 & a & 1.15 & a & 9.42 & $a$ & 59.96 & $b$ & 6.3 & a \\
\hline \multirow[t]{5}{*}{$\mathrm{CCl}-3$} & Harvest & 2.5 & & 10.10 & & 1.31 & & 7.79 & & 12.85 & & 7.3 & \\
\hline & $72 \mathrm{hnoE}$ & 3.2 & a & 9.82 & b & 1.04 & a & 9.58 & b & 69.05 & a & 6.9 & a \\
\hline & $24 \mathrm{hE}+48 \mathrm{hnoE}$ & 3.1 & a & 9.52 & $a b$ & 1.13 & $b$ & 8.56 & $a b$ & 83.20 & a & & \\
\hline & $48 \mathrm{hE}+24 \mathrm{hnoE}$ & 3.3 & a & 9.17 & a & 1.11 & $a b$ & 8.41 & a & 79.20 & a & & \\
\hline & $72 \mathrm{hE}$ & 3.6 & $b$ & 9.55 & $a b$ & 1.08 & $a b$ & 9.18 & $a b$ & 88.29 & a & 6.6 & a \\
\hline \multirow[t]{5}{*}{ CCl-4 } & Harvest & 2.4 & & 10.64 & & 1.21 & & 8.84 & & 16.68 & & 7.3 & \\
\hline & $72 \mathrm{hnoE}$ & 3.5 & $b$ & 10.60 & a & 1.22 & $a$ & 8.80 & a & 85.36 & a & 6.4 & a \\
\hline & $24 \mathrm{hE}+48 \mathrm{hnoE}$ & 3.1 & a & 10.73 & a & 1.25 & a & 8.63 & a & 83.70 & a & & \\
\hline & $48 \mathrm{hE}+24 \mathrm{hnoE}$ & 3.3 & $a b$ & 10.49 & a & 1.17 & a & 8.98 & $a$ & 85.05 & a & & \\
\hline & $72 \mathrm{hE}$ & 3.7 & c & 10.66 & a & 1.21 & a & 8.80 & a & 111.77 & $b$ & 6.4 & $a$ \\
\hline
\end{tabular}

Values in the same column for each color group with different letters are significantly different: $P \leq 0.05$. 


\section{Conclusion}

The introduction of periods without ethylene exposure during degreening treatment significantly reduced the calyx alterations associated with this treatment. The efficiency of combining periods with ethylene exposure and others without depends on the external color of fruit at harvest. For 'Clemenules' mandarins, fruit harvested with a color index of between -9 and 3 need to be degreened with a combination of 72 hours with ethylene and 48 hours without ethylene. However, for fruit harvested with an external color index of over -2, a treatment combining 24 hours with ethylene plus 48 hours without ethylene is adequate to reach the typical color of the variety with the lowest incidence of calyx alteration.

Due to the fact that 'Navelina' oranges are highly sensitive to calyx senescence when exposed to exogenous ethylene, the treatment combining 24 hours with ethylene plus 48 hours without ethylene is the only one recommended. In order for this treatment to be possible, it must be borne in mind that fruit have to be harvested with color index values of over 0 . None of the assayed degreening treatments affected the internal quality of fruit of either variety.

\section{Acknowledgments}

This research was supported by the Spanish 'Ministerio de Educación y Ciencia' (Project INIA-RTA 2007-00101-00-00) and Feder program from the EU. The authors wish to thank FONTESTAD S.A Company for its technical support.

\section{References}

Alonso, J.M., García-Martínez, J.L., Chamarro, J., 1992. 2-Dimensional gelelectrophesis pattern of total, in-vivo labeled and in-vitro translated 
polypeptides from orange flavedo during maturation and following ethylene treatment. Physiol. Plant. 85(2), 147-156.

Alonso, J.M., Granell, A., 1995. A putative vacuolar processing protease is regulated by ethylene and also during fruit ripening in citrus fruit. Plant Physiol. 109, 541-547.

Alonso, J.M., Chamarro, J., Granell, A., 1995. Evidence for the involvement of ethylene in the expression of specific RNAs during maturation of the orange, a non-climacteric fruit. Plant Mol. Biol. 29, 385-390.

Cajuste, J.F., Lafuente, M.T., 2007. Ethylene-induced tolerance to non-chilling peel pitting as related to phenolic metabolism and lignin content in 'Navelate' Fruit. Postharvest Biol. Technol. 45(2), 193-203.

Carvalho, C.P., Salvador, A., Navarro, P., Monterde, A., Martínez-Jávega, J.M., 2008. Effect of Auxin Treatments on Calyx Senescence in the Degreening of Four Mandarin Cultivars. HortScience 43, 747-752.

Cronjé, P.J.R., Crouch, E.M., Huysamer, M., 2005. Postharvest Calyx Retention of Citrus Fruit. Acta Hortic. 682, 369-374.

Cuquerella, J., Navarro, P., Salvador, A., 1999. Respuesta a la desverdización de nuevas variedades de cítricos. Levante agrícola. 348, 263-271.

Cuquerella, J., Salvador, A., Martínez-Jávega, J. M., Navarro, P., 2005. Effect of quarantine cold treatment on early-season Spanish mandarins. Acta Hortic. 682, 743-747.

Fujii, H., Shimada, T., Sugiyama, A., Nishikawa, F., Endo, T., Nakano, M., Ikoma, Y., Shimizu, T., Omura, M., 2007. Profiling of ethylene-responsive genes in mature mandarin fruit using a citrus 22K oligoarray. Plant Sci. 173, 340-348.

Hagenmaier, R.D., 2002. The flavor of mandarin hybrids with different coatings. Postharvest Biol. Technol. 24, 79-87.

Iglesias, J.D., Cercós, M., Colmenero-Flores, J.M., Naranjo, M.A., Ríos, G., Carrera, E., Ruiz-Rivero, O., Lliso, I., Morillon, R., Tadeo, F.R., Talón, M., 2007. Physiology of citrus fruiting. Braz. J. Plant Physiol. 19(4), 333-362. 
Jacob-Wilk, D., Goldschmidt, E.E., Riov, J., Sadka, A., Holland, D., 1997. Induction of a citrus gene highly homologous to plant and yeast the genes involved in thiamine biosynthesis during natural and ethylene-induced fruit maturation. Plant Mol. Biol. 35, 661-666.

Jiménez-Cuesta, M., Cuquerella, J., Martínez-Jávega, J.M. 1981. Determination of a color index for citrus fruit degreening. Proc. Int. Soc. Citriculture 2, 750753.

John-Karuppiah, K.J., Burns, J.K., 2010. Degreening behavior in 'Fallglo' and 'Lee $x$ Orlando' is correlated with differential expression of ethylene signaling and biosynthesis genes. Postharvest Biol. Technol. 58, 185-193.

Kader, A.A., 2002. Postharvest biology and technology: an overview. In: Kader, A.A. (Eds.), Postharvest Technology of Horticultural Crops. University of California Agriculture and Natural Resources, Publication, Oakland, CA, pp. 39-48.

Kazokas, W.C., Burns, J.K., 1998. Cellulase activity and gene expression in citrus fruit abscission zones during and after ethylene treatment. J. Am. Soc. Hortic. Sci. 123, 781-786.

Martínez-Jávega, J.M., Monterde, A., Navarro, P., Salvador, A., 2008. Responsse of new clementines to degreening treatment. Proc. Int. Soc. Citriculture 11, 1342-1346.

Matsumoto, H., Ikoma, Y., Kato, M., Nakajima, N., Hasegawa, Y., 2009. Effect of Postharvest Temperature and Ethylene on Carotenoid Accumulation in the Flavedo and Juice Sacs of Satsuma Mandarin (Citrus unshiu Marc.) Fruit. J. Agric. Food Chem. 57, 4724-4732.

Petracek, PD., Montalvo, L., 1997. The degreening of 'Fallglo' tangerine. J. Am. Soc. Hortic. Sci. 122(4), 547-552.

Plaza, P., Sanbruno, A., Usall, J., Lamarca, N., Torres, R., Pons, J., Viñas, I., 2004. Integration of curing treatments with degreening to control the main postharvest diseases of clementines mandarins. Postharvest Biol. Technol. 34, 29-37.

Purvis, A.C., Barmore, C.R., 1981. Involvment of ethylene in chlorophyll degradation in peel of citrus fruits. Plant Physiol. 68(4), 854-856. 
Salvador, A., Navarro, P., Monterde, A., Martínez-Jávega., J.M., 2008. Postharvest application of auxins to control calyx senescence in clementines submitted to degreening treatment. Proc. Int. Soc. Citriculture 11, 13771382.

Sdiri, S., Navarro, P., Ben abda, J., Monterde, A., Salvador. A., 2010. Antioxidant Activity and Vitamin C Are Not Affected by Degreening Treatment of Clementine Mandarins. Acta Hortic. In press.

Shemer, T.A., Harpaz-Saad, S., Belausoy, E., Lovat, N., Krokhin, O, Spicer, V., Standing, K.G., Goldschmidt, E.E., Eyal, Y., 2008. Citrus chlorophyllase dynamics at ethylene-induced fruit color-break: A study of chlorphyllase expression, posttranslational processing kinetics, and in situ intracellular localization. Plant Physiol. 148(1), 108-118.

Smilanick, J.L., Mansour, M.F., Sorenson, D., 2006. Pre- and Postharvest Treatments to Control Green Mold of Citrus Fruit During Ethylene Degreening. Plant Dis. 90, 89-96.

Testoni, A., Cazzola, R., Ragozza, L., Lanza, G., 1992. Storage behavior of orange 'Valencia Late' in rooms with ethylene removal. Proc. Int. Soc. Citriculture 3, 1092-1094.

Tietel, Z., Weiss, B., Lewinsohn, E., Fallik, E., Porat, R., 2010. Improving taste and peel color of early-season Satsuma mandarins by combining hightemperature conditioning treatments. Postharvest Biol. Technol. 57(1), 1-5.

USDA-APHIS (United States Department of Agriculture Agriculture-Animal and Plant Health Inspection Service), 2002. Importation of Clementines from Spain. Final rule. Fed. Reg. 67, 64701-64739.

Van Wyk, A.A., Huysamer, M., Barry, G.H., 2009. Extended low-temperature shipping adversely affects rind colour of 'Palmer Navel' sweet orange [Citrus sinensis (L.) Osb.] due to carotenoid degradation but can partially be mitigated by optimising post-shipping holding temperature. Postharvest Biol. Technol. 53, 109-116.

Wheaton, T.A., Stewart, I., 1973. Optimum temperature and ethylene concentration for postharvest development of carotenoid pigments in Citrus. J. Am. Soc. Hortic. Sci. 98, 337-340. 
Chapter I

Yuen, C.M.C., Tridjaja, N.O., Wills, R.B.H., Wild, B.L., 1995. Chilling injury development of 'Tahitian' lime, 'Emperor' mandarin, 'Marsh' grapefruit and 'Valencia' orange. J. Sci. Food. Agric. 67, 335-339. 


\title{
Postharvest application of a new growth regulator reduces calyx alterations of citrus fruit induced by degreening treatment
}

\author{
Sawsen Sdiri, Pilar Navarro, Alejandra Salvador \\ Centro de Tecnología Postcosecha, Instituto Valenciano de Investigaciones \\ Agrarias, Carretera Moncada-Náquera Km 4.5 s/n, 46113, Moncada, Valencia, \\ Spain
}

Reference: Postharvest Biology and Technology, 2013, 75: 68-74. 



\begin{abstract}
Synthetic auxins, specially 2,4-dichlorophenoxyacetic acid (2,4-D), have been used as a postharvest treatment to retard calyx abscission, drying and browning, which occur as the result of degreening process. Nevertheless, the use of 2,4-D is restricted by European Union (EU) legislation, which means that finding an alternative to this auxin in controlling calyx senescence is necessary. In the present research, the effect of postharvest application of a new growth regulator was studied, S-Ethyl-4-chloro-O-tolilooxytioacetate (HF-Calibra $\left.{ }^{\circledR}\right)$, currently registered for preharvest use, on the calyx senescence of early-season citrus varieties ('Oronules', 'Clemenrubi' and 'Clemenules' mandarins and 'Navelina' oranges) submitted to a commercial degreening treatment. After shelf-life, application of HF-Calibra ${ }^{\circledR}$ treatment at different concentrations significantly reduced calyx alterations. Although auxin treatments can retard color change, this delay has no negative effect from a commercial viewpoint since all the studied varieties reached a commercially acceptable color. The application of HF-Calibra ${ }^{\circledR}$ at 10, 20, 40 or $60 \mathrm{mg} / \mathrm{L}$ affected neither weight loss nor the sensory quality of fruits (firmness, total soluble solids, titratable acidity, acetaldehyde and ethanol content and flavor) of any variety. The postharvest application of HF-Calibra $\AA$ could prove to be an alternative to $2,4-\mathrm{D}$ to avoid calyx senescence of citrus fruits induced by a degreening treatment and to maintain fruit quality.
\end{abstract}

Keywords: auxin application; calyx senescence; clementines; external color; oranges; fruit quality; postharvest ethylene exposure. 


\section{Introduction}

Postharvest degreening with exogenous ethylene application is used worldwide to promote peel degreening in early-season citrus varieties in which the pulp reaches maturity and becomes edible when the peel is still green, and to achieve uniform external coloration in fruit (Sdiri et al., 2010). Nevertheless, the postharvest application of ethylene during degreening not only causes the desirable color change in citrus fruit, but can also produce undesirable effects relating to accelerated fruit senescence such as drying, browning and abscission of the calyx (Cohen, 1978; Cronjé et al., 2005; Martínez-Jávega et al., 2008a; Salvador et al., 2008, 2010). There have been reports that susceptibility to these undesirable effects of ethylene is cultivar-dependent (Carvalho et al., 2008; Sdiri et al., 2012), although the incidence of these alterations is associated mainly with inappropriate degreening process conditions; the longer the exposure time, the more susceptible citrus fruits to senescence alterations becomes. Furthermore, the incidence of these disorders is accentuated by post-treatment storage time until taken to the market. The fruit destined to the EU presents less physiological disorders than that exported to more distant countries like the USA or Japan, which requires strict coldquarantine treatment against Mediterranean fruit fly (Ceratitis capitata) during overseas transport.

Many studies have been conducted, by our research group, on both the development of new degreening treatments reducing the time in which fruit is exposed to exogenous ethylene (Sdiri et al., 2012) and the application of synthetic auxin in order to reduce calyx senescence and to improve the external quality of degreened citrus fruit (Martínez-Jávega et al., 2008b; Carvalho et al., 2008; Salvador et al., 2008, 2010).

Synthetic auxins, such as 2,4-dichlorophenoxyacetic acid (2,4-D), 2,4dichlorophenoxy propionic acid (2,4-DP) or 3,5,6-trichloro-2-pyridyloxyacetic acid (3,5,6-TPA), are widely used by citrus growers as a preharvest treatment to increase fruit size, juice, and sugar and acid contents with a view to preventing fruit abscission and senescence, and to control fruit creasing and the incidence of splitting (Tumminelli et al., 2005; Greenberg et al., 2006; Mesejo et al., 2011; Agustí et al., 1992, 2002, 2006, 2007; Serciloto et al., 2003). 
On the other hand, 2,4-D has been extensively reported as a postharvest treatment to retard calyx abscission, drying and browning, and to maintain the final quality of the exported citrus fruit (Jiménez-Cuesta et al., 1983; Cronje et al., 2005; Martinez-Jávega et al., 2008b; Salvador et al., 2008). Moreover, studies into the effect of the postharvest application of 3,5,6-TPA on the incidence of calyx senescence induced by the degreening treatment are underway, and positive results have been reported for different concentrations (Carvalho et al., 2008; Salvador et al,. 2010). Nevertheless, despite all the studies conducted on the postharvest use of 2,4-D and 3,5,6-TPA, the literature available on the effect of the postharvest application of other synthetic auxins to control calyx abscission is limited.

Since presently none of the cited products is already registered in the EU for postharvest application, and as the use of 2,4-D is restricted even as a preharvest application, it is necessary to find other synthetic auxins as alternatives to 2,4-D in order to avoid the physiological changes in the calyx of citrus fruit submitted to postharvest degreening. For these reasons, the efficacy of a new growth regulator to reduce calyx alterations induced by postharvest ethylene exposure is being evaluated. Since 2007 , the trade name HF-Calibra ${ }^{\circledR}$ (SIPCAM INAGRA, Spain), with active ingredient MCPA-thioethyl (S-Ethyl-4chloro-o-tolyloxythioacetate), is registered as a plant growth regulator for preharvest use to increase the fruit size of mandarins, oranges and apples, and to also advance the maturity of peaches, apricots, nectarines and plum fruits.

The present study is the first report of the postharvest use of HF-Calibra $\AA$, in which both the effectiveness of this auxin at different concentrations on calyx senescence and the fruit quality parameters of the most important Spanish early-season citrus fruits subjected to degreening treatment under commercial conditions have been evaluated. 


\section{Material and Methods}

\subsection{Plant material}

'Navelina' oranges (Citrus sinensis L. Osbeck), and clementines (Citrus clementina Hort. Ex. Tan) cv. Clemenules, Oronules and Clemenrubí, grown in Valencia (Spain), were harvested in an internal maturity stage (commercial maturity index) during two consecutive seasons (2009 and 2010) from midSeptember to mid-November from two different growers. After harvest, fruits were transported to a commercial packinghouse (FONTESTAD S.A. Company) where they were calibrated by size and color according to the external color index (CCl=1000a/Lb; Jiménez-Cuesta et al., 1981) using a color electronic calibrator. Afterward, fruits were transported to the Postharvest Technology Center at the Instituto Valenciano de Investigaciones Agrarias (IVIA) where auxin treatments were applied prior to the degreening treatment.

\subsection{Auxin treatment}

The following auxins were used: 2,4-dichlorophenoxyacetic acid isopropyl ester (Citrus Fix; Amvac Chemical Corp., Los Angeles, USA) and S-Ethyl-4chloro-O-tolilooxytioacetate, (HF-Calibra®, SIPCAM INAGRA,S.A., Spain).

During the first study season (2009), the following treatments were applied: 1) Control (water) (CTL); 2) $10 \mathrm{mg} / \mathrm{L}$ of 2,4-D (2,4-D); 3) $10 \mathrm{mg} / \mathrm{L}$ of HFCalibra ${ }^{(H F-10)}$; 4) 20 mg/L of HF-Calibra ${ }^{\circledR}$ (HF-20). During the 2010 season, and according to the results obtained in the first experiment, the HF-Calibra $\AA$ concentrations applied were higher, so fruits were subjected to the following treatments: 1) Control (water) (CTL); 2) $10 \mathrm{mg} / \mathrm{L}$ of 2,4-D (2,4-D); 3) $20 \mathrm{mg} / \mathrm{L}$ of HF-Calibra ${ }^{\circledR}$ (HF-20); 4$) 40$ mg/L of HF-Calibra ${ }^{\circledR}$ (HF-40); 5) $60 \mathrm{mg} / \mathrm{L}$ of HFCalibra ${ }^{(H F-60)}$. Lots of 100 fruits were arranged per treatment.

After applying different auxin dips at room temperature for 2 min, fruits were air-dried and then submitted to the degreening treatment under commercial conditions $\left(2 \mu \mathrm{L} / \mathrm{L}, 21^{\circ} \mathrm{C}, 95 \% \mathrm{RH}\right)$. The duration of the treatment depended on the initial fruit color upon harvest. So, fruits were exposed to 
exogenous ethylene for 96 hours and 120 hours during the 2009 and the 2010 season, respectively.

After the degreening treatments, fruits were coated with a commercial wax ('Waterwax TTT-2l', Fomesa Fruitech S.L.U., Spain) and separated into two lots; one lot was stored at $5^{\circ} \mathrm{C}$ and $90-95 \% \mathrm{RH}$ for 3 days, simulating the export conditions to the EU and the second lot was exposed to a cold quarantine treatment at $1^{\circ} \mathrm{C}$ for 16 days to comply with the phytosanitary requirement for shipping fruit to the USA. At the end of both the cold storage periods, fruits were maintained at $20^{\circ} \mathrm{C}$ for 7 days, simulating shelf-life conditions.

At harvest and after shelf-life, the following parameters were determined: calyx senescence (abscission and browning), color index, weight loss, firmness, total soluble solids (TSS), titratable acidity (TA), maturity index (TSS/TA), acetaldehyde and ethanol content, as well as fruit flavor. Calyx senescence was also evaluated one day after the degreening treatment.

\subsection{Calyx quality assessment}

Calyx senescence of 100 fruit per treatment was evaluated visually. This evaluation consisted of testing each fruit for a loose calyx by rubbing the hand over the calyx. Calyx counts were made after shelf-life and the calyces were classified as calyx abscission and calyx browning. The results were expressed as the percentage of alteration compared to the total number of fruit.

\subsection{Analysis of quality attributes}

Peel color was measured with a Minolta colorimeter (model CR-300; Minolta Co. Ltd., Osaka, Japan) using 30 fruit per treatment and 3 measurements were taken on the equatorial zone of each fruit. The mean values for lightness (L), red-green (a), and yellow-blue (b) Hunter parameters were calculated for each fruit and expressed as a citrus color index $(\mathrm{CCl}=1000 \mathrm{a} / \mathrm{Lb})$ (Jiménez-Cuesta et al., 1981). Firmness measurements were taken with an Instron Universal Testing Machine (model 3343, Instron Limited, Buckinghamshire, UK) using 20 fruit per treatment. The results were expressed 
as the percentage of $\mathrm{mm}$ of fruit deformation resulting from a pressure of $10 \mathrm{~N}$ on the longitudinal axis at a constant speed.

For each treatment, three samples of ten fruit each were squeezed in an electric juice extractor with a rotating head (Lomi®, Model 4, Lorenzo Miguel, S.L., Madrid, Spain). Titratable acidity (TA) was determined by titration with 0.1 $\mathrm{N} \mathrm{NaOH}$, using phenolphthalein as an indicator and expressed as $\mathrm{g}$ of citric acid per $100 \mathrm{~mL}$ of juice. The soluble solids content (SSC) in the juice was determined by digital refractometer (Atago PR-1, Atago Co., Ltd., Tokyo, Japan) and the data were expressed as \%.

\subsection{Analysis of ethanol and acetaldehyde}

For the ethanol and acetaldehyde content, three samples were analyzed from each juice. Five milliiters of the juice were transferred to $10 \mathrm{~mL}$ vials with crimp-top caps TFE/silicone septa seal and then frozen at $-20^{\circ} \mathrm{C}$ until analysis. Ethanol and acetaldehyde levels were determined by headspace analysis on a gas chromatograph (model 1020, Perkin Elmer Corp., Norwalk, CT, USA) equipped with a flame ionization detector and a $1 / 8$ in. $\times 1.2 \mathrm{~m}$ Porapak QS $80 / 100$ column. The injector was set at $175^{\circ} \mathrm{C}$, the column at $150^{\circ} \mathrm{C}$, the detector (FID) at $200^{\circ} \mathrm{C}$ and the carrier gas at 12.3 psi. A $1 \mathrm{~mL}$ aliquot of the headspace was withdrawn from vials previously equilibrated for $1 \mathrm{~h}$ at $20^{\circ} \mathrm{C}$ and $10 \mathrm{~min}$ at $30^{\circ} \mathrm{C}$, and injected into the gas chromatograph. Ethanol and acetaldehyde were identified by comparison of retention time with a standard solution and expressed as $\mathrm{mg} / 100 \mathrm{~mL}$.

\subsection{Sensory evaluation}

Sensory evaluation was carried out by eight to ten semi-trained judges after degreening plus 7 days. Panelists rated flavor on a 9-point scale, where 1 $=$ extremely unpleasant, $5=$ fair (commercially acceptable), and $9=$ excellent. $\mathrm{A}$ sample consisting of segments taken from about 4 to 5 fruit per treatment was used. Samples were presented to panelists on trays labeled with random threedigit codes and served at room temperature. Spring water was provided for rinsing between samples. 


\subsection{Statistical analysis}

Statistical procedures were performed using a commercial statistical software (Statgraphics plus 5.1, Manugistics, Inc., Rockville, MD, USA). All the data were subjected to analysis of variance and means were compared using LSD test at $P<0.05$. The values of calyx senescence were arcsin-transformed because the values were originally recorded as percentages. The transformed data were subjected to analysis of variance using the previously described process.

\section{Results and Discussion}

\subsection{Effect of HF-Calibra ${ }^{\circledR}$ treatement on the calyx senescence}

For all the assayed varieties, the percentage of fruit with symptoms of calyx senescence after the degreening treatment and the posterior storage periods is represented for each season separately in Figures 1-4, except for 'Oronules' mandarins, for which we had data of only one year. For each variety, the values are the means of both growers since there was no significant effect of the growers.

Susceptibility to calyx disorders during the degreening treatment depended on variety. Previous studies have mentioned the great importance that cultivar aptitude has on citrus fruit's susceptibility to calyx alterations (Jiménez-Cuesta et al., 1983; Carvalho et al., 2008; Sdiri et al., 2012).

For the 'Clemenrubi' mandarins, fruits from the 2010 season, submitted to degreening for $120 \mathrm{~h}$ (Figure 1B), showed a higher percentage of total calyx senescence than those from the 2009 season, when fruits were exposed to exogenous ethylene for $96 \mathrm{~h}$ (Figure 1A). This fact could be explained by the longer degreening period applied in the second year. It has been reported that the longer the exposure time during the degreening process, the more 
susceptible to calyx changes citrus fruits become (Cuquerella, 1997; Petracek and Montalvo, 1997; Carvalho et al., 2008; Sdiri et al., 2012). During both seasons, and after simulating exports to EU and USA markets, the application of HF-Calibra ${ }^{\circledR}$ treatments at different concentrations (HF-20, HF-40 and HF60 ) reduced the incidence of abscised and browned calyxes if compared to the controls, showing the same behavior as 2,4-D, but with no significant differences among treatments. Even the application of HF- Calibra $₫$ proved more effective than 2,4-D when fruits treated with HF-20 and were submitted to a $96-\mathrm{h}$ ethylene exposure to be then stored 3 days at $5^{\circ} \mathrm{C}$ plus shelf-life.

'Clemenules' mandarins have been reported as a variety with low sensibility to ethylene exposure (Carvalho et al., 2008). This finding was observed during the season 2010, when the fruits from the control treatment presented low percentages of senescent calyxes with values below $15 \%$, although the fruits had been subjected to degreening for a 120-h ethylene exposure (Figure 2B). It is noteworthy that during the 2009 season, 'Clemenules' mandarins presented high sensitivity to the degreening treatment as they presented a high percentage of calyx senescence (Figure 2A). The percentage of calyx alterations in the control fruits exceeded $80 \%$. This fact indicates that, besides the cultivar and the degreening treatment conditions, other preharvest factors might be involved in this disorder. In all cases, the postharvest application of HF-Calibra ${ }^{\circledR}$ at different concentrations as well as 2,4-D significantly reduced the calyx senescence of 'Clemenules' mandarins when compared to the controls. After 3 days of storage at $5^{\circ} \mathrm{C}$, the fruits treated with 2,4-D and HF-20 presented the lowest percentages of calyx disorders with no significant difference between treatments (22\% and $27 \%$ respectively). When fruits were submitted to cold quarantine storage, 2,4-D was shown to be the most effective treatment in reducing calyx alterations as values below $15 \%$ were obtained for the fruits presenting calyx senescence symptoms.

In the present study, and as previously reported, 'Oronules' mandarins presented high sensitivity to calyx alteration after degreening (Figure 3); only 1 day after degreening, $42 \%$ of the fruits presented altered calyxes with the control treatment. The application of auxin treatments significantly reduced calyx alterations when compared to the controls as $77 \%$ and $96 \%$ of the fruits submitted to a marketing simulation to the EU and those subjected to 
quarantine treatment presented calyx disorders, respectively. The HF-60 treatment was seen to be the most effective to control calyx disorders with significantly lower abscised and browned calyxes values than the fruit treated with 2,4-D after degreening and the posterior cold quarantine treatment plus shelf-life.

'Navelina' oranges' sensitivity to calyx senescence, even when degreened without ethylene exposure, has been reported as high (Sdiri et al., 2012). In the present study, this variety presented elevated percentages of altered fruits being higher this incidence in the fruits from the season 2009 exposed to ethylene for $96 \mathrm{~h}$, where the percentage of affected fruit was above $80 \%$. On the other hand, the percentage of calyx browned was generally higher than calyx abscised if compared to the clementine varieties assayed in this research work. The HF-Calibra ${ }^{\circledR}$ treatments at different concentrations significantly reduced total calyx senescence symptoms if compared to the controls. No significant differences were found between the fruits treated with HF-Calibra $\AA$ and those treated with 2,4-D. When fruits were submitted to degreening for 96 h, HF-20 was seen to be the most effective in reducing calyx alterations, and less than $20 \%$ of the fruits exhibited calyx disorders.

In general, all the studied auxins treatments were effective in reducing calyx alterations in all the assays carried out. HF-Calibra ${ }^{\circledR}$ treatments at different doses proved effective to reduce calyx alterations if compared with the controls, and the observed reduction was similar to or higher than that obtained by 2,4-D. The effectiveness of 2,4-D on control calyx abscission in degreened citrus fruit observed herein corroborates previously reported results (JiménezCuesta et al., 1983; Cronjé at al., 2005; Carvalho et al., 2008; Martinez-Jávega et al., 2008b; Salvador et al., 2008). The obtained data showed a similar effectiveness of HF-Calibra ${ }^{\circledR}$ on reducing calyx senescence than 2,4-D treatment in all the assayed varieties. 


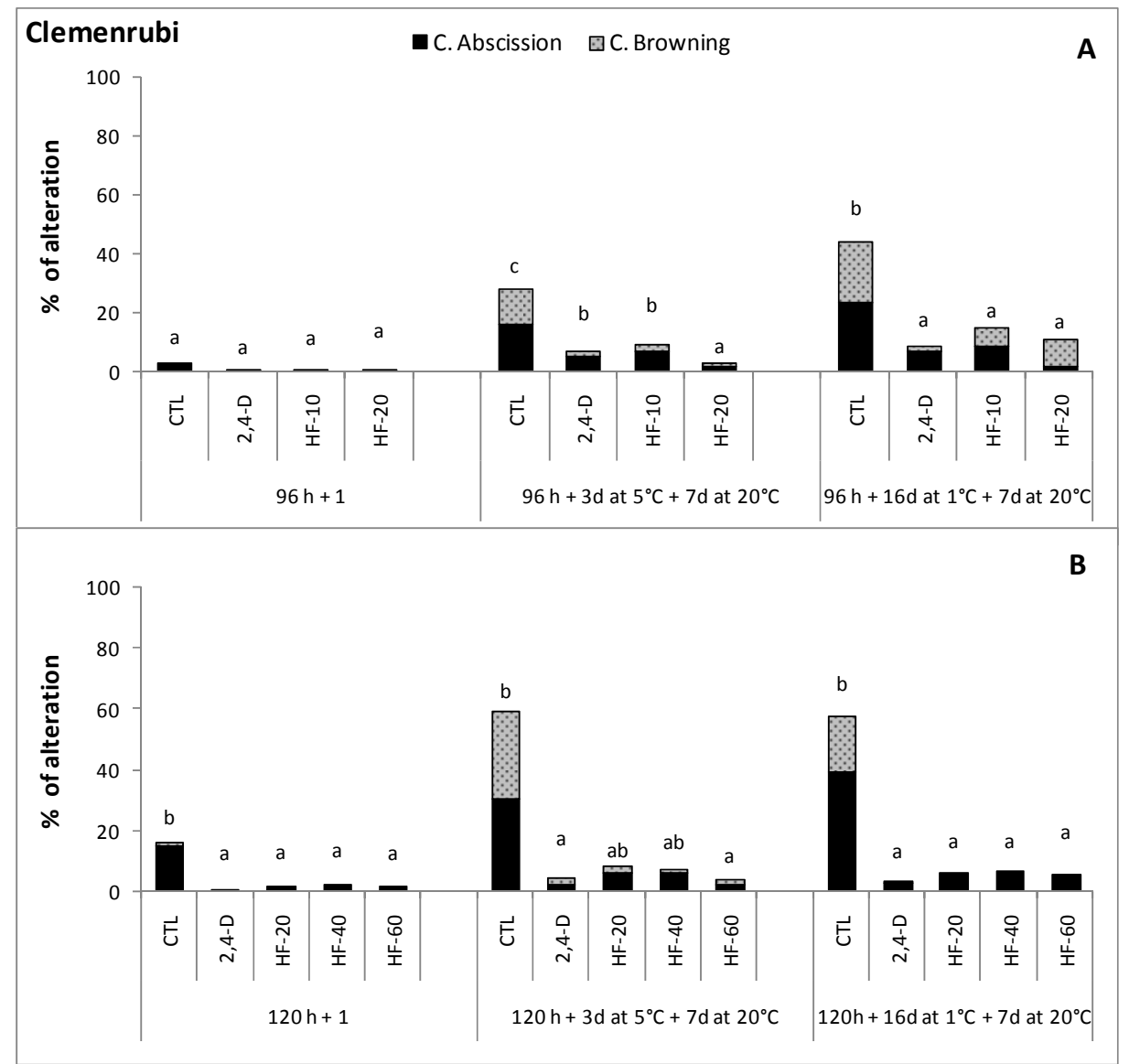

Fig. 1. Effect of postharvest auxin treatments on the calyx alterations of 'Clemenrubi' mandarins after degreening treatment $\left(2 \mu \mathrm{L} / \mathrm{L}\right.$ of ethylene, $\left.21^{\circ} \mathrm{C}, 95 \% \mathrm{RH}\right)$ during 96 hours $(\mathrm{A})$ or 120 hours (B) plus one day, and plus short cold storage $\left(5^{\circ} \mathrm{C}, 3 \mathrm{~d}\right)$ or quarantine treatment $\left({ }^{\circ} \mathrm{C}, 16\right.$ days $)$ plus shelf-life $\left(20^{\circ} \mathrm{C}, 7\right.$ days $)$.

Treatments applied: control fruit (CTL); $10 \mathrm{mg} / \mathrm{L}$ of 2,4-D (2,4-D); 10, 20, 40 or $60 \mathrm{mg} / \mathrm{L}$ of HFCalibra® (HF-10, HF-20, HF-40 and HF-60).

Percentages with different letters within the same storage period are significantly different according to $L S D$ test $(P \leq 0.05)$. 


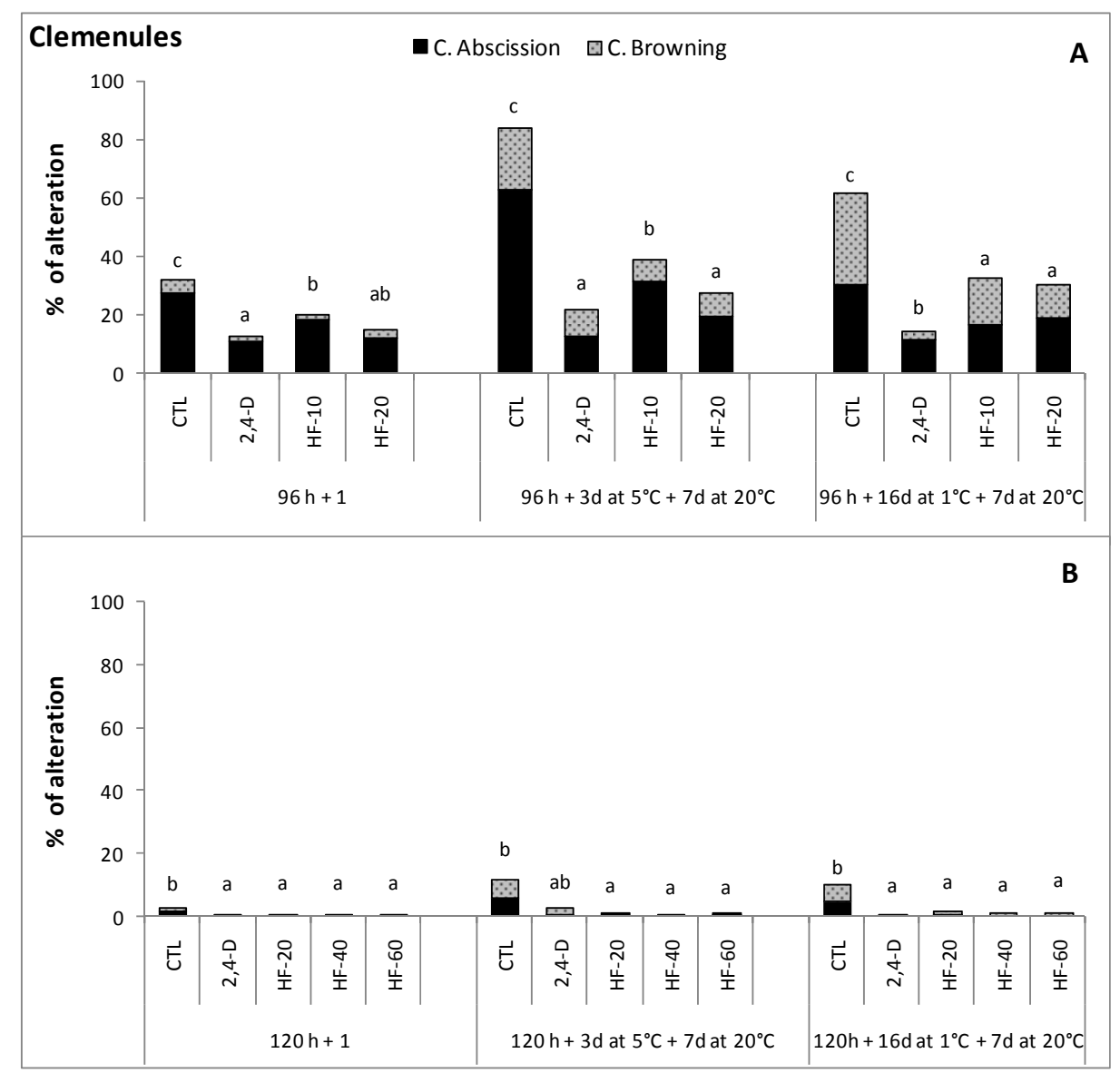

Fig. 2. Effect of postharvest auxin treatments on the calyx alterations of 'Clemenules' mandarins after degreening treatment $\left(2 \mu \mathrm{L} / \mathrm{L}\right.$ of ethylene, $\left.21^{\circ} \mathrm{C}, 95 \% \mathrm{RH}\right)$ during 96 hours $(\mathrm{A})$ or 120 hours (B) plus one day, and plus short cold storage $\left(5^{\circ} \mathrm{C}, 3 \mathrm{~d}\right)$ or quarantine treatment $\left(1^{\circ} \mathrm{C}, 16\right.$ days $)$ plus shelf-life $\left(20^{\circ} \mathrm{C}, 7\right.$ days $)$.

Treatments applied: control fruit (CTL); $10 \mathrm{mg} / \mathrm{L}$ of 2,4-D (2,4-D); $10,20,40$ or $60 \mathrm{mg} / \mathrm{L}$ of HFCalibra® (HF-10, HF-20, HF-40 and HF-60).

Percentages with different letters within the same storage period are significantly different according to $L S D$ test $(P \leq 0.05)$. 


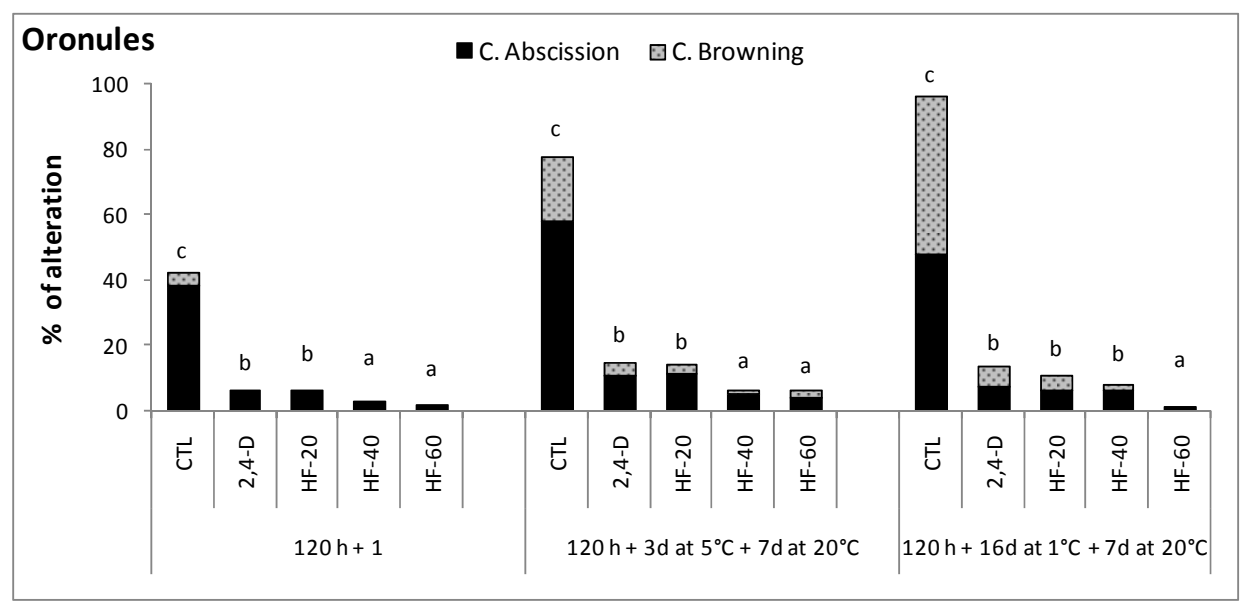

Fig. 3. Effect of postharvest auxin treatments on the calyx alterations of 'Clemenrubi' mandarins after degreening treatment $\left(2 \mu \mathrm{L} / \mathrm{L}\right.$ of ethylene, $\left.21^{\circ} \mathrm{C}, 95 \% \mathrm{RH}\right)$ during 120 hours (B) plus one day, and plus short cold storage $\left(5^{\circ} \mathrm{C}, 3 \mathrm{~d}\right)$ or quarantine treatment $\left(1^{\circ} \mathrm{C}, 16\right.$ days) plus shelf-life $\left(20^{\circ} \mathrm{C}, 7\right.$ days $)$.

Treatments applied: control fruit (CTL); $10 \mathrm{mg} / \mathrm{L}$ of 2,4-D (2,4-D); 20,40 or $60 \mathrm{mg} / \mathrm{L}$ of HFCalibra (HF-20, HF-40 and HF-60).

Percentages with different letters within the same storage period are significantly different according to LSD test $(P \leq 0.05)$. 


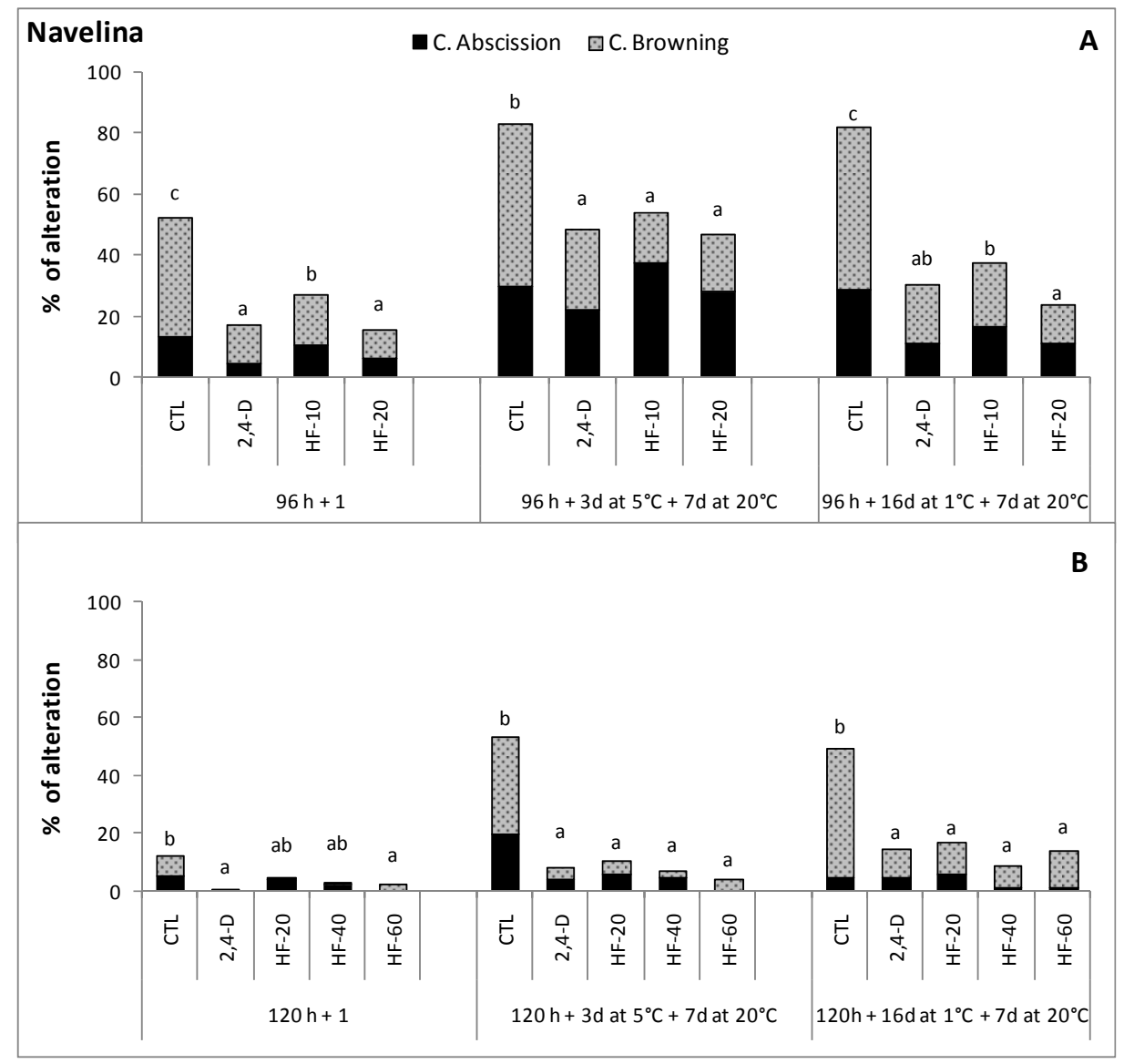

Fig. 4. Effect of postharvest auxin treatments on the calyx alterations of 'Navelina' oranges after degreening treatment $\left(2 \mu \mathrm{L} / \mathrm{L}\right.$ of ethylene, $\left.21^{\circ} \mathrm{C}, 95 \% \mathrm{RH}\right)$ during 96 hours $(\mathrm{A})$ or 120 hours $(\mathrm{B})$ plus one day, and plus short cold storage $\left(5^{\circ} \mathrm{C}, 3 \mathrm{~d}\right)$ or quarantine treatment $\left(1^{\circ} \mathrm{C}, 16\right.$ days $)$ plus shelf-life $\left(20^{\circ} \mathrm{C}, 7\right.$ days $)$.

Treatments applied: control fruit (CTL); $10 \mathrm{mg} / \mathrm{L}$ of 2,4-D (2,4-D); 10, 20, 40 or $60 \mathrm{mg} / \mathrm{L}$ of HFCalibra® (HF-10, HF-20, HF-40 and HF-60).

Percentages with different letters within the same storage period are significantly different according to $L S D$ test $(P \leq 0.05)$. 


\subsection{Effect of HF-Calibra ${ }^{\circledR}$ treatment on quality parameters of citrus fruit}

Since growers had no significant effect, the effect of postharvest application of the different auxins on the color index and quality attributes of only one grower of each variety is shown in Tables 1 and 2. The values provided were obtained after the degreening process, followed by a cold quarantine treatment plus 7 days of shelf life at $20^{\circ} \mathrm{C}$.

'Clemenrubí' mandarins harvested at a $\mathrm{CCl}$ close to +2 and degreened for $96 \mathrm{~h}$ (the 2009 season) reached peel color index values of over +17 , which were similar to those achieved when fruit were picked with a $\mathrm{CCl}$ of about -4 and then submitted to degreening for up $120 \mathrm{~h}$ (the 2010 season). It has been reported that the time required of ethylene exposure to obtain the typical variety color depends on the color of fruit at harvest (Carvalho et al., 2008; Sdiri et al., 2012). No significant differences were observed among auxin treatments when compared to control fruits.

After $120 \mathrm{~h}$ of ethylene exposure, 'Oronules' mandarins also achieved a high $\mathrm{CCl}$ value similar to that of 'Clemenrubi' fruits. These two cultivars are characterized by a reddish external color at optimum maturity (Soler and Soler, 2006). 'Oronules' fruits treated with 2,4-D and HF-20 presented CCl similar values to control fruits. Nevertheless, the color index change was slightly lower in fruits treated with the highest HF-Calibra ${ }^{\circledR}$ concentrations (HF-40 and HF$60)$.

In the case of 'Clemenules' mandarins, when they were harvested with a $\mathrm{CCl}$ of about -0.4 and degreened for $96 \mathrm{~h}$, fruits achieved the typical external coloration of the variety with peel color index values above +10 . Nevertheless, when fruits were picked with lower $\mathrm{CCl}$ values $(-4.4)$ and then submitted to a longer ethylene exposure $(120 \mathrm{~h})$, the peel color index achieved was lower, but was above +6 in all cases, which is the limit for marketing clementines. The postharvest application of HF-Calibra ${ }^{\circledR}$ at all the assayed concentrations, as well as $2,4-\mathrm{D}$ at $10 \mathrm{ppm}$, delayed color change respect to the control treatment. 
The purpose of the postharvest degreening treatment when 'Navelina' oranges were harvested with a high color index of about +7 was to achieve uniform external coloring. Degreening treatment of up to $96 \mathrm{~h}$ induced color change, with $\mathrm{CCl}$ values reaching +14 . The application of 2,4-D or HF-10 prior to degreening did not affect external color change. However when HF-20 was applied, external color was lesser if compared to the control treatment. 'Navelina' oranges with $\mathrm{CCl}$ values of -1.9 at harvest, subjected to a $120-\mathrm{h}$ ethylene exposure, achieved a color index of about +9 with no significant differences noted if compared with the fruits pretreated with 2,4-D; the application of HF-Calibra ${ }^{\circledR}$ at concentrations of 20,40 and $60 \mathrm{ppm}$ reduced color change if compared to the control treatment.

Although auxin treatments diminish color change during the degreening treatment, this delay had no negative effect from a commercial point of view since after the shelf-life, fruits of all the varieties attained a commercially acceptable color. In general, no significant differences were found between the $\mathrm{CCl}$ of the fruits treated with $\mathrm{HF}-\mathrm{Calibra}{ }^{\circledR}$ at different concentrations and the $\mathrm{CCl}$ of the 2,4-D-treated fruits. Previous studies have also reported a delay in color evolution during the degreening process when applying auxin treatments (Cronjé et al., 2005; Carvalho et al., 2008). Nevertheless, Jiménez-Cuesta et al. (1983) and Salvador et al. (2010) observed that 2,4-D did not affect the external color change of citrus fruits.

Weight loss, as a result of transpiration, is an important parameter during the postharvest life of citrus fruits since this parameter is of crucial economical loss and induces peel senescence (Cuquerella et al., 2004). In the present research, the percentage of post-shelf life weight loss observed did not alter the commercial quality of the fruit in any studied variety. Auxin treatments did not significantly affect weight loss, even though some treatments slightly reduced this parameter in comparison to untreated fruit (data not shown). All treatments exhibited firmness loss after the degreening process and the posterior storage plus shelf-life. Nevertheless, no significant differences were observed between either auxin-treated and an untreated fruits, or among the different auxin treatments, except for 'Oronules' mandarins, in which the postharvest application of 2,4-D and HF- Calibra ${ }^{\circledR}$ at different concentrations exhibited higher firmness values if compared to the control treatment. 
In general in the fruits of all the assayed varieties, TSS slightly increased and TA reduced after shelf-life if compared with the initial values recorded at harvest (Tables 1 and 2). The drop in the juice acidity levels led to an increase in the maturity index $(\mathrm{MI})$, calculated as the TSS/TA ratio. Although some differences were found, the postharvest application of auxins did not consistently affect these quality parameters in the studied varieties. Previous studies have reported that the final quality of degreened citrus fruits treated with 2,4-D did not change (Bello et al., 2004; Carvalho et al., 2008; Salvador et al., 2010).

Citrus fruits accumulate acetaldehyde and ethanol during storage depending on the cultivars and storage conditions, and large amounts over the threshold appear to cause off-flavor (Ke and Kader, 1990; Ke et al., 1991). In the present study, the ethanol and acetaldehyde contents in juice increased after shelf-life in all the assayed varieties when compared with the values recorded at harvest. Nevertheless in all cases, this increase did not appear to negatively influence flavor since control and auxin-treated fruits presented an acceptable commercial flavor. 


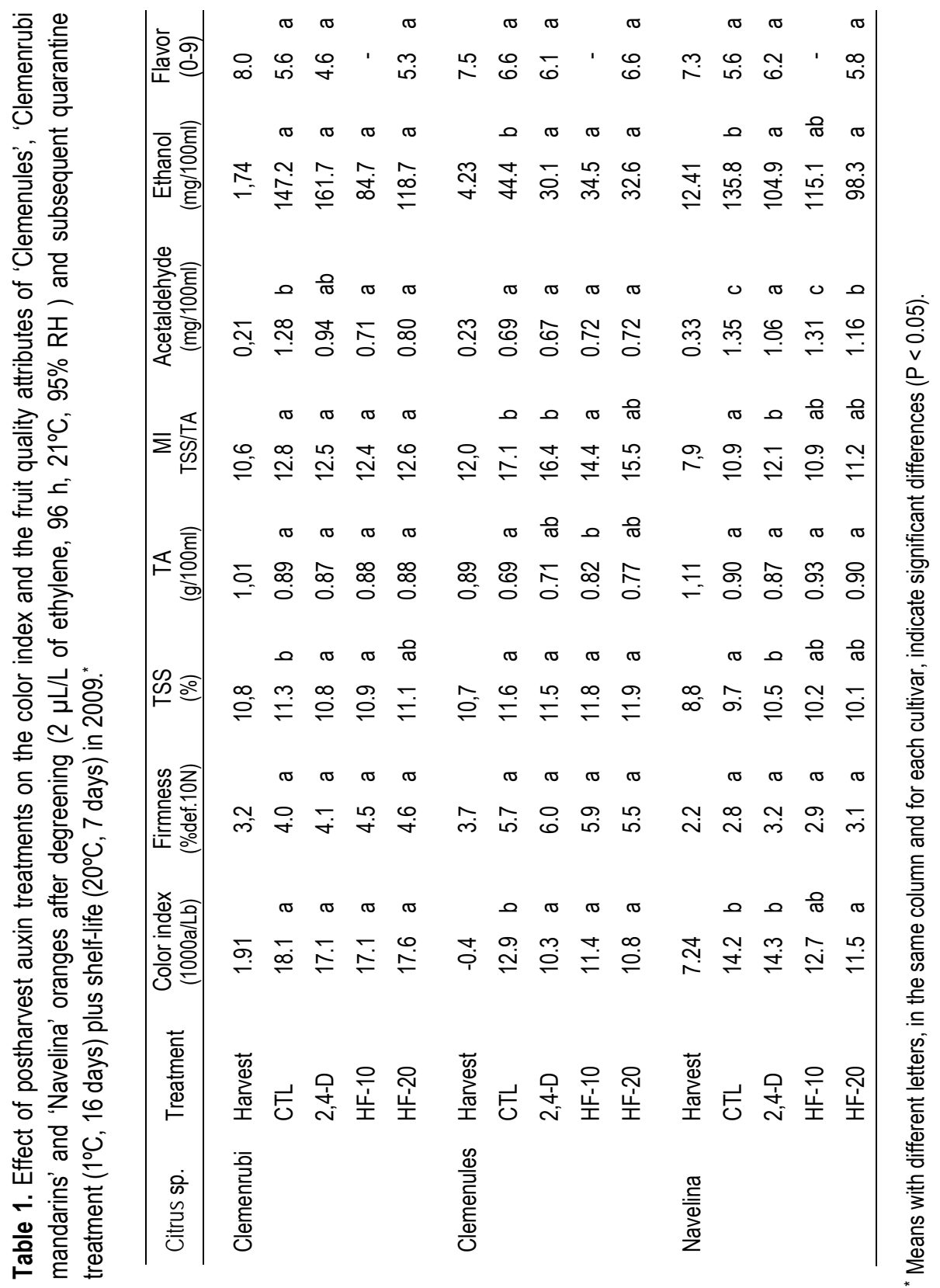


Chapter II

Table 2. Effect of postharvest auxin treatments on the color index and the fruit quality attributes of 'Clemenules', 'Clemenrubi mandarins' and 'Navelina' oranges after degreening $(2 \mu \mathrm{L} / \mathrm{L}$ of ethylene, $\left.120 \mathrm{~h}, 21^{\circ} \mathrm{C}, 95 \% \mathrm{RH}\right)$ and subsequent quarantine treatment $\left(1^{\circ} \mathrm{C}, 16\right.$ days) plus shelflife $\left(20^{\circ} \mathrm{C}, 7\right.$ days $)$ in 2010.

\begin{tabular}{|c|c|c|c|c|c|c|c|c|c|c|c|c|c|c|c|c|c|}
\hline \multirow{2}{*}{$\begin{array}{c}\text { Citrus sp. } \\
\text { Clemenrubi }\end{array}$} & \multirow{2}{*}{$\begin{array}{l}\text { Treatment } \\
\text { Harvest }\end{array}$} & \multicolumn{2}{|c|}{$\begin{array}{l}\text { Color index } \\
(1000 \mathrm{a} / \mathrm{Lb})\end{array}$} & \multicolumn{2}{|c|}{$\begin{array}{c}\text { Firmness } \\
\text { (\%def.10N) }\end{array}$} & \multicolumn{2}{|c|}{$\begin{array}{l}\text { TSS } \\
(\%)\end{array}$} & \multicolumn{2}{|c|}{$\begin{array}{c}\text { TA } \\
(\mathrm{g} / 100 \mathrm{ml})\end{array}$} & \multicolumn{2}{|c|}{$\begin{array}{c}\text { MI } \\
\text { TSS/TA }\end{array}$} & \multicolumn{2}{|c|}{$\begin{array}{c}\text { Acetaldehyde } \\
(\mathrm{mg} / 100 \mathrm{ml})\end{array}$} & \multicolumn{2}{|c|}{$\begin{array}{c}\text { EtOH } \\
(\mathrm{mg} / 100 \mathrm{ml})\end{array}$} & \multicolumn{2}{|c|}{$\begin{array}{c}\text { Flavor } \\
(0-9)\end{array}$} \\
\hline & & -4.7 & & 3.4 & & 12.5 & & 1.05 & & 12.0 & & 0.09 & & 0.10 & & 5.7 & \\
\hline & CTL & 18.5 & $\mathrm{ab}$ & 5.4 & $\mathrm{a}$ & 12.5 & $\mathrm{a}$ & 0.99 & $\mathrm{a}$ & 12.7 & $\mathrm{a}$ & 0.66 & $\mathrm{a}$ & 79.3 & $\mathrm{a}$ & 5.0 & a \\
\hline & 2,4-D & 16.8 & a & 5.1 & $\mathrm{a}$ & 12.7 & $\mathrm{a}$ & 1.01 & $\mathrm{a}$ & 12.5 & $\mathrm{a}$ & 0.69 & $\mathrm{a}$ & 123.4 & $\mathrm{a}$ & 4.3 & $\mathrm{a}$ \\
\hline & HF-20 & 18.1 & $a b$ & 5,2 & $\mathrm{a}$ & 13.1 & $\mathrm{a}$ & 1.02 & $\mathrm{a}$ & 12.3 & $\mathrm{a}$ & 0.66 & $\mathrm{a}$ & 113.0 & $\mathrm{a}$ & 5.7 & a \\
\hline & HF-40 & 19.3 & b & 5.4 & $\mathrm{a}$ & 12.8 & $\mathrm{a}$ & 1.05 & $\mathrm{a}$ & 12.1 & $\mathrm{a}$ & 0.67 & $\mathrm{a}$ & 136.4 & $\mathrm{a}$ & 5.7 & a \\
\hline & HF-60 & 16.7 & $\mathrm{a}$ & 5.0 & $\mathrm{a}$ & 12.9 & a & 1.04 & $\mathrm{a}$ & 12.4 & $\mathrm{a}$ & 0.63 & $\mathrm{a}$ & 102.7 & $\mathrm{a}$ & 6.0 & a \\
\hline \multirow[t]{6}{*}{ Clemenules } & Harvest & -4.7 & & 4.1 & & 11.8 & & 1.13 & & 10.5 & & 0.10 & & 0.06 & & 8.0 & \\
\hline & CTL & 9.1 & c & 5.9 & $\mathrm{a}$ & 12.9 & $\mathrm{a}$ & 1.18 & $a b$ & 10.9 & $\mathrm{a}$ & 0.85 & $\mathrm{a}$ & 64.9 & c & 7.0 & a \\
\hline & $2,4-\mathrm{D}$ & 8.4 & $\mathrm{~b}$ & 6.0 & $\mathrm{a}$ & 12.8 & $\mathrm{a}$ & 1.12 & $\mathrm{a}$ & 11.4 & $\mathrm{a}$ & 0.73 & $\mathrm{a}$ & 40.8 & $\mathrm{a}$ & 7.3 & a \\
\hline & HF-20 & 7.8 & $a b$ & 5.8 & $\mathrm{a}$ & 12.8 & a & 1.21 & b & 10.6 & $\mathrm{a}$ & 0.77 & $\mathrm{a}$ & 48.8 & $a b$ & 7.7 & a \\
\hline & HF-40 & 6.8 & $\mathrm{a}$ & 5.9 & $\mathrm{a}$ & 12.8 & $\mathrm{a}$ & 1.21 & b & 10.6 & $\mathrm{a}$ & 0.72 & $\mathrm{a}$ & 58.6 & bc & 7.7 & a \\
\hline & HF-60 & 7.4 & $a b$ & 6.2 & $\mathrm{a}$ & 12.7 & $\mathrm{a}$ & 1.14 & $\mathrm{a}$ & 11.1 & $\mathrm{a}$ & 0.65 & $\mathrm{a}$ & 36.8 & $\mathrm{a}$ & 7.3 & $\mathrm{a}$ \\
\hline \multirow[t]{6}{*}{ Oronules } & Harvest & -4.4 & & 3.2 & & 10.6 & & 1.17 & & 10.2 & & 0.31 & & 8.8 & & 7.5 & \\
\hline & CTL & 17.4 & c & 6.2 & c & 10.7 & $\mathrm{a}$ & 0.82 & $\mathrm{a}$ & 13.1 & $\mathrm{a}$ & 0.59 & $\mathrm{a}$ & 23.8 & $\mathrm{a}$ & 5.8 & a \\
\hline & $2,4-\mathrm{D}$ & 16.3 & bc & 5.3 & b & 10.7 & $\mathrm{a}$ & 0.86 & $\mathrm{a}$ & 12.6 & $\mathrm{a}$ & 0.77 & bc & 134.1 & c & 4.8 & a \\
\hline & HF-20 & 15.3 & abc & 5.4 & b & 10.6 & $\mathrm{a}$ & 0.80 & $\mathrm{a}$ & 13.3 & $\mathrm{a}$ & 0.71 & $\mathrm{ab}$ & 77.2 & b & 5.8 & a \\
\hline & HF-40 & 13.3 & $\mathrm{a}$ & 5.6 & b & 10.9 & ab & 0.82 & $\mathrm{a}$ & 13.4 & $\mathrm{a}$ & 0.77 & bc & 75.7 & b & 5.8 & a \\
\hline & HF-60 & 14.1 & $a b$ & 4.7 & $\mathrm{a}$ & 11.3 & b & 0.87 & $\mathrm{a}$ & 13.1 & $\mathrm{a}$ & 0.88 & c & 155.5 & c & 4.5 & a \\
\hline \multirow[t]{6}{*}{ Navelina } & Harvest & -1.9 & & 2.3 & & 10.2 & & 1.79 & & 5.7 & & 0.31 & & 17.6 & & 5.3 & \\
\hline & CTL & 9.6 & c & 2.8 & $\mathrm{a}$ & 10.3 & b & 1.47 & $\mathrm{a}$ & 7.0 & $\mathrm{a}$ & 1.02 & ab & 70.2 & $a b$ & 5.8 & $\mathrm{a}$ \\
\hline & 2,4-D & 9.3 & bc & 2.9 & $\mathrm{a}$ & 10.2 & b & 1.52 & $\mathrm{a}$ & 6.7 & $\mathrm{a}$ & 1.08 & b & 64.6 & $\mathrm{ab}$ & 5.8 & $\mathrm{a}$ \\
\hline & HF-20 & 7.3 & $\mathrm{a}$ & 2.8 & $\mathrm{a}$ & 9.6 & $\mathrm{a}$ & 1.36 & $\mathrm{a}$ & 7.1 & $\mathrm{a}$ & 0.91 & $\mathrm{a}$ & 62.3 & $\mathrm{ab}$ & 5.8 & a \\
\hline & HF-40 & 7.7 & $\mathrm{a}$ & 2.9 & $\mathrm{a}$ & 10.2 & b & 1.48 & $\mathrm{a}$ & 6.9 & $\mathrm{a}$ & 1.07 & $\mathrm{~b}$ & 75.6 & $\mathrm{~b}$ & 5.3 & $\mathrm{a}$ \\
\hline & HF-60 & 6.1 & $\mathrm{a}$ & 3.0 & $\mathrm{a}$ & 10.1 & $a b$ & 1.47 & $\mathrm{a}$ & 6.9 & a & 0.98 & $a b$ & 56.2 & $\mathrm{a}$ & 5.8 & $\mathrm{a}$ \\
\hline
\end{tabular}

${ }^{*}$ Means with different letters, in the same column and for each cultivar, indicate significant differences $(P<$ 0.05). 


\section{Conclusion}

According to the findings obtained, besides variety and process conditions, the sensitivity of citrus fruits to calyx senescence during degreening treatment can depend on preharvest conditions.

The postharvest dipping application of HF-Calibra®, prior to the commercial degreening treatment, has been shown to effectively reduce calyx senescence caused by exogenous ethylene. The higher the doses applied, the lower percentage of fruit with calyx alterations symptom.

Although auxin treatments retard color evolution, this delay does not affect the external color of fruit from a commercial point of view since the fruit of all the varieties attained a commercially acceptable color after the shelf-life. Regarding quality attributes, the postharvest application of HF-Calibra ${ }^{\circledR}$ treatments did not affect the internal quality of any studied variety.

The findings obtained in the present study suggest that auxin HF-Calibra ${ }^{\circledR}$ could be a potential alternative to 2,4-D treatment in the future to control the calyx senescence of early-season citrus fruit submitted to degreening treatment.

\section{Acknowledgments}

This research has been supported by the Instituto Valenciano de Investigaciones Agrarias and by SIPCAM INAGRA, S.A. The authors wish to thank the FONTESTAD S.A Company for its technical support. 


\section{References}

Agustí, M., Almela, V., Aznar, M., Pons, J., El-Otmani, M., 1992. The use of 2,4DP to improve fruit size in citrus. Proc. Int. Soc. Citriculture 1, 423-427.

Agustí, M., Zaragoza, S., Iglesias, D., Almela, V., Primo-Millo, E., Talón, M., 2002. The synthetic auxin 3,5,6-TPA stimulates carbohydrate accumulation and growth in citrus fruit. Plant Growth Regul. 36, 141-147.

Agustí, M., Juan, M., Martínez-Fuentes, A., Mesejo, C., Reig, C., Almela, V., 2006. Application of 2,4-dichlorophenoxypropionic acid 2-ethylhexyl ester reduces mature fruit abscission in Citrus navel cultivars. J. Hortic. Sci. Biotechnol. 81, 532-536.

Agustí, M., Juan, M., Almela, V., 2007. Response of 'Clausellina' satsuma mandarin to 3,5,6-trichloro-2-pirydiloxyacetic acid and fruitlet abscission. Plant Growth Regul. 53, 129-135.

Bello, F., Addy, L., Kulczycki Waskowicz, C., 2004. Incidencia de fitorreguladores en la calidad de cítricos Argentinos con destino a la Unión Europea y Japón. Revista Iberoamericana de Tecnología Poscosecha 6, 9598.

Carvalho, C.P., Salvador, A., Navarro, P., Monterde, A., Martínez-Jávega, J.M., 2008. Effect of auxin treatments on calyx senescence in the degreening of four mandarin cultivars. HortScience 43, 747-752.

Cohen, E., 1978. The effect of temperature and relative humidity during degreening on the coloring of Shamouti orange fruit. J. Hortic. Sci. 53, 143146.

Cronjé, P.J.R., Crouch, E.M., Huysamer, M., 2005. Postharvest calyx retention of citrus fruit. Acta Hortic. 682, 369-374.

Cuquerella J., 1997. Técnicas y prácticas de desverdización de cítricos producidos en condiciones mediterráneas. Phytoma 90, 106-111.

Cuquerella, J., Martínez-Jávega, J.M., Monteverde, A., Navarro, P., Salvador, A., 2004. Nuevo sistema de medida de color para cítricos. Levante Agrícola/ especial poscosecha 298-304. 
Greenberg, J., Kaplan, I., Fainzack, M., Egozi, Y., Giladi, B., 2006. Effects of auxins sprays on yield, fruit size, fruit splitting and the incidence of increasing of 'Nova' mandarin. Acta Hortic. 727, 249-254.

Jiménez-Cuesta, M., Cuquerella, J., Martínez-Jávega, J.M., 1981. Determination of a color index for citrus fruit degreening. Proc. Int. Soc. Citriculture 2, 750-753.

Jiménez-Cuesta, M., J.Cuquerella, and J.M. Martínez-Jávega. 1983. Teoría y práctica de la desverdización de los cítricos. Comunicación I.N.I.A, Hoja Técnica $\mathrm{n}^{\circ} 46,22 \mathrm{pp}$.

Ke, D., Kader, A., 1990. Tolerance of 'Valencia' Oranges to Controlled Atmospheres, as Determined by Physiological Responses and Quality Attributes. J. Amer. Soc. Hortic. Sci. 115, 779-783.

Ke, D., Goldstein, L., O'Mahony, M., Kader, A., 1991. Effects of short-term exposure to low $\mathrm{O}_{2}$ and high $\mathrm{CO}_{2}$ atmospheres on quality attributes of strawberries. J. Food Sci. 56, 50-54.

Martínez-Jávega, J.M., Monterde, A., Navarro, P., Salvador, A., 2008a. Response of new clementines to degreening treatment. Proc. Int. Soc. Citriculture 11, 1342-1346.

Martínez-Jávega, J.M., Salvador, A., Navarro, P., Sdiri, S., 2008b. Aplicación de tratamientos de auxinas para el control de alteraciones del cáliz en mandarinas sometidas al tratamiento de desverdización, in: Oria Almudí, R., Val Falcón, J., Ferrer Mairal, A. (Eds.), Avances en maduración y postrecolección de frutas y hortalizas. Editorial Acribia, S.A., Zaragoza, Spain, pp. $474-480$

Mesejo, C., Rosito, S., Reig, C., Martínez-Fuentes, A., Agustí, M., 2011. Synthetic auxin 3,5,6-TPA provokes Citrus clementina (Hort. Ex Tan) fruitlet abscission by reducing photosynthate availability. J. Plant Growth Regul. pp. 1-9. DOI: $10.1007 / \mathrm{s} 00344-011-9230-z$.

Petracek, P.D., Montalvo, L., 1997. The degreening of 'Fallglo' tangerine. J. Am. Soc. Hortic. Sci. 122, 547-552.

Salvador, A., Navarro, P., Monterde, A., Martínez-Jávega, J.M., 2008. Postharvest application of auxins to control calyx senescence in clementines 
submitted to degreening treatment. Proc. Int. Soc. Citriculture 11, 13771382.

Salvador, A., Sdiri, S., Navarro, P., Monterde, A., Marténez-Jávega, J.M., 2010. The use of auxins to maintain postharvest quality of citrus fruit. Acta Hortic. 877, 671-677.

Sdiri, S., Navarro, P., Salvador, A., 2010. Postharvest degreening treatment on citrus fruit: effect on external and internal quality, in: Slaker, D.A. (Ed.), Citrus Fruits: Properties, Consumption and Nutrition. Nova Science Publishers, Inc., New York, pp.137-149.

Sdiri, S., Navarro, P., Monterde, A., Ben abda, J., Salvador, A., 2012. New degreening treatments to improve the quality of citrus fruit combining different periods with and without ethylene exposure. Postharvest Biol. Technol. 63, 25-32.

Serciloto, C.M., De Camargo e Castro, P.R., Tavares, S., Medina, C.L., 2003. Thinning and fruit growth of 'Murcott' tangor with the use of bioregulators. Laranja. 24, 95-111.

Soler, J., Soler, G., 2006. Cítricos. Variedades y técnicas de cultivo. MundiPrensa, Madrid, Spain. pp. 242.

Tumminelli, R., Conti, F., Maltese, U., Pedrotti, C., Bordonaro, E., 2005. Effects of 2,4-D, 2,4-DP, triclopir and $\mathrm{GA}(3)$ on pre-harvest fruit drop and senescence of 'Tarocco commune' blood oranges in Sicilian orchards. Acta Hortic. 682, 801-805. 


\section{Antioxidant activity and vitamin $C$ are not affected by degreening treatment of Clementine mandarins}

Sawsen Sdiri ${ }^{\mathrm{a}}$, Pilar Navarro ${ }^{\mathrm{a}}$, Adela Monterde ${ }^{\mathrm{a}}$, Jameleddine Benabda $^{\mathrm{b}}$, Alejandra Salvador ${ }^{\mathrm{a}}$

\footnotetext{
${ }^{a}$ Centro de Tecnología Postcosecha, Instituto Valenciano de Investigaciones Agrarias, Carretera Moncada-Náquera Km 4.5 s/n, 46113, Moncada, Valencia, Spain

${ }^{\text {b }}$ Département d'Agroalimentaire, Institut Supérieur Agronomique de chottMariem, 4042, Sousse, Tunisia
}

Reference: Acta Horticulturae, 2012, 934: 893-899. 



\begin{abstract}
Degreening with ethylene is a common postharvest practice in citrus fruit. This treatment is commercially used worldwide to promote peel degreening in many citrus species, especially in early season fruit in which the pulp reaches maturity and becomes edible when the peel is still green, and also to achieve uniform external coloration in fruit for export markets. Although nowadays degreening treatment is an option for both conventional and organic growers, there are some consumers and growers who dislike the idea of fruit being expose to ethylene. The effect of ethylene during degreening on external color and shelf-life of the fruit it well studied, however, its effect on bioactive compounds such as vitamin $C$ and on antioxidant capacity is not-well documented. In this study, the effect of ethylene during degreening treatment on nutritional quality of 'Clemenpons' and 'Clemenules' clementine cultivars was investigated. Fruit were submitted to degreening treatment during $48 \mathrm{~h}$, $72 \mathrm{~h}$ and $120 \mathrm{~h}$ with or without application of ethylene. Following the treatment, fruit were stored at $20^{\circ} \mathrm{C}$ during 7 days simulating shelf-life. Degreening treatment without ethylene reduced calyx senescence. Nevertheless, ethylene application improves color index compared to the treatment without ethylene. The ethylene application did not affect ascorbic acid, total vitamin $\mathrm{C}$, dehydroascorbic acid content and antioxidant capacity of fruit from both cultivars. Degreening treatment with or without ethylene did not affect quality parameters.
\end{abstract}

Keywords: citrus, ethylene, color, ascorbic acid, dehydroascorbic acid, quality 


\section{INTRODUCTION}

Most of early-season varieties of citrus, mainly mandarins and oranges, reach internal maturity before full external coloration, therefore degreening with ethylene is a common postharvest treatment used to accelerate color change. Nevertheless, the application of ethylene during degreening may accelerate transpiration and drying, browning and abscission of the calyx (Cronjé et al., 2005; Salvador et al., 2008). Therefore the period of exposure to ethylene must be adequate, using optimum temperature, ethylene concentration, humidity and air renewal. Furthermore the susceptibility to these undesirable effects of ethylene is cultivar dependent (Carvalho et al., 2008).

Citrus fruit are recognized as an important component of the human diet, providing a variety of important components for human nutrition; consumption of citrus fruit has been associated with a reduced risk of certain cancers and cardiovascular diseases. For that reason, citrus fruit have received considerable attention because of its nutritional and antioxidant properties (Del caro et al., 2004; Dhuique-Mayer et al., 2005). Antioxidant activity of citrus fruit is mainly due to ascorbic acid, polyphenols and carotenoids. Regarding to bioactive compounds in citrus juice, the few studies carried out about the effect of postharvest ethylene treatment on those compounds; show that ethylene has no effect on naringin content, nor on ascorbic acid and total phenolics content (El Kazzaz et al., 1983).

The aim of the present work was to study the effect of degreening treatment with ethylene under commercial conditions on vitamin $\mathrm{C}$ content and antioxidant activity of two clementine varieties. 


\section{MATERIAL AND METHODS}

\section{Plant material and treatments}

'Clemenpons' and 'Clemenules' mandarins were harvested in Valencia (Spain) and selected according to uniformity in size and external color by a color electronic calibrator. For each cultivar, fruit were separated into six lots of 50 fruits according to external peel color index. Fruit were submitted to the degreening treatment in the packinghouse under commercial conditions (a continuous flow of $2 \mathrm{ppm}$ ethylene at $20-21^{\circ} \mathrm{C}$ and $95 \% \mathrm{RH}$ ) for 48,72 or $120 \mathrm{~h}$. After degreening, fruit were stored at $20^{\circ} \mathrm{C}$ for 7 days simulating shelf-life period.

The following parameters were evaluated at harvest, after degreening and after shelf-life: ascorbic acid, dehydroascorbic acid, total ascorbic acid content, antioxidant capacity, color index, calyx senescence, titratable acidity and total soluble solids.

\section{Ascorbic acid Analysis}

Total ascorbic acid (TAA) and ascorbic acid (AA) were quantified by highperformance liquid chromatography (HPLC) (Merck Hitachi, Germany) equipped with diode array detectors according to the method described by Sdiri et al. (2008). Calibration curves were performed with four concentrations of AA (50100-150 and 200ppm). Standards were run daily with samples for validation. The content of dehydroascorbic acid (DHAA) in the sample was calculated by subtracting the L-AA content from TAA.

\section{Determination of Antioxidant activity}

The antioxidant activity in three replicates of each treatment was based on the evaluation of the free radical scavenging capacity of the juice according to the method described by Brand-Williams et al. (1995). A solution of $0.1 \mathrm{mM}$ DPPH (2,2-diphenyl-2-picryl-hidrazyl (Sigma, Germany) in methanol was 
prepared. An aliquot of $75 \mu \mathrm{L}$ of juice was added to $2925 \mu \mathrm{L}$ of this solution. Diluted samples of juice in methanol were used. The antioxidant activity was measured by decreasing the absorbance at $515 \mathrm{~nm}$ (Shimadzu UV-1601, UVvis spectrophotometer, Columbia, Maryland, USA).The results were expressed as $\mathrm{EC}_{50}$.

\section{Quality attributes determination}

Citrus color index $(\mathrm{CCl})$ of each fruit per lot was measured with a Minolta colorimeter (model CR-300, Minolta Co. Ltd, Osaka, Japan), taking 3 measurements in the equatorial zone of each fruit. The mean values for ' $L$ ', ' $a$ ' and 'b' Hunter parameters were calculated for each fruit and expressed as Citrus Color Index $(\mathrm{CCl}=1000 \mathrm{a} / \mathrm{Lb})$. Calyx senescence of 50 fruits per treatment was evaluated visually. This evaluation consisted of testing each fruit for a loose calyx by rubbing the hand over the calyx. Calyx counts were made at 1 and 7 days after degreening and the calyx were classified as calyx abscission and calyx browning. The results were expressed as the percentage of alteration compared to the total number of fruit. Titratable acidity (TA) was determined by titration with $0.1 \mathrm{~N} \mathrm{NaOH}$ solution, using phenolphthalein as indicator and expressed as $\mathrm{g}$ of citric acid per $100 \mathrm{~mL}$ of juice. Total soluble solids (TSS) in the juice were determined by measuring the refractive index of the juice and the data were expressed as ${ }^{\circ}$ Brix (Atago Digital Refractometer PR-1, Atago Co., Ltd, Tokyo, Japan).

\section{Statistical analysis}

Statistical procedures were performed using a commercial statistical software (Statgraphics plus 5.1, Manugistics, Inc., Rockville, M.d., U.S.A.). All data were subjected to analysis of variance, and means were compared using LSD test at $P \leq 0.05$. 


\section{RESULTS AND DISCUSSION}

Effect of ethylene on ascorbic acid, total ascorbic acid and dehydroascorbic acid concentrations

L-ascorbic acid (AA) is the principal biologically active form but LDehydroascorbic acid (DHAA), an oxidation product, also exhibits biological activity. Since DHAA can be easily converted into AA in the human body it is important to measure both AA and DHAA for vitamin C activity (Lee and Kader, 2000).

According to the literature, the content of vitamin $C$ in different juices decreases during storage, depending on storage conditions, such as temperature, oxygen and light (Kabasakalis et al., 2000; Zerdin et al., 2003). Nevertheless, the effect of postharvest application of ethylene during degreening treatment on these compounds is not well documented.

In 'Clemenules' mandarins higher values of TAA and AA were observed after degreening treatment plus shelf-life compared to values at harvest. The duration of degreening treatment did not affect these parameters. No remarkable differences were showed in degreened fruit with or without ethylene. Huang et al. (2008) also observed a gradual increase in AA content in pulp of 'Cara cara' navel orange during storage. In the same way, an increase of ascorbic acid has also been reported in 'Fortune' mandarin after 15 days of storage and the subsequent shelf-life (Sdiri et al., 2008). In 'Clemenules' cultivar the increase of TAA and AA content observed in degreened fruit after shell-life could be related to the increment observed in maturity index (TSS/acid ratio) (Table 1).

For 'Clemenpons' mandarins, compared to the values at harvest, $A A$ and TAA content remained constant after different degreening treatments plus shelflife period (Fig.1), only the treatments of 72 and $120 \mathrm{~h}$ with ethylene showed slightly high values. 
For both mandarins cultivars and in the different treatments, a slightly increase of DHAA content was observed after shelf-life periods with ethylene degreening, however, the difference was not significant.

\section{Ethylene effect on antioxidant activity}

The antioxidant activity of fruit and vegetable is important for assessing their nutritional value (Huang et al., 2007). Several methods have been developed to evaluate the total antioxidant activity of citrus fruit but the reaction with $\mathrm{DPPH}^{\bullet}$ (Brand-Williams et al., 1995) has received more attention. This method, used in the present study, is based on the measurement of free radical scavenging of the antioxidant compounds using $\mathrm{DPPH}^{\bullet}$ radical. The result is expressed as $\mathrm{EC}_{50}$, which is the amount of antioxidant needed to decrease the radical concentration by $50 \%$. This $\mathrm{EC}_{50}$ is inversely related to the antioxidant capacity; the lower $\mathrm{EC}_{50}$ value the higher the antioxidant activity of a compound.

For 'Clemenules' mandarins, the antioxidant activity increased slowly due to the rise of AA content, while for 'Clemenpons' mandarin the $\mathrm{EC}_{50}$ values remained constant after shelf-life (Fig.2). Many studies found that the antioxidant activity is highly related to AA content (Huang et al., 2008). Exogenous ethylene during degreening process did not affect the antioxidant activity in fruit of both cultivars. 

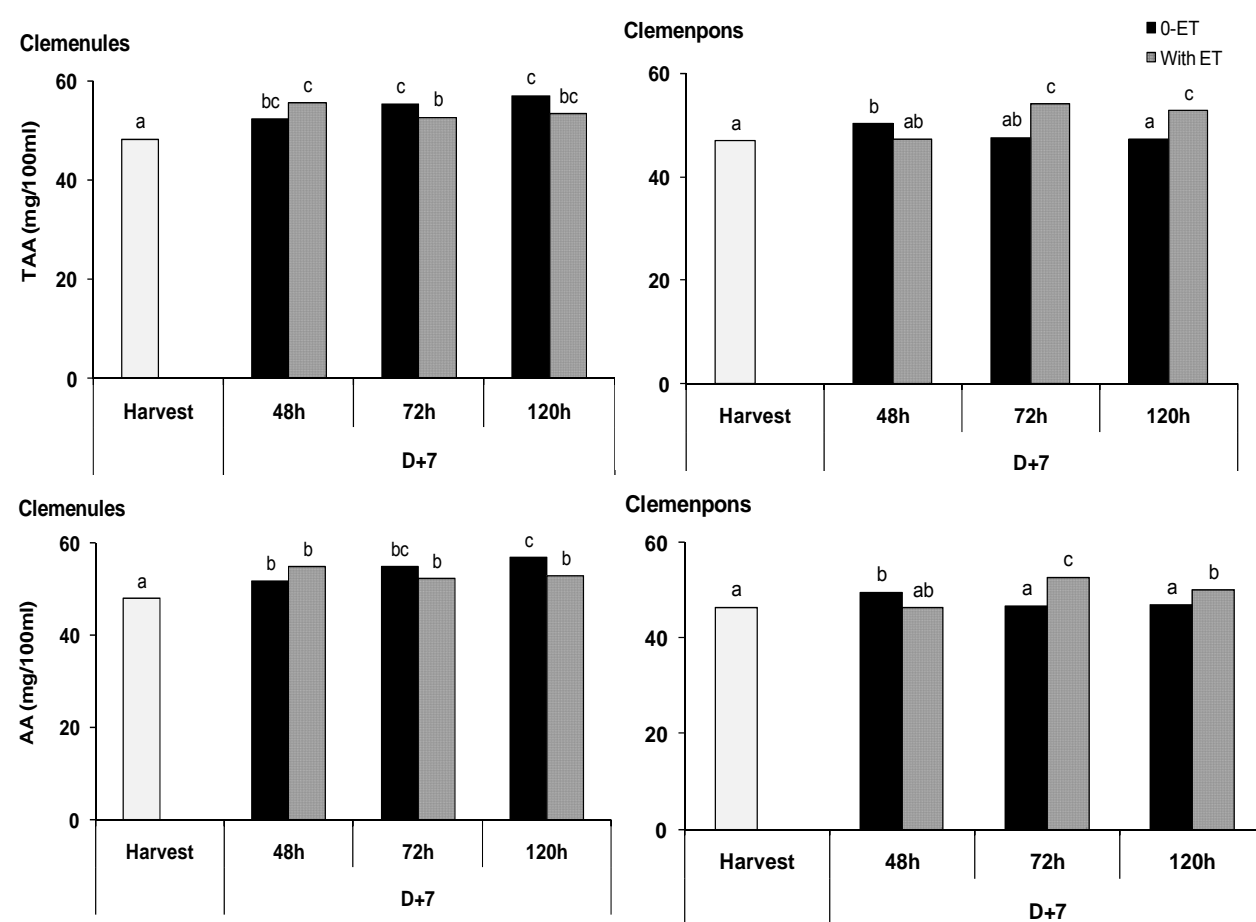

Clemenpons
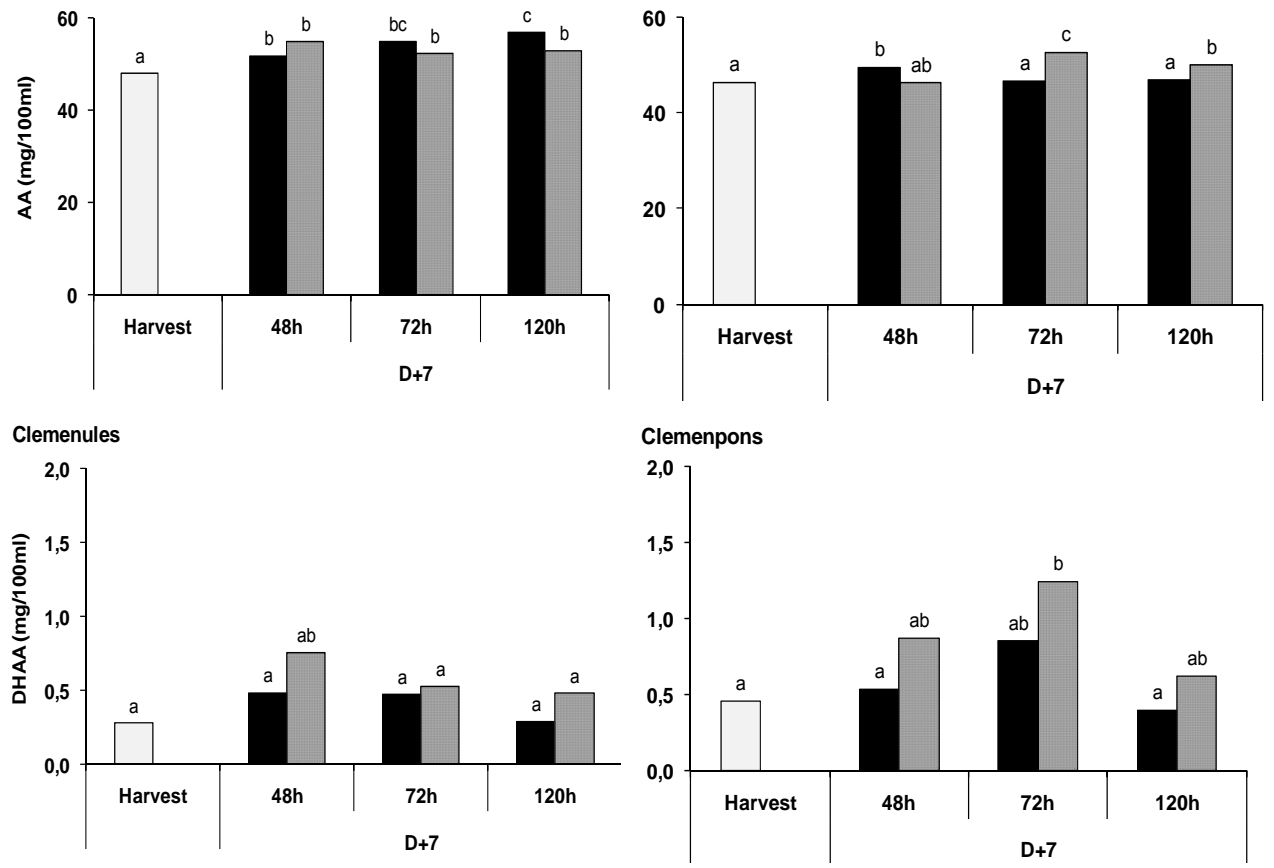

Fig.1. Effect of degreening treatment without (0-ET) or with ethylene (With ET, 2ppm) on ascorbic acid (AA), total ascorbic acid (TAA) and dehyroascorbic acid (DHAA) content of 'Clemenules' and 'Clemenpons' mandarins after $48 \mathrm{~h}, 72 \mathrm{~h}$ or $120 \mathrm{~h}$ of degreening (at $21^{\circ} \mathrm{C}$ and $90 \% \mathrm{RH}$ ) followed by 7 days of shelf-life at $20^{\circ} \mathrm{C}$. 

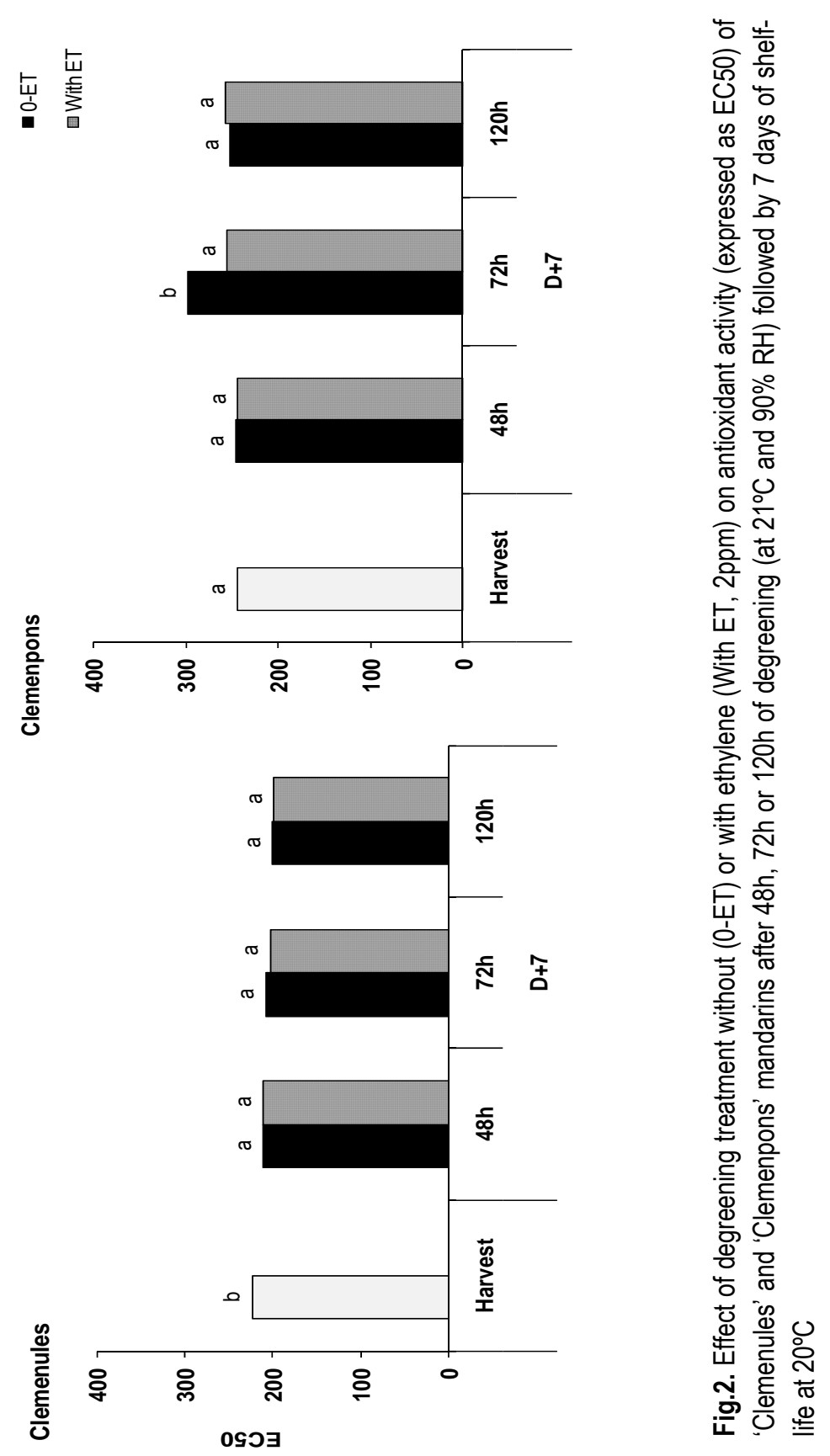


\section{Ethylene effect on external color}

Color changes after degreening, with or without ethylene, of 'Clemenules' and 'Clemenpons' are showed in Figure 3. 'Clemenules' mandarins, with lower $\mathrm{CCl}$ at harvest, showed better response to degreening than 'Clemenpons'. Values over 6 are considered as the minimum commercial limit and in 'Clemenules' cultivar were obtained after $48 \mathrm{~h}$ without ethylene application. For 'Clemenpons' mandarins, an ethylene degreening was necessary in order to reach commercial values of $\mathrm{CCl}$. For both cultivars the highest values of color were achieved in the fruit subjected to degreening treatment with ethylene. Salvador et al. (2003) found that 'Clemenules' and 'Clemenpons' mandarins degreened for 48 without ethylene application reach $\mathrm{CCl}$ values over 5 when $\mathrm{CCl}$ at harvest was about -4 .

\section{Ethylene effect on quality attributes}

'Clemenpons' mandarins were more susceptible to calyx senescence after degreening treatment than 'Clemenules' mandarins (Table 1). Carvalho et al. (2008) reported that the susceptibility of citrus fruit to calyx alterations depend on cultivar. Although the calyx alterations appeared in degreened fruit with and without ethylene, ethylene increased calyx browning and abscission in fruit of both cultivars. The percentage of alteration increased with time of degreening.

In both cultivars all treatments resulted in a slightly higher TSS values and lower titratable acidity compared to the values at harvest. Therefore maturity index, calculated as TTS/citric acid ratio, increased respect to fruit at harvest. This effect was more pronounced in 'Clemenules' than in 'Clemenpons'. No significant differences were found in these quality attributes between degreened fruit with or without ethylene. 

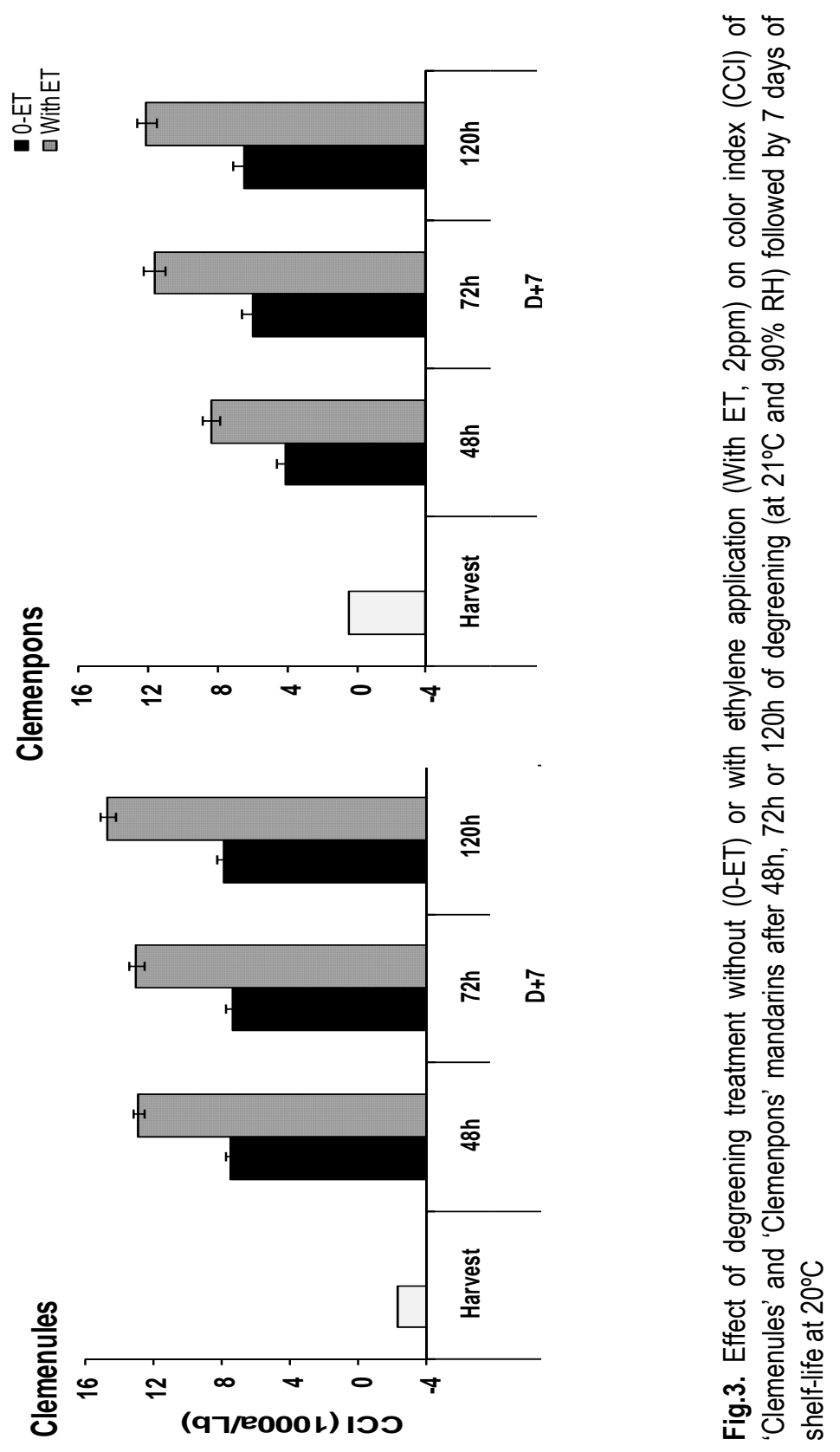


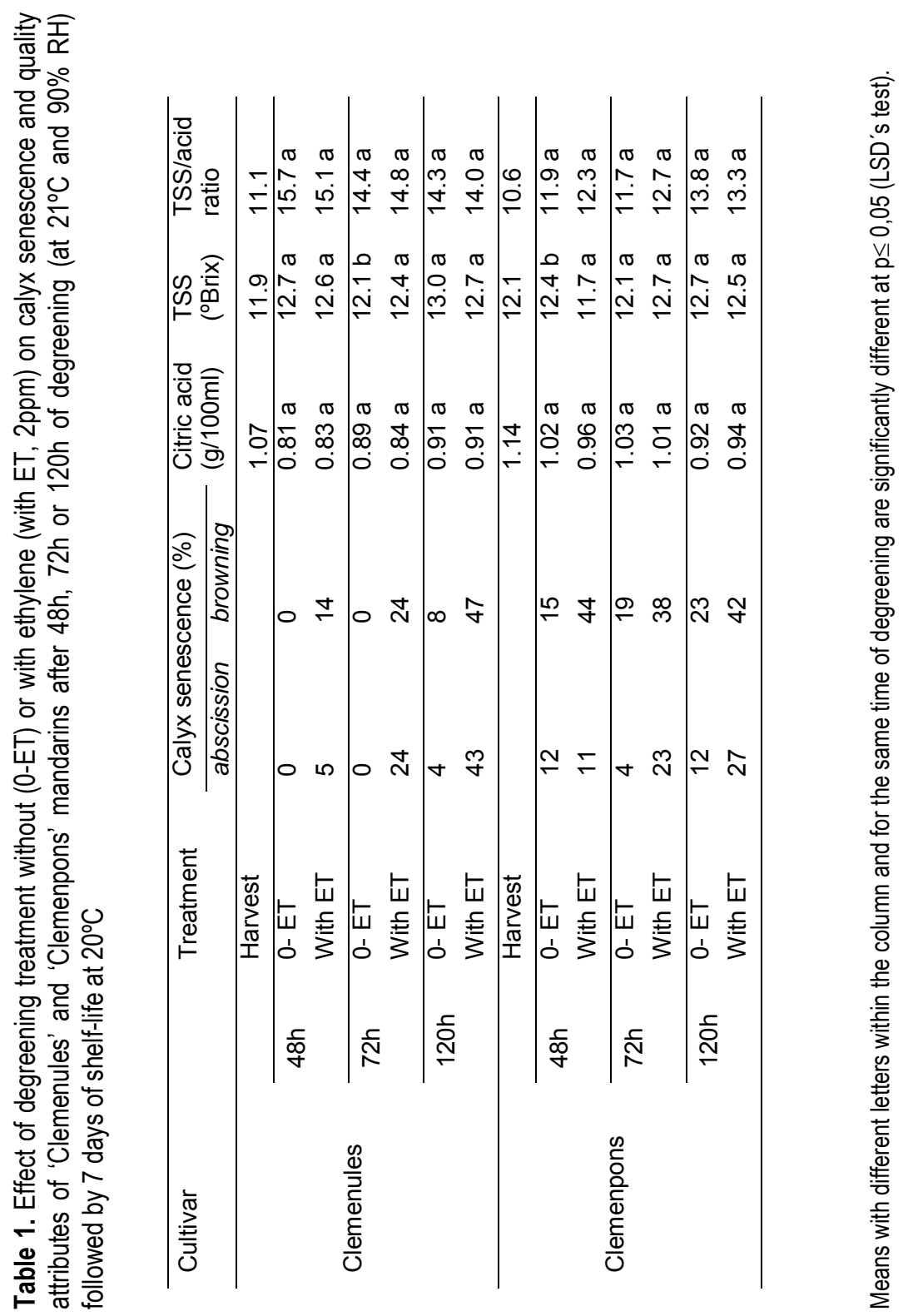




\section{CONCLUSION}

Postharvest application of ethylene did not affect ascorbic acid, total ascorbic acid content and the antioxidant activity of fruit of 'Clemenules' and 'Clemenpons' mandarins submitted to degreening treatment for up to $120 \mathrm{~h}$.

\section{ACKNOWLEDGEMENTS}

This research has been funded by the Spanish Ministerio de Educación y Ciencia (INIA Proyect RTA 2007-00101-00-00) and by the EU FEDER program. The authors wish to thank to FONTESTAD S.A. for its technical support.

\section{Literature Cited}

Brand-Williams, W., Cuvelier, M.E. and Berset, C. 1995. Use of a free radical method to evaluate antioxidant activity. L.W.T. 28: 25-30.

Carvalho, C.P., Salvador, A., Navarro, P., Monterde, A. and Martínez-Jávega, J.M. 2008. Effect of auxin treatments on calyx senescence in the degreening of four Mandarin cultivars. HortScience 43 (3): 747-752.

Cronjé, P.J.R., Crouch, E.M. and Huysamer, M. 2005. Postharvest calyx retention of Citrus fruit. Acta Hort. 682: 369-374.

Del Caro, A., Piga, A., Vacca, V. and Agabbio, M. 2004. Changes of flavonoids, vitamin $C$ and antioxidant capacity in minimally processed citrus segments and juices during storage. Food Chem. 84 (1): 99-105.

Dhuique-Mayer, C., Caris-Veyrat. C., Ollitrault, P., Curk, F. and Amiot, M.J. 2005. Varietal and interspecific influence on micronutrient contents in Citrus from the Mediterranean area. J. Agric. Food Chem. 53: 2140-2145.

El-Kazzaz, M.K., Chordas, A. and Kader, A.A. 1983. Physiological and compositional changes in Orange fruit in relation to modification of their susceptibility to Penicillium italicum by ethylene treatments. J. Amer. Soc. Hort. Sci. 108(4): 618-621. 
Huang, R., Xia, R., Hu, L., Lu, Y. and Wang, M. 2007. Antioxidant activity and oxygen-scavenging system in orange pulp during fruit ripening and maturation. Scientia Hort. 113: 166-172.

Huang, R., Xia, R., Lu, Y., Hu, L. and Xu, Y. 2008. Effect of pre-harvest salicylic acid spray treatment on post-harvest antioxidant in the pulp and peel of 'Cara cara' navel orange (Citrus sinensis L. Osbeck). J. Sci. Food Agric. 88: 229-236.

Kabasakalis, V., Siopidou, D. and Moshatou, E. 2000. Ascorbic acid content of commercial fruit juices and its rate of loss upon storage. Food Chem. 70: 325-328.

Lee, S.K. and Kader, A.A. 2000. Preharvest and postharvest factors influencing vitamin C content of horticultural crops. Postharvest Biol. Tecnol. 20: 207220.

Salvador, A., Martínez-Jávega, J. M., Cuquerella, J. and Navarro, P. 2003. Quality of Spanish mandarins following quarantine cold treatment. 21st IIR International Congress of Refrigeration. Washington , D.C. Digital Format (ISBN: 2-913149-32-4). Page Number ICR-389, 5pp.

Salvador, A., Navarro, P., Monterde, A. and Martínez-Jávega, J.M. 2008. Postharvest application of auxins to control calyx senescence in clementines submitted to degreening treatment. 11th International Citrus Congress, Wuhan, China (in press).

Sdiri, S., Monterde, A., Benabda, J., Rojas, C. And Salvador, A. 2008. Effect of postharvest heat treatments on Vitamin $C$ content and quality of 'Fortune' mandarin (Citrus reticulata, Blanca). 11th International Citrus Congress, Wuhan, China (in press).

Zerdin, K., Rooney, M.L. and Vermue, J. 2003. The vitamin C content of orange juice packed in an oxygen scavenger material. Food Chem. 82: 387-395. 



\section{Effect of postharvest degreening followed by cold-quarantine treatment on vitamin $C$, phenolic compounds and antioxidant activity of early-season citrus fruit}

Sawsen Sdiri ${ }^{\mathrm{a}}$, Pilar Navarro ${ }^{\mathrm{a}}$, Adela Monterde ${ }^{\mathrm{a}}$, Jameleddine Benabda $^{\mathrm{b}}$, Alejandra Salvador ${ }^{\mathrm{a}}$

${ }^{a}$ Centro de Tecnología Postcosecha, Instituto Valenciano de Investigaciones Agrarias, Carretera Moncada-Náquera Km 4.5 s/n, 46113, Moncada, Valencia, Spain

${ }^{\mathrm{b}}$ Département d'Agroalimentaire, Institut Supérieur Agronomique de chottMariem, 4042, Sousse, Tunisia

Reference: Postharvest Biology and Technology, 2012, 65: 13-21. 



\begin{abstract}
In the Mediterranean area, many early season citrus fruit are regularly submitted to a degreening treatment with ethylene exposure to improve their external color and, afterwards, to cold-quarantine treatment when the fruit is exported to free fruit fly (Ceratitis capitata) countries. Although the effect of the ethylene application on the quality attributes as well as the bioactive compounds are well documented, there is no information on the effect of the postharvest practices, including the treatment of degreening followed by the cold-quarantine storage on the nutritional value of citrus fruit. In this study the changes in the bioactive compounds of early-season commercial citrus varieties ('Navelina' oranges and 'Clemenules', 'Clemenpons', 'Oronules', 'Prenules', 'Basol', 'Clemenrubí' and 'Orogros' clementines) submitted to degreening treatment, without or with ethylene exposure $(0 \mu \mathrm{L} / \mathrm{L}$ or 2 $\left.\mu \mathrm{L} / \mathrm{L} \mathrm{C}_{2} \mathrm{H}_{4}, 120 \mathrm{~h}, 21^{\circ} \mathrm{C}, 95 \% \mathrm{RH}\right)$ and then cold-stored under quarantine conditions $\left(1^{\circ} \mathrm{C}, 16\right.$ days) plus shelf-life $\left(20^{\circ} \mathrm{C}, 7\right.$ days, $\left.95 \% \mathrm{RH}\right)$ were determined. These postharvest conditions did not induce detrimental changes in DPPH and FRAP antioxidant capacities, ascorbic acid, total ascorbic acid and total phenolic content. Although some changes were observed in individual flavonoid compounds, these did not contribute to a loss in the total content of flavanone and flavone after ethylene degreening and the posterior quarantine treatment.
\end{abstract}

Keywords: ethylene, clementines, oranges, vitamin C, antioxidant activity, phenolic content, flavonoids, quality. 


\section{Introduction}

In early-season citrus varieties, the fruit reaches internal maturity and the flesh becomes edible when the peel is still green. To promote peel degreening and to render the fruit more suitable for marketing, a commercial postharvest degreening treatment is used with the application of ethylene. Treatment with ethylene accelerates chlorophyll degradation and a simultaneous accumulation of carotenoids (Salveit, 1999; Rodrigo and Zacarias, 2007). In Spanish citrus production, degreening with ethylene exposure is used regularly, especially for early-season varieties such as clementines and 'Navelina' oranges. Moreover, in many cases, when these varieties have been exported to free fruit fly (Ceratitis capitata) countries, mainly the USA or Japan, a cold-quarantine treatment is required, involving the exposure of fruit to low temperatures.

Many studies investigated the effect of cold storage on the quality parameters as well as on the bioactive compounds of citrus fruit. However, the results reported in these studies are different showing that the changes observed after conservation at low temperature depending on the storage conditions and on the varieties (Palma et al., 2005; Pérez et al., 2005; Rapisarda et al., 2008; Lafuente et al., 2011; Plaza et al., 2011). On the other hand, the effect of postharvest application of ethylene on the internal quality parameters in the edible part of the citrus fruit is well documented (MartínezJávega et al., 2008; Sdiri et al., 2010; Tietel et al., 2010). Moreover, it has been recently reported the effect of ethylene during degreening treatment on the levels of vitamin $C$ and the total phenolics as well as the effect on the antioxidant activity (Sdiri et al., 2010; Mayuoni et al., 2011). However, it is not known how can the ethylene affect the levels of the phenolic compounds which most of them are specific in citrus fruit.

Although, the effect of ethylene or the cold storage has been reported, there is no information about the effect of the combination of degreening treatment with ethylene exposure and the cold quarantine storage on the bioactive compounds of citrus fruit.

The health benefits of fresh citrus fruit have been the subject of extensive research and it is well established that some of their nutrients promote health 
and provide protection against chronic diseases, as well as reducing the risks of certain cancers and cardiovascular diseases (Knekt et al., 2002; Franke et al., 2005; Dauchet et al., 2006). The protective effects of citrus fruit have been mainly attributed to the high concentrations of bioactive compounds which have antioxidant properties, such as vitamin $\mathrm{C}$, phenolic compounds and carotenoids.

Citrus fruit have a high antioxidant capacity that is mainly associated with the hydrosoluble fraction containing polyphenols and vitamin C (Gardner et al., 2000). Vitamin $C$ is considered to be the most important nutrient found in citrus fruit, an important water-soluble antioxidative component and an excellent reducing agent. The term vitamin $C$ is not only used for ascorbic acid (AA) but also includes all compounds exhibiting the biological activity of ascorbic, such as its oxidized forms and esters. Under oxidative conditions, AA is readily converted through a free radical intermediate to dehydroascorbic acid (DHAA) in a reversible process which, in part, may explain the antioxidant effect attributed to AA (Nyyssonen et al., 2000).

Although ascorbic acid accounts for a great proportion of the antioxidant activity, citrus fruit also contain phenolic compounds which have been proposed as important contributors to the total antioxidant capacity (Rapisarda et al., 1999; Burda and Oleszek, 2001). In citrus fruit, flavonoids are a widely distributed group of polyphenolics, and have been reported to act as antioxidants. The highest concentrations found in Citrus sp. correspond to flavanone glycosides, followed by flavones, flavonols and the fully polymethoxylated flavones (Nogata et al., 2006). Flavanones have a higher biological activity even if in lower concentrations and the most relevant flavanone glycosides are hesperidine, narirutin, naringin and eriocitrin (Mouly et al., 1994). The common citrus polymethoxylated flavones include sinensetin, nobiletin, heptamethoxyflavone and tangeretin (Nogata et al., 2006).

Therefore, the purpose of this study was to investigate the changes in ascorbic acid, total ascorbic acid and total phenolic contents, antioxidant activity, phenolic compounds, color index, firmness, total soluble solids, acidity, ethanol and acetaldehyde content that occur in commercial early-season citrus fruit subjected to degreening combined with the cold quarantine treatment. 


\section{Materials and Methods}

\subsection{Plant material and treatment}

'Navelina' oranges (Citrus sinensis L. Osbeck), clementines (Citrus clementina Hort. Ex. Tan) cv. Clemenules, Clemenpons, Oronules and four mutations of 'Oronules': Prenules, Basol, Clemenrubí and Orogros, from commercial orchards in Valencia (Spain) were harvested and then they were sorted in a commercial packinghouse (FONTESTAD S.A. Company, Valencia, Spain) by means of a color electronic calibrator following the uniformity of external color index $(\mathrm{CCl})$.

Fruit from each cultivar were dipped in a solution of imazalil $(400 \mathrm{mg} / \mathrm{L})$ and separated into two lots of 80 fruits each. Then, fruit from one lot were submitted to degreening treatment in the packinghouse under commercial conditions $(2$ $\mu \mathrm{L} / \mathrm{L}$ of ethylene in a chamber with continuous flow regulated at $21^{\circ} \mathrm{C}$ and $95 \%$ $\mathrm{RH}$ for 120h). Fruit from the second lot were kept under the same conditions of temperature and relative humidity for $120 \mathrm{~h}$ without ethylene exposure. After degreening, fruit were waxed (Waterwax TT-2I, Fomesa Fruitech S.L.U, Spain) and then exposed to cold quarantine treatment at $1^{\circ} \mathrm{C}$ for 16 days to comply with the phytosanitary requirement for shipping fruit to the USA. Fruit were then stored at $20^{\circ} \mathrm{C}$ for 7 days, simulating shelf-life conditions.

The following parameters were evaluated at harvest and after shelf-life: ascorbic acid, total ascorbic acid and total phenol contents, antioxidant activity, phenolic compounds, color index, firmness, total soluble solids, titratable acidity, maturity index, ethanol and acetaldehyde contents.

For the determination of bioactive compounds per treatment, three replicates of ten fruit each were squeezed and filtered and the juice was kept at $-80^{\circ} \mathrm{C}$ until analysis. 


\subsection{Analysis of quality attributes}

Peel color was measured with a Minolta colorimeter (model CR-300; Minolta Co. Ltd., Osaka, Japan) using 30 fruit per treatment and 3 measurements were taken in the equatorial zone of each fruit. The mean values for lightness (L), red-green (a), and yellow-blue (b) Hunter parameters were calculated for each fruit and expressed as citrus color index $(\mathrm{CCl}=1000 \mathrm{a} / \mathrm{Lb})$ (Jiménez-Cuesta et al., 1981).

Firmness measurements were taken with an Instron Universal Testing Machine (model 3343, Instron Limited, Buckinghamshire, UK) using 20 fruits per treatment. The results were expressed as the percentage of millimeters of fruit deformation resulting from a pressure of $10 \mathrm{~N}$ on the longitudinal axis at a constant speed.

Per treatment, three samples of ten fruit each were squeezed in an electric juice extractor with a rotating head (Lomi $囚$, Model 4, Lorenzo Miguel, S.L., Madrid, Spain). Titratable acidity (TA) was determined by titration with $0.1 \mathrm{~N}$ $\mathrm{NaOH}$ solution, using phenolphthalein as indicator and expressed as $\mathrm{g}$ of citric acid per $100 \mathrm{~mL}$ of juice. The total soluble solids (TSS) in the juice was determined by digital refractometer (Atago PR-1, Atago Co., Ltd, Tokyo, Japan) and the data were expressed as $\%$.

\subsection{Analysis of ethanol and acetaldehyde}

For the ethanol and acetaldehyde contents, three replicates from each juice sample per treatment were analyzed. Five milliliters of the juice were transferred to $10 \mathrm{~mL}$ vials with crimp-top caps TFE/silicone septa seal and frozen $\left(-20^{\circ} \mathrm{C}\right)$ until analysis. Ethanol and acetaldehyde levels were determined by carrying out a headspace analysis on a gas chromatograph (model 1020, Perkin Elmer Corp., Norwalk, Conn., U.S.A.) equipped with a flame ionization detector and a 1/8" x $1.2 \mathrm{~m}$ Porapak QS 80/100 column. The injector was set at $175^{\circ} \mathrm{C}$, the column at $150^{\circ} \mathrm{C}$, the detector (FID) at $200^{\circ} \mathrm{C}$ and the carrier gas at 12.3 psi. A one-mL aliquot of the headspace was withdrawn from vials previously equilibrated for $1 \mathrm{~h}$ at $20^{\circ} \mathrm{C}$ and $10 \mathrm{~min}$ at $30^{\circ} \mathrm{C}$, and injected in the 
gas chromatograph. Ethanol and acetaldehyde were identified by comparing retention time with that of a standard solution and expressed as $\mathrm{mg} / 100 \mathrm{~mL}$.

\subsection{Determination of ascorbic acid}

A juice sample $(4 \mathrm{~mL})$ was homogenized with $4 \mathrm{~mL}$ of extraction solution (2.5\% meta-phosphoric acid). The resulting mixture was centrifuged at 14000 $\mathrm{rpm}$ for $15 \mathrm{~min}$ at $4^{\circ} \mathrm{C}$ in a Sigma $3 \mathrm{~K} 30$ rotor (Sigma, Germany). The supernatant was filtered through a $0.45 \mu \mathrm{m}$ Whatman filter and analyzed for ascorbic acid (AA) by HPLC. To analyze Total Ascorbic Acid (TAA), $0.2 \mathrm{~mL}$ of a solution of Dithiothreitol (DTT) was added to $1 \mathrm{ml}$ of juice as a reducing agent and the samples were kept in the dark at room temperature for $2 \mathrm{~h}$ to convert any dehydroascorbic acid (DHAA) to AA. After complete conversion, the samples were filtered through a $0.45 \mu \mathrm{m}$ Whatman filter and analyzed for TAA by HPLC.

TAA and AA were quantified by high-performance liquid chromatography (HPLC) instrument (Merck Hitachi, Germany) with diode array detectors. Separation was performed on a RP-18 column ( $4 \mathrm{~mm} \times 250 \mathrm{~mm}$ ), preceded by a precolumn $(4 \times 4 \mathrm{~mm})$ with a particle diameter of $5 \mu \mathrm{m}$, using $\mathrm{KH}_{2} \mathrm{PO}_{4}(0.2 \mathrm{M}$, adjusted to $\mathrm{pH} 2.3$ with phosphoric acid) as the mobile phase at a flow rate of 1 $\mathrm{mL} / \mathrm{min}$ with UV detection at $243 \mathrm{~nm}$. The total elution time was $10 \mathrm{~min}$ and the injection volume was $20 \mu \mathrm{L}$. Three samples from each treatment were analyzed and all samples were run in triplicate. The quantification of AA was carried out using the external standard method. Calibration curves were performed with four concentrations of $\mathrm{AA}$ (50-100-150 and $200 \mathrm{mg} / \mathrm{L})$. Standards were run daily with samples for validation.

\subsection{Total Phenolic Content}

The content of total phenolics in samples was measured in a microliterbased format on the basis of the Folin-Ciocalteu colorimetric method described previously (Singleton and Rossi, 1965) and with some modifications. Briefly, 30 $\mu \mathrm{L}$ of appropriately diluted samples of juice (in methanol $80 \%$ ) were oxidized for 1 min with $150 \mu \mathrm{L}$ of Folin-Ciocalteu reagent (1:10, v/v diluted with water) and 
then the reaction was neutralized with $120 \mu \mathrm{L}$ of sodium carbonate $(7.5 \%, \mathrm{w} / \mathrm{v})$. The absorbance was measured at $765 \mathrm{~nm}$ by a Multiscan Spectrum microplate reader (Thermo electron corporation, S.A.). Gallic acid was used as standard, and the results were expressed as $\mathrm{mg}$ of gallic acid equivalent $/ \mathrm{L}$ of juice. For each treatment, eighteen replicates were measured.

\subsection{Total Antioxidant Activity}

The antioxidant activity of the citrus juices was evaluated by DPPH free radical-scavenging method and a ferric reducing antioxidant power (FRAP) assay.

The DPPH free radical-scavenging activity was measured in a microliterbased format according to the procedure of González-Molina et al. (2009) with some modifications. Briefly, in glass 96 -well reaction plate, $30 \mu \mathrm{L}$ of diluted samples $(300 \mu \mathrm{L}$ of sample in $1.2 \mathrm{~mL} 100 \%$ methanol) were combined with 270 $\mu \mathrm{L}$ of methanolic DPPH $(0.025 \mathrm{~g} / \mathrm{L}$ in methanol $100 \%)$. Following incubation at $20^{\circ} \mathrm{C}$ for $50 \mathrm{~min}$, the absorbance at $515 \mathrm{~nm}$ was read on a Multiscan Spectrum microplate reader (Thermo electron corporation, S.A.). The results were expressed as ascorbic acid equivalent / $100 \mathrm{~mL}$ of juice. For each treatment, eighteen replicates were measured.

The FRAP method was assessed according to the method of Benzie and Strain (1999) with some modifications to adapt the method to a microliter-based format. In brief, the FRAP reagent was freshly prepared by mixing $25 \mathrm{~mL}$ of $300 \mathrm{mM}$ acetate buffer (pH 3.6), $2.5 \mathrm{~mL}$ of $10 \mathrm{mM}$ TPTZ solution, and $2.5 \mathrm{~mL}$ of $20 \mathrm{mM}$ ferric chloride solution. The assay was carried out by placing $30 \mu \mathrm{L}$ of appropriately diluted samples $(0.100 \mathrm{~mL}$ of sample in $1.4 \mathrm{~mL} 100 \%$ methanol) in a 96-well microplate and then adding $270 \mu \mathrm{L}$ of FRAP reagent. After $10 \mathrm{~min}$ of incubation at $37^{\circ} \mathrm{C}$ and shaking, absorbance was read at $593 \mathrm{~nm}$. Results were compared with a standard curve prepared with different concentrations of ascorbic acid and were expressed as $\mathrm{mM}$ ascorbic acid equivalent. 


\subsection{Determination of phenolic compounds by HPLC}

Phenolic compounds were extracted by mixing $5 \mathrm{~mL}$ of juice with $5 \mathrm{~mL}$ of dimethylformamide. After centrifugation (12000 rpm for $20 \mathrm{~min}$ at $4^{\circ} \mathrm{C}$ ), $1 \mathrm{~mL}$ of the supernatant was filtered through one $0.45 \mu \mathrm{m}$ nylon filter and then $20 \mu \mathrm{L}$ were injected into the high-performance liquid chromatography (HPLC) instrument (Merck Hitachi, Germany). The HPLC was equipped with diode array detectors (L-2450), column oven (L-2300) and auto-sampler (L-2200). Separation was performed on a Lichospher 100 RP-18 column $(4 \mathrm{~mm} \times 250$ $\mathrm{mm})$ preceded by a precolumn $(4 \mathrm{~mm} \times 4 \mathrm{~mm})$, with a particle diameter of $5 \mu \mathrm{m}$. HPLC elution was carried out at room temperature and utilized a binary solvent system of acetonitrile (ACN) and water with $4 \%$ acetic acid. The solvent system was operated to start at $5 \%$ and end at $100 \%$ ACN concentration for a $45 \mathrm{~min}$ period. The elution profile was at a flow rate of $1.0 \mathrm{~mL} / \mathrm{min}$. The chromatogram was monitored simultaneously at 284 and $334 \mathrm{~nm}$ with $5 \mathrm{~nm}$ bandwidth. The concentrations were calculated following the external standard method. Dilutions of each of the phenolic standards were used to fit a standard with linear regression for each individual compound.

\subsection{Reagents and Standards}

Narirutin (NAT), didymin (DID), sinensetin (SIN), nobiletin (NOB) and tangeretin (TAN) were purchased from Extrasynthèse (Genay, France). Hesperidin (HES), naringin (NAR), gallic acid (Gac), chlorogenic acid (CG ac), quercetin (QUE), Folin-Ciocalteu's reagent, sodium carbonate $\left(\mathrm{Na}_{2} \mathrm{CO}_{3}\right)$, phosphoric acid $\left(\mathrm{H}_{3} \mathrm{PO}_{4}\right)$, meta-phosphoric acid (MPA), DL-Dithiothreitol (DTT), ascorbic acid and ferric trichloride were purchased from Sigma-Aldrich (Barcelona, Spain). 2,4,6-Tris(2-pyridyl)-s-triazine (TPTZ), 2,2-Diphenyl-1picrylhydrazyl (DPPH), diosmin (DSM) and potassium dihydrogen phosphate $\left(\mathrm{KH}_{2} \mathrm{PO}_{4}\right)$ were supplied from Fluka Chemie (Sigma Co., Barcelona, Spain). Glacial acetic acid was purchased from Sharlau (Sentmenat, Spain). HPLCgrade acetonitrile, dimethylformamide and methanol were obtained from VWR (Barcelona, Spain). Milli-Q water (Millipore, Synergy ${ }^{\circledR}$ UV, France) was used for every step. 


\subsection{Statistical analysis}

Statistical procedures were performed using commercial statistical software (Statgraphics plus 5.1, Manugistics, Inc., Rockville, M.d., U.S.A.). All data were subjected to analysis of variance, and means were compared using an LSD test at $\mathrm{P}<0.05$.

\section{Results and Discussion}

\subsection{Fruit quality parameters}

The effect that degreening, with or without ethylene, plus posterior quarantine treatment has on the color index and the juice quality of the different studied varieties is shown in Table 1.

'Navelina' oranges and the seven clementine cultivars tested in this study are commercially subjected to treatment with ethylene degreening and, in many cases subjected to cold-quarantine for export.

In every case, the fruit showed a commercial internal maturity without optimum external color at harvest. Both degreening treatments, that with and that without ethylene application, markedly enhance the external color of the fruit. Nevertheless, as expected, degreening with ethylene exposure caused a much more significant increase in peel color, which led to high color index values corresponding to the variety's typical color making the fruit more attractive to consumers. This effect has been widely reported (Martínez-Jávega et al., 2008; Matsumoto et al., 2009; Tietel et al., 2010).

In general, fruit from all the assayed varieties showed an increase in Total Soluble Solids (TSS) and a reduction in Titratable acidity (TA) after shelf-life compared with initial values at harvest. The decrease in juice acidity levels led to an increase in the maturity index (MI), calculated as TSS/TA ratio. 


\section{Chapter IV}

Degreening treatments with ethylene exposure did not significantly affect the quality parameters when compared to degreening without ethylene. Similar results have previously been reported by other authors (Martínez-Jávega et al., 2008; Sdiri et al., 2010; Tietel et al., 2010).

Although the fruit lost firmness after degreening treatments and the posterior cold-quarantine storage, no significant difference between untreated and ethylene-treated fruit was found. The ethanol and acetaldehyde contents in juice increased when compared with the values at harvest, the increase being greater when submitted to ethylene exposure. In citrus fruit, the off-flavors are related to the ethanol level in the juice (Hagenmaier, 2002). In this study, nevertheless, the values exhibited were not so high as to cause off flavors in the fruit of any of the tested varieties. Coinciding with these results, previous studies reported that the degreening treatment with ethylene exposure for up to 5 days did not affect the fruit flavor (Martínez-Jávega et al., 2008; Tietel et al., 2010). 
Table 1. Effect of degreening without $\left(120 \mathrm{~h}, 21^{\circ} \mathrm{C}, 95 \% \mathrm{RH}\right)$ or with ethylene exposure $(2$ $\left.\mu \mathrm{L} / \mathrm{L}, 120 \mathrm{~h}, 21^{\circ} \mathrm{C}, 95 \% \mathrm{RH}\right)$ followed by cold-quarantine treatment $\left(1^{\circ} \mathrm{C}, 16\right.$ days, $95 \% \mathrm{RH})$ plus shelf-life $\left(20^{\circ} \mathrm{C}, 7\right.$ days, $\left.95 \% \mathrm{RH}\right)$ on the color index and the fruit quality attributes of different citrus varieties. ${ }^{1}$

\begin{tabular}{|c|c|c|c|c|c|c|c|c|c|c|c|c|c|c|c|}
\hline \multirow{4}{*}{$\begin{array}{l}\text { Citrus sp. } \\
\text { Navelina }\end{array}$} & \multirow{4}{*}{$\begin{array}{l}\text { Treatment } \\
\text { Harvest } \\
\text { Without Et } \\
\text { With Et }\end{array}$} & \multicolumn{2}{|c|}{$\begin{array}{l}\text { Color index } \\
\text { (1000a/Lb) }\end{array}$} & \multicolumn{2}{|c|}{$\begin{array}{l}\text { Firmness } \\
\text { (\%def.10N) }\end{array}$} & \multicolumn{2}{|c|}{$\begin{array}{c}\text { TA } \\
(\mathrm{g} / 100 \mathrm{~mL})\end{array}$} & \multicolumn{2}{|c|}{$\begin{array}{l}\text { TSS } \\
(\%)\end{array}$} & \multicolumn{2}{|c|}{$\begin{array}{c}\mathrm{Ml} \\
\text { (TSS/TA) }\end{array}$} & \multicolumn{2}{|c|}{$\begin{array}{l}\text { Acetaldehyde } \\
(\mathrm{mg} / 100 \mathrm{~mL})\end{array}$} & \multicolumn{2}{|c|}{$\begin{array}{c}\text { Ethanol } \\
\text { (mg/100mL) }\end{array}$} \\
\hline & & -8.5 & & 1.6 & & 1.5 & & 9.1 & & 6.3 & & 0.27 & & 7.7 & \\
\hline & & -1.0 & a & 2.1 & a & 1.3 & $a$ & 9.6 & a & 7.7 & a & 0.86 & a & 54.5 & a \\
\hline & & 4.5 & $b$ & 2.0 & a & 1.2 & $a$ & 9.4 & a & 8.0 & a & 1.07 & $b$ & 80.9 & $b$ \\
\hline \multirow[t]{3}{*}{ Clemenules } & Harvest & -13.0 & & 3.3 & & 0.9 & & 10.6 & & 12.6 & & 0.26 & & 1.8 & \\
\hline & Without Et & -1.1 & a & 4.0 & a & 0.8 & a & 11.2 & a & 14.1 & a & 0.29 & a & 6.6 & a \\
\hline & With Et & 7.8 & $b$ & 4.5 & a & 0.7 & $a$ & 11.4 & a & 15.3 & a & 0.41 & b & 11.5 & $b$ \\
\hline \multirow[t]{3}{*}{ Clemenpons } & Harvest & -13.5 & & 3.8 & & 1.0 & & 10.1 & & 10.5 & & 0.27 & & 2.3 & \\
\hline & Without Et & -6.2 & a & 3.9 & a & 0.8 & a & 11.6 & a & 14.5 & a & 0.74 & a & 34.1 & a \\
\hline & With Et & 6.2 & $b$ & $4.1 \mathrm{a}$ & a & 0.9 & a & 11.8 & a & 13.8 & a & 0.66 & a & 40.5 & a \\
\hline \multirow[t]{3}{*}{ Oronules } & Harvest & -10.5 & & 4.6 & & 1.3 & & 10.5 & & 8.3 & & 0.28 & & 2.4 & \\
\hline & Without Et & 0.7 & a & 6.2 & a & 1.0 & a & 10.9 & a & 10.9 & a & 0.89 & a & 107.7 & a \\
\hline & With Et & 10.3 & $b$ & 6.0 & a & 0.9 & a & 10.6 & a & 11.3 & a & 1.43 & $b$ & 124.2 & a \\
\hline \multirow[t]{3}{*}{ Prenules } & Harvest & -10.8 & & 3.2 & & 1.5 & & 11.3 & & 7.6 & & 0.30 & & 2.5 & \\
\hline & Without Et & 0.1 & a & 4.6 & a & 1.3 & $a$ & 11.5 & a & 8.6 & a & 0.69 & a & 40.5 & a \\
\hline & With Et & 12.8 & b & 4.6 & a & 1.4 & a & 11.4 & a & 8.5 & a & 0.87 & b & 98.1 & $\mathrm{~b}$ \\
\hline \multirow[t]{3}{*}{ Basol } & Harvest & -10.6 & & 2.4 & & 1.1 & & 8.8 & & 8.5 & & 0.25 & & 2.1 & \\
\hline & Without Et & 0.4 & a & 5.2 & a & 1.0 & a & 10.5 & a & 10.5 & $a$ & 0.51 & a & 35.2 & a \\
\hline & With Et & 10.8 & $b$ & 5.5 & a & 1.0 & $a$ & 10.8 & a & 10.8 & $a$ & 0.69 & $b$ & 83.9 & $b$ \\
\hline \multirow[t]{3}{*}{ Clemenrubí } & Harvest & -10.2 & & 2.6 & & 1.3 & & 10.9 & & 8.3 & & 0.24 & & 2.7 & \\
\hline & Without Et & -1.4 & a & 5.0 & a & 1.1 & $a$ & 11.3 & a & 10.0 & a & 0.53 & a & 21.7 & a \\
\hline & With Et & 10.8 & $b$ & 4.6 & a & 1.2 & a & 11.4 & a & 9.8 & a & 0.70 & $b$ & 40.6 & $b$ \\
\hline \multirow[t]{2}{*}{ Orogros } & Harvest & -11.2 & & 2.5 & & 1.4 & & 11.2 & & 8.1 & & 0.37 & & 6.8 & \\
\hline & Without Et & 0.7 & $a$ & 5.5 & a & 1.4 & $a$ & 11.4 & a & 8.4 & a & 0.61 & a & 32.7 & a \\
\hline
\end{tabular}

${ }^{1}$ Means with different letters, in the same column and for each cultivar, indicate significant differences $(P<0.05)$. 


\subsection{Ascorbic acid and Total ascorbic acid}

As vitamin $C$ is the major antioxidant compound found in citrus fruit, its retention has been used as a quality indicator during the shelf-life both of citrus fruit and also its derived products (Pérez et al., 2005). Vitamin $C$ is an umbrella term for ascorbic acid (AA) and dehydroascorbic acid (DHAA). Therefore, in this study, the content of the total ascorbic acid (vitamin $\mathrm{C}$ ) was measured after the reduction of DHAA to $A A$.

In the present study, at harvest, 'Clemenules' and 'Clemenpons' fruits had a lower content of AA and Total ascorbic acid (TAA) than 'Oronules' fruits and the new clementine varieties, namely 'Prenules', 'Basol', 'Clemenrubi' and 'Orogros'. Of these, 'Prenules' clementines exhibited the highest concentrations (57.47 and $61.19 \mathrm{mg} / 100 \mathrm{mLfor}$ AA and TAA, respectively) (Table 2). 'Navelina' oranges displayed values of about 45.90 and $46.20 \mathrm{mg} / 100 \mathrm{~mL}$ of AA and TAA, respectively. The TAA contents found in 'Oronules', 'Clemenules' and 'Clemenpons' clementines and in 'Navelina' oranges coincided with those reported by Cano et al. (2008).

AA content in 'Navelina' oranges and 'Clemenules', 'Clemenpons', 'Oronules' and 'Basol' clementines was not affected by the quarantine treatment or by ethylene exposure; after shelf-life, the AA values remained constant and there was no significant difference found between fruit submitted to ethylene exposure treatment and that which was not subjected, when compared to the levels at harvest. Nevertheless, in 'Prenules', 'Clemenrubi' and 'Orogros', an increase in AA content was observed after shelf-life.

In most of the cultivars tested, no changes in TAA levels were found after the degreening process plus quarantine treatment if compared with the values at harvest. A significant increase was only observed in the 'Orogros' clementine.

It has been reported that the changes in $A A$ and TAA content during storage depend on the storage conditions as well as the variety. Some studies have reported that the cold storage of 'Clemenules' mandarins and of 'Tarocco Messina', 'Tarocco Meli' and 'Navelina' oranges led to a decrease in their 
vitamin C content (Pérez et al., 2005; Rapisarda et al., 2008; Plaza et al., 2011). Nevertheless, there was a significant increase in the vitamin C content in 'Cara cara' and 'Valencia Late' oranges and in 'Fortune' mandarins after storage at low temperatures (Huang et al., 2008; Rapisarda et al., 2008; Sdiri et al., 2008). Del Caro et al. (2004) and Palma et al. (2005) did not find any changes in the vitamin $\mathrm{C}$ content during cold storage.

As far as the effect of ethylene exposure on the content of vitamin $C$ is concerned, our previous studies observed no changes in AA and TAA content in 'Clemenules' and 'Clemenpons' mandarins submitted to ethylene-degreening treatment (Sdiri et al., 2010). This coincides with the result obtained in the present research.

\subsection{Total Phenolic Content}

The total phenolic content (TPC), measured by the Folin-Ciocalteu assay, ranged from 519.3 to $635.8 \mathrm{mg} \mathrm{GAE} / \mathrm{L}$ (Table 2) which agree with those reported in the literature (Wang et al., 2007; Rapisarda et al., 2009).

At harvest, the highest values of TPC were found in 'Prenules' and 'Clemenrubí' fruits, $611.0 \mathrm{mg}$ GAE/L and $635.8 \mathrm{mg} \mathrm{GAE} / \mathrm{L}$ respectively. These varieties also presented the highest values of TAA; it has been known that the Folin-Ciocalteu reagent is nonspecific for phenolic compounds and also reacts with other reducing compounds, such as carotenoids, amino acids, sugars and vitamin C (Vinson et al., 2001). The contribution of ascorbic acid in TPC, measured by the Folin-Ciocalteu assay, has also been reported by Rapisarda et al. (2008).

Although no changes were observed in 'Clemenules' and 'Prenules' clementines after degreening and the posterior cold-quarantine treatment, TPC showed an increase in 'Navelina' oranges and in 'Basol', 'Clemenrubi' and 'Orogros' clementines. According to previous studies the changes in the level of total phenolics in citrus fruit depend on the storage conditions as well as on the 
cultivar; Palma et al. (2005) found no differences in the TPC of 'Fortune' mandarins after 90 days of storage at $5^{\circ} \mathrm{C}$, nevertheless in different orange cultivars and grapefruit an increase in TPC was reported after long-cold storage (Rapisarda et al., 2008; Patil et al., 2004).

The postharvest exposure to ethylene did not affect the content of TPC. Although there is limited comparative evidence of the effect of ethylene degreening as a postharvest treatment in citrus fruit, the changes in polyphenolic substances in other fruits were well documented; the postharvest exposure of carrots, asparagus, potatoes, peppers, apples, peaches, strawberries and table grapes to ethylene did not induce a change in the phenolic content in each fruit when compared to air control after cold storage (Fox et al., 2005; Heredia and Cisneros-Zevallos, 2009).

\subsection{Antioxidant activity}

Several methods have been developed to evaluate the total antioxidant activity of citrus fruit. In our study, the antioxidant activity of 'Navelina' oranges and different varieties of clementine were evaluated using DPPH free radicalscavenging and ferric reducing antioxidant power (FRAP) tests. Both methods are recommended by many authors as easy and accurate assays for measuring the antioxidant activity of fruit juices (Klimczak et al., 2007).

At harvest, based on the DPPH ${ }^{\bullet}$ assay, 'Oronules' fruit and the new clementine varieties displayed the highest values of antioxidant activity, ranging from 226.0 to $227.0 \mathrm{mg} \mathrm{AAE} / 100 \mathrm{~mL}$ (Table 2).

No significant changes were found in the antioxidant activity of 'Navelina' oranges and 'Clemenules', 'Clemenpons', 'Prenules' and 'Basol' clementines after degreening and the posterior cold quarantine treatment. On the other hand, the antioxidant capacity in 'Orogros' and 'Clemenrubi' clementines increased after shelf-life, whereas 'Oronules' mandarins showed a significant decrease. Coinciding with our results, in previous studies it has also been 
reported that the changes in antioxidant activity during storage depend on the varieties; for instance, the antioxidant activity in cold stored 'Navelina' oranges, expressed as $\mathrm{EC}_{50}$, remains relatively constant for 12 days at $4^{\circ} \mathrm{C}$ (Plaza et al., 2011). In the same way, Lafuente et al. (2011) did not observe changes in the total antioxidant activity of 'Fortune' mandarins during long-term cold storage. Nevertheless, Rapisarda et al. (2008) reported an increase in antioxidant capacity, measured by DPPH ${ }^{\bullet}$ assay, in blood and blond oranges after cold storage at $6^{\circ} \mathrm{C}$ for 65 days. On the contrary, Del Caro et al. (2004) described a slight decrease in the TEAC (trolox equivalent antioxidant capacity) value, obtained by the DPPH' method, for 'Salustiana' oranges stored at $4^{\circ} \mathrm{C}$.

In citrus fruit, the antioxidant capacity is due to the combined activity of various antioxidants, mainly ascorbic acid (Gardner et al., 2000; Del Caro et al., 2004; Abeysinghe et al., 2007; González-Molina et al., 2009) and phenolics (Rapisarda et al., 1999; Abeysinghe et al., 2007). In general, the changes in antioxidant activity experimented in our study were accompanied by similar changes in both TAA and TPC, except in the case of 'Oronules' mandarins when, although antioxidant activity decreased, no loss in TPC or AA were found. It is necessary to take into account that in addition to AA and phenolics, the antioxidant activity also depends on the possible synergic effect of other phytochemicals (Plaza et al., 2011).

The ferric reducing antioxidant power assay (FRAP) is one of the most useful assays for examining the interactions among various antioxidants by taking into account their oxidation-reduction potential. The FRAP assay measures the antioxidant effect of any substance in the reaction medium as its reducing ability and is a convenient and reproducible assay. Recently, it has been extensively used to study the antioxidant activity of hydrophilic extracts of fruits and vegetables (Gardner et al., 2000; Abeysinghe et al., 2007; Klimczak et al., 2007).

At harvest, the FRAP values ranged from 3.25 to $4.35 \mathrm{mM} \mathrm{AAE}$ for 'Clemenpons' and 'Prenules' mandarins, respectively (Table 2). In general, the changes in antioxidant activity, based on the FRAP assay of all the tested citrus varieties, exhibited the same trend as that obtained by the $\mathrm{DPPH}^{\bullet}$ assay. 


\section{Chapter IV}

According to our findings, the exposure to ethylene did not significantly affect the antioxidant activity, measured by DPPH ${ }^{\bullet}$ and FRAP tests, after shelflife. Likewise, in our previous studies, the $\mathrm{DPPH}^{\bullet}$ method showed up no changes in the $\mathrm{EC}_{50}$ values for 'Clemenules' and 'Clemenpons' mandarins after degreening (Sdiri et al., 2010). 


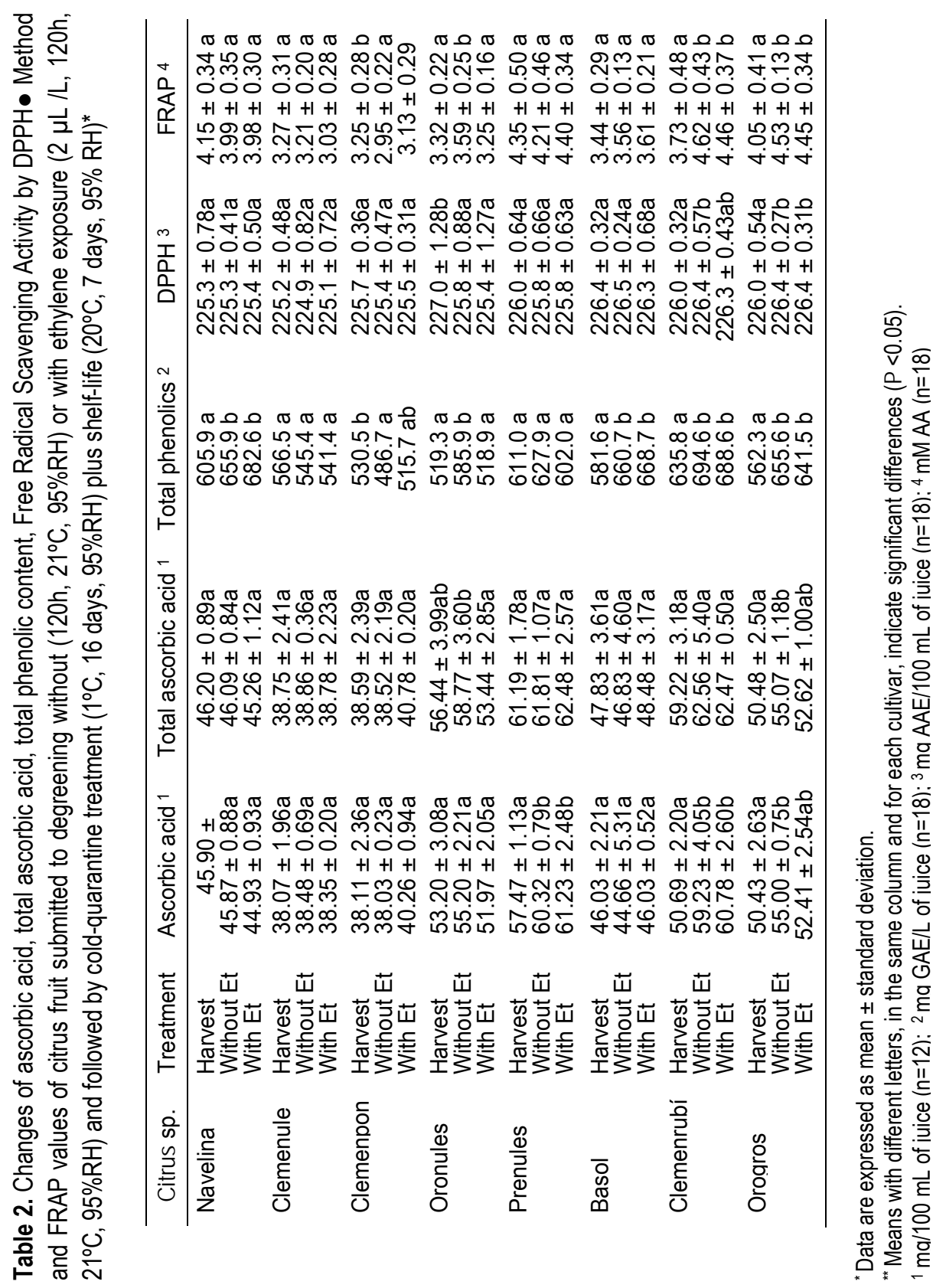




\subsection{Phenolic Compounds}

Phenolic compounds are secondary metabolic products, which mainly include flavonoids and phenolic acids in citrus fruit (Abeysinghe et al., 2007).

The effect of degreening treatment and the subsequent quarantine treatment on the phenolic compounds of different citrus varieties was studied. A total of 11 phenolic compounds were identified and quantified in the juice of the different citrus varieties, including flavanones [4], flavones [1], polymethaoxyflavones [3], flavanols [1], hydroxybenzoic acids [1] and hydroxycinnamic acids [1].

Table 3 shows the content of four flavanones (Hesperidin, Narirutin, Naringin and Didymin) in 'Navelina' oranges and in the seven varieties of clementine, both at harvest and after being submitted to the degreening process plus cold-quarantine treatment.

Hesperidin (HES) was the major flavanone detected at harvest in all of the studied varieties, ranged from 15.49 to $26.35 \mathrm{mg} / 100 \mathrm{~mL}$ in clementines; 'Navelina' oranges showed the highest content of about $35.22 \mathrm{mg} / 100 \mathrm{~mL}$. Other authors have also reported that HES is the key flavonoid in most citrus cultivars (Cano et al., 2008; Dhuique-Mayer et al., 2005; Wang et al., 2007; Stuetz et al., 2010); in some hybrids, HES represents about $50-80 \%$ of the total flavonoids (Rapisarda et al., 2009). Nevertheless, in some cultivars other flavanones have been detected as being the most abundant flavonoid; for instance, in 'Wendun' and 'Peyou' cultivars, the Naringin (NAR) content is much higher than HES (Wang et al., 2007). In our study, the level of NAR at harvest ranged from 0.15 to $0.34 \mathrm{mg} / 100 \mathrm{~mL}$ in clementines and was not detected in 'Navelina' oranges. Del Caro et al. (2004) did not detect NAR in other oranges, such as 'Shamouti' or 'Salustiana'.

The Narirutin (NAT) content in clementines varied from $0.93 \mathrm{mg} / 100 \mathrm{~mL}$ in 'Oronules' to $3.47 \mathrm{mg} / 100 \mathrm{~mL}$ in 'Clemenpons'; in 'Navelina' oranges the value was higher $(7.70 \mathrm{mg} / 100 \mathrm{~mL})$. Coinciding with our results, Cano et al. (2008) detected a higher concentration of HES and NAT in oranges than in mandarins; 
the levels of these compounds reported for 'Navelina' and 'Oronules' were similar to those obtained in our study.

Didymin (DID) was also present in all the varieties at harvest; the levels in clementine cultivars ranged from $0.09 \mathrm{mg} / 100 \mathrm{~mL}$ in 'Basol' to $0.64 \mathrm{mg} / 100 \mathrm{~mL}$ in 'Clemenpons'. 'Navelina' displayed the highest concentration of DID (2.26 $\mathrm{mg} / 100 \mathrm{~mL}$ ). In previous studies, DID has also been detected in some citrus hybrids (Del Caro et al., 2004; Rapisarda et al., 2009).

After the degreening process and the posterior cold-quarantine treatment, there was a reduction observed in all the flavanones measured in 'Navelina' oranges and 'Clemenpons' mandarins, leading to a significant reduction in the level of total flavanones (HES+NAT+NAR+DID). This decrease was not observed in the other clementines; even in 'Oronules' the content of the flavanone compounds increased after shelf-life compared with the values at harvest. Consistent with previous results, the changes in the citrus fruit flavonoids after harvest seem to depend on the variety and the storage conditions. Rapisarda et al. (2008) found that storage of blood oranges for up to 65 days at low temperatures $\left(6^{\circ} \mathrm{C}\right)$ stimulated flavanone biosynthesis, whereas in blond oranges, the flavanone content decreased during the same period of storage. Other authors reported no changes in HES, DID and NAT content in 'Fortune' mandarins after long-term storage at $5^{\circ} \mathrm{C}$ (32 days), whereas when this cultivar was submitted to quarantine treatment, there were no changes observed in HES but there was an increase in NAT levels (Lafuente et al., 2011).

In no case does ethylene affect the content of flavanones, since the levels of these compounds found in fruit that had been degreened both with or without ethylene exposure after shelf-life were the same. The exceptions were 'Clemenrubi' and 'Clemenpons' clementines, in which the ethylene-treated fruit presented a higher content of total flavanones than untreated fruit after shelflife.

Del Caro et al. (2004) observed a significant increase in flavanone compounds, mainly in HES, in packaged minimally processed 'Shamouti' oranges and 'Palezzi' while stored for 12 days at $4^{\circ} \mathrm{C}$. This increase might be 
related to the fact that the peel is not acting as a barrier in the minimally processed citrus pulp segments used by these authors. Nevertheless the authors reported that the high concentration of ethylene inside the boxes could have caused the increase of flavonoid compounds, since some authors have demonstrated that exposure to ethylene stimulates PAL activity with the consequent production of the main phenolic compounds. This effect of ethylene cannot be corroborated with our results, since in the present study, the fruit was only exposed to exogenous ethylene for $120 \mathrm{~h}$, whereas the exposure time was much longer in minimally processed fruit.

Flavone Diosmin (DSM) and polymethoxylated flavones, such as Sinensetin (SIN), Nobiletin (NOB) and Tangeretin (TAN) were examined in all the varieties both after harvest and after degreening (with or without ethylene) followed by quarantine treatment (Table 4).

In our study, DSM was the major flavone detected in all the varieties. The level of DSM in 'Navelina' oranges was the highest at harvest $(1,10 \mathrm{mg} / 100 \mathrm{~mL})$ and the lowest values were shown in 'Basol' $(0.27 \mathrm{mg} / 100 \mathrm{~mL})$ and 'Clemenrubi' ( $0.29 \mathrm{mg} / 100 \mathrm{~mL})$. Nogata et al. (2006) also detected DSM in all citrus species.

In all the tested varieties, the content of SIN was very scarce at harvest, ranging from 0.005 to $0.06 \mathrm{mg} / 100 \mathrm{~mL}$. These results agree with those obtained by other authors, who reported very low values of SIN in the juice of most citrus cultivars, so low in some of them that it is not even detectable (Nogata et al., 2006; Wang et al., 2007; Sentrandreu et al., 2007).

In our study, the detected values of NOB and TAN were also very low in all the varieties. As reported previously, these compounds were scarce in the juice vesicle, with the highest concentration found in the flavedo of the fruit (Nogata et al., 2006; Sentandreu et al., 2007).

The ethylene application followed by the quarantine conditions did not induce changes in any flavone content in 'Navelina' oranges. In clementines, however, the variations in the level of these compounds depend on the 
varieties. In this sense, no relevant changes in the DSM content were found in any of the tested clementines. Although this level increased in 'Oronules' and 'Clemenrubi' after shelf-life, no significant differences were observed whether the fruit was submitted or not to ethylene exposure. In 'Oronules' and 'Clemenules', the NOB content increased after shelf-life; nevertheless, a decrease was observed in 'Clemenrubi' and 'Orogros', both when degreened with or without ethylene. The 'Prenules', 'Basol' and 'Clemenpons' fruits submitted to ethylene treatment retained the same level of NOB compared to the values at harvest, whereas a loss of this compound was observed in fruit which was degreened ethylene-free. The changes observed in the TAN content were similar to those shown in NOB. Previous studies have reported a decrease in NOB and an increase in TAN contents in 'Fortune' mandarins after cold storage (Lafuente et al., 2011).

The changes shown in individual flavone compounds did not lead to any relevant changes in the total flavone content. Only in 'Oronules' mandarins a higher level was found after degreening and the posterior cold quarantine treatment and there was no difference between ethylene-treated and untreated fruit.

In our study, Quercetin (QUE) was also measured (Table 5). The content of this flavonol in 'Navelina' oranges and clementine cultivars ranged from 0.04 to $0.07 \mathrm{mg} / 100 \mathrm{~mL}$ at harvest and no changes were found after degreening plus cold quarantine treatment, except in 'Navelina,' which showed an increase after shelf-life.

Chlorogenic acid ( $C G$ ac) is one of the major phenolic acids present in citrus fruit (Wang et al., 2007). The cold storage required for quarantine led to a rise in CG ac content in most of the cultivars tested, whether or not they had been previously submitted to ethylene exposure (Table 5). Gallic acid was also detected and its content enhanced after shelf-life in 'Oronules', 'Basol', 'Prenules' and 'Clemenrubi', with no differences found in the rest of the varieties. 
Table 3. Changes of flavanones contents of citrus fruit submitted to postharvest degreening without $\left(120 \mathrm{~h}, 20^{\circ} \mathrm{C}, 95 \% \mathrm{RH}\right)$ or with ethylene exposure $(2 \mu \mathrm{L} / \mathrm{L}, 120 \mathrm{~h}$, $\left.20^{\circ} \mathrm{C}, 95 \% \mathrm{RH}\right)$ followed by cold-quarantine treatment $\left({ }^{\circ} \mathrm{C}, 16\right.$ days, $\left.95 \% \mathrm{RH}\right)$ plus shelflife $\left(20^{\circ} \mathrm{C}, 7 \text { days, } 95 \% \mathrm{RH}\right)^{*}$

\begin{tabular}{|c|c|c|c|c|c|c|}
\hline \multirow[t]{2}{*}{ Citrus sp. } & \multirow[t]{2}{*}{ Treatment } & \multicolumn{5}{|c|}{ Content $(\mathrm{mg} / 100 \mathrm{~mL})$} \\
\hline & & Narirutin & Naringin & Hesperidin & Didymin & Total \\
\hline \multirow[t]{3}{*}{ Navelina } & Harvest & $7.70 \pm 0.39 b^{* *}$ & & $35.22 \pm 3.51 b$ & $2.26 \pm 0.21 b$ & $45.18 b$ \\
\hline & Without Et & $5.74 \pm 0.79 a$ & $0.03 \pm 0.08 a$ & $27.35 \pm 3.11 a$ & $1.72 \pm 0.33 a$ & $34.84 \mathrm{a}$ \\
\hline & With Et & $5.73 \pm 0.26 a$ & $0.03 \pm 0.07 a$ & $24.29 \pm 0.90 a$ & $1.72 \pm 0.13 a$ & $31.77 \mathrm{a}$ \\
\hline \multirow[t]{3}{*}{ Clemenules } & Harvest & $2.65 \pm 0.75 a$ & $0.27 \pm 0.06 a$ & $26.35 \pm 5.59 a$ & $0.26 \pm 0.06 a$ & $29.53 \mathrm{a}$ \\
\hline & Without Et & $2.51 \pm 0.27 a$ & $0.27 \pm 0.03 a$ & $27.68 \pm 3.63 a$ & $0.31 \pm 0.12 \mathrm{a}$ & $30.77 \mathrm{a}$ \\
\hline & With Et & $2.46 \pm 0.13 a$ & $0.26 \pm 0.05 a$ & $25.38 \pm 3.14 a$ & $0.25 \pm 0.12 a$ & $30.43 a$ \\
\hline \multirow[t]{3}{*}{ Clemenpons } & Harvest & $3.47 \pm 0.29 b$ & $0.34 \pm 0.01 b$ & $26.15 \pm 0.82 c$ & $0.64 \pm 0.04 b$ & $30.49 \mathrm{c}$ \\
\hline & Without Et & $2.63 \pm 0.21 a$ & $0.30 \pm 0.02 a$ & $21.18 \pm 0.89 a$ & $0.52 \pm 0.02 a$ & $24.32 \mathrm{a}$ \\
\hline & With Et & $2.79 \pm 0.31 a$ & $0.31 \pm 0.02 a$ & $22.75 \pm 0.93 b$ & $0.56 \pm 0.03 a$ & $26.25 b$ \\
\hline \multirow[t]{3}{*}{ Oronules } & Harvest & $0.93 \pm 0.08 a$ & $0.15 \pm 0.02 a$ & $15.49 \pm 0.55 a$ & $0.27 \pm 0.007 a$ & $16.72 \mathrm{a}$ \\
\hline & Without Et & $1.25 \pm 0.18 c$ & $0.20 \pm 0.01 b$ & $21.06 \pm 0.38 b$ & $0.32 \pm 0.008 b$ & $21.89 b$ \\
\hline & With Et & $1.15 \pm 0.03 b$ & $0.19 \pm 0.02 b$ & $20.40 \pm 0.62 b$ & $0.31 \pm 0.008 b$ & $22.83 b$ \\
\hline \multirow[t]{3}{*}{ Prenules } & Harvest & $1.47 \pm 0.17 a$ & $0.21 \pm 0.02 a$ & $18.71 \pm 2.19 a$ & $0.37 \pm 0.04 a$ & $20.77 \mathrm{a}$ \\
\hline & Without Et & $1.55 \pm 0.07 a$ & $0.20 \pm 0.02 a$ & $19.02 \pm 0.31 a$ & $0.37 \pm 0.03 a$ & $21.08 \mathrm{a}$ \\
\hline & With Et & $1.59 \pm 0.10 a$ & $0.22 \pm 0.03 a$ & $19.32 \pm 2.08 \mathrm{a}$ & $0.38 \pm 0.01 a$ & $21.45 \mathrm{a}$ \\
\hline \multirow[t]{3}{*}{ Basol } & Harvest & $1.17 \pm 0.13 a$ & $0.25 \pm 0.04 a$ & $20.65 \pm 1.84 b$ & $0.09 \pm 0.10 a$ & $22.15 b$ \\
\hline & Without Et & $1.16 \pm 0.06 a$ & $0.23 \pm 0.02 a$ & $18.30 \pm 0.32 a$ & $0.20 \pm 0.16 a$ & $19.89 a$ \\
\hline & With Et & $1.23 \pm 0.10 a$ & $0.26 \pm 0.03 a$ & $19.98 \pm 0.94 a b$ & $0.07 \pm 0.14 a$ & $21.52 \mathrm{ab}$ \\
\hline \multirow[t]{3}{*}{ Clemenrubi } & Harvest & $1.40 \pm 0.03 a$ & $0.20 \pm 0.02 a$ & $21.27 \pm 1.09 a b$ & $0.20 \pm 0.21 a$ & $23.06 \mathrm{a}$ \\
\hline & Without Et & $1.47 \pm 0.03 a$ & $0.21 \pm 0.01 a$ & $20.61 \pm 0.37 a$ & $0.36 \pm 0.03 a b$ & $22.58 \mathrm{a}$ \\
\hline & With Et & $1.60 \pm 0.05 b$ & $0.21 \pm 0.02 a$ & $22.23 \pm 0.75 b$ & $0.38 \pm 0.05 b$ & $24.42 b$ \\
\hline \multirow[t]{3}{*}{ Orogros } & Harvest & $1.62 \pm 0.05 b$ & $0.25 \pm 0.01 a$ & $21.84 \pm 0.44 a$ & $0.47 \pm 0.04 b$ & $24.16 \mathrm{a}$ \\
\hline & Without Et & $1.54 \pm 0.07 a$ & $0.26 \pm 0.01 a$ & $21.89 \pm 0.82 a$ & $0.42 \pm 0.03 a$ & $24.10 \mathrm{a}$ \\
\hline & With Et & $1.62 \pm 0.08 b$ & $0.26 \pm 0.01 a$ & $22.47 \pm 0.21 a$ & $0.44 \pm 0.03 a b$ & $24.61 \mathrm{a}$ \\
\hline
\end{tabular}

*Data are expressed as mean \pm standard deviation $(n=6)$.

${ }^{*}$ Means with different letters, in the same column and for each cultivar, indicate significant differences $(P<0.05)$. 
Table 4. Changes of flavones contents of citrus fruit submitted to postharvest degreening without $\left(120 \mathrm{~h}, 20^{\circ} \mathrm{C}, 95 \% \mathrm{RH}\right)$ or with ethylene exposure $\left(2 \mu \mathrm{L} / \mathrm{L}, 120 \mathrm{~h}, 20^{\circ} \mathrm{C}, 95 \% \mathrm{RH}\right)$ followed by cold-quarantine treatment $\left(1^{\circ} \mathrm{C}, 16\right.$ days, $\left.95 \% \mathrm{RH}\right)$ plus shelf-life $\left(20^{\circ} \mathrm{C}, 7\right.$ days, $95 \% \mathrm{RH})^{*}$

\begin{tabular}{|c|c|c|c|c|c|c|}
\hline \multirow{2}{*}{ Citrus sp. } & \multirow{2}{*}{ Treatment } & \multicolumn{5}{|c|}{ Content (mg/100mL) } \\
\hline & & Diosmin & Sinensetin & Nobiletin & Tangeretin & Total \\
\hline \multirow[t]{3}{*}{ Navelina } & Harvest & $1.10 \pm 0.03 a^{* *}$ & $0.06 \pm 0.04 a$ & $0.06 \pm 0.01 a$ & $0.02 \pm 0.01 a$ & $1.23 \mathrm{a}$ \\
\hline & Without Et & $1.24 \pm 0.28 a$ & $0.04 \pm 0.01 a$ & $0.07 \pm 0.02 a$ & $0.02 \pm 0.01 a$ & $1.36 \mathrm{a}$ \\
\hline & With Et & $1.19 \pm 0.02 a$ & $0.06 \pm 0.02 a$ & $0.08 \pm 0.02 a$ & $0.02 \pm 0.00 \mathrm{a}$ & $1.34 \mathrm{a}$ \\
\hline \multirow[t]{3}{*}{ Clemenules } & Harvest & $0.58 \pm 0.08 a$ & $0.01 \pm 0.00 a$ & $0.02 \pm 0.01 \mathrm{a}$ & $0.01 \pm 0.02 a$ & $0.61 \mathrm{a}$ \\
\hline & Without Et & $0.60 \pm 0.07 a$ & $0.01 \pm 0.01 a$ & $0.04 \pm 0.01 b$ & $0.01 \pm 0.02 \mathrm{a}$ & $0.66 \mathrm{a}$ \\
\hline & With Et & $0.61 \pm 0.04 a$ & $0.01 \pm 0.01 a$ & $0.05 \pm 0.01 b$ & $0.01 \pm 0.02 a$ & $0.67 \mathrm{a}$ \\
\hline \multirow[t]{3}{*}{ Clemenpons } & Harvest & $0.65 \pm 0.02 b$ & $0.010 \pm 0.01 \mathrm{~b}$ & $0.06 \pm 0.02 b$ & $0.01 \pm 0.01 \mathrm{a}$ & $0.74 b$ \\
\hline & Without Et & $0.59 \pm 0.03 a$ & $0.006 \pm 0.0 \mathrm{a}$ & $0.03 \pm 0.01 a$ & $0.01 \pm 0.01 a$ & $0.63 \mathrm{a}$ \\
\hline & With Et & $0.67 \pm 0.03 b$ & $0.009 \pm 0.0 \mathrm{ab}$ & $0.06 \pm 0.004 b$ & $0.02 \pm 0.00 \mathrm{a}$ & $0.75 \mathrm{~b}$ \\
\hline \multirow[t]{3}{*}{ Oronules } & Harvest & $0.45 \pm 0.06 b$ & $0.005 \pm 0.00 \mathrm{a}$ & $0.04 \pm 0.02 a$ & $0.01 \pm 0.00 \mathrm{a}$ & $0.51 \mathrm{a}$ \\
\hline & Without Et & $0.59 \pm 0.08 a$ & $0.010 \pm 0.00 \mathrm{a}$ & $0.06 \pm 0.01 a$ & $0.02 \pm 0.01 \mathrm{a}$ & $0.68 \mathrm{~b}$ \\
\hline & With Et & $0.60 \pm 0.04 a$ & $0.020 \pm 0.01 \mathrm{~b}$ & $0.09 \pm 0.01 b$ & $0.05 \pm 0.02 b$ & $0.74 b$ \\
\hline \multirow[t]{3}{*}{ Prenules } & Harvest & $0.49 \pm 0.07 a$ & $0.01 \pm 0.01 a$ & $0.13 \pm 0.04 b$ & $0.05 \pm 0.03 b$ & $0.69 a$ \\
\hline & Without Et & $0.49 \pm 0.05 a$ & $0.01 \pm 0.01 a$ & $0.07 \pm 0.02 a$ & $0.02 \pm 0.01 \mathrm{a}$ & $0.60 \mathrm{a}$ \\
\hline & With Et & $0.54 \pm 0.08 a$ & $0.02 \pm 0.01 a$ & $0.10 \pm 0.01 \mathrm{ab}$ & $0.04 \pm 0.01 \mathrm{ab}$ & $0.70 \mathrm{a}$ \\
\hline \multirow[t]{3}{*}{ Basol } & Harvest & $0.27 \pm 0.27 a$ & $0.01 \pm 0.01 a$ & $0.10 \pm 0.01 b$ & $0.05 \pm 0.02 b$ & $0.41 \mathrm{a}$ \\
\hline & Without Et & $0.37 \pm 0.22 a$ & $0.01 \pm 0.00 a$ & $0.05 \pm 0.01 a$ & $0.02 \pm 0.01 a$ & $0.44 a$ \\
\hline & With Et & $0.47 \pm 0.29 a$ & $0.01 \pm 0.01 a$ & $0.09 \pm 0.01 \mathrm{~b}$ & $0.05 \pm 0.01 \mathrm{~b}$ & $0.63 a$ \\
\hline \multirow[t]{3}{*}{ Clemenrubí } & Harvest & $0.29 \pm 0.24 a$ & $0.02 \pm 0.01 a$ & $0.14 \pm 0.03 b$ & $0.08 \pm 0.03 b$ & $0.51 \mathrm{a}$ \\
\hline & Without Et & $0.47 \pm 0.05 a b$ & $0.01 \pm 0.01 a$ & $0.06 \pm 0.02 a$ & $0.04 \pm 0.02 a$ & $0.57 \mathrm{a}$ \\
\hline & With Et & $0.53 \pm 0.04 b$ & $0.01 \pm 0.01 a$ & $0.08 \pm 0.01 a$ & $0.04 \pm 0.02 a$ & $0.66 \mathrm{a}$ \\
\hline \multirow[t]{3}{*}{ Orogros } & Harvest & $0.68 \pm 0.05 a$ & $0.03 \pm 0.01 a$ & $0.13 \pm 0.04 b$ & $0.05 \pm 0.02 b$ & $0.90 \mathrm{a}$ \\
\hline & Without Et & $0.72 \pm 0.06 a$ & $0.02 \pm 0.01 a$ & $0.08 \pm 0.03 a$ & $0.03 \pm 0.01 a$ & $0.85 a$ \\
\hline & With Et & $0.71 \pm 0.04 a$ & $0.02 \pm 0.01 \mathrm{a}$ & $0.07 \pm 0.02 a$ & $0.04 \pm 0.02 a b$ & $0.83 a$ \\
\hline
\end{tabular}

* Data are expressed as mean \pm standard deviation $(n=6)$.

** Means with different letters, in the same column and for each cultivar, indicate significant differences $(P<0.05)$. 
Table 5. Changes of quercetin, gallic acid and chlorogenic acid contents of citrus fruit submitted to postharvest degreening without $\left(120 \mathrm{~h}, 20^{\circ} \mathrm{C}, 95 \% \mathrm{RH}\right)$ or with ethylene exposure $\left(2 \mu \mathrm{L} / \mathrm{L}, 120 \mathrm{~h}, 20^{\circ} \mathrm{C}, 95 \% \mathrm{RH}\right)$ followed by cold-quarantine treatment $\left({ }^{\circ} \mathrm{C}, 16\right.$ days, $95 \% \mathrm{RH})$ plus shelf-life $\left(20^{\circ} \mathrm{C}, 7 \text { days, } 95 \% \mathrm{RH}\right)^{*}$

\begin{tabular}{|c|c|c|c|c|}
\hline \multirow{2}{*}{ Citrus sp. } & \multirow{2}{*}{ Treatment } & \multicolumn{3}{|c|}{ Content (mg/100mL) } \\
\hline & & Quercetin & Gallic acid & Chlorogenic acid \\
\hline \multirow[t]{3}{*}{ Navelina } & Harvest & $0.07 \pm 0.01 a^{* *}$ & $0.30 \pm 0.05 a$ & $2.42 \pm 0.01 \mathrm{a}$ \\
\hline & Without Et & $0.25 \pm 0.15 b$ & $0.30 \pm 0.09 a$ & $2.54 \pm 0.20 \mathrm{~b}$ \\
\hline & With Et & $0.16 \pm 0.09 a b$ & $0.27 \pm 0.06 a$ & $2.81 \pm 0.11 b$ \\
\hline \multirow[t]{3}{*}{ Clemenules } & Harvest & $0.04 \pm 0.01 a$ & $0.34 \pm 0.04 a$ & $1.58 \pm 0.18 b$ \\
\hline & Without Et & $0.04 \pm 0.03 a$ & $0.36 \pm 0.02 a$ & $0.94 \pm 0.04 a$ \\
\hline & With Et & $0.06 \pm 0.03 a$ & $0.35 \pm 0.03 a$ & $0.92 \pm 0.02 a$ \\
\hline \multirow[t]{3}{*}{ Clemenpons } & Harvest & $0.06 \pm 0.03 a$ & $0.34 \pm 0.01 a$ & $1.43 \pm 0.04 a$ \\
\hline & Without Et & $0.04 \pm 0.02 a$ & $0.34 \pm 0.01 a$ & $1.41 \pm 0.05 a$ \\
\hline & With Et & $0.05 \pm 0.02 a$ & $0.34 \pm 0.01 \mathrm{a}$ & $1.45 \pm 0.03 a$ \\
\hline \multirow[t]{3}{*}{ Oronules } & Harvest & $0.04 \pm 0.02 a$ & $0.22 \pm 0.03 a$ & $1.37 \pm 0.10 \mathrm{a}$ \\
\hline & Without Et & $0.05 \pm 0.01 a$ & $0.35 \pm 0.03 b$ & $1.53 \pm 0.06 b$ \\
\hline & With Et & $0.06 \pm 0.04 a$ & $0.35 \pm 0.01 b$ & $1.50 \pm 0.10 \mathrm{~b}$ \\
\hline \multirow[t]{3}{*}{ Prenules } & Harvest & $0.07 \pm 0.03 a$ & $0.21 \pm 0.01 a$ & $1.14 \pm 0.05 a$ \\
\hline & Without Et & $0.05 \pm 0.04 a$ & $0.24 \pm 0.01 b$ & $1.10 \pm 0.02 a$ \\
\hline & With Et & $0.05 \pm 0.03 a$ & $0.27 \pm 0.01 \mathrm{c}$ & $1.11 \pm 0.05 a$ \\
\hline \multirow[t]{3}{*}{ Basol } & Harvest & $0.04 \pm 0.05 a$ & $0.22 \pm 0.01 \mathrm{a}$ & $1.11 \pm 0.11 \mathrm{a}$ \\
\hline & Without Et & $0.04 \pm 0.03 a$ & $0.27 \pm 0.01 b$ & $1.19 \pm 0.02 \mathrm{ab}$ \\
\hline & With Et & $0.06 \pm 0.04 a$ & $0.29 \pm 0.02 c$ & $1.28 \pm 0.05 b$ \\
\hline \multirow[t]{3}{*}{ Clemenrubí } & Harvest & $0.05 \pm 0.04 a$ & $0.19 \pm 0.02 a$ & $1.17 \pm 0.06 \mathrm{ab}$ \\
\hline & Without Et & $0.07 \pm 0.03 a$ & $0.24 \pm 0.01 b$ & $1.24 \pm 0.05 b$ \\
\hline & With Et & $0.07 \pm 0.04 a$ & $0.25 \pm 0.06 \mathrm{~b}$ & $1.01 \pm 0.31 a$ \\
\hline \multirow[t]{3}{*}{ Orogros } & Harvest & $0.05 \pm 0.03 a$ & $0.20 \pm 0.01 a$ & $1.22 \pm 0.07 a$ \\
\hline & Without Et & $0.07 \pm 0.04 a$ & $0.19 \pm 0.04 a$ & $1.48 \pm 0.05 b$ \\
\hline & With Et & $0.07 \pm 0.04 a$ & $0.21 \pm 0.03 a$ & $1.46 \pm 0.09 b$ \\
\hline
\end{tabular}

*Data are expressed as mean \pm standard deviation $(n=6)$.

${ }^{* *}$ Means with different letters, in the same column and for each cultivar, indicate significant differences $(P<0.05)$. 


\section{Conclusion}

According to our results, degreening under commercial conditions $(2 \mu \mathrm{L} / \mathrm{L}$ $\left.\mathrm{C}_{2} \mathrm{H}_{4}, 120 \mathrm{~h}, 21^{\circ} \mathrm{C}, 95 \% \mathrm{RH}\right)$ followed by the cold quarantine treatment $\left(1^{\circ} \mathrm{C}, 16\right.$ days) enhance the external color of 'Navelina' oranges and the seven varieties of clementines, preserving the quality attributes of the fruit.

Although the changes in DPPH and FRAP antioxidant capacities, ascorbic acid, total ascorbic acid and total phenolic content due to postharvest degreening followed by cold quarantine varied depending on the variety, no detrimental effects were associated with the combination on these postharvest treatments. As far as the individual flavonoid compounds are concerned, despite some changes were observed, neither the quarantine treatment nor ethylene exposure induced a loss in the total content of flavanone and flavone. Likewise, the concentrations of flavonol, quercetin and phenolic acids (chlorogenic and gallic acids) were not affected.

These results provide new evidence that, in addition to improving the external quality of the early-season citrus fruit, the ethylene degreening treatment under commercial conditions does not cause loss of nutritional value in the fruit.

\section{Acknowledgments}

This research was supported by the Spanish 'Ministerio de Educación y Ciencia' (Project INIA-RTA 2007-00101-00-00). The authors wish to thank FONTESTAD S.A Company for its technical support. 


\section{References}

Abeysinghe, D.C., Li, X., Sun, C.D., Zhang, W.S., Zhou, C.H., Chen, K.S., 2007. Bioactive compounds and antioxidant capacities in different edible tissues of citrus fruit of four species. Food Chem. 104, 1338-1344.

Benzie, I.F., Strain, J., 1999. Ferric reducing/antioxidant power assay: direct measure of total antioxidant activity of biological fluids and modified version for simultaneous measurement of total antioxidant power and ascorbic acid concentration: Methods Enzymol. 299, 15-27.

Burda, S., Oleszek, W., 2001. Antioxidant and antiradical activities of flavonoids. J. Agric. Food Chem. 49, 2774-2779.

Cano, A., Medina, A., Bermejo, A., 2008. Bioactive compounds in different citrus varieties. Discrimination among cultivars. J. Food Compos. Anal. 21, 377-381.

Dauchet, L., Amouyel, P., Hercberg, S., Dallongeville, J., 2006. Fruit and vegetable consumption and risk of coronary heart disease: A meta-analysis of cohort studies. J. Nutr. 136, 2588-2593.

Del Caro, A., Piga, A., Vacca, V., Agabbio, M., 2004. Changes of flavonoids, vitamin $\mathrm{C}$ and antioxidant capacity in minimally processed citrus segments and juices during storage. Food Chem. 84, 99-105.

Dhuique-Mayer, C., Caris-Veyrat. C., Ollitrault, P., Curk, F., Amiot, M. J., 2005. Varietal and interspecific influence on micronutrient contents in Citrus from the Mediterranean area. J. Agric. Food Chem. 53, 2140-2145.

Fox, A.J., Del Pzo-Insfran, D., Lee, J.H., Sargent, S.A., Talcott, S.T., 2005. Ripening-induced chemical and antioxidant changes in bell peppers as affected by harvest maturity and postharvest ethylene exposure. HortScience. 40, 732-736.

Franke, S.I.R., Pra, D., Erdtmann, B., Henriques, J.A.P., Da Silva, J., 2005. Influence of orange juice over the genotoxicity induced by alkalating agents: an in vivo analysis. Mutagenesis. 20, 279-283.

Gardner, P.T., White, T.A.C., McPhail, D.B., Duthie, G.G., 2000. The relative contributions of vitamin $\mathrm{C}$, carotenoids and phenolics to the antioxidant potential of fruit juices. Food Chem. 68, 471-474.

González-Molina, E., Moreno, D.A., García-Viguera, C., 2009. A new drink rich in healthy bioactives combining lemon and pomegranate juices. Food Chem. 115, 1364-1372. 
Hagenmaier, R.D., 2002. The flavor of mandarin hybrids with different coatings. Postharvest Biol. Technol. 24, 79-87.

Heredia, J.B., Cisneros-Zevallos, L., 2009. The effects of exogenous ethylene and methyl jasmonate on the accumulation of phenolic antioxidants in selected whole and wounded fresh produce. Food Chem. 115, 1500-1508.

Huang, R., Xia, R., Lu, Y., Hu, L., Xu, Y., 2008. Effect of pre-harvest salicylic acid spray treatment on post-harvest antioxidant in the pulp and peel of 'Cara cara' navel orange (Citrus sinensis L. Osbeck). J. Sci. Food Agric. 88, 229-236.

Jiménez-Cuesta, M., Cuquerella, J., Martínez-Jávega, J.M., 1981. Determination of a color index for citrus fruit degreening. Proc. Int. Soc. Citriculture 2, 750-753.

Klimczak, I., Malecka, M., Szlachta., M., Gliszczynska-Swiglo, A., 2007. Effect of storage on the content of polyphenols, vitamin $C$ and the antioxidant activity of orange juices. J. Food Compos. Anal. 20, 313-322.

Knekt, P., Kumpulainen, J., Jarvinen, R., Rissanen, H., Heliovaara, M., Reunanen, A., Hakulinen, T., Aromaa, A., 2002. Flavonoid intake and risk of chronic diseases. Am. J. Clin. Nutr. 76, 560-568.

Lafuente, M.T., Ballester, A.R., Calejero, J., Gonzalez-Candelas, L., 2011. Effect of high temperature-conditioning treatments on quality, flavonoid composition and vitamin $\mathrm{C}$ of cold stored 'Fortune' mandarins. Food Chem. 128, 1080-1086.

Martínez-Jávega, J.M., Monterde, A., Navarro, P., Salvador, A., 2008. Responsse of new clementines to degreening treatment. Proc. Int. Soc. Citriculture 11, 1342-1346.

Matsumoto, H., Ikoma, Y., Kato, M., Nakajima, N., Hasegawa, Y., 2009. Effect of Postharvest Temperature and Ethylene on Carotenoid Accumulation in the Flavedo and Juice Sacs of Satsuma Mandarin (Citrus unshiu Marc.) Fruit. J. Agric. Food Chem. 57, 4724-4732.

Mayuoni, L., Tietel, Z., Patil, B.S., Porat, R., 2011. Does ethylene degreening affect internal quality of citrus fruit? Postharvest Biol. Technol. 62, 50-58.

Mouly, P.P., Arzouyan, C.R., Gaydou, E.M., Estienne, J.M., 1994. Differentiation of citrus juices by factorial discriminant analysis using liquid chromatography of flavanone glycosides. J. Agric. Food Chem. 42, 70-79. 
Nogata, Y., Sakamoto, K., Shiratsuchi, H., Ishii, T., Yano, M., Ohta, H., 2006. Flavonoid composition of fruit tissues of Citrus species. Biosci. Biotechnol. Biochem. 70, 178-192.

Nyyssonen, K., Salonen, J.T., Parviainen, M.T., 2000. Ascorbic acid. In Leenheer, A.P.D., Lambert, E., Bocxlaer, J.F. (Eds.), Modern Chromatogragraphic Analysis of Vitamins. Marcel Dekker, New York, pp. 271-300.

Palma, A., D'Aquino, S., Agabbio, M., Schirra, S., 2005. Changes in flavonoids, ascorbic acid, polyphenol content and antioxidant activity in cold stored 'Fortune' Mandarin. Acta Hortic. 682, 617-622.

Patil, B.S., Vanamal, J., Hullman, G., 2004. Irradiation and storage influence on bioactive components and quality of early and late season 'Rio Red' grapefruit (Citrus parasidi Macf.). Postharvest Biol. Technol. 34, 53-64.

Pérez, A.G., Luaces, P., Oliva, J., Ríos, J.J., Sanz, C., 2005. Changes in vitamin $\mathrm{C}$ and flavour components of mandarin juice due to curing of fruits. Food Chem. 91, 19-24.

Plaza, L., Crespo, I., de Pascual-Teresa, S., de Ancos, B., Sánchez-Moreno, C., Muñoz, M., Cano, M.P., 2011. Impact of minimal processing on orange bioactive compounds during refrigerated storage. Food Chem. 124, 646651.

Rapisarda, P., Tomaino, A., Lo Cascio, R., Bonina, F., De Pasquale, A., Saija, A., 1999. Antioxidant effectiveness as influenced by phenolic content of fresh orange juices. J. Agric. Food Chem. 47, 4718-4723.

Rapisarda, P., Lo Bianco, M., Pannuzzo, P., Timpanaro, N., 2008. Effect of cold storage on vitamin $\mathrm{C}$, phenolics and antioxidant activity of five orange genotypes [Citrus sinensis (L.) Osbeck]. Postharvest Biol. Technol. 49, 348354.

Rapisarda, P., Fabroni, S., Peterek, S., Russi, G., Mock, H.P., 2009. Juice of new citrus hybrids (Citrus clementina Hort.ex Tan. x C. sinensis L. Osbeck) as a source of natural antioxidants. Food Chem. 117, 212-218.

Rodrigo, M.J., Zacarias, L., 2007. Effect of postharvest ethylene treatment on carotenoid accumulation and the expression of carotenoid biosynthesis genes in the flavedo of orange (Citrus sinensis L. Osbeck) fruit. Postharvest Biol. Technol. 43, 14-22.

Saltveit, M.E., 1999. Effect of ethylene on quality of fresh fruits and vegetables. Postharvest Biol. Technol. 15, 279-292. 
Sdiri, S., Monterde, A., Benabda, J., Rojas, C., Salvador, A., 2008. Effect of postharvest heat treatments on vitamin $\mathrm{C}$ content and quality of 'Fortune' mandarin (Citrus reticulata, Blanca). Proc. Int. Soc. Citriculture 11, 13511355.

Sdiri, S., Navarro, P., Benabda, J., Monterde, A., Salvador, A., 2010. Antioxidant activity and vitamin $\mathrm{C}$ are not affected by degreening treatment of Clementine mandarins. Acta Hortic. In press.

Sentandreu, E., Navarro, J.L., Sendra, J.M., 2007. Effect of technological processes and storage on flavonoids content and total, cumulative fastkinetics and cumulative slow kinetics antiradical activities of citrus juices. Eur. Food Res. Technol. 225, 905-912.

Singleton, V.L., Rossi, J.A., 1965. Colorimetry of total phenolics with phospomolybdic-phosphotungstic acid reagents. Am. J. Enol. Vitic. 16, 144158.

Stuetz, W., Prapamontol, T., Hongsibsong, S., Biesalski, H.K., 2010. Polymethoxylated Flavones, Flavanone Glycosides, Carotenoids, and Antioxidants in Different Cultivation Types of Tangerines (Citrus reticulata Blanco cv. Sainampueng) from Northern Thailand. J. Agric. Food Chem. 58, 6069-6074.

Tietel, Z., Weiss, B., Lewinsohn, E., Fallik, E., Porat, R., 2010. Improving taste and peel color of early-season Satsuma mandarins by combining hightemperature conditioning treatments. Postharvest Biol. Technol. 57, 1-5.

Vinson, J.A., Su, X., Zubik, L., Bose, P., 2001. Phenol antioxidant quantity and quality in foods: Fruits. J. Agric. Food Chem. 49, 5315-5321.

Wang, Y.C., Chuang, Y.C., Ku, Y.H., 2007. Quantitation of bioactive compounds in citrus fruits cultivated in Taiwan. Food Chem. 102, 11631171. 



\section{Changes in the Volatile Profile of Citrus Fruit submitted to Postharvest Degreening and Cold-Quarantine Treatment}

Sawsen Sdiri ${ }^{1}$, José Luis Rambla ${ }^{2}$, Cristina Besada ${ }^{2}$, Antonio Granell $^{2}$, Alejandra Salvador ${ }^{1}$

\footnotetext{
${ }^{1}$ Centro de Tecnología Postcosecha, Instituto Valenciano de Investigaciones Agrarias, Carretera Moncada-Náquera Km 4.5 s/n, 46113, Moncada, Valencia, Spain

${ }^{2}$ Instituto de Biología Molecular y Celular de Plantas (CSIC-UPV), Universidad Politécnica de Valencia, Ciudad Politécnica de la Innovación, Edificio 8E, Ingeniero Fausto Elio s/n, 46022 Valencia, Spain.
}

Reference: Submitted to Journal of Agricultural and Food Chemistry. 



\begin{abstract}
Degreening and cold-quarantine treatments are commonly applied to early season citrus fruit exported to countries free of fruit fly (Ceratitis capitata Wiedemann). We report the effect of degreening with or without ethylene exposure followed by quarantine treatment on the volatile composition of six early-season citrus varieties ('Navelina' oranges, 'Clemenules' and 'Oronules' mandarins, and three mutations of 'Oronules', namely 'Prenules', 'Basol' and 'Clemenrubi'). After quarantine treatment fruit degreened under ethylene exposure showed higher content of ethanol than air degreened fruit; nevertheless it was not associated to off-flavor development. The effect of ethylene during degreening treatment on other volatile compounds depended on the variety. No significant differences were observed between 'Clemenules' degreened with or without ethylene. The volatile profile of 'Navelina', 'Prenules' and 'Basol' was slightly affected by ethylene exposure, whilst 'Oronules' and 'Clemenrubi' showed the most dramatic changes. Our analysis, based on 87 unequivocally identified volatile compounds, also permitted to identify a characteristic volatile profile for each variety.
\end{abstract}

Keywords: Oranges; mandarins; ethylene; quarantine treatment; aroma-active compounds; SPME; GC/MS. 


\section{Introduction}

Early-season citrus fruit grown under the Mediterranean climates require degreening treatment in order to enhance external color change, since the fruit reaches internal maturity while the peel remains green. Commonly, the degreening treatment is applied using exogenous ethylene application under standard conditions of temperature and relative humidity. However, in a recent study, the introduction of a degreening without ethylene exposure, maintaining the same conditions of temperature and relative humidity, has been investigated. Although the fruit subjected to ethylene exposure reach the highest external coloration, the fruit degreened without ethylene application also attained a commercially acceptable color. ${ }^{1}$

An important quantity of the Spanish degreened citrus fruit are exported to free-fruit fly countries such as USA and Japan which require strict quarantine measures against the Mediterranean fruit fly (Ceratitis capitata). To satisfy the phytosanitary requirements of those countries, a quarantine treatment involving the exposure of fruit to low temperatures is applied during overseas transport. ${ }^{2}$

The effect of postharvest treatments such as coating and storage on the volatile composition of fresh citrus fruit has been extensively investigated. ${ }^{3-7} \mathrm{~A}$ very limited number of studies however have reported the effect of ethylene on aroma of degreened fruit. ${ }^{8}$

Ethylene exposure during degreening treatment followed by coldquarantine storage has been shown to have no negative effect on neither the internal quality attributes nor on the levels of bioactive compounds when compared to degreening without ethylene. ${ }^{9,10}$ Nevertheless, no information exists about the effect of these two postharvest treatments on the aroma volatile compounds of early season citrus fruit.

The aroma of a fresh citrus juice results from a complex combination of a subset of the more than 300 volatile compounds, defined as volatile organic compounds or VOCs, which include hydrocarbon terpenes, alcohols, aldehydes, esters and ketones. ${ }^{11-13}$ Although hydrocarbon terpenes are the 
predominant chemical class within citrus volatiles, this fraction makes little contribution to the odor perception because of their high odor thresholds. Aldehydes and esters are classes of compounds with a higher impact on citrus aroma. Thus, aldehydes have long been described to contribute to the orange aroma with citrus-like, green, fatty and metallic notes, while esters would be responsible for the fruity top-notes present in fresh juice. ${ }^{14,15}$

A combination of GC / olfactometry techniques permits the identification of the compounds likely to contribute to aroma. Aroma-active compounds are those components with levels equal or greater than their odor threshold. ${ }^{14}$ According to the literature, more than thirty compounds have been identified as odor-active in citrus fruit. Amongst them ethyl butanoate, hexanal, ethyl hexanoate, octanal, limonene, linalool, nonanal, decanal, acetaldehyde, ethanol, $\alpha$-pinene and myrcene are the most reported. ${ }^{5,14,16-30}$ Ethanol has been extensively reported as the main volatile compound associated to flavor deterioration during postharvest life of citrus fruit. The level of this compound increases rapidly during citrus fruit ripening; under anaerobic conditions or storage at low temperature for long periods, citrus fruit experiment an important enhance of ethanol accumulation which is related to the development of offflavors. ${ }^{3,5-7,31-34}$

In the present work, the changes on VOCs composition of early-season citrus fruit (orange cv. Navelina and mandarins cvs. Clemenules, Oronules, Prenules, Basol and Clemenrubí) submitted to degreening without or with ethylene exposure followed by cold-quarantine treatment under commercial conditions were studied. The inter-varietal variation among the fruits of the six cultivars at harvest is also reported, this report being the first time that the volatile profile of 'Oronules' and its mutants ('Prenules', 'Basol' and 'Clemenrubi'') is described. 


\section{MATERIAL AND METHODS}

\subsection{Plant material and commercial application of treatments}

'Navelina' oranges (Citrus sinensis L. Osbeck) and clementines (Citrus clementina Hort. Ex. Tan) cv. Clemenules, Oronules and three mutations of 'Oronules' - Prenules, Basol, Clemenrubí - were harvested at commercial maturity stage from orchards in Valencia (Spain) and then sorted by color in a commercial packinghouse (FONTESTAD S.A. Company, Valencia, Spain) using a color electronic calibrator according to an external color index.

Following packinghouse procedures, fruits from each cultivar were dipped in a solution of Imazalil ( $400 \mathrm{mg} / \mathrm{L}$, Fomesa Fruitech S.L.U, Spain) and were subsequently separated into two lots. Fruits from one lot were subjected to a standard degreening treatment in the packinghouse under commercial conditions $(2 \mu \mathrm{L} / \mathrm{L}$ of ethylene in a chamber with continuous flow regulated at $21^{\circ} \mathrm{C}$ and $95 \% \mathrm{RH}$ for $120 \mathrm{~h}$ ). Fruits from the second lot were submitted to degreening without ethylene by maintaining the fruit under the same conditions of temperature and relative humidity for $120 \mathrm{~h}$ without ethylene exposure. After degreening, fruits were waxed (Waterwax TTT-2I, Fomesa Fruitech S.L.U, Spain) and then exposed to cold quarantine treatment at $1^{\circ} \mathrm{C}$ for 16 days to comply with the phytosanitary requirement for shipping fruits to the USA. Fruits were then stored at $20^{\circ} \mathrm{C}$ for 7 days, simulating shelf-life conditions.

Samples corresponding to fruit at harvest and after shelf-life simulation, were analyzed for VOCs as indicated below with the concentration of ethanol determined separately from the other VOCs. Three juice samples per treatment (eight fruits per juice) were obtained using a hand extractor, in order to prevent contamination of the juice with peel components. $5 \mathrm{~mL}$ aliquots of each juice sample were placed in $10 \mathrm{~mL}$ crimp cap headspace vials and kept frozen at $80^{\circ} \mathrm{C}$ until analyzed. Besides, fruit flavor was sensory evaluated from five fruits per treatment. 


\subsection{HS-SPME extraction conditions}

The volatile compounds in the fruit juice fruit were analyzed according to the method described by González-Mas et al. ${ }^{12}$ with minor modifications. Briefly, before GC-MS analysis, samples were thawed at $25^{\circ} \mathrm{C}$ for ten minutes and 4 $\mathrm{mL}$ of sample were transferred into a $20 \mathrm{~mL}$ crimp cap headspace vial. Solid Phase Micro-extraction was performed on the headspace by means of a 50/30 $\mu \mathrm{m}$ DVB/CAR/PDMS fiber (Supelco, Bellefonte, PA, USA). Three biological replicates of each treatment were analyzed. Pre-incubation and extraction times were 10 and $20 \mathrm{~min}$, respectively. A temperature of $50^{\circ} \mathrm{C}$ was selected for both pre-incubation and extraction. Desorption was performed for $1 \mathrm{~min}$ at $250^{\circ} \mathrm{C}$ in splitless mode.

\subsection{Gas chromatography-mass spectrometry conditions}

Sampling was performed by using a COMBI-PAL autosampler (CTC Analytics, Zwingen, Switzerland) coupled to a $6890 \mathrm{~N}$ gas chromatograph and a 5975B mass spectrometer (Agilent Technologies, Santa Clara, CA, USA). Compound separation was conducted on a DB-5ms fused silica capillary column (5\%-phenyl-95\%-dimethylpolysiloxane as stationary phase, $60 \mathrm{~m}$ length, $0.25 \mathrm{~mm}$ i.d., and $1 \mu \mathrm{m}$ thickness film) (J\&W Scientific). Oven temperature conditions were $40^{\circ} \mathrm{C}$ for $2 \mathrm{~min}, 5^{\circ} \mathrm{C} / \mathrm{min}$ ramp until $250^{\circ} \mathrm{C}$ and then held isothermally at $250^{\circ} \mathrm{C}$ for $5 \mathrm{~min}$. Helium was used as carrier gas at 1.2 $\mathrm{mL} /$ min constant flow. Mass spectrometer operated in the El mode (ionization energy, $70 \mathrm{eV}$; source temperature $230^{\circ} \mathrm{C}$ ). Data acquisition was done in scanning mode (mass range $m / z$ 35-220; seven scans per second). Chromatograms and spectra were recorded and processed using the Enhanced ChemStation software for GC-MS (Agilent).

\subsection{Compound identification}

Compound identification was based both on the comparison between the MS for each putative compound with those of the NIST 2005 Mass Spectral library and also by matching against a GC retention time and Mass Spectra custom library. Compounds used to build this costum reference library were of 
analytical grade and purchased from Sigma-Aldrich Química (Madrid, Spain). The only exception were ethyl heptanoate, methyl octanoate, methyl nonanoate, and ethyl nonanoate, which were synthesized by acid-catalyzed esterification from analytical grade reagents according to the method described in González-Mas et al. ${ }^{12}$ For relative compound quantification, the peak area at a given retention time was integrated from the extracted ion chromatogram corresponding to a specific ion previously selected for each compound. A mixture of extracts representing the six varieties analyzed was injected regularly as part of the injection series and was used as a reference for correction for temporal variation and fiber aging. Finally, normalized values for each compound were expressed as ratios to the levels in the reference mixture.

\subsection{Quantification of ethanol}

For ethanol quantification, three replicates of each juice sample per treatment were analyzed. Ethanol levels were determined by headspace analysis on a gas chromatograph (model 1020, Perkin Elmer Corp., Norwalk, Conn., U.S.A.) equipped with a flame ionization detector and a $1 / 8$ " $\times 1.2 \mathrm{~m}$ Porapak QS $80 / 100$ column. The injector was set at $175^{\circ} \mathrm{C}$, the column at $150^{\circ} \mathrm{C}$, the detector (FID) at $200^{\circ} \mathrm{C}$ and the carrier gas at $12.3 \mathrm{psi} .1 \mathrm{~mL}$ aliquot of the headspace of vials which contain the samples previously equilibrated for $1 \mathrm{~h}$ at $20^{\circ} \mathrm{C}$ and $10 \mathrm{~min}$ at $30^{\circ} \mathrm{C}$ were injected in the gas chromatograph. Ethanol was identified by comparing retention time with that of a standard solution and expressed as $\mathrm{mg} / 100 \mathrm{~mL}$.

\subsection{Sensory evaluation}

A sensory evaluation was obtained by eight to ten semi-trained judges. Panelists rated the flavor on a 9-point scale, where $1=$ extremely unpleasant, $5=$ fair (commercially acceptable), and $9=$ excellent. For each variety, a sample consisting of segments taken from about 4-5 fruits per treatment was used. Samples were presented to panelists on trays labeled with random three-digit codes and served at room temperature. Spring water was provided for rinsing between samples. 


\subsection{Statistical analysis}

For Principal Component Analysis (PCA) the complete dataset of all replicates was considered. The ratio of the signal relative to the reference was $\log 2$ transformed. For this analysis the program SIMCA-P version 11 (Umetrics, Umea, Sweden) was used with Pareto scaling. Analysis of variance was used for the statistical difference between treatments and means were compared using LSD test at $P<0.05$. This analysis was performed using the statistical software Statgraphics Plus 5.1 (Manugistics, Inc., Rockville, MD, U.S.A.).

\section{RESULTS AND DISCUSSION}

\subsection{Volatile compounds at harvest: discrimination among varieties}

In the present study 87 volatile compounds were unequivocally identified in the juice of the citrus varieties and listed in Table 1. A total of 21 aldehydes ( 9 saturated aliphatic, 6 monounsaturated aliphatic, 2 diunsaturated aliphatic, 3 unsaturated terpenic and 1 norcarotenoid), 23 esters (15 aliphatic and 8 terpenic acetates), 16 alcohols (8 aliphatic and 8 monoterpenic), 14 terpenes (10 monoterpene hydrocarbons and 4 sesquiterpene hydrocarbons), 9 ketones (4 aliphatic, 4 terpenic and 1 norcarotenoid) and 4 furans were identified. All the compounds cited above are widely reported in the literature except 3methylfuran, ethyl nonanoate, methyl octanoate, methyl nonanoate and methyl decanoate which have been only recently identified as VOCs in citrus fruit. ${ }^{12}$ 


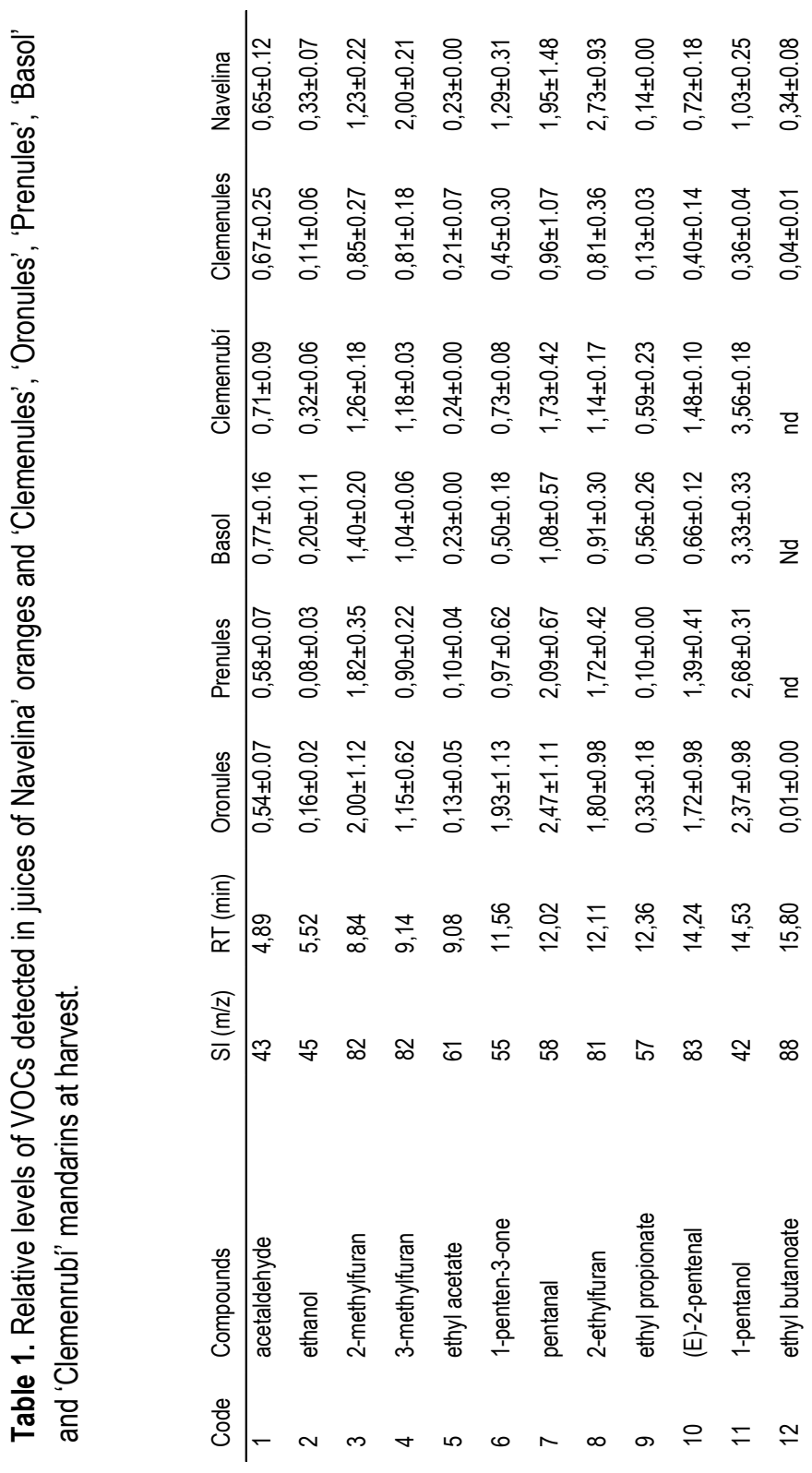




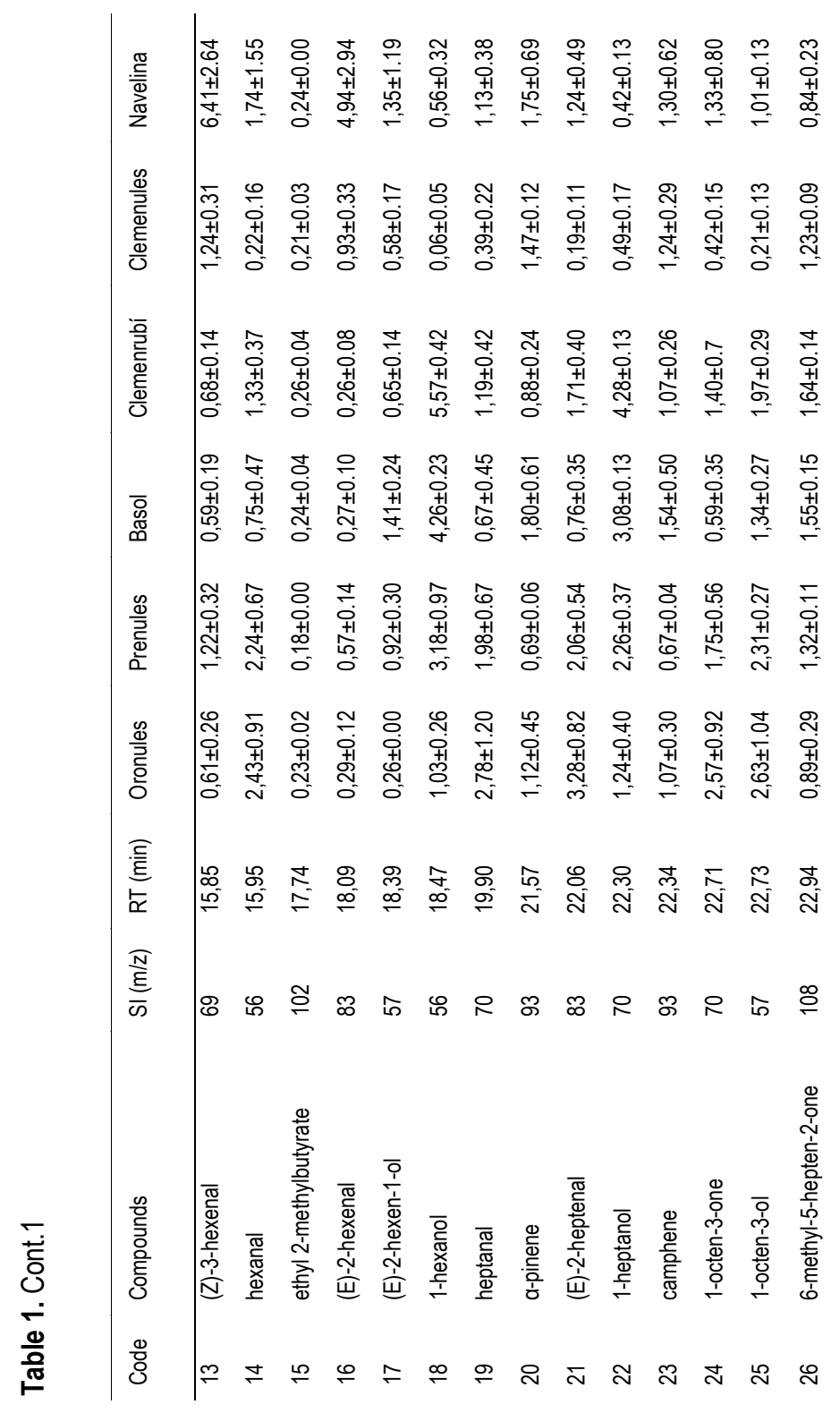




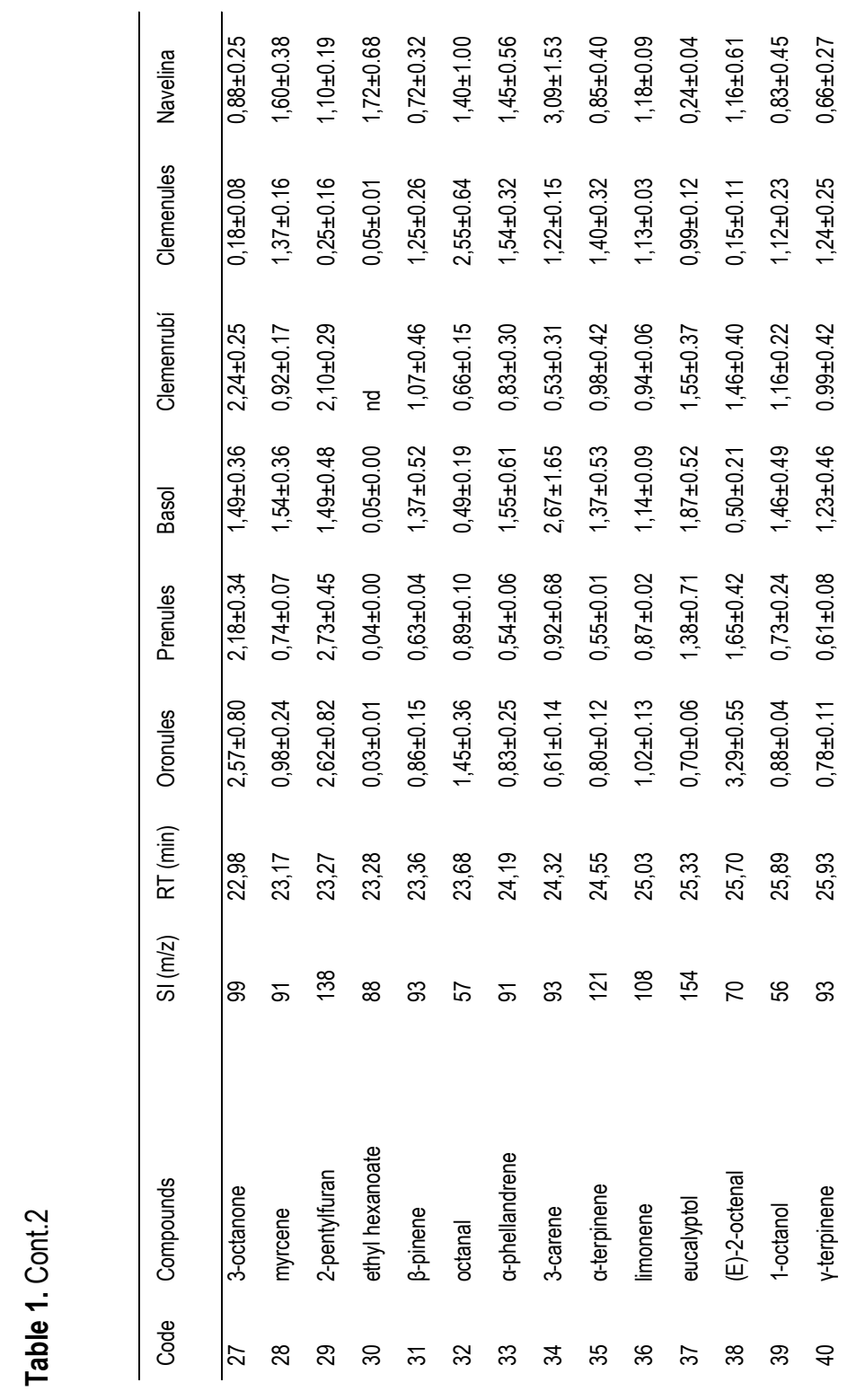




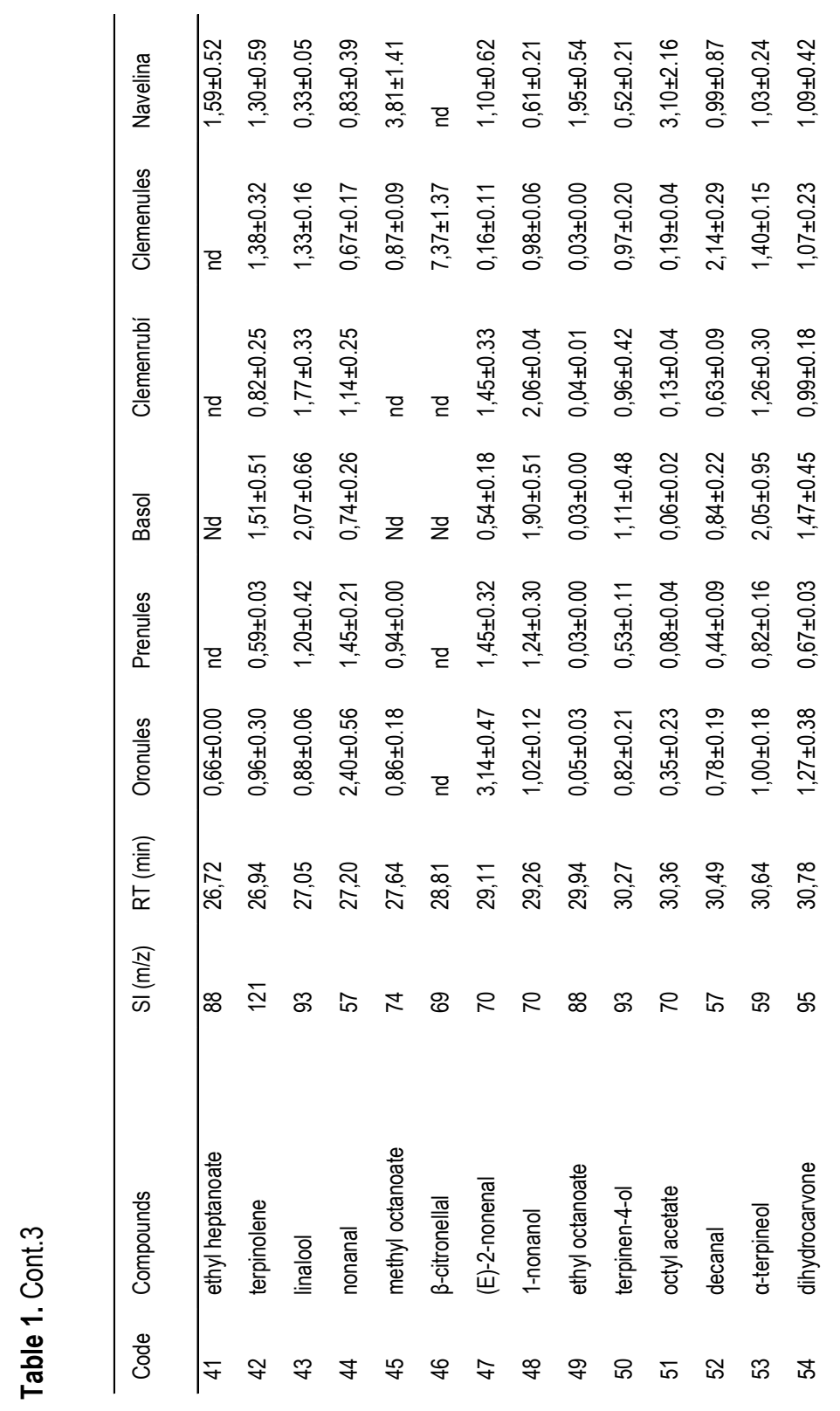




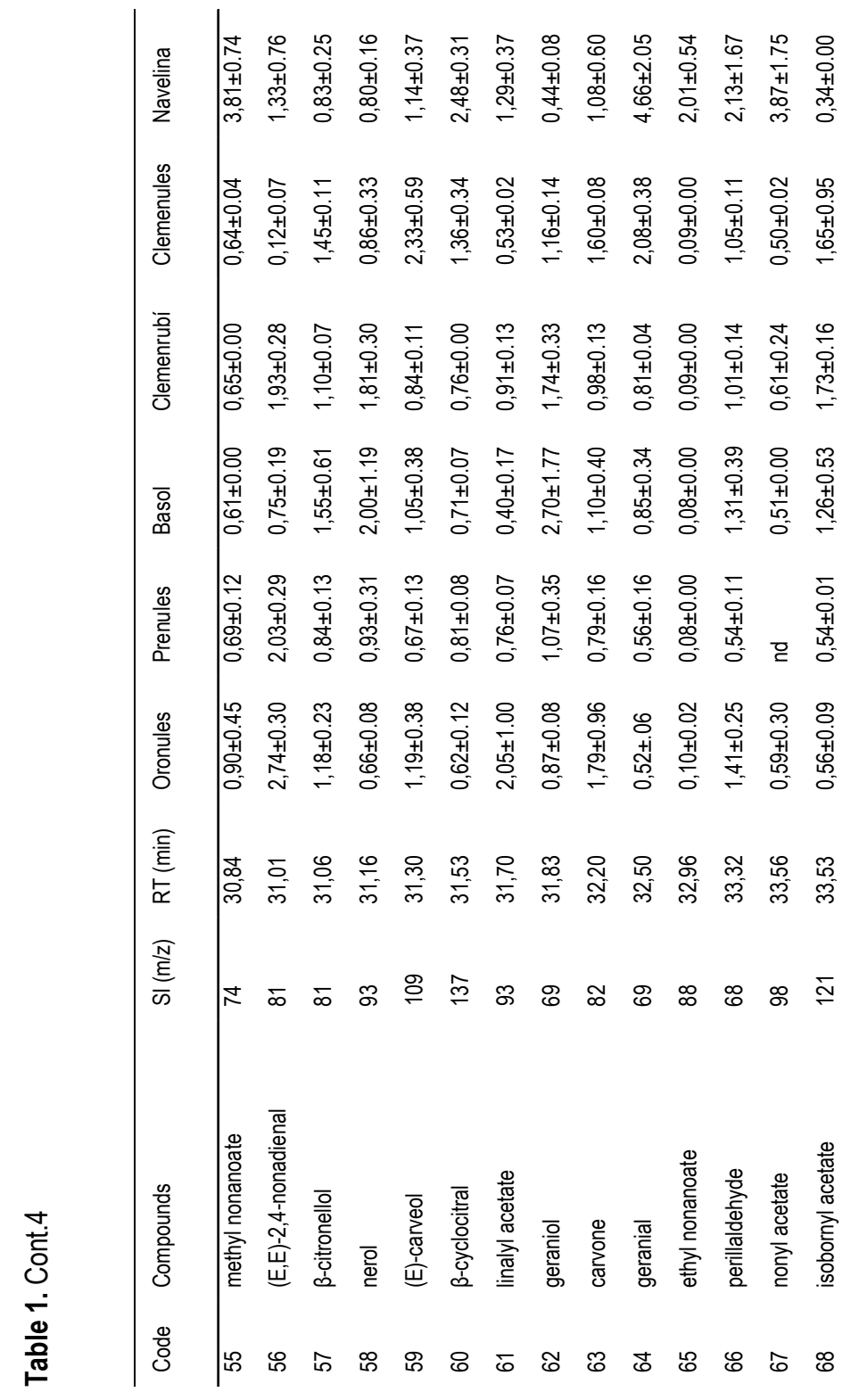




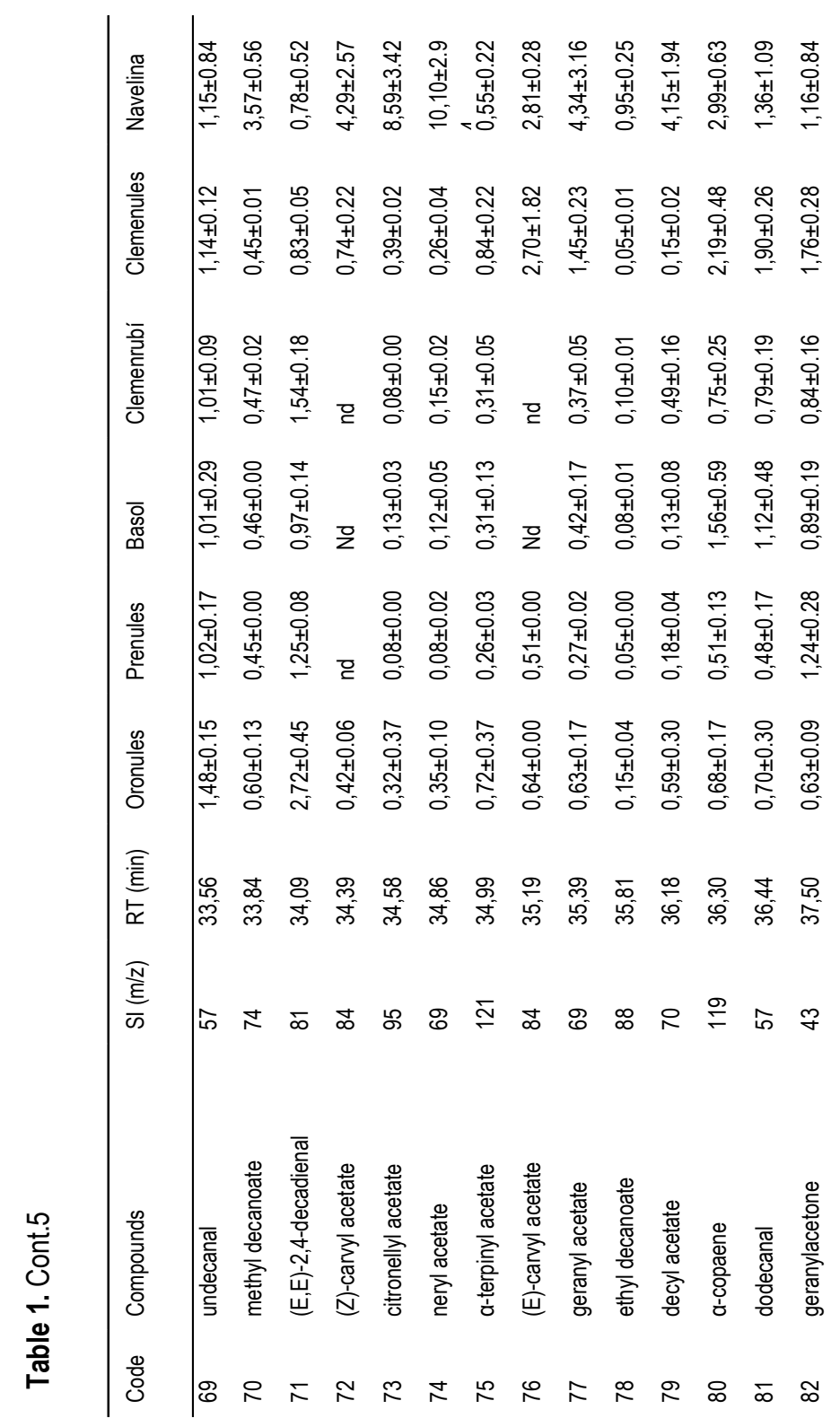




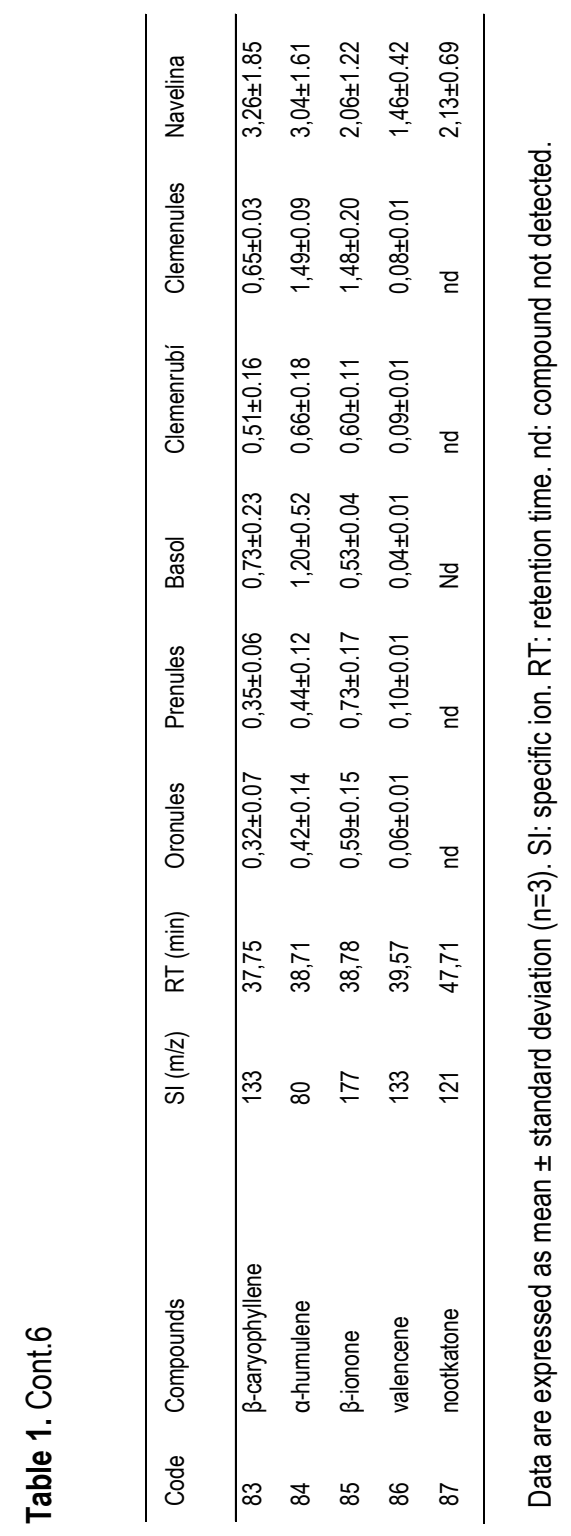


Principal Component Analysis (PCA) performed on the total data set of volatile compounds of the six studied varieties at harvest indicated that the first two components explain as much as $70 \%$ of the variance and separate the set of samples into three groups: 'Navelina' orange, 'Clemenules' and a third group where 'Oronules' and its mutations are included.

Not surprisingly, the analysis revealed that 'Navelina' oranges showed the most different volatile profile and was the major source of variability in the set of varieties studied, its particular profile defining the first component accounting for almost $42 \%$ of the variability in the whole dataset (Figure 1A). When compared to clementines, the 'Navelina' orange variety produced higher levels of a large set of ester compounds, both terpene-derived (citronellyl acetate, neryl acetate, (Z)-carvyl acetate) and non-terpen-derived (most notably ethyl butanoate, ethyl hexanoate, ethyl octanoate, octyl acetate, ethyl nonanoate, ethyl decanoate and decyl acetate, and in a lesser extent also methyl octanoate, methyl nonanoate, nonyl acetate and methyl decanoate), and also higher levels of (Z)-3-hexenal, (E)-2-hexenal and the sesquiterpenes valencene and nootkatone. Nootkatone is a sesquiterpene ketone and a key character-compound of grapefruit but is present in much lower concentrations in orange oil. The odor intensity of this compound in freshly squeezed orange juice is weak.15 'Navelina' variety was also characterized by lower levels of a set of alcohols, both monoterpenic (eucalyptol, linalool, geraniol) and lipid-derived (1-pentanol, 1-hexanol, 1heptanol, 1-nonanol) (Table 1, Figure 2A).

A PCA performed only with the 5 clementine varieties clearly separated 'Clemenules' mandarins from the other four, which otherwise grouped closely together (Figure 1B). This clustering can be explained by the fact that these varieties are strongly phyllogenetically related, being 'Clemenrubi', 'Prenules' and 'Basol' mutations of 'Oronules'. When compared to the other four clementine varieties, the volatile profile of 'Clemenules' was characterized by higher levels of a set of monoterpenic compounds such as $\beta$-citronellal, (E)carveol or geranial, some aliphatic aldehydes such as decanal or dodecanal, the acetic esters of many of these compounds (citronellyl acetate, (E)-carvyl acetate, geranyl acetate, a-terpinyl acetate, decyl acetate) and the sesquiterpenes $\alpha$-copaene and $\alpha$-humulene. 'Clemenules' mandarins also showed lower levels of a large set of lipid-derived compounds, including some 
saturated aldehydes and alcohols (hexanal, heptanal, 1-pentanol, 1-hexanol and 1-heptanol), many unsaturated aldehydes, alcohols and ketones ((E)-2pentenal, (E)-2-heptenal, (E)-2-octenal, (E)-2-nonenal, (E,E)-2,4-nonadienal, 1octen-3-ol, 1-octen-3-one and 3-octanone), and 2-pentylfuran (Table 1, Figure 2B).

Nevertheless, when the variability between 'Oronules' mandarins and the varieties originated from it was explored, it became evident that 'Oronules' has a particular volatile fingerprint that allowed a clear separation between it and its mutants (Figure 1C), each of which also showed a characteristic volatile profile. Compared to that of its mutants, the volatile profile of 'Oronules' mandarins is characterized by higher levels of saturated aldehydes such as heptanal, octanal, nonanal and undecanal, and of some olefinic aldehydes, namely $(E)-2-$ heptenal, (E)-2-octenal, (E)-2-nonenal, (E,E)-2,4-nonadienal and (E,E)-2,4decadienal. 'Oronules' also showed higher levels of some ketones (1-penten-3one, 1-octen-3-one) and non-terpenic compounds (neryl acetate, octyl acetate, linalyl acetate, decyl acetate, neryl acetate, $\alpha$-terpinyl acetate, geranyl acetate, citronellyl acetate and ethyl decanoate) and lower contents of some alcohols (namely (E)-2-hexen-1-ol, 1-hexanol, 1-heptanol and eucalyptol) and ethyl butanoate than its mutants (Table 1, Figure 2C). 

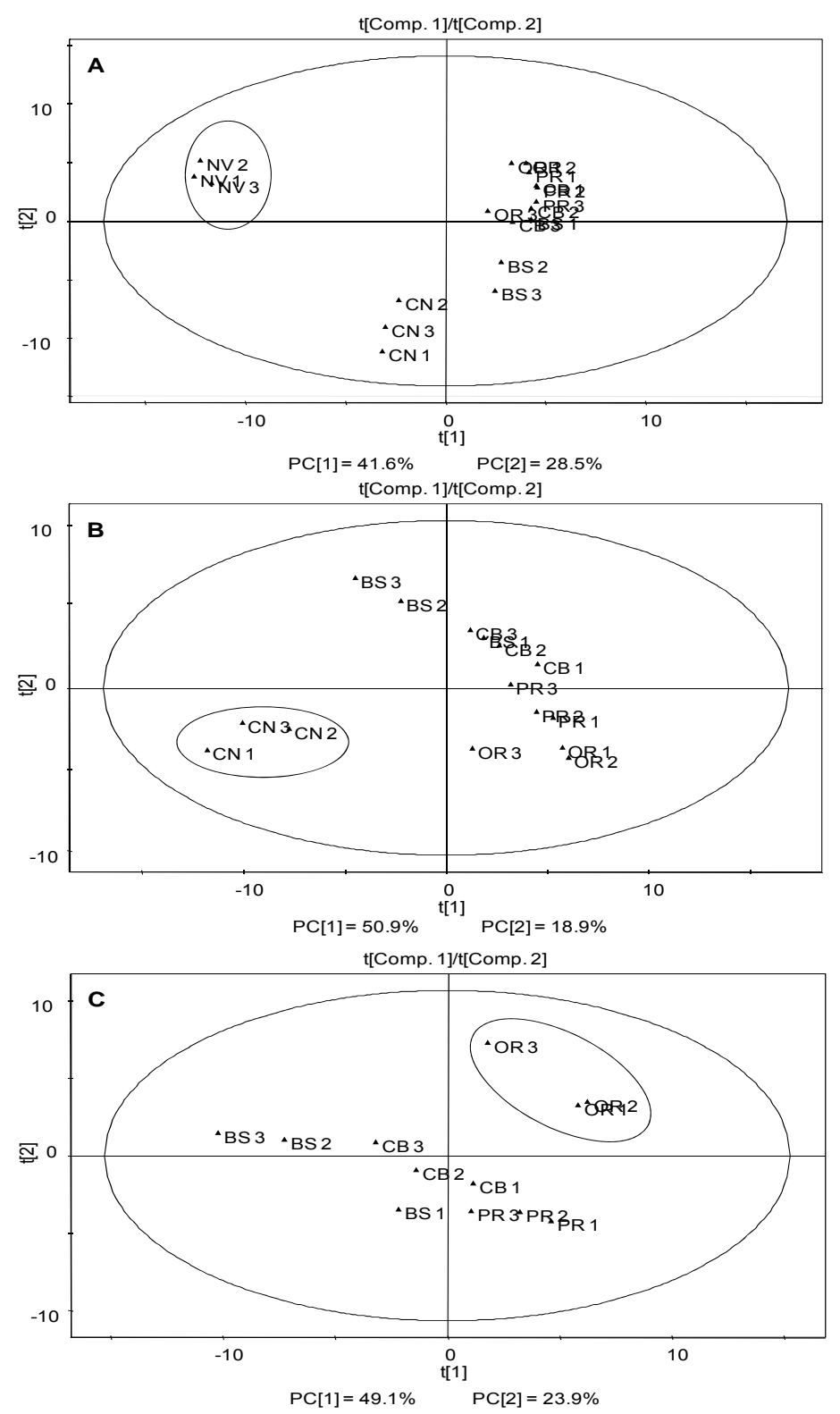

Figure 1. Principal Component Analysis score plot based on the levels of 87 VOCs of 'Navelina' orange (NV) and 'Clemenules' (CN), 'Oronules' (OR), 'Prenules' (PR), 'Basol' (BS) and 'Clemenrubi' (CB) mandarins at harvest. (A) PCA with the data of all the varieties; (B) PCA with the data of only the mandarin varieties; (C) PCA with the data of only 'Oronules' and its mutants 'Prenules', 'Basol' and 'Clemenrubí'. 

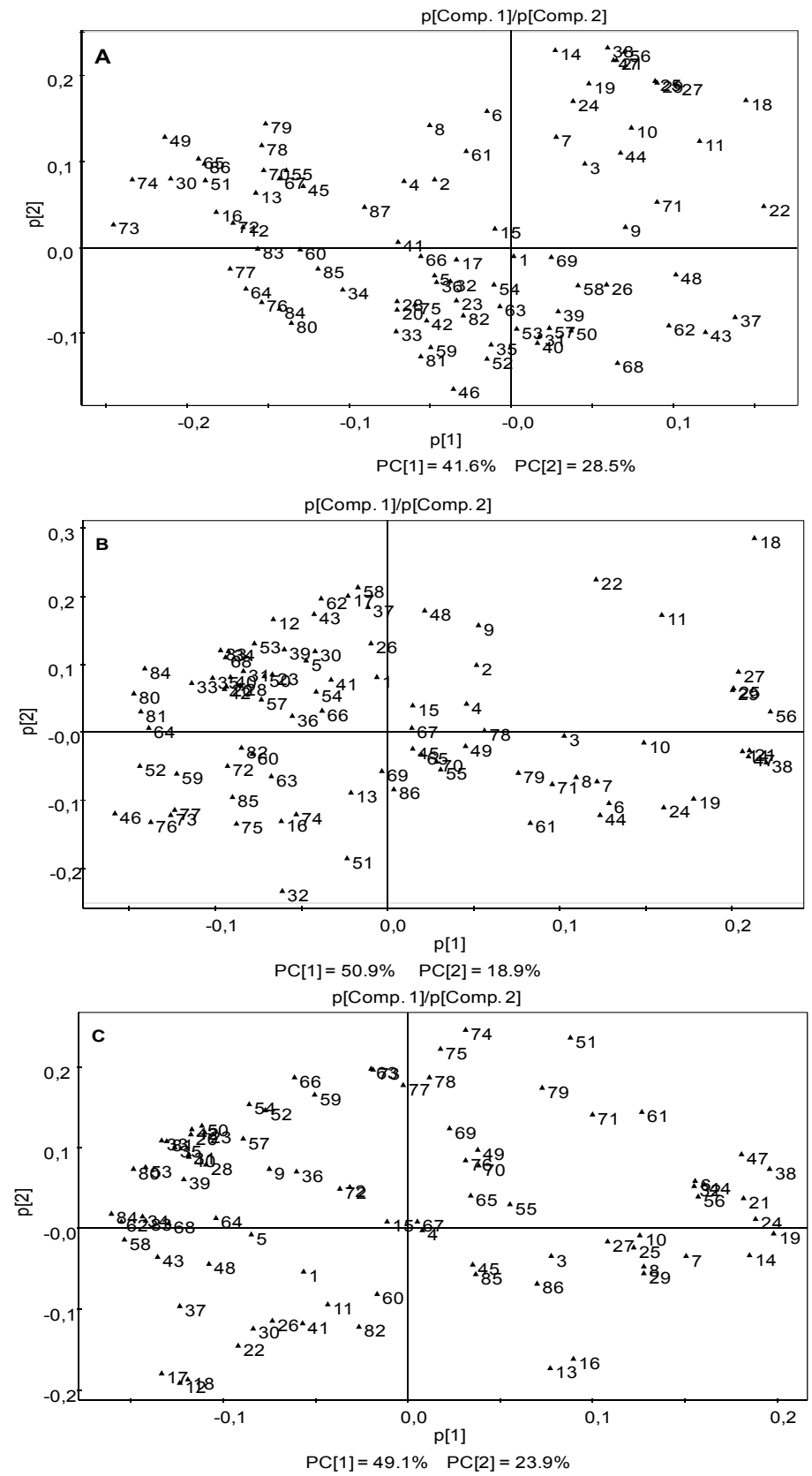

Figure 2. Principal Component Analysis loading plot. Each number corresponds to a particular volatile compound, as indicated in Table 1. 


\subsection{Changes of VOCs after degreening with or without ethylene followed by the cold-quarantine treatment}

The PCA, including the 87 volatile compounds identified in the fruit juice at harvest $(H)$ and after degreening without $(A)$ and with $(E)$ ethylene exposure plus cold-quarantine storage, is shown in Figure 3 . The first component, that explains between 43.9 to $70.3 \%$ of the variability depending on the variety, separated the volatile profile at harvest from that after shelf-life, indicating that the levels of several volatile compounds changed significantly after degreening with or without ethylene plus the posterior cold-quarantine treatment. After shelf-life, a common pattern was observed for all the varieties consisting on increased levels of ethanol, acetaldehyde, some ethyl ester compounds (ethyl acetate, ethyl propionate, ethyl butanoate, ethyl 2-methylbutyrate, ethyl hexanoate, ethyl octanoate, ethyl nonanoate and ethyl decanoate) and of the sesquiterpene valencene. Besides, the levels of some aldehydes (pentanal and (Z)-3-hexenal) and alcohols (1-pentanol, 1-hexanol and 1-heptanol) decreased after shelf-life (Supplementary figure 3A) (Annex 1).

The volatile profile of 'Oronules' and 'Clemenrubi' mandarins was the most responsive to ethylene exposure; for both varieties the second component of the PCA (explaining about $15 \%$ of the variability) clearly separated ethylenetreated and non-treated samples (Figure 3). This fact indicates that the levels of many VOCs were significantly affected by degreening with ethylene application (E) when compared to the treatment with air $(A)$.

PCA applied to VOCs of 'Prenules' mandarins indicates that this variety shows little response to ethylene, since the first component slightly separated fruit degreened with ethylene exposure from those degreened in air.

The PCA of the volatile profiles of 'Navelina', 'Clemenules' and 'Basol' varieties reveals that the ethylene exposure did not affect further the levels of volatile compounds (Figure 3 ). 

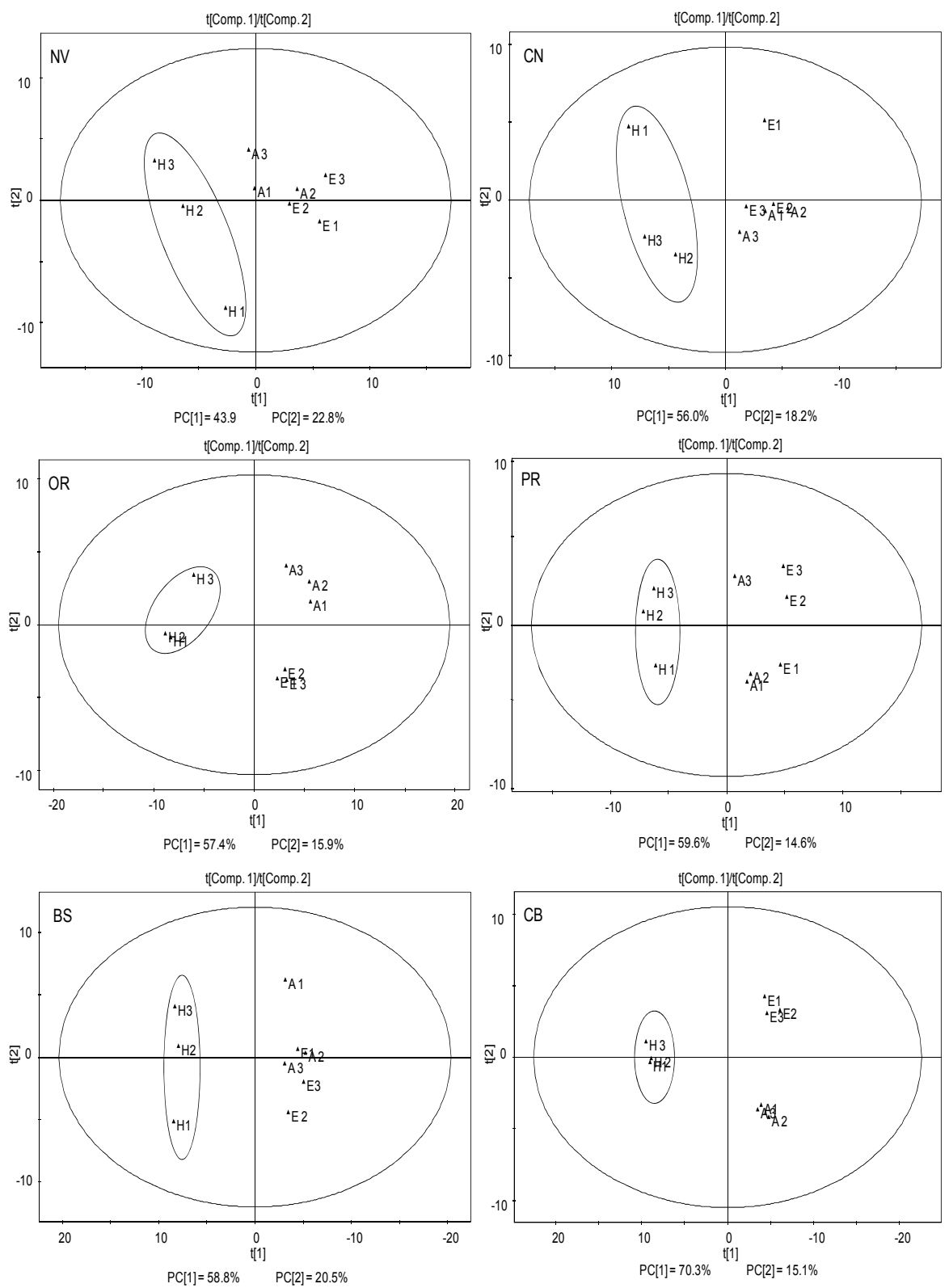

Figure 3. Principal Component Analysis of the volatile profiles of 'Navelina' oranges (NV) and 'Clemenules' (CN), 'Oronules' (OR), 'Prenules' (PR), 'Basol' (BS) and 'Clemenrubi' (CB) mandarins at harvest $(H)$ and after degreening without $(A)$ and with $(E)$ ethylene exposure and the posterior cold-quarantine treatment plus shelf-life. 


\subsection{Effect of ethylene application on the levels of aroma-active compounds}

In order to evaluate the effect of ethylene exposure during degreening treatment on fruit aroma in depth, in the following part of study we focused on 28 volatile compounds using the analysis of variance of the levels of VOCs of fruit degreened without ethylene exposure (A) and those degreened with ethylene (E) (Tables 2 and 3). The reason for targeting our analysis to those compounds is that after a thorough review of the literature they are considered to be major contributors to the typical aroma of citrus fruits. ${ }^{5,14,16-30}$

Among these aroma-active compounds, a special attention was paid here to ethanol and its concentration was quantified separately to overcome the limitations of a combined analysis with minor volatiles. Although ethanol is a precursor of natural aroma compounds, ${ }^{35}$ high amounts may cause development of off-flavor in citrus fruit. ${ }^{3,5,31-34,36}$ In all the varieties, the content of ethanol after shelf-life was higher in fruits exposed to ethylene than in fruits degreened without ethylene application. The maximum values that were observed in 'Oronules' mandarins $(124.2 \mathrm{mg} / 100 \mathrm{~mL})$ did not exceed the value reported in the literature as the threshold above which ethanol may affect the citrus flavor negatively $\left(1500 \mu \mathrm{L} / \mathrm{L}\right.$ in mandarins). ${ }^{33}$ The absence of off-flavors was corroborated by the sensory evaluation results since in all cases the panel qualified all fruits with high flavor scores (Table 3). In agreement with our results, previous studies also reported that degreening treatments under standard conditions did not affect the sensory quality of citrus fruit. ${ }^{1,9,37}$

Ethyl butanoate is one of the major aroma compounds in citrus juice in terms of flavor with an important contribution to the fruity-floral desirable aroma in orange products. In our study, ethyl butanoate was not detected in 'Prenules', 'Basol' and 'Clemenrubí' mandarins. This compound was found at low levels in 'Oronules' and 'Clemenules' mandarins; nevertheless, high levels were detected in 'Navelina' oranges. In accordance to this, Hagenmaier and Shaw3 reported higher concentration of ethyl butanoate in 'Temple' oranges, while for mandarin fruits ('Fallglo', 'Robinson', 'Sunburst', 'Murcott', 'Dancy' and 'Nova') ethyl butanoate was found in trace levels. Other studies also reported high levels of ethyl butanoate in different orange fruits. ${ }^{17,26}$ The analysis of variance 
revealed that the ethylene application during degreening treatment did not affect the levels of ethyl butanoate in 'Navelina' oranges and 'Oronules' and 'Clemenules' mandarins (Table 2).

In 'Prenules', 'Basol' and 'Clemenrubi' mandarins an increase in ethyl acetate accompanied by increase in ethyl propionate was shown in fruit submitted to ethylene exposure compared to non-treated fruit. Contrary to our findings, Mayouni et al. ${ }^{8}$ found that exposure of 'Satsuma' mandarins, 'Navel' oranges and 'Star Ruby' grapefruit to ethylene did not enhance accumulation of ethyl acetate when compared to fruit degreened without ethylene application.

Regarding the other aroma-active compounds, the effect of ethylene was dependent on the variety (Table 2). In 'Clemenules' mandarins, in the same way as shown by the PCA, the analysis of variance performed for the odor-active volatiles showed that ethylene exposure did not significantly affect the levels of aroma-active compounds. Slight aroma volatile response to ethylene exposure was shown by 'Navelina' oranges and 'Basol' and 'Prenules' mandarins. In 'Basol' mandarins, in addition to ethyl acetate and ethyl propionate, only a significant increase in the level of acetaldehyde as well as ethyl-2methylbutyrate and decrease in that of (Z)-3-hexenal were found in fruit submitted to degreening with ethylene exposure when compared with the fruit degreened without ethylene. This decrease of (Z)-3-hexenal level was also found in 'Navelina' oranges. In agreement with our findings, Mayuoni et al.8 reported a significant decrease of (Z)-3-hexenal after degreening of Navel oranges with ethylene exposure. Ethylene-degreened fruit showed higher levels of geraniol in 'Navelina' oranges and of ethyl-2-methylbutyrate, 1-octen-3-one and limonene in 'Prenules' mandarins compared to fruit degreened without ethylene exposure.

In 'Oronules' mandarins, exposure to ethylene significantly increased the levels of four aldehydes (hexanal, octanal, nonanal, (E)-2-nonenal), two esters (ethyl propionate, ethyl octanoate), and the ketone 1-octen-3-one, and decreased those of two alcohols (linalool, and geraniol), and the aldehyde decanal. 'Clemenrubi' mandarins showed also a high response to ethylene exposure with increased levels of acetaldehyde, a-pinene, myrcene, limonene, linalool and ethyl octanoate in comparison to air treated fruit. Mayuoni et al. ${ }^{8}$ 
found that in 'Satsuma' mandarins ethylene exposure increased the content of linalool.

In general, although the degreening with ethylene exposure changed the volatile profile of some early-season citrus varieties, by increasing or decreasing the levels of some of the compounds considered to provide the characteristic citrus aroma, it had no impact on the global flavor of the fruit. This was reflected by the high fruit flavor acceptability reported by the taste panels with no differences due to ethylene

In the present study, the volatile profile at harvest of 'Navelina' oranges and mandarines cv. Clemenules, Oronules and its mutations Prenules, Basol, Clemenrubí was determined. 'Navelina', 'Clemenules 'and 'Oronules' varieties are characterized by a specific volatile composition while the three mutants of 'Oronules' shared a very similar volatile profile.

Changes in the aroma-active compounds of these six varieties of citrus fruit when submitted to degreening with or without ethylene and the posterior cold quarantine treatment depends on the variety. The odor-active components of 'Navelina', 'Clemenules' and 'Basol' were not affected by ethylene exposure; 'Prenules' showed little response to ethylene, while 'Oronules' and 'Clemenrubi' were the cultivars with higher response to ethylene.

Despite degreening treatment with ethylene and the posterior coldquarantine resulted in increased levels of ethanol when compared to air degreened fruit, such levels were not associated to development of off-flavor and all the fruits were sensory evaluated with high flavor scores. Besides, ethylene exposure enhanced the levels of some odor-active aldehydes with citrus-like notes. 


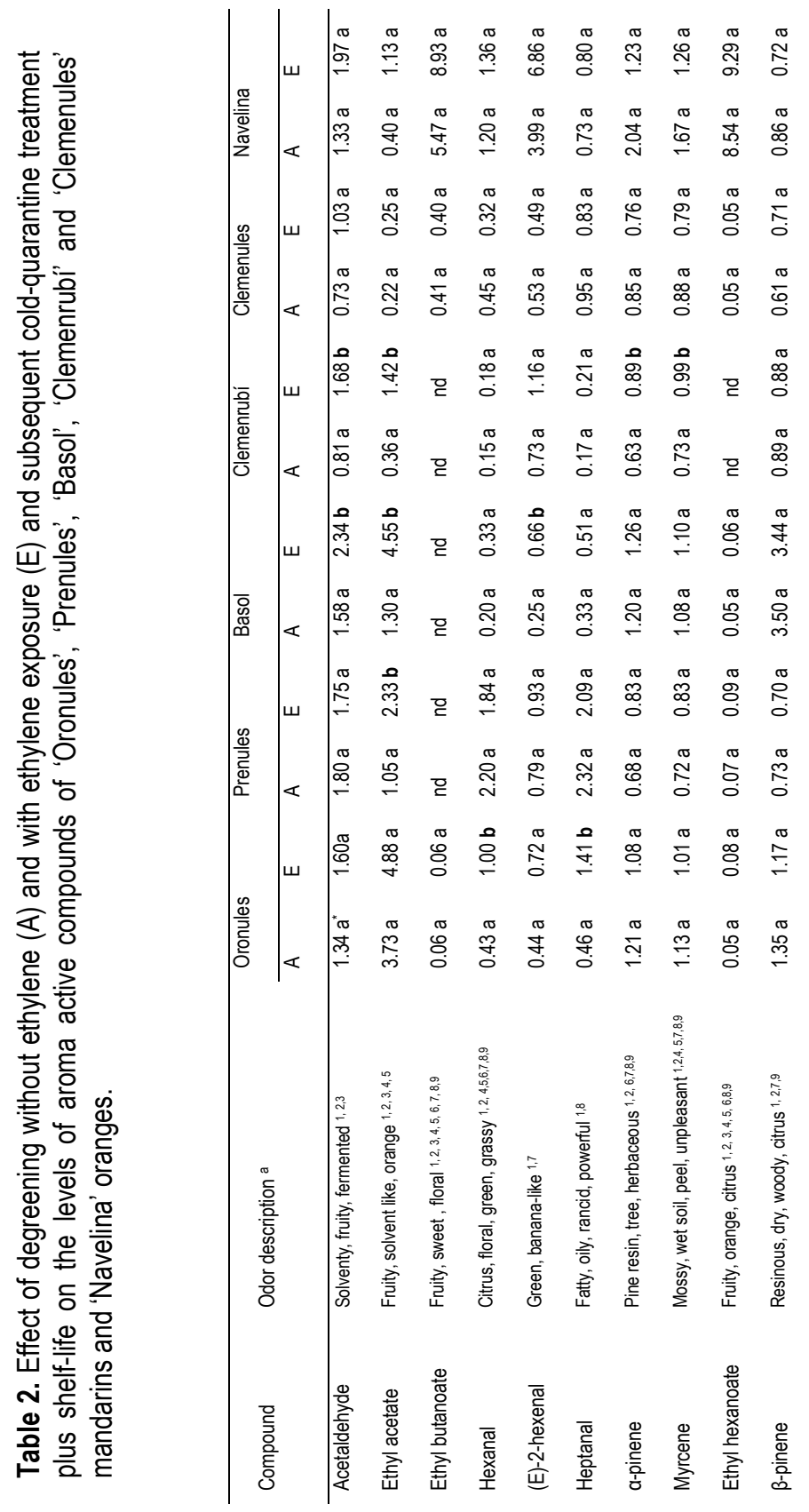




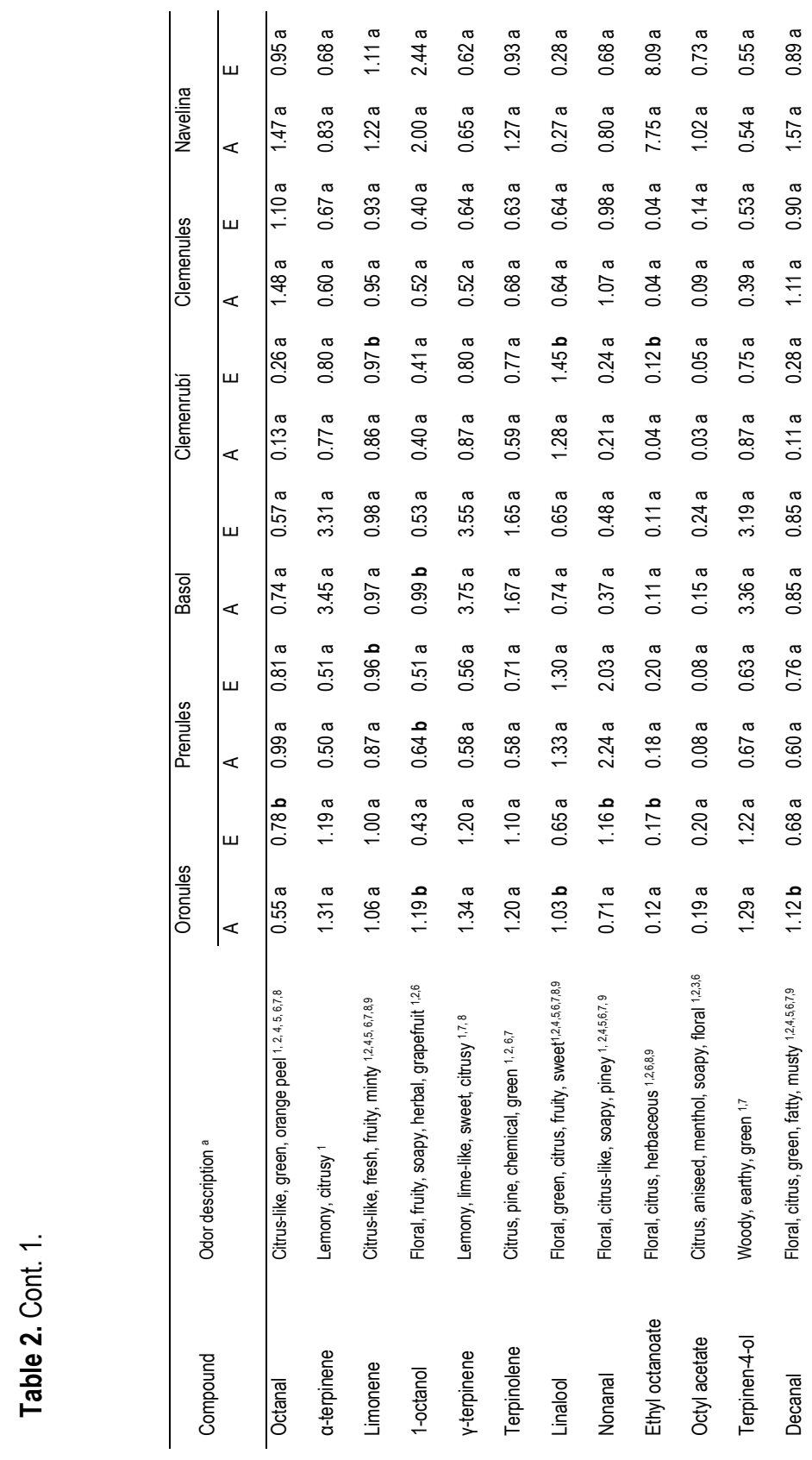




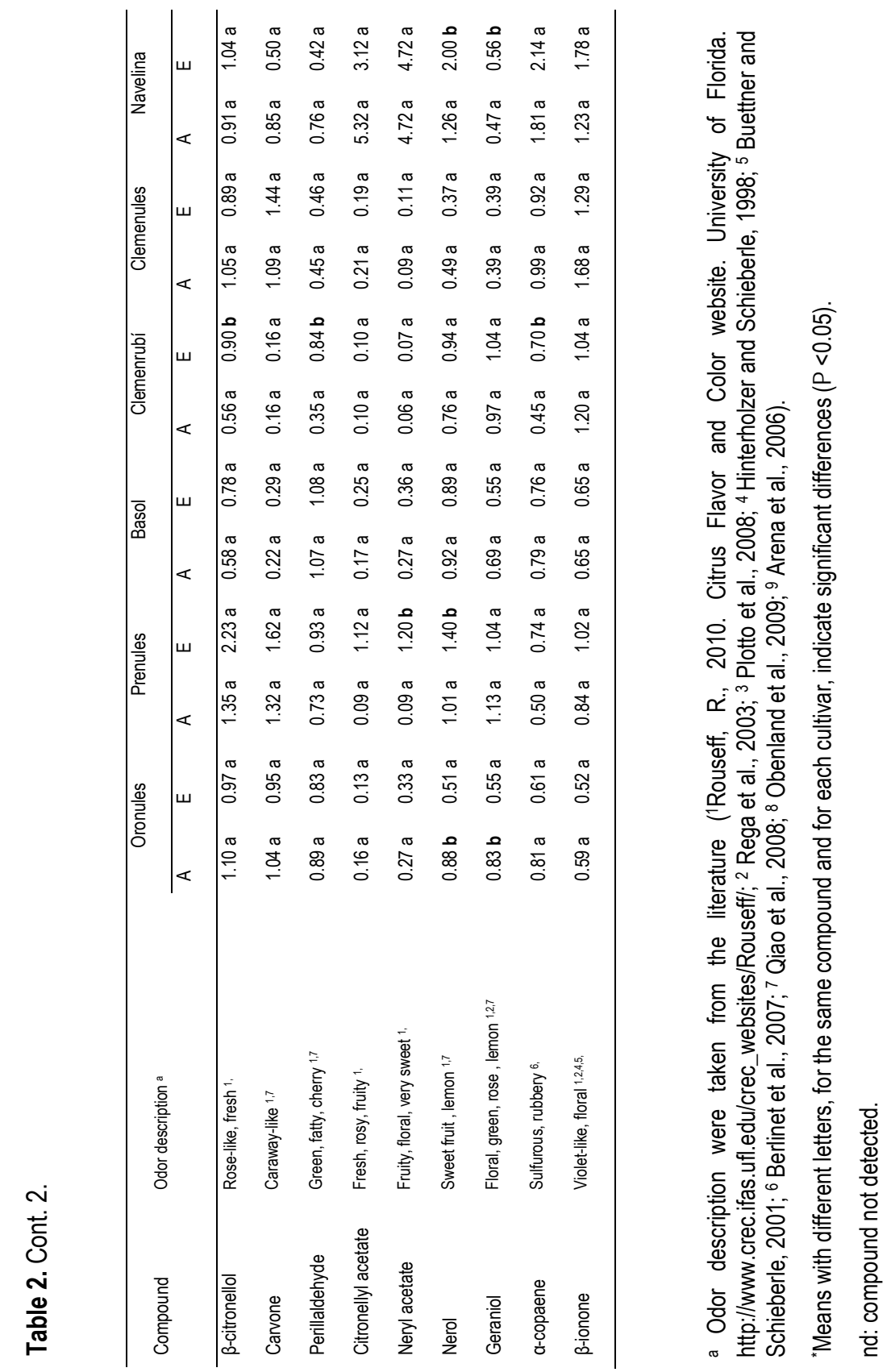


Table 3. Effect of degreening without ethylene $(A)$ and with ethylene exposure $(E)$ and the posterior cold-quarantine treatment plus shelf-life on ethanol content and the flavor of 'Oronules', 'Prenules', 'Basol', 'Clemenrubi' and 'Clemenules' mandarins and 'Navelina' oranges

\begin{tabular}{llll}
\hline Citrus sp. & Treatment & $\begin{array}{l}\text { Ethanol } \\
(\mathrm{mg} / 100 \mathrm{ml})\end{array}$ & $\begin{array}{l}\text { Flavor } \\
(1-9)\end{array}$ \\
\hline Oronules & $\mathrm{A}$ & $107.7 \mathrm{a}$ & $5.0 \mathrm{a}$ \\
& $\mathrm{E}$ & $124.2 \mathrm{a}$ & $5.0 \mathrm{a}$ \\
\hline Prenules & $\mathrm{A}$ & $40.5 \mathrm{a}$ & $6.6 \mathrm{a}$ \\
& $\mathrm{E}$ & $98.1 \mathrm{~b}$ & $6.8 \mathrm{a}$ \\
\hline Basol & $\mathrm{A}$ & $35.2 \mathrm{a}$ & $7.0 \mathrm{a}$ \\
& $\mathrm{E}$ & $83.9 \mathrm{~b}$ & $6.4 \mathrm{a}$ \\
\hline Clemenrubí & $\mathrm{A}$ & $21.7 \mathrm{a}$ & $7.0 \mathrm{a}$ \\
& $\mathrm{E}$ & $40.6 \mathrm{~b}$ & $6.5 \mathrm{a}$ \\
\hline Clemenules & $\mathrm{A}$ & $6.59 \mathrm{a}$ & $7.5 \mathrm{a}$ \\
& $\mathrm{E}$ & $11.55 \mathrm{~b}$ & $6.7 \mathrm{a}$ \\
\hline Navelina & $\mathrm{A}$ & $54.48 \mathrm{a}$ & $7.0 \mathrm{a}$ \\
& $\mathrm{E}$ & $80.84 \mathrm{~b}$ & $6.4 \mathrm{a}$
\end{tabular}

* Means with different letters, in the same column and for each variety, indicate significant differences $(P$ $<0.05)$. 


\section{Acknowledgments}

This research was supported by the Spanish 'Ministerio de Educación y Ciencia' and the 'Instituto Valenciano de Investigaciones Agrarias'. The authors wish to thank FONTESTAD S.A Company for its technical support, Dr. MarieCarmen González-Mas for her assistance and the IBMCP metabolomics laboratory for GC-MS analysis.

\section{Supporting Information Available:}

Principal Component Analysis loading plot corresponding to the figure 3 . Each number corresponds to a particular volatile compound, as indicated in Table 1.

\section{Literature Cited}

(1) Sdiri, S.; Navarro, P.; Monterde, A.; Benabda, J.; Salvador, A. New degreening treatments to improve the quality of citrus fruit combining different periods with and without ethylene exposure. Postharvest Biol. Technol. 2012a, 63, 25-32.

(2) USDA-APHIS. United States Department of Agriculture - Animal and Plant Health Inspection Service. Importation of Clementines from Spain. Final rule. Federal Register 2002, 67, 64702-64739.

(3) Hagenmaier, R.D.; Shaw, P.E. Changes in volatile components of stored tangerines and other specialty Citrus fruits with different coatings. J. Food Sci. 2002, 65, 1742-1745.

(4) Porat, R.; Weiss, B.; Cohen, L.; Daus, A.; Biton, A. Effects of polyethylene wax content and composition on taste, quality, and emission of off-flavor volatiles in 'Mor' mandarins. Postharvest Biol. Technol. 2005, 38, 262-268.

(5) Obenland, D.; Collin, S.; Sievert, J.; Fjeld, K.; Doctor, J.; Arpaia, M.L. Commercial packing and storage of navel oranges alters aroma volatiles and reduces flavor quality. Postharvest Biol. Technol. 2008, 47, 159-167. 
(6) Obenland, D.; Collin, S.; Mackey, B.; Sievert, J.; Arpaia, M.L. Storage temperature and time influences sensory quality of mandarins by altering soluble solids and aroma volatile composition. Postharvest Biol. Technol. 2011, 59, 187-193.

(7) Tietel, Z.; Bar, E.; Lewinsohn, E.; Feldmesser, E.; Fallik, E.; Porat, R. Effects of wax coatings and postharvest storage on sensory quality and aroma volatile composition of 'Mor' mandarins. J. Sci. Food Agric. 2010a, 90, 9951007.

(8) Mayuoni, L.; Tietel, Z.; Patil, B.S.; Porat, R. Does ethylene degreening affect internal quality of citrus fruit? Postharvest Biol. Technol. 2011, 62, 50-58.

(9) Martínez-Jávega, J.M.; Monterde, A.; Navarro, P.; Salvador, A. Response of new clementines to degreening treatment. Proc. Int. Soc. Citriculture 2008, 2, 1342-1346.

(10) Sdiri, S.; Navarro, P.; Monterde, A.; Benabda, J.; Salvador, A. Effect of postharvest degreening followed by a cold-quarantine treatment on vitamin $\mathrm{C}$, phenolic compounds and antioxidant activity of early-season citrus fruit. Postharvest Biol. Technol. 2012b, 65, 13-21.

(11) Rouseff, R.L.; Pérez-Cacho, P.R.; Jabalpurwala, F. Historical review of Citrus flavor research during the past 100 years. J. Agric. Food Chem. 2009, 57, 8115-8124.

(12) González-Mas, M.C.; Rambla, J.L.; Alamar, M.C.; Gutiérrez, A.; Granell, A. Comparative analysis of the volatile fraction of fruit juice from different Citrus species. PLoS ONE 2011, 6(7), e22016. doi:10.1371/journal.pone.0022016.

(13) Miyazaki, T.; Plotto, A.; Goodner, K.; Gmitter, Jr F.G. Distribution of aroma volatile compounds in tangerine hybrids and proposed inheritance. J. Sci. Food Agric. 2010, 91, 449-460.

(14) Plotto, A.; Margaria, C.A.; Goodner, K.L.; Baldwin, E.A. Odour and flavor thresholds for key aroma components in an orange juice matrix: esters and miscellaneous compounds. Flavour Frag. J. 2008, 23, 398-406.

(15) Pérez-Cacho, P.R.; Rouseff, R.L. Processing and storage effects on orange juice aroma: a review. J. Agric. Food Chem. 2008, 48, 681-695. 
(16) Hinterholzer, A.; Schieberle, P. Identification of the most odour-active volatiles in fresh, hand-extracted juice of Valencia Late oranges by odour dilution techniques. Flavour Frag. J. 1998, 13, 49-55.

(17) Buettner, A.; Schieberle, P. Evaluation of aroma differences between handsqueezed juices from Valencia Late and Navel oranges by quantitation of key odorants and flavor reconstitution experiments. J. Agric. Food Chem. 2001, 49, 2387-2394.

(18) Rega, B.; Fournier, N.; Guichard, E. Solid phase microextraction (SPME) of orange juice flavor: odor representativeness by direct gas chromatography olfactometry (D-GC-O). J. Agric. Food Chem. 2003, 51, 7092-7099.

(19) Arena, E.; Guarrera, N.; Campisi, S.; Nicolosi Asmundo, C. Comparison of odour active compounds detected by gas-chromatography-olfactometry between hand-squeezed juices from different orange varieties. Food Chem. 2006, 98, 59-63.

(20) Berlinet, C.; Guichard, E.; Fournier, N.; Ducruet, V. Effect of pulp reduction and pasteurization on the release of aroma compounds in industrial orange juice. J. Food Sci. 2007, 72, 535-543.

(21) Qiao, Y.; Xie, B.J.; Zhang, Y.; Zhang, Y.; Fan, G.; Yao, X.L.; Pan, S.Y. Characterization of aroma active compounds in fruit juice and peel oil of Jinchen sweet orange fruit (Citrus sinensis (L.) Osbeck) by GC-MS and GCO. Molecules 2008, 13, 1333-1344.

(22) Obenland, D.; Collin, S.; Mackey, B.; Sievert, J.; Fjeld, K.; Arpaia, M.L. Determinants of flavor acceptability during the maturation of navel oranges. Postharvest Biol. Technol. 2009, 52, 156-163.

(23) Buettner, A.; Schieberle, P. Evaluation of Key aroma coumpounds in handsqueezed grapefruit juice (Citrus parasidis Macfadyen) by quantification and flavor reconstitution experiments. J. Agric. Food Chem. 2001b, 49, 13581363.

(24) Tietel, Z.; Porat, R.; Weiss, K.; Ulrich, D. Identification of aroma-active compounds in fresh and stored 'Mor' mandarins. Int. J. Food Sci. Technol. 2011, 46, 2225-2231. 
(25) Bazmore, R.; Goodner, K.; Rouseff, R. Volatiles from Unpasteurized and Excessively Heated Orange Juice Analyzed with Solid Phase Microextraction and GC-Olfactometry. J. Food Sci. 1999, 64, 800-803.

(26) Selli, S.; Kelebek, H. Aromatic profile and odour-activity value of blood orange juices obtained from Moro and Sanguinello (Citrus sinensis L. Osbeck). Ind. Crop. Prod. 2011, 33, 727-733.

(27) Miyazaki, T.; Plotto, A.; Baldwin, E.A.; Reyes-De-Corcuera, J.; Gmitter Jr, F.G. Aroma characterization of tangerine hybrids by gas-chromatographyolfactometry and sensory evaluation. J. Sci. Food Agric. 2012, 92, 727-735.

(28) Chung, H.; Chung, W.Y.; Yoo, E.S.; Cho, S.K.; Oh, S.K.; Kim, Y.S. Characterization of volatile aroma-active compounds in Dangyooja (Citrus grandis Osbeck). J. Korean Soc. Appl. Biol. Chem. 2012, 55, 133-136.

(29) Mahattanatawee, K.; Rouseff, R.; Valim, M.F.; Naim, M. Identification and Aroma Impact of Norisoprenoids in Orange Juice. J. Agric. Food Chem. 2005, 53, 393-397.

(30) Buettner, A.; Schieberle, P. Characterization of the Most Odor-Active Volatiles in Fresh, Hand-Squeezed Juice of Grapefruit (Citrus paradisi Macfayden). J. Agric. Food Chem. 1999, 47, 5189-5193.

(31) Cohen, E.; Shalom, Y.; Rosenburger, I. Postharvest ethanol buildup and off-flavor in 'Murcott' tangerine fruits. J. Am. Soc. Hortic. Sci. 1990, 115, 775-778.

(32) Ke, D.; Kader, A.A. Tolerance of 'Valencia' Oranges to Controlled Atmospheres, as Determined by Physiological Responses and Quality Attributes. J. Am. Soc. Hortic. Sci. 1990, 115, 779-783.

(33) Hagenmaier, R.D. The flavor of mandarin hybrids with different coatings. Postharvest Biol. Technol. 2002, 24, 79-87.

(34) Shi, J.X.; Porat, R.; Goren, R.; Goldschmidt, E.E. Physiological responses of 'Murcott' mandarins and 'Star Ruby' grapefruit to anaerobic stress conditions and their relation to fruit taste, quality and emission of off-flavor volatiles. Postharvest Biol. Technol. 2005, 38, 99-105. 
(35) Pesis, E. The role of the anaerobic metabolites, acetaldehyde and ethanol, in fruit ripening, enhancement of fruit quality and fruit deterioration. Postharvest Biol. Technol. 2005, 37, 1-19.

(36) Marcilla, A.; Martínez, M.; Carot, J.M.; Palou, L.; Del Río, M.A. Relationship between sensory and physico-chemical quality parameters of cold-stored 'Clemenules' mandarins coated with two commercial waxes. Span. J. Agric. Res. 2009, 7, 181-189.

(37) Tietel, Z.; Weiss, B.; Lewinsohn, E.; Fallik, E.; Porat, R. Improving taste and peel color of early-season Satsuma mandarins by combining hightemperature conditioning treatments. Postharvest Biol. Technol. 2010b, 57, $1-5$.

(38) Fan, G.; Lu, W.; Yao, X.; Zhang, Y.; Wang, K.; Pan, S. Effect of fermentation on free and bound volatile compounds of orange juice. Flavour Frag. J. 2009, 24, 219-225.

(39) Rouseff, R. (2010) Citrus Flavor and Color website. University of Florida, USA. (www.crec.ifas.ufl.edu/crec_websites/Rouseff/) (Accessed 18 Marsh 2012). 


\section{III.2. POSTHARVEST BEHAVIOR OF NEW TRIPLOID MANDARINS}





\title{
Phenolic composition, organic acids, sugars, vitamin $C$ and antioxidant activity in the juice of two new triploid late-season mandarins
}

\author{
Sawsen Sdiri ${ }^{\mathrm{a}}$, Bermejo Almudena ${ }^{\mathrm{b}}$, Pablo Aleza ${ }^{\mathrm{c}}$, Pilar \\ Navarro $^{\mathrm{a}}$, Alejandra Salvador ${ }^{\mathrm{a}}$
}

${ }^{a}$ Centro de Tecnología Postcosecha, Instituto Valenciano de Investigaciones Agrarias, Carretera Moncada-Náquera Km 4.5 s/n, 46113, Moncada, Valencia, Spain

${ }^{\mathrm{b}}$ Centro de Citricultura y Producción Vegetal, Instituto Valenciano de Investigaciones Agrarias, Carretera Moncada-Náquera Km 4.5 s/n, 46113, Moncada, Valencia, Spain.

${ }^{\text {c } C e n t r o ~ d e ~ P r o t e c c i o ́ n ~ V e g e t a l ~ y ~ B i o t e c n o l o g i ́ a, ~ I n s t i t u t o ~ V a l e n c i a n o ~ d e ~}$ Investigaciones Agrarias, Carretera Moncada-Náquera Km 4.5 s/n, 46113, Moncada, Valencia, Spain.

Reference: Food Research International, 2012, 49(1): 462-468. 



\begin{abstract}
Fruit juice of 'Safor' $[(C$. clementina $\times$ C. tangerina $) \times(C$. unshiu $\times C$. nobilis)] and 'Garbi' [(C. clementina $\times$ C. tangerina) $\times(C$. reticulata $\times$ C. sinensis) mandarins were analyzed in order to compare the main nutritional components of fruit to those of their respective parents. Vitamin C, total phenolics, flavonoids, phenolic acids, organic acids and sugars content as well as juice yield, total soluble solids (TSS), titratable acidity (TA) and maturity index (TSS/TA) were determined. Antioxidant activity was measured by two methods, the free radical-scavenging (DPPH) and ferric reducing/antioxidant power (FRAP) tests. 'Safor' and 'Garbi' hybrids showed both high quality parameters of juice at maturity which makes them good for fresh consumption. The results of this study show that 'Safor' fruit exhibited high levels of vitamin C, total phenolics, flavonoids and antioxidant activity. In addition, the organic acids content in the fruit juice of these new triploid mandarins was superior than those of their parents. Generally, 'Safor' and 'Garbi' mandarins displayed similar content of health-promoting components to those of their parents.
\end{abstract}

Keywords: 'Fortune' mandarin, 'Kara' mandarin, 'Murcott' tangor, vitamin $\mathrm{C}$, antioxidant activity, flavanones, polymethoxyflavones, organic acids 


\section{Introduction}

'Safor' and 'Garbi' mandarins are new triploid hybrids recently released by the Plant Protection and Biotechnology Center in the Instituto Valenciano de Investigaciones Agrarias (IVIA, Spain) (Navarro, Juárez, Aleza, Pina, OlivaresFuster, Cuenca, \& Julve, 2005). Triploid citrus plants can be recovered directly from crosses between two diploid genotypes resulting from the union of a $2 n$ megagametophyte with an haploid pollen (Esen \& Soost, 1971; Esen \& Soost 1973; Geraci, Esen, \& Soost, 1975). Both varieties are characterized by their high quality and seedless fruits. 'Safor' mandarin, obtained from a cross between 'Fortune' mandarin (Citrus clementina Hort. ex Tan. x C. tangerina Hort. ex Tan.) and 'Kara' mandarin (C. unshiu Marc. $x$ C. nobilis Lour), is a midlate ripening cultivar; fruits can be harvested from mid-February until the end of March (Aleza, Cuenca, Juárez, Pina, \& Navarro, 2009; Cuenca, Aleza, Juárez, Pina, \& Navarro, 2010). 'Garbi' mandarin, obtained from a cross between 'Fortune' mandarin and 'Murcott' tangor (C. reticulata Blanco $\times$ C. sinensis L.), is a late-maturing cultivar; fruits can reach optimum maturity at the end of March, although they can be harvested from mid-February until the end of April (Aleza, Cuenca, Juárez, Pina, \& Navarro, 2009; Aleza, Cuenca, Juárez, Pina, \& Navarro, 2010).

Nowadays, consumers demand high sensory, nutritional and health related qualities of fruit and their derivatives products. Citrus fruits are recognized as an important component of the human diet, providing a range of key nutrients as well as very many non-nutrient phytochemicals which are important to human nutrition since they possess antioxidant properties. The antioxidant and antiradical activity of citrus fruit is mainly due to the hydrosoluble fraction containing polyphenols and vitamin $\mathrm{C}$ and also to the apolar fraction including carotenoids, leading to their protective effects against chronic and degenerative diseases (Byers \& Perry, 1992; Gorinstein, Martin-Belloso, Park, Haruenkit, Lojek et al., 2001; Tripoli, La Guardia, Giammanco, Di Majo, \& Giammanco, 2007). Vitamin $C$ is considered to be one of the most important nutrients found in citrus fruit, and it is an important water-soluble antioxidant that plays a crucial role in the suppression of superoxide radicals (Kaur \& Kapoor, 2001). 
Citrus fruits are also rich in phenolic compounds including flavonoids, and benzoic and hydroxycinnamic acids, with potential health-promoting properties. These components have been proposed as important contributors to the total antioxidant capacity (Burda \& Oleszek, 2001; Rapisarda, Tomaino, Lo Cascio, Bonina, De Pasquale, \& Saija, 1999). Flavonoids, the most abundant phenolics in citrus fruits (Nogata, Sakamoto, Shiratsuchi, Ishii, Yano, \& Ohta, 2006), are shown to have many biological functions in antioxidative, anticarcinogenic, cardiovascular, and anti-inflammatory activities (Benavente-Garcia \& Castillo, 2008; Huang \& Ho, 2010). The highest concentrations found in Citrus sp. correspond to flavanone glycosides, followed by flavones, flavonols and the fully polymethoxylated flavones (PMFs) (Kawaii, Tomono, Katase, Ogawa, \& Yano, 1999; Peterson, Dwyer, Beecher, Bhagwat, Gebhardt et al., 2006; Tripoli, La Guardia, Giammanco, Di Majo, \& Giammanco, 2007; Nogata, Sakamoto, Shiratsuchi, Ishii, Yano, \& Ohta,, 2006). Hesperidin, narirutin, naringin, eriocitrin and neohesperidin are the major flavanone glycosides (Mouly, Arzouyan, Gaydou, \& Estienne, 1994; Peterson, Dwyer, Beecher, Bhagwat, Gebhardt et al., 2006). PMFs exist exclusively in Citrus genus especially in the peels of mandarins, sweet and sour oranges (Gattuso, Barreca, Caristi, Gargiulli, \& Leuzzi, 2007). Although citrus juice contains low concentrations of PMFs, these compounds exhibit high biological activity and have been reported as having anti-tumor and anticarcinogenic activity (Murakami, Nakamura, Torikai, Tanaka, Koshiba et al., 2000; Du \& Chen, 2010).

In addition to flavonoids, a major part of phenolic compounds of citrus fruits are benzoic and hydroxycinnamic acids. Previous studies have reported that hydroxycinnamic acids also possess significant antioxidant activity and chemoprotective effects, as shown by in vitro and in vivo studies (Natella, Nardini, Di Felice, \& Scaccini, 1999).

On the other hand, citrus fruits are classified as acid fruits, since their soluble solids are composed mainly of organic acids and sugars. Organic acids, including citric, malic, succinic and tartaric acids in citrus juice are important components which contribute to flavor attributes and largely affect taste characteristic and organoleptic quality (Igual, García-Martínez, Camacho, \& Martínez-Navarrete, 2010). High concentrations of organic acids and low pH in most fruits are critical for the preservation of derivative products. They also help 
to stabilize ascorbic acid and anthocyanins and influence browning in citrus juices (Uckoo, Jayaprakasha, Nelson, \& Patil, 2011). Sugars are the major components of citrus juice soluble solids and sweetness of citrus juice is intrinsic to its sugar composition. Sucrose is present in the largest amounts in citrus juice followed by fructose and glucose (Kelebek, 2010; Kelebek \& Selli, 2011).

The excellent traits regarding fruit quality, including fruit size and good agronomic performance of these new varieties, makes it necessary to study their nutritional composition.

Therefore, the objective of the present study was to determine the content of vitamin $\mathrm{C}$, total phenolic, phenolic compounds, organic acids and sugars as well as the antioxidant activity of 'Safor' and 'Garbi' new triploid mandarins and their parents 'Fortune', 'Kara' and 'Murcott', in order to evaluated if the healthpromoting properties of these two new varieties increased respect to their parents.

\section{Materials and Methods}

\subsection{Reagents}

Narirutin, didymin, sinensetin, nobiletin and tangeretin were purchased from Extrasynthèse (Genay, France). Hesperidin, naringin, gallic acid, chlorogenic acid, quercetin, Folin-Ciocalteu's reagent, sodium carbonate $\left(\mathrm{Na}_{2} \mathrm{CO}_{3}\right)$, phosphoric acid $\left(\mathrm{H}_{3} \mathrm{PO}_{4}\right)$, meta-phosphoric acid, DL-Dithiothreitol (DTT), $L$-ascorbic acid, ferric trichloride, sucrose, glucose, fructose, citric acid, malic acid and succinic acid were purchased from Sigma-Aldrich (Barcelona, Spain). 2,4,6-Tris(2-pyridyl)-s-triazine (TPTZ), 2,2-Diphenyl-1-picrylhydrazyl (DPPH) and potassium dihydrogen phosphate $\left(\mathrm{KH}_{2} \mathrm{PO}_{4}\right)$ were supplied from Fluka Chemie (Sigma Co., Barcelona, Spain). Glacial acetic acid was purchased from Sharlau (Sentmenat, Spain). HPLC-grade acetonitrile, 
dimethylformamide and methanol were obtained from VWR (Barcelona, Spain). Milli-Q water (Millipore, Synergy $\AA$ UV, France) was used throughout.

\subsection{Plant material and sampling}

Fruits of 'Safor' and 'Garbi' hybrids and of 'Fortune' mandarin (Citrus. clementina Hort. ex Tan. x C. tangerina Hort. ex Tan.), 'Kara' mandarin (C. unshiu Marc. $x$ C. nobilis Lour) and 'Murcott' tangor (C. reticulata Blanco x $C$. sinensis L. Osb.) were harvested at the third week of February, from the Field Collection of Citrus Germoplasm Bank held at Instituto Valenciano de Investigaciones Agrarias (IVIA), located at Moncada (Valencia, Spain). After harvest, fruit were transported to the Postharvest Technology Center for analysis. The juice from the new hybrids and their parents were extracted, filtered and then used fresh or stored at $-80^{\circ} \mathrm{C}$ until analysis.

Juices were analyzed for vitamin C, antioxidant activity, flavonoids, phenolic acids, total phenolics, sugars and organic acids content as well as the quality attributes such as juice yield, total soluble solids, titratable acidity, maturity index.

\subsection{Analysis of quality attributes}

Representative samples (24 fruits per cultivar) received at maturity stage (maturity index: a relationship between ${ }^{\circ}$ Brix and acidity), were collected from three trees per cultivar and separated into three replicates. The juice was obtained using an electric juice extractor with a rotating head (Lomi®, Model 4, Lorenzo Miguel, S.L., Spain) and immediately analyzed for ${ }^{\circ}$ Brix with a digital refractometer (PR-1, Atago Co. Ltd., Japan) and for acidity by titration with $0.1 \mathrm{~N}$ $\mathrm{NaOH}$ using phenolphthalein as indicator. The maturity index (MI) was calculated as TSS/TA ratio. The juice yield was measured with a graduated test tube and the data were expressed as percentage. 


\subsection{General procedure for extraction and analysis of total vitamin $C$}

Vitamin $\mathrm{C}$ was determined according to the method described previously (Sdiri et al., 2012). Briefly, a juice sample $(0.7 \mathrm{~mL})$ was homogenized with 0.7 $\mathrm{mL}$ of extraction solution (4.5\% meta-phosphoric acid). The resulting mixture was centrifuged at $12000 \mathrm{rpm}$ for $10 \mathrm{~min}$ at $4^{\circ} \mathrm{C}$ in a Centrifuge $5810 \mathrm{R}$ (Eppendorf, Germany). The procedure used to analyze vitamin C content was the reduction of dehydroascorbic acid to ascorbic acid, using DL-dithiothreitol (DTT) as reducing reagent: $0.2 \mathrm{ml}$ of a solution of Dithiothreitol (DTT) was added to $1 \mathrm{~mL}$ of juice as a reducing agent and the samples were kept in the dark at room temperature for $2 \mathrm{~h}$. After complete conversion, the samples were filtered through a $0.45 \mu \mathrm{m}$ Whatman filter and analyzed for vitamin $\mathrm{C}$ by HPLC.

Total vitamin C (ascorbic acid and dehydroascorbic acid) was quantified by high-performance liquid chromatography (HPLC) instrument (LachromElite, Merck Hitachi, Germany) equipped with a diode array detector (L-2450), column oven (L-2300) and auto-sampler (L-2200). Separation was performed on a RP18 column $(4 \mathrm{~mm} \times 250 \mathrm{~mm})$, preceded by a precolumn $(4 \times 4 \mathrm{~mm})$ with a particle diameter of $5 \mu \mathrm{m}$, using $\mathrm{KH}_{2} \mathrm{PO}_{4}(0.2 \mathrm{M}$, adjusted to $\mathrm{pH} 2.3$ with phosphoric acid) as the mobile phase at a flow rate of $1 \mathrm{~mL} / \mathrm{min}$ with UV detection at $243 \mathrm{~nm}$. The total elution time was $10 \mathrm{~min}$ and the injection volume was $20 \mu \mathrm{L}$. Three samples from each cultivar were analyzed and all samples were run in triplicate. The quantification of total vitamin $C$ was carried out using the external standard method. Calibration curves were performed with four concentrations of $L$-ascorbic acid (50-100-150 and 200ppm). Standards were run daily with samples for validation.

\subsection{Total Phenolic Content}

The content of total phenolics in samples was measured in a microliterbased format on the basis of the Folin-Ciocalteu colorimetric method (Singleton \& Rossi, 1965) with some modifications according to the procedure described previously (Sdiri et al., 2012). Briefly, $30 \mu \mathrm{L}$ of appropriately diluted samples of juice (in methanol $80 \%$ ) were oxidized for 1 min with $150 \mu \mathrm{l}$ of Folin-Ciocalteu reagent $(1: 10, v / v$ diluted with water) and then the reaction was neutralized with $120 \mu \mathrm{L}$ of sodium carbonate $(7.5 \%, \mathrm{w} / \mathrm{v})$. The absorbance was measured at 765 
$\mathrm{nm}$ by a Multiscan Spectrum microplate reader (Thermo electron corporation, S.A.). Gallic acid was used as standard, and the results were expressed as $\mathrm{mg}$ of gallic acid equivalent $/ L$ of juice. For each cultivar, eighteen replicates were measured.

\subsection{Total Antioxidant Activity}

The antioxidant activity of the citrus juices was evaluated by the 2,2diphenyl-1-picrylhydrazyl (DPPH) free radical-scavenging method and the ferric reducing/antioxidant power (FRAP) assay.

The DPPH free radical-scavenging activity was measured in a microliterbased format according to the procedure of Sdiri et al. (2012). Briefly, in glass 96-well reaction plate, $30 \mu \mathrm{l}$ of diluted samples in $100 \%$ methanol were combined with $270 \mu \mathrm{L}$ of methanolic DPPH $(0.025 \mathrm{~g} / \mathrm{L}$ in methanol $100 \%)$. Following incubation at $20^{\circ} \mathrm{C}$ for $50 \mathrm{~min}$, the absorbance at $515 \mathrm{~nm}$ was read on a Multiscan Spectrum microplate reader (Thermo electron corporation, S.A.). The results were expressed as ascorbic acid equivalent / $100 \mathrm{~mL}$ of juice. For each cultivar, eighteen replicates were measured.

The FRAP method was assessed according to the method of Benzie \& Strain (1999) with some modifications to adapt the method to a microliter-based format described previously by Sdiri et al. (2012). In brief, the FRAP reagent was freshly prepared by mixing $25 \mathrm{~mL}$ of $300 \mathrm{mM}$ acetate buffer ( $\mathrm{pH} 3.6), 2.5$ $\mathrm{mL}$ of $10 \mathrm{mM}$ TPTZ solution, and $2.5 \mathrm{~mL}$ of $20 \mathrm{mM}$ ferric chloride solution. The assay was carried out by placing $30 \mu \mathrm{L}$ of appropriately diluted samples in a 96well microplate and then adding $270 \mu \mathrm{L}$ of FRAP reagent. After $10 \mathrm{~min}$ of incubation at $37^{\circ} \mathrm{C}$ and shaking, absorbance was read at $593 \mathrm{~nm}$. Results were compared with a standard curve prepared with different concentrations of ascorbic acid and were expressed as $\mathrm{mM}$ ascorbic acid equivalent. 


\subsection{General procedure for extraction and analysis of phenolic compounds}

Phenolic compounds were extracted and determined according to the procedure described by Sdiri, Navarro, Monterde, Benabda, \& Salvador (2012). Briefly, $5 \mathrm{~mL}$ of juice were mixed with $5 \mathrm{~mL}$ of dimethylformamide and centrifuged at $12000 \mathrm{rpm}$ for $20 \mathrm{~min}$ at $4^{\circ} \mathrm{C}$. After centrifugation, $1 \mathrm{~mL}$ of the supernatant was filtered through one $0.45 \mu \mathrm{m}$ nylon filter and then $20 \mu \mathrm{L}$ were injected into the HPLC-DAD (LachromElite, Merck Hitachi, Germany) equipped with a diode array detector (L-2450), column oven (L-2300) and auto-sampler (L-2200). Separation was performed on a RP-18 column (4 mm x $250 \mathrm{~mm}$ ), preceded by a precolumn $(4 \times 4 \mathrm{~mm})$ with a particle diameter of $5 \mu \mathrm{m}$, at room temperature and using a binary solvent system of ACN and water with $4 \%$ acetic acid. The solvent system was operated to start at $15 \%$ and end at $100 \%$ ACN concentration for a 45 min period. The elution profile was at a flow rate of $1.0 \mathrm{~mL} / \mathrm{min}$. The chromatogram was monitored simultaneously at 284 and 334 $\mathrm{nm}$ with $5 \mathrm{~nm}$ bandwidth. The concentrations were calculated following the external standard method. Dilutions of each of the phenolic standards were used to fit a standard with linear regression for each individual compound.

\subsection{General procedure for extraction and analysis of carbohydrates}

Two $\mathrm{mL}$ of juice were centrifuged at $10000 \mathrm{rpm}$ for $5 \mathrm{~min}$ at $4^{\circ} \mathrm{C}$. The samples were filtered through $0.45 \mu \mathrm{m}$ nylon filter and analyzed by an HPLC system equipped with a Waters 515 HPLC pump, a Waters 2414 refractive index detector, a column Tracer Carbohydr $5 \mu \mathrm{m}(250 \mathrm{~mm} \times 4.5 \mathrm{~mm})$ (Teknokroma, Barcelona, Spain), and a 20 $\mu \mathrm{L}$ loop Rheodyne injector were used for sugar analysis. Empower 2 software (Waters, Spain) was used for data processing. The mobile phase was composed by ACN and water (75:25) at a flow rate of $1.0 \mathrm{~mL} / \mathrm{min}$. Fructose, glucose and sucrose sugars were indentified comparing their retention time with a standard and quantified using an external calibration curve (Bermejo et al., 2011). 


\subsection{General procedure for extraction and analysis of organic acids}

Extraction method was the same as the procedure described previously (Bermejo et al., 2011). Briefly, $1 \mathrm{~mL}$ of filtered juice was mixed with $1 \mathrm{~mL}$ of $0.1 \% \mathrm{H}_{2} \mathrm{SO}_{4}$ solution, and then the sample was centrifuged at $4^{\circ} \mathrm{C}$ for $5 \mathrm{~min}$ at $12000 \mathrm{rpm}$. The supernatant were filtered through $0.45 \mu \mathrm{m}$ filter and analysed by HPLC-DAD, and confirmed by HPLC-MS working in electrospray ion negative conditions. Analysis was made using an Alliance liquid chromatographic system (Waters, Barcelona, Spain) equipped with a 2695 separation module, coupled to a 2996 photodiode array detector and a ZQ2000 mass detector. A thermostat column oven, a ICSep ICE-COREGEL 87H3 column (Transgenomic), a ICSep ICE-COREGEL 87H guard kit, and an automatic injector were used for chromatographic separation. Empower 2 software was used for data acquisition. Sample temperature was $5^{\circ} \mathrm{C}$ and column temperature was $35^{\circ} \mathrm{C}$. The capillary voltage was $3.0 \mathrm{kV}$, cone voltage $23 \mathrm{~V}$, source temperature $100^{\circ} \mathrm{C}$, desolvation temperature $200^{\circ} \mathrm{C}$ and desolvation gas flow $400 \mathrm{~L} / \mathrm{Hr}$. Full data acquisition was performed scanning 100 to 400 uma in centroid mode. The solvent system was an isocratic mobile phase of $0.1 \% \mathrm{H}_{2} \mathrm{SO}_{4}$ solution. The total run time was $20 \mathrm{~min}$ at $0.6 \mathrm{~mL} / \mathrm{min}$, and injection volume was $5 \mu \mathrm{L}$. Compounds were indentified on the basis of comparing their retention times, UV-Vis spectra and mass spectrum data with corresponding authentic standards. Concentrations were determined using an external calibration curve with citric acid $\left(r_{T}=8.01 \mathrm{~min} ;[\mathrm{M}-\mathrm{H}]+191 \mathrm{~m} / \mathrm{z}\right)$, malic acid $\left(r_{T}=9.41 \mathrm{~min} ;[M-H]+133 \mathrm{~m} / \mathrm{z}\right)$, and succinic acid $\left(r_{T}=11.43 \mathrm{~min} ;[\mathrm{M}-\mathrm{H}]+\right.$ $117 \mathrm{~m} / \mathrm{z})$.

\subsection{Statistical analysis}

Statistical procedures were performed using a commercial statistical software (Statgraphics plus 5.1, Manugistics, Inc., Rockville, M.d., U.S.A.). All data were subjected to analysis of variance, and means were compared using LSD test at $P<0.05$. 


\section{Results and discussion}

\subsection{Juice yield, TSS, TA and TSS/TA ratio}

The quality parameters, including juice yield, titratable acidity (TA), total soluble solids (TSS) and maturity index (MI=TSS/TA) of 'Safor' and 'Garbi' mandarins and those of their parents were shown in Table 1. These parameters are important factors to evaluate the internal quality of new citrus cultivars. Among all the studied varieties, 'Garbí' fruits displayed the greatest TSS values whereas 'Murcott' presented the lowest values. With respect to the acidity, 'Garbi', 'Fortune' and 'Kara' mandarins exhibited high and similar values of TA, while the lowest value was registered in 'Murcott' tangor. 'Safor' mandarins presented higher values of $\mathrm{Ml}$ compared to its parents. This result is in agreement with that reported previously by Cuenca et al. (2010) who found that, at the optimum ripening stage (second half of February), 'Safor' mandarin displayed higher MI than 'Fortune' and 'Kara' mandarins. In the present study, 'Garbí mandarins also exhibited greater values of MI than its parents 'Fortune' and 'Murcott'. Nevertheless, Aleza et al. (2010) found that, at the same harvest period, the ratio of 'Garbi' mandarin is lower than 'Fortune' mandarin and 'Murcott' tangor. Regarding the juice yield, 'Safor' and 'Garbi' mandarins showed higher values than those of the male parents 'Kara' and 'Murcott' respectively. 
Table 1. Fruit quality parameters of 'Safor' and 'Garbi' triploids and their parents

\begin{tabular}{lcccc}
\hline Citrus sp. & $\begin{array}{c}\text { Juice } \\
(\%)\end{array}$ & $\begin{array}{c}\mathrm{TA}^{1} \\
(\mathrm{~g} / 100 \mathrm{~mL})\end{array}$ & $\begin{array}{c}\mathrm{TSS}^{2} \\
\left({ }^{\circ} \mathrm{Brix}\right)\end{array}$ & $\begin{array}{c}\mathrm{MI}^{3} \\
(\mathrm{TSS} / \mathrm{TA})\end{array}$ \\
\hline SAFOR & $48.0 \mathrm{~b}^{*}$ & $1.37 \mathrm{~b}$ & $14.5 \mathrm{c}$ & $10.61 \mathrm{c}$ \\
GARBí & $47.7 \mathrm{~b}$ & $1.62 \mathrm{c}$ & $16.7 \mathrm{e}$ & $10.33 \mathrm{c}$ \\
FORTUNE & $52.9 \mathrm{c}$ & $1.66 \mathrm{c}$ & $15.7 \mathrm{~d}$ & $9.46 \mathrm{~b}$ \\
KARA & $46.7 \mathrm{~b}$ & $1.62 \mathrm{c}$ & $13.6 \mathrm{~b}$ & $8.41 \mathrm{a}$ \\
MURCOTT & $43.3 \mathrm{a}$ & $1.12 \mathrm{a}$ & $9.3 \mathrm{a}$ & $8.24 \mathrm{a}$ \\
\hline
\end{tabular}

${ }^{1}$ TA: Titratable acidity; ${ }^{2}$ TSS: Total Soluble Solids; ${ }^{3}$ MI: Maturity index

${ }^{*}$ Means with different letters, in the same column, indicate significant differences $(P<0.05)$. 


\subsection{Vitamin $C$ and Total phenolic contents}

The nutritional quality of citrus fruit is primarily related to the vitamin $C$ content, which is the major antioxidant compound found in these fruits (Gardner et al., 2000; Zerdin et al., 2003). The total vitamin C levels were determined and ranged from 21.19 to $29.80 \mathrm{mg} / 100 \mathrm{~mL}$ (Table 2). In the present study, 'Fortune' and 'Safor' mandarins displayed the highest values in total vitamin C, followed by 'Kara' mandarins. Although 'Garbi' fruit presented the lowest concentration of vitamin $\mathrm{C}$, this content was in the range of the content reported previously for different citrus varieties (Palma et al., 2005; Abeysinghe et al., 2007; Cano et al., 2008).

With regard to the total phenolic content, the amounts varied between 54.12 for 'Murcott' and $73.88 \mathrm{mg} \mathrm{GAE} / 100 \mathrm{~mL}$ for 'Kara' (Table 2). These values are in agreement with those reported in the literature for other citrus varieties (Palma et al., 2005; Wang et al., 2007; Sdiri et al., 2012). Our results indicate that as a result of the introduction of 'Kara' parentage, 'Safor' fruits presented high level of total phenolics compared to the female parent, whereas Garbi' fruits exhibited similar values than its respective parents 'Fortune' and 'Murcott' mandarins.

\subsection{Antioxidant activity}

Because of the synergistic effect that could exist between different antioxidant in the juice, the use of more than one assay was strongly recommended for the evaluation of the antioxidant activity of citrus juice by different assays. Nearly all comparison studies on antioxidant capacity assays showed difference from test to test. Therefore, in the present study, in order to measure the antioxidant activity of the studied varieties, two methods were used: the DPPH free radical-scavenging and ferric reducing antioxidant power (FRAP) tests. Both methods are recommended by many authors as accurate assays for measuring the antioxidant activity of fruit and vegetable juice extracts (Klimczak et al., 2007). 
Regarding the antioxidant activity measured by $\mathrm{DPPH}^{*}$ assay, no significant differences were observed among the juices of the different tested varieties, with the only exception being the 'Garbi' mandarins which showed the lowest value of antioxidant activity of about $190.7 \mathrm{mg} \mathrm{AAE} / 100 \mathrm{~mL}$ (Table 2). This value can be related to the lower level of vitamin C exhibited by 'Garbi' fruits when compared with the other studied varieties.

When measuring the antioxidant activity by FRAP method, the hybrid 'Safor' displayed high values of antioxidant activity similar to those exhibited by its parents 'Fortune' and 'Kara' mandarins. The lowest values of antioxidant capacity were shown in 'Murcott' and 'Garbi' juices; which could be related to the the lowest content of vitamin $C$ and total phenolics. The data showed that the antioxidant activity assessed by FRAP tests could be ascribed to both vitamin $\mathrm{C}$ and total phenolic content, which in agree with the literature (Gardner et al., 2000). It is necessary to take into account that in addition to AA and phenolics, the antioxidant activity also depends on the possible synergic effect of other phytochemicals (Plaza et al., 2011). 


\begin{tabular}{|c|c|c|c|c|c|c|c|}
\hline 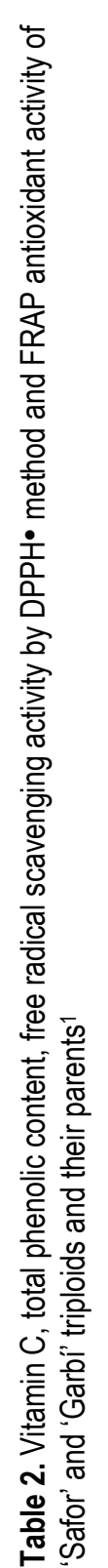 & 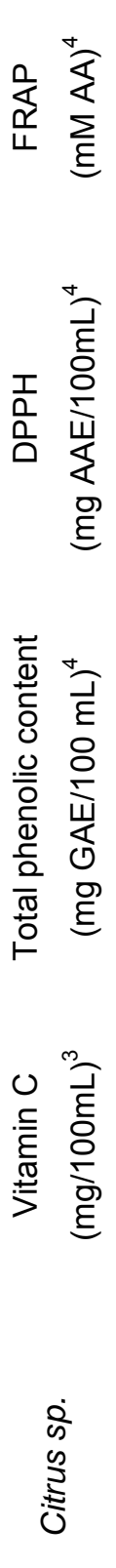 & 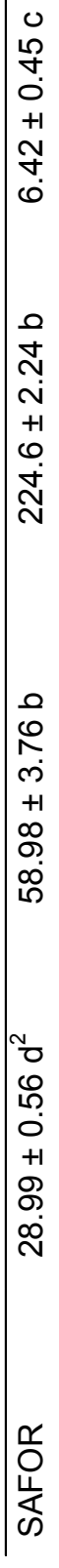 & 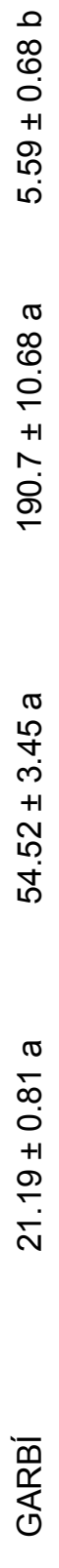 & 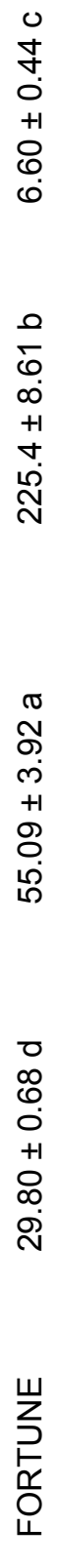 & 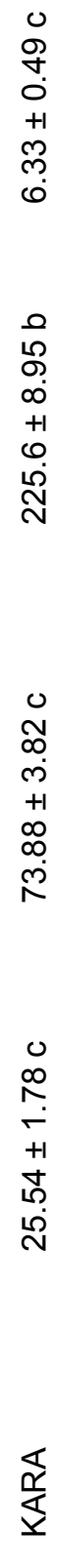 & 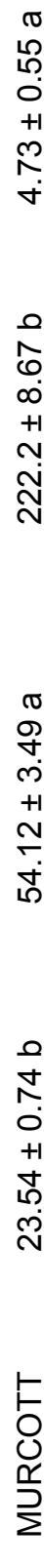 & 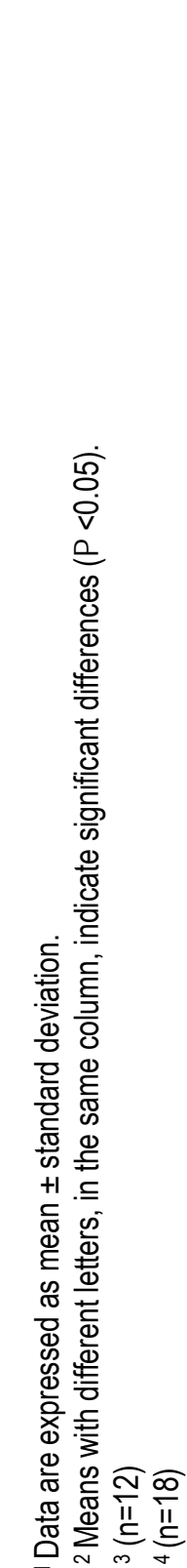 \\
\hline
\end{tabular}




\subsection{Phenolic compounds}

Phenolic compounds were determined in the juice for the hybrids 'Safor' and 'Garbi' as well as in their parents 'Fortune', 'Kara' and 'Murcott' mandarins. A total of 15 phenolic compounds were identified and quantified in the juice of the different citrus varieties, including flavanones [7], flavones [2], polymethoxyflavones [3], flavonols [1], hydroxybenzoic acids [1] and hydroxycinnamic acids [1] (Tables 3 and 4 ).

Among flavanones, that are the major flavonoids in citrus fruits, eriocitrin, neoeriocitrin, narirutin, naringin, hesperidin, didymin, and naringenin were quantified in the studied mandarin juices (Table 3). As previously reported, hesperidin, narirutin and didymin were the most abundant flavanone found in the parental and the new hybrids fruit juices. Hesperidin was the major flavanone detected in 'Safor', 'Garbi', 'Fortune' and 'Kara' mandarins. It has been reported that hesperidin is also the most dominant flavanone in other mandarins varieties (Nogata et al., 2006; Cano et al., 2008; Stuetz et al., 2010; $\mathrm{Ye}$ et al., 2011). The greatest level of hesperidin was detected in 'Kara' mandarins $(87.29 \mathrm{mg} / 100 \mathrm{~mL})$ which could explain the high content found in 'Safor' fruit juice $(79.96 \mathrm{mg} / 100 \mathrm{~mL})$. The hybrid 'Garbi' displayed levels of hesperidin superior than those exhibited by its parents 'Fortune' mandarins and 'Murcott' tangor.

In recent studies the level of naritutin was superior than that of hesperidin in citrus varieties such as 'Murcott' tangor and in Mineola tangelo (Huang \& Ho, 2010; Ramful et al., 2011). In the present study, 'Murcott' fruit juice was the richest in narirutin $(14.50 \mathrm{mg} / 100 \mathrm{~mL})$ whereas the lowest contents were detected in 'Fortune' and 'Safor' fruit juices. 'Garbi' mandarins also displayed high content of narirutin $(10.98 \mathrm{mg} / 100 \mathrm{~mL})$ which could be related to the greatest content exhibited by its male parent 'Murcott' tangor.

Regarding the didymin levels, the values shown in all the studied varieties are in agreement with previous studies reported in tangor and mandarin fruits (Lafuente et al., 2011; Ramful et al., 2011). Compared to their respective parents, both hybrids 'Safor' and 'Garbi', exhibited higher significant contents of 
didymin. No significant differences were found among juices from 'Fortune', 'Kara' and 'Murcott' fruits.

Neoeriocitrin was also quantified, and the greatest amount were detected in 'Kara' fruit juice followed by 'Murcott' juice, while 'Fortune' fruit displayed the lowest amount with a value of $0.76 \mathrm{mg} / 100 \mathrm{~mL}$. Crossbreeding between 'Fortune' and 'Kara' mandarins and on the other hand between 'Fortune' and 'Murcott' mandarins enhanced the content of neoeriocitrin in the juice of the hybrids 'Safor' and 'Garbi' with respect to their female parent ('Fortune' mandarin). Thus, the content of neoeriocitrin of these hybrids were intermediate between those of their respective parents.

The level of eriocitrin varied widely among varieties although the values reported are within the range previously reported by Nogata et al. (2006) in other citrus varieties. The highest content of eriocitrin was detected in 'Safor' juice with a concentration of $1.27 \mathrm{mg} / 100 \mathrm{~mL}$, that was significantly superior than those exhibited by its parents. 'Garbi' fruits displayed low level of eriocitrin, similar to 'Fortune' mandarins.

In the present study, naringin was not detected only in 'Kara' juice, as it was reported in some mandarin and tangor varieties (Abeysinghe et al., 2007; Ramful et al., 2011; Ye et al., 2011). However, 'Safor' mandarins exhibited considerably high level of naringin. 'Garbi' fruits displayed the highest content of naringin $(1.63 \mathrm{mg} / 100 \mathrm{~mL})$ followed by 'Fortune' $(1.51 \mathrm{mg} / 100 \mathrm{~mL})$.

Currently naringenin is not determined in citrus juices since its content is at the limit of detection; nevertheless this flavanone was found to have an antiviral, hypolipidemic and anti-inflammatory effects even at low concentration (Goldwasser et al., 2011; Shulman et al., 2011). In the present study, naringenin was detected, and similar values were found in all the tested varieties, ranged from 0.011 to $0.028 \mathrm{mg} / 100 \mathrm{~mL}$. These content are higher than those previously reported in different mandarin varieties (Kawaii et al., 1999). 


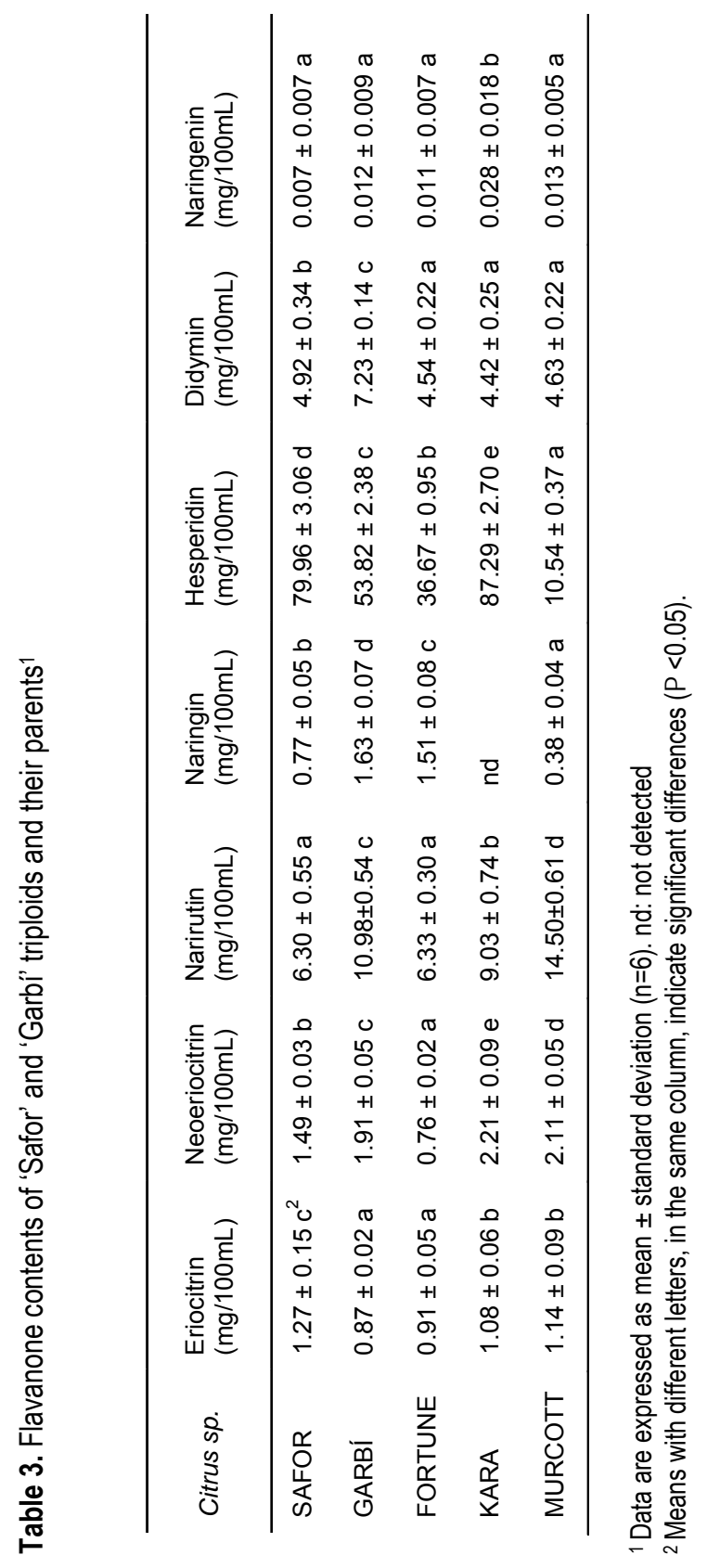


With respect to flavone compounds, apigenin and diosmin were also quantified in the juices of all the studied varieties (Table 4). The results show that diosmin is the most dominant flavone in all the juices. The content were ranged from 0.93 to $2.94 \mathrm{mg} / 100 \mathrm{~mL}$ which are in agreement with those reported in citrus fruits (Nogata et al., 2006; Kawaii et al., 1999; Wang et al., 2007). 'Safor' and 'Garbi' mandarins displayed the highest contents of diosmin compared to their parents $(2.94$ and $2.23 \mathrm{mg} / 100 \mathrm{~mL}$ respectively). The levels of apigenin present in both hybrids and their parents were similar showing very low concentrations.

Moreover, three polymethoxyflavones (PMFs) have been determined. Among them nobiletin was more abundant than tangeretin and sinensetin (Table 4). This finding is also consistent with literature that reported high concentrations of nobiletin in citrus fruit compared to the other PMFs (Nogata et al., 2006; Huang \& Ho, 2010). The content of PMFs in 'Safor' mandarins was superior than that quantified in 'Garbí fruit. Compared to its parents, 'Safor' mandarins exhibited higher content of tangeretin, and similar values of sinensetin and nobiletin. Nevertheless, 'Garbi' fruits displayed slightly lower values of PMFs than its parents 'Fortune' mandarins and 'Murcott' tangor.

The content of quercetin flavonol as well as gallic and chlorogenic acids were also determined and the data are reported in Table 5. The content of quercetin was ranged from 0.07 to $0.66 \mathrm{mg} / 100 \mathrm{~mL}$ in 'Fortune' and 'Kara' fruits, respectively. 'Safor' and 'Garbi' fruits displayed a quercetin levels relatively higher than that exhibited by the female parent ('Fortune' mandarin). With regard to the detected phenolic acids, the results indicate that 'Safor' and 'Garbi mandarins are the richest in chlorogenic acid presenting contents of about 4.53 and $2.83 \mathrm{mg} / 100 \mathrm{~mL}$, respectively. These new hybrids also presented a high content of gallic acid $(1.18$ and $1.06 \mathrm{mg} / 100 \mathrm{~mL}$ for 'Safor' and 'Garbi' respectively). Previously, Wang et al. (2007) reported that chlorogenic acid is the major phenolic acids present in the edible part of citrus fruit. 


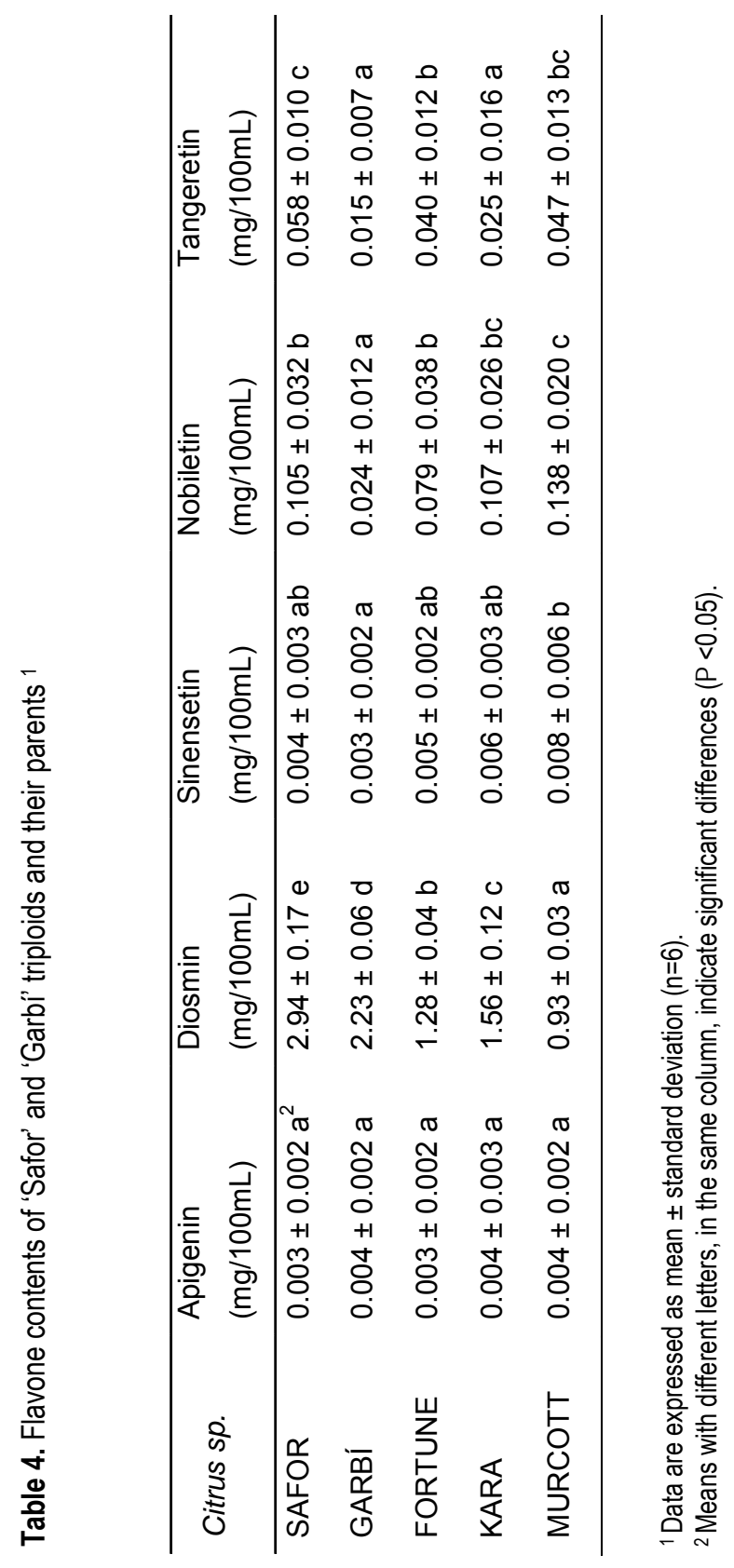


Table 5. Quercetin, gallic acid and chlorgenic acid contents of 'Safor' and 'Garbi' triploids and their parents 1

\begin{tabular}{lccc}
\hline Citrus sp. & $\begin{array}{c}\text { Quercetin } \\
(\mathrm{mg} / 100 \mathrm{~mL})\end{array}$ & $\begin{array}{c}\text { Gallic acid } \\
(\mathrm{mg} / 100 \mathrm{~mL})\end{array}$ & $\begin{array}{c}\text { Chlorogenic acid } \\
(\mathrm{mg} / 100 \mathrm{~mL})\end{array}$ \\
\hline SAFOR & $0.15 \pm 0.09 \mathrm{ab}^{2}$ & $1.18 \pm 0.03 \mathrm{~d}$ & $4.53 \pm 0.24 \mathrm{e}$ \\
GARBÍ & $0.28 \pm 0.08 \mathrm{c}$ & $1.06 \pm 0.03 \mathrm{~b}$ & $2.83 \pm 0.08 \mathrm{~d}$ \\
FORTUNE & $0.07 \pm 0.04 \mathrm{a}$ & $1.13 \pm 0.03 \mathrm{c}$ & $2.18 \pm 0.04 \mathrm{~b}$ \\
KARA & $0.66 \pm 0.15 \mathrm{~d}$ & $1.71 \pm 0.05 \mathrm{e}$ & $1.63 \pm 0.06 \mathrm{a}$ \\
MURCOTT & $0.21 \pm 0.16 \mathrm{bc}$ & $0.79 \pm 0.03 \mathrm{a}$ & $2.37 \pm 0.05 \mathrm{c}$ \\
\hline
\end{tabular}

${ }^{1}$ Data are expressed as mean \pm standard deviation $(n=6)$.

${ }^{2}$ Means with different letters, in the same column, indicate significant differences $(P<0.05)$. 


\subsection{Sugars and organic acids}

The flavor of the fruit flesh is highly dependent on the balance between soluble sugars and organic acids. In the present study, the organic acid profile was determined and three acids were quantified (Table 6). For all the acids level, the differences among varieties were found significant. It is known that, the organic acid content vary depending on the variety (Marsh et al., 2003). The measurement of the organic acids revealed that the major acid was citric acid as indicated by previous researchers (Kelebek \& Selli, 2011; Roussos, 2011). It is known that citric acid imparts the tart flavor of citrus which makes it an important component of sensorial quality. Among all the studied varieties, 'Garbi' exhibited the greatest level of citric acid (16.91 g/L) similar to that shown in the female parent 'Fortune' mandarin. In recent study carried out on this new hybrid (Aleza et al., 2010), high quantity of acids has been reported, which resulted in flavor slightly acidic of 'Garbi' fruit like 'Fortune' mandarin. Nevertheless, 'Safor' mandarins displayed the lowest content of citric acid which explain the low values of titratable acidity (TA) (Table 1) registered for this hybrid, since the TA was calculated as the citric acid equivalent per $100 \mathrm{~mL}$ of juice. At the optimum ripening stage, Cuenca et al. (2010) also reported inferior quantity of acids in 'Safor' fruits than 'Fortune and 'Kara' mandarins. Considerable variation was found in the content of malic and succinic acids exhibiting the same pattern among varieties. The hybrid 'Garbi' displayed superior significant levels of all organic acids; followed by 'Safor' mandarins with higher contents of these acids than its parents.

Additionally, sugar composition was determined and three sugars were quantified in all the studied varieties (Table 6). The predominant sugar was found as sucrose which in agreement with the literature (Albertini et al., 2006; Roussos, 2011). 'Garbi' fruit juice displayed the greatest levels of sucrose presenting concentration of $66.22 \mathrm{~g} / \mathrm{L}$. 'Safor' fruits exhibited higher content of sucrose than its male parent. The highest levels of fructose and glucose were detected in 'Kara' fruit juice while the lowest concentrations were reported in 'Murcott' tangor. 'Safor' and 'Garbi' fruits contain similar contents of these sugars to 'Fortune' mandarin which is the female parent. The high contents of sugar exhibited by the new hybrids were reflected in the high values of TSS as well as that of MI. 


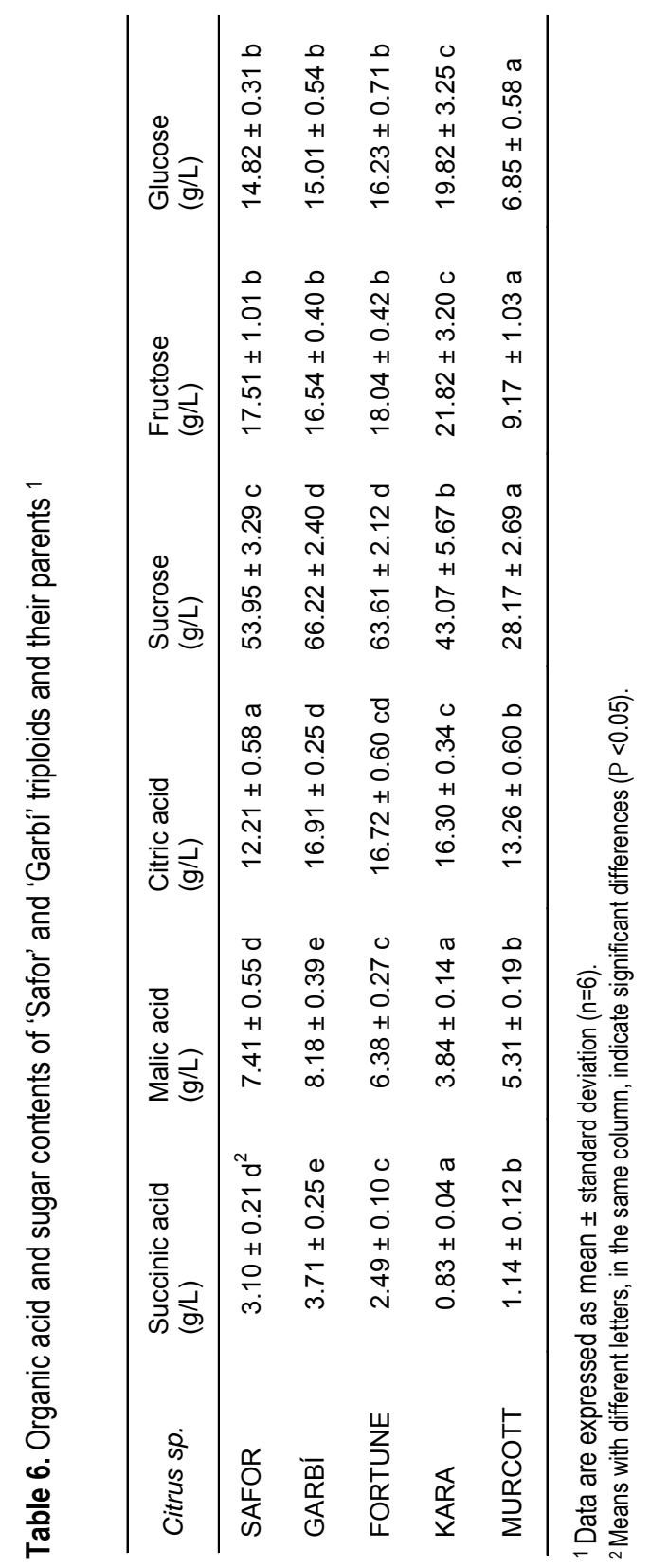

226 


\section{Conclusion}

The analysis of chemical composition of the new triploid late-season mandarins, 'Safor' and 'Garbi', showed that both hybrids have high quality parameters of juice. It is already known that quality and nutritional attributes are mainly determined by multigenic inheritance (Fanciullino, Dhuique-Mayer, Luro, Morillon, \& Ollitrault, 2007). Therefore, the genetic background of the new analyzed triploid hybrids and complex trait inheritance causes great variability on the triploid progeny for each analyzed parameter, which has been shown with the obtained results. The quality of the parent cultivars has been kept or improved in the new varieties, and nutritional bio-components were affected differently. 'Safor' mandarin displayed a higher level of vitamin C, eriocitrin, didymin, diosmin, tangeretin, and chlorogenic acid compared to its parents 'Fortune' and 'Kara' mandarins. In addition, this hybrid possesses remarkable high antioxidant activity. The introduction of 'Kara' mandarin parentage enhanced the total phenolics and hesperidin content in 'Safor' fruit juice. 'Garbi' fruits were found to be rich in sugars and organic acids. The results of the present study highlighted that the new mandarins 'Safor' and Garbi' can be considered as a significant source of phytochemicals that may be used as natural antioxidants.

\section{Acknowledgements}

This research was supported by the Spanish 'Ministerio de Educación y Ciencia' and Instituto Valenciano de Investigaciones Agrarias. The authors wish to thank Pr. Luis Navarro for his support.

\section{References}

Abeysinghe, D.C., Li, X., Sun, C.D., Zhang, W.S., Zhou, C.H., Chen, K.S. (2007). Bioactive compounds and antioxidant capacities in different edible tissues of citrus fruit of four species. Food Chemistry, 104, 1338-1344. 
Albertini, M.B., Carcouet, E., Pailly, O., Gambotti, C., Luro, F., Berti, L. (2006). Changes in organic acids and sugars during early stages of development of acidic and acidless citrus fruit. Journal of Agricultural and Food Chemistry, $54,8335-8339$.

Aleza, P., Cuenca, J., Juárez, J., Pina, J.A., Navarro, L. (2009). Mandarinos 'Garbí' y 'Safor', dos nuevos híbridos triploides obtenidos en el IVIA. Levante Agrícola, 395, 85-87.

Aleza, P., Cuenca, J., Juárez, J. Pina, J.A., Navarro, L. (2010). 'Garbi' mandarin, a new late-maturing triploid hybrid. HortScience, 45, 139-141.

Benavente-Garcia, O., \& Castillo, J. (2008). Update on uses and properties of citrus flavonoids: New finding in anticancer, cardiovascular, and antiinflammatory activity. Journal of Agricultural and Food Chemistry, 56, 61856205.

Benzie, I.F., \& Strain, J. (1999). Ferric reducing/antioxidant power assay: direct measure of total antioxidant activity of biological fluids and modified version for simultaneous measurement of total antioxidant power and ascorbic acid concentration: Methods in Enzymology, 299, 15-27.

Bermejo, A., Pardo, J., Cano, A. (2011). Influence of gamma irradiation on seedless citrus production: pollen germination and fruit quality. Food and Nutrition Sciences, 2, 169-180.

Burda, S., \& Oleszek, W. (2001). Antioxidant and antiradical activities of flavonoids. Journal of Agricultural and Food Chemistry, 49, 2774-2779.

Byers, T., \& Perry, G. (1992). Dietary carotenes, vitamin C, and vitamin E as protective antioxidants in human cancers. Annual Review of Nutrition, 12, 139-159.

Cano, A., Medina, A., Bermejo, A. (2008). Bioactive compounds in different citrus varieties. Discrimination among cultivars. Journal of Food Composition and Analysis, 21, 377-381.

Cuenca, J., Aleza, P., Juárez, J., Pina, J.A., Navarro, L. (2010). 'Safor' mandarin: a new mid-late citrus triploid hybrid. HortScience, 45, 977-980. 
Du, Q., \& Chen, H. (2010). The methoxyflavones in Citrus reticulata Blanco cv. Ponkan and their antiproliferative activity against cancers cells. Food Chemistry, 19, 567-572.

Fanciullino, A.L., Dhuique-Mayer, C., Luro, F., Morillon, R., \& Ollitrault, P. (2007). Carotenoid biosynthetic pathway in the Citrus genus: number of copies and phylogenetic diversity of seven genes. Journal of Agricultural and Food Chemistry, 55, 7405-7417.

Gardner, P.T., White, T.A.C., McPhail, D.B., Duthie, G.G. (2000). The relative contributions of vitamin $C$, carotenoids and phenolics to the antioxidant potential of fruit juices. Food Chemistry, 68, 471-474.

Gattuso, G., Barreca, D., Caristi, C., Gargiulli, C., Leuzzi, U. (2007). Distribution of flavonoids and furocoumarins in juices from cultivars of Citrus bergamia Risso. Journal of Agricultural and Food Chemistry, 55, 9921-9927.

Goldwasser, J., Cohen, P.Y., Lin, W.Y., Kitsberg, D., Balaguer, P., Polyak, S.J., Chung, R.T., Yarmush, M.L., Nahmias, Y. (2011). Naringenin inhibits the assembly and log-term production of infectious hepatitis $C$ virus particles through a PPAR-mediated mechanism. Journal of Hepatology, 55, 963-971.

Gorinstein, S., Martin-Belloso, O., Park, Y., Haruenkit, R., Lojek, A., Ciz, M., Caspi, A., Libman, A., Trakhtenberg, S. (2001). Comparison of some biochemical characteristics of different citrus fruits. Food Chemistry, 74, 309315.

Huang, Y.S., \& Ho, S.C. (2010). Polymethoxyflavones are responsible for the anti-inflammatory activity of citrus fruit peel. Food Chemistry, 119, 868-873.

Igual, M., García-Martínez, E., Camacho, M., Martínez-Navarrete, N. (2010). Effect of termal treatment and storage on the stability of organic acids and the functional value of grapefruit juice. Food Chemistry, 118, 291-299.

Kawaii, S., Tomono, Y., Katase, E., Ogawa, K., Yano, M. (1999). Quantitation of flavonoid constituents in citrus fruits. Journal of Agricultural and Food Chemistry, 47, 3565-3571.

Kelebek, H. (2010). Sugars, organic acids, phenolic compositions and antioxidant activity of Grapefruit (Citrus paradisi) cultivars grown in Turkey. Industrial Crops and Products, 32, 269-274. 
Kelebek, H., \& Selli, S. (2011). Determination of volatile, phenolic, organic acid and sugar components in Turkish cv. Dortyol (Citrus sinensis L. Osbeck) orange juice. Journal of the Science of Food and Agriculture, 91, 1855-1862.

Klimczak, I., Malecka, M., Szlachta., M., Gliszczynska-Swiglo, A. (2007). Effect of storage on the content of polyphenols, vitamin $\mathrm{C}$ and the antioxidant activity of orange juices. Journal of Food Composition and Analysis, 20, 313322.

Lafuente, M.T., Ballester, A.R., Calejero, J., Gonzalez-Candelas, L. (2011). Effect of high temperature-conditioning treatments on quality, flavonoid composition and vitamin C of cold stored 'Fortune' mandarins. Food Chemistry, 128, 1080-1086.

Marsh, K. B., Richardson, A. C., Erner, Y. (2003). Effect of environmental conditions and horticultural practices on citric acid content. Proceeding of the International Society of Citriculture, IX Congress Orlando, 640-643.

Mouly, P.P., Arzouyan, C.R., Gaydou, E.M., Estienne, J.M. (1994). Differentiation of citrus juices by factorial discriminant analysis using liquid chromatography of flavanone glycosides. Journal of Agricultural and Food Chemistry, 42, 70-79.

Murakami, A., Nakamura, Y., Torikai, K., Tanaka, T., Koshiba, T., Koshimizu, K., Kuwahara, S., Takahashi, Y., Ogawa, K., Yano, M., Tokuda, H., Nishino, H., Mimaki, Y., Sashida, Y., Kitanaka, S., Ohigashi, H. (2000). Inhibitory effect of citrus nobiletin on phorbol ester-induced skin inflammation, oxidative stress, and tumor promotion in mice. Cancer Research, 15, 50595066 .

Natella, F., Nardini, M., Di Felice, M., Scaccini, C. (1999). Benzoic and cinnamic acid derivatives as antioxidants structure-activity relation. Journal of Agricultural and Food Chemistry, 47, 1453-1459.

Nogata, Y., Sakamoto, K., Shiratsuchi, H., Ishii, T., Yano, M., Ohta, H. (2006). Flavonoid composition of fruit tissues of Citrus species. Bioscience Biotechnology and Biochemistry, 70, 178-192.

Peterson, J.J., Dwyer, J.T., Beecher, G.R., Bhagwat, S.A., Gebhardt, S.E., Haytowitz, D.B., Holden, J.M. (2006). Flavanones in oranges, tangerines (mandarins), tangors and tangelos: a compilation and review of the data 
from the analytical literature. Journal of Food Composition and Analysis, 19, S66-S73.

Palma, A., D'Aquino, S., Agabbio, M., Schirra, S. (2005). Changes in flavonoids, ascorbic acid, polyphenol content and antioxidant activity in cold stored 'Fortune' Mandarin. Acta Horticulturae. 682, 617-622.

Plaza, L., Crespo, I., de Pascual-Teresa, S., de Ancos, B., Sánchez-Moreno, C., Muñoz, M., Cano, M.P. (2011). Impact of minimal processing on orange bioactive compounds during refrigerated storage. Food Chemistry, 124, 646651.

Ramful, D., Tarnus, E., Aruoma, O.I., Bourdon, E., Bahroun, T. (2011). Polyphenol composition, vitamin C content and antioxidant capacity of Mauritian citrus fruit pulps. Journal Research International, 44, 2088-2099.

Rapisarda, P., Tomaino, A., Lo Cascio, R., Bonina, F., De Pasquale, A., Saija, A. (1999). Antioxidant effectiveness as influenced by phenolic content of fresh orange juices. Journal of Agricultural and Food Chemistry, 47, 47184723.

Roussos, P.A. (2011). Phytochemicals and antioxidant capacity of orange (Citrus sinensis (I). Osbeck cv. Salustiana) juice produced under organic and integrated farming system in Greece. Sciencia Horticulturae, 129, 253-258.

Sdiri, S., Navarro, P., Monterde, A., Benabda, J., Salvador, A. (2012). Effect of postharvest degreening followed by a cold-quarantine treatment on vitamin $\mathrm{C}$, phenolic compounds and antioxidant activity of early-season citrus fruit. Postharvest Biology and Technology, 65, 13-21.

Shulman, M., Cohen, M., Soto-Gutierrez, A., Yagi, H., Wang, H.Y., Goldwasser, J., Lee-Parsons, C.W., Benny-Ratsaby, Yarmush, M.L., Nahmias, Y. (2011). Enhancement of naringenin bioavailability by complexation with hydroxypropoyl-beta-cyclodextrin. PLOS ONE, 6 (4) DOI: 10.1371/journal.pone.0018033.

Singleton, V.L. \& Rossi, J.A. (1965). Colorimetry of total phenolics with phospomolybdic-phosphotungstic acid reagents. American Journal of Enology and Viticulture, 16, 144-158.

Stuetz, W., Prapamontol, T., Hongsibsong, S., \& Biesalski, H.K. (2010). Polymethoxylated flavones, flavanone glycosides, carotenoids, and 
antioxidants in different cultivation types of tangerines (Citrus reticulata Blanco cv. Sainampueng) from northern Thailand. Journal of Agricultural and Food Chemistry, 58, 6069-6074.

Tripoli, E., La Guardia, M., Giammanco, S., Di Majo, D., Giammanco, M. (2007). Citrus flavonoids: Molecular structure, biological activity and nutritional properties: A review. Food Chemistry, 104, 466-479.

Uckoo, R.M., Jayaprakasha, G,K., Nelson, S.D, Patil, B.S. (2011). Rapid simultaneous determination of amines and organic acids in citrus using highperformance liquid chromatography. Talanta, 83, 948-954.

Wang, Y.C., Chuang, Y.C., \& Ku, Y.H. (2007). Quantitation of bioactive compounds in citrus fruits cultivated in Taiwan. Food Chemistry, 102, 11631171.

Ye, X.Q., Chen, J.C., Liu, D.H., Jiang, P., Shi, J., Xue, S., Wu, D., Xu, J.G., Kakuda, Y. (2011). Identification of bioactive composition and antioxidant activity in young mandarin fruits. Food Chemistry. 124, 1561-1566.

Zerdin, K., Rooney, M. L., Vermue, J. (2003). The vitamin C content of orange juice packed in an oxygen scavenger material. Food Chemistry, 82, 387395. 


\title{
Juice of new triploids late-maturing mandarins as a rich source of vitamin C, flavonoids and antioxidant capacity
}

\author{
Sawsen Sdiri ${ }^{1}$, José Cuenca ${ }^{2}$, Pilar Navarro ${ }^{1}$, Alejandra \\ Salvadora ${ }^{1}$, Almudena Bermejo ${ }^{3}$
}

\footnotetext{
${ }^{1}$ Centro de Tecnología Postcosecha, Instituto Valenciano de Investigaciones Agrarias, Carretera Moncada-Náquera Km 4.5 s/n, 46113, Moncada, Valencia, Spain

${ }^{2}$ Centro de Protección Vegetal y Biotecnología, Instituto Valenciano de Investigaciones Agrarias, Carretera Moncada-Náquera Km 4.5 s/n, 46113, Moncada, Valencia, Spain.

${ }^{3}$ Centro de Citricultura y Producción Vegetal, Instituto Valenciano de Investigaciones Agrarias, Carretera Moncada-Náquera Km 4.5 s/n, 46113, Moncada, Valencia, Spain.
}

Reference: Submitted to Journal of Agricultural and Food Chemistry. 



\begin{abstract}
Juices from nine new late-season triploid mandarins (FORMCO96097, FORMCO96-082, FORMUR96-086, FORKAR96-073, FORELL96058, FORELL96-060, FORMUR96-019, FORMUR96-023 and FORELL96-023) and from their parents were analyzed for mainly internal quality attributes, vitamin $\mathrm{C}$, total phenolics, flavonoids, phenolic and organic acids. Antioxidant activity was measured by two methods, the DPPH free radical-scavenging and ferric reducing antioxidant power (FRAP) tests. All the new hybrids exhibited high internal and nutritional quality which may be considerate rich sources of phytochemicals. Among the nine varieties, FORELL96-023 hybrid was shown to be the richest in vitamin $\mathrm{C}$, flavanones (hesperidin, eriocitrin and neoeriocitrin), polymethoxyflavones, malic and succinic acids. Furthermore, the juice of this new triploid hybrid displayed high antioxidant capacity which may make it important for human diet as a source of health promoting components. On other hand, FORELL96-060, FORELL96-023 and FORELL96-058 fruit juices exhibited greater content of eriocitrin and neoeriocitrin than the others.
\end{abstract}

Keywords: mandarin, hybrids, vitamin C, antioxidant activity, flavanones, polymethoxyflavones, organic acids 


\section{Introduction}

Citrus is one of the most important commercial fruit crop in a large number of countries in tropical and subtropical climates. Out of 100 million tons worldwide production, 21 million tons are mandarins, clementines and satsumas. ${ }^{1}$ Spain, the leading producing country in the Mediterranean area, is the second world producer and the first exporting country of fresh mandarins. ${ }^{2}$ The harvest season of small fruits (satsumas, clementines and hybrids) in Spain is extended from September to February. The lack of mandarin production after this period and the steady increase in consumption and demand for these sweet fruits lead to find new varieties to supply the market, mainly in the period from February to May.

Since 1996, a breeding program is carried out in the Plant Protection and Biotechnology Center in the Instituto Valenciano de Investigaciones Agrarias (IVIA) located at Moncada (Valencia, Spain), in order to obtain new latematuring triploid mandarin varieties. As a result, more than 13,000 triploid hybrids have been produced. ${ }^{3}$ Currently, from these released triploids, fourteen varieties have been selected for the commercial production because of their great interest and their good agronomic performance. Fruits from these new hybrids are mid- and late-maturing, and present excellent traits regarding to fruit quality, including fruit size, seedless, good rind color and easy peeling. Besides of these quality parameters, it would be interesting to know the nutritional quality of these new varieties since chemical and nutritional composition are also important traits for fresh citrus consumption.

The beneficial effects of citrus fruits have been mainly attributed to the high contents of micronutrients and phytochemical substances which possess antioxidant properties. ${ }^{4-6}$ The main part of the total antioxidant capacity is due to the hydrophilic compounds present in citrus fruits. Vitamin $\mathrm{C}$ is considered as a potent antioxidant that may inhibit the development of major oxidative human reactions. ${ }^{7}$ In addition to vitamin $\mathrm{C}$, citrus fruits contain also high content of phenolics which represent a varied class of compounds. Recent studies have been focused on the phenolic compounds of citrus fruits and suggested that these components might play an important role on the antioxidant capacity of citrus fruits. ${ }^{4,8}$ The major part of phenolic compounds in citrus fruit are 
flavonoids that include flavanone, flavones and flavonols. ${ }^{9}$ Hydroxycinnamic and hydroxybenzoic are phenolic acids that also possess high antioxidant activity. ${ }^{4,10,11}$

In addition, citrus fruits are classified as acid fruits, since they are a good source of organic acids. The nature and concentration of organic acids in citrus fruits largely affect the sensory properties and contribute to the flavor attributes of the juices. The main organic acids of citrus fruits are citric and malic acids. In addition, tartaric, benzoic, oxalic and succinic acids have been reported in smaller amounts. ${ }^{12,13}$

The health-promoting components such as vitamin C, phenolic compounds as well as the quality attributes, the organic acids and the antioxidant activity were evaluated in order to better understand the pattern of nine new triploid mandarins and their parents.

\section{Materials and Methods}

\subsection{Plant material}

The selected triploid mandarins shown in Table 1, as well as their parents Fortune, Kara and Willow Leaf mandarins and Murcott and Ellendale tangors, were harvested from the beginning of February to the end of March, from the Field Collection of Citrus Germoplasm Bank held at IVIA. After harvested, fruit were transported to the Postharvest Technology Center. Then, the juice from fruits (three replicates of ten fruits) was obtained by a juice squeezer, filtered and used fresh or stored at $-80^{\circ} \mathrm{C}$.

The following parameters were evaluated: vitamin C, total phenol content, antioxidant activity, phenolic acids, flavonoids and organic acids as well as the physicochemical properties such as total soluble solids, titratable acidity and maturity index. 


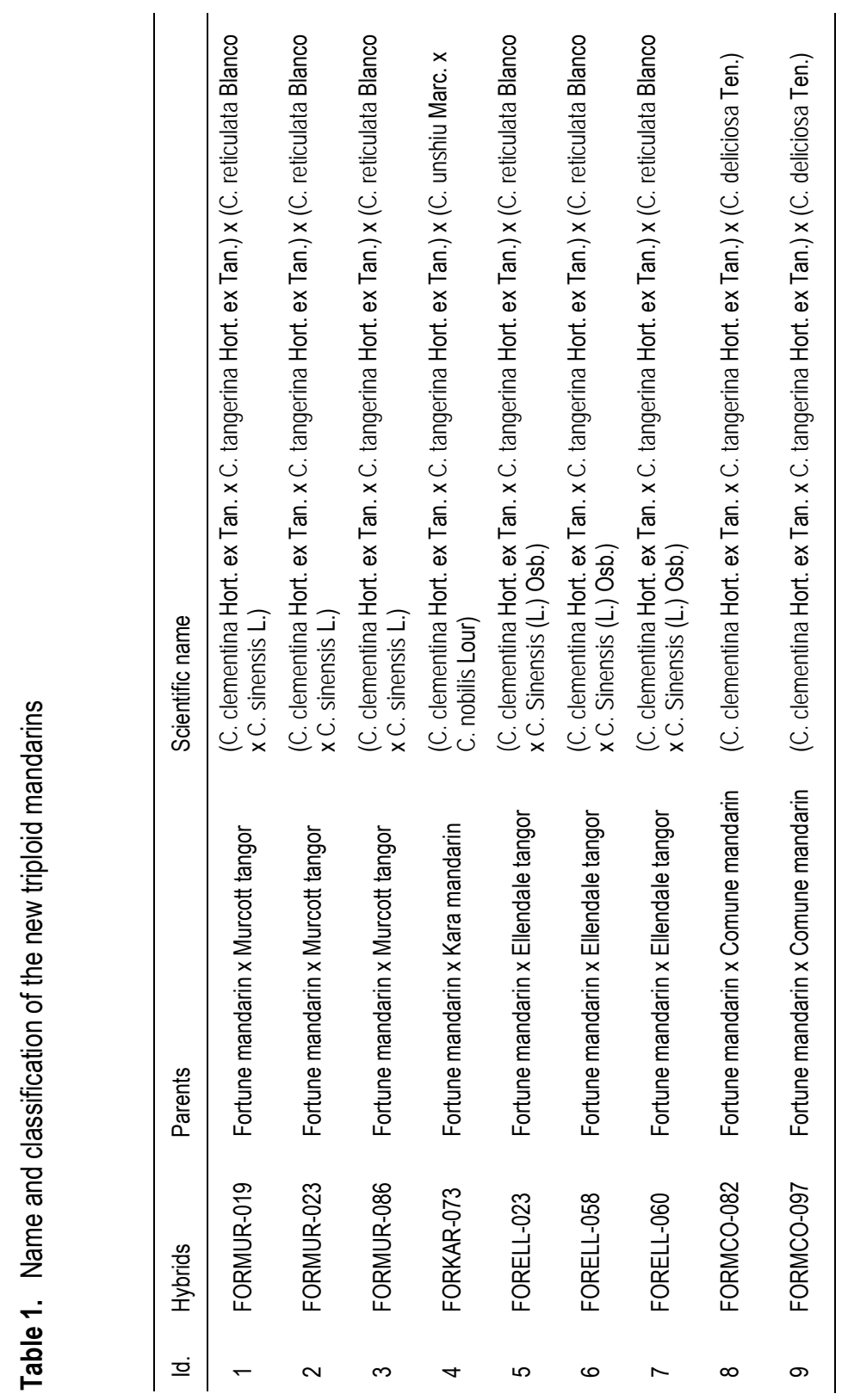




\subsection{Reagents and standards}

Narirutin, didymin, sinensetin, nobiletin and tangeretin were purchased from Extrasynthèse (Genay, France). Hesperidin, naringin, gallic acid, apigenin, chlorogenic acid, quercetin, Folin-Ciocalteu's reagent, sodium carbonate $\left(\mathrm{Na}_{2} \mathrm{CO}_{3}\right)$, phosphoric acid $\left(\mathrm{H}_{3} \mathrm{PO}_{4}\right)$, meta-phosphoric acid, DL-Dithiothreitol (DTT), ascorbic acid and ferric trichloride were purchased from Sigma-Aldrich (Barcelona, Spain). Also citric acid, malic acid and succinic acid were obtained from Sigma-Aldrich (Barcelona, Spain). 2,4,6-Tris(2-pyridyl)-s-triazine (TPTZ), 2,2-Diphenyl-1-picrylhydrazyl (DPPH) and potassium dihydrogen phosphate $\left(\mathrm{KH}_{2} \mathrm{PO}_{4}\right)$ were supplied from Fluka Chemie (Sigma Co., Barcelona, Spain). Glacial acetic acid was purchased from Sharlau (Sentmenat, Spain). HPLCgrade acetonitrile, dimethylformamide and methanol were obtained from VWR (Barcelona, Spain). Milli-Q water (Millipore, Synergy ${ }^{\circledR}$ UV, France) was used throughout.

\subsection{Analysis of physicochemical properties}

Per variety, three samples of ten fruits each were squeezed in an electric juice extractor with a rotating head (Lomi $\Omega$, Model 4, Lorenzo Miguel, S.L., Madrid, Spain). Titratable acidity (TA) was determined by titration with $0.1 \mathrm{~N}$ $\mathrm{NaOH}$ solution, using phenolphthalein as indicator and expressed as $\mathrm{g}$ of citric acid per $100 \mathrm{~mL}$ of juice. The total soluble solids in the juice were determined by digital refractometer (Atago PR-1, Atago Co., Ltd, Tokyo, Japan) and the data were expressed as \%. The maturity index (MI) was calculated as TSS/TA ratio.

\subsection{Determination of vitamin C: general procedure for extraction and analysis}

Total vitamin C (ascorbic acid and dehydroascorbic acid) was determined according to the method described by Sdiri et al. ${ }^{14} \mathrm{~A}$ high-performance liquid chromatography (HPLC) (LachromElite, Merck Hitachi, Germany) equipped with a diode array detector (L-2450), column oven (L-2300) and auto-sampler (L2200) was used. The procedure utilized was the reduction of dehydroascorbic acid to ascorbic acid, using DL-dithiothreitol (DTT) as reducing reagent. A juice 
sample $(0.7 \mathrm{~mL})$ was homogenized with $0.7 \mathrm{~mL}$ of extraction solution $(4.5 \%$ meta-phosphoric acid). The resulting mixture was centrifuged at $12000 \mathrm{rpm}$ for $10 \mathrm{~min}$ at $4^{\circ} \mathrm{C}$ in a Centrifuge $5810 \mathrm{R}$ (eppendorf, Germany). One millilitre of supernatant was mixed with $0.2 \mathrm{~mL}$ of DTT $(20 \mathrm{mg} / \mathrm{mL})$ and left to react at room temperature for $2 \mathrm{~h}$, then filtered through $0.45 \mu \mathrm{m}$ Whatman filter and analyzed for vitamin C by HPLC-DAD. Separation was performed on a Lichospher 100 $\mathrm{RP}-18$ column $(4 \mathrm{~mm} \times 250 \mathrm{~mm})$, preceded by a precolumn $(4 \times 4 \mathrm{~mm})$ with a particle diameter of $5 \mu \mathrm{m}$. The column was equilibrated for $10 \mathrm{~min}$ and then an isocratic elution of $\mathrm{KH}_{2} \mathrm{PO}_{4}(0.2 \mathrm{M}$, adjusted to $\mathrm{pH} 2.3$ with phosphoric acid) was used as the mobile phase at a flow rate of $1 \mathrm{~mL} / \mathrm{min}$ with UV detection at 243 $\mathrm{nm}$. The total elution time was $10 \mathrm{~min}$ and the injection volume was $20 \mu \mathrm{L}$. Three samples from each treatment were analyzed and all samples were run in triplicate. After sample analysis, the column was washed during 10 min with methanol. The quantification of vitamin $C$ was carried out using the external standard method. Calibration curves were performed with four concentrations of ascorbic acid (50-100-150 and $200 \mathrm{mg} / \mathrm{L})$. Standards were run daily with samples for validation.

2.5. Analysis of phenolic compounds: general procedure for extraction and analysis

Phenolic compounds were extracted and analyzed according to the method described by Sdiri et al. ${ }^{14}$ Briefly, $5 \mathrm{~mL}$ of juice were mixed with $5 \mathrm{~mL}$ of dimethylformamide and then centrifuged at $12000 \mathrm{rpm}$ for $20 \mathrm{~min}$ at $4^{\circ} \mathrm{C}$. $1 \mathrm{~mL}$ of the supernatant was filtered through one $0.45 \mu \mathrm{m}$ nylon filter and then $20 \mu \mathrm{L}$ were injected into the HPLC-DAD system. HPLC elution was carried out at room temperature and utilized a binary solvent system of $\mathrm{ACN}$ and water with $4 \%$ acetic acid. The solvent system was operated to start at $15 \%$ and end at $100 \%$ ACN concentration for 45 min period. The elution profile was, at a flow rate of $1.0 \mathrm{~mL} / \mathrm{min}$. The chromatogram was monitored simultaneously at 284 and $334 \mathrm{~nm}$ with $5 \mathrm{~nm}$ bandwidth. Calculation of concentrations was based on the external standard method. Dilutions of each of the phenolic standards were used to fit a standard with linear regression for each individual compound. 


\subsection{Total Phenolic Content (Folin-Ciocalteu assay)}

The contents of total phenolics in samples were measured in a microliterbased format on the basis of the Folin-Ciocalteu colorimetric method 15 with

some modifications. ${ }^{14}$ Briefly, $30 \mu \mathrm{L}$ of appropriately diluted samples of juice (in methanol $80 \%$ ) were oxidized for 1 min with $150 \mu \mathrm{L}$ of Folin-Ciocalteu reagent $(1: 10, v / v$ diluted with water) and then the reaction was neutralized with $120 \mu \mathrm{L}$ of sodium carbonate $(7.5 \%, \mathrm{w} / \mathrm{v})$. The absorbance was measured at $765 \mathrm{~nm}$ by a Multiscan Spectrum microplate reader (Thermo electron corporation, S.A.). Gallic acid was used as standard, and the results were expressed as mg of gallic acid equivalent $/ L$ of juice. For each variety eighteen replicates were measured.

\subsection{Antioxidant Activity}

The antioxidant activity of the citrus juices was evaluated by DPPH free radical-scavenging method, ferric reducing antioxidant power (FRAP) assay and ABTS method.

The DPPH free radical-scavenging activity measurement was assessed according to Brand-Williams et al. ${ }^{16}$ with some modifications to adapt the method to a microliter-based format according to the procedure described by Sdiri et al. ${ }^{14}$ Briefly, in glass 96 -well reaction plate, $30 \mu \mathrm{L}$ of diluted samples in $100 \%$ methanol were combined with $270 \mu \mathrm{L}$ of methanolic DPPH $(0.025 \mathrm{~g} / \mathrm{L}$ in methanol $100 \%$ ). Following incubation at $20^{\circ} \mathrm{C}$ for $50 \mathrm{~min}$, the absorbance at $515 \mathrm{~nm}$ was read on a Multiscan Spectrum microplate reader (Thermo electron corporation, S.A.). The results were expressed as ascorbic acid equivalent $/ 100 \mathrm{~mL}$ of juice. For each variety eighteen replicates were measured.

The FRAP method was assessed according to the method of Benzie and Strain ${ }^{17}$ with some modifications to adapt the method to microliter-based format described previously by Sdiri et al. ${ }^{14}$ In brief, the FRAP reagent was freshly prepared by mixing $25 \mathrm{~mL}$ of $300 \mathrm{mM}$ acetate buffer (pH 3.6), $2.5 \mathrm{~mL}$ of $10 \mathrm{mM}$ TPTZ solution, and $2.5 \mathrm{~mL}$ of $20 \mathrm{mM}$ ferric chloride solution. The assay was carried out by placing $30 \mu \mathrm{L}$ of appropriate diluted samples in a 96-well 
microplate and then adding $270 \mu \mathrm{L}$ of FRAP reagent. After 10 min of incubation at $37^{\circ} \mathrm{C}$ and shaking, absorbance was read at $593 \mathrm{~nm}$. Results were compared with a standard curve prepared with different concentrations of ascorbic acid and were expressed as $\mathrm{mM}$ ascorbic acid equivalents.

Total antioxidant activity (TAA) was also measured using the method of $\operatorname{Re}$ et al. ${ }^{18}$, based on the capacity of antioxidant molecules to reduce the radical cation of $A B T S$, determined by the discoloration of $\mathrm{ABTS}^{+}$, and measured as the quenching of the absorbance at $734 \mathrm{~nm}$. Values obtained for each sample were compared to the concentration-response curve of the standard Trolox solution and expressed as Trolox Equivalent Antioxidant Capacity (TEAC).

\subsection{Analysis of Organic Acids by HPLC}

Extraction method was the same as the procedure described previously. ${ }^{19}$ Briefly, $1 \mathrm{~mL}$ of filtered juice was mixed with $1 \mathrm{~mL}$ of $0.1 \% \mathrm{H}_{2} \mathrm{SO}_{4}$ solution, and then the sample was centrifuged at $4^{\circ} \mathrm{C}$ for $5 \mathrm{~min}$ at $12.000 \mathrm{rpm}$. The supernatant were filtered through $0.45 \mu \mathrm{m}$ filter and analyzed by HPLC-DAD, and confirmed by HPLC-MS working in electrospray ion negative conditions with a quadrupole mass analyzer (ZQ2000 mass detector). Analysis was made using an Alliance liquid chromatographic system (Waters, Barcelona, Spain) equipped with a 2695 separation module, coupled to a 2996 photodiode array detector and a ZQ2000 mass detector. A thermostat column oven, a ICSep ICE-COREGEL 87H3 column (Transgenomic), a ICSep ICE-COREGEL 87H guard kit, and an automatic injector were used for chromatographic separation. Empower 2 software was used for data acquisition. Sample temperature was $5^{\circ} \mathrm{C}$ and column temperature was $35^{\circ} \mathrm{C}$. The capillary voltage was $3.0 \mathrm{kV}$, cone voltage $23 \mathrm{~V}$, source temperature $100^{\circ} \mathrm{C}$, desolvation temperature $200^{\circ} \mathrm{C}$ and desolvation gas flow $400 \mathrm{~L} / \mathrm{Hr}$. The column was equilibrated for $20 \mathrm{~min}$ and then an isocratic mobile phase of $0.1 \% \mathrm{H} 2 \mathrm{SO} 4$ solution was used as solvent system. The total run time was $20 \mathrm{~min}$ at $0.6 \mathrm{~mL} / \mathrm{min}$, injection volume was 5 $\mu \mathrm{L}$, and washing time used was $10 \mathrm{~min}$. Needle-wash solvents used were acetonitrile and water. Full data acquisition was performed scanning 100 to 400 uma in centroid mode. Compounds were indentified on the basis of comparing their retention times, UV-Vis spectra and mass spectrum data with corresponding authentic standards. Concentrations were determined using an 
external calibration curve with citric acid $\left(\mathrm{r}_{\mathrm{T}}=8.01 \mathrm{~min} ;[\mathrm{M}-\mathrm{H}]+191 \mathrm{~m} / \mathrm{z}\right)$, malic acid $\left(r_{T}=9.41 \mathrm{~min} ;[M-H]+133 \mathrm{~m} / \mathrm{z}\right)$, and succinic acid $\left(r_{\mathrm{T}}=11.43 \mathrm{~min} ;[\mathrm{M}-\mathrm{H}]+\right.$ $117 \mathrm{~m} / \mathrm{z})$.

\subsection{Statistical analysis}

Statistical procedures were performed using a commercial statistical software (Statgraphics plus 5.1, Manugistics, Inc., Rockville, M.d., U.S.A.). All data were subjected to analysis of variance, and means were compared using LSD test at $P<0.05$. For Principal Component Analysis (PCA) the complete dataset of all replicates was considered. For this analysis the program SIMCA-P version 11 (Umetrics, Umea, Sweden) was used with Pareto scaling.

\section{Results and Discussion}

\subsection{Quality parameters}

Quality parameters, including total soluble solids (TSS), titratable acidity (TA) and maturity index (MI=TSS/TA ratio) of the hybrids and their parents are reported in Table 2. The TSS values ranged from 9.3\% in Murcott to $15.7 \%$ in Fortune fruits. All the studied new hybrids displayed slightly lower values of TSS than their female parent Fortune mandarin; nevertheless the values were superior to their respective male parents, except FORELL96-023 and FORELL96-058 mandarins which presented the same values of TSS as their male parent (Ellendale tangor). Among the new triploids the values of TA were ranged from 1.11 to $1.59 \mathrm{~g}$ of citric acid $/ 100 \mathrm{~mL}$ of juice. The varieties resulting from crossing Fortune mandarin $x$ Murcott tangor (FORMUR96-019, FORMUR96-023 and FORMUR96-086) resulted in similar or higher TA than those arising from the male parent Murcott tangor. FORKAR96-073 exhibited similar TA as their parents Fortune and Kara mandarins. Nevertheless, FORELL96-023, FORELL96-058 and FORELL96-060 as well as FORMCO96082 and FORMCO96-097 displayed inferior TA than their male parents 
Chapter VII

Ellendale tangor and Willow Leaf mandarin respectively. In general, all the tested triploids presented higher values of MI than their parents. 
Table 2. Total soluble solids (TSS), titratable acidity (TA) and maturity index (MI) of the nine triploid mandarins and their parents

\begin{tabular}{lccc}
\hline Hybrids & $\begin{array}{c}\text { TSS } \\
(\%)\end{array}$ & $\begin{array}{c}\text { TA } \\
(\mathrm{g} / 100 \mathrm{~mL})\end{array}$ & $\begin{array}{c}\text { Ml } \\
(\mathrm{TSS} / \mathrm{TA})\end{array}$ \\
\hline FORMUR-019 & $13.7 \mathrm{~cd}$ & $1.34 \mathrm{c}$ & $10.2 \mathrm{f}$ \\
FORMUR-023 & $13.7 \mathrm{~cd}$ & $1.17 \mathrm{ab}$ & $11.7 \mathrm{~g}$ \\
FORMUR-086 & $14.6 \mathrm{ef}$ & $1.29 \mathrm{bc}$ & $11.3 \mathrm{~g}$ \\
FORKAR-073 & $15.0 \mathrm{fg}$ & $1.59 \mathrm{~d}$ & $9.4 \mathrm{de}$ \\
FORELL-023 & $14.4 \mathrm{e}$ & $1.27 \mathrm{bc}$ & $11.4 \mathrm{~g}$ \\
FORELL-058 & $14.4 \mathrm{e}$ & $1.66 \mathrm{~d}$ & $8.8 \mathrm{~cd}$ \\
FORELL-060 & $14.9 \mathrm{f}$ & $1.29 \mathrm{bc}$ & $11.5 \mathrm{~g}$ \\
FORMCO-082 & $14.0 \mathrm{~d}$ & $1.11 \mathrm{a}$ & $12.6 \mathrm{~h}$ \\
FORMCO-097 & $15.2 \mathrm{~g}$ & $1.33 \mathrm{c}$ & $11.5 \mathrm{~g}$ \\
FORTUNE & $15.7 \mathrm{~h}$ & $1.66 \mathrm{~d}$ & $9.5 \mathrm{e}$ \\
KARA & $13.6 \mathrm{c}$ & $1.62 \mathrm{~d}$ & $8.4 \mathrm{c}$ \\
MURCOTT & $9.3 \mathrm{a}$ & $1.12 \mathrm{a}$ & $8.2 \mathrm{c}$ \\
COMUNE & $13.6 \mathrm{c}$ & $2.16 \mathrm{f}$ & $6.3 \mathrm{a}$ \\
ELLENDALE & $14.4 \mathrm{e}$ & $1.76 \mathrm{e}$ & $8.2 \mathrm{c}$ \\
\hline
\end{tabular}

${ }^{1}$ Means with different letters, in the same column, indicate significant differences $(P<0.05)$. 


\subsection{Vitamin C content}

Citrus fruits are regarded as good source of vitamin $C$ which was found to be the major antioxidant compound in citrus juice. ${ }^{8}$ The content of vitamin $\mathrm{C}$ can be influenced by various factors such as genotypic differences, climatic conditions, cultural practices and postharvest treatment. ${ }^{20}$ Data of total ascorbic acid of the nine hybrids tested as well as of their parents are reported in Table 3. The vitamin $C$ levels of all the varieties were ranged from 19.68 to 41.05 $\mathrm{mg} / 100 \mathrm{~mL}$. The amounts of vitamin $\mathrm{C}$ shown in all the studied varieties are in agreement with the range of the content in clementines and hybrid mandarins reported by Cano et al. ${ }^{6}$ FORELL96-023 was shown to be the richest in vitamin $\mathrm{C}$, which could be explained by the high content of vitamin $\mathrm{C}$ exhibited by its male parent Ellendale tangor. FORMCO96-097 and FORMUR96-019 presented also greater levels of vitamin C (33.45 and $32.80 \mathrm{mg} / 100 \mathrm{~mL}$ respectively) than their female parent Fortune and their respective male parents Willow Leaf mandarin and Murcott tangor. High content of vitamin $C$ was also found in FORMCO96-082 with similar levels than those exhibited by its parents Fortune and Willow Leaf mandarins. No significant differences were shown between the vitamin C level in FORELL96-060 and Fortune mandarin. FORKAR96-073 and FORELL96-058 contain similar vitamin C levels showing values of 23.20 and $24.32 \mathrm{mg} / 100 \mathrm{~mL}$ respectively, such contents are smaller than those of their female parent Fortune mandarin and than their respective male parents Kara mandarin and Ellendale tangor. Among the studied varieties, the lowest levels of vitamin C were found in FORMUR96-023 and FORMUR96-086 which could be due to the small content exhibited by their male parent Murcott tangor that had the lowest level among the studied parents.

\subsection{Total Phenolic Content}

The Folin-Ciocalteu assay is the method commonly used to estimate the total phenolic content (TPC) in fruits and vegetables. The TPC levels of hybrid juices and their parents varied widely ranging from 385.7 to $738.8 \mathrm{mg} \mathrm{GAE} / \mathrm{L}$ (Table 3). Different content of phenolic were previously reported; Tounsi et al. ${ }^{21}$ reported values of only $106.32 \mathrm{mg} \mathrm{GAE} / \mathrm{L}$ in mandarin fruits and $255 \mathrm{mg}$ GAE/L 
in blood oranges. Nevertheless, total phenolics content were ranged from 507 to $696 \mathrm{mg} / \mathrm{L}$ in 'Tarocco Messina', 'Tarocco Meli', 'Moro', 'Ovale' and 'Valencia' oranges. ${ }^{22}$ Within the hybrid fruits FORKAR96-073 exhibited the highest content of total phenolics. This great level of TPC found in FORKAR96-073 juice could be explained by the introduction of Kara mandarin parentage, since this cultivar displayed the highest content of total phenolics (738.8 mg GAE/L). In the same way, the introduction of Ellendale mandarins, with high content of TPC, increased the content of total phenolics only in FORELL96-023, which presented higher level of TPC than that of Fortune mandarins (580.4 and 550.9 mg GAE/L in FORELL96-023 and Fortune respectively). FORMC096-097 also contained high level of total phenolics showing value of about $546.9 \mathrm{mg} \mathrm{GAE} / \mathrm{L}$ similar to that exhibited by its female parent Fortune mandarin. High contents were also found in FORMUR96-019, FORMUR96-023, FORMCO96-082 and FORELL96-058 mandarins without significant differences among them. FORELL96-060 is the hybrid showing the lowest phenolics content.

\subsection{Antioxidant activity}

The antioxidant activity of fruits and vegetable is important for assessing their nutritional value. ${ }^{23}$ Several methods have been developed to evaluate the total antioxidant activity of citrus fruits. In our study, the antioxidant activity of all the new hybrids was evaluated using DPPH free radical-scavenging and ferric reducing antioxidant power (FRAP) assay.

The DPPH test is the oldest indirect method for determining the antioxidant activity which is based on the ability of the stable free radical 2,2-diphenyl-1picrylhydrazyl to react with hydrogen donors including phenols. ${ }^{24}$ For the studied new hybrids, the antioxidant capacity evaluated by DPPH radical scavenging resulted in high values ranged from 220.8 to $228.2 \mathrm{mg} \mathrm{AAE} / 100 \mathrm{~mL}$ (Table 3). FORELL96-023, FORELL96-058 and FORELL96-060 hybrids presented values of antioxidant activity similar to that displayed by their parents Fortune mandarin and Ellendale tangor. All the tested new hybrids displayed similar values of antioxidant activity than their parents, except FORMUR96-086 which presented the lowest content. 
The FRAP ferric reducing antioxidant power assay is one of the useful assays for examining the interactions among various antioxidants. The FRAP assay measured the ability of antioxidants to reduce $\mathrm{Fe}\left(3^{+}\right)$to $\mathrm{Fe}(2+)$. Recently, it has been extensively used to study the antioxidant activity of hydrophilic extracts of fruits. ${ }^{8,25,26}$ The antioxidant activity of the tested hybrids and their parents determined by FRAP method are shown in Table 3. Amongst the tested hybrids, FORMCO96-097, FORMCO96-082, FORKAR96-073, FORMUR96-019 and FORELL96-023 fruits exhibited high values of FRAP without significant differences among them. FORMC096-082 and FORMC096-097 hybrids presented the same FRAP values as their male parent Willow Leaf mandarin. Values slightly smaller were found in FORMUR96-023 and FORMUR96-086 fruits which exhibited similar antioxidant activity to that of Murcott tangor. FORELL96-060 mandarin exhibited the lowest antioxidant activity which could be correlated to its low content of total phenolics. This correlation is consistent with the finding reported by Abeysinghe et al. ${ }^{25}$

ABTS method is reported as a decolorization assay applicable to both lipophilic and hydrophilic antioxidants, including flavonoids, hydroxycinnamates, carotenoids, and plasma antioxidants. The values of antioxidant capacity of the studied varieties determined by the ABTS method ranged from 2.84 to $3.73 \mathrm{mM}$ Trolox. Amongst the tested triploids, FORMUR96-019 presented the highest content of antioxidant activity. Almost all new varieties exhibited values of antioxidant capacity similar to that displayed by their parents, except FORMUR96-086, FORELL96-058 and FORELL96-060 hybrids which presented the lowest content. 


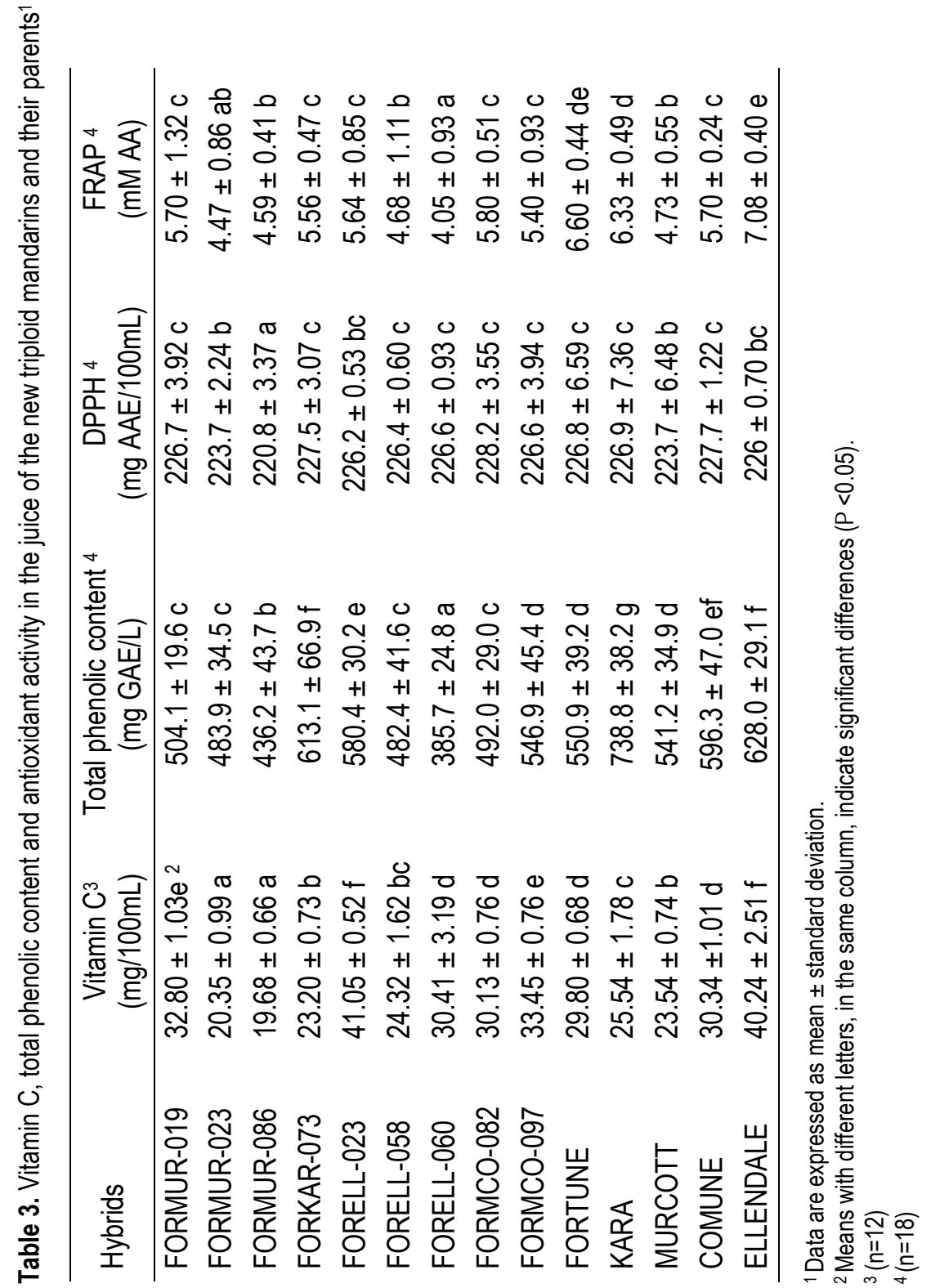




\subsection{Phenolic Composition}

Phenolic compounds are secondary metabolites, which mainly include flavonoids and phenolic acids in citrus fruits. ${ }^{25}$ Flavonoids are widely distributed in fruits and each species is characterized by a particular flavanone glycoside pattern. Flavanone is the major flavonoids found in mandarin fruits followed by flavones, flavonols and fully polymethoxylated flavones (PMFs). ${ }^{9}$ The tested hybrids and their parents showed different trends for flavanone contents (Table 4). In all varieties, hesperidin was found to be the predominant flavanone, followed by narirutin and didymin which is in agreement with the literature. .,9,26-29 $^{-1}$ In this study, the hesperidin content varied widely from 10.54 in Murcott to 87.29 $\mathrm{mg} / 100 \mathrm{~mL}$ in Kara. Similar variation in hesperidin level was reported by Cano et al. ${ }^{6}$ which found values ranged from $13.6 \mathrm{mg} / 100 \mathrm{~g} \mathrm{FW}$ in Hernandina to 60.6 $\mathrm{mg} / 100 \mathrm{~g}$ FW in Arrufatina clementines. The new hybrid showing the highest hesperidin content was FORELL96-023 (48.03 mg/100mL), followed by FORMUR96-019 hybrid with value of $39.36 \mathrm{mg} / 100 \mathrm{~mL}$. Both hybrids displayed higher level of hesperidin than Fortune mandarin as the common female parent $(36.87 \mathrm{mg} / 100 \mathrm{~mL})$ and their respective male parents $(23.90$ and 10.54 $\mathrm{mg} / 100 \mathrm{~mL}$ for Ellendale and Murcott tangor respectively). High level of hesperidin was also shown in the juice from FORMC096-097 (35.15 $\mathrm{mg} / 100 \mathrm{~mL}$ ) which was similar to the content exhibited by its parents Fortune and Willow Leaf mandarin. FORMUR96-086 and FORMUR96-023 hybrids presented higher levels of this flavanone than their male parent Murcott tangor.

The narirutin content reported previously ranged from 1.77 to 4.34 $\mathrm{mg} / 100 \mathrm{~mL}$ in mandarin fruits. ${ }^{29,30}$ In the present study, similar values were found in Willow Leaf mandarin and FORMC096-097 fruits. Nevertheless, the other tested varieties exhibited greater levels of this flavanone.

All the tested new hybrids exhibited higher content of narirutin than that of the female parent Fortune mandarin except in FORELL96-060 and FORMC096-097 cultivars. FORMUR96-023 hybrid is notable for its high level of narirutin showing similar value as its male parent Murcott tangor (14.5 $\mathrm{mg} / 100 \mathrm{~mL}$ ). FORKAR96-073 fruits also exhibited high content of narirutin similar to the content reported in its male parent Kara mandarin (9.44 and 9.03 $\mathrm{mg} / 100 \mathrm{~mL}$ in FORKAR96-073 and Kara respectively). The levels of narirutin 
displayed by FORMC096-082 and FORMC096-097 hybrids were higher than the content showed in Willow Leaf mandarin as is their male parent; alike, FORELL96-023, FORELL96-058 and FORELL96-060 triploids also exhibited greater narirutin level than their parent Ellendale tangor.

As with hesperidin and narirutin, the didymin content also varied among varieties ranging from 0.39 in Willow Leaf mandarin to $9.62 \mathrm{mg} / 100 \mathrm{~mL}$ in FORMUR96-019 hybrid. Small content of didymin was previously reported in mandarin and tangor fruits. ${ }^{26,29}$ FORMUR96-019 fruit displayed the greatest content of didymin. High levels of didymin were also shown in FORELL96-058 and FORMCO96-082 hybrids (6.40 and $5.92 \mathrm{mg} / 100 \mathrm{~mL}$ respectively), exceeding the content displayed by their female parent Fortune mandarin and their male parents Ellendale tangor and Willow Leaf mandarin respectively. FORKAR96-073 fruit also exhibited elevated content of didymin similar to that found in its parents Fortune and Kara mandarins.

Although citrus fruits contain low level of eriocitrin, it has been reported that this flavanone has antioxidative activity on lipid peroxidation and a suppressive effect on oxidative stress in vivo. ${ }^{3} 1$ Interestingly, in the present study, high levels of eriocitrin were detected in FORELL96-023, FORELL96-058 and FORELL96-060 hybrids (4.66, 3.68 and $3.52 \mathrm{mg} / 100 \mathrm{~mL}$ respectively). Nevertheless, in the other studied varieties, low values of eriocitrin were detected and the values ranged from 0.54 to $1.25 \mathrm{mg} / 100 \mathrm{~mL}$ which were in range of those reported in the literature. ${ }^{9}$ Among the tested new hybrids, the distribution pattern of neoeriocitrin resembled to that of eriocitrin, being found the highest concentrations in FORELL96-060, FORELL96-058 and FORELL96023 juices $(1.96,1.88$ and $1.71 \mathrm{mg} / 100 \mathrm{~mL}$ respectively).

Regarding the flavanone naringin, FORMCO96-082 fruits displayed the greatest content $(2.24 \mathrm{mg} / 100 \mathrm{~mL})$ while the lowest value observed was found in Willow Leaf mandarin $(0.12 \mathrm{mg} / 100 \mathrm{~mL})$. Overall, all the studied triploids exhibited higher levels of naringin than their male parents. FORKAR96-073, FORELL96-023 and FORELL96-058 presented relatively high content of naringin whereas this compound was not detected in their respective male parents Kara and Ellendale. Previous studies did not found naringin in different citrus varieties. ${ }^{9,25,32,33}$ The level of naringenin was ranged from 0.004 


\section{Chapter VII}

$\mathrm{mg} / 100 \mathrm{~mL}$ in FORMUR96-023 to $0.028 \mathrm{mg} / 100 \mathrm{~mL}$ in Kara mandarins. Among the new hybrids, FORELL96-060 hybrid displayed the highest content of naringenin superior than that exhibited by its parents Fortune mandarin and Ellendale tangor. The other new hybrids presented similar levels of this compound to that showed in the juice of their respective parents. 


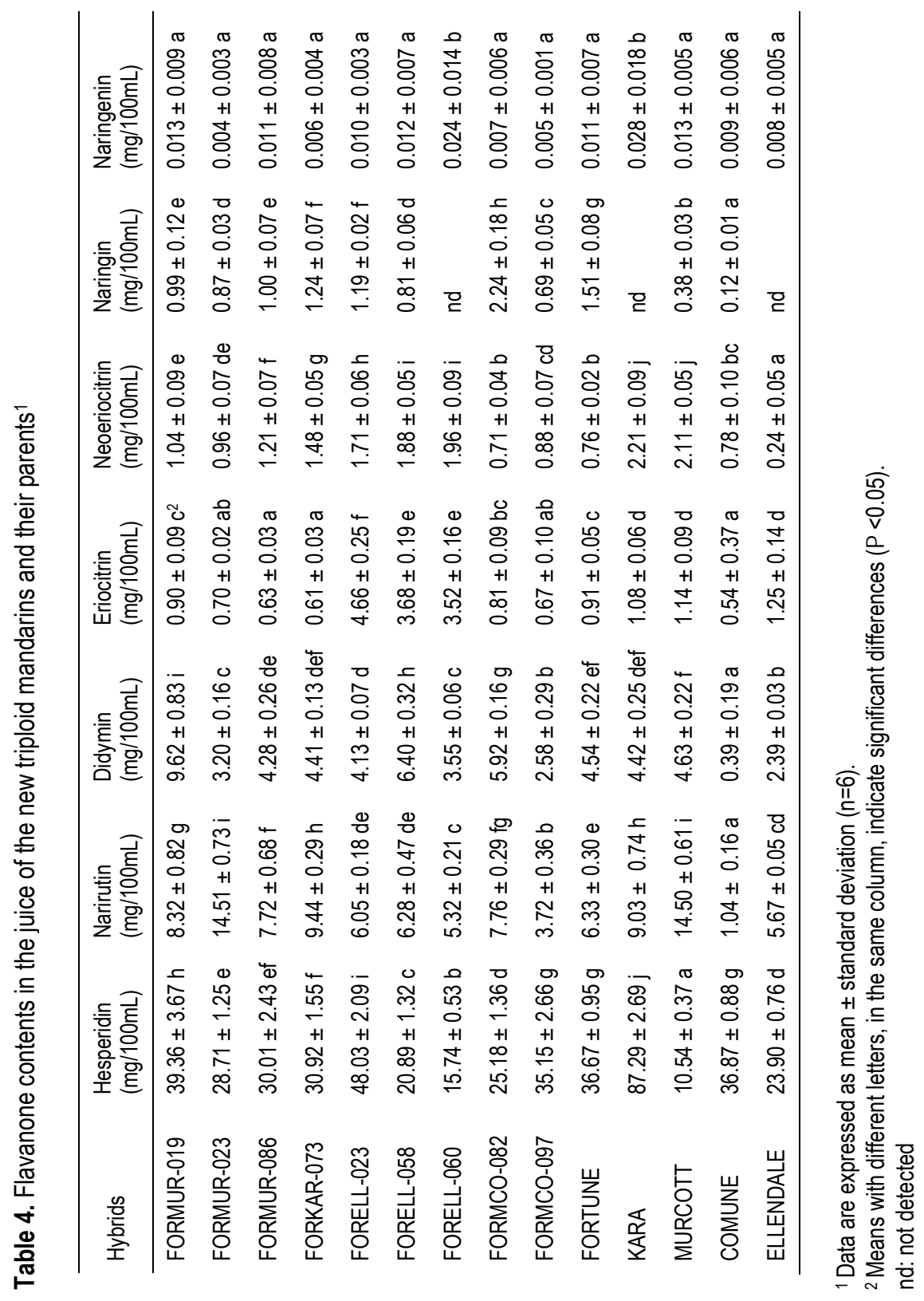


Flavone content of the nine tested triploids mandarins and of their parents are presented in Table 5. Diosmin compound was the most dominant flavone in all analyzed fruit juices in agreement with those previously reported in Citrus sp. ${ }^{5,9,34}$ FORMUR96-019, FORELL96-023 and FORMCO96-097 hybrid juices exhibited the highest levels, without significant difference among them. FORMUR96-086, FORKAR96-073 and FORELL96-058 hybrids displayed similar content of diosmin than that of their female parent Fortune mandarin. The lowest levels of diosmin were reported in FORELL96-060, FORMUR96-023 and Ellendale fruits. With respect to apigenin, which is the least abundant flavone, the levels were at the limit of detection and the concentrations found ranged from 0.001 to 0.004 without significant differences among all the studied varieties.

The concentration of PMFs is very low in the pulp of citrus fruits as compared to other flavonoids; nevertheless, an attention was paid to these compounds as they are almost exclusively found in citrus and because they act inhibiting several common diseases even though they occur in much lower concentrations. 35 Herein, the three commons PMFs, tangeretin, nobiletin and sinensetin, were identified and quantified (Table 5). In all tested juices, nobiletin was the major PMFs which is in accordance with the data previously reported in mandarin and orange juice..$^{9,33,34,35}$ The introduction of the parentage Willow Leaf mandarin and Ellendale and Murcott tangor enhanced the content of nobiletin in respectively FORMCO96-097, FORELL96-023 and FORMUR96019 hybrids which exhibited higher levels than their female parent Fortune mandarin. With respect to tangeretin content, FORELL96-023 juice displayed the greatest level $(0.104 \mathrm{mg} / 100 \mathrm{~mL})$ while FORMUR96-023 and Kara mandarins presented the lowest values $(0.025$ and $0.029 \mathrm{mg} / 100 \mathrm{~mL}$ respectively). FORMUR96-019 and FORMCO96-097 hybrids showed also high levels of tangeretin which were similar to their male parents and higher than their female parent Fortune mandarin. Low levels of sinensetin were observed in all the studied fruits in agreement with those previously reported in other citrus varieties. ${ }^{9}$ The greatest content was shown in Willow Leaf mandarin. FORELL96-023 hybrid also exhibited high level of sinensetin superior than its female parent (Fortune mandarin) and similar to that showed in its male parent (Ellendale tangor). No significant differences were found among the other hybrids presenting similar values as their female parent Fortune mandarin. 


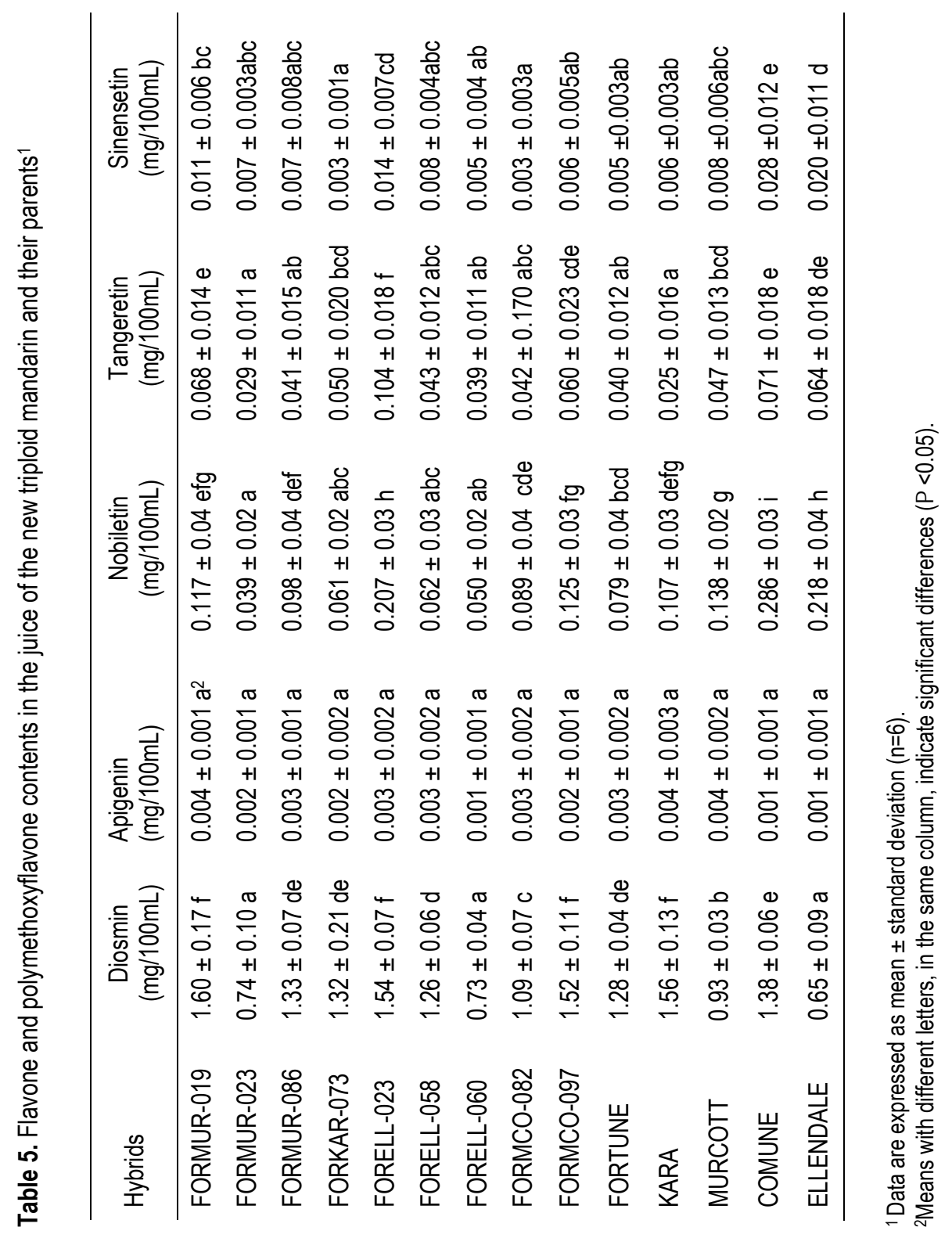


Quercetin flavonol, contained in the juice of the nine new triploid varieties and their parents were also examined and the data are shown in Table 6 . The levels of quercetin found in the present study were in the range of those reported by Wang et al. ${ }^{5}$ Kara mandarin exhibited the greatest content of quercetin which explains the high content found in FORKAR96-073 hybrid. All other triploids presented similar values as their parents. Chlorogenic and gallic acids, in all the triploids cultivars and in their parents were also quantified (Table 6). The most important phenolic acid in citrus fruit is hydroxycinnamic acid and its derivates 37 among them cholorogenic acid was found to be the major phenolic acid. ${ }^{5}$ In the present study FORMC096-097 and FORELL96-060, FORKAR96-073 and FORMUR96-086 hybrids displayed the highest content of chlorogenic acid (from 2.87 to $3.29 \mathrm{mg} / 100 \mathrm{~mL}$ ) superior than that of Fortune mandarin and their respective male parents. High levels were also detected in FORELL96-023 and FORELL96-058 which are greater than that exhibited by their male parent Ellendale tangor. Hydroxybenzoic acids such as gallic acid are also present in low concentrations in citrus fruits. 38 The results of the present study showed that all the triploids displayed slightly lower levels than their parents; being FORELL96-023 the richest with value of $0.96 \mathrm{mg} / 100 \mathrm{~mL}$. 
Table 6. Quercetin flavonol, gallic, and chlorogenic acid contents in the juice of the new triploid mandarin and their parents ${ }^{1}$

\begin{tabular}{llll}
\hline Hybrids & $\begin{array}{l}\text { Quercetin } \\
(\mathrm{mg} / 100 \mathrm{~mL})\end{array}$ & $\begin{array}{l}\text { Gallic acid } \\
(\mathrm{mg} / 100 \mathrm{~mL})\end{array}$ & $\begin{array}{l}\text { Chlorogenic acid } \\
(\mathrm{mg} / 100 \mathrm{~mL})\end{array}$ \\
\hline FORMUR-019 & $0.13 \pm 0.05 \mathrm{ab}^{2}$ & $0.80 \pm 0.04 \mathrm{~d}$ & $1.82 \pm 0.36 \mathrm{ab}$ \\
FORMUR-023 & $0.09 \pm 0.06 \mathrm{a}$ & $0.85 \pm 0.03 \mathrm{~d}$ & $1.99 \pm 0.06 \mathrm{bc}$ \\
FORMUR-086 & $0.24 \pm 0.16 \mathrm{c}$ & $0.67 \pm 0.07 \mathrm{~b}$ & $2.87 \pm 0.07 \mathrm{fg}$ \\
FORKAR-073 & $0.24 \pm 0.07 \mathrm{c}$ & $0.83 \pm 0.02 \mathrm{~d}$ & $2.95 \pm 0.11 \mathrm{gh}$ \\
FORELL-023 & $0.10 \pm 0.06 \mathrm{a}$ & $0.96 \pm 0.09 \mathrm{e}$ & $2.58 \pm 0.01 \mathrm{~cd}$ \\
FORELL-058 & $0.10 \pm 0.05 \mathrm{a}$ & $0.69 \pm 0.04 \mathrm{bc}$ & $2.32 \pm 0.05 \mathrm{~d}$ \\
FORELL-060 & $0.07 \pm 0.04 \mathrm{a}$ & $0.52 \pm 0.04 \mathrm{a}$ & $3.17 \pm 0.22 \mathrm{hi}$ \\
FORMCO-082 & $0.06 \pm 0.04 \mathrm{a}$ & $0.73 \pm 0.02 \mathrm{c}$ & $1.62 \pm 0.06 \mathrm{a}$ \\
FORMCO-097 & $0.10 \pm 0.03 \mathrm{a}$ & $0.71 \pm 0.04 \mathrm{bc}$ & $3.29 \pm 0.07 \mathrm{i}$ \\
FORTUNE & $0.07 \pm 0.04 \mathrm{a}$ & $1.13 \pm 0.02 \mathrm{f}$ & $2.18 \pm 0.04 \mathrm{~cd}$ \\
KARA & $0.66 \pm 0.15 \mathrm{~d}$ & $1.71 \pm 0.05 \mathrm{~h}$ & $1.63 \pm 0.06 \mathrm{a}$ \\
MURCOTT & $0.21 \pm 0.17 \mathrm{bc}$ & $0.80 \pm 0.03 \mathrm{~d}$ & $2.37 \pm 0.05 \mathrm{de}$ \\
COMUNE & $0.09 \pm 0.07 \mathrm{a}$ & $1.62 \pm 0.03 \mathrm{~g}$ & $2.64 \pm 0.02 \mathrm{ef}$ \\
ELLENDALE & $0.15 \pm 0.07 \mathrm{abc}$ & $1.07 \pm 0.01 \mathrm{f}$ & $1.65 \pm 0.06 \mathrm{a}$ \\
\hline
\end{tabular}

${ }^{1}$ Data are expressed as mean \pm standard deviation $(n=6)$.

${ }^{2}$ Means with different letters, in the same column, indicate significant differences $(P<0.05)$. 


\subsection{Organic acids content}

Three organic acids (citric, malic and succinic acids) were separated and identified in the juice of the tested new hybrids and their parents (data of organic acids are reported in Table 7). Citric acid is commonly present in fruits and it is the main organic acid of citrus fruits while malic and succinic acids were present in minor quantities. ${ }^{37,39}$ Willow Leaf mandarin, exhibited superior content of citric acid $(27.33 \mathrm{~g} / \mathrm{L})$ which explain the high values of acidity shown in this variety. The new hybrid with the highest content of citric acid was FORELL96-023, presenting similar values as its male parent Ellendale tangor. No significant differences were found between FORMUR96-086 and FORKAR96-073 hybrids and their female parent Fortune mandarin. The tested hybrids as well as their parents displayed higher content of malic acid than those previously reported by Kelebek and Selli ${ }^{37}$ except in Kara mandarin which presented the lowest amount $(3.84 \mathrm{~g} / \mathrm{L})$. The juice of FORELL96-023 hybrid was the richest in malic acid with similar values to that exhibited by its male parent Ellendale. FORMCO96-097 fruits displayed higher content than its parents Fortune and Willow Leaf mandarins. The levels detected in FORMUR96-019 and FORMUR96-023 hybrids were greater than that of their male parent Murcott tangor. Likewise, FORKAR96-073 fruits presented higher amount than its male parent Kara mandarins. Regarding succinic acid, the content varied widely ranging from $0.83 \mathrm{~g} / \mathrm{L}$ in Kara mandarin to $4.53 \mathrm{~g} / \mathrm{L}$ in FORELL96-060 fruit. Overall, the tested hybrids exhibited greater content of succinic acid than that displayed by their respective male parents. 
Table 7. Citric, malic and succinic acid contents in the juice of the new triploid mandarin and their parents ${ }^{1}$

\begin{tabular}{llll}
\hline Hybrids & $\begin{array}{l}\text { Citric acid } \\
(\mathrm{g} / \mathrm{L})\end{array}$ & $\begin{array}{l}\text { Malic acid } \\
(\mathrm{g} / \mathrm{L})\end{array}$ & $\begin{array}{l}\text { Succinic acid } \\
(\mathrm{g} / \mathrm{L})\end{array}$ \\
\hline FORMUR-019 & $10.94 \pm 0.19 \mathrm{a}$ & $5.93 \pm 0.19 \mathrm{e}$ & $2.37 \pm 0.10 \mathrm{e}$ \\
FORMUR-023 & $13.33 \pm 0.44 \mathrm{bc}$ & $5.96 \pm 0.17 \mathrm{e}$ & $3.12 \pm 0.07 \mathrm{~h}$ \\
FORMUR-086 & $17.63 \pm 0.40 \mathrm{e}$ & $4.90 \pm 0.23 \mathrm{~b}$ & $3.04 \pm 0.11 \mathrm{~h}$ \\
FORKAR-073 & $16.84 \pm 2.14 \mathrm{de}$ & $5.49 \pm 0.31 \mathrm{~cd}$ & $2.77 \pm 0.13 \mathrm{~g}$ \\
FORELL-023 & $13.92 \pm 0.31 \mathrm{bc}$ & $7.62 \pm 0.38 \mathrm{~h}$ & $3.60 \pm 0.23 \mathrm{i}$ \\
FORELL-058 & $21.70 \pm 0.19 \mathrm{f}$ & $4.72 \pm 0.24 \mathrm{~b}$ & $1.80 \pm 0.15 \mathrm{~d}$ \\
FORELL-060 & $13.98 \pm 0.47 \mathrm{bc}$ & $5.57 \pm 0.37 \mathrm{~d}$ & $4.53 \pm 0.11 \mathrm{j}$ \\
FORMCO-082 & $14.24 \pm 0.37 \mathrm{c}$ & $5.22 \pm 0.19 \mathrm{c}$ & $2.63 \pm 0.27 \mathrm{fg}$ \\
FORMCO-097 & $10.41 \pm 0.55 \mathrm{a}$ & $6.81 \pm 0.13 \mathrm{~g}$ & $1.68 \pm 0.08 \mathrm{~d}$ \\
FORTUNE & $16.72 \pm 0.60 \mathrm{de}$ & $6.38 \pm 0.27 \mathrm{f}$ & $2.49 \pm 0.10 \mathrm{ef}$ \\
KARA & $16.30 \pm 0.34 \mathrm{~d}$ & $3.84 \pm 0.14 \mathrm{a}$ & $0.83 \pm 0.04 \mathrm{a}$ \\
MURCOTT & $13.26 \pm 0.60 \mathrm{~b}$ & $5.31 \pm 0.19 \mathrm{~cd}$ & $1.14 \pm 0.12 \mathrm{~b}$ \\
COMUNE & $27.33 \pm 1.18 \mathrm{~g}$ & $6.20 \pm 0.38 \mathrm{ef}$ & $1.36 \pm 0.11 \mathrm{c}$ \\
ELLENDALE & $21.65 \pm 0.95 \mathrm{f}$ & $7.70 \pm 0.34 \mathrm{~h}$ & $1.03 \pm 0.09 \mathrm{~b}$ \\
\hline
\end{tabular}

${ }^{1}$ Data are expressed as mean \pm standard deviation $(n=6)$.

${ }^{2}$ Means with different letters, in the same column, indicate significant differences $(P<0.05)$. 


\subsection{Principal component analysis}

The heritability of traits such as vitamin C, phenolic compounds, organic acids and antioxidant activity in the juice belonging to the new triploid respect to their respective parents has been well discussed above. An important nutritional aspect arise from the data presented, showing the new hybrids with a major concentration in antioxidant compounds as an important factor to choose varieties with a high potential as nutraceutical source. All these new triploid hybrids were obtained from $2 \times 1 \times 2 x$ crosses, sharing 'Fortune' as female parent. Despite of the double genetic information transmitted by this parent to its progeny when such a strategy is adopted, the recombination events that take place during meiosis lead to new genetic combinations within the triploid progenies ${ }^{40}$ In fact, the $2 \mathrm{n}$ megagametophyte in 'Fortune' is formed through second division restitution, ${ }^{41}$ which implies that only around $40 \%$ of the heterozygous loci in the female parent are transmitted unchanged to the triploid offspring; moreover, the male parental influence is remarkable, due to the general high heterozygosity level in citrus cultivars. Furthermore, quality and nutritional attributes are mainly determined by multigenic inheritance. ${ }^{42}$ Therefore, the genetic background of the new analyzed triploid hybrids and complex trait inheritance causes great variability on the triploid progeny for each analyzed parameter, which has been shown with the obtained results (Tables 37). Principal Component Analysis (PCA) was used in an attempt to establish a cultivar classification using the data obtained. PCA performed on the total data set of the phytochemical compounds in the fruit juice of the new triploids indicated that the first two components, that explain $44 \%$ of the total variance, allow the nine new hybrids to be classified into different categories based on nutritional criteria (Figure 1A). The first component, accounted for $27.3 \%$ of the variance, permitted the separation of the hybrids FORELL96-060, FORMUR96019 and FORMC096-097. This differentiation is explained by a high load of vitamin C (VIT C), tangeretin (TAN), nobiletin (NOB), diosmin (DSM), malic acid (Malic) and hesperidin (HES) (Figure 1B). The second component accounting for almost $17 \%$ of the variability in the whole dataset is correlated positively with narirutin (NAT) and naringin (NAR) and inversely with eriocitrin and neoeriocitrin (Figure 1B). Interestingly, this component allowed the separation of the triploids FORELL96-023, FORELL96-058 and FORELL96-060 from the other new hybrids. This clustering could be explained by the fact that these 
varieties are strongly phyllogenetically related; having the same parents Fortune mandarins as a female parent and Ellendale tangor as a male parent.

The PCA revealed that FORELL96-023 was clearly differentiated from the other hybrids displaying the highest content of vitamin $\mathrm{C}$, hesperidin, eriocitrin, neoeriocitrin, diosmin, sinensetin, nobeletin and tangeretin, gallic acid, as well as a greater antioxidant capacity and total phenolic content (Figure 1B). FORELL96-060 also was distinguished by its higher contents of eriocitrin, neoeriocitrin and naringenin, and chlorogenic and succinic acids. 


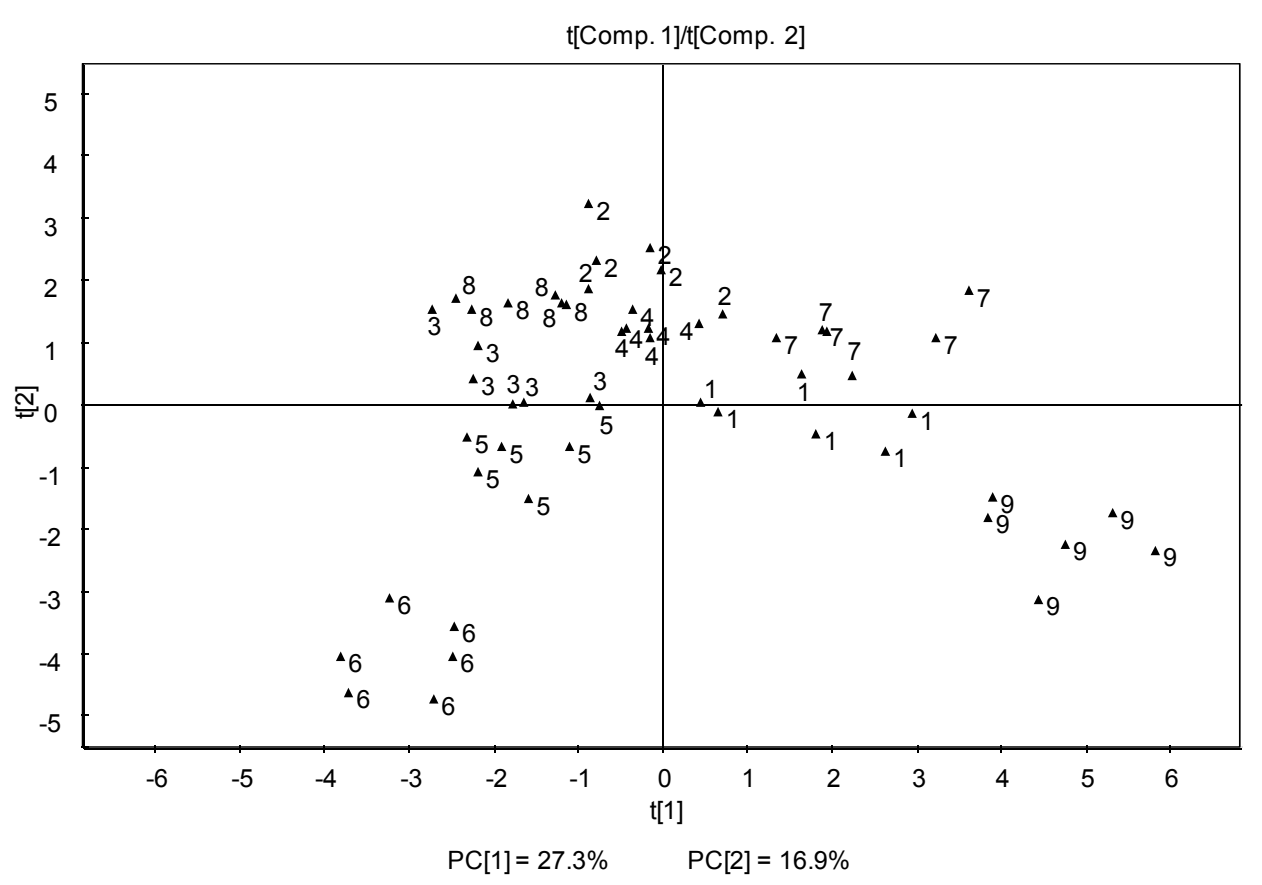

Figure 1A. Principal Component Analysis score plot based on the contents of the phytochemical compounds of the nine new triploids hybrids. Each number corresponds to a particular hybrid, as indicated in Table 1. 


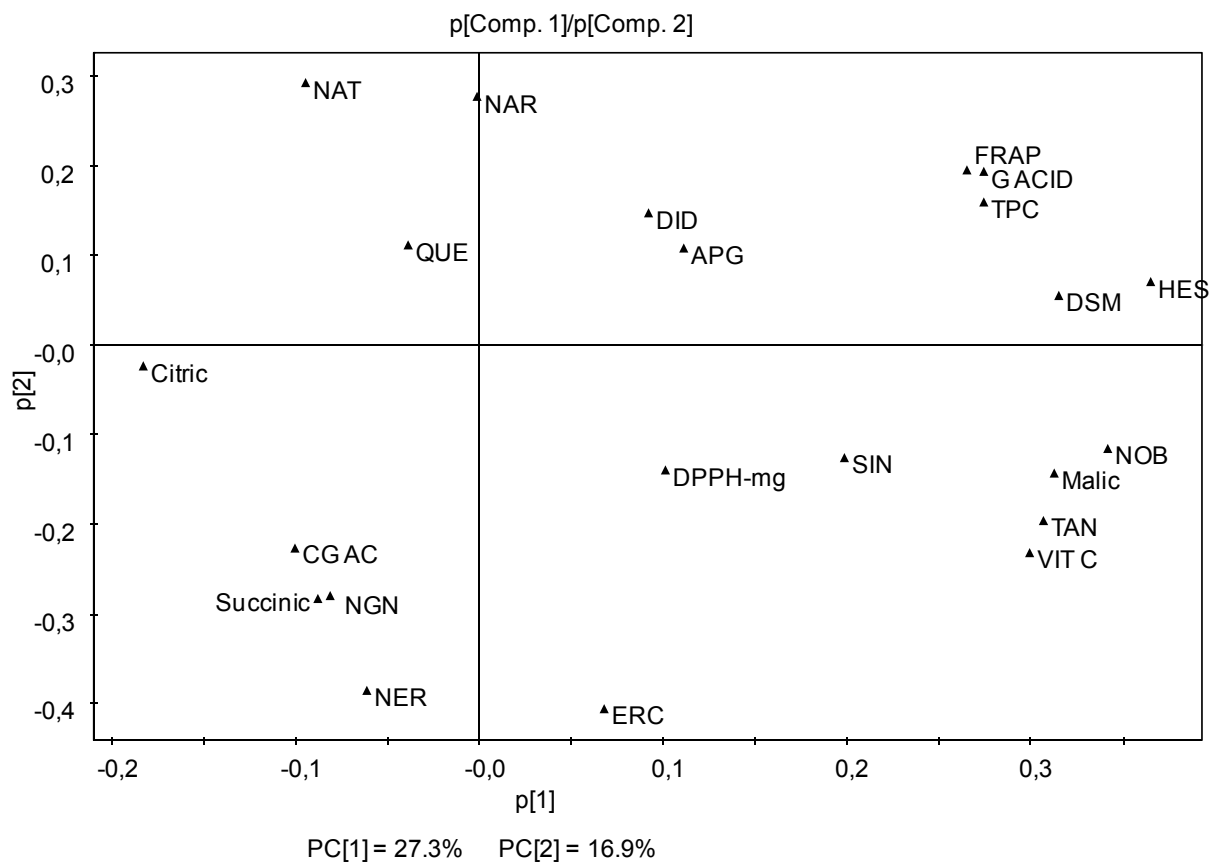

Figure 1B. Principal Component Analysis loading plot. (APG: apigenin, CG AC: cholorgenic acid, Citric: citric acid, DID: didymin, DPPH-mg: antioxidant activity measured with DPPH method, DSM: diosmin, ERC: eriocitrin, FRAP: antioxidant activity measured with FRAP method, G ACID: gallic acid, HES: hesperidin, Malic: malic acid, NAR: naringin, NAT: narirutin, NER: neoeriocitrin, NGN: naringenin, NOB: nobiletin, QUE: quercetin; SIN: sinensetin, Succinic: succinic acid, TAN: tangeretin, TPC: total phenolic content, VIT C: vitamin C). 


\section{Acknowledgment}

This research was supported by the Instituto Valenciano de Investigaciones Agrarias. The authors wish to thank Dr. Luis Navarro for his support.

\section{Literature Cited}

(1) FAO (Food and Agriculture Organization of the United Nations) (2009). Citrus Fruit, Fresh and Processed. Annual statistics. Retrieved October 02, 2011 from http://faostat.fao.org/

(2) MAGRAM (Ministerio de Medio Ambiente y Medio Rural y Marino). Anuario de Estadística. 2009. http://www.marm.es/es/estadistica. (Retrieved April 30, 2011).

(3) Navarro, L.; Juárez, J.; Aleza, P.; Pina, J.A.; Olivares-Fuster, O.; Cuenca, J.; Julve, J.M. Programa de obtención de híbridos triploides de mandarino en España. Phytoma, 2005, 170, 97-104.

(4) Rapisarda, P.; Tomaino, A.; Lo Cascio, R.; Bonina, F.; De Pasquale, A.; Saija, A. Antioxidant effectiveness as influenced by phenolic content of fresh orange juices. J. Agric. Food Chem. 1999, 47, 4718-4723.

(5) Wang, Y.C.; Chuang, Y.C.; Ku, Y.H. Quantitation of bioactive compounds in citrus fruits cultivated in Taiwan. Food Chem. 2007, 102, 1163-1171.

(6) Cano, A.; Medina, A.; Bermejo, A. Bioactive compounds in different citrus varieties. Discrimination among cultivars. J. Food Comp. Anal. 2008, 21, 377-381.

(7) Cano, A.; Alcaraz, O.; Acosta, M.; Arnao, M.B. On-line antioxidant activity determination: comparison of hydrophilic and lipophilic antioxidant activity using the ABTS-+ assay. Redox Rep. 2002, 7, 103-109.

(8) Gardner, P.T.; White, T.A.C.; McPhail, D.B.; Duthie, G.G. The relative contributions of vitamin $\mathrm{C}$, carotenoids and phenolics to the antioxidant potential of fruit juices. Food Chem. 2000, 68, 471-474. 
(9) Nogata, Y.; Sakamoto, K.; Shiratsuchi, H.; Ishii, T.; Yano, M.; Ohta, H. Flavonoid composition of fruit tissues of Citrus species. Biosci. Biotechnol. Biochem. 2006, 70, 178-192.

(10) Rice-Evans, C.A.; Miller, N.J.; Paganga, G. Structure-antioxidant activity relationships of flavonoids and phenolic acids. Free Radical Biol. Med. 1996, 20, 933-956.

(11) Pulido, R.; Bravo, L.; Saura-Calixto, F. Antioxidant Activity of Dietary Polyphenols As Determined by a Modified Ferric Reducing/Antioxidant Power Assay. J. Agric.Food Chem.2000, 48, 3396-3402.

(12) Albertini, M.V. ; Carcouet, E. ; Pailly, O. ; Gambotti C. ; Luro, F. ; Berti, L. Changes in organic acids and sugars during early stages of development of acidic and acidless citrus fruit. J. Agric.Food Chem.2006, 54, 8335-8339.

(13) Kelebek, H. Sugars, organic acids, phenolic compositions and antioxidant activity of Grapefruit (Citrus paradisi) cultivars grown in Turkey. Ind. Crop. Prod. 2010, 32, 269-274.

(14) Sdiri, S.; Navarro, P.; Monterde, A.; Benabda, J.; Salvador, A. Effect of postharvest degreening followed by a cold-quarantine treatment on vitamin $\mathrm{C}$, phenolic compounds and antioxidant activity of early-season citrus fruit. Postharvest Biol. Technol. 2012, 65, 13-21.

(15) Singleton, V.L.; Rossi, J.A. Colorimetry of total phenolics with phospomolybdic-phosphotungstic acid reagents. Am. J. Enol. Vitic. 1965, $16,144-158$.

(16) Brand-Williams, W.; Cuvelier, M.E.; Berset, C. Use of a free radical method to evaluate antioxidant activity. LWT Food Sci. Technol. 1995, 28, 25-30.

(17) Benzie, I.F.; Strain, J. Ferric reducing/antioxidant power assay: direct measure of total antioxidant activity of biological fluids and modified version for simultaneous measurement of total antioxidant power and ascorbic acid concentration: Methods Enzymol. 1999, 299, 15-27.

(18) Re, R.; Pellegrini, N.; Proteggente, A.; Pannala, A.; Yang, M.; Rice-Evans, C. Antioxidant activity applying an improved ABTS radical cation decolorizing assay. Free Radical Biol. Med. 1999, 26, 1231-1237. 
(19) Bermejo, A.; Pardo, J.; Cano, A. Influence of gamma irradiation on seedless citrus production: pollen germination and fruit quality. Food Nutri. Sci. 2011, 2, 169-180.

(18) Lee, S.K.; Kader, A.A. Preharvest and postharvest factors influencing vitamin C content of horticultural crops. Postharvest Biol. Technol. 2000, 20, 207-220.

(19) Tounsi, M.S.; Wannes, W.A.; Ourghemmi, I.; Jegham, S.; BenNjima, Y.; Hamdaoui, G.; Zemni, H.; Marzouk, B. Juice components and antioxidant capacity of four Tunisian Citrus varieties. J. Sci. Food Agric. 2011, 91, 142151.

(20) Rapisarda, P.; Lo Bianco, M.; Pannuzzo, P.; Timpanaro, N. Effect of cold storage on vitamin $C$, phenolics and antioxidant activity of five orange genotypes [Citrus sinensis (L.) Osbeck]. Postharvest Biol. Technol. 2008, $49,348-354$.

(21) Huang, R.; Xia, R.; Hu, L.; Lu, Y.; Wang, M. Antioxidant activity and oxygen-scavenging system in orange pulp during fruit ripening and maturation. Scientia Hortic. 2007, 113, 166-172.

(22) Roginsky, V.; Lissi, E.A. Review of methods to determine chain-breaking antioxidant activity in food. Food Chem. 2005, 92, 235-254.

(23) Abeysinghe, D.C.; Li, X.; Sun, C.D.; Zhang, W.S.; Zhou, C.H.; Chen, K.S. Bioactive compounds and antioxidant capacities in different edible tissues of citrus fruit of four species. Food Chem. 2007, 104, 1338-1344.

(24) Klimczak, I.; Malecka, M.; Szlachta., M.; Gliszczynska-Swiglo, A. Effect of storage on the content of polyphenols, vitamin $\mathrm{C}$ and the antioxidant activity of orange juices. J. Food Comp. Anal. 2007, 20, 313-322.

(25) Peterson, J.J.; Dwyer, J.T.; Beecher, G.R.; Bhagwat, S.A.; Gebhardt, S.E.; Haytowitz, D.B.; Holden, J.M. Flavanones in oranges, tangerines (mandarins), tangors, and tangelos: a compilation and review of the data from the analytical literature. J. Food Comp. Anal. 2006, 19, S66-S73.

(26) Rapisarda, P.; Fabroni, S.; Peterek, S.; Russi, G.; Mock, H.P. Juice of new citrus hybrids (Citrus clementina Hort.ex Tan. x C. sinensis L. Osbeck) as a source of natural antioxidants. Food Chem. 2009, 117, 212-218. 
(27) Stuetz, W.; Prapamontol, T.; Hongsibsong, S.; Biesalski, H.K. Polymethoxylated Flavones, Flavanone Glycosides, Carotenoids, and Antioxidants in Different Cultivation Types of Tangerines (Citrus reticulata Blanco cv. Sainampueng) from Northern Thailand. J. Agric. Food Chem. 2010, 58, 6069-6074.

(28) Dhuique-Mayer, C. ; Caris-Veyrat, C. ; Ollitrault, P. ; Curk, F. ; Amiot, M.J. Varietal and interspecific influence on micronutrient contents in Citrus from the Mediterranean area. J. Agric. Food Chem. 2005, 53, 2140-2145.

(29) Minato, K.; Miyake, Y.; Fukumoto, S.; Yamamoto, K.; Kato, Y.; Shimomura, Y.; Osawa, T. Lemon flavonoid, erioctrin, suppresses exercise-induced oxidative damage in rat liver. Life Sci. 2003, 72, 1609-1616.

(30) Xu, G.; Liu, D.; Chen, J.; Ye, X.; Ma, Y.; Shi, J. Juice components and antioxidant capacity of citrus varieties cultivated in China. Food Chem. 2008, 106, 545-551.

(31) Ye, X.Q.; Chen, J.C.; Liu, D.H.; Jiang, P.; Shi, J.; Xue, S.; Wu, D.; Xu, J.G.; Kakuda, Y. Identification of bioactive composition and antioxidant activity in young mandarin fruits. Food Chem. 2011, 124, 1561-1566.

(32) Kawaii, S.; Tomono, Y.; Katase, E.; Ogawa, K.; Yano, M. Quantitation of flavonoid constituents in citrus fruits. J. Agri. Food Chem. 1999, 47, 35653571.

(33) Tripoli, E.; La Guardia, M.; Giammanco, S.; Di Majo, D.; Giammanco, M. Citrus flavonoids: Molecular structure, biological activity and nutritional properties: A review. Food Chem. 2007, 104, 466-479.

(34) Kawaii, S.; Tomono, Y.; Katase, E.; Ogawa, K. Quantitative study of fruit flavonoids in Citrus hybrids of King (C.nobilis) and Mukaku Kishu (C. kinokuni). J. Agric. Food Chem. 2001, 49, 3982-3986.

(35) Kelebek, H.; Selli, S. Determination of volatile, phenolic, organic acid and sugar components in Turkish cv. Dortyol (Citrus sinensis L. Osbeck) orange juice. J. Sci. Food Agric. 2010, 91, 1855-1862.

(36) Kelebek, H.; Canbas, A.; Selli, S. Determination of phenolic composition and antioxidant capacity of blood orange juices obtained from cvs. Moro and Sanguinello (Citrus sinensis (L.) Osbeck) grown in Turkey. Food Chem. 2008, 107, 1710-1716. 
(37) Roussos, P.A. (2011). Phytochemicals and antioxidant capacity of orange (Citrus sinensis (I). Osbeck cv. Salustiana) juice produced under organic and integrated farming system in Greece. Scientia Hortic. 2011, 129, 253258.

(38) Ollitrault, P.; Dambier. D.; Luro, F.; Froelicher, Y. Ploidy manipulation for breeding seedless triploid citrus. In Plant Breeding Reviews, edition no.: Janick, J., Ed.; John Wiley \& Sons, Inc., Hoboken, NJ, USA, 2008, pp. 323352.

(39) Cuenca, J.; Froelicher Y.; Aleza, P.; Juárez, J.; Navarro, L.; Ollitrault, P. Multilocus half-tetrad analysis and centromere mapping in citrus: evidence of SDR mechanism for $2 \mathrm{n}$ megagametophyte production and partial chiasma interference in mandarin cv 'Fortune'. Heredity 2011, 107, 462470.

(40) Fanciullino, A.L. ; Dhuique-Mayer, C. ; Luro, F. ; Morillon, R. ; Ollitrault, P. Carotenoid Biosynthetic Pathway in the Citrus Genus: Number of Copies and Phylogenetic Diversity of Seven Genes. J. Agric. Food Chem. 2007, 55, 7405-7417. 


\section{Postharvest behavior of 'Garbi' and 'Safor' - new triploid mandarins}

Sdiri, S. ${ }^{1}$; Navarro, P. ${ }^{1}$; Monterde, A. ${ }^{1}$; Cuenca, J. ${ }^{2}$; Aleza, P. ${ }^{2}$; Ben Abda, J. ${ }^{3}$; Salvador, A. ${ }^{1}$

\footnotetext{
${ }^{1}$ Centro de Tecnología Postcosecha, Instituto Valenciano de Investigaciones Agrarias, Carretera Moncada-Náquera Km 4.5 s/n, 46113, Moncada, Valencia, Spain.

${ }^{2}$ Centro de Protección Vegetal y Biotecnología, Instituto Valenciano de Investigaciones Agrarias, Carretera Moncada-Náquera Km 4.5 s/n, 46113, Moncada, Valencia, Spain.

${ }^{3}$ Département d'Agroalimentaire, Institut Supérieur Agronomique de chottMariem, 4042, Sousse, Tunisia
}

Reference: Acta Horticulturae, 2012, 945: 255-262. 



\begin{abstract}
'Garbi' (Fortune X Murcott) and 'Safor' (Fortune X Kara) are the Valencian Institute of Agrarian Research's most recent citrus varieties to be released for commercial production. Those two new varieties are late-maturing triploid mandarins, and they were studied and tested in the Plant Protection and Biotechnology Center in the IVIA. During two seasons the postharvest behavior of both varieties were evaluated in the Postharvest Technology Center. The effect of storage temperature on quality of 'Garbi' and 'Safor' mandarins were studied. Fruit were stored up to 30 days at $1^{\circ} \mathrm{C}, 5^{\circ} \mathrm{C}$, or $9^{\circ} \mathrm{C}$, and then fruit were stored at $20^{\circ} \mathrm{C}$ during 6 days simulating shelf-life. The incidence of chilling injury was evaluated; 'Garbi' mandarins were more sensitive to chilling injury than 'Safor' mandarins when stored at $1^{\circ} \mathrm{C}$ or $5^{\circ} \mathrm{C}$. However, this sensitivity was lower than that shown by 'Fortune' mandarins in previous studies. 'Safor' mandarins did not show symptoms of chilling injury at any storage temperature studied, when the fruit were previously coated. For both mandarin varieties, fruit quality, including firmness, weight loss, soluble solids, titratable acidity, and ethanol content were not affected by storage at low temperature.
\end{abstract}

Keywords: citrus, storage, chilling injury, temperature, fruit quality 


\section{INTRODUCTION}

In the Plant Protection and Biotechnology Center in the Valencian Institute of Agrarian Research, an ambitious triploid breeding program for obtaining new mid- and late-maturing triploid mandarins is being carried out (Navarro et al., 2002). 'Safor' and 'Garbi' mandarins are the new triploids hybrids released that were characterized by their high quality and seedless fruits. 'Safor' mandarin, obtained from a cross between 'Fortune' mandarin ( $C$. clementina $\times C$. tangerina) and 'Kara' mandarin (C. unshiu $\times$ C. nobilis), is a mid-late ripening cultivar; fruit can be harvested from mid-February until the end of March (Aleza, 2009; Cuenca et al., 2010). 'Garbi' mandarin, obtained from a cross between 'Fortune' mandarin (C. clementina $\times$ C. tangerina) and 'Murcott' tangor ( $C$. reticulata $\times C$. sinensis), is a late-maturing cultivar; fruit can reach optimum maturity at the end of March, although they can be harvested from midFebruary until the end of April (Aleza et al., 2009, 2010). These new cultivars are being released for commercial propagation which requires the study of postharvest behavior of fruit, and in particular the assessment of the suitability for cold storage, in order to extend the fruit marketing.

Some citrus varieties are susceptible to chilling injury $(\mathrm{Cl})$ when exposed to prolonged cold storage at low temperatures (Sanchez-Ballesta et al., 2003). The critical temperature, at which the chilling injury can appear in different types of physiological disorders, largely depends on the variety (Martínez -Jávega et al, 2004). For that reason, it is necessary to study the susceptibility of 'Garbi' and 'Safor' mandarins to develop chilling injury symptoms when stored at low temperatures, since, their parent is 'Fortune' mandarin. It has been known that 'Fortune' mandarin (Citrus clementina Hort. ex Tanaka x Citrus tangerina Hort. Ex Tan) is a citrus cultivar very sensitive to chilling injury either on the tree (Vercher et al., 1994) or when stored at temperatures below $10^{\circ} \mathrm{C}$ (MartínezTéllez and Lafuente, 1993; Schirra and D'hallewin, 1997).

The aim of the present work was to study the sensitivity to chilling injury of 'Safor' and 'Garbí mandarins subjected to cold storage at different temperatures. 


\section{MATERIAL AND METHODS}

\section{Plant material and treatments}

'Safor' and 'Garbi' mandarins were harvested from the experimental farm (Anecoop Museros Foundation) at two harvest dates ( $\mathrm{H} 1$ and $\mathrm{H} 2)$. The experiments were replicated during two years (2008 and 2010). After harvest, undamaged fruit from both cultivars were selected according to uniformity in size, dipped in a solution of Imazalil (400ppm) and then separated into different lots of 25-50 fruits, depending on the availability of fruit, for storage.

During the first season (2008), uncoated fruit from both cultivars were stored at $1^{\circ} \mathrm{C}, 5^{\circ} \mathrm{C}$ or $9^{\circ} \mathrm{C}$ for 15 or 30 days followed by 6 days at $20^{\circ} \mathrm{C}$ simulating shelf-life period. During the second season (2010), in addition to the storage of coated fruit (Waterwax TT-2I, Fomesa Fruitech S.L.U, Spain) at $1^{\circ} \mathrm{C}$, $5^{\circ} \mathrm{C}$, or $9^{\circ} \mathrm{C}$, another lot of fruit was stored at $5^{\circ} \mathrm{C}$ for 5 days simulating the marketing to the European Union (EU), followed by shelf-life conditions. The incidence of physiological disorders, weight loss, firmness, total soluble solids, titratable acidity, juice yield and ethanol content were evaluated. Sensory evaluation of fruit flavor was also performed.

\section{Quality attributes determination}

At harvest, the color index of each fruit per lot was measured with a Minolta colorimeter (model CR-300, Minolta Co. Ltd, Osaka, Japan), taking 3 measurements in the equatorial zone of each fruit. The mean values for ' $L$ ', ' $a$ ' and ' $b$ ' Hunter parameters were calculated for each fruit and expressed as Citrus Color Index $(\mathrm{CCl})(\mathrm{CCl}=1000 \mathrm{a} / \mathrm{Lb})$. Firmness measurements were made with an Universal Testing Machine (model 3343, Instron Limited, Buckinghamshire, England) using 20 fruits per treatment; the results were expressed as the percentage of millimetres of fruit deformation resulting from 10 $\mathrm{N}$ pressure on the longitudinal axis at a constant speed. Twenty fruits per treatment were used to measure weight loss and the results were expressed as a percentage of weight loss from initial weight. The maturity index was calculated as TSS/TA ratio; for each treatment, juices from three samples of ten 
fruit each were obtained. Titratable acidity (TA) was determined by volumetric titration with $0.1 \mathrm{NaOH}$ solution on $5 \mathrm{~mL}$ of juice. Total soluble solids content (TSS) in the juice was determined by measuring the refractive index of the juice and the data were expressed as ${ }^{\circ}$ Brix. The juice yield was expressed as a percentage. Three replicates from each juice sample per treatment were analyzed with the headspace method (Ke and Kader, 1990) by gas chromatography. Ethanol was identified by comparison of retention time with a standard solution and expressed as $\mathrm{mg} / 100 \mathrm{~mL}$. The sensory evaluation was assessed by eight to ten semi-trained judges. Flavor was determined using a 9point scale, where $1=$ extremely unpleasant, $5=$ fair, and $9=$ excellent. Physiological disorders that appeared during the cold storage were classified as chilling injury $(\mathrm{Cl})$ by visual rating, according to the rind surface affected, on the scale: $0=$ none; $1=$ slight $(<25 \%) ; 2=$ moderate $(25-50 \%) ; 3=$ severe $(>50 \%)$.

\section{Statistical analysis}

Statistical procedures were performed using a statistical software (Statgraphics plus 5.1, Manugistics, Inc., Rockville, MD, U.S.A.). All data were subjected to analysis of variance, and means were compared using LSD test at $P \leq 0.05$.

\section{RESULTS AND DISCUSSION}

\section{Chilling injury susceptibility}

\section{'Garbí' mandarins}

The effect of different storage conditions on the susceptibility to chilling injury of 'Garbi' mandarins is shown in Tables 1 and 2. In 2010 season, the fruit did not show any physiological disorders when submitted to a simulation of marketing to the European Union, showing after 5 days at $5^{\circ} \mathrm{C}$ plus 6 days at $20^{\circ} \mathrm{C}$ high external quality. After 15 days at $1^{\circ} \mathrm{C}$ and $5^{\circ} \mathrm{C}$ fruit from $\mathrm{H} 2$ showed 
no symptoms of chilling injury in 2008. The alterations observed in 2010 season were related to symptoms of dehydration.

According to the results of the first year of study, after storage for up to 30 days, fruit were sensitive to low temperatures and showed peel pitting disorders as a symptoms of chilling injury, reaching values of $\mathrm{Cl}$ index of about 0.9 and 0.45 at $1{ }^{\circ} \mathrm{C}$ and $5^{\circ} \mathrm{C}$ respectively. Fruit stored at $9^{\circ} \mathrm{C}$ presented symptom of peel dehydration which reflected in the high $\mathrm{Cl}$ index values. One of the main causes of quality loss during postharvest handling of citrus fruit is the water loss through transpiration. It is known that water stress may be a major determinant of peel pitting (BenYehoshua et al., 2001; Lafuente and Sala, 2002; Porat et al., 2004; Alférez et al., 2005; Henriod, 2006).

\section{'Safor' mandarins}

The effect of different storage conditions on the susceptibility to chilling injury of 'Safor' mandarins is shown in Tables 3 and 4. In 2010 season, fruit submitted to the simulation of marketing to the European Union showed lower sensitivity to chilling injury. During both seasons, 'Safor' mandarins did not show relevant symptoms related to cold-induced damage or dehydration at $1^{\circ} \mathrm{C}, 5^{\circ} \mathrm{C}$ and $9^{\circ} \mathrm{C}$ for 15 days of storage. In 2008 season, when stored for 30 days fruit showed higher incidences of $\mathrm{Cl}$, reaching values of $\mathrm{Cl}$ index of about $0.80,0.42$ and 0.63 at $1^{\circ} \mathrm{C}, 5^{\circ} \mathrm{C}$ and $9^{\circ} \mathrm{C}$ respectively. Nevertheless, in the season 2010 , the symptoms of chilling injury were lower; this fact is due to the wax application. It is known that waxing minimize the $\mathrm{Cl}$ and peel pitting of mandarins stored at $5^{\circ} \mathrm{C}$ (Bajwa and Anjum, 2007).

\section{Fruit quality}

\section{‘Garbí' mandarins}

Changes in fruit quality parameters of the 'Garbi' mandarins after storage at different conditions are shown in tables 1 and 2 . 
'Garbi' mandarins were harvested with external color index $(\mathrm{CCl})$ values higher than 13, greater than the minimum established for this cultivar (Aleza et al., 2010). At harvest, and for both harvest dates, 'Garbi' mandarins had an excellent internal quality, with high values of TSS and TA contents, which is reflected in a suitable TSS/TA ratio with high sensory assessment.

The weight loss was significantly greater at $5^{\circ} \mathrm{C}$ than at $1{ }^{\circ} \mathrm{C}$, but only exceeded $10 \%$ in the fruit stored at $9^{\circ} \mathrm{C}$ (Table 1). The fruit firmness decreased after cold storage with the percentage deformation being significantly greater after storage at $9^{\circ} \mathrm{C}$ for 30 days (Table 1). In 2010, the lower percentages of weight loss correlated with the lower percentage deformation due to the wax application. Previous studies found that wax application reduce weight loss and maintain firmness of citrus fruit (Hagenmaier and Baker, 1995; Chien et al., 2007; Valencia-Chamorro et al., 2009).

TA, TSS and TSS/TA were not strongly affected by the storage at different temperatures and periods. In all cases, the juice yield values decreased slightly after storage, but remained higher than the required minimum quality standards for citrus (40\%). The ethanol content increased during storage; the higher the storage temperature, the higher the ethanol content. The increase in ethanol concentration, however, did not appear to negatively influence flavor as flavor scores at harvest were similar to those after harvest. 


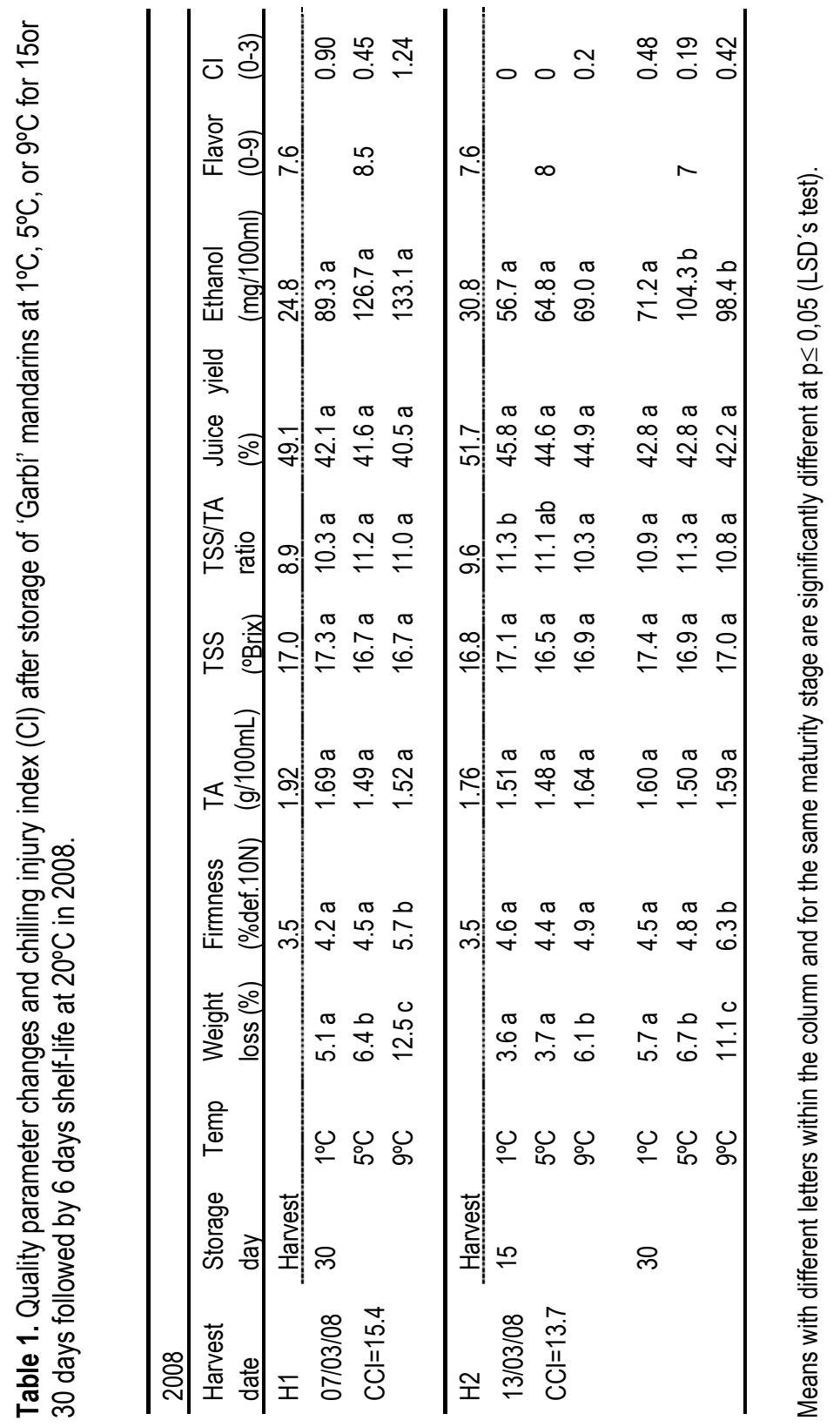




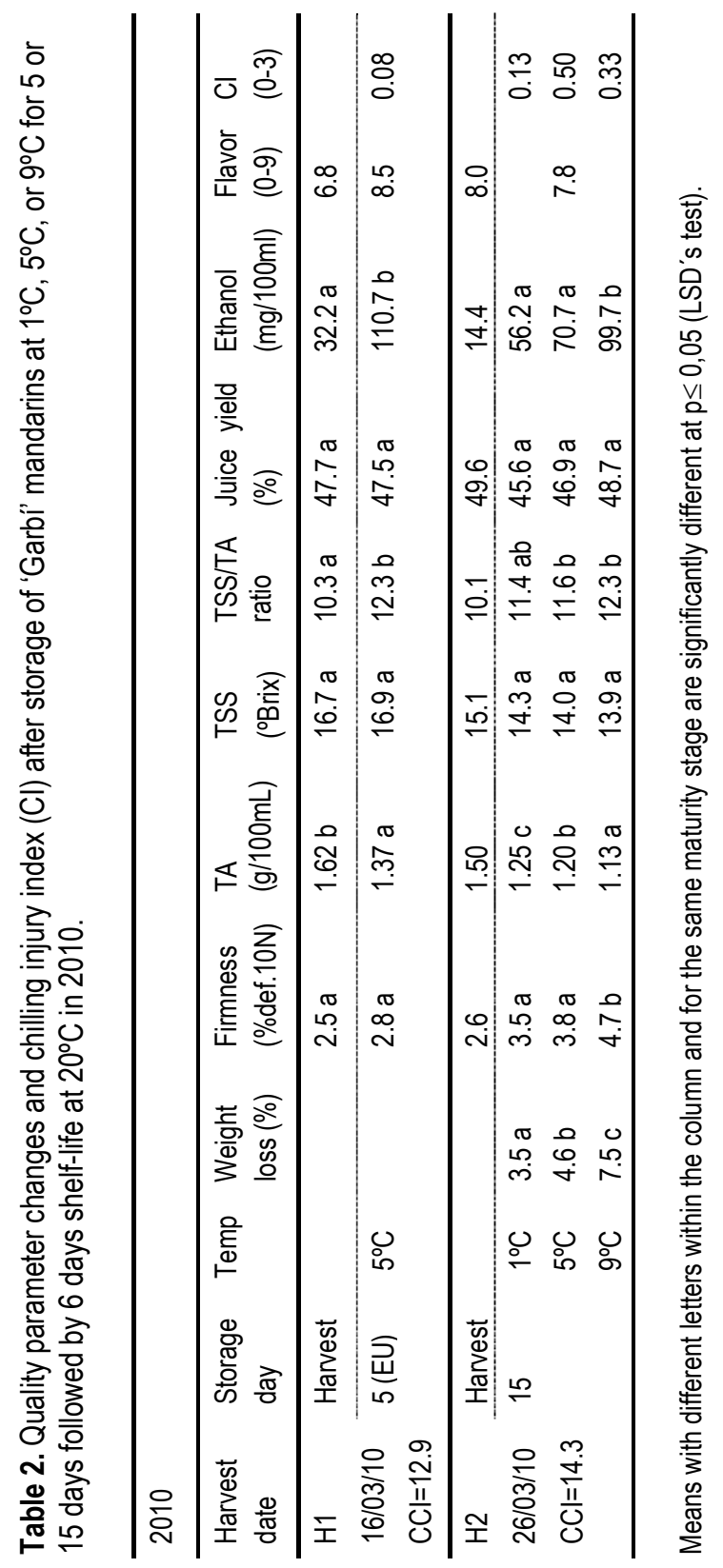




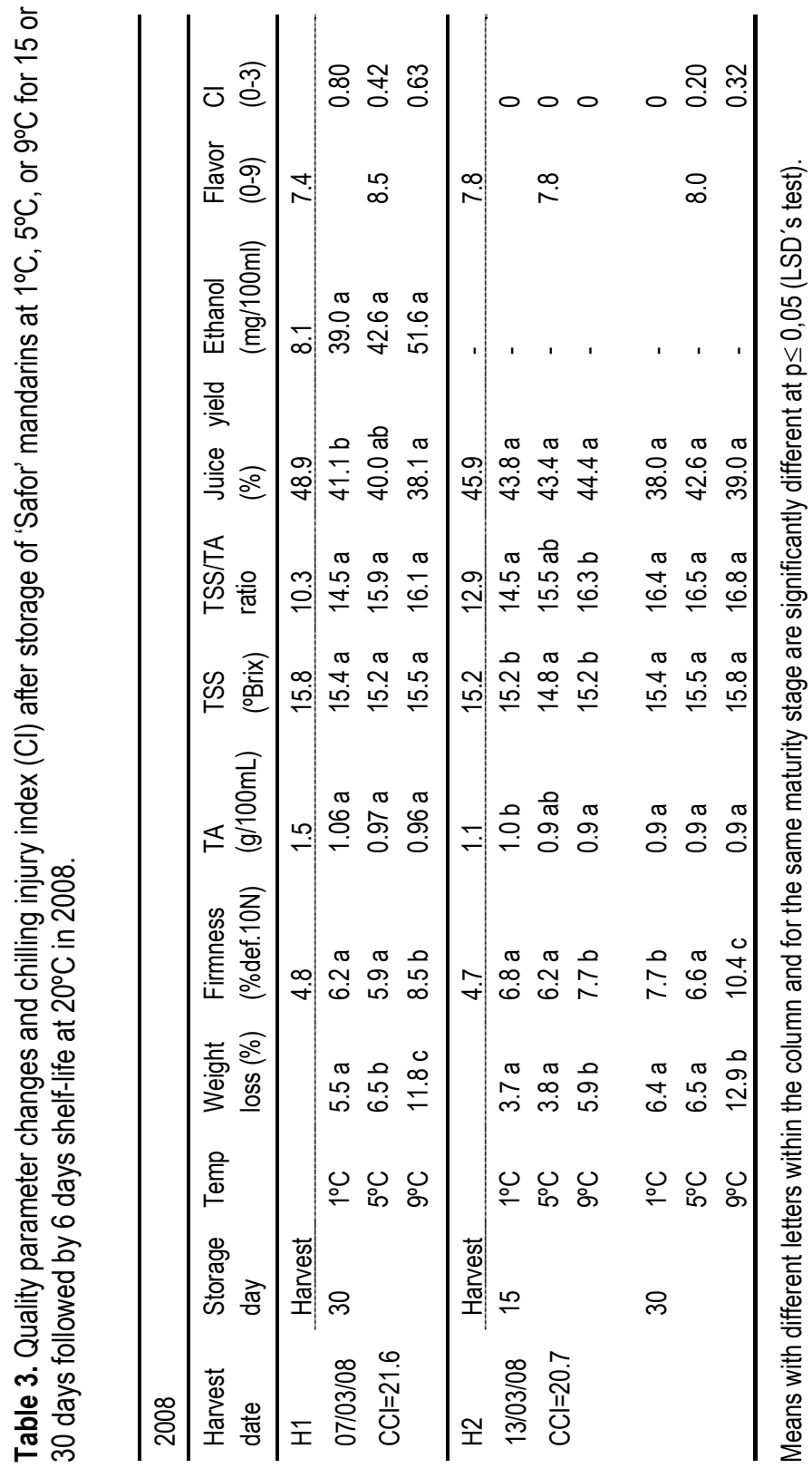




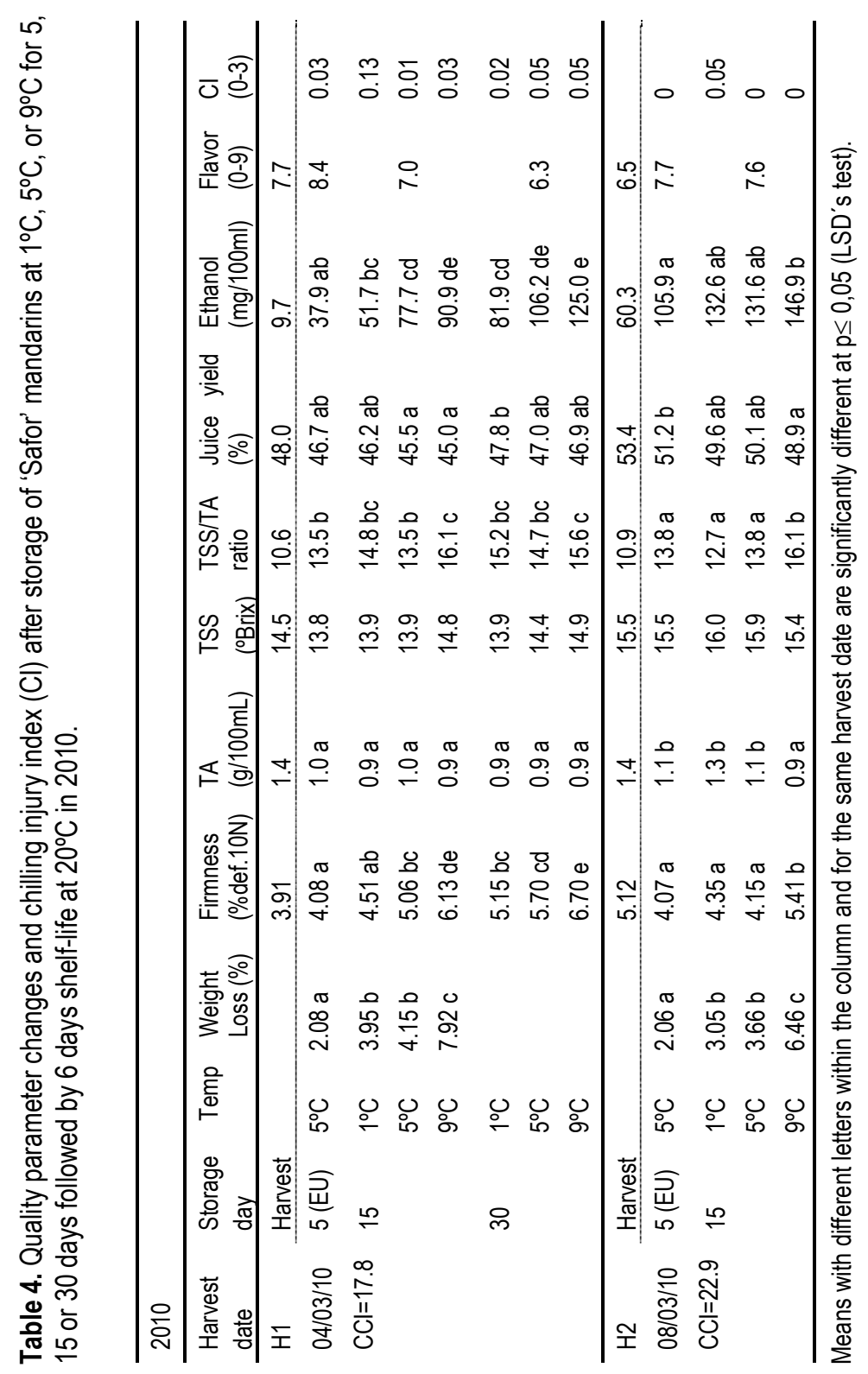




\section{CONCLUSION}

According to the obtained results, both 'Safor' and 'Garbi' mandarins, harvested at optimum maturity, can be marketed for European Union without any risk of quality loss. Furthermore, fruit can be stored at $1^{\circ} \mathrm{C}$ or $5^{\circ} \mathrm{C}$ during 15 days without showing physiological disorders that limit the fruit marketing.

Although 'Safor' and 'Garbí' mandarins have presented some sensitivity to chilling injury during storage at $1^{\circ} \mathrm{C}$ and $5^{\circ} \mathrm{C}$, especially in prolonged storage of 30 days, this sensitivity was much lower than that exhibited by the 'Fortune' mandarins.

In order to confirm the preliminary data obtained in these two seasons, a third season of study is required; it is necessary to establish the optimum temperature and time conditions suitable for the storage of 'Safor' and 'Garbi' mandarins.

\section{ACKNOWLEDGEMENTS}

This research has been funded by the Spanish Ministerio de Educación y Ciencia (INIA Proyect RTA 2007-00101-00-00) and by the EU FEDER program. The authors wish to thank to FONTESTAD S.A. for its technical support.

\section{Literature Cited}

Aleza, P., Cuenca, J., Juárez, J. Pina, J.A. and Navarro, L. 2010. 'Garbí' mandarin, a new late-maturing triploid hybrid. HortScience. 45:139-141.

Aleza, P., Cuenca, J., Juárez, J., Pina, J.A. and Navarro, L. 2009. Mandarinos 'Garbí' y 'Safor', dos nuevos híbridos triploides obtenidos en el IVIA. Levante Agrícola. 395:85-87. 
Alférez, F., Zacarías, L. and Burns, J. 2005. Low relative humidity at harvest and before storage at high humidity influences the severity of postharvest peel pitting in citrus. J. Amer. Soc. Hort. Sci. 130: 225-231.

Bajwa, B.E. and Anjum, F.M. 2007. Improving storage performance of Citrus reticulate Blanco mandarins by controlling some physiological disorders. International J. Food Sci. Technol. 42: 495-501.

Ben Yehoshua, S., Peretz, J., Moran, R., Lavie, B. and Kim, J.J. 2001. Reducing the incidence of superficial flavedo necrosis (noxan) of 'Shamouti' oranges (Citrus sinensis, Osbeck). Postharvest Biol. Technol. 22, 19-27.

Chien, P.-J, Sheu, F. and Lin, H.-R, 2007. Coating citrus (Murcott tangor) fruit with low molecular weight chitosan increases postharvest quality and shelf life. Food Chem. 100: 1160-1164.

Cuenca, J., Aleza, P., Juárez, J., Pina, J.A. and Navarro, L. 2010. 'Safor' mandarin: a new mid-late citrus triploid hybrid. HortScience. 45:977-980.

Hagenmaier, R. and Baker, R., 1995. Layered coatings to control weight loss and preserve gloss of citrus fruit. HortScience. 30: 296-298.

Hagenmaier, R. D. and Shaw, P. E. 2002. Changes in volatile components of stored tangerines and other specialty citrus fruits with different coatings. J. Food Sci. 67: 1742-1745.

Henriod, R.E. 2006. Postharvest characteristics of navel oranges following high humidity and low temperature storage and transport. Postharvest Biol. Technol. 42: 57-64.

Ke, D. and Kader, A.A. 1990. Tolerance of 'Valencia' oranges to controlled atmospheres as determined by physiological responses and quality attributes. J. Amer. Soc. Hort. Sci. 115(5): 779-783.

Lafuente, M.T. and Sala, J.M. 2002. Abscisic acid levels and the influence of ethylene, humidity and storage temperature on the incidence of postharvest rindstaining of 'Navelina' orange (Citrus sinensis L. Osbeck) fruit. Postharvest Biol. Technol. 25: 49-57.

Martínez-Jávega, J.M., Cuquerella, J., Salvador, A., Monterde, A. and Navarro, P. 2004. Adecuación de tratamientos postcosecha a parámetros de 
recolección de mandarinas y naranjas de España. Red Interamericana de Cítricos. No. 23 y 24: 23-33.

Martínez-Téllez, M.A. and Lafuente, M.T. 1993. Chilling induced changes in phenylalanine ammonia-lyase, peroxidase, and polyphenol oxidase activities in citrus flavedo tissue. Acta Hort. 343: 257-263.

Navarro, L., Juárez, J., Aleza, P., Pina, J.A., Olivares-Fuster, O., Cuenca, J. and Julve, J.M. 2005. Programa de obtención de híbridos triploides de mandarino en España. Phytoma. 170: 97-104.

Porat, R., Weiss, B., Cohen, L., Daus, A. and Aharoni, N. 2004. Reduction of postharvest rind disorders in citrus fruit by modified atmosphere packaging. Postharvest Biol. Technol. 33: 35-43.

Sanchez-Ballesta, M.T., Lluch, Y., Gosalbes, M.J., Zacarias, L., Granell, A. and Lafuente, M.T., 2003. A survey of genes differentially expressed during long-term heat-induced chilling tolerance in citrus fruits. Planta. 218: 65-70.

Schirra, M. and D'hallewin, G. 1997. Storage performance of 'Fortune' mandarins following hot water dips at various temperatures. Postharvest Biol. Technol. 10: 229-238.

Valencia-Chamorro, S.A., Pérez-Gago, M.B., Del Río, M.A. and Palou, L. 2009. Effect of antifungal hydroxypropyl methylcellulose (HPMC)-lipid edible composite coatings on postharvest decay development and quality attributes of cold-stored 'Valencia' oranges. Postharvest Biol. Technol. 54: 72-79.

Vercher, R., Tadeo, F.R., Almela, V., Zaragoza, S., Primo-Millo, E. and Agustí, M. 1994. Rind structure, epicuticular wax morphology and water permeability of 'Fortune' mandarin fruits affected by peel pitting. Ann. Bot. 74: 619-625. 



\title{
Estudio del comportamiento postcosecha de nuevas variedades triploides de mandarinas tardías
}

\author{
Sdiri, S. ${ }^{1}$; Navarro, P. ${ }^{1}$; Cuenca, J. ${ }^{2}$; Salvador, A. ${ }^{1}$ \\ ${ }^{1}$ Centro de Tecnología Postcosecha, Instituto Valenciano de Investigaciones \\ Agrarias, Carretera Moncada-Náquera Km 4.5 s/n, 46113, Moncada, Valencia, \\ Spain. \\ ${ }^{2}$ Centro de Protección Vegetal y Biotecnología, Instituto Valenciano de \\ Investigaciones Agrarias, Carretera Moncada-Náquera Km 4.5 s/n, 46113, \\ Moncada, Valencia, Spain.
}

Reference: Submitted to Levante Agrícola 



\section{Resumen}

En el Centro de Protección Vegetal y Biotecnología del IVIA se está llevando a cabo un programa de mejora para la obtención de variedades triploides de mandarinas tardías sin semillas destinadas al consumo en fresco. En la actualidad se han seleccionado nueve de ellas, que están en proceso de registro, por su elevada calidad organoléptica y su buen comportamiento agronómico. En el presente estudio se evaluó la aptitud a la conservación de estas nuevas variedades triploides. Para ello la fruta de todas las variedades fue recolectada de las parcelas experimentales del IVIA y almacenada a $1^{\circ} \mathrm{C}, 5^{\circ} \mathrm{C}$ ó $9^{\circ} \mathrm{C}$ durante un periodo máximo de 30 días. Además se conservó fruta a $5^{\circ} \mathrm{C}$ durante 3 días simulando las condiciones de comercialización a países de la Unión Europea. Tras las diferentes condiciones de conservación, se observó que los cambios en los parámetros de calidad interna en la fruta de las diferentes variedades no fue una limitación para su comercilaización. Sin embargo la manifestación de los daños por frio como consecuencia de la sensibilidad a las bajas temperaturas fue diferente en cada una de las variedades. Las variedades PRI-48 (FORELL 96-023) y TRI-5 (FORMCO 95-097) no mostraron síntomas de daños por frío o de deshidratación bajo ninguna de las condiciones de almacenamiento ensayadas, presentando una buena aptitud a la frigoconservación. La fruta de las variedades PRI-43 (FORELL 96-058), PRI-46 (FORMUR 96-019) y TRI-7 (FORMUR 96-086) presentó buen aspecto sin incidencia de alteraciones tras la simulación de comercialización a la UE. Las variedades TRI-6 (FORMCO 96-082), PRI-44 (FORELL 96-060) y PRI-47 (FORMUR 96-023) mostraron una mayor sensibilidad a las bajas temperaturas desarrollando síntomas de daños por frío cuando la fruta fue almacenada incluso en la simulación de las condiciones de comercialización a la UE. La variedad TRI-8 (FORKAR 96073) presentó síntomas de ennegrecimiento de glándulas tras la conservación frigorífica, que se relacionó con la sensibilidad al daño mecánico provocado por el paso por línea de confección.

Palabras claves: triploides, frigoconservación, temperatura, daños por frío, calidad. 


\section{1- INTRODUCCIÓN}

Los cítricos son el principal cultivo frutal en el mundo, cuya producción mundial ha experimentado un crecimiento continuo en las últimas décadas. Actualmente, según datos de la $\mathrm{FAO}$ en el año 2009 se produjeron 100 millones de toneladas, siendo España el cuarto productor de cítricos del mundo después de Brasil, Estados Unidos y China. En el marco de la producción y exportación de frutos cítricos para el consumo en fresco, en la cuenca mediterránea, España es el principal país productor y exportador de cítricos, cuya producción en 2010 superó los 6 millones de toneladas, de los cuales más de 2 millones corresponden a clementinas, satsumas y otras mandarinas. La gran mayoría de la producción española de mandarinas está destinada a la exportación, siendo la Unión Europea el principal destino (MAGRAMA, 2012), sin olvidar que actualmente están aumentando las exportaciones a países de ultramar donde se exige tratamiento de cuarentena por frío para la eliminación de la mosca del mediterráneo (USA, Japón, Corea y China).

El período de recolección de mandarinas (satsumas, clementinas e híbridos) en España se extiende desde septiembre a mayo con una concentración de la oferta en el período que va desde mediados de octubre a final de enero. A partir de esta fecha la oferta de mandarinas se reduce de forma importante, quedando en el mercado únicamente los híbridos. Para alargar el período de oferta se están haciendo grandes esfuerzos en la introducción de nuevas variedades de mandarinas de recolección tardía con frutos de alta calidad y sin semillas. En este sentido, en el Centro de Protección Vegetal y Biotecnología del Instituto Valenciano de Investigaciones Agrarias (IVIA) se está trabajando desde 1995 para la obtención de nuevas variedades sin semillas destinadas al consumo en fresco (Navarro et al., 2005). Este programa de mejora ha permitido obtener más de 13.000 híbridos triploides de los cuales 50 han sido preseleccionado y para 14 de ellos se ha solicitado el Titulo de Obtención Vegetal para su inclusión en el registro de variedades protegidas. Dos de ellos, las variedades Garbí y Safor están actualmente registradas y se encuentran a disposición de los viveros para su propagación comercial. Las otras 12 variedades se encuentran en el proceso de registro. 
Para la obtención de estos híbridos se han utilizado fundamentalmente como parentales femeninos el mandarino Fortune y el clementino Hernandina y como parentales masculinos los mandarinos 'Murcott', 'Ellendale', 'Kara', 'Nova', 'Común' y 'Ortanique' (Navarro et al., 2005). Las nuevas variedades triploides se pueden recolectar desde principios de febrero hasta finales de abril, lo que permite alargar notablemente la oferta de mandarinas en el mercado. Los frutos de estas nuevas variedades se caracterizan por una excelente calidad y un color externo naranja muy atractivo.

La introducción de estas variedades en el mercado exige el estudio previo de su comportamiento postcosecha, y en concreto evaluar la aptitud a la conservación frigorífica de éstas, que por la época de recolección sería importante conocer para poder comercializarlas en el momento óptimo de oferta-demanda. Por ello, desde el año 2008, se está evaluando en el Departamento de Tecnología Postcosecha del IVIA la aptitud a la conservación de estas nuevas variedades. Recientemente se han publicado los resultados preliminares del estudio del comportamiento postcosecha de las variedades Garbí y Safor (Navarro et al., 2010; Sdiri et al., 2012).

La frigoconservación es la técnica más ampliamente utilizada para la conservación de frutas y hortalizas en general y los cítricos en particular. Esta técnica permite reducir las pérdidas cualitativas y cuantitativas debidas a desórdenes fisiológicos y podredumbres, retrasar la maduración y senescencia y prolongar la vida comercial de los productos hortofrutícolas en general, con calidad idónea para consumo en fresco o industrial (Artés, 1987; MartínezJávega, 1997). Sin embargo, existen limitaciones en cuanto a las temperaturas mínimas que pueden aplicarse en el almacenamiento en frío. Algunas variedades de cítricos presentan una sensibilidad a las bajas temperaturas que se manifiesta por distintas alteraciones y manchas en la piel, conocidas como lesión de frío, daño por frío o chilling injury $(\mathrm{Cl})$, y que implican una alta pérdida de calidad comercial. Los estudios que han evaluado la aptitud a la frigoconservación de muchas variedades de cítricos con interés comercial, han determinado aquellas temperaturas más adecuadas para evitar la aparición de daños por frío y mantener la calidad de los frutos para el consumo en fresco. Las temperaturas de almacenamiento frigorífico recomendadas para 
mandarinas y naranjas varían desde $1^{\circ} \mathrm{C}$ a $10^{\circ} \mathrm{C}$ (Cuquerella et al., 2004; Martínez-Jávega et al., 2004).

Es conocido que la susceptibilidad de los cítricos a bajas temperaturas, además de la especie y variedad, depende de numerosos factores tanto previos como posteriores a la cosecha como en las condiciones ambientales en el momento de la cosecha (Guerra, 1996).

Teniendo en cuenta que las nuevas variedades objeto de estudio, tienen como parental femenino el mandarino 'Fortune', variedad con elevada sensibilidad a las bajas temperaturas (Cuquerella y Navarro, 1989; MartínezJávega et al., 1992), se hace necesario estudiar la posible susceptibilidad a la aparición de alteraciones fisiológicas de estos híbridos cuando son sometidos a diferentes temperaturas de conservación.

En el presente trabajo se estudió la aptitud de nueve de las nuevas variedades triploides a la conservación a bajas temperaturas, evaluando su susceptibilidad al desarrollo de síntomas de daños por frío así como la calidad del fruto durante la frigoconservación.

\section{MATERIALES Y MÉTODOS}

\subsection{Material vegetal}

En este estudio se han empleado frutos de nueve variedades triploides procedentes del Banco de Germoplasma de cítricos del IVIA que se encuentran en el proceso de registro (Tabla 1). Las parcelas experimentales, se encuentran situadas en los Términos Municipales de Museros (Valencia) y Villareal (Castellón). 


\subsection{Metodología}

Durante tres campañas se recolectaron frutos de las distintas variedades entre los meses de Febrero y Abril. En la Tabla 2 se muestran las fechas de todas las recolecciones efectuadas, así como los valores de los diferentes parámetros de calidad analizados en el momento de la cosecha. 


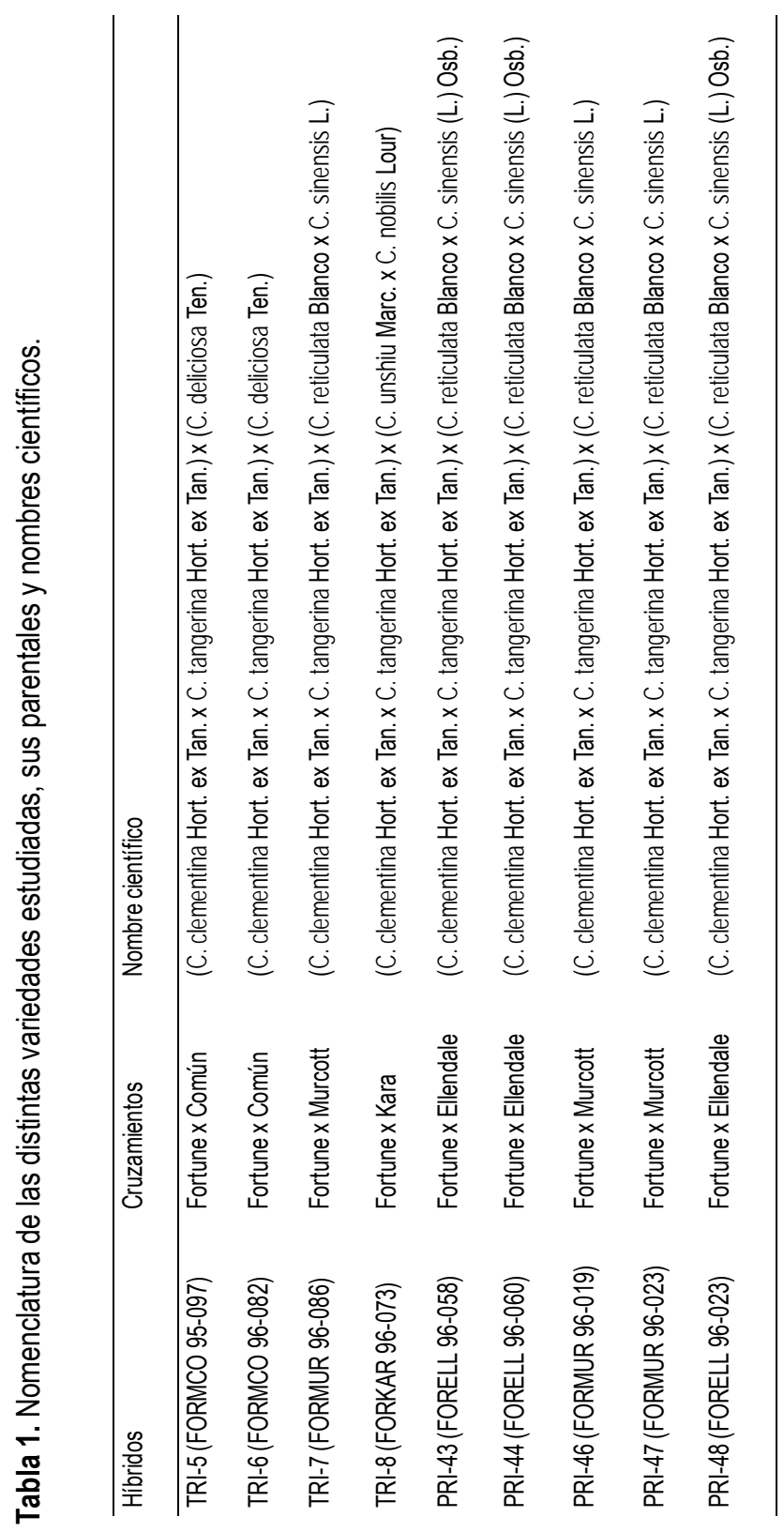


Tabla 2. Fecha de recolección y parámetros de calidad en el momento de cosecha de las nuevas variedades triploides estudiadas en diferentes campañas.

\begin{tabular}{|c|c|c|c|c|c|c|c|}
\hline Cultivar & $\begin{array}{l}\text { Fecha } \\
\text { recc. }\end{array}$ & $\begin{array}{c}\text { Color } \\
\text { (1000.a/L.b) }\end{array}$ & $\begin{array}{c}\text { TA } \\
(\mathrm{g} / 100 \mathrm{~mL}) \\
\end{array}$ & $\begin{array}{c}\text { SST } \\
\left({ }^{\circ} \text { Brix }\right) \\
\end{array}$ & $\begin{array}{c}\text { IM } \\
\text { SST/TA }\end{array}$ & $\begin{array}{c}\text { Zumo } \\
(\%)\end{array}$ & $\begin{array}{c}\text { Sabor } \\
(0-9)\end{array}$ \\
\hline TRI-5 & $\begin{array}{l}25-2-08 \\
08-3-10 \\
11-3-10 \\
\end{array}$ & $\begin{array}{l}15.1 \\
21.5 \\
20.7\end{array}$ & $\begin{array}{l}1.40 \\
1.33 \\
1.38 \\
\end{array}$ & $\begin{array}{l}14.1 \\
15.2 \\
16.1\end{array}$ & $\begin{array}{l}10.1 \\
11.5 \\
11.7\end{array}$ & $\begin{array}{l}47.4 \\
48.8 \\
49.8 \\
\end{array}$ & $\begin{array}{l}7.3 \\
7.8 \\
8.8 \\
\end{array}$ \\
\hline TRI-6 & $\begin{array}{l}07-2-08 \\
05-2-10 \\
10-2-11 \\
\end{array}$ & $\begin{array}{l}18.9 \\
18.5 \\
18.6 \\
\end{array}$ & $\begin{array}{l}1.07 \\
1.11 \\
1.09 \\
\end{array}$ & $\begin{array}{l}13.7 \\
14.0 \\
14.6 \\
\end{array}$ & $\begin{array}{l}12.9 \\
12.6 \\
13.3 \\
\end{array}$ & $\begin{array}{l}40.6 \\
49.7 \\
48.6\end{array}$ & $\begin{array}{l}7.0 \\
7.0 \\
7.2 \\
\end{array}$ \\
\hline TRI-7 & $\begin{array}{l}06-3-08 \\
23-2-10 \\
26-3-10 \\
04-2-11 \\
\end{array}$ & $\begin{array}{l}26.5 \\
22.6 \\
24.6 \\
20.5\end{array}$ & $\begin{array}{l}1.18 \\
1.63 \\
1.29 \\
1.83 \\
\end{array}$ & $\begin{array}{l}15.3 \\
15.6 \\
14.6 \\
15.5\end{array}$ & $\begin{array}{c}12.9 \\
9.6 \\
11.3 \\
8.5\end{array}$ & $\begin{array}{l}40.5 \\
51.6 \\
47.5 \\
47.3 \\
\end{array}$ & $\begin{array}{c}8.0 \\
7.2 \\
- \\
6.7 \\
\end{array}$ \\
\hline TRI-8 & $\begin{array}{l}06-3-08 \\
12-2-10 \\
10-2-11 \\
\end{array}$ & $\begin{array}{l}21.1 \\
20.9 \\
18.7\end{array}$ & $\begin{array}{l}1.38 \\
1.59 \\
1.09 \\
\end{array}$ & $\begin{array}{l}15.4 \\
14.9 \\
14.6 \\
\end{array}$ & $\begin{array}{c}11.2 \\
9.4 \\
13.3 \\
\end{array}$ & $\begin{array}{l}46.4 \\
49.7 \\
51.0 \\
\end{array}$ & $\begin{array}{l}8.0 \\
5.5 \\
6.7 \\
\end{array}$ \\
\hline PRI-43 & $\begin{array}{l}08-3-10 \\
31-3-10\end{array}$ & $\begin{array}{l}17.0 \\
15.2\end{array}$ & $\begin{array}{l}1.66 \\
1.33\end{array}$ & $\begin{array}{l}14.5 \\
11.6\end{array}$ & $\begin{array}{l}8.8 \\
8.8\end{array}$ & $\begin{array}{l}53.7 \\
52.5\end{array}$ & $\begin{array}{l}7.0 \\
6.8\end{array}$ \\
\hline PRI-44 & $\begin{array}{l}04-4-08 \\
08-3-10 \\
21-4-10 \\
\end{array}$ & $\begin{array}{c}13.9 \\
15.9 \\
- \\
-\end{array}$ & $\begin{array}{l}1.62 \\
2.16 \\
1.33 \\
\end{array}$ & $\begin{array}{l}14.8 \\
14.9 \\
12.9 \\
\end{array}$ & $\begin{array}{l}9.2 \\
6.9 \\
9.7 \\
\end{array}$ & $\begin{array}{l}50.1 \\
56.4 \\
53.9 \\
\end{array}$ & $\begin{array}{l}7.4 \\
6.8 \\
7.4 \\
\end{array}$ \\
\hline PRI-46 & $\begin{array}{l}25-2-08 \\
05-2-10 \\
07-3-11 \\
21-3-11 \\
\end{array}$ & $\begin{array}{l}14.3 \\
16.2 \\
17.0 \\
17.5\end{array}$ & $\begin{array}{l}1.24 \\
1.26 \\
1.50 \\
0.86\end{array}$ & $\begin{array}{l}16.9 \\
15.9 \\
18.3 \\
16.0 \\
\end{array}$ & $\begin{array}{l}13.6 \\
12.6 \\
12.3 \\
18.6\end{array}$ & $\begin{array}{l}47.3 \\
49.9 \\
47.7 \\
48.0\end{array}$ & $\begin{array}{l}7.4 \\
7.7 \\
8.0 \\
6.8 \\
\end{array}$ \\
\hline PRI-47 & $\begin{array}{l}04-2-10 \\
23-2-10 \\
04-2-11 \\
10-2-11\end{array}$ & $\begin{array}{l}19.6 \\
21.6 \\
19.1 \\
20.3\end{array}$ & $\begin{array}{l}1.17 \\
1.13 \\
1.26 \\
1.15 \\
\end{array}$ & $\begin{array}{l}13.7 \\
14.3 \\
13.9 \\
14.2 \\
\end{array}$ & $\begin{array}{l}11.7 \\
12.6 \\
11.0 \\
12.3 \\
\end{array}$ & $\begin{array}{l}48.6 \\
50.7 \\
45.0 \\
50.3\end{array}$ & $\begin{array}{l}7.8 \\
6.8 \\
6.8 \\
6.6 \\
\end{array}$ \\
\hline PRI-48 & $\begin{array}{l}25-2-08 \\
19-2-10 \\
23-2-10 \\
04-2-11\end{array}$ & $\begin{array}{l}23.9 \\
21.9 \\
23.6 \\
20.5\end{array}$ & $\begin{array}{l}1.20 \\
1.30 \\
1.27 \\
1.65\end{array}$ & $\begin{array}{l}14.1 \\
14.6 \\
14.4 \\
14.3\end{array}$ & $\begin{array}{c}11.8 \\
11.3 \\
11.4 \\
8.7\end{array}$ & $\begin{array}{l}43.1 \\
49.4 \\
49.3 \\
49.4\end{array}$ & $\begin{array}{l}8.1 \\
8.2 \\
7.6 \\
7.0\end{array}$ \\
\hline
\end{tabular}


Tras la cosecha, se efectuó una selección de la fruta, eliminando los frutos defectuosos o manchados, y se formaron lotes homogéneos que fueron sometidos a una simulación de manipulación comercial de cítricos en la línea experimental del IVIA. Los frutos fueron inicialmente lavados con detergente neutro (Fruit-Cleaner $\AA$, Fomesa Fruitech S.L.U.) enjuagados y posteriormente encerados con un recubrimiento comercial del $14 \%$ con 2000 ppm de imazalil como funguicida ("Waterwax TTT-2I@, Fomesa Fruitech S.L.U.). Tras el paso por la línea de confección se formaron lotes homogéneos para ser sometidos a diferentes condiciones de conservación: $1^{\circ} \mathrm{C}, 5^{\circ} \mathrm{C}$ y $9^{\circ} \mathrm{C}$ durante 15 y 30 días y además se ensayaron condiciones de comercialización a países de la Unión Europea (3-5 días a $5^{\circ} \mathrm{C}+6$ días a $20^{\circ} \mathrm{C}$ ). En número de frutos por lote, así como la planificación de las diferentes condiciones de almacenamiento, dependió siempre de la disponibilidad de frutos en campo, ya que se trata de variedades nuevas en proceso de experimentación, con un reducido número de árboles en producción y en consecuencia con disponibilidad de material vegetal muy limitado en algunos casos. En la primera campaña de estudio (2008), la fruta fue almacenada sin aplicación de recubrimiento céreo.

Tras los distintos períodos de comercialización, se evaluó la incidencia de alteraciones fisiológicas, y se realizaron determinaciones de pérdida de peso, firmeza, sólidos solubles, acidez, rendimiento en zumo y contenido en etanol. También se realizó la evaluación sensorial de la fruta.

\subsection{Análisis y determinaciones}

\subsubsection{Parámetros de calidad}

Las determinaciones de color y textura se realizaron sobre 20 frutos por tratamiento. El color se determinó mediante un colorímetro por reflexión Minolta, utilizando los parámetros de Hunter L, a, b y expresando los resultados como índice de color (IC=1000.a/L.b) (Jiménez-Cuesta et al., 1981). La textura se evaluó mediante un texturómetro Instron Universal Machine modelo 3343 
(Instron Limited, Buckinghamshire, UK), expresando los resultados como porcentaje de deformación al aplicar una fuerza de $10 \mathrm{~N}$ en la zona ecuatorial del fruto. Los sólidos solubles totales (TSS), acidez total (TA) y contenido en etanol se determinaron en 3 zumos de 10 frutos por tratamiento. Los sólidos solubles totales ( $\left.{ }^{\circ} \mathrm{Brix}\right)$ se midieron con un refractómetro digital Atago modelo PR-1 (Atago Co., Ltd, Tokyo, Japan). La acidez total, expresada como gramos de ácido cítrico en $100 \mathrm{ml}$ de zumo se determinó por titulación con hidróxido sódico $0.1 \mathrm{~N}$ usando fenolftaleína como indicador. El índice de madurez (TSS/TA) se calculó como cociente entre los ${ }^{\circ}$ Brix y la acidez.

\subsubsection{Calidad sensorial}

La evaluación organoléptica de los frutos se realizó mediante un panel entrenado de 10-12 catadores empleando escalas de sabor de nueve niveles según la norma UNE 87004 (AENOR, 1997). Para la preparación de las muestras se tomaron de cada tratamiento 10 frutos al azar que se pelaron y dividieron en gajos que fueron presentados a los jueces debidamente codificados. Para la evaluación de la calidad olfato-gustativa se utilizó una escala del 1 a 9 , donde se agruparon los valores en tres grados de calidad (1-3 = calidad no aceptable, 4-6 = calidad aceptable y 7-9 = calidad excelente).

\subsubsection{Evaluación de las alteraciones externas}

La evaluación de las alteraciones externas, tanto de daños por frío como de síntomas de deshidratación, se realizó sobre el total de frutos de cada lote (entre 20 y 100 frutos, dependiendo de la disponibilidad de cada una de las variedades y para cada recolección efectuada), determinando de forma visual la superficie dañada. Se usó una escala de 0 a 3, basada en la intensidad de las alteraciones $(0=\sin$ lesiones, $1=$ lesiones ligeras, $2=$ lesiones moderadas, $3=$ lesiones severas) y se calculó la media ponderada, lo que se ha denominado Índice de alteraciones (IA). Las alteraciones se consideran ligeras cuando no sobrepasan el $10 \%$ de la superficie y severas cuando sobrepasan el $20 \%$. 


\subsubsection{Análisis de etanol}

Las concentraciones de etanol en zumo, se determinaron por triplicado sobre muestras de 3 zumos de 10 frutos por tratamiento, mediante cromatografía gaseosa de espacio de cabeza según el método de Ke y Kader (1990).

Muestras de $5 \mathrm{~mL}$ de zumo se colocaron en viales de $10 \mathrm{~mL}$, debidamente sellados con tapón de TFE/silicona, y se almacenaron a $-20{ }^{\circ} \mathrm{C}$ hasta el momento de su análisis. Previo el análisis, los viales se descongelaron en un baño maría a $20^{\circ} \mathrm{C}$ durante una hora y luego se incubaron a $30^{\circ} \mathrm{C}$ durante 10 minutos. Tras la incubación los viales se agitaron con un vibrador Spinmix durante 5 segundos y se extrajo una submuestra de $1 \mathrm{~mL}$ de gas del espacio de cabeza existente sobre la muestra, con una jeringa Hamilton 1001 LT de $1 \mathrm{~mL}$ que se inyectó en el cromatógrafo de gases Perkin Elmer (modelo 1020, Perkin Elmer Corp., Norwalk, CT, USA) equipado con un detector de ionización de llama (FID) y columna empacada Porapack QS 80/100 (1.2 m x 1/8 pulgada) de acero inoxidable. Las condiciones de operación en el cromatógrafo fueron: temperatura del horno de $150^{\circ} \mathrm{C}$, temperatura del inyector de $175^{\circ} \mathrm{C}$, temperatura del detector FID de $200^{\circ} \mathrm{C}$. El gas portador fue el He a una presión de $12.3 \mathrm{psi}$. El etanol de las muestras se cuantificó por comparación con soluciones patrón que fueron previamente preparados y conservados en viales de $10 \mathrm{~mL}$. Los resultados se expresaron en $\mathrm{mg}$ de etanol por $100 \mathrm{~mL}$ de zumo.

\subsubsection{Diseño experimental}

El análisis estadístico de los datos se realizó con el paquete estadístico Statgraphics Plus Versión 5, mediante el análisis de la varianza (ANOVA). Las diferencias mínimas entre las medias se establecieron a partir del test LSD (diferencia mínima significativa) con un nivel de confianza del 95\%. 


\section{RESULTADOS Y DISCUSIÓN}

En la comercialización de cítricos los principales parámetros de calidad contemplados en las normativas vigentes son: sanidad y calibre del fruto así como requisitos mínimos de madurez definidos por la coloración externa, contenido en zumo e índice de madurez (Reglamento UE Nº 543/2011).

Tras la recolección y hasta su consumo, los frutos cítricos experimentan pérdidas de calidad que depende de los tratamientos y manipulaciones a los que están sometidos durante su vida postcosecha.

En las Tablas 3-11 se muestran los cambios en los parámetros de calidad (firmeza, acidez, sólidos solubles, índice de madurez, sabor, contenido de zumo y etanol), así como los porcentajes de pérdidas de peso y alteraciones fisiológicas de la fruta tras la frigoconservación en diferentes condiciones de almacenamiento para cada una de las variedades estudiadas.

\subsection{Pérdidas de peso y de firmeza}

Una de las principales causas de deterioro fisiológicos en los frutos cítricos es el estrés de agua producido al separarse de la planta madre por la transpiración y falta de reposición. La pérdida de agua a través de la piel del fruto, provoca una serie de efectos negativos directos como son las pérdidas de peso (pérdida cuantitativa) e indirectos como es la disminución de la firmeza (pérdida cualitativa). La firmeza o textura de los frutos cítricos está íntimamente relacionada con las pérdidas de peso ya que el ablandamiento proviene fundamentalmente de la pérdida de agua por evapotranspiración, a diferencia de lo que ocurre en gran número de otros frutos en los que la pérdida de firmeza se debe principalmente a la degradación, durante las últimas fases de su maduración, de las sustancias pécticas y carbohidratos poliméricos que éstos contienen (Cuquerella y Navarro, 1997).

La medida objetiva de estos parámetros nos permite cuantificar las pérdidas de peso y firmeza de los frutos, pero en la normativa actualmente 
existente no existe como tal un valor cuantitativo máximo de estos dos parámetros que nos indique el período máximo de almacenamiento de un producto vegetal fresco.

En la práctica se considera que valores de pérdida de peso superiores al $10 \%$ pueden llegar a comprometer la calidad durante la conservación, tanto por las pérdidas cuantitativas que esto supone directamente como por la pérdida de calidad que el ablandamiento de los frutos lleva consigo, considerándose que valores de firmeza (medida como porcentaje de deformación ecuatorial al aplicar $10 \mathrm{~N}$ de fuerza) superiores al $5 \%$ y $10 \%$ en naranjas y mandarinas respectivamente podrían limitar su comercialización al corresponderse con frutos demasiado blandos para ser considerados de Categoría Extra o Primera (Cuquerella y Navarro, 1997, Martínez-Jávega et al., 2004).

En este sentido hay que tener en cuenta que la firmeza inicial de los frutos en el momento de la cosecha es un factor de suma importancia ya que teniendo en cuenta la progresiva disminución de la misma durante el almacenamiento, se ha recomendado que la recolección se realice con valores de deformación inferiores al $2 \%$ y $5 \%$ en naranjas y mandarinas respectivamente para que después de la manipulación, conservación y transporte no lleguen a sobrepasarse los límites anteriormente citados (Martínez-Jávega et al., 2004).

En general, los resultados obtenidos muestran que las pérdidas de peso se incrementaron de forma significativa con la temperatura y el tiempo de almacenamiento. La disminución de la firmeza también aumentó con la temperatura y duración de conservación, aunque no mostrando en todos los casos diferencias significativas. Como es de suponer, las menores pérdidas de peso y firmeza se han obtenido en todos los casos en las condiciones de comercialización a la UE y las mayores en el almacenamiento a $9^{\circ} \mathrm{C}$ durante 30 días.

En el presente trabajo, los resultados obtenidos muestran que las pérdidas de peso registradas en todas las variedades se han situado por debajo del $10 \%$, excepto en el caso de la variedad TRI- 5 en que se superó ligeramente este límite $(10.6 \%)$, aunque hay que señalar que este valor se alcanzó en las 
condiciones más desfavorables, después de un almacenamiento sin recubrimiento previo a $9^{\circ} \mathrm{C}$ durante 30 días más 6 días a $20^{\circ} \mathrm{C}$ (datos no mostrados).

Por otro lado, el porcentaje de deformación de los frutos no ha sido superior al $10 \%$ en ningún caso, llegando a registrarse valores máximos de deformación próximos al $8 \%$ únicamente en aquellas variedades con mayor valor inicial en el momento de cosecha, como ocurre en las variedades TRI-5, PRI-48 y TRI-6 en la primera campaña y almacenadas durante 30 días a $9^{\circ} \mathrm{C}$ sin previa aplicación de recubrimiento céreo, alcanzando valores de deformación del $8.41,8.31$ y $8.12 \%$ respectivamente (datos no mostrados).

\subsection{Contenido en ácidos y sólidos solubles totales}

El índice de madurez (IM) de los frutos cítricos se define como el cociente entre la cantidad de azúcares y el contenido total en ácidos. Las normas europeas de comercialización de cítricos (Reglamento UE $N^{\circ}$ 543/2011) exigen para mandarinas y sus híbridos un IM mínimo de 7.5.

Durante el almacenamiento de los frutos cítricos se produce una disminución progresiva en el contenido total en ácidos mientras que el contenido en azúcares se mantiene constante o se incrementa ligeramente. En algunas variedades la disminución del contenido en ácidos puede limitar la duración del almacenamiento al traducirse en frutos insípidos y carentes de su sabor característico.

En el presente estudio, todas las variedades ensayadas se caracterizan por su elevado contenido en ácidos y azúcares en el momento de la cosecha; los valores de acidez observados variaron desde un mínimo de $1.07 \mathrm{~g}$ ácido cítrico/100mL en TRI-6 hasta $2.16 \mathrm{~g}$ ácido cítrico/100mL en PRI-44. Los valores de azúcares oscilaron entre $11.60^{\circ} \mathrm{Brix}$ (PRI-43) y $18.32^{\circ} \mathrm{Brix}$ (PRI-46). 
En todos los casos, el IM en el momento de la recolección fue superior al mínimo exigido por la legislación excepto en PRI-44 (campaña 2010) que fue cosechada con IM de 7, sin embargo tras la comercialización a la UE ya alcanzó el mínimo exigido de 7.5 , superándolo tras 15 días de almacenamiento a la tres temperaturas ensayadas.

En general se observó que la reducción de la acidez con respecto al valor de cosecha fue mayor con el incremento de la temperatura de conservación, aunque en la mayoría de los casos las diferencias entre los valores obtenidos no fueron significativas.

En general, durante las dos campañas y en todas las variedades ensayadas, se produjo un incremento significativo en el IM de la fruta a las tres temperaturas de estudio, siendo mayor cuanto más alta fue la temperatura de conservación. Los incrementos observados en el IM son debidos principalmente a la disminución de la acidez durante el período de conservación, ya que los sólidos solubles no se vieron modificados.

De forma general, los cambios observados en los parámetros de calidad no fueron limitantes para la comercialización de la fruta tras los diferentes periodos de almacenamiento.

\subsection{Contenido en zumo}

La Normativa vigente exige un contenido mínimo en zumo del 33\% para todas las mandarinas excepto para clementinas que se requiere un mínimo del $40 \%$. Todas las variedades estudiadas presentaron en el momento de cosecha valores de porcentaje de zumo muy elevados, entre el 40 y $55 \%$.

Tras el almacenamiento a las diferentes condiciones ensayadas los valores de rendimiento en zumo no experimentaron cambios importantes en ninguna de las variedades evaluadas, situándose siempre por encima del mínimo exigido y sin diferencias destacables entre temperaturas y tiempos de conservación. 


\subsection{Contenido en etanol}

El etanol está presente en al aroma de los frutos cítricos y ha sido reportado como un precursor natural de compuestos aromático (Pesis, 2005). La concentración de etanol en zumo de los frutos cítricos en el momento de cosecha normalmente es baja aunque depende de factores como variedad y estado de madurez (Chalutz et al., 1981).

Normalmente durante el almacenamiento de los frutos se produce un incremento en el contenido de este volátil inducido por el incremento de la respiración, mayor con la temperatura y la duración del almacenamiento (Cohen et al., 1990; Ke y Kader, 1990; Hagenmaier, 2002; Hagenmaier y Show, 2002; Shi et al., 2005; Marcilla et al., 2006; Obenland et al., 2008, 2011; Tietel et al., 2010). Además, la aplicación del recubrimiento céreo que habitualmente se realiza en su manipulación y confección, contribuye a su incremento, dependiendo sobre todo de la composición y espesor del recubrimiento empleado (Hagenmaier y Shaw, 2002; Porat et al., 2005; Tietel et al., 2010). El incremento de concentración del etanol en zumo ha sido ampliamente reportado que puede llevar al desarrollo de malos sabores (Hagenmaier, 2002; Marcilla et al., 2006; Obenland et al., 2008, 2011; Tietel et al., 2010).

En el presente estudio, se observó un incremento en el contenido de etanol de todas las variedades ensayadas tras el almacenamiento, siendo mayor con el aumento de la temperatura y del periodo de conservación.

La variedad PRI-44 no superó los $150 \mathrm{mg} / 100 \mathrm{~mL}$ de etanol tras los periodos de almacenamiento ensayados. Las variedades PRI-43, PRI-48, TRI5, TRI-6, PRI-47 llegaron a valores máximos de etanol de $300 \mathrm{mg} / 100 \mathrm{~mL}$; las variedades PRI-46, TRI-7 y TRI-8 superaron los $300 \mathrm{mg} / 100 \mathrm{~mL}$. En mandarinas, niveles de etanol en el zumo superiores a $150 \mathrm{mg} / 100 \mathrm{~mL}$ han sido reportados como valores límites para el desarrollo de malos sabores (Hagenmaier, 2002). Sin embargo, en el presente estudio no fueron detectados malos sabores en ninguna de las variedades tras las diferentes condiciones de conservación; en todos los casos, la puntuación de sabor dada por el panel de 
catadores para todos los frutos fue alta siendo valorados como comercialmente aceptables. La alta calidad sensorial observada en todas las variedades incluso en aquellas que presentaron los niveles de etanol más altos, puede ser explicada por los altos niveles de acidez que presentan, incluso tras periodos prolongados de almacenamiento. El límite de detección de los malos sabores inducidos por la acumulación de etanol ha sido correlacionado con el nivel de acidez y azúcar de la variedad; así un nivel alto de acidez puede disminuir la percepción de malos sabores (Salvador, 1999; Marcilla et al., 2009).

\subsection{Alteraciones y daños por frío}

Los daños por frío son las alteraciones más comunes que pueden desarrollar los frutos cítricos tras una conservación bajo temperaturas. La susceptibilidad de los cítricos a bajas temperaturas depende de la especie y variedad, además influyen otros factores tanto previos a la cosecha como posteriores a ella. La severidad de los daños por frío está altamente relacionada con la temperatura y la duración del almacenamiento. Además hay que tener en cuenta que durante el almacenamiento prolongado a bajas temperaturas también se producen alteraciones relacionadas con deshidratación y senescencia de la piel.

A continuación se exponen los resultados de la incidencia de alteraciones fisiológicas observadas en cada una de las variedades estudiadas debido al diferente comportamiento que ha tenido cada una de ellas.

\section{PRI-44 (FORELL 96-060)}

En la primera campaña de estudio (2008), tras una conservación de 30 días no hubo problemas de alteraciones a ninguna de las temperaturas ensayadas (datos no mostrados). Sin embargo en la segunda campaña (2010) en las dos recolecciones, en las que la fruta fue cosechada con un estado de madurez muy diferente, esta variedad presentó sensibilidad a DF, depresiones oscuras por toda la superficie, a $1^{\circ} \mathrm{C}$ tras $15 \mathrm{~d}$ de conservación. A $5^{\circ} \mathrm{C}$, tras los 
primeros 15 días no aparecieron alteraciones y la fruta presentó buen aspecto, después de $30 \mathrm{~d}$ apareció algún fruto con estos síntomas. A $9^{\circ} \mathrm{C}$ las alteraciones fueron más importantes, un porcentaje elevado de fruta presentó depresiones oscurecidas como síntomas de deshidratación y envejecimiento de piel.

En la simulación a UE en la primera recolección de la segunda campaña de estudio, algún fruto presentó manchas irregulares muy ligeras, mientras que en la segunda recolección estas manchas se extendieron por toda la superficie del fruto, manifestándose como síntomas de deshidratación con depresiones oscurecidas.

\section{PRI-43 (FORELL 96-058)}

En las dos recolecciones realizadas (2010) la fruta presentó buen aspecto sin incidencia de alteraciones tras la simulación de comercialización a la UE.

Después de 15 días de almacenamiento a $1^{\circ} \mathrm{C}$ y $5^{\circ} \mathrm{C}$ la fruta mostró síntomas de daños por frío con depresiones oscurecidas por toda la superficie, mostrando mayor incidencia de alteraciones en la segunda recolección, llegando a alcanzar valores del $58 \%$ de fruta afectada. Cuando se realizó el almacenamiento a $9^{\circ} \mathrm{C}$, mientras que en la primera recolección no aparecieron alteraciones visibles, en la segunda recolección se observaron síntomas de deshidratación en un $20 \%$ de la fruta, con depresiones irregulares en la superficie.

Después de 30 días de almacenamiento a $5^{\circ} \mathrm{C}$ las alteraciones se incrementaron de manera importante.

\section{PRI-48 (FORELL 96-023)}

Esta variedad no presentó sensibilidad a los daños por frío ni síntomas importantes de deshidratación a ninguna de las temperaturas ensayadas, mostrando los frutos muy buen aspecto incluso después de 30 días de 
almacenamiento. Los resultados han sido similares en las tres campañas de estudio $(2008,2010,2011)$.

\section{$\underline{T R I-5(\text { FORMCO 95-097) }}$}

Después de 15 días de almacenamiento a $1^{\circ} \mathrm{C}, 5^{\circ} \mathrm{C}$ y $9^{\circ} \mathrm{C}$ esta variedad no presentó ningún tipo de alteración fisiológica que limita la comercialización. En la primera campaña de estudio (2008) (datos no mostrados), en la que la fruta no fue encerada, no presentó síntomas de daños por frío o deshidratación incluso después de 30 días de almacenamiento a las tres temperaturas ensayadas, lo que se corroboró en las dos recolecciones realizadas en la segunda campaña de estudio (2010).

\section{$\underline{\text { TRI-6 (FORMCO 96-082) }}$}

En la primera campaña de estudio (2008) tras una conservación de 15 días a $1^{\circ} \mathrm{C}, 5^{\circ} \mathrm{C}$ ó $9^{\circ} \mathrm{C}$ la fruta presentó buen aspecto, sin alteraciones. Sin embargo después de 30 días de almacenamiento a $1^{\circ} \mathrm{C}$ y $5^{\circ} \mathrm{C}$ aparecieron síntomas de DF, manifestándose como glándulas oscurecidas y pitting en un porcentaje de fruta de $22 \%$ y $16 \%$ respectivamente. La fruta que se mantuvo a $9^{\circ} \mathrm{C}$ no presentó ninguna alteración.

En las dos campañas de estudio posteriores (2010, 2011), esta variedad mostró una mayor sensibilidad a las bajas temperaturas. Tras la simulación de exportación a la UE, la fruta manifestó alteraciones en la piel en un porcentaje elevado de fruta. Los síntomas observados fueron similares a los registrados en la campaña anterior. Durante una conservación más prolongada, de 15 y 30 días, la incidencia de estas alteraciones fue aumentando con el tiempo de almacenamiento en la fruta mantenida a $1^{\circ} \mathrm{C}$ y $5^{\circ} \mathrm{C}$, siendo mayor a $1^{\circ} \mathrm{C}$. La fruta almacenada a $9^{\circ} \mathrm{C}$ también presentó alteraciones importantes tras 15 días; los síntomas observados se asociaron a una deshidratación intensa que llevó a provocar áreas oscurecidas localizadas. 


\section{PRI-46 (FORMUR 96-019)}

En la primera campaña de estudio (2008), en la que la fruta se almacenó sin recubrimiento céreo a $1^{\circ} \mathrm{C}$ y $5^{\circ} \mathrm{C}$, la fruta no mostró ningún tipo de alteración, presentando buen aspecto externo tras un periodo de 30 días de almacenamiento (datos no mostrados).

En las campañas posteriores, tras la simulación de exportación a la UE, la fruta tampoco manifestó ninguna alteración externa.

En la campaña 2010 , la fruta mantenida 15 días a $1^{\circ} \mathrm{C}$ presentó síntomas de DF, aunque la incidencia fue mínima, alcanzando un índice de manchado de 0.16; a 5 y $9^{\circ} \mathrm{C}$ no se observó ningún tipo de alteración externa.

En la campaña 2011, la fruta de la primera recolección se mostró algo más susceptible al estrés por frío y manifestó síntomas de DF tanto a $1^{\circ} \mathrm{C}$ como a $5^{\circ} \mathrm{C}$ tras 15 días de almacenamiento, aumentando la severidad con el tiempo de conservación. En la segunda recolección de esta misma campaña las alteraciones solo aparecieron tras 30 días de conservación a $5^{\circ} \mathrm{C}$. A $9^{\circ} \mathrm{C}$ únicamente en un porcentaje de fruta muy bajo se observaron síntomas ligeros de deshidratación, no viéndose comprometida la calidad externa de los frutos.

Las alteraciones mostradas por esta variedad durante la conservación, además de la sensibilidad a las bajas temperaturas se podrían relacionar con el estado de la piel de la fruta en el momento de la cosecha ya que se ha mostrado especialmente sensible a la manifestación de alteraciones en la zona del cáliz en la fruta que presentó síntomas de 'clavillet' en el momento de cosecha.

\section{PRI-47 (FORMUR 96-023)}

Tras la simulación de exportación a la UE, esta variedad presentó un porcentaje de fruta, que superó en algún caso el $20 \%$, con áreas deprimidas y en muchos casos oscurecidas. 
Cuando la fruta fue conservada por un periodo de 15 días, se observaron estas mismas alteraciones en la fruta mantenida a $1^{\circ} \mathrm{C}, 5^{\circ} \mathrm{C}$ y $9^{\circ} \mathrm{C}$, con mayor severidad cuanto más baja fue la temperatura. La manifestación de los daños se agravó en el almacenamiento más prolongado de 30 días, alcanzando un $26 \%, 13 \%$ y $17 \%$ de fruta afectada a $1^{\circ} \mathrm{C}, 5^{\circ} \mathrm{C}$ Y $9^{\circ} \mathrm{C}$ respectivamente en la segunda recolección del 2011 , en la que la fruta presentó mayor sensibilidad.

\section{$\underline{\text { TRI-7 (FORMUR 96-086) }}$}

Esta variedad no presentó ningún problema en la simulación de exportación a la UE, mostrando muy buen aspecto en todos los ensayos realizados en las diferentes campañas de estudio.

En la conservación a bajas temperaturas la fruta manifestó daños por frío, con síntomas claros de pitting, a partir de 15 días de almacenamiento, presentando mayor severidad la fruta mantenida a $5^{\circ} \mathrm{C}$ que a aquella que se conservó $1^{\circ} \mathrm{C}$. Las alteraciones se agravaron con el tiempo de conservación, llegando a presentar un $16 \%$ de fruta afectada tras 30 días de almacenamiento a las dos temperaturas. Hay que resaltar que esta sensibilidad a las bajas temperaturas fue observada en la fruta que recolectada con IM más bajo (cercano a 9) en las dos campañas de estudio, ya que en la recolección realizada en la campaña 2010, en la que la fruta presentó en el momento de cosecha un IM de 11,3 no mostró ningún síntoma de daños por frío a ninguna de las temperaturas de estudio.

En el almacenamiento a $9^{\circ} \mathrm{C}$ los frutos de esta variedad no presentaron ninguna alteración, mostrando una elevada calidad externa, incluso después de 30 días de almacenamiento.

\section{TRI-8 (FORKAR 96-073)}

En las tres campañas de estudio esta variedad mostró una importante susceptibilidad al ennegrecimiento glandular, que se ha asociado con el paso por línea de confección. La severidad de esta alteración se agravó cuanto más baja fue la temperatura de conservación. Sin embargo no se puede relacionar 
con sensibilidad a las bajas temperaturas, ya que se realizó un estudio paralelo en el que la fruta fue sometida o no al paso por línea de confección y mantenida posteriormente a temperatura ambiente y solo aquella que fue confeccionada en línea presentó estos síntomas. 


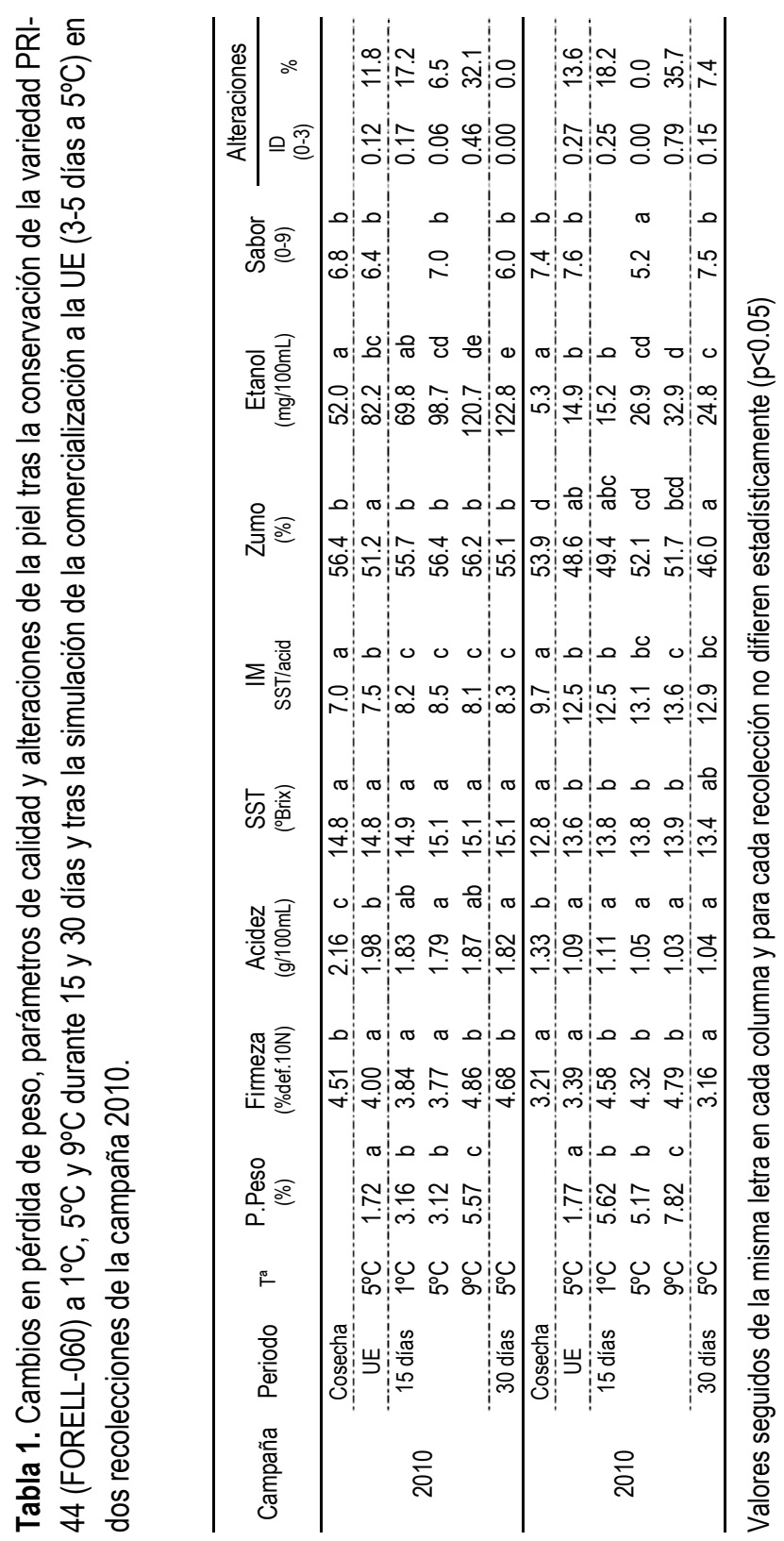




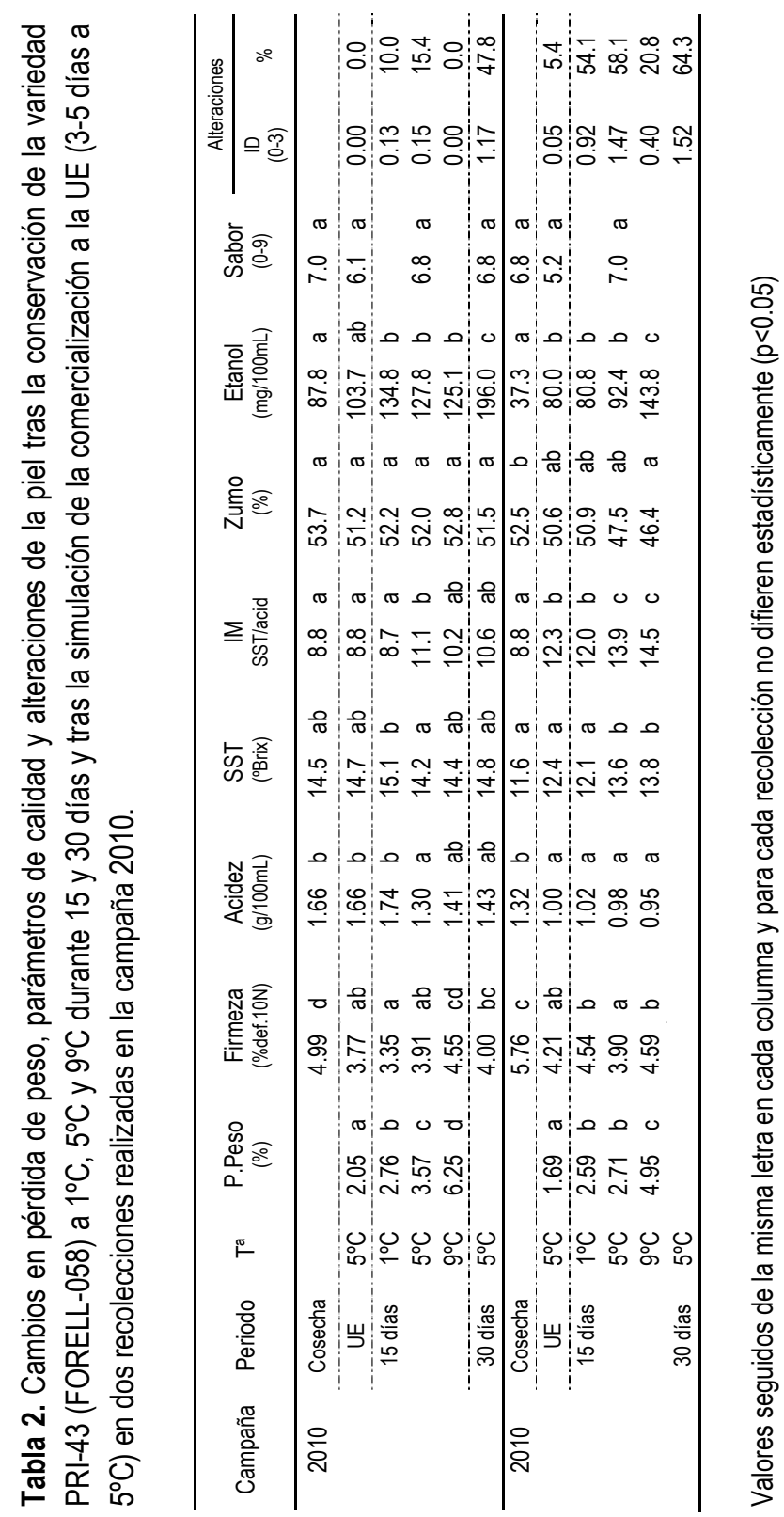




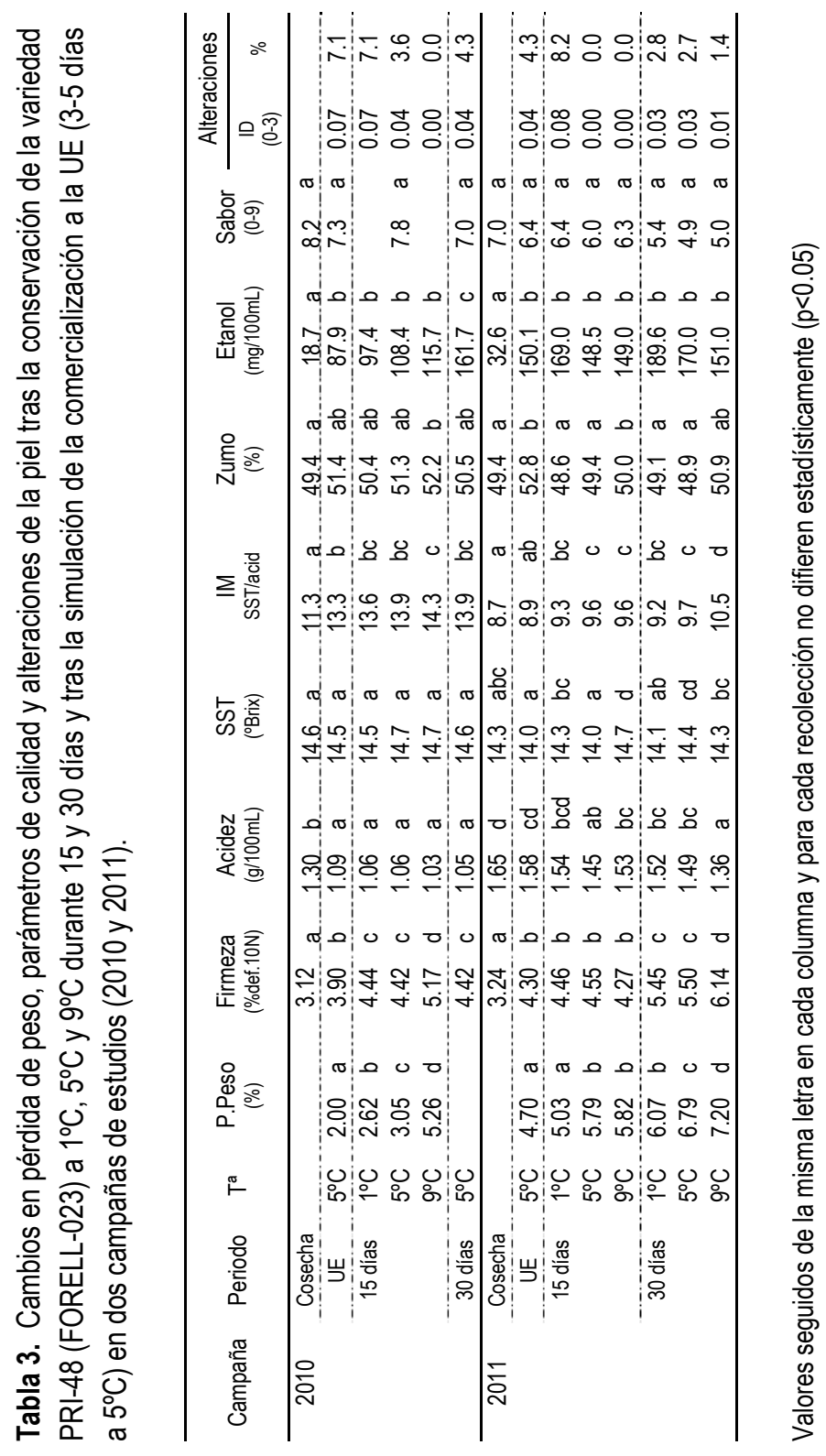




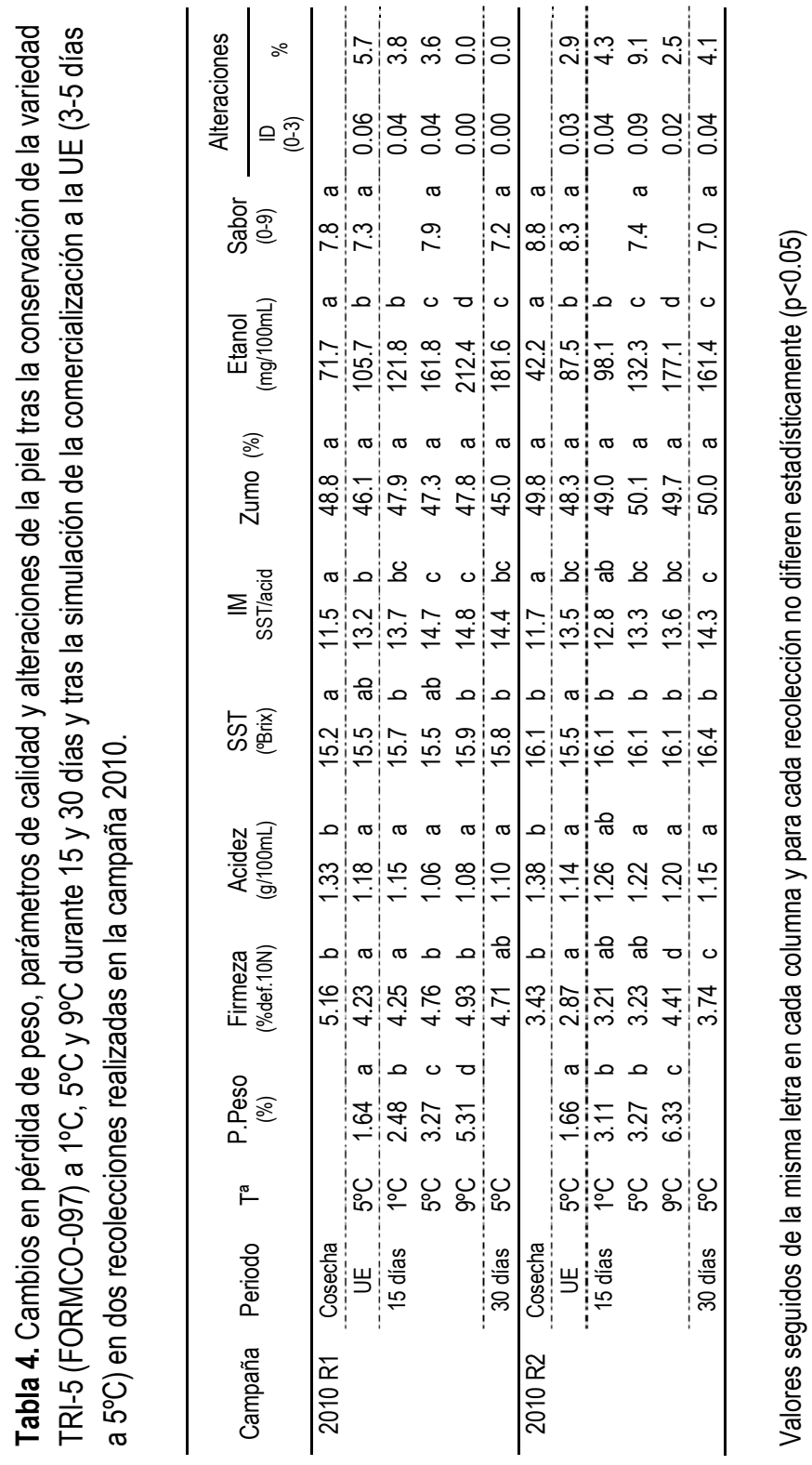




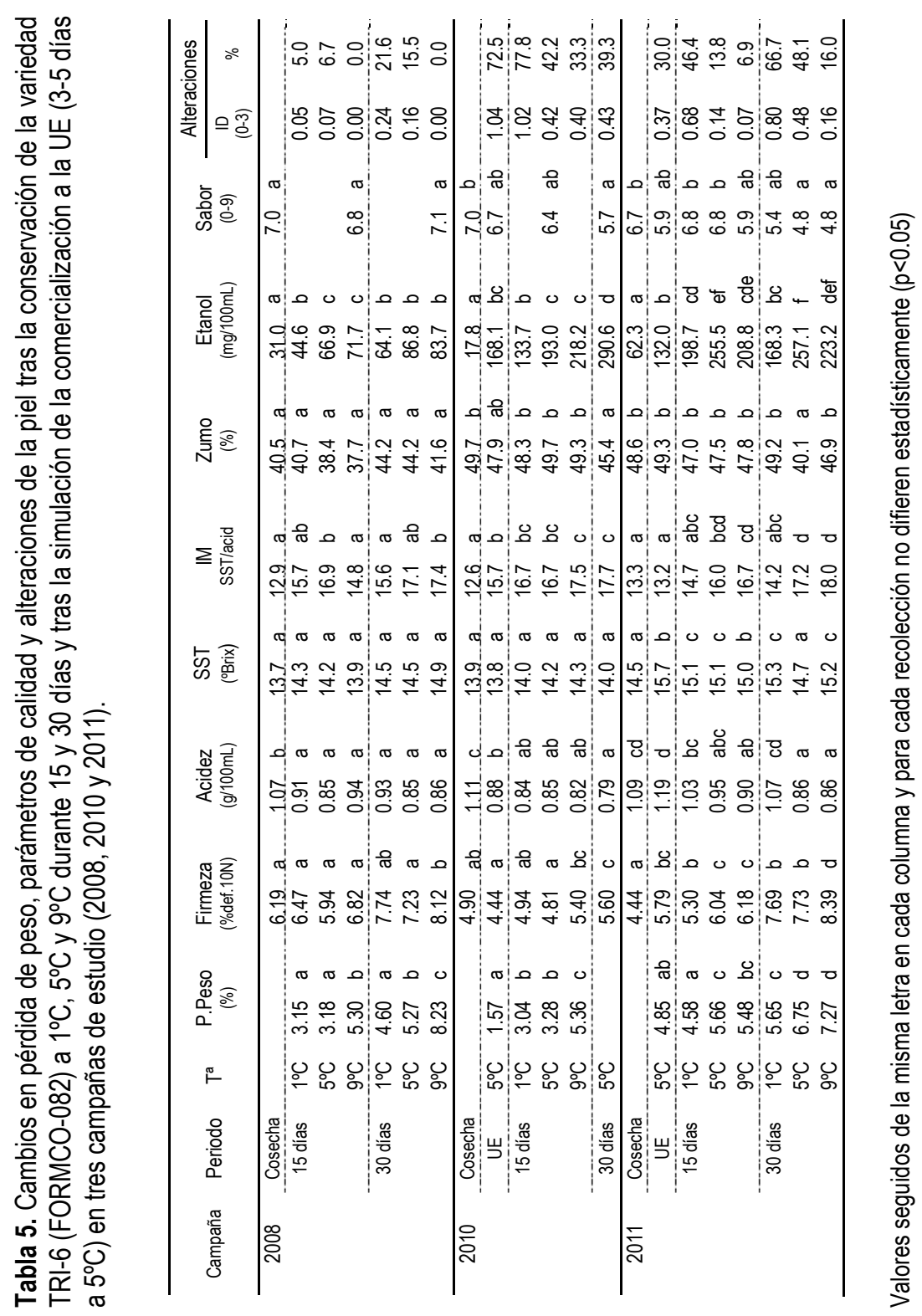




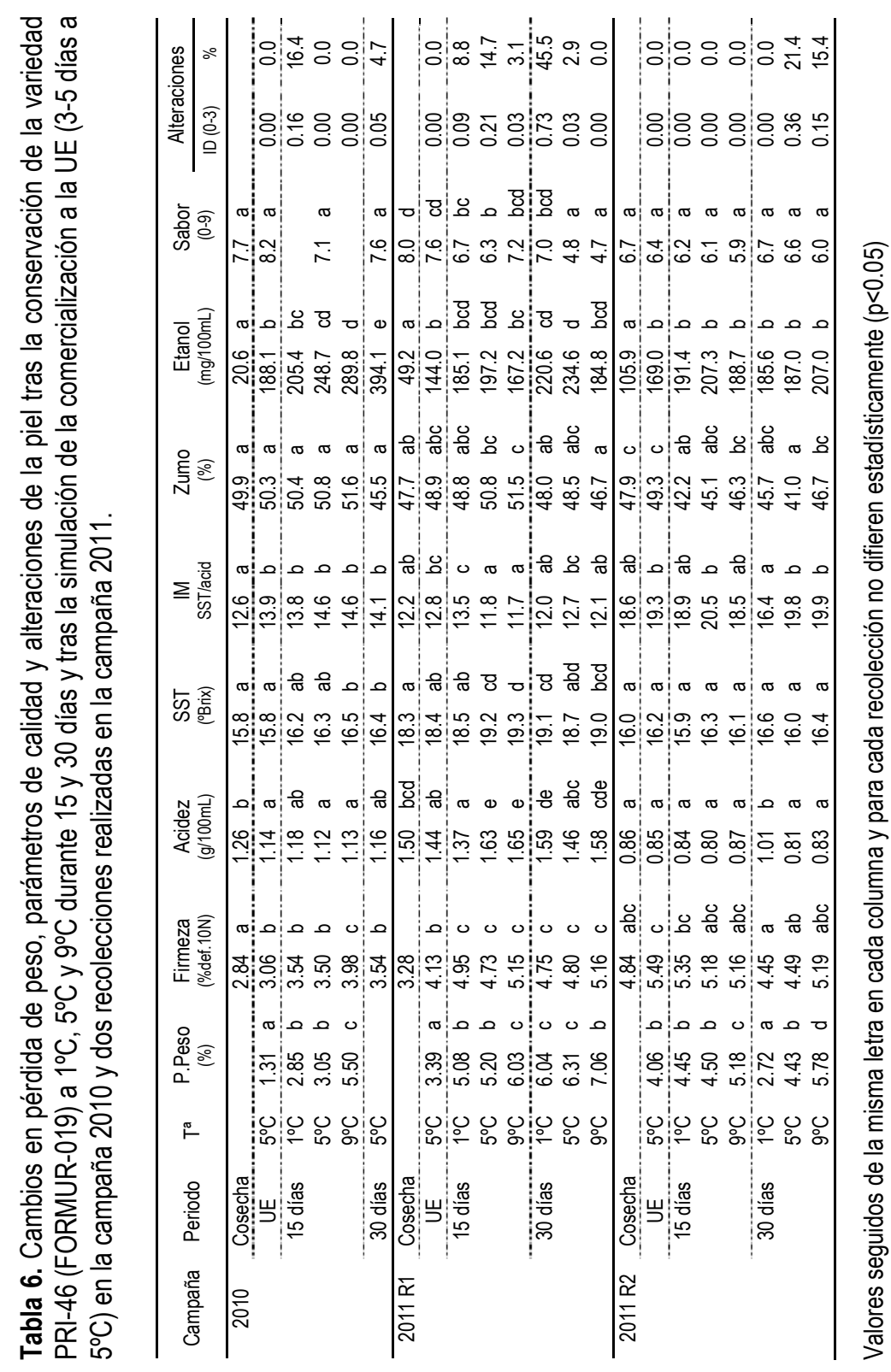




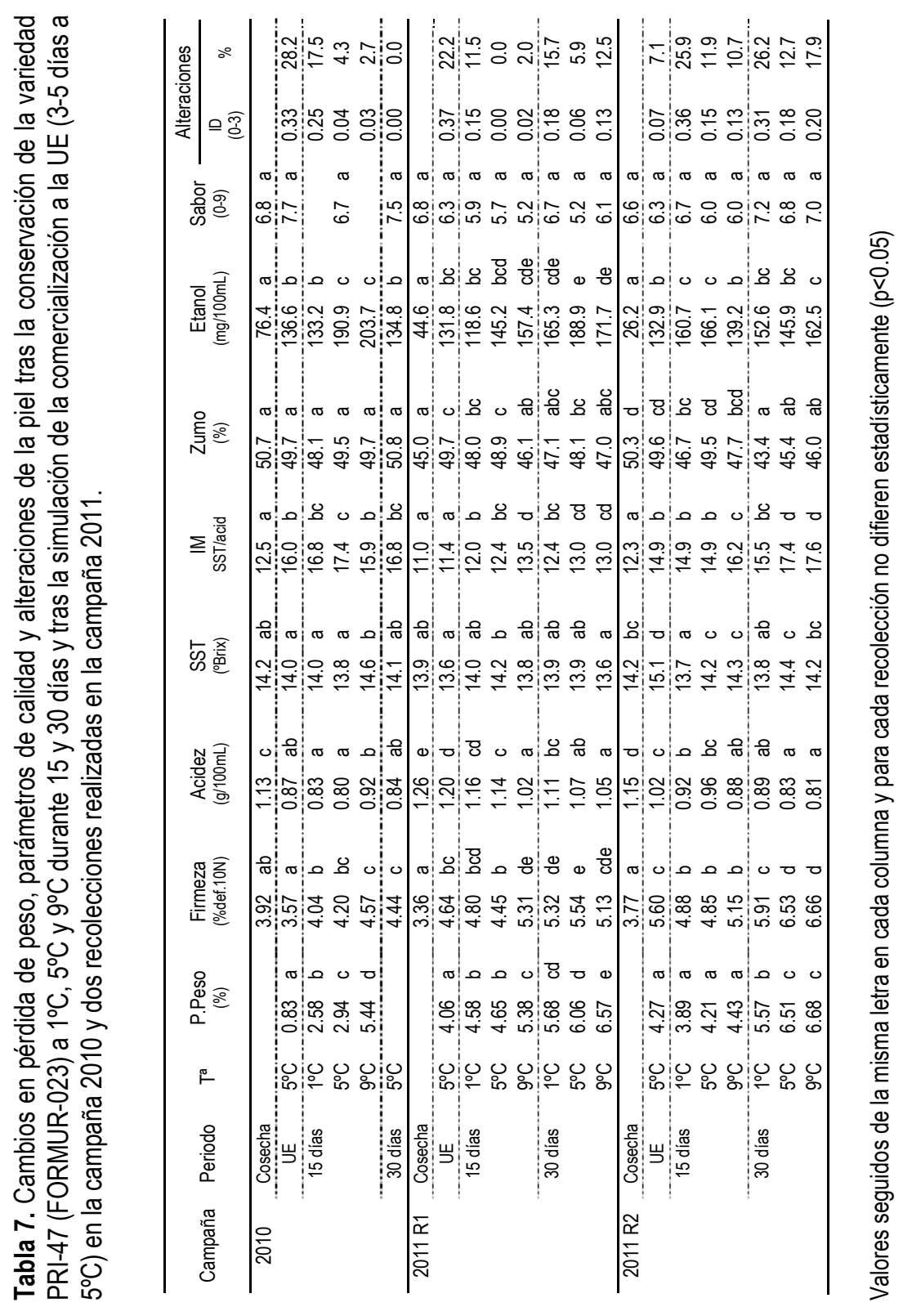




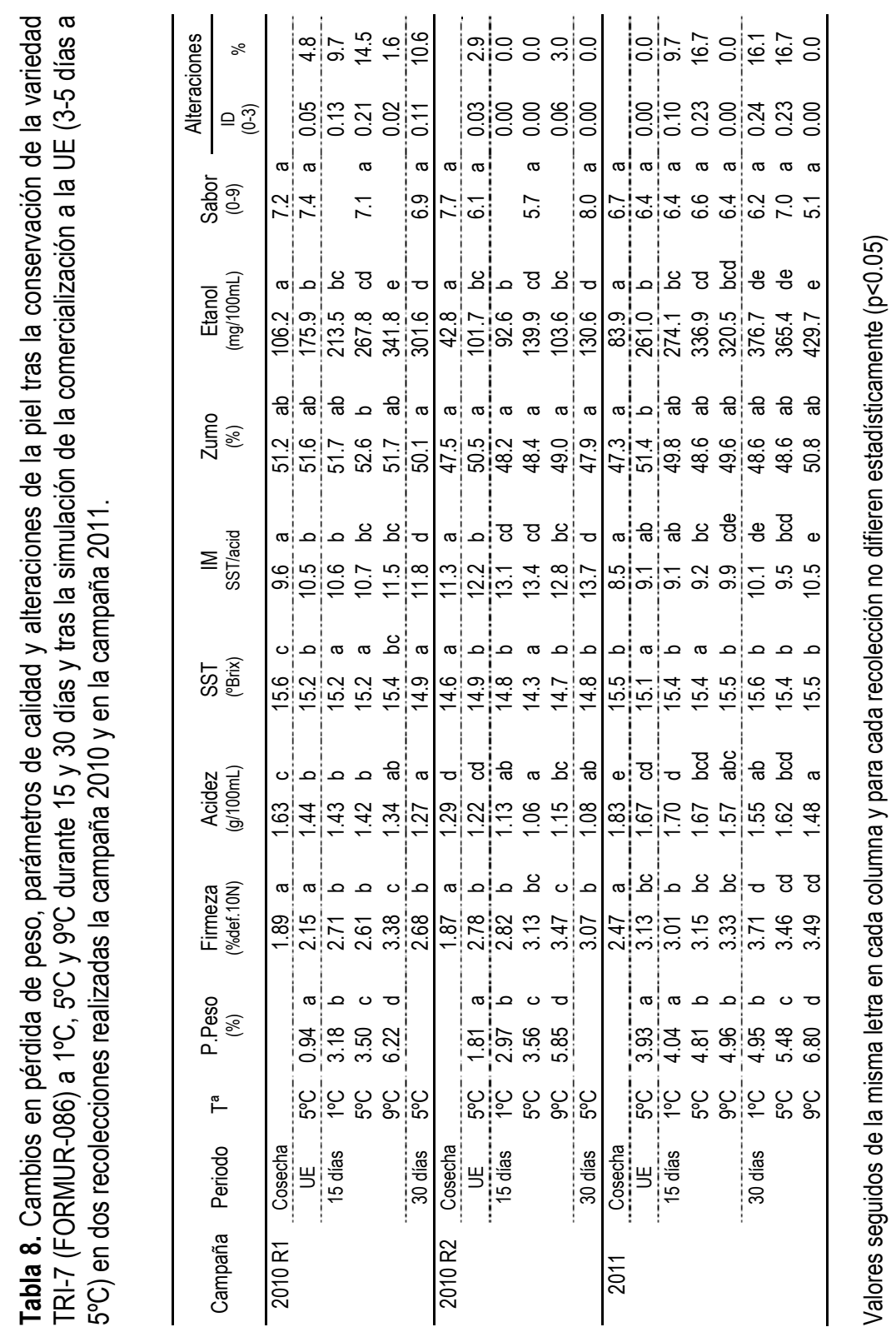




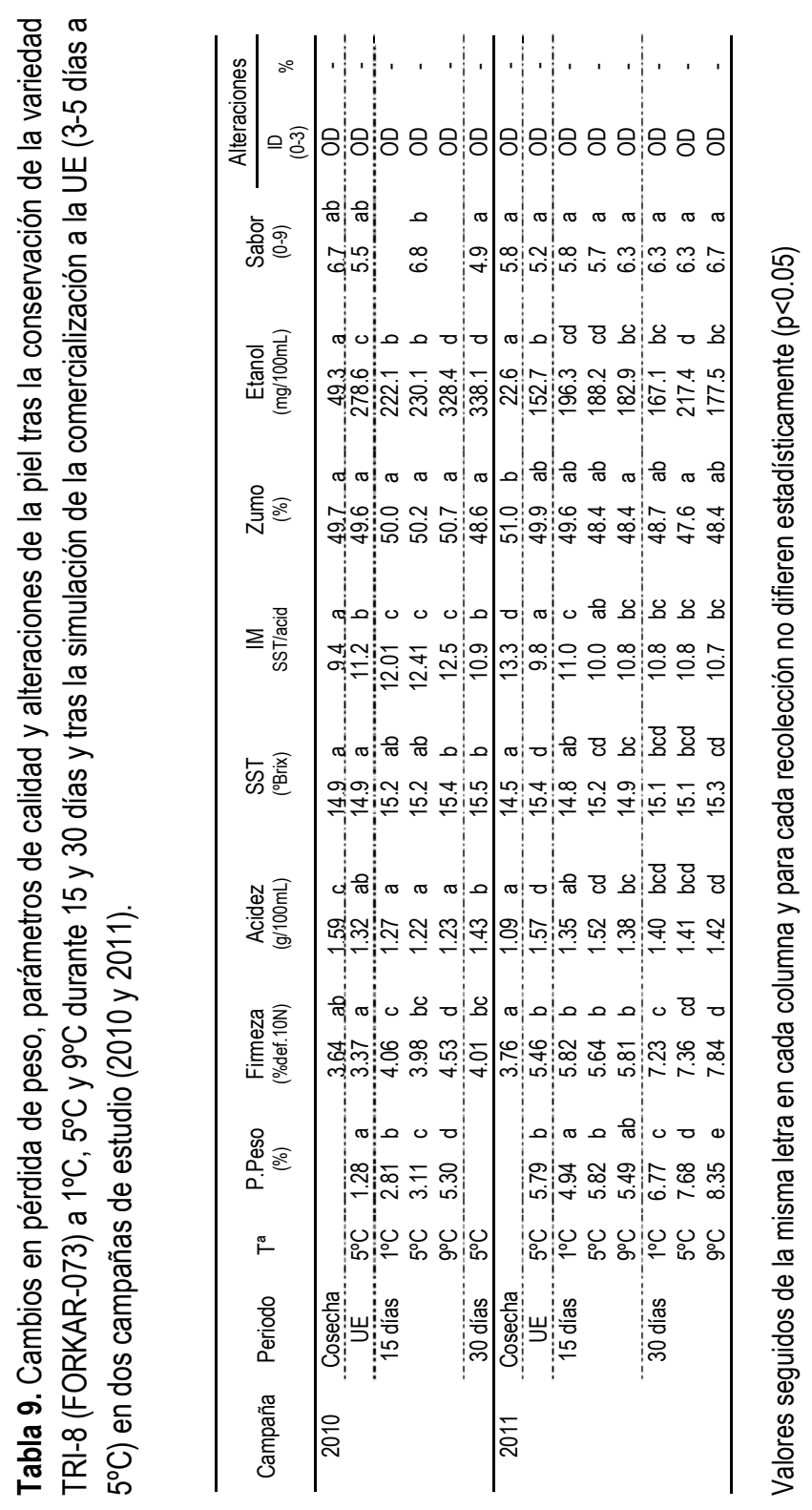




\section{CONCLUSIÓN}

Todas las nuevas variedades estudiadas presentan alta calidad organoléptica y sensorial, con alto contenido en azúcares y acidez. Los resultados del presente trabajo confirman que, en los cítricos, la sensibilidad a los daños por frío depende altamente de la variedad. Además, el desarrollo de las alteraciones relacionadas con el estrés por frío aumentan con el almacenamiento a bajas temperaturas y se agravan con el periodo de conservación.

La diferente sensibilidad que mostraron las variedades evaluadas a las bajas temperaturas, compromete en algunos casos la calidad externa tras periodos prolongados de almacenamiento. Mientras que las variedades PRI-48 (FORELL 96-023) y TRI-5 (FORMCO 95-097) presentaron una buena aptitud a la conservación frigorífica, las variedadesTRI-6 (FORMCO 96-082), PRI-44 (FORELL 96-060) y PRI-47 (FORMUR 96-023) mostraron una elevada susceptibilidad a la manifestación de síntomas de daños por frío, incluso cuando la fruta fue sometida a condiciones de simulación de comercialización a la UE. La fruta de las variedades PRI-43 (FORELL 96-058), PRI-46 (FORMUR 96-019) y TRI-7 (FORMUR 96-086) presentó buen aspecto sin incidencia de alteraciones tras la simulación de comercialización a la UE. Por otra parte la variedad TRI-8 (FORKAR 96-073) presentó gran sensibilidad al desarrollo de alteraciones relacionadas con daño mecánico provocado por el paso por línea de confección.

\section{Agradecimientos.}

Este trabajo ha sido integramnete financiado por el Instituto Valenciano de Investigaciones Agrarias. 


\section{Bibliografía}

Artés, F. (1987). Refrigeración y comercialización hortofrutícolas en la Región de Murcia. II Edición. Ed. CEBAS-CSIC. 150 p.

Chalutz, E., Waks, J., Schiffmann-Nadel, M. 1981. The different responses of several citrus fruits cultivars to low temperatures. Proceedings of the International Society of Citriculture, 2: 773-774.

Cohen, E., Shalom, Y., Rosenburger, I. 1990. Postharvest ethanol buildup and off-flavor in 'Murcott' tangerine fruits. Journal of the American Society for Horticultural Science, 115: $775-778$.

Cuquerella, J. y Navarro, P. 1989. Estado actual de la frigoconservación de los cítricos. Fruticultura Profesional, 25: 122-129.

Cuquerella, J. y Navarro, P. 1997. Medidas objetivas de calidad en frutos cítricos con tratamiento de cuarentena por frío. In: Medición de la Calidad en Frutos Tropicales y Subtropicales con Tratamientos Físicos de Cuarentena. Saucedo V. C., y J. M. Martínez (eds). Instituto Valenciano de Inv. Agrarias. Moncada, Valencia (España). pp: 1-20.

Cuquerella, J., Salvador, A., Monterde, A., Navarro, P., Martínez-Jávega, J.M. 2004. Influencia de los tratamientos postcosecha en la evolución de los parámetros de calidad de mandarinas y naranjas. Agrícola, 12: 24-28.

Guerra, F. 1996. Tecnología post-cosecha de frutos cítricos. Curso integral de citricultura. Instituto de Investigaciones de Fruticultura Tropical, pp. 242-257.

Hagenmaier, R.D. y Shaw, P.E. 2002. Changes in volatile components of stored tangerines and other specialty Citrus fruits with different coatings. Journal of Food Science, 65: 1742-1745.

Hagenmaier, R.D. 2002. The flavor of mandarin hybrids with different coatings. Postharvest Biology and Technology, 24: 79-87.

Jiménez-Cuesta, M., Cuquerella, J., Martínez-Jávega, J.M. 1981. Determination of a color index for citrus fruit degreening. Proceedings of the International Society of Citriculture, 2, 750-753.

Ke, D. y Kader, A.A. 1990. Tolerance of 'Valencia' Oranges to Controlled Atmospheres, as Determined by Physiological Responses and Quality Attributes. Journal of the American Society for Horticultural Science, 115: 779-783.

MAGRAMA (Ministerio de Agricultura, Alimentación y Medio Ambiente). RESUMEN DE LOS AVANCES DE SUPERFICIES Y PRODUCCIONES AGRÍCOLAS. 2012. 
Retrieved June 26, 2012 from: http://www.magrama.gob.es/es/estadistica/temas/estadisticas-agrarias.

Marcilla, A., Zarzo, M., del Río, M.A. 2006. Effect of storage temperature on the flavour of citrus fruit. Spanish Journal of Agricultural Research, 4: 336-344

Marcilla, A., Martínez, M., Carot, J.M., Palou, L., Del Río, M.A. 2009. Relationship between sensory and physico-chemical quality parameters of cold-stored 'Clemenules' mandarins coated with two commercial waxes. Spanish Journal of Agricultural Research, 7: 181-189.

Martínez- Jávega J.M. 1997. La frigoconservación en naranjas y mandarinas. Phytoma, 90: $136-140$

Martinez-Javega, J. M., Saucedo, C., Del Rio, M.A., Mateos, M. 1992. Influence of storage temperature and coating on the keeping quality of "Fortune" mandarins. Proceedings of the International Society of Citriculture, 3: 1102-1103.

Martínez-Jávega, J.M., Cuquerella, J., Salvador, A., Monterde, A., Navarro, P. 2004. Adecuación de tratamientos postcosecha a parámetros de recolección de mandarinas y naranjas de España. Red Interamericana de Cítricos, No. 23 y 24: 2333.

Navarro, L., Juárez, J., Aleza, P., Pina, J.A., Olivares-Fuster, O., Cuenca, J., Julve, J.M. 2005. Programa de obtención de híbridos triploides de mandarino en España. Phytoma, 170: 97-104.

Navarro, P., Monterde, A., Sdiri, S., Cuenca, J, Aleza, P., Salvador, A. 2010. Resultados preliminares sobre la respuesta a la conservación frigorífica de las nuevas variedades de mandarinas triploides garbí y safor. Levante Agrícola, 401: 204-208.

Obenland, D., Collin, S., Mackey, B., Sievert, J., Arpaia, M.L. 2011. Storage temperature and time influences sensory quality of mandarins by altering soluble solids and aroma volatile composition. Postharvest Biology and Technology, 59: 187-193.

Obenland, D., Collin, S., Sievert, J., Fjeld, K., Doctor, J., Arpaia, M.L. 2008. Commercial packing and storage of navel oranges alters aroma volatiles and reduces flavor quality. Postharvest Biology and Technology, 47: 159-167.

Pesis, E. 2005. The role of the anaerobic metabolites, acetaldehyde and ethanol, in fruit ripening, enhancement of fruit quality and fruit deterioration. Postharvest Biology and Technology, 37: 1-19.

Porat, R., Weiss, B., Cohen, L., Daus, A., Biton, A. 2005. Effects of polyethylene wax content and composition on taste, quality, and emission of off-flavor volatiles in 'Mor' mandarins. Postharvest Biology and Technology, 38: 262-268. 
Reglamento UE. 2011. REGLAMENTO DE EJECUCIÓN (UE) N543/2011 DE LA COMISIÓN de 7 de junio de 2011. Diario Oficial de la Unión Europea.

Salvador, A. 1999. Estudio de la aptitud para la desverdización de nuevas variedades 'Clemenpons', 'Loretina' y 'Beatriz'; y el comportamiento en frigoconservación de las mandarinas 'Ellendalle' y 'Ortanique'. Tesis Doctoral. Universidad Politécnica de Valencia, España, 193 pp.

Sdiri, S., Navarro, P., Monterde, A., Cuenca, P., Ben Abda, J., Salvador, A. 2012. Postharvest behavior of 'Garbi' and 'Safor'. New triploid mandarins. Acta Horticulturae, 945: 255-262.

Shi, J.X., Porat, R., Goren, R., Goldschmidt, E.E. 2005. Physiological responses of 'Murcott' mandarins and 'Star Ruby' grapefruit to anaerobic stress conditions and their relation to fruit taste, quality and emission of off-flavor volatiles. Postharvest Biology and Technology, 38: 99-105.

Tietel, Z., Bar, E., Lewinsohn, E., Feldmesser, E., Fallik, E., Porat, R. 2010. Effects of wax coatings and postharvest storage on sensory quality and aroma volatile composition of 'Mor' mandarins. Journal of the Science of Food and Agriculture, 90: 995-1007. 
IV. GENERAL DISCUSSION 



\title{
IV.1. POSTHARVEST DEGREENING OF EARLY-SEASON CITRUS FRUIT
}

\author{
IV.1.1. QUALITY IMPROVEMENT OF EARLY SEASON CITRUS FRUIT \\ SUBMITTED TO POSTHARVEST DEGREENING BY CONTROLLING \\ PHYSIOLOGICAL DISORDERS ASSOCIATED TO EXOGENOUS ETHYLENE \\ EXPOSURE
}

Postharvest degreening with exogenous ethylene exposure is used worldwide to accelerate the color change in early-season citrus varieties in which the internal maturity is reached before the full external coloration (Sdiri et al., 2010). The effectiveness of the degreening treatment depends on factors intrinsic to the process such as ethylene concentration, temperature or relative humidity, as well as on others factors such cultivar and initial external color of the fruit.

In citrus fruit, the exogenous application of ethylene during degreening treatment, not only causes the acceleration of color change, but also can produce undesirable effects related to the enhancement of fruit senescence such as drying, browning and abscission of the calyx (Cronjé et al., 2005; Martínez-Jávega et al., 2008a, 2008b; Salvador et al., 2008, 2010). It has been reported that the susceptibility to these undesirable effects of ethylene is cultivar dependent (Carvalho et al., 2008; Sdiri et al., 2012a) although the incidence of these alterations is mainly associated with inappropriate condition of degreening process. One important parameter to take into account during the postharvest degreening treatment is the concentration of ethylene. High levels of ethylene above the threshold (> 5ppm) can increase fruit deterioration causing serious quality losses. Another important factor to consider in the degreening process is the time required to reach the desired color of the fruit, which is dependent on the initial fruit color (Martínez-Jávega et al., 2008a), but it must be taking into account that the longer the exposure time, the more susceptible citrus fruit to senescence alterations.

Furthermore, the incidence of these disorders is accentuated by the posttreatment storage time taken until market; therefore the degreened fruit has less 
risk of manifesting disorders if intended for the European Union market than if is exported to more distant countries like the USA or Japan, even more when a strict cold-quarantine treatment is required against Mediterranean fruit fly (Ceratitis capitata).

In the Postharvest Technology Center in the Instituto Valenciano de Investigaciones Agrarias (Spain), many studies have been conducted in order to improve the quality of degreened citrus fruit. Therefore one of the objectives of the present Thesis was to evaluate the effect of new degreening treatments combining different periods of exposure to ethylene with periods without the addition of ethylene on the quality of citrus fruit. To achieve this aim, a study has been carried out with different fruit groups from 'Clemenules' mandarins and 'Navelina' oranges, separated based on the external color at harvest and subjected to different treatments combining periods with and without ethylene for up to $72 \mathrm{~h}$ and $120 \mathrm{~h}$.

The results obtained in this study showed that 'Clemenules' mandarins exhibited lower sensitiveness to calyx senescence under all assayed degreening treatments than 'Navelina' oranges, which exhibited high incidence of calyx alteration even when degreened without ethylene exposure. The susceptibility to this undesirable disorder associated to ethylene exposure has been previously reported that is cultivar dependent (Carvalho et al., 2008).

As expected, for all color groups in both cultivars the incidence of abscised and browned calyxes increased the longer the exposure to ethylene. Thus the incidence of calyx change in fruit with submitted to shorter degreening treatments, up to $72 \mathrm{~h}$, was lower than in the fruit subjected to degreening treatments of up to $120 \mathrm{~h}$.

Regarding color evolution for both varieties, all degreening treatments combining different periods with and without exposure to ethylene improved the external coloration after the simulated market period. However the increase in color index was higher when ethylene exposure was longest which is in agreement with previous studies (Cuquerella et al., 1999; Martínez-Jávega et al., 2008a). 
The efficacy of combining periods with ethylene exposure and others without on the color changes depended on the color index of fruit at harvest. For 'Clemenules' mandarins, degreening treatment combining $72 \mathrm{~h}$ with ethylene plus $48 \mathrm{~h}$ without ethylene was necessary to achieved the commercial color of the variety with the lowest incidence of calyx change when fruit were harvested with a color index of between -9 and -3 . However, for fruit harvested with an external color index of over -2 , a treatment combining $24 \mathrm{~h}$ with ethylene plus $48 \mathrm{~h}$ without ethylene was adequate to reach the typical color of the variety.

Since 'Navelina' oranges is highly sensitive to calyx senescence when exposed to exogenous ethylene, the only degreening treatment recommended consisted on combining $24 \mathrm{~h}$ with ethylene plus $48 \mathrm{~h}$ without ethylene. In order for this treatment to be possible, fruit have to be harvested with color index values of over 0 .

Every degreening treatment combining different periods with and without ethylene exposure did not consistently affect the quality parameters or global flavor of citrus fruit. Previous studies have reported that fruit submitted to exogenous ethylene show similar physical and biochemical changes to untreated fruit (Plaza et al., 2004; Martínez-Jávega et al., 2008a; Tietel et al., 2010; Sdiri et al., 2012b).

In addition, the postharvest use of application a new growth regulator on the calyx senescence as well as the fruit quality parameters of the most important of Spanish early-season citrus fruit subjected to degreening treatment under commercial conditions has been investigated.

Synthetic auxins, especially 2,4-dichlorophenoxyacetic acid (2,4-D), have been reported as a useful postharvest treatment to retard calyx disorders that occur as a consequence of degreening process (Cronje et al., 2005; MartinezJavega et al., 2008b; Salvador et al., 2008). Since, at the present, the use of 2,4-D is restricted even as preharvest application, it is necessary to find other synthetic auxins as alternative to 2,4-D in order to avoid the physiological changes in the calyx of citrus fruit submitted to postharvest degreening. 
In the present Thesis, the effect of the postharvest application of S-Ethyl-4chloro-O-tolilooxytioacetate (HF-Calibra ${ }^{\circledR}$ ), a new growth regulator registered for a preharvest use, on the calyx senescence as well as the fruit quality parameters of the most important of spanish early-season citrus fruit ('Navelina' oranges and 'Clemenules', 'Oronules' and 'Clemenrubi' mandarins) subjected to degreening treatment under commercial conditions has been evaluated.

For all varieties the application of HF-Calibra ${ }^{\circledR}$ at different concentrations $(20,40$ and $60 \mathrm{ppm})$ reduced the incidence of abscised and browned calyxes if compared with non-treated fruit and showing the same behavior as 2,4-D; even in some cases, such as in 'Clemenrubi' mandarins the HF treatments resulted more effective than the $2,4 \mathrm{D}$.

The auxin treatments delayed the color evolution of the fruit when compared to the non-treated fruit. In general, no significant differences were found between the color values of fruit treated with HF-Calibra $\AA$ at different concentrations and those of 2,4-D treated fruit. Nevertheless, the delay observed in color changes had no negative effect from a commercial point of view, since in all cases the fruit achieved a commercially acceptable color.

On the other hand, the obtained results showed that the postharvest application of HF-Calibra ${ }^{\circledR}$ at different did not induce detrimental effects on global internal quality of any citrus variety.

The results highlight the effect of the auxin HF-Calibra ${ }^{\circ}$ as a potential alternative to 2,4-D reducing the calyx disorders which appear during the postharvest degreening treatment of early-season citrus fruits. 


\section{IV.1.2. EVALUATION OF THE EFFECT OF ETHYLENE APPLICATION DURING POSTHARVEST DEGREENING ON NUTRITIONAL COMPOSITION AND VOLATILE COMPOUNDS OF EARLY SEASON CITRUS FRUIT}

Citrus fruit are recognized by their nutritional quality as well as their characteristic taste and aroma. Many studies reported the effects of postharvest application of ethylene on internal quality properties of the edible part of the citrus fruit (Martinez-Javega et al., 2008a; Sdiri et al., 2012a; Tietel et al., 2010). Therefore, in the present Thesis, the effect of ethylene degreening on bioactive and volatile compounds was evaluated.

A preliminary study was conducted in order to investigate the effect of ethylene application (2 ppm) and the duration of treatment $(48,72$ or $120 \mathrm{~h})$ on ascorbic acid (AA), total ascorbic acids (TAA) and dehydroascorbic acid (DHAA) content as well as the antioxidant activity of 'Clemenules' and 'Clemenpons' mandarins. The results showed that neither the duration of degreening treatment nor the ethylene exposure affected TAA and AA content; no remarkable differences were showed between degreened fruit with or without ethylene. Moreover, exogenous ethylene during degreening process did not affect the antioxidant activity, assessed by DPPH method, of early season citrus fruit.

A significant percentage of the Spanish citrus fruit is exported to more distant countries such as USA, which require strict cold quarantine treatment against Mediterranean fruit fly (Ceratitis capitata). These conditions may adversely affect the final quality of the fruit, especially when it has been previously degreened. For this reason one of the objective of the present Thesis was to investigate the effect of degreening treatment with and without ethylene exposure followed by cold-quarantine storage on the bioactive components as well as the aroma volatile compounds of citrus fruit.

The postharvest degreening without or with ethylene exposure and the subsequent cold-stored under quarantine conditions plus shelf-life did not affect neither the content of ascorbic acid and total ascorbic acid nor the total phenolic content (TPC) of the studied varieties of citrus fruit ('Navelina' oranges and 'Clemenules', 'Clemenpons', 'Oronules', 'Prenules', 'Clemenrubí', 'Basol' and 
'Orogros' mandarins) . In general, these contents were not significantly affected by ethylene exposure during degreening treatment. These postharvest conditions did not significantly affect the antioxidant activity of all the varieties evaluated using DPPH free radical-scavenging and ferric reducing antioxidant power (FRAP) tests. Another point to remark is that the changes in antioxidant activity found in our study follow the same behavior as the changes in both TAA and total phenolic content. Previous studies reported that, in citrus fruit, the antioxidant capacity is due to the combined activity of various antioxidants, mainly ascorbic acid (Gardner et al., 2000; Del Caro et al., 2004; Abeysinghe et al., 2007; Gonzalez-Molina et al., 2009) and phenolics (Rapisarda et al., 1999; Abeysinghe et al., 2007).

Regarding flavanone components, although some changes in individual compounds due to postharvest degreening followed by cold-quarantine were observed and varied depending on the variety, the combination on these postharvest treatments did not induce detrimental effects in the content of these compounds since the total contents of flavanones were not affected.

The results of this study demonstrate that, after degreening treatment and the posterior cold-quarantine storage, some differences among treatments were also shown in individual flavone compounds; nevertheless, these changes did not lead to a loss in the total flavones content. Moreover, no significant differences were found between ethylene-treated and untreated fruits.

In this study, degreening under commercial conditions followed by the coldquarantine treatment enhanced the external color of 'Navelina' oranges and of the seven studied varieties of clementines, and preserved the quality attributes of the fruit (Martínez-Javega et al., 2008a; Sdiri et al., 2012c; Tietel et al., 2010).

To investigate the changes of volatile compounds of degreened citrus fruits under simulation to USA market, commercial early-season citrus varieties ('Navelina' oranges, 'Clemenules', 'Oronules', 'Prenules', 'Basol' and 'Clemenrubí) were submitted to degreening without or with ethylene exposure under commercial conditions followed by cold-quarantine storage. 
A total of 87 volatile compounds were unequivocally identified in the juice of the citrus varieties. Our analysis permitted to identify inter-varietal difference of volatile profile at harvest. The Principal Component Analysis (PCA) performed on the total data set of volatile compounds of the six studied varieties at harvest, allowed the separation of the samples into three groups: 'Navelina' orange, 'Clemenules' and a third group where 'Oronules' and its mutations are included.

After degreening treatment with or without ethylene followed by coldquarantine storage, the levels of several volatile compounds changed significantly. The response to ethylene exposure depended on the variety being 'Oronules' and 'Clemenrubi' mandarins the most responsive, while the ethylene exposure did not affect further the levels of volatile compounds of 'Navelina', 'Clemenules' and 'Basol' varieties.

Ethylene-degreened fruit submitted to cold-quarantine storage showed higher content of ethanol than air-degreened fruit; nevertheless in any variety the level of this compound was associated to off-flavor development and all the fruits were sensory evaluated with high flavor scores.

When focused on the aroma-active compounds, it was found that changes in these components depend on the variety. 'Clemenules' did not show significant differences in the levels of aroma active compounds between degreened fruit with and without ethylene. The odor-active compounds of 'Navelina', 'Prenules' and 'Basol' were only slightly affected by ethylene exposure. The most dramatic changes in aroma-active volatiles in response to ethylene degreening were observed in 'Oronules' and 'Clemenrubi' by increasing the levels of some aldehydes and alcohols when exposed to exogenous ethylene. 


\section{IV.2. POSTHARVEST BEHAVIOR OF NEW TRIPLOIDS MANDARINS}

A triploid breeding program has been carried out in the Plant Protection and Biotechnology Center in the Instituto Valenciano de Investigaciones Agrarias (IVIA) based on sexual hybridization, embryo rescue and ploidy analysis by flow cytometry in order to obtain new triploid mandarin varieties with late harvest.

The introduction of these new varieties makes it necessary to study their nutritional composition as well as their postharvest behavior to know the availability of mandarins in the market.

\section{IV.2.1. DETERMINATION OF THE INTERNAL QUALITY ATTRIBUTES AND HEALTH-PROMOTING PROPERTIES OF THE NEW CITRUS CULTIVARS COMPARING TO THOSE OF THEIR PARENTS}

In the present Thesis, the content of vitamin C, total phenolic, phenolic acids, organic acids and sugars as well as the antioxidant activity of 'Safor' and 'Garbí' mandarins, registered and available and available for commercial propagation, and nine other new triploid mandarins were determined and compared with those of their parents.

Almost all the new hybrids exhibited high content of vitamin $C$ and total phenolics in some case superior than that of their parents. FORELL-023, FORMCO-097 and FORMUR-019 presented greater levels of vitamin C. High content of vitamin C was also found in 'Safor', FORMCO-082 and FORELL-060 with similar levels than those exhibited by their parents. The results of these studies indicated that the introduction of 'Kara' parentage enhanced the level of total phenolics in 'Safor' and FORKAR-073 mandarins. In general, the vitamin C and total phenolic contents of the studied new varieties was in the range of the content reported previously for different citrus varieties (Palma et al., 2005; Abeysinghe et al., 2007; Wang et al., 2007; Cano et al., 2008; Tounsi et al., 2011; Sdiri et al., 2012b). Almost all the tested new hybrids displayed higher or similar values of antioxidant activity, evaluated by DPPH radical scavenging method and by FRAP assay, than their parents. 
'Safor' mandarin exhibited high level of hesperidin which could be explained by the introduction of 'Kara' parentage that contained the highest content. The hybrids 'Garbi', FORELL-023, FORMUR-019 displayed levels of hesperidin superior than those exhibited by their parents. In general, compared to their respective parents, the new hybrids exhibited higher significant or similar contents of narirutin, didymin, naringenin, naringin, diosmin and polymethoxyflavones as well as phenolic and organic acids.

The levels of quercetin found in the present study were in the range of those reported by Wang et al. (2007). Kara mandarin exhibited the greatest content of quercetin which explain the high content found in 'Safor' and FORKAR-073 triploids. 'Garbí' fruits displayed a quercetin levels relatively higher than that exhibited by the female parent ('Fortune' mandarin). All the other triploids presented similar values as their parents.

'Safor' and 'Garbi' fruits contain similar contents of these sugars to 'Fortune' mandarin which is the female parent. The high contents of sugar exhibited by the new hybrids were reflected in the high values of TSS as well as that of Ml.

\section{IV.2.2. STUDY OF THE APTITUDE OF THE NEW CITRUS CULTIVARS FOR COLD STORAGE, EVALUATING THEIR SUSCEPTIBILITY TO LOW TEMPERATURE}

The quality of fresh fruits and vegetables declines after harvest because they are living tissues which continue to respire and can be maintaining by optimal temperature control. Temperature management is the predominant method used to preserve postharvest life and to extend marketing time of citrus fruits. At present, cold storage is the storage system being used extensively commercially to slow respiration and other metabolic processes in order to preserve postharvest life and to extend marketing time of citrus fruits. However, application of improper storage temperature leads to physiological disorders reducing consumer acceptance. Some citrus varieties are susceptible to chilling 
injury $(\mathrm{Cl})$ when exposed to prolonged cold storage at low temperatures depending upon variety. Each variety has a critical temperature for the occurrence of $\mathrm{Cl}$ and therefore each variety has an optimum temperature for keeping quality depending on the duration of storage (Murata, 1997; MartínezJávega et al., 1999). Hence, it is necessary to establish a suitable storage temperature and duration depending on the response of the cultivar to those temperatures.

The releasing of new cultivars requires the study of their postharvest behavior and in particular the assessment of the suitability for cold storage, in order to extend the fruit marketing. Taking into account, that all the new varieties recently released in the IVIA have 'Fortune' mandarin (Citrus clementina Hort. ex Tanaka x Citrus tangerina Hort. Ex Tan) as female parent, make it necessary to study their susceptibility to develop chilling injury symptoms when stored at low temperatures. It has been known that 'Fortune' mandarin is a citrus cultivar very sensitive to chilling injury when stored at temperatures below $10^{\circ} \mathrm{C}$ (Martínez-Jávega et al., 1992). This peel disorder causes a high reduction of the external fruit quality and so decreases its commercial value.

In the present Thesis, the postharvest behavior of new late-maturing triploid mandarins was studied in order to establish the optimum storage conditions for safe and long-term storage of fruit. To accomplish this goal, fruits from 'Safor', 'Garbí' and nine new triploid varieties were stored up to 30 days at $1^{\circ} \mathrm{C}, 5^{\circ} \mathrm{C}$ and $9^{\circ} \mathrm{C}$ during 3 seasons. The incidence of $\mathrm{Cl}$ as well as changes in internal quality parameters, weight loss, firmness and ethanol content was evaluated at the end of the storage period.

The susceptibility to develop $\mathrm{Cl}$ symptoms increased with the duration of storage being higher after 30 days than 15 days of conservation. The results also show that the incidence of $\mathrm{Cl}$ was higher at low temperatures. In this way, the fruits stored at $1^{\circ} \mathrm{C}$ presented higher symptoms of $\mathrm{Cl}$ than those stored at $5^{\circ} \mathrm{C}$, while fruits maintained at $9^{\circ} \mathrm{C}$ developed symptoms of peel dehydration. It has been reported that $\mathrm{Cl}$ severity is directly related to temperature and duration of exposure; that is, injury generally increases as temperatures decrease and storage periods are extended (Henriod et al., 2005). 
'Safor' mandarins did not show relevant symptoms related to cold-induced damage or dehydration at $1^{\circ} \mathrm{C}, 5^{\circ} \mathrm{C}$ and $9^{\circ} \mathrm{C}$ for 30 days when were previously coated. Fruit from 'Garbí mandarins were more sensitive to storage at low temperature than 'Safor' variety. Fruit stored at $1^{\circ} \mathrm{C}$ and $5^{\circ} \mathrm{C}$ developed symptoms of $\mathrm{Cl}$ while fruit stored at $9^{\circ} \mathrm{C}$ presented symptoms of peel dehydration. Fruit quality, including firmness, weight loss, soluble solids, titratable acidity, and ethanol content were not affected by storage at low temperature.

Regarding the other nine new triploid mandarins, when stored at different storage conditions, it was clearly showed that the susceptibility to develop $\mathrm{Cl}$ symptoms is variety dependent. Fruit from PRI-48 (FORELL 96-023) and TRI-5 (FORMCO 95-097) mandarins did not present any symptoms of $\mathrm{Cl}$ or of peel dehydration even when stored at $1^{\circ} \mathrm{C}$ for 30 days.

Although fruit from PRI-43 (FORELL 96-058), PRI-46 (FORMUR 96-019) and TRI-7 (FORMUR 96-086) presented high external quality without symptoms of $\mathrm{Cl}$ when stored at $5^{\circ} \mathrm{C}$ during 3 days simulating the marketing to the European Union, in some varieties such as TRI-6 (FORMCO 96-082), PRI-44 (FORELL 96-060) and PRI-47 (FORMUR 96-023) some symptoms of $\mathrm{Cl}$ were observed in fruit stored 3 days at $5^{\circ} \mathrm{C}$ plus 6 days at $20^{\circ} \mathrm{C}$.

Fruit from TRI-8 (FORKAR 96-073) did show sensitivity to $\mathrm{Cl}$ or dehydration; however, they developed during all the assayed seasons, symptoms of oil darkening which was related to the postharvest handling of fruits. In order to better understand the postharvest behavior of this variety, more studies have to be conducted in the future.

The symptoms of $\mathrm{Cl}$ observed in some varieties could be related to the percentage of weight loss. It is known that water stress may be a major determinant of peel pitting (BenYehoshua et al., 2001; Lafuente and Sala, 2002; Porat et al., 2004; Alférez et al., 2005; Henriod, 2006). The weight loss significantly increased with the storage temperature and duration. In general, the lower values of weight loss were found in fruit stored at $1^{\circ} \mathrm{C}$ and were significantly greater at $9^{\circ} \mathrm{C}$ than at $5^{\circ} \mathrm{C}$. For all the studied varieties, the results demonstrate that the values of weight loss were less than $10 \%$, percentage 
reported as limit for the commercialization of citrus fruit. The fruit firmness decreased after cold storage of all the new varieties. The fruit deformation show the same behavior as weight loss, presenting high values the longer the period of conservation and the higher the storage temperature.

Although the development of $\mathrm{Cl}$ symptoms was influenced by cultivar, temperature and storage period other additional factors can affect the sensitivity to $\mathrm{Cl}$ disorders climactic and preharvest factors, maturity stage and peel quality at harvest as well as postharvest handling. Hence, further work is required to determine the importance of these factors in relation to $\mathrm{Cl}$ susceptibility.

All the studied triploids did not show alterations in the internal fruit quality, even those which showed a high sensibility to storage at low temperature and the development of $\mathrm{Cl}$ symptoms, presenting good sensorial quality after shelflife. 


\section{REFERENCES}

Abeysinghe, D.C., Li, X., Sun, C.D., Zhang, W.S., Zhou, C.H., Chen, K.S. (2007). Bioactive compounds and antioxidant capacities in different edible tissues of citrus fruit of four species. Food Chemistry, 104, 1338-1344.

Alférez, F., Zacarias, L., Burns, J. (2005). Low relative humidity at harvest and before storage at high humidity influences the severity of postharvest peel pitting in citrus. Journal of the American Society of Horticultural Science, 130, 225-231.

Ben-Yehoshua, S., Peretz, J., Moran, R., Lavie, B., Kim, J.J. (2001). Reducing the incidence of superficial flavedo necrosis (noxan) of Shamouti oranges (Citrus sinensis L. Osbeck). Postharvest Biology and Technology. 22, 19-27.

Cano, A., Medina, A., Bermejo, A. (2008). Bioactive compounds in different citrus varieties. Discrimination among cultivars. Journal of Food Composition and Analysis, 21, 377-381.

Carvalho, C.P., Salvador, A., Navarro, P., Monterde, A., Martinez-Jávega, J.M., 2008. Effect of auxin treatments on calyx senescence in the degreening of four mandarin cultivars. HortScience 43, 747-752.

Cronjé, P.J.R., Crouch, E.M., Huysamer, M., 2005. Postharvest calyx retention of citrus fruit. Acta Hortic. 682, 369-374.

Cuquerella, J.; Navarro, P.; Salvador, A. 1999. Respuesta a la desverdización de nuevas variedades de cítricos. Levante agrícola, 348: 263-271.

Del Caro, A., Piga, A., Vacca, V., Agabbio, M. (2004). Changes of flavonoids, vitamin $\mathrm{C}$ and antioxidant capacity in minimally processed citrus segments and juices during storage. Food Chemistry, 84, 99-105.

Gardner, P.T., White, T.A.C., McPhail, D.B., Duthie, G.G. (2000). The relative contributions of vitamin $\mathrm{C}$, carotenoids and phenolics to the antioxidant potential of fruit juices. Food Chemistry, 68, 471-474.

Gonzalez-Molina, E., Moreno, D.A., Garcia-Viguera, C. (2009). A new drink rich in healthy bioactives combining lemon and pomegranate juices. Food Chemistry, 115, 1364-1372.

Henriod, R. E., M. R. Gibberd, and M. T. Treeby. 2005. Storage temperature effects on moisture loss and the development of chilling injury in 'Lanes Late' navel orange. Australian Journal of Experimental Agriculture, 45(4): 453-458.

Henriod, R. E. 2006. Postharvest characteristics of navel orange following high humidity and low temperature storage and transport. Postharvest Biology and Technology, 42(1): 57-64.

Lafuente, M.T. and Sala, J.M. (2002). Abscisic acid levels and the influence of ethylene, humidity and storage temperature on the incidence of postharvest 
rindstaning of "Navelina" orange (Citrus sinensis L.Osbeck) fruit. Postharvest Biology and Technology, 25, 49-57.

Martínez-Jávega, J.M., Saucedo, C., Del Rio, M.A., Mateos, M. (1992). Influence of storage temperatura and coating on the keeping quality of 'Fortune' mandarins. Proceedings of the International Society of Citriculture, 11021103.

Martínez-Jávega, J.M., Navarro, P., Cuquerella, J., del Rio, M.A. (1999) Aplicaciones del frío en postcosecha de cítricos: panorama actual. Levante Agrícola-Especial Postcosecha, 348, 253-262.

Martínez-Jávega, J.M., Monterde, A., Navarro, P., Salvador, A., 2008a. Response of new clementines to degreening treatment. Proceedings of the International Society of Citriculture, 11, 1342-1346.

Martínez-Jávega, J.M., Salvador, A., Navarro, P., Sdiri, S., 2008b. Aplicación de tratamientos de auxinas para el control de alteraciones del cáliz en mandarinas sometidas al tratamiento de desverdización, in: Oria Almudí, R., Val Falcón, J., Ferrer Mairal, A. (Eds.), Avances en maduración y postrecolección de frutas y hortalizas. Editorial Acribia, S.A., Zaragoza, Spain, pp.474-480.

Murata, T., 1997. Citrus in: Postharvest physiology and storage of tropical and subtropical fruits Mitral S.K. Ed. CAB International New York, USA, pp2147.

Palma, A., D’Aquino, S., Agabbio, M., Schirra, S. (2005). Changes in flavonoids, ascorbic acid, polyphenol content and antioxidant activity in cold stored 'Fortune' mandarin. Acta Horticulturae, 682, 617-622.

Plaza, P., Sanbruno, A., Usall, J., Lamarca, N., Torres, R., Pons, J., Viñas, I., 2004. Integration of curing treatments with degreening to control the main postharvest diseases of clementines mandarins. Postharvest Biol. Technol. 34, 29-37.

Porat, R., Weiss, B., Cohen, L., Daus, A., Aharoni, N. (2004). Reduction of postharvest rind disorders in citrus fruit by modified atmosphere packaging. Postharvest Biology and Technology, 33, 35-43.

Rapisarda, P., Tomaino, A., Lo Cascio, R., Bonina, F., De Pasquale, A., Saija, A. (1999). Antioxidant effectiveness as influenced by phenolic content of fresh orange juices. Journal of Agricultural and Food Chemistry, 47, 4718-4723.

Salvador, A., Navarro, P., Monterde, A., Martínez-Jávega., J.M. (2008). Postharvest application of auxins to control calyx senescence in clementines submitted to degreening treatment. Proceeding of the International Society of Citriculture, 11, 1377-1382. 
Salvador, A., Sdiri, S., Navarro, P., Monterde, A., Marténez-Jávega, J.M., 2010. The use of auxins to maintain postharvest quality of citrus fruit. Acta Hortic. 877, 671-677.

Sdiri, S., Navarro, P., Salvador, A., 2010. Postharvest degreening treatment on citrus fruit: effect on external and internal quality, in: Slaker, D.A. (Ed.), Citrus Fruits: Properties, Consumption and Nutrition. Nova Science Publishers, Inc., New York, pp.137-149.

Sdiri, S., Navarro, P., Monterde, A., Ben abda, J., Salvador, A., 2012a. New degreening treatments to improve the quality of citrus fruit combining different periods with and without ethylene exposure. Postharvest Biol. Technol. 63, 25-32.

Sdiri, S., Navarro, P., Monterde, A., Ben Abda, J., Salvador, A. (2012b). Antioxidant Activity and Vitamin C Are Not Affected by Degreening Treatment of Clementine Mandarins. Acta Horticulturae, 934: 893-899.

Sdiri, S., Navarro, P., Monterde, A., Benabda, J., Salvador, A. (2012c). Effect of postharvest degreening followed by a cold-quarantine treatment on vitamin $\mathrm{C}$, phenolic compounds and antioxidant activity of early-season citrus fruit. Postharvest Biology and Technology, 65, 13-21.

Tietel, Z., Weiss, B., Lewinsohn, E., Fallik, E., Porat, R., 2010. Improving taste and peel color of early-season Satsuma mandarins by combining hightemperature conditioning treatments. Postharvest Biol. Technol. 57(1): 1-5.

Tounsi, M.S., Wannes, W.A., Ouerghemmi, I., Jegham, S., Ben Njima, Y., Hamdaoui, G., Zemni, H., Marzouk, B. (2011). et al., 2011. Juice components and antioxidant capacity of four Tunisian Citrus varieties. Journal of the Science of Food and Agriculture, 91, 142-151.

Wang, Y.C., Chuang, Y.C., Ku, Y.H. (2007). Quantitation of bioactive compounds in citrus fruits cultivated in Taiwan. Food Chemistry, 102, 11631171 . 



\section{GENERAL CONCLUSIONS}





\section{V.1. POSTHARVEST DEGREENING OF EARLY-SEASON CITRUS FRUIT}

1- Application of new degreening treatments with and without ethylene exposure reduces the incidence of calyx senescence of citrus fruit without altering the fruit quality.

The duration of degreening treatment as well as the efficacy of the new treatments combining periods with ethylene exposure and others without depends on the external color of citrus fruit at harvest. The external color of fruits enhances as the duration of exogenous ethylene increases.

'Clemenules' mandarins harvested with a color index of between -9 and 3 can be degreened under treatment combining $72 \mathrm{~h}$ with ethylene application plus $48 \mathrm{~h}$ without ethylene reaching the typical color of the variety with the lowest incidence of calyx senescence.

$\checkmark$ Treatment combining $24 \mathrm{~h}$ with ethylene exposure plus $48 \mathrm{~h}$ without ethylene is recommended for 'Clemenules' mandarins harvested with color index higher than -2 and for 'Navelina' oranges harvested with a color index of over 0 .

$\checkmark$ The susceptibility to calyx changes associated to the degreening treatment is cultivar depended.

$\checkmark$ Degreening treatement combining periods with and without ethylene exposure does not alter the internal quality of citrus fruits.

2- The postharvest application of HF-Calibra ${ }^{\circledR}$ could be an alternative to 2,4-D to avoid calyx senescence of citrus fruits induced by a degreening treatment and to maintain fruit quality.

$\checkmark$ The postharvest application of HF-Calibra $\AA$, prior to the commercial degreening treatment, at different concentrations of $10,20,40$ or $60 \mathrm{ppm}$, effectively reduces calyx senescence of the studied citrus fruits. The higher the doses applied, the lower percentage of fruit with calyx alterations symptom.

$\checkmark$ The application of HF-Calibra ${ }^{\circledR}$ at $10,20,40$ or $60 \mathrm{ppm}$ affects neither weight loss nor the sensory quality of fruits (firmness, total soluble solids, 
titratable acidity, acetaldehyde and ethanol content and flavor) of the studied citrus fruits.

3- In addition to improving the external quality of the early-season citrus fruit, the ethylene degreening treatment does not cause harmful changes neither in the nutritional quality nor in the aroma-active compounds of citrus fruits.

$\checkmark$ The ethylene application during degreening treatment $\left(2 \mathrm{ppm} \mathrm{C}_{2} \mathrm{H}_{4}, 21^{\circ} \mathrm{C}\right.$, $95 \% \mathrm{RH}$ ) for 48,72 and $120 \mathrm{~h}$ does not affect total ascorbic acid, ascorbic acid and dehydroascorbic acid of 'Clemenules' and 'Clemenpons' fruits.

$\checkmark$ Degreening under commercial conditions $\left(2 \mathrm{ppm} \mathrm{C}_{2} \mathrm{H}_{4}, 120 \mathrm{~h}, 21^{\circ} \mathrm{C}, 95 \%\right.$ $\mathrm{RH})$ followed by the cold-quarantine treatment $\left(1^{\circ} \mathrm{C}, 16\right.$ days) enhances the external color of the studied citrus varieties preserving the quality attributes of the fruit.

$\checkmark$ Degreening treatment with ethylene exposure $\left(2 \mathrm{ppm} \mathrm{C}_{2} \mathrm{H}_{4}, 21^{\circ} \mathrm{C}\right.$, $95 \% \mathrm{RH}$ ) for up to $120 \mathrm{~h}$ followed by cold-quarantine storage does not affect total ascorbic acid, ascorbic acid and dehydroascorbic acid, total phenolics, flavonoids contents nor DPPH and FRAP antioxidant capacities of citrus fruits.

$\checkmark$ Ethylene application during degreening treatment does not provoke detrimental changes in the levels of the volatile organic compounds since fruits from the studied varieties subjected to postharvest degreening with ethylene exposure followed by cold-quarantine storage presented high flavor acceptability.

\section{IV.2. POSTHARVEST BEHAVIOR OF NEW TRIPLOIDS MANDARINS}

1- The new triploid mandarins, with mid- late season maturity, are good fruits for fresh consumption since they display high quality parameters of juice at maturity.

$\checkmark$ The quality of the parent cultivars of the new hybrids varieties has been kept or improved in the new varieties, and nutritional bio-components were affected differently. 
The studied new mid- late maturing mandarins exhibited high internal and nutritional quality which may be considerate significant source of phytochemicals that may be used as natural antioxidants.

2- In general, the studied new mid-late maturing triploid mandarins can be stored at low temperature presenting high fruit quality.

$\checkmark$ The incidence of chilling injury $(\mathrm{Cl})$ during cold storage of citrus fruits depends on the variety, the storage temperature and duration as well as preharvest conditions.

$\checkmark$ The new mid-late maturing mandarins can be marketed for European Union ( 5 days at $5^{\circ} \mathrm{C}$ plus 7 days at $20^{\circ} \mathrm{C}$ ) without significant risk of quality loss.

$\checkmark$ In general fruits of the new triploid mandarins can be stored at $1^{\circ} \mathrm{C}$ or $5^{\circ} \mathrm{C}$ during 15 days without showing detrimental physiological disorders that limit the fruit marketing.

$\checkmark$ The $\mathrm{Cl}$ disorder has no effect on internal fruit quality, since all the triploids varieties presented high sensorial quality after shelf-life.

$\checkmark$ In order to confirm the preliminary data obtained, more study is required in the future in order to establish the optimum temperature and duration conditions for postharvest storage of the new triploid mandarins. 

VI. ANNEXES 

Annex 1.
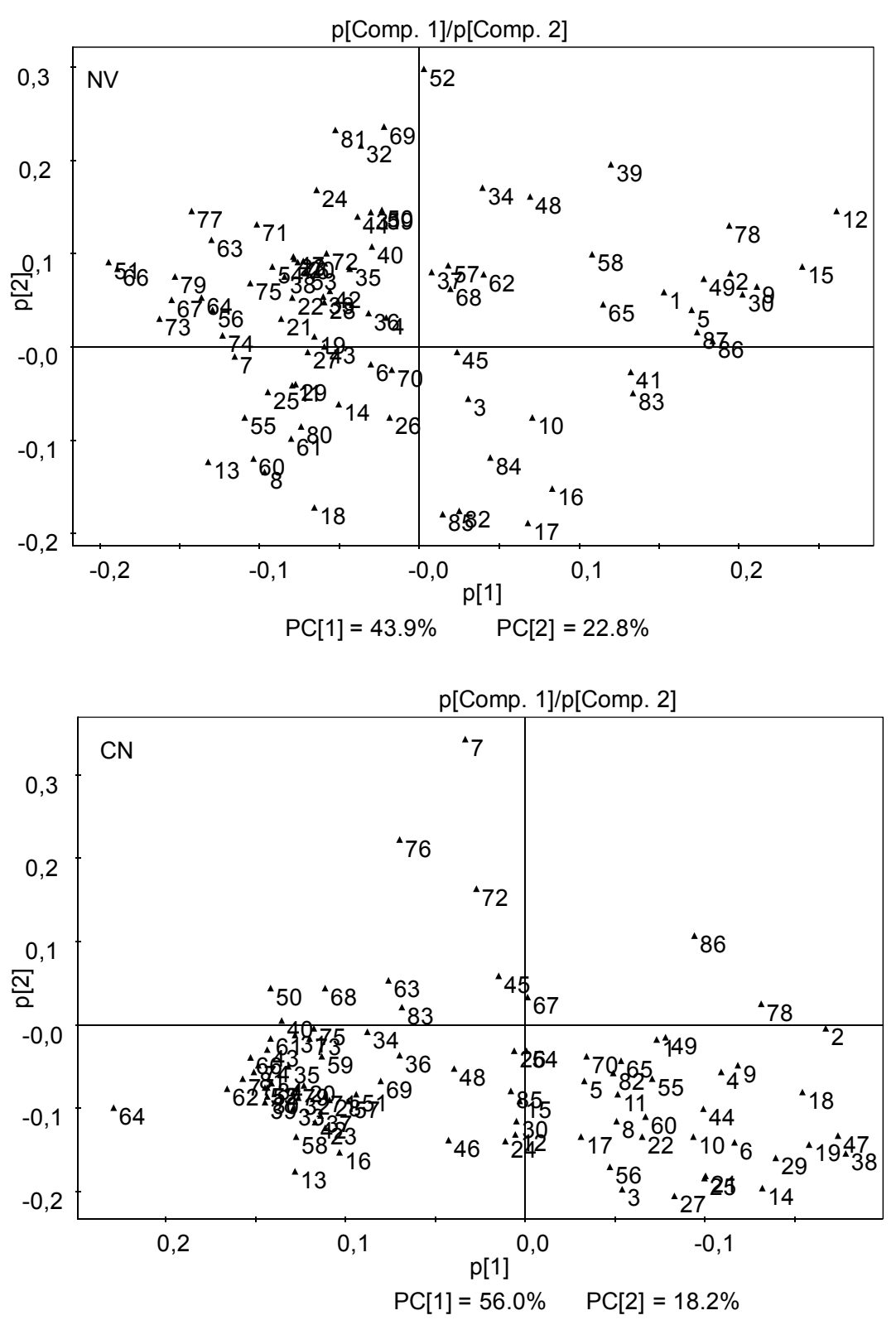
p[Comp. 1]/p[Comp. 2]

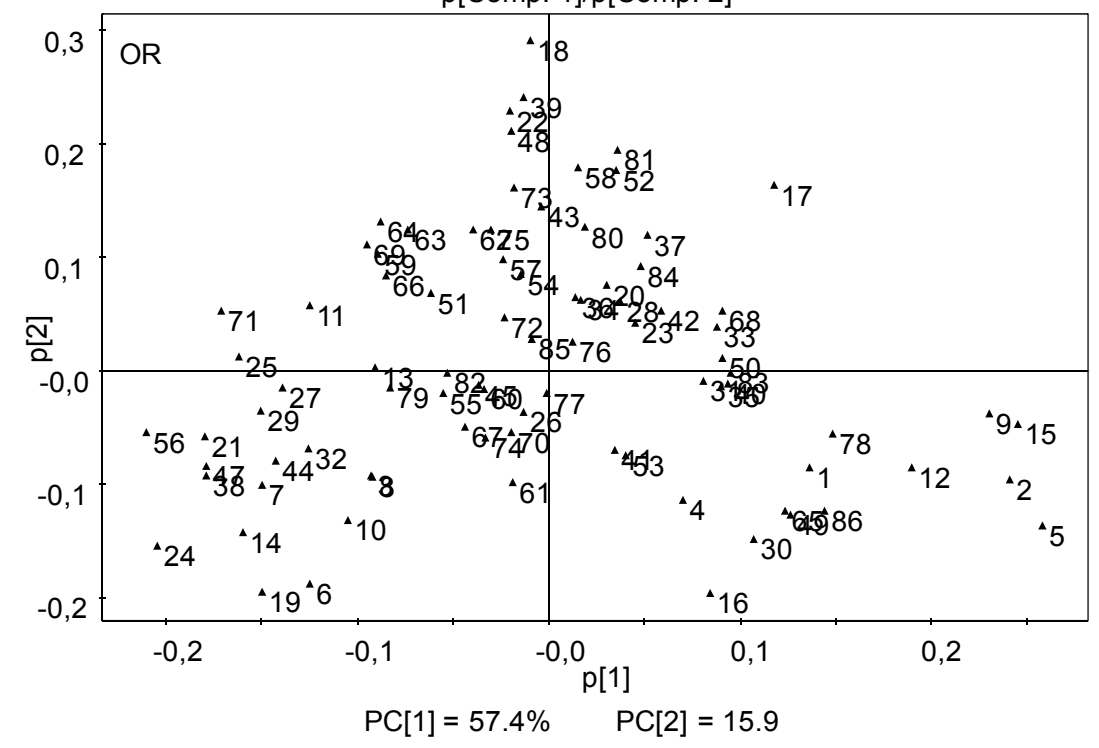

p[Comp. 1]/p[Comp. 2]

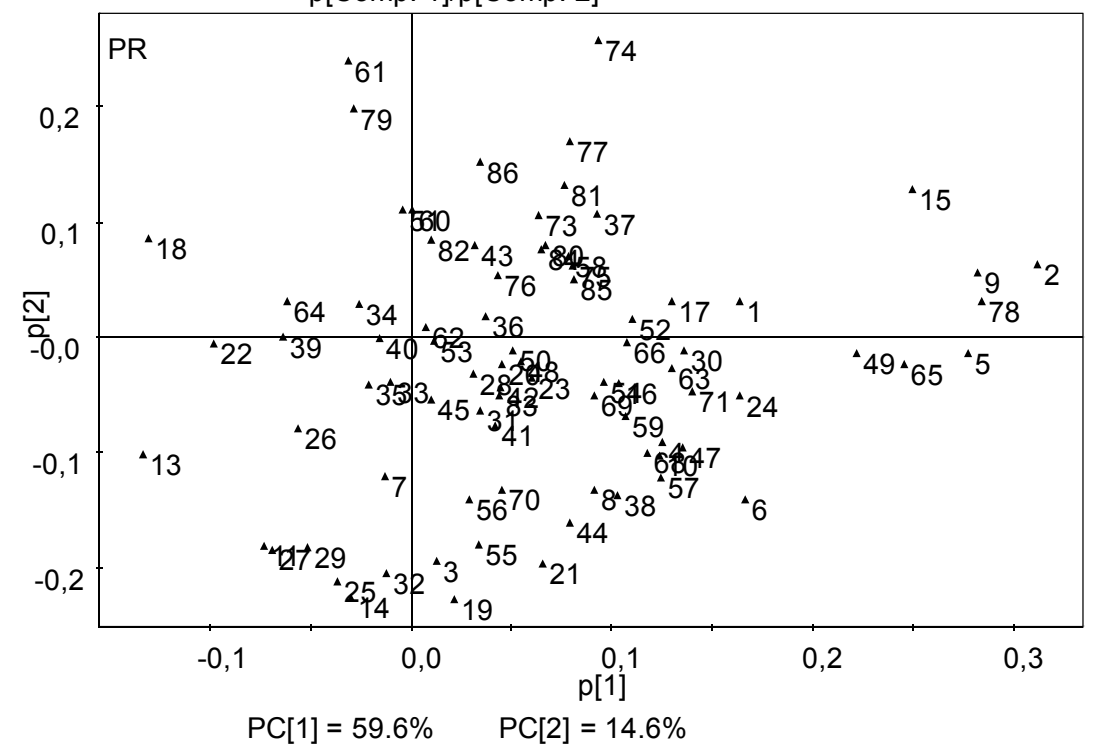


p[Comp. 1]/p[Comp. 2]

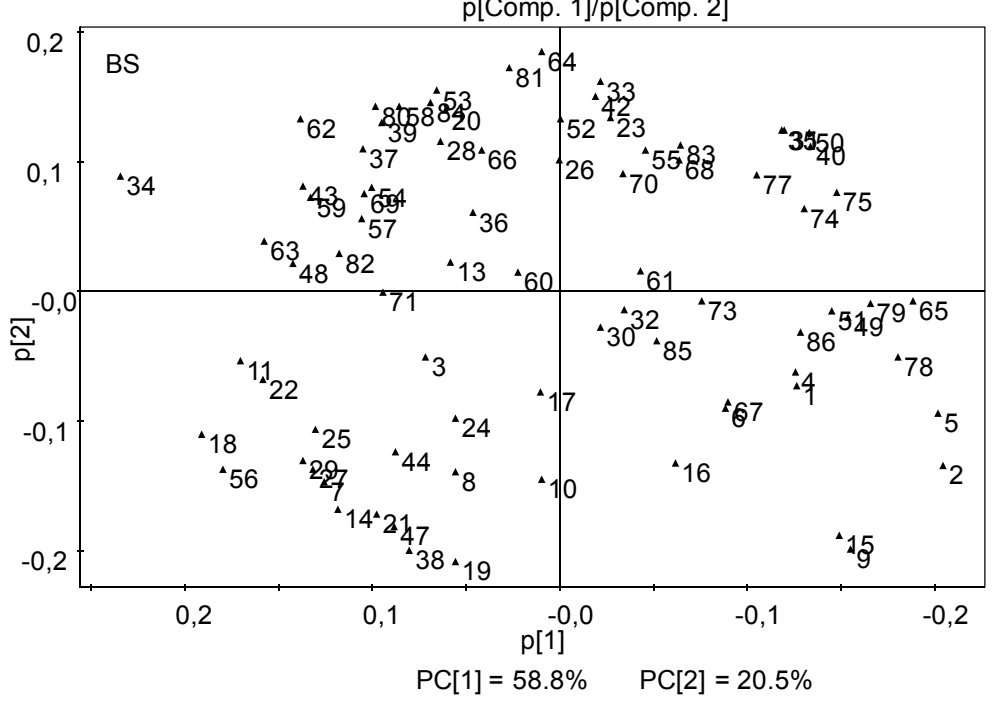

p[Comp. 1]/p[Comp. 2]

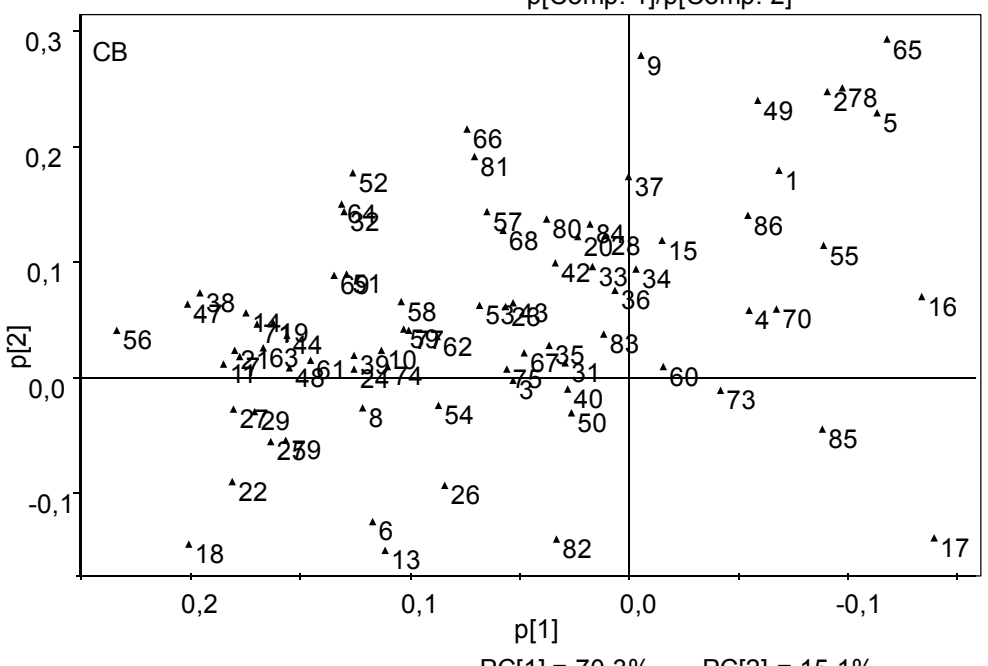

$P C[1]=70.3 \% \quad P C[2]=15.1 \%$

Supplementary figure 3A. Principal Component Analysis loading plot. Each number corresponds to a particular volatile compound, as indicated in Table 1. 
Annex 2.

Relative levels of VOCs detected in juices of 'Prenules' and 'Basol' mandarins at harvest $(\mathrm{H})$ and after degreening without $(A)$ and with $(E)$ ethylene exposure and the posterior cold-quarantine treatment plus shelf-life.

\begin{tabular}{|c|c|c|c|c|c|c|c|c|}
\hline ID & Compounds & RT & \multicolumn{3}{|c|}{ Prenules } & \multicolumn{3}{|c|}{ Basol } \\
\hline & & & $\mathrm{H}$ & A & $E$ & $\mathrm{H}$ & A & $E$ \\
\hline 1 & acetaldehyde & 4,89 & $0,58 \pm 0.07$ & $1,80 \pm 0.1$ & $1,75 \pm 0.28$ & $0,77 \pm 0.16$ & $1,58 \pm 0.18$ & $2,34 \pm 0.18$ \\
\hline 2 & ethanol & 5,52 & $0,08 \pm 0.03$ & $1,52 \pm 0.4$ & $4,13 \pm 0.14$ & $0,20 \pm 0.11$ & $1,37 \pm 0.60$ & $2,88 \pm 0.45$ \\
\hline 3 & 2-methylfuran & 8,84 & $1,82 \pm 0.35$ & $1,94 \pm 0.5$ & $1,91 \pm 0.50$ & $1,40 \pm 0.20$ & $1,00 \pm 0.00$ & $1,05 \pm 0.09$ \\
\hline 4 & 3-methylfuran & 9,14 & $0,90 \pm 0.22$ & $1,71 \pm 0.3$ & $1,79 \pm 0.18$ & $1,04 \pm 0.06$ & $2,16 \pm 0.38$ & $3,25 \pm 0.41$ \\
\hline 5 & ethyl acetate & 9,08 & $0,10 \pm 0.04$ & $1,05 \pm 0.0$ & $2,33 \pm 0.45$ & $0,23 \pm 0.00$ & $1,30 \pm 0.28$ & $4,55 \pm 1.08$ \\
\hline 6 & 1-penten-3-one & 11,56 & $0,97 \pm 0.62$ & $2,48 \pm 0.5$ & $2,95 \pm 0.53$ & $0,50 \pm 0.18$ & $0,82 \pm 0.05$ & $0,89 \pm 0.21$ \\
\hline 7 & pentanal & 12,02 & $2,09 \pm 0.67$ & $1,79 \pm 0.4$ & $2,09 \pm 1.26$ & $1,08 \pm 0.56$ & $0,29 \pm 0.08$ & $0,45 \pm 0.13$ \\
\hline 8 & 2-ethylfuran & 12,11 & $1,72 \pm 0.42$ & $2,42 \pm 0.4$ & $2,54 \pm 0.40$ & $0,91 \pm 0.29$ & $0,61 \pm 0.13$ & $0,71 \pm 0.11$ \\
\hline 9 & ethyl propionate & 12,36 & $0,10 \pm 0.00$ & $0,84 \pm 0.1$ & $2,90 \pm 0.39$ & $0,56 \pm 0.26$ & $1,55 \pm 1.03$ & $5,23 \pm 1.44$ \\
\hline 10 & (E)-2-pentenal & 14,24 & $1,39 \pm 0.41$ & $2,17 \pm 0.2$ & $2,82 \pm 0.64$ & $0,66 \pm 0.12$ & $0,49 \pm 0.22$ & $0,84 \pm 0.09$ \\
\hline 11 & 1-pentanol & 14,53 & $2,68 \pm 0.31$ & $2,26 \pm 0.8$ & $1,75 \pm 0.60$ & $3,33 \pm 0.32$ & $0,66 \pm 0.28$ & $0,65 \pm 0.14$ \\
\hline 12 & ethyl butanoate & 15,80 & nd & nd & nd & nd & nd & nd \\
\hline 13 & (Z)-3-hexenal & 15,85 & $1,22 \pm 0.31$ & $0,64 \pm 0.0$ & $0,53 \pm 0.09$ & $0,59 \pm 0.18$ & $0,60 \pm 0.04$ & $0,28 \pm 0.03$ \\
\hline 14 & hexanal & 15,95 & $2,24 \pm 0.67$ & $2,20 \pm 0.5$ & $1,84 \pm 0.55$ & $0,75 \pm 0.46$ & $0,20 \pm 0.09$ & $0,33 \pm 0.11$ \\
\hline 15 & ethyl 2-methylbutyrate & 17,74 & $0,18 \pm 0.00$ & $0,69 \pm 0.2$ & $3,60 \pm 1.01$ & $0,24 \pm 0.04$ & $0,54 \pm 0.42$ & $3,33 \pm 1.08$ \\
\hline 16 & (E)-2-hexenal & 18,09 & $0,57 \pm 0.14$ & $0,78 \pm 0.1$ & $0,93 \pm 0.09$ & $0,27 \pm 0.09$ & $0,25 \pm 0.01$ & $0,66 \pm 0.09$ \\
\hline 17 & (E)-2-hexen-1-ol & 18,39 & $0,92 \pm 0.30$ & $2,02 \pm 0.8$ & $2,04 \pm 0.47$ & $1,41 \pm 0.24$ & $0,95 \pm 0.39$ & $1,76 \pm 0.65$ \\
\hline 18 & 1-hexanol & 18,47 & $3,18 \pm 0.96$ & $1,42 \pm 0.4$ & $1,45 \pm 0.05$ & $4,26 \pm 0.23$ & $0,35 \pm 0.25$ & $0,64 \pm 0.20$ \\
\hline 19 & heptanal & 19,90 & $1,98 \pm 0.67$ & $2,32 \pm 0.4$ & $2,09 \pm 0.71$ & $0,67 \pm 0.45$ & $0,33 \pm 0.15$ & $0,51 \pm 0.20$ \\
\hline 20 & a-pinene & 21,57 & $0,69 \pm 0.06$ & $0,68 \pm 0.0$ & $0,83 \pm 0.10$ & $1,80 \pm 0.60$ & $1,20 \pm 0.46$ & $1,26 \pm 0.49$ \\
\hline 21 & (E)-2-heptenal & 22,06 & $2,06 \pm 0.54$ & $2,79 \pm 0.6$ & $2,71 \pm 0.71$ & $0,76 \pm 0.34$ & $0,25 \pm 0.11$ & $0,48 \pm 0.12$ \\
\hline 22 & 1-heptanol & 22,30 & $2,26 \pm 0.37$ & $1,45 \pm 0.5$ & $1,37 \pm 0.23$ & $3,08 \pm 0.13$ & $0,67 \pm 0.22$ & $0,80 \pm 0.16$ \\
\hline 23 & camphene & 22,34 & $0,67 \pm 0.04$ & $0,73 \pm 0.0$ & $0,82 \pm 0.05$ & $1,54 \pm 0.50$ & $1,74 \pm 0.30$ & $1,86 \pm 0.90$ \\
\hline 24 & 1-octen-3-one & 22,71 & $1,75 \pm 0.56$ & $2,88 \pm 0.5$ & $6,42 \pm 1.43$ & $0,59 \pm 0.35$ & $0,39 \pm 0.00$ & $0,39 \pm 0.00$ \\
\hline 25 & 1-octen-3-ol & 22,73 & $2,31 \pm 0.27$ & $2,34 \pm 0.6$ & $1,88 \pm 0.55$ & $1,34 \pm 0.27$ & $0,40 \pm 0.13$ & $0,57 \pm 0.08$ \\
\hline 26 & 6-methyl-5-hepten-2-one & 22,94 & $1,32 \pm 0.11$ & $1,16 \pm 0.1$ & $1,06 \pm 0.02$ & $1,55 \pm 0.15$ & $1,68 \pm 0.20$ & $1,48 \pm 0.36$ \\
\hline 27 & 3-octanone & 22,98 & $2,18 \pm 0.34$ & $2,11 \pm 0.4$ & $1,43 \pm 0.29$ & $1,49 \pm 0.36$ & $0,37 \pm 0.14$ & $0,64 \pm 0.17$ \\
\hline 28 & myrcene & 23,17 & $0,74 \pm 0.07$ & $0,72 \pm 0.0$ & $0,83 \pm 0.07$ & $1,54 \pm 0.36$ & $1,08 \pm 0.33$ & $1,10 \pm 0.28$ \\
\hline 29 & 2-pentylfuran & 23,27 & $2,73 \pm 0.45$ & $2,33 \pm 0.4$ & $2,16 \pm 0.58$ & $1,49 \pm 0.48$ & $0,39 \pm 0.14$ & $0,55 \pm 0.15$ \\
\hline 30 & ethyl hexanoate & 23,28 & $0,04 \pm 0.00$ & $0,07 \pm 0.0$ & $0,09 \pm 0.01$ & $0,05 \pm 0.00$ & $0,05 \pm 0.00$ & $0,06 \pm 0.01$ \\
\hline 31 & $\beta$-pinene & 23,36 & $0,63 \pm 0.04$ & $0,73 \pm 0.1$ & $0,70 \pm 0.07$ & $1,37 \pm 0.52$ & $3,50 \pm 0.84$ & $3,44 \pm 1.63$ \\
\hline 32 & octanal & 23,68 & $0,89 \pm 0.10$ & $0,99 \pm 0.2$ & $0,81 \pm 0.21$ & $0,49 \pm 0.19$ & $0,74 \pm 0.29$ & $0,57 \pm 0.17$ \\
\hline 33 & a-phellandrene & 24,19 & $0,54 \pm 0.06$ & $0,45 \pm 0.0$ & $0,53 \pm 0.07$ & $1,55 \pm 0.61$ & $1,75 \pm 0.50$ & $1,73 \pm 0.71$ \\
\hline 34 & 3-carene & 24,32 & $0,92 \pm 0.68$ & $0,62 \pm 0.2$ & $0,69 \pm 0.13$ & $2,67 \pm 1.64$ & $0,11 \pm 0.17$ & $0,15 \pm 0.03$ \\
\hline 35 & a-terpinene & 24,55 & $0,55 \pm 0.01$ & $0,50 \pm 0.1$ & $0,51 \pm 0.06$ & $1,37 \pm 0.54$ & $3,45 \pm 0.74$ & $3,31 \pm 1.47$ \\
\hline 36 & limonene & 25,03 & $0,87 \pm 0.02$ & $0,87 \pm 0.0$ & $0,96 \pm 0.04$ & $1,14 \pm 0.10$ & $0,97 \pm 0.10$ & $0,98 \pm 0.09$ \\
\hline 37 & eucalyptol & 25,33 & $1,38 \pm 0.71$ & $2,27 \pm 0.4$ & $2,09 \pm 0.18$ & $1,87 \pm 0.52$ & $0,98 \pm 0.50$ & $0,82 \pm 0.32$ \\
\hline 38 & (E)-2-octenal & 25,70 & $1,65 \pm 0.42$ & $2,63 \pm 0.4$ & $2,70 \pm 0.58$ & $0,50 \pm 0.21$ & $0,17 \pm 0.09$ & $0,39 \pm 0.13$ \\
\hline 39 & 1-octanol & 25,89 & $0,73 \pm 0.23$ & $0,64 \pm 0.0$ & $0,51 \pm 0.03$ & $1,46 \pm 0.48$ & $0,99 \pm 0.23$ & $0,53 \pm 0.07$ \\
\hline 40 & $y$-terpinene & 25,93 & $0,61 \pm 0.08$ & $0,58 \pm 0.1$ & $0,56 \pm 0.07$ & $1,23 \pm 0.46$ & $3,74 \pm 0.72$ & $3,56 \pm 1.54$ \\
\hline 41 & ethyl heptanoate & 26,72 & nd & $1,12 \pm 0.2$ & $1,17 \pm 0.19$ & nd & nd & nd \\
\hline 42 & terpinolene & 26,94 & $0,59 \pm 0.03$ & $0,58 \pm 0.0$ & $0,71 \pm 0.06$ & $1,51 \pm 0.51$ & $1,67 \pm 0.40$ & $1,65 \pm 0.64$ \\
\hline 43 & linalool & 27,05 & $1,20 \pm 0.41$ & $1,33 \pm 0.0$ & $1,30 \pm 0.06$ & $2,07 \pm 0.66$ & $0,74 \pm 0.19$ & $0,65 \pm 0.03$ \\
\hline 44 & nonanal & 27,20 & $1,45 \pm 0.21$ & $2,24 \pm 0.3$ & $2,03 \pm 0.52$ & $0,74 \pm 0.26$ & $0,37 \pm 0.09$ & $0,48 \pm 0.10$ \\
\hline 45 & methyl octanoate & 27,64 & $0,94 \pm 0.00$ & $1,04 \pm 0.1$ & $0,94 \pm 0.00$ & nd & nd & nd \\
\hline 46 & $\beta$-citronellal & 28,81 & nd & nd & nd & nd & nd & nd \\
\hline 47 & (E)-2-nonenal & 29,11 & $1,45 \pm 0.32$ & $2,76 \pm 0.4$ & $3,18 \pm 0.62$ & $0,54 \pm 0.18$ & $0,19 \pm 0.09$ & $0,40 \pm 0.14$ \\
\hline 48 & 1-nonanol & 29,26 & $1,24 \pm 0.30$ & $1,60 \pm 0.0$ & $1,45 \pm 0.14$ & $1,90 \pm 0.51$ & $0,61 \pm 0.06$ & $0,58 \pm 0.06$ \\
\hline 49 & ethyl octanoate & 29,94 & $0,03 \pm 0.00$ & $0,18 \pm 0.0$ & $0,20 \pm 0.02$ & $0,03 \pm 0.00$ & $0,11 \pm 0.02$ & $0,12 \pm 0.02$ \\
\hline 50 & terpinen-4-ol & 30,27 & $0,53 \pm 0.11$ & $0,67 \pm 0.1$ & $0,63 \pm 0.06$ & $1,11 \pm 0.47$ & $3,36 \pm 0.74$ & $3,19 \pm 1.41$ \\
\hline
\end{tabular}


Annex 2.

Cont.

\begin{tabular}{|c|c|c|c|c|c|c|c|c|}
\hline ID & Compounds & RT & \multicolumn{3}{|c|}{ Prenules } & \multicolumn{3}{|c|}{ Basol } \\
\hline & & & $\mathrm{H}$ & A & $\mathrm{E}$ & $\mathrm{H}$ & A & $\mathrm{E}$ \\
\hline 51 & octyl acetate & 30,36 & $0,08 \pm 0.04$ & $0,08 \pm 0.0$ & $0,08 \pm 0.02$ & $0,06 \pm 0.02$ & $0,15 \pm 0.07$ & $0,24 \pm 0.11$ \\
\hline 52 & decanal & 30,49 & $0,44 \pm 0.08$ & $0,60 \pm 0.0$ & $0,76 \pm 0.11$ & $0,84 \pm 0.21$ & $0,85 \pm 0.32$ & $0,85 \pm 0.16$ \\
\hline 53 & a-terpineol & 30,64 & $0,82 \pm 0.15$ & $0,85 \pm 0.0$ & $0,83 \pm 0.02$ & $2,05 \pm 0.94$ & $1,40 \pm 0.37$ & $1,16 \pm 0.15$ \\
\hline 54 & dihydrocarvone & 30,78 & $0,67 \pm 0.03$ & $0,88 \pm 0.1$ & $1,02 \pm 0.05$ & $1,47 \pm 0.45$ & $0,71 \pm 0.16$ & $0,80 \pm 0.12$ \\
\hline 55 & methyl nonanoate & 30,84 & $0,69 \pm 0.12$ & $1,02 \pm 0.3$ & $0,73 \pm 0.10$ & $0,61 \pm 0.00$ & $1,19 \pm 0.34$ & $0,62 \pm 0.01$ \\
\hline 56 & $(\mathrm{E}, \mathrm{E})-2,4$-nonadienal & 31,01 & $2,03 \pm 0.29$ & $2,23 \pm 0.4$ & $2,28 \pm 0.60$ & $0,75 \pm 0.19$ & $0,08 \pm 0.06$ & $0,18 \pm 0.10$ \\
\hline 57 & $\beta$-citronellol & 31,06 & $0,84 \pm 0.13$ & $1,35 \pm 0.5$ & $2,23 \pm 1.16$ & $1,55 \pm 0.61$ & $0,57 \pm 0.07$ & $0,79 \pm 0.12$ \\
\hline 58 & nerol & 31,16 & $0,93 \pm 0.31$ & $1,01 \pm 0.0$ & $1,40 \pm 0.15$ & $2,00 \pm 1.19$ & $0,92 \pm 0.32$ & $0,89 \pm 0.23$ \\
\hline 59 & (E)-carveol & 31,30 & $0,67 \pm 0.13$ & $1,03 \pm 0.2$ & $1,14 \pm 0.19$ & $1,05 \pm 0.38$ & $0,35 \pm 0.07$ & $0,37 \pm 0.05$ \\
\hline 60 & $\beta$-cyclocitral & 31,53 & $0,81 \pm 0.08$ & $0,73 \pm 0.0$ & $0,85 \pm 0.11$ & $0,71 \pm 0.06$ & $0,67 \pm 0.00$ & $0,68 \pm 0.02$ \\
\hline 61 & linalyl acetate & 31,70 & $0,76 \pm 0.07$ & $0,83 \pm 0.5$ & $0,72 \pm 0.44$ & $0,40 \pm 0.17$ & $0,39 \pm 0.18$ & $0,75 \pm 0.56$ \\
\hline 62 & geraniol & 31,83 & $1,07 \pm 0.35$ & $1,13 \pm 0.0$ & $1,04 \pm 0.08$ & $2,70 \pm 1.77$ & $0,69 \pm 0.10$ & $0,55 \pm 0.12$ \\
\hline 63 & carvone & 32,20 & $0,79 \pm 0.16$ & $1,32 \pm 0.3$ & $1,63 \pm 0.04$ & $1,10 \pm 0.40$ & $0,22 \pm 0.04$ & $0,30 \pm 0.06$ \\
\hline 64 & geranial & 32,50 & $0,56 \pm 0.16$ & $0,45 \pm 0.0$ & $0,41 \pm 0.02$ & $0,85 \pm 0.34$ & $0,99 \pm 0.61$ & $0,69 \pm 0.09$ \\
\hline 65 & ethyl nonanoate & 32,96 & $0,08 \pm 0.00$ & $0,59 \pm 0.2$ & $1,04 \pm 0.40$ & $0,08 \pm 0.00$ & $0,56 \pm 0.17$ & $0,65 \pm 0.27$ \\
\hline 66 & perillaldehyde & 33,32 & $0,54 \pm 0.11$ & $0,73 \pm 0.1$ & $0,93 \pm 0.02$ & $1,31 \pm 0.39$ & $1,07 \pm 0.50$ & $1,08 \pm 0.19$ \\
\hline 67 & nonyl acetate & 33,56 & nd & nd & nd & $0,51 \pm 0.00$ & $0,66 \pm 0.26$ & $1,69 \pm 1.15$ \\
\hline 68 & isobornyl acetate & 33,53 & $0,54 \pm 0.01$ & $0,83 \pm 0.2$ & $1,05 \pm 0.17$ & $1,26 \pm 0.52$ & $2,03 \pm 0.27$ & $1,60 \pm 0.41$ \\
\hline 69 & undecanal & 33,56 & $1,02 \pm 0.17$ & $1,53 \pm 0.1$ & $1,45 \pm 0.16$ & $1,01 \pm 0.28$ & $0,51 \pm 0.10$ & $0,53 \pm 0.07$ \\
\hline 70 & methyl decano & 33,84 & $0,45 \pm 0.00$ & $0,85 \pm 0.2$ & $0,50 \pm 0.09$ & $0,46 \pm 0.00$ & $0,67 \pm 0.19$ & $0,46 \pm 0.00$ \\
\hline 71 & $(\mathrm{E}, \mathrm{E})$-2,4-decadienal & 34,09 & $1,25 \pm 0.08$ & $2,47 \pm 0.4$ & $2,78 \pm 0.28$ & $0,97 \pm 0.14$ & $0,47 \pm 0.08$ & $0,65 \pm 0.06$ \\
\hline 72 & (Z)-carvyl acetate & 34,39 & nd & nd & nd & nd & nd & nd \\
\hline 73 & citronellyl acetate & 34,58 & $0,08 \pm 0.00$ & $0,08 \pm 0.0$ & $0,13 \pm 0.05$ & $0,13 \pm 0.03$ & $0,16 \pm 0.06$ & $0,25 \pm 0.08$ \\
\hline 74 & neryl acetate & 34,86 & $0,08 \pm 0.02$ & $0,09 \pm 0.0$ & $0,20 \pm 0.02$ & $0,12 \pm 0.05$ & $0,26 \pm 0.02$ & $0,36 \pm 0.08$ \\
\hline 75 & a-terpinyl acetate & 34,99 & $0,26 \pm 0.03$ & $0,39 \pm 0.0$ & $0,35 \pm 0.05$ & $0,31 \pm 0.13$ & $0,98 \pm 0.10$ & $1,07 \pm 0.21$ \\
\hline 76 & (E)-carvyl acetate & 35,19 & $0,51 \pm 0.00$ & $0,51 \pm 0.0$ & $0,69 \pm 0.30$ & nd & nd & nd \\
\hline 77 & geranyl acetate & 35,39 & $0,27 \pm 0.02$ & $0,35 \pm 0.1$ & $0,43 \pm 0.11$ & $0,42 \pm 0.17$ & $0,76 \pm 0.06$ & $0,86 \pm 0.16$ \\
\hline 78 & ethyl decanoate & 35,81 & $0,05 \pm 0.00$ & $0,65 \pm 0.1$ & $1,30 \pm 0.21$ & $0,08 \pm 0.01$ & $0,40 \pm 0.12$ & $0,58 \pm 0.09$ \\
\hline 79 & decyl acetate & 36,18 & $0,18 \pm 0.04$ & $0,19 \pm 0.1$ & $0,17 \pm 0.07$ & $0,13 \pm 0.08$ & $0,54 \pm 0.54$ & $1,76 \pm 1.74$ \\
\hline 80 & a-copaene & 36,30 & $0,51 \pm 0.13$ & $0,50 \pm 0.0$ & $0,74 \pm 0.18$ & $1,56 \pm 0.59$ & $0,79 \pm 0.39$ & $0,76 \pm 0.34$ \\
\hline 81 & dodecanal & 36,44 & $0,48 \pm 0.16$ & $0,54 \pm 0.0$ & $0,74 \pm 0.22$ & $1,12 \pm 0.48$ & $0,96 \pm 0.30$ & $0,84 \pm 0.22$ \\
\hline 82 & geranylacetone & 37,50 & $1,24 \pm 0.28$ & $1,24 \pm 0.0$ & $1,27 \pm 0.17$ & $0,89 \pm 0.19$ & $0,42 \pm 0.10$ & $0,39 \pm 0.07$ \\
\hline 83 & $\beta$-caryophyllene & 37,75 & $0,35 \pm 0.06$ & $0,35 \pm 0.0$ & $0,42 \pm 0.02$ & $0,73 \pm 0.23$ & $1,02 \pm 0.14$ & $1,09 \pm 0.43$ \\
\hline 84 & a-humulene & 38,71 & $0,44 \pm 0.12$ & $0,44 \pm 0.0$ & $0,61 \pm 0.11$ & $1,20 \pm 0.52$ & $0,72 \pm 0.27$ & $0,77 \pm 0.29$ \\
\hline 85 & $\beta$-ionone & 38,78 & $0,73 \pm 0.17$ & $0,84 \pm 0.0$ & $1,02 \pm 0.04$ & $0,53 \pm 0.04$ & $0,65 \pm 0.09$ & $0,65 \pm 0.09$ \\
\hline 86 & valencene & 39,57 & $0,10 \pm 0.01$ & $0,08 \pm 0.0$ & $0,15 \pm 0.04$ & $0,04 \pm 0.01$ & $0,08 \pm 0.01$ & $0,15 \pm 0.01$ \\
\hline 87 & nootkatone & 47,71 & nd & nd & nd & nd & nd & nd \\
\hline
\end{tabular}


Annex 3.

Relative levels of VOCs detected in juices of 'Oronules' and 'Clemenrubí' mandarins at harvest $(\mathrm{H})$ and after degreening without $(\mathrm{A})$ and with $(\mathrm{E})$ ethylene exposure and the posterior coldquarantine treatment plus shelf-life.

\begin{tabular}{|c|c|c|c|c|c|c|c|c|}
\hline ID & Compounds & RT & \multicolumn{3}{|c|}{ Oronules } & \multicolumn{3}{|c|}{ Clemenrubí } \\
\hline & & & $\mathrm{H}$ & A & $E$ & $\mathrm{H}$ & A & $E$ \\
\hline 1 & acetaldehyde & 4,89 & $0,54 \pm 0.07$ & $1,34 \pm 0.33$ & $1,60 \pm 0.28$ & $0,58 \pm 0.07$ & $0,71 \pm 0.09$ & $0,81 \pm 0.21$ \\
\hline 2 & ethanol & 5,52 & $0,16 \pm 0.01$ & $3,26 \pm 0.14$ & $3,83 \pm 0.24$ & $0,08 \pm 0.03$ & $0,32 \pm 0.06$ & $0,36 \pm 0.03$ \\
\hline 3 & 2-methylfuran & 8,84 & $2,00 \pm 1.12$ & $0,88 \pm 0.31$ & $1,15 \pm 0.33$ & $1,82 \pm 0.35$ & $1,26 \pm 0.18$ & $1,00 \pm 0.00$ \\
\hline 4 & 3-methylfuran & 9,14 & $1,15 \pm 0.62$ & $1,78 \pm 0.86$ & $1,79 \pm 0.15$ & $0,90 \pm 0.22$ & $1,18 \pm 0.03$ & $1,39 \pm 0.15$ \\
\hline 5 & ethyl acetate & 9,08 & $0,13 \pm 0.05$ & $3,73 \pm 1.45$ & $4,88 \pm 1.06$ & $0,10 \pm 0.04$ & $0,24 \pm 0.00$ & $0,36 \pm 0.04$ \\
\hline 6 & 1-penten-3-one & 11,56 & $1.93 \pm 1.13$ & $0.46 \pm 0.15$ & $1,06 \pm 0.20$ & $0.97 \pm 0.62$ & $0,73 \pm 0.08$ & $0.41 \pm 0.22$ \\
\hline 7 & pentanal & 12,02 & $2,47 \pm 1.10$ & $0,57 \pm 0.37$ & $0,89 \pm 0.42$ & $2,09 \pm 0.67$ & $1,73 \pm 0.42$ & $0,22 \pm 0.07$ \\
\hline 8 & 2-ethylfuran & 12,11 & $1,80 \pm 0.98$ & $0,82 \pm 0.30$ & $1,05 \pm 0.33$ & $1,72 \pm 0.42$ & $1,14 \pm 0.16$ & $0,47 \pm 0.10$ \\
\hline 9 & ethyl propionate & 12,36 & $0,33 \pm 0.18$ & $6,08 \pm 2.45$ & $3,54 \pm 0.58$ & $0,10 \pm 0.00$ & $0,59 \pm 0.22$ & $0,28 \pm 0.06$ \\
\hline 10 & (E)-2-pentenal & 14,24 & $1,72 \pm 0.98$ & $0,62 \pm 0.07$ & $1,09 \pm 0.24$ & $1,39 \pm 0.41$ & $1,48 \pm 0.10$ & $0,62 \pm 0.09$ \\
\hline 11 & 1-pentanol & 14,53 & $2,37 \pm 0.98$ & $1,01 \pm 0.15$ & $0,75 \pm 0.25$ & $2,68 \pm 0.31$ & $3,56 \pm 0.18$ & $0,38 \pm 0.03$ \\
\hline 12 & ethyl butanoate & 15,80 & $0,01 \pm 0.00$ & $0.06 \pm 0.03$ & $0,06 \pm 0.01$ & nd & nd & nd \\
\hline 13 & (Z)-3-hexenal & 15,85 & $0,61 \pm 0.26$ & $0,36 \pm 0.16$ & $0,28 \pm 0.03$ & $1,22 \pm 0.31$ & $0,68 \pm 0.14$ & $0,38 \pm 0.05$ \\
\hline 14 & hexanal & 15,95 & $2,43 \pm 0.90$ & $0,42 \pm 0.11$ & $1,00 \pm 0.21$ & $2,24 \pm 0.67$ & $1,33 \pm 0.36$ & $0,15 \pm 0.06$ \\
\hline 15 & ethyl 2-methylbutyrate & 17,74 & $0,23 \pm 0.02$ & $5,39 \pm 1.95$ & $3,93 \pm 1.11$ & $0,18 \pm 0.00$ & $0,26 \pm 0.04$ & $0,23 \pm 0.00$ \\
\hline 16 & (E)-2-hexenal & 18,09 & $0,29 \pm 0.12$ & $0,44 \pm 0.14$ & $0,72 \pm 0.13$ & $0,57 \pm 0.14$ & $0,26 \pm 0.08$ & $0,73 \pm 0.08$ \\
\hline 17 & (E)-2-hexen-1-ol & 18,39 & $0,26 \pm 0.00$ & $1,12 \pm 0.49$ & $0,33 \pm 0.10$ & $0,92 \pm 0.30$ & $0,65 \pm 0.14$ & $4,56 \pm 1.77$ \\
\hline 18 & 1-hexanol & 18,47 & $1,03 \pm 0.26$ & $1,92 \pm 0.36$ & $0,33 \pm 0.14$ & $3,18 \pm 0.96$ & $5,57 \pm 0.42$ & $0,58 \pm 0.11$ \\
\hline 19 & heptanal & 19,90 & $2,78 \pm 1.20$ & $0,46 \pm 0.10$ & $1,41 \pm 0.21$ & $1,98 \pm 0.67$ & $1,19 \pm 0.42$ & $0,17 \pm 0.04$ \\
\hline 20 & a-pinene & 21,57 & $1,12 \pm 0.45$ & $1,21 \pm 0.16$ & $1,08 \pm 0.17$ & $0,69 \pm 0.06$ & $0,88 \pm 0.24$ & $0,63 \pm 0.03$ \\
\hline 21 & (E)-2-heptenal & 22,06 & $3,28 \pm 0.82$ & $0,55 \pm 0.15$ & $0,97 \pm 0.17$ & $2,06 \pm 0.54$ & $1,71 \pm 0.39$ & $0,19 \pm 0.03$ \\
\hline 22 & 1-heptanol & 22,30 & $1,24 \pm 0.40$ & $1,76 \pm 0.21$ & $0,47 \pm 0.10$ & $2,26 \pm 0.37$ & $4,28 \pm 0.12$ & $0,65 \pm 0.08$ \\
\hline$\frac{22}{23}$ & camphene & 22,34 & $1,07 \pm 0.30$ & $1,22 \pm 0.18$ & $1,16 \pm 0.02$ & $0,67 \pm 0.04$ & $1,07 \pm 0.27$ & $0,73 \pm 0.14$ \\
\hline 24 & 1-octen-3-one & 22,71 & $2,57 \pm 0.93$ & $0,16 \pm 0.00$ & $0,64 \pm 0.18$ & $1,75 \pm 0.56$ & $1,40 \pm 0.71$ & $0,42 \pm 0.00$ \\
\hline 25 & 1-octen-3-ol & 22,73 & $2,63 \pm 1.03$ & $0,68 \pm 0.05$ & $0,67 \pm 0.11$ & $2,31 \pm 0.27$ & $1,97 \pm 0.29$ & $0,41 \pm 0.04$ \\
\hline 26 & 6-methyl-5-hepten-2-one & 22,94 & $0,89 \pm 0.29$ & $0,86 \pm 0.19$ & $0,77 \pm 0.06$ & $1,32 \pm 0.11$ & $1,64 \pm 0.14$ & $1,16 \pm 0.11$ \\
\hline 27 & 3-octanone & 22,98 & $2,57 \pm 0.79$ & $0,90 \pm 0.12$ & $1,00 \pm 0.13$ & $2,18 \pm 0.34$ & $2,24 \pm 0.25$ & $0,30 \pm 0.05$ \\
\hline 28 & myrcene & 23,17 & $0,98 \pm 0.24$ & $1,13 \pm 0.15$ & $1,01 \pm 0.13$ & $0,74 \pm 0.07$ & $0,92 \pm 0.17$ & $0,73 \pm 0.02$ \\
\hline 29 & 2-pentylfuran & 23,27 & $2,62 \pm 0.82$ & $0,76 \pm 0.01$ & $0,95 \pm 0.13$ & $2,73 \pm 0.45$ & $2,10 \pm 0.29$ & $0,35 \pm 0.06$ \\
\hline 30 & ethyl hexanoate & 23,28 & $0,03 \pm 0.00$ & $0,05 \pm 0.01$ & $0,08 \pm 0.02$ & $0,04 \pm 0.00$ & nd & nd \\
\hline 31 & $\beta$-pinene & 23,36 & $0,86 \pm 0.15$ & $1,35 \pm 0.47$ & $1,17 \pm 0.13$ & $0,63 \pm 0.04$ & $1,07 \pm 0.46$ & $0,89 \pm 0.14$ \\
\hline 32 & octanal & 23,68 & $1,45 \pm 0.36$ & $0,55 \pm 0.03$ & $0,78 \pm 0.05$ & $0,89 \pm 0.10$ & $0,66 \pm 0.15$ & $0,13 \pm 0.03$ \\
\hline 33 & a-phellandrene & 24,19 & $0,83 \pm 0.25$ & $1,27 \pm 0.25$ & $1,13 \pm 0.08$ & $0,54 \pm 0.06$ & $0,83 \pm 0.30$ & $0,65 \pm 0.12$ \\
\hline 34 & 3-carene & 24,32 & $0,61 \pm 0.14$ & $0,74 \pm 0.22$ & $0,68 \pm 0.35$ & $0,92 \pm 0.68$ & $0,53 \pm 0.31$ & $0,44 \pm 0.06$ \\
\hline 35 & a-terpinene & 24,55 & $0,80 \pm 0.12$ & $1,31 \pm 0.41$ & $1,19 \pm 0.16$ & $0,55 \pm 0.01$ & $0,98 \pm 0.42$ & $0,77 \pm 0.18$ \\
\hline 36 & limonene & 25,03 & $1,02 \pm 0.13$ & $1,06 \pm 0.03$ & $1,00 \pm 0.01$ & $0,87 \pm 0.02$ & $0,94 \pm 0.06$ & $0,86 \pm 0.01$ \\
\hline 37 & eucalyptol & 25,33 & $0,70 \pm 0.06$ & $1,12 \pm 0.09$ & $0,73 \pm 0.29$ & $1,38 \pm 0.71$ & $1,55 \pm 0.37$ & $1,10 \pm 0.13$ \\
\hline 38 & (E)-2-octenal & 25,70 & $3,29 \pm 0.55$ & $0,49 \pm 0.26$ & $1,14 \pm 0.10$ & $1,65 \pm 0.42$ & $1,46 \pm 0.40$ & $0,09 \pm 0.03$ \\
\hline 39 & 1-octanol & 25,89 & $0,88 \pm 0.04$ & $1,19 \pm 0.25$ & $0,43 \pm 0.02$ & $0,73 \pm 0.23$ & $1,16 \pm 0.22$ & $0,40 \pm 0.05$ \\
\hline 40 & $y$-terpinene & 25,93 & $0,78 \pm 0.10$ & $1,34 \pm 0.42$ & $1,20 \pm 0.26$ & $0,61 \pm 0.08$ & $1,00 \pm 0.42$ & $0,87 \pm 0.17$ \\
\hline 41 & ethyl heptanoate & 26,72 & $0,66 \pm 0.00$ & $0,71 \pm 0.06$ & $0,84 \pm 0.16$ & nd & nd & nd \\
\hline 42 & terpinolene & 26.94 & $0.96 \pm 0.30$ & $120 \pm 0.22$ & $1.10 \pm 0.07$ & $0.59+0.03$ & $0.82 \pm 0.26$ & $0.59+0.14$ \\
\hline 43 & linalool & 27.05 & $0.88+0.06$ & $1.03+0.08$ & $0.65 \pm 0.02$ & $120 \pm 0.41$ & $1,77 \pm 0.33$ & $128+0.05$ \\
\hline 44 & nonanal & 27,20 & $2,40 \pm 0.56$ & $0,71 \pm 0.16$ & $1,16 \pm 0.05$ & $1,45 \pm 0.21$ & $1,14 \pm 0.25$ & $0,21 \pm 0.02$ \\
\hline 45 & methyl octanoate & 27,64 & $0,86 \pm 0.18$ & $0,76 \pm 0.00$ & $0,76 \pm 0.00$ & $0,94 \pm 0.00$ & nd & nd \\
\hline 46 & $\beta$-citronellal & 28,81 & nd & nd & nd & nd & nd & nd \\
\hline 47 & (E)-2-nonenal & 29,11 & $3,14 \pm 0.47$ & $0,49 \pm 0.29$ & $1,07 \pm 0.05$ & $1,45 \pm 0.32$ & $1,45 \pm 0.33$ & $0,08 \pm 0.02$ \\
\hline 48 & 1-nonanol & 29,26 & $1,02 \pm 0.12$ & $1,29 \pm 0.25$ & $0,54 \pm 0.05$ & $1,24 \pm 0.30$ & $2,06 \pm 0.04$ & $0,44 \pm 0.04$ \\
\hline 49 & ethyl octanoate & 29,94 & $0,05 \pm 0.03$ & $0,12 \pm 0.01$ & $0,17 \pm 0.02$ & $0,03 \pm 0.00$ & $0,04 \pm 0.00$ & $0,04 \pm 0.01$ \\
\hline 50 & terpinen-4-ol & 30,27 & $0,82 \pm 0.21$ & $1,29 \pm 0.24$ & $1,22 \pm 0.32$ & $0,53 \pm 0.11$ & $0,96 \pm 0.42$ & $0,87 \pm 0.14$ \\
\hline
\end{tabular}


Annex 3.

Cont.

\begin{tabular}{|c|c|c|c|c|c|c|c|c|}
\hline ID & Compounds & RT & \multicolumn{3}{|c|}{ Oronules } & \multicolumn{3}{|c|}{ Clemenrubí } \\
\hline & & & $\mathrm{H}$ & A & $\mathrm{E}$ & $\mathrm{H}$ & A & $E$ \\
\hline 51 & octyl acetate & 30,36 & $0,35 \pm 0.23$ & $0,19 \pm 0.08$ & $0,20 \pm 0.06$ & $0,08 \pm 0.04$ & $0,13 \pm 0.05$ & $0,03 \pm 0.01$ \\
\hline 52 & decanal & 30,49 & $0,78 \pm 0.19$ & $1,12 \pm 0.27$ & $0,68 \pm 0.03$ & $0,44 \pm 0.08$ & $0,63 \pm 0.09$ & $0,11 \pm 0.03$ \\
\hline 53 & a-terpineol & 30,64 & $1,00 \pm 0.18$ & $1,09 \pm 0.09$ & $3,34 \pm 4.21$ & $0,82 \pm 0.15$ & $1,26 \pm 0.31$ & $0,79 \pm 0.06$ \\
\hline 54 & dihydrocarvone & 30,78 & $1,27 \pm 0.37$ & $1,17 \pm 0.11$ & $1,11 \pm 0.28$ & $0,67 \pm 0.03$ & $0,99 \pm 0.18$ & $0,61 \pm 0.06$ \\
\hline 55 & methyl nonanoate & 30,84 & $0,90 \pm 0.44$ & $0,64 \pm 0.00$ & $0,64 \pm 0.00$ & $0,69 \pm 0.12$ & $0,65 \pm 0.00$ & $0,95 \pm 0.21$ \\
\hline 56 & $(\mathrm{E}, \mathrm{E})-2,4$-nonadienal & 31,01 & $2,74 \pm 0.29$ & $0,24 \pm 0.16$ & $0,53 \pm 0.08$ & $2,03 \pm 0.29$ & $1,93 \pm 0.29$ & $0,05 \pm 0.00$ \\
\hline 57 & $\beta$-citronellol & 31,06 & $1,18 \pm 0.23$ & $1,10 \pm 0.12$ & $0,97 \pm 0.15$ & $0,84 \pm 0.13$ & $1,10 \pm 0.07$ & $0,56 \pm 0.12$ \\
\hline 58 & nerol & 31,16 & $0,66 \pm 0.08$ & $0,88 \pm 0.17$ & $0,51 \pm 0.05$ & $0,93 \pm 0.31$ & $1,81 \pm 0.30$ & $0,76 \pm 0.02$ \\
\hline 59 & (E)-carveol & 31,30 & $1,19 \pm 0.37$ & $0,69 \pm 0.07$ & $0,61 \pm 0.09$ & $0,67 \pm 0.13$ & $0,84 \pm 0.12$ & $0,39 \pm 0.03$ \\
\hline 60 & $\beta$-cyclocitral & 31,53 & $0,62 \pm 0.11$ & $0,54 \pm 0.02$ & $0,56 \pm 0.05$ & $0,81 \pm 0.08$ & $0,76 \pm 0.00$ & $0,79 \pm 0.06$ \\
\hline 61 & linalyl acetate & 31,70 & $2,05 \pm 1.00$ & $1,85 \pm 1.45$ & $2,15 \pm 0.69$ & $0,76 \pm 0.07$ & $0,91 \pm 0.13$ & $0,21 \pm 0.03$ \\
\hline 62 & geraniol & 31,83 & $0,87 \pm 0.08$ & $0,83 \pm 0.11$ & $0,55 \pm 0.06$ & $1,07 \pm 0.35$ & $1,74 \pm 0.33$ & $0,97 \pm 0.07$ \\
\hline 63 & carvone & 32,20 & $1,79 \pm 0.96$ & $1,04 \pm 0.34$ & $0,95 \pm 0.32$ & $0,79 \pm 0.16$ & $0,98 \pm 0.13$ & $0,16 \pm 0.03$ \\
\hline 64 & geranial & 32,50 & $0,52 \pm 0.06$ & $0,36 \pm 0.06$ & $0,25 \pm 0.05$ & $0,56 \pm 0.16$ & $0,81 \pm 0.04$ & $0,15 \pm 0.02$ \\
\hline 65 & ethyl nonanoate & 32,96 & $0,10 \pm 0.02$ & $0,22 \pm 0.05$ & $0,30 \pm 0.06$ & $0,08 \pm 0.00$ & $0,09 \pm 0.00$ & $0,13 \pm 0.04$ \\
\hline 66 & perillaldehyde & 33,32 & $1,41 \pm 0.25$ & $0,89 \pm 0.25$ & $0,83 \pm 0.24$ & $0,54 \pm 0.11$ & $1,01 \pm 0.14$ & $0,35 \pm 0.09$ \\
\hline 67 & nonyl acetate & 33,56 & $0,59 \pm 0.29$ & $0,43 \pm 0.04$ & $0,49 \pm 0.15$ & nd & $0,61 \pm 0.24$ & $0,45 \pm 0.00$ \\
\hline 68 & isobornyl acetate & 33,53 & $0,56 \pm 0.09$ & $1,00 \pm 0.26$ & $0,81 \pm 0.15$ & $0,54 \pm 0.01$ & $1,73 \pm 0.16$ & $0,94 \pm 0.07$ \\
\hline 69 & undecanal & 33,56 & $1,48 \pm 0.15$ & $0,97 \pm 0.22$ & $0,73 \pm 0.10$ & $1,02 \pm 0.17$ & $1,01 \pm 0.09$ & $0,23 \pm 0.04$ \\
\hline 70 & methyl decanoate & 33,84 & $0,60 \pm 0.12$ & $0,53 \pm 0.00$ & $0,61 \pm 0.13$ & $0,45 \pm 0.00$ & $0,47 \pm 0.02$ & $0,62 \pm 0.10$ \\
\hline 71 & $(\mathrm{E}, \mathrm{E})$-2,4-decadienal & 34,09 & $2,72 \pm 0.44$ & $0,67 \pm 0.29$ & $0,66 \pm 0.19$ & $1,25 \pm 0.08$ & $1,54 \pm 0.18$ & $0,18 \pm 0.05$ \\
\hline 72 & (Z)-carvyl acetate & 34,39 & $0,42 \pm 0.06$ & $0,38 \pm 0.00$ & $0,38 \pm 0.00$ & nd & nd & nd \\
\hline 73 & citronellyl acetate & 34,58 & $0,32 \pm 0.37$ & $0,16 \pm 0.02$ & $0,13 \pm 0.04$ & $0,08 \pm 0.00$ & $0,08 \pm 0.00$ & $0,10 \pm 0.02$ \\
\hline 74 & neryl acetate & 34,86 & $0,35 \pm 0.09$ & $0,27 \pm 0.12$ & $0,33 \pm 0.08$ & $0,08 \pm 0.02$ & $0,15 \pm 0.02$ & $0,06 \pm 0.02$ \\
\hline 75 & a-terpinyl acetate & 34,99 & $0,72 \pm 0.37$ & $0,57 \pm 0.12$ & $0,45 \pm 0.11$ & $0,26 \pm 0.03$ & $0,31 \pm 0.05$ & $0,24 \pm 0.05$ \\
\hline 76 & (E)-carvyl acetate & 35,19 & $0,64 \pm 0.00$ & $0,66 \pm 0.04$ & $0,64 \pm 0.00$ & $0,51 \pm 0.00$ & nd & nd \\
\hline 77 & geranyl acetate & 35,39 & $0,63 \pm 0.17$ & $0,65 \pm 0.29$ & $0,62 \pm 0.16$ & $0,27 \pm 0.02$ & $0,37 \pm 0.05$ & $0,18 \pm 0.01$ \\
\hline 78 & ethyl decanoate & 35,81 & $0,15 \pm 0.04$ & $0,46 \pm 0.11$ & $0,56 \pm 0.04$ & $0,05 \pm 0.00$ & $0,10 \pm 0.01$ & $0,13 \pm 0.02$ \\
\hline 79 & decyl acetate & 36,18 & $0,59 \pm 0.30$ & $0,32 \pm 0.19$ & $0,36 \pm 0.18$ & $0,18 \pm 0.04$ & $0,49 \pm 0.16$ & $0,10 \pm 0.03$ \\
\hline 80 & a-copaene & 36,30 & $0,68 \pm 0.16$ & $0,81 \pm 0.07$ & $0,61 \pm 0.17$ & $0,51 \pm 0.13$ & $0,75 \pm 0.25$ & $0,45 \pm 0.07$ \\
\hline 81 & dodecanal & 36,44 & $0,70 \pm 0.29$ & $1,02 \pm 0.31$ & $0,57 \pm 0.04$ & $0,48 \pm 0.16$ & $0,79 \pm 0.19$ & $0,28 \pm 0.10$ \\
\hline 82 & geranylacetone & 37,50 & $0,63 \pm 0.09$ & $0,52 \pm 0.21$ & $0,54 \pm 0.07$ & $1,24 \pm 0.28$ & $0,84 \pm 0.16$ & $0,92 \pm 0.19$ \\
\hline 83 & $\beta$-caryophyllene & 37,75 & $0,32 \pm 0.07$ & $0,51 \pm 0.07$ & $0,49 \pm 0.02$ & $0,35 \pm 0.06$ & $0,51 \pm 0.16$ & $0,45 \pm 0.04$ \\
\hline 84 & a-humulene & 38,71 & $0,42 \pm 0.14$ & $0,57 \pm 0.06$ & $0,45 \pm 0.13$ & $0,44 \pm 0.12$ & $0,66 \pm 0.18$ & $0,47 \pm 0.05$ \\
\hline 85 & $\beta$-ionone & 38,78 & $0,59 \pm 0.15$ & $0,59 \pm 0.09$ & $0,52 \pm 0.12$ & $0,73 \pm 0.17$ & $0,60 \pm 0.11$ & $1,20 \pm 0.22$ \\
\hline 86 & valencene & 39,57 & $0,06 \pm 0.01$ & $0,17 \pm 0.02$ & $0,28 \pm 0.08$ & $0,10 \pm 0.01$ & $0,09 \pm 0.00$ & $0,09 \pm 0.01$ \\
\hline 87 & nootkatone & 47,71 & $\mathrm{nd}$ & nd & nd & nd & nd & nd \\
\hline
\end{tabular}


Annex 4.

Relative levels of VOCs detected in juices of 'Navelina' oramges and 'Clemenrules' mandarins at harvest $(\mathrm{H})$ and after degreening without $(\mathrm{A})$ and with $(\mathrm{E})$ ethylene exposure and the posterior cold-quarantine treatment plus shelf-life.

\begin{tabular}{|c|c|c|c|c|c|c|c|c|}
\hline ID & Compounds & RT & \multicolumn{3}{|c|}{ Clemenules } & \multicolumn{3}{|c|}{ Navelina } \\
\hline & & & $\mathrm{H}$ & $\mathrm{A}$ & $\mathrm{E}$ & $\mathrm{H}$ & $\mathrm{A}$ & $E$ \\
\hline 1 & acetaldehyde & 4,89 & $0,67 \pm 0.23$ & $0,73 \pm 0.15$ & $1,03 \pm 0.44$ & $0,65 \pm 0.12$ & $1,33 \pm 0.36$ & $1,97 \pm 0.70$ \\
\hline 2 & ethanol & 5,52 & $0,11 \pm 0.05$ & $0,24 \pm 0.09$ & $0,35 \pm 0.12$ & $0,33 \pm 0.07$ & $1,05 \pm 0.32$ & $2,01 \pm 0.41$ \\
\hline 3 & 2-methylfuran & 8,84 & $0,85 \pm 0.27$ & $1,21 \pm 0.17$ & $0,97 \pm 0.42$ & $1,23 \pm 0.22$ & $1,25 \pm 0.25$ & $1,37 \pm 0.26$ \\
\hline 4 & 3-methylfuran & 9,14 & $0,81 \pm 0.18$ & $1,50 \pm 0.59$ & $2,11 \pm 0.99$ & $2,00 \pm 0.21$ & $1,63 \pm 0.19$ & $1,95 \pm 0.50$ \\
\hline 5 & ethyl acetate & 9,08 & $0,21 \pm 0.07$ & $0,22 \pm 0.05$ & $0,25 \pm 0.02$ & $0,23 \pm 0.00$ & $0,39 \pm 0.11$ & $1,13 \pm 0.50$ \\
\hline 6 & 1-penten-3-one & 11,56 & $0,45 \pm 0.30$ & $0,76 \pm 0.09$ & $0,66 \pm 0.37$ & $1,29 \pm 0.31$ & $0,87 \pm 0.25$ & $1,17 \pm 0.08$ \\
\hline 7 & pentanal & 12,02 & $0,96 \pm 1.07$ & $0,42 \pm 0.14$ & $1,20 \pm 1.54$ & $1,95 \pm 1.47$ & $0,59 \pm 0.17$ & $0,75 \pm 0.10$ \\
\hline 8 & 2-ethylfuran & 12,11 & $0,81 \pm 0.35$ & $0,94 \pm 0.09$ & $0,83 \pm 0.23$ & $2,73 \pm 0.93$ & $1,50 \pm 0.27$ & $1,15 \pm 0.29$ \\
\hline 9 & ethyl propionate & 12,36 & $0,13 \pm 0.03$ & $0,26 \pm 0.01$ & $0,21 \pm 0.06$ & $0,14 \pm 0.00$ & $0,42 \pm 0.20$ & $1,30 \pm 0.60$ \\
\hline 10 & (E)-2-pentenal & 14,24 & $0,40 \pm 0.14$ & $0,75 \pm 0.23$ & $0,68 \pm 0.22$ & $0,72 \pm 0.18$ & $0,72 \pm 0.04$ & $1,02 \pm 0.21$ \\
\hline 11 & 1-pentanol & 14,53 & $0,36 \pm 0.04$ & $0,46 \pm 0.09$ & $0,36 \pm 0.04$ & $1,03 \pm 0.25$ & $0,63 \pm 0.34$ & $0,69 \pm 0.12$ \\
\hline 12 & ethyl butanoate & 15,80 & $0,04 \pm 0.01$ & $0,04 \pm 0.01$ & $0,04 \pm 0.01$ & $0,34 \pm 0.08$ & $5,47 \pm 2.69$ & $8,93 \pm 6.17$ \\
\hline 13 & (Z)-3-hexenal & 15,85 & $1,24 \pm 0.31$ & $0,76 \pm 0.31$ & $0,35 \pm 0.12$ & $6,41 \pm 2.65$ & $3,59 \pm 0.39$ & $1,51 \pm 0.53$ \\
\hline 14 & hexanal & 15,95 & $0,22 \pm 0.16$ & $0,45 \pm 0.10$ & $0,32 \pm 0.07$ & $1,74 \pm 0.15$ & $1,20 \pm 0.29$ & $1,37 \pm 0.38$ \\
\hline 15 & ethyl 2-methylbutyrate & 17,74 & $0,21 \pm 0.03$ & $0,21 \pm 0.03$ & $0,21 \pm 0.02$ & $0,24 \pm 0.00$ & $1,16 \pm 0.83$ & $3,97 \pm 2.46$ \\
\hline 16 & (E)-2-hexenal & 18,09 & $0,93 \pm 0.33$ & $0,53 \pm 0.20$ & $0,48 \pm 0.13$ & $4,94 \pm 2.93$ & $3,99 \pm 0.97$ & $6,86 \pm 3.07$ \\
\hline 17 & (E)-2-hexen-1-ol & 18,39 & $0,58 \pm 0.17$ & $0,58 \pm 0.17$ & $0,72 \pm 0.41$ & $1,35 \pm 1.19$ & $0,66 \pm 0.00$ & $2,65 \pm 1.74$ \\
\hline 18 & 1-hexanol & 18,47 & $0,06 \pm 0.06$ & $0,12 \pm 0.01$ & $0,11 \pm 0.00$ & $0,56 \pm 0.32$ & $0,29 \pm 0.12$ & $0,35 \pm 0.26$ \\
\hline 19 & heptanal & 19,90 & $0,39 \pm 0.22$ & $0,95 \pm 0.18$ & $0,83 \pm 0.15$ & $1,13 \pm 0.38$ & $0,72 \pm 0.24$ & $0,80 \pm 0.06$ \\
\hline 20 & a-pinene & 21,57 & $1,47 \pm 0.12$ & $0,85 \pm 0.11$ & $0,76 \pm 0.10$ & $1,75 \pm 0.69$ & $2,04 \pm 1.35$ & $1,23 \pm 0.10$ \\
\hline 21 & (E)-2-heptenal & 22,06 & $0,19 \pm 0.11$ & $0,35 \pm 0.07$ & $0,25 \pm 0.07$ & $1,24 \pm 0.50$ & $0,85 \pm 0.29$ & $0,78 \pm 0.09$ \\
\hline 22 & 1-heptanol & 22,30 & $0,49 \pm 0.17$ & $0,63 \pm 0.10$ & $0,57 \pm 0.13$ & $0,42 \pm 0.13$ & $0,39 \pm 0.07$ & $0,29 \pm 0.06$ \\
\hline 23 & camphene & 22,34 & $1,24 \pm 0.29$ & $0,71 \pm 0.08$ & $0,64 \pm 0.11$ & $1,30 \pm 0.62$ & $1,36 \pm 0.78$ & $0,82 \pm 0.06$ \\
\hline 24 & 1-octen-3-one & 22,71 & $0,42 \pm 0.15$ & $0,42 \pm 0.15$ & $0,43 \pm 0.16$ & $1,33 \pm 0.80$ & $1,51 \pm 0.42$ & $0,81 \pm 0.18$ \\
\hline 25 & 1-octen-3-ol & 22,73 & $0,21 \pm 0.13$ & $0,37 \pm 0.10$ & $0,28 \pm 0.13$ & $1,01 \pm 0.13$ & $0,65 \pm 0.20$ & $0,63 \pm 0.14$ \\
\hline 26 & 6-methyl-5-hepten-2-one & 22,94 & $1,23 \pm 0.09$ & $1,20 \pm 0.02$ & $1,30 \pm 0.28$ & $0,84 \pm 0.23$ & $0,64 \pm 0.13$ & $0,74 \pm 0.07$ \\
\hline 27 & 3-octanone & 22,98 & $0,18 \pm 0.08$ & $0,26 \pm 0.05$ & $0,22 \pm 0.07$ & $0,88 \pm 0.25$ & $0,59 \pm 0.22$ & $0,63 \pm 0.09$ \\
\hline 28 & myrcene & 23,17 & $1,37 \pm 0.16$ & $0,88 \pm 0.11$ & $0,79 \pm 0.12$ & $1,60 \pm 0.38$ & $1,67 \pm 0.73$ & $1,26 \pm 0.09$ \\
\hline 29 & 2-pentylfuran & 23,27 & $0,25 \pm 0.16$ & $0,56 \pm 0.09$ & $0,39 \pm 0.08$ & $1,10 \pm 0.19$ & $0,70 \pm 0.23$ & $0,76 \pm 0.06$ \\
\hline 30 & ethyl hexanoate & 23,28 & $0,05 \pm 0.01$ & $0,05 \pm 0.01$ & $0,05 \pm 0.01$ & $1,72 \pm 0.68$ & $8,54 \pm 2.30$ & $9,29 \pm 3.77$ \\
\hline 31 & $\beta$-pinene & 23,36 & $1,25 \pm 0.26$ & $0,61 \pm 0.14$ & $0,71 \pm 0.07$ & $0,72 \pm 0.32$ & $0,86 \pm 0.49$ & $0,71 \pm 0.18$ \\
\hline 32 & octanal & 23,68 & $2,55 \pm 0.64$ & $1,48 \pm 0.26$ & $1,10 \pm 0.21$ & $1,40 \pm 1.00$ & $1,47 \pm 0.36$ & $0,95 \pm 0.17$ \\
\hline 33 & a-phellandrene & 24,19 & $1,54 \pm 0.32$ & $0,74 \pm 0.12$ & $0,68 \pm 0.12$ & $1,45 \pm 0.57$ & $1,38 \pm 0.62$ & $1,05 \pm 0.04$ \\
\hline 34 & 3-carene & 24,32 & $1,22 \pm 0.15$ & $0,77 \pm 0.08$ & $0,84 \pm 0.29$ & $3,09 \pm 1.54$ & $5,18 \pm 2.08$ & $4,84 \pm 1.70$ \\
\hline 35 & a-terpinene & 24,55 & $1,40 \pm 0.32$ & $0,60 \pm 0.13$ & $0,67 \pm 0.06$ & $0,85 \pm 0.41$ & $0,83 \pm 0.38$ & $0,68 \pm 0.14$ \\
\hline 36 & limonene & 25,03 & $1,13 \pm 0.03$ & $0,95 \pm 0.06$ & $0,93 \pm 0.06$ & $1,18 \pm 0.09$ & $1,22 \pm 0.21$ & $1,11 \pm 0.05$ \\
\hline 37 & eucalyptol & 25,33 & $0,99 \pm 0.11$ & $0,59 \pm 0.12$ & $0,55 \pm 0.14$ & $0,24 \pm 0.05$ & $0,24 \pm 0.04$ & $0,27 \pm 0.04$ \\
\hline 38 & (E)-2-octenal & 25,70 & $0,15 \pm 0.11$ & $0,46 \pm 0.02$ & $0,38 \pm 0.06$ & $1,16 \pm 0.62$ & $0,72 \pm 0.27$ & $0,71 \pm 0.06$ \\
\hline 39 & 1-octanol & 25,89 & $1,12 \pm 0.23$ & $0,52 \pm 0.15$ & $0,40 \pm 0.10$ & $0,83 \pm 0.45$ & $2,00 \pm 0.31$ & $2,44 \pm 0.63$ \\
\hline 40 & $\gamma$-terpinene & 25,93 & $1,24 \pm 0.25$ & $0,52 \pm 0.11$ & $0,64 \pm 0.09$ & $0,66 \pm 0.27$ & $0,65 \pm 0.26$ & $0,62 \pm 0.17$ \\
\hline 41 & ethyl heptanoate & 26,72 & nd & nd & nd & $1,59 \pm 0.51$ & $3,04 \pm 1.64$ & $4,68 \pm 2.80$ \\
\hline 42 & terpinolene & 26,94 & $1,38 \pm 0.33$ & $0,68 \pm 0.06$ & $0,63 \pm 0.18$ & $1,30 \pm 0.60$ & $1,28 \pm 0.57$ & $0,92 \pm 0.10$ \\
\hline 43 & linalool & 27,05 & $1,33 \pm 0.16$ & $0,64 \pm 0.25$ & $0,64 \pm 0.08$ & $0,33 \pm 0.05$ & $0,27 \pm 0.00$ & $0,28 \pm 0.01$ \\
\hline 44 & nonanal & 27,20 & $0,67 \pm 0.17$ & $1,07 \pm 0.02$ & $0,98 \pm 0.15$ & $0,83 \pm 0.39$ & $0,80 \pm 0.12$ & $0,68 \pm 0.11$ \\
\hline 45 & methyl octanoate & 27,64 & $0,87 \pm 0.09$ & $0,87 \pm 0.09$ & $0,88 \pm 0.10$ & $3,81 \pm 1.42$ & $6,88 \pm 0.81$ & $3,38 \pm 0.18$ \\
\hline 46 & $\beta$-citronellal & 28,81 & $7,37 \pm 1.37$ & $6,67 \pm 1.58$ & $6,00 \pm 0.88$ & nd & nd & nd \\
\hline 47 & (E)-2-nonenal & 29,11 & $0,16 \pm 0.11$ & $0,48 \pm 0.03$ & $0,43 \pm 0.06$ & $1,10 \pm 0.62$ & $0,68 \pm 0.24$ & $0,69 \pm 0.11$ \\
\hline 48 & 1-nonanol & 29,26 & $0,98 \pm 0.06$ & $0,89 \pm 0.16$ & $0,88 \pm 0.03$ & $0,61 \pm 0.21$ & $1,10 \pm 0.30$ & $1,06 \pm 0.13$ \\
\hline 49 & ethyl octanoate & 29,94 & $0,03 \pm 0.00$ & $0,04 \pm 0.01$ & $0,04 \pm 0.00$ & $1,95 \pm 0.54$ & $7,75 \pm 1.13$ & $8,09 \pm 2.38$ \\
\hline 50 & terpinen-4-ol & 30,27 & $0,97 \pm 0.19$ & $0,39 \pm 0.11$ & $0,53 \pm 0.14$ & $0,52 \pm 0.21$ & $0,54 \pm 0.20$ & $0,55 \pm 0.17$ \\
\hline
\end{tabular}


Annex 4.

Cont.

\begin{tabular}{|c|c|c|c|c|c|c|c|c|}
\hline ID & Compounds & RT & \multicolumn{3}{|c|}{ Clemenules } & \multicolumn{3}{|c|}{ Navelina } \\
\hline & & & $\mathrm{H}$ & A & $E$ & $\mathrm{H}$ & $\mathrm{A}$ & $E$ \\
\hline 51 & octyl acetate & 30,36 & $0,19 \pm 0.04$ & $0,08 \pm 0.02$ & $0,14 \pm 0.06$ & $3,10 \pm 2.17$ & $1,02 \pm 0.56$ & $0,73 \pm 0.48$ \\
\hline 52 & decanal & 30,49 & $2,14 \pm 0.29$ & $1,11 \pm 0.28$ & $0,90 \pm 0.35$ & $0,99 \pm 0.87$ & $1,57 \pm 0.53$ & $0,89 \pm 0.26$ \\
\hline 53 & a-terpineol & 30,64 & $1,40 \pm 0.15$ & $0,65 \pm 0.19$ & $0,62 \pm 0.12$ & $1,03 \pm 0.24$ & $1,09 \pm 0.37$ & $0,75 \pm 0.01$ \\
\hline 54 & dihydrocarvone & 30,78 & $1,07 \pm 0.22$ & $1,04 \pm 0.19$ & $1,10 \pm 0.03$ & $1,09 \pm 0.42$ & $0,97 \pm 0.32$ & $0,76 \pm 0.07$ \\
\hline 55 & methyl nonanoate & 30,84 & $0,64 \pm 0.04$ & $1,17 \pm 0.22$ & $0,70 \pm 0.10$ & $3,81 \pm 0.74$ & $3,68 \pm 4.82$ & $1,65 \pm 0.16$ \\
\hline 56 & $(\mathrm{E}, \mathrm{E})-2,4$-nonadienal & 31,01 & $0,12 \pm 0.07$ & $0,13 \pm 0.04$ & $0,11 \pm 0.02$ & $1,33 \pm 0.76$ & $0,67 \pm 0.33$ & $0,51 \pm 0.11$ \\
\hline 57 & $\beta$-citronellol & 31,06 & $1,45 \pm 0.11$ & $1,05 \pm 0.27$ & $0,89 \pm 0.21$ & $0,83 \pm 0.25$ & $0,91 \pm 0.27$ & $1,04 \pm 0.04$ \\
\hline 58 & nerol & 31,16 & $0,86 \pm 0.33$ & $0,49 \pm 0.20$ & $0,37 \pm 0.12$ & $0,80 \pm 0.16$ & $1,26 \pm 0.34$ & $2,00 \pm 0.13$ \\
\hline 59 & (E)-carveol & 31,30 & $2,33 \pm 0.59$ & $1,47 \pm 0.88$ & $1,38 \pm 0.10$ & $1,14 \pm 0.37$ & $1,88 \pm 1.11$ & $1,11 \pm 0.12$ \\
\hline 60 & $\beta$-cyclocitral & 31,53 & $1,36 \pm 0.34$ & $2,15 \pm 0.52$ & $1,59 \pm 0.03$ & $2,48 \pm 0.31$ & $1,15 \pm 0.20$ & $1,37 \pm 0.54$ \\
\hline 61 & linalyl acetate & 31,70 & $0,53 \pm 0.02$ & $0,26 \pm 0.09$ & $0,26 \pm 0.04$ & $1,29 \pm 0.37$ & $0,69 \pm 0.35$ & $0,81 \pm 0.14$ \\
\hline 62 & geraniol & 31,83 & $1,16 \pm 0.14$ & $0,39 \pm 0.16$ & $0,39 \pm 0.04$ & $0,44 \pm 0.08$ & $0,47 \pm 0.03$ & $0,56 \pm 0.03$ \\
\hline 63 & carvone & 32,20 & $1,60 \pm 0.08$ & $1,09 \pm 0.46$ & $1,44 \pm 0.35$ & $1,08 \pm 0.61$ & $0,85 \pm 0.55$ & $0,50 \pm 0.06$ \\
\hline 64 & geranial & 32,50 & $2,08 \pm 0.38$ & $0,38 \pm 0.25$ & $0,20 \pm 0.04$ & $4,66 \pm 2.06$ & $2,80 \pm 0.29$ & $1,90 \pm 0.29$ \\
\hline 65 & ethyl nonanoate & 32,96 & $0,09 \pm 0.00$ & $0,13 \pm 0.02$ & $0,09 \pm 0.00$ & $2,01 \pm 0.54$ & $9,01 \pm 11.4$ & $6,93 \pm 1.22$ \\
\hline 66 & perillaldehyde & 33,32 & $1,05 \pm 0.11$ & $0,45 \pm 0.15$ & $0,46 \pm 0.08$ & $2,13 \pm 1.67$ & $0,76 \pm 0.32$ & $0,42 \pm 0.01$ \\
\hline 67 & nonyl acetate & 33,56 & $0,50 \pm 0.02$ & $0,50 \pm 0.02$ & $0,49 \pm 0.04$ & $3,87 \pm 1.75$ & $2,22 \pm 1.09$ & $1,74 \pm 1.09$ \\
\hline 68 & isobornyl acetate & 33,53 & $1,65 \pm 0.95$ & $1,11 \pm 0.57$ & $0,64 \pm 0.05$ & $0,34 \pm 0.00$ & $0,53 \pm 0.08$ & $0,37 \pm 0.04$ \\
\hline 69 & undecanal & 33,56 & $1,14 \pm 0.12$ & $0,91 \pm 0.19$ & $0,80 \pm 0.08$ & $1,15 \pm 0.84$ & $1,38 \pm 0.44$ & $0,99 \pm 0.15$ \\
\hline 70 & methyl decanoate & 33,84 & $0,45 \pm 0.01$ & $0,52 \pm 0.11$ & $0,54 \pm 0.08$ & $3,57 \pm 0.56$ & $4,05 \pm 1.81$ & $3,58 \pm 0.73$ \\
\hline 71 & $(\mathrm{E}, \mathrm{E})$-2,4-decadienal & 34,09 & $0,83 \pm 0.05$ & $0,57 \pm 0.17$ & $0,43 \pm 0.06$ & $0,78 \pm 0.52$ & $0,55 \pm 0.06$ & $0,39 \pm 0.07$ \\
\hline 72 & (Z)-carvyl acetate & 34,39 & $0,74 \pm 0.22$ & $0,55 \pm 0.16$ & $0,92 \pm 0.33$ & $4,29 \pm 2.57$ & $4,34 \pm 2.34$ & $3,71 \pm 1.10$ \\
\hline 73 & citronellyl acetate & 34,58 & $0,39 \pm 0.02$ & $0,22 \pm 0.03$ & $0,19 \pm 0.04$ & $8,59 \pm 3.42$ & $5,32 \pm 3.23$ & $3,12 \pm 1.33$ \\
\hline 74 & neryl acetate & 34,86 & $0,26 \pm 0.04$ & $0,09 \pm 0.04$ & $0,11 \pm 0.02$ & $10,10 \pm 2.9$ & $8,81 \pm 7.19$ & $4,72 \pm 1.35$ \\
\hline 75 & a-terpinyl acetate & 34,99 & $0,84 \pm 0.22$ & $0,31 \pm 0.02$ & $0,52 \pm 0.23$ & $0,55 \pm 0.22$ & $0,27 \pm 0.17$ & $0,35 \pm 0.20$ \\
\hline 76 & (E)-carvyl acetate & 35,19 & $2,70 \pm 1.82$ & $1,61 \pm 0.96$ & $2,84 \pm 1.98$ & $2,81 \pm 0.28$ & $6,05 \pm 7.19$ & $1,94 \pm 0.77$ \\
\hline 77 & geranyl acetate & 35,39 & $1,45 \pm 0.23$ & $0,53 \pm 0.04$ & $0,46 \pm 0.10$ & $4,34 \pm 3.17$ & $3,05 \pm 1.83$ & $1,69 \pm 0.34$ \\
\hline 78 & ethyl decanoate & 35,81 & $0,05 \pm 0.01$ & $0,12 \pm 0.04$ & $0,13 \pm 0.02$ & $0,95 \pm 0.25$ & $5,39 \pm 1.98$ & $8,47 \pm 0.75$ \\
\hline 79 & decyl acetate & 36,18 & $0,15 \pm 0.02$ & $0,06 \pm 0.01$ & $0,08 \pm 0.02$ & $4,15 \pm 1.94$ & $2,67 \pm 1.22$ & $1,78 \pm 1.04$ \\
\hline 80 & a-copaene & 36,30 & $2,19 \pm 0.48$ & $0,99 \pm 0.24$ & $0,92 \pm 0.18$ & $2,99 \pm 0.63$ & $1,81 \pm 0.63$ & $2,14 \pm 0.47$ \\
\hline 81 & dodecanal & 36,44 & $1,90 \pm 0.26$ & $0,92 \pm 0.28$ & $0,76 \pm 0.25$ & $1,36 \pm 1.08$ & $1,57 \pm 0.53$ & $0,96 \pm 0.13$ \\
\hline 82 & geranylacetone & 37,50 & $1,76 \pm 0.28$ & $2,73 \pm 1.45$ & $1,85 \pm 0.13$ & $1,16 \pm 0.84$ & $0,72 \pm 0.09$ & $0,98 \pm 0.27$ \\
\hline 83 & $\beta$-caryophyllene & 37,75 & $0,65 \pm 0.03$ & $0,37 \pm 0.02$ & $0,61 \pm 0.05$ & $3,26 \pm 1.85$ & $4,87 \pm 1.79$ & $7,20 \pm 2.39$ \\
\hline 84 & a-humulene & 38,71 & $1,49 \pm 0.10$ & $0,65 \pm 0.06$ & $0,68 \pm 0.18$ & $3,04 \pm 1.61$ & $2,48 \pm 0.79$ & $3,52 \pm 0.67$ \\
\hline 85 & $\beta$-ionone & 38,78 & $1,48 \pm 0.20$ & $1,68 \pm 0.58$ & $1,29 \pm 0.20$ & $2,06 \pm 1.22$ & $1,23 \pm 0.11$ & $1,78 \pm 0.78$ \\
\hline 86 & valencene & 39,57 & $0,08 \pm 0.01$ & $0,10 \pm 0.02$ & $0,33 \pm 0.02$ & $1,46 \pm 0.42$ & $2,83 \pm 0.37$ & $7,24 \pm 1.17$ \\
\hline 87 & nootkatone & 47,71 & nd & $\mathrm{nd}$ & $\mathrm{nd}$ & $2,13 \pm 0.69$ & $5,11 \pm 0.29$ & $16,52 \pm 4.4$ \\
\hline
\end{tabular}

